\title{
VERHANDELINGEN
}

VAN HET KONINKLIJK INSTITUUT VOOR DE TAAL-, LAND. EN VOLKENKUNDE VAN NEDERLANDSCH-INDIË

DEEL VI

\section{BANGGAISCH ADATRECHT}

\author{
DOOR \\ Dr. J. J. DORMEIER
}

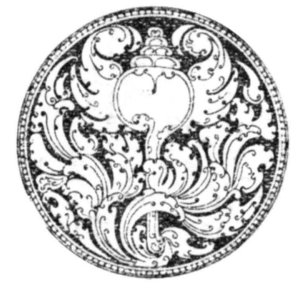

S-GRAVENHAGE - MARTINUS NIJHOFF - 1947 
J.J. Dormeier - 978-90-04-28627-6

Downloaded from Brill.com04/26/2023 03:14:19PM via free access 
AAN MIJN VROUW. 
Dit werk, oorspronkelijk in slechts enkele gestencilde exemplaren vermenigvuldigd, is het proefschift, waarop de schrijver den 26en Juni 1945 aan 's rijksuniversiteit te Leiden den graad van doctor in de rechtsgeleerdheid verkreeg, met prof. dr. V. E. Korn als promotor. 


\section{INHOUD.}

blz.

HOOFDSTUK I: ALGEMEENE GEGEVENS BETREFFENDE HET LANDSCHAP BANGGAI . . . . . 1

1. Grenzen, blz. 1 ; 2. Bevolking; talen, blz. 4; 3. Middelen van bestaan, blz. 8; 4. Godsdienst, blz. 9; 5. Banggai als studieobject, blz. 14 ; 6 . Volks- en vorstensfeer; Gouvernementsinvloed, blz. 16; 7. Systematiek, blz. 17.

HOOFDSTUK II : TRADITIE EN HISTORIE

1. Voormalige rijken in den Archipel en op den Vaste-Wal, blz. 20 ; 2. De historische traditie te Banggai, blz. 36; 3. Historische gegevens, blz. 42; 4. Transmigraties en immigraties, blz. 43 .

HOOFDSTUK III : RECHTSGEMEENSCHAPPEN

1. Algemeene trekken, blz. 50; ( V olks orden ing): 2. Vormen, blz. $51 ; 3$. Structuur en omvang der streekgemeenschappen, blz. 64 ; 4. Rechtgemeenschappen bij transen immigranten, blz. 68; 5. Bijzondere groepeeringen, blz. 71; ( V o r sten invloed): 6 . Wijzigingen in vorm of getal der lagere rechtsgemeenschappen onder invloed van het vorstengezag, blz. 76; ( G o u ver n e me n t sinvloed ): 7. Dorpsvorming en territorialiteitsbeginsel, blz. 79.

HOOFDSTUK IV : INDIVIDUEN .

1. Standen, blz. 84 ; 2. Rechten en verplichtingen, blz. 89 ;

3. Naamgeving, blz. 92.

HOOFDSTUK V : BESTUUR, RECHTSPRAAK, REGELING

A. B estuur: 1. Bestuursorganisatie der volksgroepeeringen, blz. $94 ; 2$. Aanwijzing tot de verschillende functies, blz. 100 ; 3. Omvang der bestuursfuncties, blz. 106; 4. De vorstensfeer, blz. $113 ; 5$. Het Ternataansche toezicht te 
blz.

Banggai, blz. 129; 6. Gouvernementsinvloed, blz. 139; 7. Godsdienstbeambten, blz. 144.

B. Rechtspraak: 8. Rechtsbedeeling in de sfeer der volksordening, blz. 146; 9. De procedure (bewijs; godsoordeel ; executie), blz. 155 ; 10. Vorstenrechtspraak; rijksraad Ternate (voor 1 April 1908), blz. 160; 11. Zelfbestuursrechtspraak (na 1908), blz. 164; 12. Godsdienstige rechtspraak, blz. 166.

C. Regeling: 13. Regeling door de lagere rechtsgemeenschappen, blz. 170; 14. Regeling door sultan of vorst, blz. 170; 15. Regeling in Gouvernementssfeer, blz. 171.

HOOFDSTUK VI: ADATVOLKENRECHT

1. Conflicten tusschen streekgemeenschappen; verdragen en bondgenootschappen, blz. 173; 2. Verhouding van Banggai tot andere vorstendommen; onveiligheid eertijds, blz. 178; 3. Gevolgen van Banggai's positie als vazal van Ternate, blz. 181; 4. Vestiging van het Nederlandsche gezag, blz. 183.

HOOFDSTUK VII : VERWANTSCHAPSRECHT

1. De verhouding van het kind tot zijn ouders, blz. 185;

2. De positie van het kind in het sociale stelsel, blz. 187;

3. Kindaanneming, blz. 192.

\section{HOOFDSTUK VIII : HUWELIJKSRECHT}

1. Vóór-huwelijksche verhoudingen. Huwelijksverboden in bepaalde bloedverwantschappen. Voorkeurhuwelijk op bloedverwantschap gebaseerd, blz. 194; 2. De normale verloving en haar rechtsgevolgen, blz. 201;3. Huwelijksgeschenk; huwelijkssluiting, blz. 207; 4. Vluchthuwelijk; andere huwelijksvormen, blz. 219; 5. Gemengde huwelijken, blz. 222 ; 6. Huwelijksgoederenrecht, blz. 222; 7. Meervrouwendom, blz. 224; 8. Huwelijksontbinding, blz. 226; 9. Verzorging van kinderen; voogdij, blz. 230.

HOOFDSTUK IX : ERFRECHT

1. Onverdeeld blijven van boedelgoederen, blz. 232;

2. Boedelverdeeling, blz. 233; 3. Erfgenamen, blz. 233;

4. Bestanddeelen van den boedel, blz. 235. 
1. Het beschikkingsrecht, blz. 239; 2. Uitingen van het beschikkingsrecht in zijn werking naar binnen, blz. 241; 3. De werking naar buiten, blz. 250; 4. Invloed van het vorstenbestuur op het adatgrondenrecht, blz. $252 ; 5$. Invloed van het Gouvernement op het adatgrondenrecht, blz. 253; 6. Grondtransacties, blz. $255 ; 7$. Eenige bijzondere objecten, blz. 257.

HOOFDSTUK XI: SCHULDENRECHT

1. Rechten op huizen, gewas, blz. 258; 2. Verkoop van roerende goederen, blz. 258; 3. Deelwinning, blz. 259; 4. Leening en zekerheidsstelling, blz. $260 ; 5$. Samenwerking, blz. 265 ; 6. Lastgeving, blz. 267 ; 7. Loondienst en belooning; aanneming, blz. 267.

HOOFDSTUK XII : DELICTENRECHT

1. Delicten waardoor de groep in haar geheel bedreigd wordt, blz. 272 ; 2. Delicten waarbij spanningen tusschen individuen ontstaan, blz. 278; 3. Algemeene leerstukken, blz. 286; 4. Asylrecht, blz. 289.

SLOTBESCHOUWING . . . . . . . . . . . . . 290

CONCLUSION . . . . . . . . . . . . . . . . 292

REGISTERS :

Geraadpleegde literatuur . . . . . . . . . . . . 295

Termen aki . . . . . . . . . . . . . . . . 297

Termen madi . . . . . . . . . . . . . . . . 300

Termen sian . . . . . . . . . . . . . . . . 302

Wijzer der plaatsnamen . . . . . . . . . . . . 304

Toelichting bij de schetskaart van het Landschap Banggai 306 
J.J. Dormeier - 978-90-04-28627-6

Downloaded from Brill.com04/26/2023 03:14:19PM via free access 


\section{HOOFDSTUK I.}

\section{Algemeene gegevens betreffende het landschap Banggai.}

\section{Grenzen.}

Het landschap Banggai, omvattende de onderafdeeling van dien naam, vormt administratief een onderdeel der afdeeling Poso van de residentie Manado. Het bestaat uit de Oostelijke helft van den Oostarm van Midden-Celebes, en de Zuid-Oostwaarts daarvan gelegen eilanden. Het landschap, vroeger vormende een afdeeling van het sultanaat Ternate, staat sedert 1 April 1908 in rechtstreeksche verhouding tot het Nederlandsch-Indisch Gouvernement; de bestuursvorm is sedert dien die van zelfbestuur onder Korte Verklaring.

Staatsblad 1907 no. 367 regelt de toevoeging van eenige van Ternate afgescheiden zelfbesturen, waaronder Banggai, bij het Gouvernement Celebes en Onderhoorigheden, waar een nieuwe afdeeling Oostkust van Celebes wordt gevormd; standplaats van den afdeelingschef is Loewoek, gelegen in het Banggaische gedeelte van Celebes. Hierin komt in 1911 (stbl. no. 605) wijziging, waarbij de standplaats van dezen ambtenaar naar Baoe-Baoe verlegd wordt. Bij stbl. 1924 no. 365 worden eenige landschappen, o.a. Banggai, bij de residentie Manado gevoegd, terwijl in het staatsblad no. 366 van dat jaar de administratieve indeeling dier residentie wordt aangegeven: de afdeeling Poso wordt in het leven geroepen, het landschap Banggai wordt in twee onderafdeelingen gesplitst. In 1932 stbl. no. 571, worden de beide onderafdeelingen weer samengevoegd tot de onderafdeeling Banggai, met Loewoek als standplaats van den onderafdeelingschef.

De grenzen van het landschap Banggai zijn nergens uitdrukkelijk geregeld. Waar eertijds (tot 1 April 1908) Banggai een deel uitmaakte van het sultanaat Ternate moet althans de westelijke grens van Banggai vastliggen, voor zoover deze samenvalt met de voormalige westgrens van Ternate. Bosscher en Mathijsen ${ }^{1}$ ) spreken in 1854 over Tandjong Api in de Tominibocht als grenspunt, terwij1

1) Bosscher en Mathijsen, Schetsen, blz. 90.

Verh. dl. VI. 
de Regeerings-Almanak van $1875^{2}$ ) eveneens dat punt noemt. Bij het contract met den sultan van Ternate den 30en October $1880^{3}$ ) gesloten behoort een opgave van het gebied tot het sultanaat behoorend. Hierin zijn wel genoemd de Banggai-eilanden, doch op den vasten wal van Celebes alleen „Balanta, Mendong” zonder verdere aanduiding (beide genoemde gebieden zijn verminkte namen van rechtsgemeenschappen; zie hoofdstuk III). Den 11en December $1887^{4}$ ) sloot de resident van Manado een contract met den radja van Todjo, Banggai's westelijken buurman in de Tominibocht; in art. 1 staat als verklaring van dezen vorst, dat Todjo zich uitstrekt westwaarts van Tandjong Api tot.... (volgt een naam), terwijl in de nota van toelichting te vinden is, dat het oostelijk grenspunt van Todjo, Tandjong Api, de residentie Manado scheidt van het onder de residentie Ternate ressorteerende gedeelte van Celebes. Bij het volgende contract met Todjo echter, dat van 25 Mei $1897^{5}$ ), wordt in art. 2 de grensomschrijving als volgt aangegeven: „Het gebied van het landschap Todjo wordt begrensd ten Oosten door het riviertje Balingara bij Tandjong Api, ten Westen ...." enz. Hierdoor werd de grens een aanzienlijk eind oostwaarts naar de Balingararivier verlegd. Door onvoldoende terreinkennis vermoedelijk is men niet op het idee gekomen om na tegaan of wellicht Ternate's (Banggai's) gebied werd aangetast, terwijl het verschil tusschen beide grensomschrijvingen (Tandjong Api is iets anders dan „bij” Tandjong Apil) wellicht de Algemeene Secretarie niet is opgevallen. Het verschil langs het strand bedraagt $\pm 30 \mathrm{KM}$.

Dat de Clerq ${ }^{6}$ ) in 1880 Tandjong Api als westelijke grens aangeeft is dus volkomen correct, doch als in 1906 Goedhart $^{7}$ ) schrijft dat de westgrens van Banggai begint bij Tandjong Api in de Tominibocht, blijkt daaruit dat men te Banggai ò niet op de hoogte was van het Todjo-contract, òf dat men er zich niet bij had neergelegd. Een voor het adatvolkenrecht interessant uitvloeisel van een en ander zal in hoofdstuk VI par. 4 worden medegedeeld.

Het zuidelijk punt van de westgrens wordt gevormd door Togong Téong. Toen de Clerq als Resident van Ternate een hier gerezen

2) Regeeringsalmanak 1875, blz. 226.

3) Indische Gids 1882, deel I, blz. 693-708.

4) Bijlagen 2e Kamer 1888-'89, no. 76-29 en 30 .

5) Bijlagen 2e Kamer 1898-'99, no. 166-27.

B) De Clercq, Ternate, blz. 133. Dezelfde auteur spreekt op blz. 173 over Kaap Valsch of Taliaboe(?).

7) Goedhart, Drie landschappen, blz. 443. 
grensgeschil met Boengkoe (dat ook tot het sultanaat Ternate behoorde) onderzocht, was hiermede dus niet de uitwendige grens van dat sultanaat gemoeid, doch slechts een voor dat rijk interne kwestie. Als grens werd, na bespreking met de medegenomen hoofden, het in het contract (welk?) als grens opgegeven eiland Téong behouden ${ }^{8}$ ). Thans nog is dit de grens tusschen Banggai en Boengkoe aan de zuidoostkust van Celebes.

De afpaling van Banggai's oostgrens werd pas een probleem nà Banggai's afscheiding van Ternate, dus na 1 April 1908, want toen viel Ternate's westgrens samen met Banggai's oostgrens. Herhaaldelijk hebben zich daarover moeilijkheden voorgedaan tusschen hoofden van Banggai en van Taliaboe (onderafdeeling Soelaeilanden). Volgens de Clerq $^{9}$ ) behooren Timpaoes en Masoni tot Banggai; Goedhart ${ }^{10}$ ) duidt de oostgrens niet nader aan. In 1913 ontkende Banggai de rechten van Taliaboe op Masoni, doch blijkens de alignementen vermeld in bijlage $\mathrm{A}^{1}$, behoorende bij het op 22 Februari 1910 goedgekeurde en bekrachtigde, op 28 Juni 1909 met den sultan van Ternate gesloten ${ }^{11}$ ) contract, behooren de eilanden Salaoewe en Timpaoes tot Banggai, het eiland Masoni echter tot Ternate.

Thans is de Balingara de westgrens, waarbij Banggai dus grondgebied aan Todjo verloor; aan den anderen kant zijn de op het eiland Masoni aanwezige klappereigenaren en visschers (er zijn geen kampongs) op Timpaoes in de landschapsbelasting geregistreerd, waardoor dus feitelijk de kas van Banggai inkomsten geniet die haar rechtens niet toekomen.

Het gebied van het landschap is eenvoudig in eenige deelen te verdeelen, te weten den Archipel (waarvan de voornaamste eilanden zijn Peling, Banggai, Labobo en Bangkoeloe), en den Vaste-Wal. Van de eilanden wordt het grootste, Peling, door de bevolking zelve niet zoo genoemd, of hoogstens in navolging van de bestuursambtenaren. Bij het volk heet het Togong doi tanga (= eiland in het midden) ${ }^{12}$ ). De Vaste-Wal, in den Archipel vaak „tanah

8) De Clercq, Ternate, blz. 145-146.

9) De Clercq, Ternate, blz. 123.

10) Goedhart, Drie landschappen, blz. 442.

11) Mededeelingen Encyclopaedisch Bureau No. XV (Soela-eilanden), blz. 1 noot 1 . Hierin wordt ook vermeld dat Goedhart in zijn memorie gesteld zou hebben dat Timpaoes en Masoni tot Taliaboe behooren, en dat over de Salaoeweeilanden geschil zou bestaan. Deze mededeeling heb ik echter bij Goedhart niet aangetroffen.

12) O.a. Kruyt, Vorsten, blz. 505. 
besar" ${ }^{13}$ ) genoemd, heeft aan zijn oostelijk einde een schiereiland; dit paddenstoelvormig gedeelte wordt door de bestuursambtenaren vaak Vogelkop genoemd. In den loop der volgende bladzijden zullen herhaaldelijk deze drie deelen (Archipel; Vogelkop; rest Vaste-Wal) genoemd worden.

\section{Bevolking; talen.}

In geen der mij bekende ethnografische werken wordt een indeeling der Banggai-bevolking bij één der groote omliggende groepen aangegeven; er is ethnografisch en anthropologisch te weinig bekend om een dergelijke indeeling thtans te rechtvaardigen. De Volkskaart van Nederlandsch-Indië van R. E. Kaltofen geeft Midden-Celebesvolken aan, warbij o.a. de geheele bevolking van het landschap wordt ingedeeld, met uitzondering van plaatselijke vestigingen van Badjo's. „De Volken van Nederlandsch-Indië” (1921) behandelt in deel II de bewoners van Midden-Celebes, waartoe alleen de Oost-Toradja's en de bewoners van Poso gerekend worden; verder worden de bewoners der noordelijke Molukken (Halmaherra, Morotai, Ternate, Tidore, Obi en Batjan) en der zuidelijke Molukken (Ambon, Haroehoe, Saparoea, Noesa-Laoet) behandeld. Bij deze opsomming blijven het gebied van Banggai en de Soela-eilanden onbesproken. Terloops zij opgemerkt dat de bevolkingstypen op de platen der blzz. 58, 60, 61, 67 en 77 veel doen denken aan de Banggaische bevolking, speciaal die van Oost-Peling. Volgens Bosscher en Mathijsen ${ }^{14}$ ) behoort de bevolking van Peling tot denzelfden stam als de inboorlingen van Soela, met wie zij de meeste overeenkomst in taal heeft.

De gegevens van de volkstelling $1930^{15}$ ) geven een totaal van 95.515 zielen van op Banggaisch gebied wonenden. Gesplitst naar bevolkingsgroepen, tevens territoriaal naar Archipel en Vaste-Wal, is dit als volgt te verdeelen:

13) De Clercq, Ternate, blz. 53 noot 2: „In de wandeling noemen de inboor„lingen Halmahera steeds „groot land"; volgens de in den geheelen Indischen "Archipel bestaande eigenaardigheid om uitgestrektheden land, die niet te over„zien zijn, nooit den naam van eiland te geven. Men vindt hetzelfde o.a. te "Soela voor Mangolé en te Banggai voor Pélèng".

Dit laatste nu is mij niet bekend; naar mijn weten slaat de uitdrukking „tanah besar”, te Banggai gebruikt, uitsluitend op den Vaste-Wal.

14) Bosscher en Mathijsen, Schetsen, blz. 95.

15) Volkstelling 1930, deel V, tabel I, blz. 122. 


$\begin{array}{crrr}\text { Archipel : inl. } & 25.437 \mathrm{~m}+23.765 \mathrm{vr}= & 49.202 \\ \text { eur. } & 33 \mathrm{~m}+\quad 22 \mathrm{vr}= & 55 \\ \text { chin. } & 363 \mathrm{~m}+ & 212 \mathrm{vr}= & 575 \\ \text { arab. } & 3 \mathrm{~m}+\quad 1 \mathrm{vr}= & 4 \\ & & & \end{array}$

$\begin{array}{rrrr}\text { Vaste-Wal : inl. } & 23.343 \mathrm{~m}+20.947 \mathrm{vr}= & 44.290 \\ \text { eur. } & 22 \mathrm{~m}+\quad 15 \mathrm{vr}= & 37 \\ \text { chin. } & 564 \mathrm{~m}+\quad 371 \mathrm{vr}= & 935 \\ \text { arab. } & 211 \mathrm{~m}+\quad 206 \mathrm{vr}= & 417 \\ & & & \end{array}$

Het betrekkelijk groot aantal Europeanen in den Archipel vindt zijn oorzaak in een groep afstammelingen van Manillareesche duikers, die op Oost-Peling verblijven; zij zijn Europeanen krachtens art. 163 lid 2, ten $3 \mathrm{e}$ der Indische Staatsregeling, doch verkeeren overigens in materieel dezelfde omstandigheden als de inlandsche landschapsbevolking.

Het oppervlak van den Archipel bedraagt 3.164.06 $\mathrm{KM}^{2}$, dat van den Vaste-Wal 8.859.38 $\mathrm{KM}^{2}{ }^{16}$ ); de bevolkingsdichtheid dezer deelen bedraagt dus onderscheidenlijk 15,75 en 5.16 .

In het landschap worden drie talen gesproken, door Adriani ${ }^{17}$ ) met het Bobongkosche (Togean-eilanden, Tominibocht) tot één groep, de Loinangsche, vereenigd. Van deze heet het in de Encyclopaedie van Nederlandsch-Indië ${ }^{18}$ ): „De Loinansche taalgroep is te beschouwen ,als de zuidetlijke uitlooper der Gorontaleesche. $\mathrm{Zij}$ heeft haar weg „over de Togean-eilanden genomen”. „De woordenschat dezer taal"groep verschilt zoozeer van dien der Toradja'sche en Boengkoesch„Morische talen, dat zij een afzonderlijke groep moet vormen. Het „Bobongko'sch heeft van de Loinansche talen nog de meeste woorden „,met het Gorontaleesch gemeen; het naast bij het Bobongko'sch staat „het Loinansch. Het Balantaksch staat weer iets verder af en het „Banggaisch vormt den overgang tot meer O'lijk gesproken talen”.

Het Loinansch (in engen zin) kent als ontkenningswoord madi en wordt gesproken op den Vaste-Wal, met uitzondering van het zuidelijk

16) Volkstelling 1930, deel V, tabel 9, blz. 156.

17) Adriani-Kruyt, Bare'e III, blz. 275.

18) Deel II, blz. 614. 
en oostelijk deel van den Vogelkop; in dit uitgezonderde gebied spreekt men het Balantaksch met het ontkenningswoord (ko)sian. In den Archipel tenslotte spreekt men het Banggaisch, met het ontkenningswoord $a k i$. Over het gebruik van het woord Loinan nog een enkel woord. Het aantal dergenen, die het Loinansch in engen zin, het madi dus, spreken, is aanzienlijk grooter dan dat der menschen die wij in de volgende bladzijden als To Loinang zullen aanduiden, zulks in navolging van dr. Alb. C. Kruyt (wij volgen ook in dezen zijn schrijfwijze). Met dezen laatsten naam wordt een groep bergbewoners aangegeven in het binnenland van den Vaste-Wal, verdeeld in de menschen van Lingketing en die van Baloa.

Adriani ${ }^{19}$ ) trekt de grenslijn met de Toradja-talen van TandjongApi (dus dit is ook een taalgrens!) naar Ondolean; deze laatste woordvorm bewijst dat deze plaats in Loinansch taalgebied heeft gelegen. Een nieuwe indeeling maakt dr. S. J. Esser, die eenerzijds onderscheidt het Loinansch (met de onderdeelen Loinansch, Bobongkosch en Balantaksch), anderzijds het Banggaisch ${ }^{20}$ ). Coolhaas ${ }^{21}$ ) stelt verwantschap tusschen het Banggaisch, Soelaasch (dus conform Bosscher en Mathijsen), Oost-Makiansch en Batjansch (hij noemt ze de westelijke talen van de zuidelijke Halmaheragroep) welke samenhang vertoonen met de talen van Midden-Celebes, terwijl de oostelijke talen overgangen vertoonen tot de Melanesische talen van noord-west Nieuw-Guinea.

Een merkwaardigheid van het Banggaisch, die in de overige talen der Loinansche groep niet optreedt, is het voorkomen van den z.g. averechtschen genitief. Adriani ziet in den Banggaischen averechtschen niets anders dan een jongere constructie van den Loinanschen en Bobongkoschen rechtschen genitief ${ }^{22}$ ). De Encyclopaedie van Nederlandsch-Indië geeft, dat het Banggaisch een drievoudige genitiefconstructie bezit ${ }^{23}$ ).

De aki-sprekers rekenen zich tot twee afdeelingen, een oostelijke en een westelijke. Er is dialectisch verschil, dat nog daardoor geaccentueerd wordt dat de westelijke groep de $\mathrm{k}$ en de $\mathrm{g}$ midden in de woorden wegwerpt en er een hamzah voor in de plaats stelt (het

\footnotetext{
19) Adriani-Kruyt, Bare'e III, blz. 4, 16.

20) Zie talenkaart blad $9 \mathrm{~b}$ in den Atlas Tropisch Nederland, groepen IX en IXa.

21) Coolhaas W. Ph., Mededeelingen betreffende de onderafdeeling Batjan, B. K. I. 82 (1926), blz. 418.

22) Adriani-Kruyt, Bare'e III, blz. 286, 287.

23) Encyclopaedie van Nederlandsch-Indië, deel I, blz. 614.
} 
ontkenningswoord is dus daar a'i, enz.) ${ }^{24}$ ). Kruyt stelt dat deze beide deelen èèn volk zijn, weliswaar met kleine verschillen in taal en adat, die echter ontstaan kunnen zijn door een uit elkaar raken der twee deelen, waarbij het contact verbroken werd. De oostelijke groep heeft vermoedelijk in aanraking gestaan met de buitenwereld en meer den invloed daarvan ondergaan dan de westelijke. Die invloed concentreerde zich voornamelijk om het vorstenhuis (van Ternataansche origine; zie hoofdstuk II), dat tot op heden in Oost-Peling meer invloed heeft dan in het westen van dat eiland ${ }^{25}$ ).

Aan den anderen kant kunnen we met reden Kruyts stelling betwijfelen als we weten dat juist bij die westelijke meer geïsoleerde helft de kunst van pottenbakken, ijzersmeden en kopergieten, en (eertijds) katoenweven, bekend $\left.z^{i j n}{ }^{26}\right)$. Eigenaardige verschijnselen bij de lijkbezorging (het gebruik van steenen in den grafkuil in Kindandal; het voorkomen van de resten van een steenen doodkist in Sea-Sea ${ }^{27}$ ) en een afwijkende organisatie bij den socialen opbouw der rechtsgemeenschappen (zie hoofdstuk III) mogen m.i. aanleiding zijn de these der eenheid in oorsprong van de beide deelen met de noodige voorzichtigheid te hanteeren. Kruyt zelf merkt op dat de bewoners van den Banggai-archipel vermoedelijk ontstaan zijn uit een vermenging van rassen, waaronder hij vele typen opmerkte, menschen met baarden, met gekroesd haar, velen zeer donker gekleurd ${ }^{28}$ ). Beziet men tenslotte de afbeeldingen van Negroïden en Weddaïden, dan komt men welhaast tot de veronderstelling dat wellicht vooral de Sea-Sea (WestPeling) met hen verwant zijn.

Naast deze bevolking die we gemakshalve als autochthoon zullen aanmerken komen immigranten voor. Men treft eenige Boegineesche kolonies aan, die soms rechtsgemeenschappen werden, men vindt een Gorontaleesche kampong met eigen bestuur en vermogen, en verder wonen op vele plaatsen Badjo's in hun typische op palen in zee gebouwde huizen, waarvan de bewoners eigen hoofden en een eigen adat bezitten. Behalve deze immigranten van blijvenden aard treft men veelvuldig Boetonneezen (veeleer Moenaneezen) aan, die als tijdelijke werkkrachten (voornamelijk in den Archipel) rondzwerven; soms blijven zij slechts eenige maanden in het landschap, doch ook komt het voor dat zij zich gedurende eenige jaren in een dorp op-

\footnotetext{
24) Kruyt, Pilogot, blz. 115, noot 1 .

25) Kruyt, Bewoners, blz. 69.

26) Kruyt, Bewoners, blz. 78-88.

27) Kruyt, Ziekte en dood, blz. 162; Memorie.

28) Kruyt, Bewoners, blz. 67.
} 
houden als klapperplukker of kleinhandelaar. $\mathrm{Zij}$ huwen hoogst zelden met dochteren des lands, hokken veelal samen in een of meer kleine huisjes buiten het dorp, en stichtten in het Banggaische voor zoover mij bekend geen eigen rechtsgemeenschappen.

\section{Middelen van bestaan.}

Het algemeen bodemaspect is zeer geaccidenteerd; daarbij komt dat de grond zeer kalkrijk is in belangrijke deelen van het land, waardoor plaatselijk groote waterschaarschte bekend is. De kusten der eilanden zijn grillig van vorm, met vele baaien en inhammen en talrijke riffen en ondiepe plaatsen ervoor. De meeste dorpen liggen thans aan of in de nabijheid van de kust, waardoor algemeen visscherij wordt uitgeoefend, met den gunstigen invloed daarvan op den voedseltoestand. Voor haar dagelijksche behoeften voorziet de bevolking vrijwel geheel in haar eigen voeding. Als hoofdvoedsel worden in den Archipel uitsluitend diverse knolgewassen gebruikt; het zijn voornamelijk oebi en keladi (Dioscorea alata Lin., resp. Colocasia antiquorum) ${ }^{29}$ ). In het aki heet oebi bakoe, hetgeen letterlijk beteekent: proviand, teerkost. Omtrent den oorsprong van de oebi bestaat een verhaal als elders op Celebes t.a.v. den oorsprong van de rijst, nl. dat in den vóórtijd èèn der zeven kinderen van Nabi in stukken werd gehakt, uit welke lichaamsdeelen het gewas ontstond.

Keladi wordt het gewas der geesten genoemd: men vond deze plant in de wildernis en bracht haar op gecultiveerden grond over, zegt men. In legenden uit den oertijd van West-Peling is keladi het voedingsmiddel; men voegt er aan toe, dat er in dien tijd nog geen oebi was. In West-Peling heet het verder dat de keladi tegelijk met de eerste menschen op den berg Tokolong geschapen werd; in Oost-Peling beweert men echter dat oebi eerder dan keladi als voedingsmiddel werd gebruikt. Wellicht is dit een verdere aanduiding dat er verschil bestaat tusschen de bewoners van West- en Oost-Peling.

Op den Vogelkop wordt thans rijst als hoofdvoedsel algemeen gebruikt. In het overige gedeelte van den Vaste-Wal gebruikt men, al naar de bodem het planten toelaat, oebi, mais en rijst door elkaar.

Naast dezen geheel op eigen verbruik gerichten verbouw van voedingsgewassen levert de cultuur van cocospalmen, en het verwerken der vruchten tot copra, het voornaamste uitvoerartikel. Om een indruk te geven van den omvang dezer (grootendeels bevolkings-) cultuur zij

29) Kruyt, Landbouw, blz. 475-476. 
vermeld dat in 1938 bijna $1 \frac{1}{2}$ millioen vruchtdragende klapperboomen in de belastingregisters der landschapsonderhoorigen waren opgenomen, terwijl nog bijna 2 millioen boomen geplant doch nog niet vruchtdragend waren. Uitvoercijfers zijn wegens het ontbreken van tolkantoren in de onderafdeeling niet beschikbaar, doch de geschatte jaarproductie van het klapperbezit der landschapsonderhoorigen is rond 365.000 picol $\left( \pm 230.000\right.$ quintalen ${ }^{30}$ ).

\section{Godsdienst.}

De bevolking van het landschap was tot het begin van deze eeuw overwegend heiden. Slechts te Banggai, woonplaats van den vorst, en op eenige woonsteden elders, trof men reeds in oude tijden kernen van Islamieten aan. Gelijktijdig met de meer intensieve bestuursbemoeienis (na 1 April 1908) kwam een nieuwe tijd ook voor godsdienstzaken. Een uitbreiding van den Islam onder de heidenen, voornamelijk in Oost-Peling en op den Vaste-Wal, werd eenige jaren later gevolgd door de intrede van het Christendom, vooral in West-Peling en Balantak. In de Koloniale Verslagen na $1914^{31}$ ) komen steeds berichten voor over het doopen van ,alfoeren" (waaronder hier te verstaan : heidenen) in beide gebieden. In 1921 begon de Missie eveneens haar arbeid, oorspronkelijk ten bate der in Oost-Peling aanwezige Manillareezen, later ter kerstening der heidensche bevolking. Eind 1938 waren er rond 26.500 Protestante en 1.700 Katholieke Christenen ${ }^{32}$ ). De rest van de bevolking wordt aangemerkt als Mohammedaan, op kleine heidensche eenheden na. De Mohammedaan voelt en acht zich goed Islamiet; hij heeft de gezindheid het te zijn.

Het zal echter duidelijk zijn, dat waar zoo betrekkelijk kort geleden beide groote godsdiensten hun intrede deden onder de bevolking, zeer veel van het oude heidendom onder den dekmantel van den godsdienst nog moet leven. Niet alleen wijzen allerlei gebruiken bij den landbouw op de belangrijke plaats die goden en geesten in het dagelijksch leven innemen, doch een goed stuk van de sociale organisatie bleek mij te

30) Memorie.

31) Koloniaal Verslag 1914/15: In Lamala zijn 2400 Alfoeren gedoopt; K. V. 1915/16: In Lamala zijn thans 4000 Christenen; K. V. 1916/17: In Lamala zijn nu 5500 Christenen; K. V. 1917/18: Lamala telt thans 6000 Christenen; K. V. 1919/20: Er worden 400 doopelingen in Lamala gemeld; K. V. 1920/21: Opnieuw laten zich 400 heidenen in Lamala doopen; K. V. 1922/23: Op den Vaste-Wal zijn thans 17 Zendingsscholen; K. V. 1923/24: In West-Peling gaat de kerstening goed vooruit K. V. 1924/25: In 1923 lieten zich in WestPeling 5464 personen doopen.

32) Memorie; cijfers vlg. Indisch Predikant en Missionaris. 
rusten op heidensche vooroudervereering. Eenige specifieke trekken uit dit heidendom mogen hier volgen.

Naast elkaar leven zondvloed- en scheppingsverhalen: het is niet steeds duidelijk of daarin het ontstaan der vorsten- en hoofdengeslachten, dan wel van alle menschen wordt vermeld (zie b.v. de legende van het Banggaische vorstenhuis, hoofdstuk II); in Oost-Peling worden vele der legenden aan den berg Tomoesi, in West-Peling aan de bergen Lipoe Babasal en Tokolong vastgeknoopt.

Men spreekt in West-Peling van Temeneno, voor velen een dubbelwezen, waarvan de man neerdaalde op den Tokolong, de vrouw oprees uit de aarde; men zegt dan dat de vrouw zich den Lipoe Babasal tot woon verkoos, aldus een huwelijksverhouding scheppende tusschen beide bergtoppen (van belang voor de betrekking tusschen de groepen die zich rond deze bergen als magisch centrum hebben gevormd). Temeneno was het die het eerste menschenpaar schiep. Dit wezen heeft vier zoons, t.w. Soelape, den god der oebituinen, Tompoedaoe, den god van de jacht, Sama, den god van de vischvangst, en Samalangan, den god der bijen en van den koeskoes ${ }^{33}$ ).

De geesten waarmee het dagelijksch leven van den Banggaier geheel vervuld is zijn de pilogot; het pilogotgeloof is duidelijk vooroudervereering. Naast de pilogot kent men het geloof aan balakat, wonderdoende voorwerpen of plaatsen, welke in wisselwerking staan tot de pilogot. In West-Peling is het pilogotgeloof, in Oost-Peling daarentegen het balakatgeloof met iets gewijzigde beteekenis op den voorgrond gekomen.

De West-Pelingsche huisgoden, pilogot, in elke woning zetelend, zijn vier in getal; ze zijn: Batanaas, de voorman, ontstaan uit het leven van den oervader der familie; elke doode die in de familie voorkomt voegt zijn leven (onderscheiden van de ziel) bij Batanaas. Het is èèn wezen, de verzameling van het leven van alle gestorven leden der familie. Pali is ontstaan uit de placenta van den eersten voorvader en het bloed bij zijn geboorte gestort; de placenta van elken nakomeling en het geboortebloed van dien voegen zich bij Pali. Denkt men Batanaas (en de beide nog te behandelen pilogot) als man, Pali ziet men als een vrouwelijk wezen. Mboli ( $=$ wat mag, wat mogelijk is) is ontstaan uit het vruchtwater van den oervader; de krachten opgesloten in het vruchtwater zijner nakomelingen voegen zich steeds bij Mboli. Tenslotte is Balani (= dapper) ontstaan uit het men-

33) Kruyt, Pilogot, blz. 114-117. 
struaal bloed der oermoeder, vergroot met dat harer dochteren ${ }^{\mathbf{3 4}}$ ).

Deze pilogot beheerschen op zoo'n intense wijze het dagelijksch leven van den West-Pelinger, dat zoowel Tomeneno als zijn vier zoons, misschien met uitzondering van Tompoedaoe, alsook de balakat, op den achtergrond geraken. Als balakat beschouwt men hier de bergtoppen waaraan de scheppingsverhalen zijn verbonden, Tokolong en Lipoebabasal, en wellicht andere.

In Oost-Peling daarentegen beheerscht de balakatvereering het geheele sociale bestel. Als definitie van balakat in Oost-Pelingschen zin stelde ik, tezamen met P. van den Berg M.S.C. uit Noelion, het volgende op. Primair wordt met balakat aangegeven een met rede begiftigd, bovennatuurlijk wezen, dat een zichtbaar aardsch bestaan heeft geleid, doch dat daarna onzichtbaar is geworden (mal.: „lenjap”) ${ }^{\mathbf{3 5}}$ ), dat echter tot op heden een zegenbrengenden invloed kan uitoefenen, meer speciaal op het lot zijner nakomelingen. Secundair duidt men met balakat verder aan voorwerpen (soms versteeningen) door een dergelijk bovennatuurlijk wezen achtergelaten. Deze genieten de vereering van de menschen die zich volgens de traditie en hun eigen innerlijke overtuiging afstammeling voelen van dit wezen; zij zijn onvervangbaar en vormen een onmisbaar middel om met de(n) voorouder in contact te komen. Elke streekgemeenschap (zie hoofdstuk III) heeft haar eigen balakat.

$\mathrm{Bij}$ de balakatvereering komt ook het begrip koesali ter sprake; in West-Peling is dit een klein rustbed, in het huis van den priester (aki: talapoe), waarop geacht wordt dat de pilogot neerstrijkt; in Oost-Peling is de koesali echter een voor den balakat, in de nabijheid der vereerde voorwerpen opgerichte, tempel, meestal iets kleiner dan een gewone dorpswoning, en vaak buiten het dorp gelegen. Een dergelijke tempel heeft een eigen bewaker (bewaakster) (aki : pakanggi ${ }^{\mathbf{3 6}}$ ).

Wij kunnen hier dus twee typen van vooroudervereering waarnemen. De pilogot van West-Peling is een vier-eenheid, die zich steeds vergroot bij elke geboorte, elk sterfgeval, enz. De pilogot worden gedacht als wezens wien niets menschelijks vreemd is, die zich als menschen beleedigd kunnen achten, die men dus moet vleien en vereeren, daar ze anders kwaad kunnen berokkenen. Wordt de familie

34) Kruyt, Pilogot, blz. 117-123.

35) Verg. Friedericy H. J., De standen bij de Boegineezen en Makassaren, blz. 23, 25 en 26, waar gesproken wordt over de eerste Goasche vorsten, die niet stierven, doch $z$ wevend verdwenen.

36) Kruyt, o.a. Vorsten, blz 605-610. 
echter te uitgebreid, dan kan men tenslotte een gedeelte dezer voorouders uitschakelen ${ }^{37}$ ). De Oost-Pelingsche balakat is echter een wezen dat eenmaal is, dat geen uitbreiding meer ondergaat door zijn nog levende nakomelingen, dat echter ook niet terzijde kan worden geschoven bij de vereering van andere dergelijke geesten. De gesteldheid van de balakat lijkt van hooger en edeler gehalte dan van de pilogot.

In West-Peling is de balakat wel het zinnebeeld der sociale groepeering geworden, doch de pilogot zijn het middelpunt der religieuze vereering voor de leden dezer groepen; in Oost-Peling echter werd de balakat sociaal en religieus centrum tegelijkertijd, daar hier de balakat het middelpunt van menschengroepen werd, die zich gezamenlijk traditioneel aan dat bovennatuurlijk wezen gebonden voelen, wier wel en wee in dit aardsch bestaan nog goeddeels beheerscht wordt door dien oervader (oermoeder; ook vrouwelijke balakat komen voor). Dergelijke menschengroepen zooals die zich om een religieus centrum groepeerden, dan wel zich bewust bleven een zelfde balakat te hebben, werden rechtsgemeenschappen (zie hoofdstuk III).

In Balantak kent men een scheppingsverhaal, gecombineerd met een zondvloedgebeuren ${ }^{38}$ ). Verder is het woord pilogot hier ook bekend, doch men duidt daarmee den scheppenden geest als zoodanig aan : pilogot mola; deze woont in de zon en wordt ook wel genoemd Toempoenta ( $=$ die ons bezit, onze eigenaar); hij straft het kwade. Een tweede geest, een oude vrouw, woont volgens sommigen in de aarde. Men gebruikt verder het woord pilogot ook wel ter aanduiding van de geesten op twee bergen van den Vogelkop, die beschouwd worden als de bakermat, dan wel als de stamvader van de beide rechtsgemeenschappen, waarin het Balantakvolk verdeeld is. Voor deze geesten gebruikt men ook wel den term berkat (verg. mal. berkat $=$ zegen, zegenrijke invloed).

Ook de Loinangs kennen het begrip pilogot; het zijn de voornaamste en misschien wel de meest oorspronkelijke geesten, want zij zijn de zielen der lang geleden gestorven stamvaders. Elke familie in uitgebreiden zin heeft zijn pilogot of stamvader en aangezien elk dorp door één familie in uitgebreiden zin wordt bewoond, heeft elk dorp zijn pilogot, die slechts vereerd kan worden door de afstammelingen van dezen oervader. Wanneer de pilogot wordt aangeroepen

37) Kruyt, Pilogot, blz. 118-119.

38) Kruyt, Balantaksche Studiën, blz. 330 v., 364, 366. 
wordt zijn naam gewoonlijk verbonden met balakat (berkat); dit woord is vlg. Kruyt waarschijnlijk via Ternate onder de Loinangs gekomen; er wordt mee bedoeld de zegen die langs magischen weg uitstroomt van de vorsten van Ternate en Banggai. Bemiddeling tusschen deze pilogot en zijn nakomelingen is uitsluitend mogelijk door het hoofd der familie, waarvan de pilogot de stamvader is. Ook hier dus weer vooroudervereering met duidelijke sociale gevolgen ${ }^{38}$ ), zooals die in Oost-Peling zich als balakat-vereering manifesteert. Hoe belangrijk het samengaan van religieus en sociaal centrum is, blijkt o.a. uit de mededeeling dat alleen bepaalde hoofden der Loinangs (daka'njo of tonggol; zie hoofdstuk V) deze bemiddeling tot stand brengen met de beide voornaamste pilogot, en dat het de geest van den daka'njo Kamboa, den eersten en grootsten onder de hoofden van Lingketing, is die de groote en machtige pilogot voor dit volk is geworden ${ }^{40}$ ).

Overeenkomstigen gedachtengang en gedeeltelijk dezelfde terminologie vindt men op Halmahera en Soela. Van laatstgenoemde streek heet het ${ }^{41}$ ): „Algemeen vereerde of vereert men op de Soela„eilanden nog de wongi, de ,geesten der overledenen”. „In het leven „der Soelaneezen nam (neemt) de vereering der sania, dat is de wongi „van den stam, den .,Urahn” welke men beschouwde ( $t$ ) als heer van „het land (toean-tanah) een voorname plaats in. Voorheen bouwde „en onderhield men speciaal voor dezen geest in elk district een oema „sania (sania-huis) waarin volgens het volksgeloof deze geest zijn „,verblijfplaats had”. „Nieuw aangestelde sangadji's moesten, voor zij „,hun ambt aanvaardden, de „oema-sania” bezoeken”. „Ook na den „oogst werd een dergelijk feest gevierd in de onmiddellijke nabijheid ,der oema-sania, bij welke gelegenheid tevens het verplichte aandeel van „den oogst aan den sangadji werd afgedragen”. „Behalve de sania of ,stamgeest, worden ook de zeer talrijke familiegeesten (bekend onder „den naam wongi) vereerd”. „Deze famileigeesten houden verblijf in „een klein huisje - de oema hoga - dat men ergens aan de kust „of in het binnenland heeft gebouwd. Vaak ook wordt voor deze ,geesten een verblijf ingericht in de woning der familie. Deze ver„,blijfplaats heet oema papasia. In de oema hoga ... vindt men bij de „Islamieten een uit hout gesneden menschenkop... van denzelfden

39) Wellicht beter: correlaties; in Indonesische visie zijn het gevolgen.

40) Kruyt, To Loinang, blz. $401 \mathrm{v}$.

41) Mededeelingen Encyclopaedisch Bureau No. XV (Soela-eilanden), blz. $46-48$, en noot 1 op blz. 48. 
„vorm als op Halmahera wordt aangetrof fen”. In een noot wordt ter vergelijking medegedeeld, dat een op Halmahera in den vorm van een menschenkop gesneden en als beschermer van eigendommen gebruikt stuk hout den naam pilogoti draagt.

Op Halmahera heet het ${ }^{42}$ ): „Ook de pilogo, een klein soort huisje, „staande bij de woningen, en waarin gewoonlijk allerlei met toover„spreuken beprevelde voorwerpen liggen, alle houten en bamboezen „wapens, dient volgens zendeling Hueting tot afwering van onheil „,en het dooden van booze geesten”. Op een foto van een dergelijke pilogo kan men duidelijk den nagemaakten houten menschenkop onderscheiden. Ook lezen we: „De wongi is de dorpsbeschermgeest, „de geest van den „Urahn”, van het geslacht of den stam, die een „dorp bewoont; wordt ook dodadi genoemd, in den zin van: de „verwekker, de oorsprong, de eerste mensch van het dorp (het geslacht „of den stam)".

Hueting ${ }^{43}$ ) bespreekt eveneens deze huisjes onder den naam o pilogutu en o pilogutu ma tau. Hij neemt echter aan dat deze zaken van vreemden oorsprong zijn, terwijl het woord niet uit het Tobeloreesch te verklaren is; aangezien er vroeger veel verkeer was tusschen Banggai en Tobelo (o.a. werden vaak Banggaiers als slaven geroofd en meegevoerd naar Halmahera) kan het mogelijk zijn dat een oorspronkelijk Banggaische eeredienst op Tobelo gevonden wordt, zij het dan ook met een ietwat verbasterden naam. Men verstaat er daar primitieve huisjes onder, waarin eenige nabootsingen van wapens e.a. Gewoonlijk behoort er ook toe een ruw, uit hout gesneden menschenhoofd, zeer zelden uitgehold, met een schedel erin. Men offert hier spijs en wierook op gewone wijze aan den hier wonenden geest. Het feit dat men dezen eeredienst ook bij de Mohammedanen, en in Kau meer dan in Tobelo vindt, schrijft Hueting eveneens toe aan invloed van lieden uit Banggai.

Uit vergelijking dezer gegevens kunnen we dus alleen het vermoeden uitspreken dat de vooroudervereering van Banggai en Soela in wezen dezelfde trekken vertoont, doch dat de overeenkomst met sommige punten van Halmahera's heidendom een toevallige is.

\section{Banggai als studieobject.}

Adatrechtelijke gegevens over de Groote Oost in het algemeen

42) Mededeelingen Encyclopaedisch Bureau No. XIII (Halmahera en Morotai), blz. 54, 51, 48.

43) A. Hueting, De Tobeloreezen in hun denken en doen (tweede gedeelte), B. K. I. 78 (1922), blz. 186-187. 
zijn schaarsch; over sommige streken is meer bekend, doch tot deze behoort zeker Banggai niet, noch de omliggende landen. Wijlen Professor ter Haar legt hierop dan ook op blz. 247 van zijn „Beginselen en stelsel van het adatrecht" den nadruk, waar hij wijst op de noodzaak van adatrechtelijke bewerking der voorhanden ethnografische literatuur, en stelselmatige samenvatting dezer gegevens.

Rechtstreeks op Banggai hebben betrekking een reeks tijdschriftartikelen van Dr. Alb. C. Kruyt, waar een menigte van adatrechtelijke gegevens verscholen ligt tusschen een groot aantal mededeelingen op volkenkundig terrein. Naast eenige oudere werken die eveneens Banggai behandelen, vindt men in verspreide literatuur vaak een enkel bericht.

De op het onderafdeelingskantoor te Loewoek aanwezige memories geven over het algemeen bitter weinig adatrecht; en wat er in staat is vaak door den steller van een latere uit een vroegere memorie overgenomen. Mijn eigen memorie, beëindigd Mei 1939, richtte zich in de eerste plaats op de volksordening, daar ik tijdens mijn bestuursperiode het doel nastreefde de genegeerde rechtsgemeenschappen op te sporen. Al moge dit niet geheel bereikt zijn, het resultaat is toch geweest dat er op dit punt thans meer bekend is dan tevoren. Vroeger toch heette het: „Een zonder enig verband of enigen samenhang „over de eilanden verspreid wonen wordt van de bewoners van den „Banggai-archipel vermeld. De hoofden, tenggol, die men daar kent, „schijnen inzetsels der inheemsche vorsten van vreemden oor„sprong ${ }^{44}$ )". Ik hoop met gegevens uit mijn (niet gepubliceerde) memorie in hoofdstuk $\mathrm{V}$ hierop een ander licht te kunnen doen schijnen.

Als bijlagen van die memorie dienen verder eenige nota's genoemd te worden; allereerst een op mijn verzoek door Pater van den Bergh M.S.C. te Noelion (Oost-Peling) samengesteld, betreffende het huwelijksrecht; verder eenige verslagen van den A.I.B. Tangkilisan, waarin hij de resultaten van een tournee naar Lingketing en het Doehian-gebied heeft neergelegd, van belang als aanvulling op Kruyt's artikel betreffende de To Loinang ${ }^{45}$ ).

Al deze bronnen hebben het kenmerk van eenzijdigheid; betreffende de To Loinang beschikken we thans over betrekkelijk volledige gegevens, doch is het natuurlijk de vraag in hoeverre deze gelden voor

44) Ter Haar, Beginselen, blz. 45.

45) Zullen na bewerking worden opgenomen in den eerlang te verschijnen Arb. XLIV. 
de overige madi-sprekers. Bij de rangschikking en rubriceering van het materiaal rezen dus vele vragen; helaas was het niet mogelijk door het verbreken der verbinding met Indië hierover nadere inlichtingen in te winnen. Niettegenstaande deze lacunes leek het toch van belang een zoo volledig mogelijke beschrijving van het adatrecht van Banggai te leveren; hiermee is dan het vragenderwijs te behandelen gebied afgepaald, zoodat eventueel aanvullend onderzoek in dezen vergemakkelijkt wordt.

Vrijwel uitsluitend was eertijds de aandacht der bestuursambtenaren gericht op de vorstensfeer; men dacht de verhoudingen in het landschap te kennen als men die bestudeerd had. Wat de kennis hiervan betreft, stelt het uitmuntende artikel van Dr. Alb. C. Kruyt „De vorsten van Banggai" al het andere verre in de schaduw. Zooals echter in de hoofdstukken III en V nader zal worden aangetoond is de vorstensfeer scherp gescheiden van de volkssfeer; uit eigen waarneming te Banggai is mij gebleken, dat vele waardigheidsbekleeders daar niets weten van de volksordening op Peling, laat staan van die van den Vaste-Wal.

\section{Volks- en vorstensfeer; Gouvernementsinvloed.}

Het euvel van zich te veel concentreeren op de vorstenorganisatie, samengaand met negatie der volksordening, concretiseerde zich in eenige ernstige bestuursfouten, indertijd in de onderafdeeling gemaakt, zooals benoeming van verkeerde hoofden, foutieve afbakening van bestuursressorten, miskenning van rechthebbende hoofdenfamilie's (bv. te Boenta, waar de moeilijkheden hierdoor veroorzaakt zelfs zoo ernstig waren, dat in 1926 een hunner, aangesloten bij de P.K.I., naar Digoel moest worden verbannen). De opzet mijner memorie was in de eerste plaats gericht op beschrijving der lagere rechtsgemeenschappen; daarbij diende in de practijk tevens de vraag verbonden te worden of deze nog leven, en of daaraan een andere, meer organische bestuursorganisatie kon worden vastgeknoopt. Het was daarbij niet mogelijk b.v. erfrecht en schuldenrecht tevens in studie te nemen; voor andere hoofdstukken (individuen, rechtskrenkingen) kon soms toevalligerwijs wel uit de memorie of de bijlagen geput worden.

Bij de behandeling der stof zal zooveel mogelijk getracht worden de volksordening afgescheiden te houden van de vorstenorganisatie; als derden factor hebben we daarbij den invloed van het Gouvernement op beide te beschouwen. 


\section{Systematiek.}

Alvorens het overzicht van de adatrechtelijke gegevens, voor zoover beschikbaar, te beginnen moge nog de vraag beantwoord worden van welken rechtskring Banggai volgens de bestaande adatrechtliteratuur een onderdeel vormt.

In den eersten druk van het "Adatrecht van Nederlandsch-Indië” (1918) van Prof. C. van Vollenhoven vindt men tegenover blz. 1 de, zeer voorloopige, adatrechtkaart (welke om mij onbekende reden in den 2den druk ontbreekt). Volgens deze is het landschap Banggai (tezamen met de landschappen Boengkoe en Mori) ingedeeld bij rechtskring XI (Zuid-Celebes), met uitzondering van het tot het landschap Banggai behoorend eiland Poat, dat in rechtskring IX (Gorontalo) ingedeeld is. Verder loopt de grens met rechtskring XII (Ternate) op deze kaart tusschen de eilanden Masoni en SoelaTaliaboe, en die met rechtskring $\mathrm{X}$ ('Toradja) langs de Balingararivier.

De adatrechtelijke literatuur houdt zich over het algemeen hieraan, zij het ook met afwijkingen, Zoo zijn in de „Literatuurlijst voor het adatrecht van Indonesië" (2e druk, 1927) twee werken van Dr. Alb. C. Kruyt en één van J. Kruyt, betreffende Mori en Boengkoe ${ }^{46}$ ), en Mori ${ }^{47}$ ), opgenomen in rubriek Toradja. In Arb. XXIX vindt men op de bladzijden 17-37 twee vonnissen van den godsdienstigen rechter van Boengkoe in boedelzaken uit 1925; beide zijn eveneens gerubriceerd onder Toradja. In de Pandecten van het Adatrecht X (Adatstrafrecht) slaan de plaatsen $290 \mathrm{t} / \mathrm{m} \mathrm{297,} 1167 \mathrm{t} / \mathrm{m} \mathrm{1174,} \mathrm{1808,}$ 2057 en 2058 op Banggai; zij staan alle onder de Toradja-paragraaf (10), doch plaats 1816 is opgenomen onder paragraaf 11 (ZuidCelebes). In Pandecten IX (Schuldenrecht) zijn eveneens de plaatsen 386 (betreffende Boengkoe; er staat Toboengkoe) en 520 (een aanhaling uit Goedhart's nota) ondergebracht onder Zuid-Celebes. Ter Haar deelt zoowel to lainang (To Loinang ?) als den Banggai-archipel bij rechtskring 10 (Toradja) in; ook de to mori rangschikt hij in deze groep, doch Boengkoe noemt hij niet ${ }^{48}$ ).

$\mathrm{Er}$ is dus blijkbaar geen eenstemmigheid tot welken rechtskring men Banggai moet rekenen. Het zal goed zijn de drie voornaamste aangrenzende kringen in hun specifieke trekken te schetsen, waarna

46) Kruyt, Het rijk Mori, T. A. G. 17 (1900); Id., Eenige ethnografische aanteekeningen omtrent de Toboengkoe en de Tomori, M. N. Z. G. 44 (1900).

47) Kruyt J., De Moriërs van Tinompo, B. K. I. 80 (1924).

48) Ter Haar, Beginselen, blz. 252.

Verh. dl. VI. 
het wellicht mogelijk zal zijn, na kennisname van het Banggaische adatrecht, dit landschap bij één daarvan in te deelen, dan wel het geheel of gedeeltelijk als een gouw van een dezer te gaan aanmerken.

Rechtskring X: Toradja-gebied.

Bij Van Vollenhoven: Het genealogisch stelsel is toonaangevend. De stam speelt geen rol als rechtgemeenschap; als zoodanig treden de stamgenooten-dorpen op; het rechtsgezag berust bij in die dorpen onder genealogische dorpshoofden bijeenwonende groepjes van stamgenooten, voor wie het geestenhuis tevens tot dorpsraadhuis strekt, en die beschikkingsrecht hebben ${ }^{49}$ ).

Bij ter Haar: Rechtsgemeenschappen, wier oorsprong de stam in eigen stamgebied was, doch die reeds geheel in stamgenootendorpen zijn uiteengevallen, zijn die der bare'e-sprekende Toradja's, hoewel krachtige hoofden toch wel gezag over verwante gemeenschappen buiten hun dorp uitoefenen. Het kenmerk van dezen kring is de tweezijdige genealogische groep, de stam of de onderdeelen daarvan, de geslachten (soms stamgenootendorpen) die een eigen territoir bewonen ${ }^{50}$ ).

Rechtskring XI : Zuid-Celebes.

Bij Van Vollenhoven: Het territoriale stelsel is toonaangevend. De voor de volksordening belangrijkste groep is hier de gaoekangstichting, de groep personen die naar inlandsche opvatting door een gaoekang of wonderdadig kleinood is bijeengebracht en die thans een complex van dorpen of vlekken bewonend, het gezag erkent van hem die de gaoekang onder zich heeft, den kleinoodbewaarder of heer ${ }^{51}$ ).

Bij ter Haar: Streekgemeenschappen, waarbij de materialisatie van de eenheid der levenskracht van de gemeenschap sterken nadruk verkreeg; dit zijn dan de ornamentschappen, waarbij de innerlijke verbondenheid ontstaat door den band met een magisch kleinood. De gemeenschappen zijn overal territoriaal ${ }^{52}$ ).

Rechtskring XII : Ternate.

Bij Van Vollenhoven: De Ternate-kring veroont verschillende elementen, zoowel uit het genealogische als uit het territoriale stelsel, terwijl de punten van het deels genealogische, deels territoriale stelsel eveneens aan te wijzen zijn. Zoo treft men in sommige deelen van den Ternate-archipel alleen de door genealogische hoofden bestuurde

49) C. van Vollenhoven, Adatrecht I, blz. $145 ; 139$.

50) Ter Haar, Beginselen, blz. 38, 37.

51) C. van Vollenhoven, Adatrecht I, blz. 145; 142.

52) Ter Haar, Beginselen, blz. 41. 
stamgenootendorpen met hun dorpstempel aan; de engere familie en het gezin hebben geen rechtsgezag, evenmin de stam, al wordt veelal de landstreek waar de dorpen van één stam bijeenliggen, bij het vorstengezag vertegenwoordigd door een hoofd (sangadji), die zoowel de belangen der bevolking bij den vorst eenerzijds, als die van den vorst bij de bevolking anderzijds (bevelen van den vorst) moet behartigen. Het proces van territoriale dorpsvorming is nog niet ingetreden.

Daarnaast treft men eveneens in den Ternate-archipel deelen aan, waar de stamgenootendorpen uiteengevallen zijn (al is het stamverband daarom niet met één slag uit het volksgeheugen verdwenen), waar hun bezit tot familiebezit is saamgetrokken en zich als een locaal dorpsgezag is gaan vormen: het territoriale dorp als rechtsgemeenschap en daaronder als rechtsgemeenschappen de families ${ }^{\mathbf{5 3}}$ ).

Ter Haar vermeldt deze streken niet, met een beroep op het gebrek aan gegevens, geldend voor de geheele Groote Oost.

Het doel van dit werk is dan tweeledig, t.w.:

1. aan de hand van de beschikbare gegevens een zoo volledig mogelijke beschrijving te geven van het adatrecht van het landschap Banggai ;

2. naar aanleiding van deze resultaten te komen tot eventueele herziening van de grenzen der rechtskringen X, XI en XII, waar deze elkaar ontmoeten.

63) C. van Vollenhoven, Adatrecht I, blz. $145 ; 139-141$. 


\section{HOOFDSTUK II.}

\section{Traditie en historie.}

Tot beter begrip der verhoudingen, zoowel tusschen de lagere rechtsgemeenschappen onderling, als tusschen deze en het landschap, leek het mij dienstig een overzicht te geven van wat de overlevering betreffende de voormalige rijkjes inhoudt, om vervolgens eenige geschiedkundige feiten te vermelden.

\section{Voormalige rijken in den Archipel ${ }^{1}$ ) en op den Vaste-Wal.}

In West-Peling vinden wij de rijkjes Boeoeko en Boelagi, in Midden-Peling Kadoepang, Lipoetomoendo en Sisipan, in Oost-Peling het rijk van Bongganan; wellicht was dit laatste gedeeld in een oostelijke helft, Tambalam of Pijom, en een westelijke, Kiok-Kiok (SiokSiok?). Op Banggai noemt men een drietal rijkjes; twee van de vorsten zijn broeders, de derde is hun aangenomen broer. $\mathrm{Er}$ is een drie-eenheid te bespeuren. Overigens omvat dit Banggai, zoolang het legendarisch is, niets meer dan het eiland van dien naam. Op den Vaste-Wal tenslotte moet op de noordkust van den Vogelkop het rijk Boalemo gelegen hebben, terwijl uit het zuidelijk deel van den VasteWal de drie-eenheid Motindok, Bola en Lowa, en bovendien nog het rijkje Gori-Gori gemeld worden.

In den Archipel wordt onderling verband gelegd tusschen de daar genoemde rijkjes, zoowel in de scheppings-mythen als in de huwelijksverhouding der vorstenhuizen. Als middelpunt van het rijk Boeoeko noemt men den berg Tokolong; voor Boelagi is het de Lipoebabasal; in het oosten van Peling (Bongganan etc.) is het de Tomoesi, waaraan zich de legenden vastknoopen, terwijl op het eiland Banggai de Boloekon de belangrijkste plaats inneemt. Er wordt dan b.v. op den Tokolong een menschenpaar gevormd, waarna de vrouw naar den

1) Zie ook Kruyt, Vorsten, blz. 506-514. Alleen spreekt hij van de mian Sea-Sea als de bevolking van geheel West- en westelijk Midden-Peling; ik beperk deze benaming en geef haar uitsluitend aan de onderhoorigen van basalo Boeoeko, in overeenstemming met de eigen benaming door de bevolking zelve. Vergelijk ook Kruyt, Bewoners, blz. 71, waar blijkt dat de menschen van Boelagi (door Kruyt ook bij de Sea-Sea ingedeeld) zich in 1930 bij de volkstelling daartegen verzetten. Betreffende Kadoepang zie Vorsten, blz. 616/617. 
Lipoebabasal gaat: poging om verwantschap te leggen tusschen Boeoeko en Boelagi. Van Boelagi-zijde geeft men er een ander karakter aan; daar gaat het verhaal uit van den Lipoebabasal, waar uit één menschenpaar en huwelijken hunner kinderen tenslotte acht paren kleinkinderen ontstaan, die het aanzijn geven aan vorstenhuizen te Lipoebabasal (Boelagi), Tokolong (Boeoeko), Banggai (wellicht in dit verband hetzelfde als Bongganan), Boengkoe (in de onderafdeeling Kolonedale, eertijds evenals Banggai onder den sultan van Ternate), Java (vele legenden wijzen terug naar Java), Boalemo (op den Vogelkop), Bokan (tusschen Banggai en Soela ; ook in Bongganan kent men een prinses, die naar Bokan ging) en Tokala (?); ook worden genoemd Ternate, Kadoepang en andere. Dit zijn alle pogingen om verwantschap te leggen tusschen genoemde rijken. Een ander verhaal vertelt van een Banggaische prinses, die zich tijdelijk in een varken veranderde, en na de jacht met den jager, een vorstenzoon van Boelagi, huwde; een dergelijke legende kent men eveneens te Boeoeko, waaraan dan toegevoegd wordt, dat de vrouw na twist met haar echtgenoot, naar haar geboorteland terugkeerde; een zoon van het paar werd vervolgens vorst te Banggai. Ook in Boeoeko kent men het verhaal, dat te Banggai een kat op den troon zat, en daar vorstelijke eer genoot; in Boelagi vertelt men dit als een gebeurtenis uit eigen geschiedenis: een kat op den troon te Boelagi (de legende van een kat op den troon, als vorst vereerd, kent men ook te Banggai; zie volgende paragraaf). Van al deze verwantschappen weet men te Banggai weinig; slechts deelt men mee, dat een Banggaische prins huwde met een om haar schoonheid beroemde vorstin van Boeoeko. Zoo werd de vorst van Banggai gerechtigd tot een deel der nalatenschap van de vorsten van Boeoko; en omdat de erfenis was opgemaakt nam de Banggaier land en volk. Deze Banggaische vorst zou de broeder geweest zijn van de verkwistende Boeoekosche vorstin.

Over een vorstengeslacht te Peling vindt men een vage aanduiding: een zuster van den vorst van Boelagi zou te Peling het aanzijn hebben gegeven aan een nieuw vorstendom.

In Midden-Peling wordt een strijd gemeld tusschen het rijk van Sisipan en het meer zuidelijk gelegen Lipoetomoendo (aki : vorstenland); de vorst van dit laatste rijk was een broeder van den vorst van Banggai; hun beider zuster werd balakat van Lipoetomoendo. Er ontstond door niet vermelde oorzaak strijd tusschen Sisipan en Lipoetomoendo, waarbij eerstgenoemd rijkje volkomen van den aardbodem werd weggevaagd: de bevolking werd geheel uitgemoord. Men 
wijst nog de sterkte aan, waarin zij zich verschanst had. Na den oorlog ging de overwinnende vorst naar Banggai (bood zijn broeder de heerschappij over Lipoetomoendo aan?) en verbleef verder te Banggai, waar hij later na zijn broer's dood eveneens vorst werd.

Een ander rijk van Midden-Peling is dat van Kadoepang; ook hier wordt familieverwantschap met de vorsten te Banggai aangegeven, eveneens met die van Ternate, Boalemo, Tokolong (Boeoeko). Men vertelt van een Banggaischen prins die een prinses van Kadoepang huwde; de prinses volgde haar gemaal naar Banggai, waar twist ontstond tusschen het jonge paar en den Banggaischen vorst; de prinses keerde daarop naar Kadoepang terug, haar gemaal volgde. Later riep de Banggaische vorst de hulp in van Kadoepang om een opstandigen vazal te Salaoep te tuchtigen; dit lukte, dank zij de bovennatuurlijke gaven van een Kadoepangsch voorvechter. Uit naijver lieten de Banggaiers echter dien voorvechter op verraderlijke wijze dooden, waarop de twist tusschen Kadoepang en Banggai weer hoog oplaaide. Eerstgenoemde liet twaalf varkenskoppen fijnhakken en in het paleis van den Banggaier werpen. Tijdens den nu volgenden oorlog delfde Kadoepang het onderspit; de vorst vluchtte naar Lolantang en stelde zich onder bescherming van den Lipoeadino aldaar, waardoor zijn gebied onder 't oppergezag van dat hoofd kwam te staan.

Uit Oost-Peling wordt het rijk van Bongganan gemeld; van de organisatie is nog bekend, dat den vorst een raad van vier adviseurs ter zijde stond, en dat het volk in twaalf onderdeelen verdeeld was (in afwijking van een mededeeling aan Kruyt noemde men mij die als Ponding-Ponding, Tatakalai, Loeoksago, Kombotokan, Totikom, Sambioet, Popiisi, Pelei, Boniton, Paisoeoeloeno, Tambolok en SiokSiok). De vorst verbleef in de sterkte Bebengketan, een aanzienlijke kota in de bergen boven Salakan gelegen, aangelegd in den vorm van een ringmuur van koraalsteen, uit den berg gebroken; de omvatte ruimte heeft een middellijn van naar schatting 400 meter. Dit rijk werd aangevallen door Ternate en Goa (ook andere vijanden worden genoemd), waardoor het uiteenviel. De vijanden roofden een heilig voorwerp, naar men zegt een gouden pop, en brachten het naar Goa, waar het echter zooveel kwaad stichtte, dat zij besloten het aan den eigenaar, den naar Banggai gevluchten vorst, van Bongganan, terug te brengen. Het eiland Banggai zou toen nog niet bewoond zijn geweest. Zoo kwam deze balakat op Banggai; thans nog is dit vereerde voorwerp daar te vinden, maar niemand mag het zien, behalve de bewaker. 
Het groote voormalige rijk van den Vaste-Wal is Boalemo geweest. Volgens Kruyt ${ }^{2}$ ) is het vermoedelijk door immigratie uit het oosten gevormd; overigens was de Vaste-Wal bewoond door een primitief volk (door Kruyt het Saloean-volk genoemd). Om een of andere reden wekte Boalemo het ongenoegen van den sultan van Ternate, die het door zijn beruchte zeekrijgers, de Tobelo's, geholpen door Gorontaleezen liet tuchtigen. Boalemo werd verwoest, men wijst nog de resten der kota's aan; de vorst Lologani viel in den strijd, terwijl een deel zijner onderdanen als slaven werd meegevoerd naar Gorontalo (waar zij tot heden in het district Tilamoeta dezer onderafdeeling zijn begrepen).

Enkele afdeelingen van het Boalemo-volk konden zich echter door de vlucht van dood of slavernij redden en begaven zich westwaarts, sommige langs de noordkust, andere langs de zuidkust van den Vaste-Wal. Wij moeten aannemen, dat dit Boalemo-volk een hoogere trap van beschaving bezat dan het Saloean-volk. Met kleine, dan weer groote groepen trokken zij het binnenland in, waar zij door hun meerdere kennis als hoofden door de oorspronkelijke bevolking erkend werden. De Boalemoërs van de zuidkust kwamen weldra in aanraking met den vorst van Banggai, en door dezen met den sultan van Ternate, dan wel werden aan hun gezag onderworpen. Zoo werden deze hoofden aan de zuidkust opgenomen in het Banggaische staatsbestel, toen zich te Banggai onder Ternataansche invloed een centraal gezag over de eilanden van den Archipel aan het vormen was (c.q. had gevormd; zie volgende paragraaf). Nadat er weer contact was ontstaan tusschen de verwanten die langs de noord- en zuidkust waren getrokken, kwamen de eersten, die hoofden in het binnenland waren geworden, in ondergeschikte positie te staan tot hun broeders aan de zuidkust; dit uitte zich o.a. door de verplichting huldegift aan hen op te brengen, waarvan ruiling de basis zou zijn geweest, dan wel hulp van met meer aardsche goederen gezegenden aan minder bedeelden. Tenslotte verwierven de hoofden aan de zuidkust den titel bosanjo (madi: de groote), welke titel hun waarschijnlijk verleend werd in overeenstemming met de titulatuur die de hoofden op Peling hadden verworven (basalo, aki, eveneens: groote). De voornaamste hoofden in het binnenland ontvingen (c.q. namen aan?) lagere titels, zooals bv. daka'njo (madi : de groote; doch daka'njo is in waardeering lager dan bosanjo).

2) Kruyt, To Loinang, blz. 340-353; anders in Vorsten, blz. 614-616 en Balantaksche Studiën, blz. 328 noot 1. 
Die oorspronkelijke, meer primitieve bevolking, waarover de Boalemosche immigranten het hoofdschap verwierven, wordt in de traditie steeds aangeduid als koetoe no tano (madi); deze oerbevolking is in het westelijk deel van den Vaste-Wal raszuiverder gebleven dan in het oostelijk, waar een min of meer intensieve vermenging met de immigranten heeft plaats gehad. Van die westelijke groep, door Kruyt als Baloa-clan aangeduid, is wellicht een, eerst in 1939 geregistreerde, groep aan de bovenloop van de Tobelombangrivier het zuiverst, het minst vermengd. Ten aanzien van een eveneens onvermengd gedeelte van deze Baloa-groep publiceerde Dr. J. P. Kleiweg de Zwaan een anthropologische studie, waarbij hij tot de slotsom komt dat de onderzochte Simpang-groep (onderdeel van de Baloa-clan) kan geacht worden te zijn opgebouwd uit drie verschillende bevolkingselementen, t.w. het Wedda-element en het Proto- en Deutero-Maleische raselement, waarbij vooral het Wedda-element een grooteren invloed heeft gehad dan bij de overige volken op Celebes ${ }^{3}$ ). In de oostelijke groep, bij Kruyt Lingketing-clan, en in het oostelijk daaraan grenzende Pokooehan, vindt men vele mengtypen tusschen oerbevolking en immigranten. De eerste heeft Melanesische trekken, de Boalemo-menschen vallen op door lichte huidskleur en sterke mongolenplooi (oogen). Dit type vindt men het zuiverst terug in het dorp Lingketing, waar de daka'njo woont.

Een verdere verwijzing naar het rijk Boalemo vinden we in de figuur van den Lipoeadino. De legende wil dat Lologani (zie blz. 23) in den strijd viel, maar dat zijn zuster Mapaang, die hem den strijd had aangedaan, zich na de verwoesting van haar land onder bescherming van den vorst van Banggai stelde; zij kreeg de plek Lampa als woonplaats voor zich en haar volgelingen aangewezen, niet ver van den zetel van den Banggaischen vorst. Een zoon van Mapaang, dan wel een neef, zoon van Lologani, die er het leven afbracht, verwierf van den Banggaischen vorst een bijzondere positie; hem werd de plaats Lolantang in West-Peling aangewezen, en eigen gebied ter beschikking gesteld; hij nam den titel Lipoeadino aan (of verkreeg dien?). Vorstelijke eer werd hem bewezen, zich uitende in Banggai's toestemming, den witten hoofddoek (aki : koekoep mooete) te dragen, een van Ternate overgenomen vorstelijk prerogatief ${ }^{4}$ ). Later zou de gebiedskring van den Lipoeadino zich zoowel op Peling als op den

3) Dr. J. P. Kleiweg de Zwaan, Bijdrage tot de Anthropologie van Celebes; T. A. G. 1929 , blz. $782-792$.

4) De Clercq, Ternate, blz. 42. 
Vaste-Wal uitgebreid hebben: op Peling, doordat Kadoepang zich na zijn nederlaag vrijwillig onder hem stelde, op den Vaste-Wal, doordat de Lipoeadino op een zijner reizen derwaarts twee groepen menschen ontdekte in de nabijheid van het bosanjoschap Mangkiin Piala, die nog geen heer hadden. Hij wierp zich als zoodanig op, zoodat zij in den vervolge schatplichtig waren aan hem; het zijn Keleke en Lo'nsom.

Weinig gegevens zijn bekend over het rijk Motindok, een drieeenheid vormend met Bola en Lowa; men meldt over deze drie deelen onderscheidenlijk een radja Ali Asine, zijn jongere zuster Amina en de jongere broer Lohat (dus weer verwantschapsverhouding tusschen vorstenhuizen). Toen de grondlegger van het huidige Banggaische rijk (Moemboe doi Djawa; zie volgende paragraaf) op zijn veroveringstochten ook te Motindok kwam, huwde hij daar Ali Asine's dochter Noeroe Sapa (in de Banggaische versie is deze prinses een Ternataansche echtgenoote van dien Moemboe doi Djawa), en stelde den zoon van Noeroe Sapa's broer Sasong Beloewangi aan tot eersten bosanjo van Batoei; deze heette Ama.

Op den Vogelkop treffen we naast Boalemo geen voormalige rijkjes aan. De legenden der sian-sprekers geven slechts aan dat eenige menschen op een bergtop geschapen werden, waar ze zich vermenigvuldigden; verder weet men daar nog te vertellen van een zondvloed, waardoor het ontstane menschengeslacht wederom grootendeels werd weggevaagd ${ }^{5}$ ). Merkwaardig is dat overeenkomstige namen optreden bij de westelijke (Lamala) en oostelijke (Dale-Dale) helft der bevolking, waaruit we wel tot gemeenschappelijke afstamming mogen besluiten. Er vormden zich twee groepen, een die den berg Pinoentoean (volgens anderen Pinoentoenoean) en een die den berg Kaoe Totoloe (wellicht dezelfde als Pinoentoean) als hun bakermat beschouwden.

Ten westen daarvan vinden we een kleine groep die wellicht verwant is met de Boalemo-menschen, doch ook relaties met Boeol (noordkust van Celebes) opgeeft.

In het zuidelijkste gedeelte van den Vaste-Wal kent men tenslotte nog het vorstendommetje Gori-Gori, welks bewoners een aparte taal spraken, het $i d o$, tot nu toe bij weinige ouden van dagen in gebruik. In hun onmiddellijke nabijheid wonen afstammelingen van een groep immigranten, ToWana, van wie niet bekend is hoe lang geleden ze zich hier gevestigd hebben, doch die reeds lang vóór 1908 hun plaatsje in het Banggaische staatsbestel innamen.

5) Kruyt, Balantaksche Studiën, blz. 328-336. 
Betreffende de titulatuur der voormalige vorsten ten slotte nog het volgende : in Boeoeko droeg de vorst den titel adi; hoe hij in Boelagi en Peling heette is niet duidelijk, doch vermoedelijk niet adi. In Midden- en Oost-Peling vinden wij den titel tomoendo; men spreekt dus over tomoendo Kadoepang, tomoendo Sisipan, tomoendo Pijom, etc. De vorst van Bebengketan (Bongganan) voerde vóór de verwoesting van zijn rijk den titel moemboe, daarna adi (anders bij Kruyt ${ }^{6}$ ). Te Banggai trof men eerst adi aan, onder hen tomoendo. De titel der vorsten van Boalemo is niet aangegeven, maar de vorstelijke afstammelingen van Lologani voerden, toen zij nog zelfstandig waren, den titel toetoei (madi : de echte, de ware). In Gori-Gori noemt men ook de tomoendo-titel, uit Motindok ten leste meldden we reeds den radja-titel; is deze inheemsch? Het valt op dat de persoonsnamen daar Moslimsch zijn.

Deze rijkjes of de deelen waarin ze zijn uiteen gevallen hebben de bouwsteenen geleverd van het huidige landschap Banggai. We moeten ons nl. voorstellen (uitgebreider onder de volgende paragraaf), dat Banggai, een der vorstendommetjes, geenszins primus inter pares overigens, met hulp van buiten (Ternate), de suprematie verwierf over de andere, hooger genoemde eenheden en de hoofden daarvan schatplichtig aan zich maakte, onder verleening van een bepaalde titulatuur. Deze hoofden, in den Archipel basalo (aki: de groote), elders met overeenkomstige namen aangeduid, voeren meerendeels zoowel hun eigen afstamming als die hunner onderhoorigen terug tot genoemde eenheden uit het verleden.

Wij zullen in Hoofdstuk III de volgende basaloschappen of overeenkomstige groepeeringen leeren kennen:

Op het eiland Banggai: 1. Tano Bonoenoengan

2. Dodoeoeng

3. Monsoongan

4. Gong-Gong

5. Lampa

6. Poetal

7. Boneaka

Op het eiland Peling: 8. Het gebied van den Lipoeadino van Lolantang. Dit omvatte 12 eenheden, waarvan zeven een basalo, de overige een lager hoofd hebben; het zijn :

6) Kruyt, Vorsten, blz. 511. 

a. Lolantang
e. Tombos
i. Basosol
b. Palabatoe
f. Keleke
j. Papadang
c. Soeit
g. Lo'nsom Wal
k. Batoeanano
d. Patoekoeki
h. Belalon
1. Toi-Toi.

9. Tinangkoeng

10. Liang

11. Paisoeoeloeno

12. Peling

13. Boelagi

14. Boeoeko

15. Totikom

16. Sambioet

17. Popiisi
18. Ponding-Ponding

19. Tatakalai

20. Pelei

21. Kombotokan

22. Loeoksago

23. Tambolok

24. Apal

25. Boniton

26. Loeokpanenteng.

Op den Vaste-Wal treffen we aan:

27. Batoei

28. Tangkiang; min of meer zelfstandige onderdeelen zijn:
a. Doehian
b. Awok
c. Pongeman.

29. Kintom; min of meer zelfstandige onderdeelen zijn:
a. Inetes (Lingketing)
d. Bangkoehan
g. Baba
b. Mehangi
e. Ondjoelaan
h. Tombang.
c. Pokooehan
f. Bojo

30. Mendono; min of meer zelfstandige onderdeelen zijn:
a. Saloean (Basaboengan)
d. Dondalon
b. Padang (Lambangan)
e. Bakoetan
c. Koewajang
f. Pona.

31. Lontio

32. Nambo

33. Mangkiin Piala (Loewoek)

34. Basama

35. Tanotoeran

36. Dale-Dale (Pokobondolong)

37. Sinohoan

38. Minahaki.

Het verband met het verleden wordt als volgt gelegd: De no.'s 1 tot en met 4 nemen een belangrijke plaats in de geschiedenis van eigenlijk Banggai in, en zullen daarom in de volgende paragraaf behandeling vinden, evenals Poetal en Boneaka. Lampa (No. 5) leerden 
we reeds kennen als verblijfplaats van Lologani's zuster Mapaang (blz. 24).

Lolantang werd toegewezen aan den Lipoeadino, in wien wij dus een Boalemosch vorstentelg kunnen zien (blz. 24). Van de hem onderhoorige groepen melden zoowel Palabatoe als Lolantang afkomstig te zijn van een vorstendom Salaoep, eertijds te vinden in de bergen boven Lolantang (zie blz. 22 voor den strijd tegen Salaoep). Soeit kan geen verband opgeven met een of ander legendarisch rijkje. In Tombos gaat een verhaal dat een kleinzoon van Lologani de stichter zou zijn; Patoekoeki lijkt een groep oorspronkelijke bewoners van het eiland Peling, over wie de djogoegoe van Banggai (zie Hoofdstuk V) een hoofd aanstelde, waarna het groepje aan den Lipoeadino werd overgedragen. Keleke en Lo'nsom zijn toegevoegd aan het gebied van den Lipoeadino, omdat hij zichzelf als heer over hen stelde. Over Belalon ontbreken gegevens. Basosol is de voortzetting van Kadoepang (zie blz. 22); het beweert dat eertijds Tombos, Patoekoeki en Papadang ook onder den vorst van Kadoepang stonden. Over Batoeanano en Toi-Toi ontbreken gegevens.

Als no. 9 vinden we Tinangkoeng vermeld; dit is de voortzetting van het rijk van Bongganan (blz. 22); de hoofden beweren af te stammen van de vorsten van dit rijkje. Opvallend is de bijzondere eer die in den naam Tinangkoeng ligt; het beteekent (aki: degeen die gedragen wordt, een handelwijze die eertijds inderdaad werd toegepast op dezen basalo als hij te Banggai kwam ${ }^{7}$ ). Ook in zijn kleedij onderscheidt hij zich van de overige. Het volk zou de voortzetting zijn van Siok-Siok, terwijl de als onderdeelen van Bongganan opgesomde eenheden een eigen rechtsleven gingen leiden toen de band die hen bond verbroken werd met de vernietiging van dit rijkje. De thans in Oost-Peling te vinden basaloschappen moeten de voortzettingen zijn van die onderdeelen van het oude Bongganan (no.'s $11 ; 15 \mathrm{t} / \mathrm{m} \mathrm{23} ; 25$ ).

In de plaatselijke legenden vindt men het volgende: over Paisoeoeloeno ontbreken gegevens; Totikom kent familieverwantschap tusschen de basalo en de vorsten van Bongganan; Sambioet knoopt eerst aan de legendarische geschiedenis van Banggai aan, om daarna verwantschap met Bongganan (in de stammoeder b.v.) te stellen; Popiisi geeft familieverwantschap in de basalo-familie met het vorstenhuis van Bongganan aan; Ponding-Ponding kent als stammoeder der basalo een Bongganansche prinses; men is zich nog bewust eertijds huldegift naar Bongganan te hebben gebracht; later kwam hierin

7) Kruyt, Vorsten, blz. 516. 
verandering, men maakte zich los van Bongganan (wellicht niet langs vreedzamen weg) en bracht nu zijn huldegift naar Banggai; reden tot deze losscheuring was de zware druk, dien Bongganan op PondingPonding legde. Tatakalai kent als stamvader der basalo een Bonggananschen prins ; men weet dat de vijfde basalo niet meer onder Bongganan stond, doch rechtstreeks onder Banggai. Pelei verbindt zijn legendarische geschiedenis met den Tomoesi, den heiligen berg van Oost-Peling, centrum van de scheppingsgeschiedenis van Bongganan en Tinangkoeng; men kent ook hier een scheidslijn in het oosten van het rijk, zoodat men naast den vorst van Bongganan een vorst van $\mathrm{Pijom}$ onderscheidt; vermoedelijk waren zij broers. In de legende van Pelei ligt bovendien het merkwaardige dat het volk van het eiland Banggai afkomstig heet te zijn, althans gedeeltelijk. Kombotokan kent in zijn legende geen verbinding met Bongganan; de basalo-familie (en het volk ?) beweert af te stammen van Ternate. Loeoksago erkent van Bongganan af te stammen; een dochter van den vorst noemt men als eerste basalo; na gedurende acht generaties met de te Siok-Siok wonende groep samen te zijn geweest, splitste zich een deel af; de reden wordt niet opgegeven, wel moest de vorst van Banggai hiervoor zijn toestemming geven; als eerste basalo na de afsplitsing noemt men een slaaf. Tambolok heeft slechts zeer schaarsche gegevens; men spreekt er van een vrouwelijk hoofd met den titel kapitan, doch onbekend is of deze van Bongganan afstamde. Boniton werd gevormd uit de bewakers van den grooten balakat van Aboe Kasim (zie volgende paragraaf); daartoe werden vier echtparen, één uit elk der basaloschappen Paisoeoeloeno, Popiisi, Pelei en Totikom aangewezen; de basalo-familie schijnt verwant te zijn vooral met de basalo van Paisoeoeloeno.

Liang (no. 10) is de voortzetting van Lipoetomoendo ${ }^{8}$ ). Peling, Boelagi en Boeoeko (no.'s 12 t/m 14) zijn de voortzettingen der gelijknamige rijkjes uit West-Peling. Van den band tusschen het vorstenhuis van Banggai en de voormalige heerschers, thans basalo, van Boeoeko is men zich nog bewust; als b.v. deze basalo te Banggai kwam om den vorst zijn opwachting te maken, sprak hij dezen met ,jij" en ,jou" aan en behoefde zijn zonnehoed in zijn tegenwoordigheid niet af te zetten ${ }^{0}$ ); ja, er wordt zelfs verteld dat hij den vorst als

8) Kruyt, Vorsten, blz. 512 noemt Liang als een der onderdeelen van Bongganan. Tegenover mij ontkende men dit en hield men zich vast aan de afstamming van Lipoetomoendo.

9) Kruyt, Vorsten, blz. 517. 
welkomstgroet de voeten toestak. Onderhoorigen van dezen basalo (Sea-Sea geheeten) mochten, als zij eertijds ter hoofdplaats Banggai voor eenig werk waren opgeroepen, vrij alles wegnemen, wat langs hen ging, een kip, een geit b.v., ja zij mochten zelfs den voorbijgangers de kleeren van het lijf vragen.

Apal is een uitsplitsing van Liang; het was daarvan tevoren een gehucht; een doofstomme van Apal reisde met lieden van Liang in een prauw en werd bij voortduring door hen gesard; 's nachts vermoordde hij hen allen. Dit was de reden dat Liang deze groep uitstootte; de vorst van Banggai vond (later?) goed, dat het hoofd over dat gehucht den titel basalo aannam; de uitsplitsing is vermoedelijk betrekkelijk recent, want men noemt slechts 5 basalo vóór 1908. Loeokpanenteng tenslotte is vermoedelijk een uitzwerming van Banggaiers, want de balakat van dit groepje (Lipoemopook; aki: zwart land) is een broer van balakat Boneaka (welke we in de volgende paragraaf als een der magische centra van Banggai zullen leeren kennen).

Naar den Vaste-Wal ove1gaande krijgen we daar het volgende:

Batoe (no. 27) is de voortzetting van Motindok-Lowa-Bola; men spreekt er een aparte taal, het baha, volgens Adriani een soort verbasterd Ampanaasch.

Tangkiang geeft aan af te stammen van Boalemo; men noemt oorspronkelijk twee groepen, die beide aan de zuidkust zetelden en ontdekt werden door een Banggaisch edele; deze regelde dat de lieden huldegift aan den vorst van Banggai zouden brengen, terwijl het hoofd van een der groepen als bosanjo aangesteld (erkend?) werd.

Als onderhoorigen van Tangkiang staan een drietal groepen vermeld. Doehian is de groep die we hooger aanduidden (blz. 24) als de Baloa-clan; het hoofd verbleef meestal te Doehian. Awok, eveneens onder Tangkiang, wordt ook door Kruyt een paar maal genoemd; de legende is nauw verbonden met die van Tangkiang, Lingketing en andere van Boalemo afkomstige groepen; men geeft gezamenlijke afstamming aan in broersverhouding. Merkwaardig is voorts de mededeeling dat een deel van Awok later onder Kintom kwam te staan, nadat de groep verhuisd was naar Mehangi. Pongeman ten slotte werd gevormd door een kleine groep onderhoorigen van bosanjo Tankiang, oorspronkelijk landinwaarts van deze plaats; na eenige generaties ging het groepje echter in oostelijke richting door het terrein trekken en vestigde zich ten slotte aan de noordkust van den Vogelkop, ten oosten nog van het voormalige Boalemo. Als reden 
voor deze verhuizing gaf men op, dat de bosschen daar rijker zijn aan bijenwas, met welk product men eertijds de huldegift aan hoofden en vorst opbracht. De groep Pongeman vormde kort na 1908 de kampong Nipa aan het noordstrand van den Vogelkop.

Kintom (no. 29) geeft in zijn traditie aan rechtstreeks af te stammen van Boalemo; de bosanja noemden zich gedurende acht generaties, toen zij nog niet onder den Banggaischen vorst stonden, toetoei, een titel, die aan vorstelijke personen toekomt (madi: de echte, de ware); zij beweren rechtstreeksche afstammelingen van Lologani te zijn. In de overlevering komen dezelfde namen voor als elders, slechts wordt uiteraard de meeste nadruk gelegd op de handelingen van den stamvader, terwijl hetgeen zijn ,broers” deden (die b.v. een rol spelen in Tangkiang, Lingketing, Pokooehan) minder aandacht verwierf. Hier komt duidelijk het immigratie-element der hoofden uit, waar de stamvader Mangamben op zijn tochten zeven groepen menschen aantrof in het binnenland, die daar reeds van oudsher aanwezig waren, oorspronkelijke bevolking vormend (madi: koetoe na tano), waarover hij zich als hun hoofd opwierp.

Het voornaamste der onderdeelen van Kintom is wel Lingketing, onder een hoofd met den titel daka'njo; men spreekt naar zijn woonplaats wel van den daka'njo Inetes. Deze beweert, evenals de bosanjo, rechtstreeks van de vorsten van Boalemo af te stammen; men vertelt zeer nauwkeurig wat aan de beide broers Mangamben en Tongkoi overkwam. De eerste werd stamvader der bosanjo van Kintom aan de zuidkust, de tweede die der daka'njo van Lingketing in de bergen. Ook hier deelt men mede, dat Tongkoi op eenige groepen oorspronkelijke bewoners stuitte (koetoc no tano), waarover hij zich als hun hoofd opwierp (Kruyt spreekt zelfs van het vorstengeslacht der Loinangs). Op een zijner tochten kwam Tongkoi in aanraking met zijn broer Mangamben, waarbij zij afspraken van hun oogst te ruilen; en doondat de broeder aan het strand meer eischte ontstond het beeld dat de broeder in de bergen een huldegift aan den broeder aan het strand opbracht (in dit kleed steekt de legende de verhouding tusschen beide verwante groepen). Overigens verklaart dit niet waarom de gift van den daka'njo bestemd was voor den vorst van Banggai; het is ook niet duidelijk waarom juist hij bij leven en dood zoo'n belangrijke plaats innam, want bij zijn aanstelling ontving hij van den sultan van Ternate, via den vorst van Banggai, ambtskleeding, terwijl zijn overlijden ook den sultan moest worden gemeld ${ }^{10}$ ).

10) Kruyt, To Loinang, blz. 356, 358. 
Als tweede zelfstandige groep vond ik te Mehangi lieden van Kintom afkomstig, die naar aanleiding van een twist tusschen broer en zuster, waarvan de laatste bosanjo was (?), zou zijn weggetrokken; verder noemt men vele trekken uit de Lologani-legende en de omzwervingen zijner zoons. De groep stond rechtstreeks onder den bosanjo van Kintom. Hoe het te Tangkiang opgegeven verband met deze groep door lieden van Kintom zelf wordt gelegd (blz.30) is onbekend.

Pokooehan vormt een derde zelfstandige groep, waarvan het hoofd, daka'njo, eveneens rechtstreeksche afstammeling van Lologani's zoon beweert te zijn (Lakaoeta of Selena); in het verhaal zooals het hier luidt is de bosanjo van Kintom een zuster van den stamvader; deze laatste, in de bergen verblijvend, zond zijn zwakkere zuster elk jaar een deel van den oogst en eenige boschproducten; hieruit dan heeft zich de huldegift aan Kintom ontwikkeld. Interessant is verder, dat deze vrouwelijke bosanjo een zuster had, die met een der min of meer legendarische vorsten van Banggai gehuwd was; aan deze zuster te Banggai zond de bosanjo van Kintom een deel der gaven van haar broer in de bergen door, waaruit zich eveneens een ondergeschiktheidsverhouding Kintom-Banggai ontwikkelde. Ook hier kent men een oerbevolking, die door de immigranten werd onderworpen en ook hier heeten deze lieden koetoe no tano (madi). Tevens vindt men hier eenige lieden van Poa (dit is ook de naam van een onderdeel van Keleke, dat onder den Lipoeadino stond). Deze lieden deelen mee van Lolantang afkomstig, doch vandaar verbannen te zijn wegens een huwelijk in verboden graad in de basalofamilie, waarop het schuldige paar met twee huisgezinnen werd weggejaagd; hieruit ontwikkelde zich de groep Poa. Er gaat bovendien een verhaal van Lingketingsche zijde, dat deze lieden schuldslaven waren van een hoofd in Pinapoean, doch op de een of andere wijze hun vrijheid verwierven en zich daarna onder den daka'njo Pokooehan stelden.

Als volgende zelfstandige groep noemde ik Bangkoehan; op de plaats van dezen naam was een hoog Kintomsch edele gevestigd, de kapitan kompania. Deze is feitelijk de bevelhebber van een kleine legermacht die den bosanjo ter beschikking stond binnen zijn versterkte woonplaats. Om een of andere reden heeft in later tijd, doch eenige generaties vóór 1908, een dezer bevelhebbers er de voorkeur aan gegeven zich ten noorden van de waterscheiding, even oostelijk van Pokooehan, te vestigen; de groep bleef echter onder den bosanjo 
van Kintom staan. De niet-adellijken stonden te Bangkoehan onder een anoe matoe'a (dit lijkt wel Boegineesch!).

Een verdere uitsplitsing is Ondjoelaän. Deze is ook afkomstig van Kintom. Het verhaal wil dat juist de aanstelling van den jongsten van twee broers tot hoofd, den oudsten reden was om gebelgd weg te trekken; weldra volgden anderen en gezamenlijk werd een reeks woonplaatsen gemaakt op den hals van den Vogelkop; ten slotte trokken zij na 1908 noordwaarts naar de kust en vestigden zich te Poh en omgeving. Eveneens van Kintom is afkomstig Tombang, uitgezwermd in verband met den akkerbouw. Deze lieden zijn tezamen met leden van een groep van Lingketing (nl. Tinaän) ver oostwaarts getrokken; in het uiterste oosten van de noordkust van den Vogelkop werden twee kampongs gevormd door deze groepen (na 1908): Tombang vormde de kampong Malik, Tinaän werd Binsil. Hoofd der lieden van Tombang was een pabisala of pabisara.

De beide laatste zelfstandige onderdeelen, Bojo en Baba, moeten onder bosanjo Kintom hebben gestaan; zij zijn thans practisch uitgestorven, doch hebben indertijd kleine uitzwermingen van de moederkampong gevormd.

Mendono (no. 30) is eveneens ontstaan uit vermenging van een immigrantengroep, vorsten van Boalemo, die op hun vlucht, van de zuidkust landwaarts in, een groep oerbewoners, koetoe no tano, aantroffen. Men weet niet meer te vertellen hoe men onder Banggaïsche heerschappij kwam.

Betreffende de onderdeelen van Mendono het volgende: Saloean is een uitzwerming van de moederkampong ten gevolge van een twist tusschen het hoofd en diens zoon; de laatste trok weg, noordwaarts door de bergen, en overschreed tenslotte de waterscheiding, terwijl de groep (want volgelingen waren meegetrokken) zich een terrein koos in de nabijheid van de noordkust. Dit feit, in de madi-taal geheeten malaloean boengkoctnjo (de bergen overtrekken) zou aanleiding zijn geweest tot de naamsgeving aan deze groep; het mian saloean zou dus beteekenen: zij die de bergen zijn overgetrokken. Een andere verklaring ligt in saloean als anduiding voor korte kniebroek; mian saloean moet in dezen zin beteekenen: broekedragers, zulks in tegenstelling tot de toen nog heidensche schaamgordeldragers, voornamelijk koetoe no tano. Een groep van deze laatste stond onder het hoofd van Saloean. Interessant is dat een ander deel van deze zelfde groep, aangeduid als mian Keheketon, onder Pokooehan stond, en wel het grootste deel (in de legende: de moeder), terwijl het

Verh. dl. VI. 
kleinere deel (het kind) onder Saloean kwam. Reden tot deze deeling was, dat de koetoe na tano tegelijk door de hoofden van Pokooehan en Saloean werden ontdekt in het bosch. Verder waren de lieden van Saloean afkomstig van de moederkampong Mendono.

Ook de tweede groep, Padang, heet daarvan te zijn gekomen. Hier vermeldt men een twist in de hoofdenfamilie, en een wegtrekken van een deel hunner onder een hoofd. Weliswaar legt men geen verband tusschen dit wegtrekken en dat van Saloean, doch van het eerste hoofd van Padang wordt wel gemeld dat hij tevens hoofd over Saloean werd. De afstammelingen van dit eerste hoofd splitsen zich verder in twee takken. $\mathrm{Zij}$ die hun afstamming terugvoeren tot een adellijke stammoeder zijn van adel en worden de hoofden, waarbij zij den titel imam aannemen; de afstammelingen van den anderen tak, die als stammoeder een slavin hebben, leveren de onderhoorigen, en kunnen slechts lagere functies vervullen.

Kompanga geeft aan een uitsplitsing te zijn van een deel van de moederkampong Mendono. Van een zuster en een broer werd de zuster hoofd over dat deel, terwijl de broer wegtrok op zoek naar vruchtbare gronden; daarbij bewoog hij zich met zijn volgelingen oostwaarts en vestigde zich tenslotte ten oosten van de golf van Sioena; deze laatste naam is het verbasterde sioeknjo, de naam door deze lieden gegeven aan hun uiteindelijke woonplaats; het woord beteekent hoek.

Dondalon leidt zijn afkomst van hetzelfde deel van Mendono af; hier echter meldt men als oorzaak der scheiding precies het omgekeerde: de jongere zuster trok met volgelingen weg, de oudere broer bleef als hoofd achter. De groep trok noordwaarts door de bergen en vestigde zich eerst in de nabijheid van de stamverwante groep Padang; een der dochters van het hoofd huwde met een imam van Padang, en werd, zooals hooger gemeld, hun adellijke stammoeder. Aangelokt echter door de goede oogsten door de stamverwanten te Sioeknjo verworven, begaf de groep zich derwaarts en vestigde zich in de nabijheid van de (eveneens verwante) groep Dondalon.

Vage mededeelingen zijn voorts beschikbaar over een uitzwerming uit Mendono naar het westen van de noordkust, waar ze zich te Bakoetan zou hebben gevestigd; daarbij moeten zich lieden gevoegd hebben van Saloean afkomstig, die een hoofd te Banoea Daka kregen. Sommige bewoners van het district Boenta zijn afkomstig van deze zwervers.

Als laatste groep onder Mendono noemde ik Pona; deze bestond 
uit slaven van den bosanjo. De mian Pona vormden na 1908 (toen pas feitelijk aan de slavernij een einde kwam) een eigen kampong op het eiland Poat, nl. het dorp Balaigondi.

Als no. 31 is Lontio vermeld. Zoowel hoofden als volk van dit kleine bosanjoschap voeren hun afstamming terug tot Boalemo, doch men kan niet van generatie tot generatie opgeven hoe dat verband gelegd wordt; wie der zoons van Lologani als stamvader der bosanjo Lontio beschouwd wordt is mij niet duidelijk geworden. Koetoe no tano worden in dit groepje niet aangetrof fen. De vrouwen van Lontio zijn bekend om haar schoonheid en haar lichte huidskleur; het laatste is een duidelijke trek van het Boalemovolk.

Ook hoofden en volk van Nambo (no. 32) voeren hun oorsprong terug tot Boalemo, al weet men ook hier niet meer hoe men te Nambo kwam, en hoe het verband met de vorsten van Boalemo gelegd moet worden. Merkwaardig is dat men meldt eerst onder een lager hoofd gestaan te hebben, daarna onder den Banggaischen vorst te zijn gekomen, en dat toen pas een bosanjo optrad, op verzoek der lieden van Nambo zelve. Onder het volk bevinden zich geen resten van oerbevolking.

Van Mangkiin Piala (later Loewoek; no. 33) is legendarisch nog minder bekend; slechts deelt men mede van Boalemo afkomstig te zijn; de bosanja-familie weet echter geen directe afstamming op te geven van een van Lologani's zoons, slechts geeft zij op dat ook vreemde elementen, als Boegineezen, ingehuwd zijn. Onder het volk zouden zich geen elementen van koetoe no tano gemengd hebben.

In Basama (Masama) kent men de namen van Lologani en Mapaang, en geeft als oorsprong op een groep lieden van Boalemo afkomstig, waaruit zich de groep Basama heeft ontwikkeld.

Tanotoeran en Dalé-Dalé zijn de twee eenheden waarin de siansprekers verdeeld worden; zij beschouwen onderscheidenlijk de bergen Pinoentoean en Kaoe Totoloe als hun magisch centrum; zij geven echter geen verband met het rijk van Boalemo op. De groep DaléDalé maakte tenslotte een versterkte plaats (sian: bala $=$ heg, vesting), waaruit de naam Balantak is ontstaan, terwijl de groep Tanotoeran den naam Lamala aannam (kreeg?).

De laatste nummers van de lijst zijn Sinohoan en Minahaki. De menschen van Sinohoan stammen af van de bewoners van het rijkje Gori-Gori, de ido-sprekers, terwijl in Minahaki de To-Wana woonden (thans in de kampong Toroka). Het ido is een varieteit van het bare'e, terwijl het taa, de taal der To Wana, een verbasterd soort 
Ampanaasch is ${ }^{11}$ ). Deze geïmmigreerde To Wana noemen zich hier wel To Polembah (bare'e : zij die aan weerszijden dragen, zooals men een vracht aan een stok over den schouder draagt); hiermee duidt men aan, dat zij èn in Todjo (Ampanaasch gebied) èn in Banggai huldegift verschuldigd waren.

\section{De historische traditie te Banggai.}

Op blz. 20 kwam Banggai reeds even ter sprake, terwijl ik aanstipte dat het toen nog niets meer beteekende dan een der vele voormalige rijkjes in den Archipel; zijn gebied was nog beperkt tot het eiland van dien naam. Verder noemde ik op blz. 28 Sambioet, dat in zijn traditie vele gemeenschappelijke trekken met Banggai stelt.

Dr. Alb. C. Kruyt maakte een uitvoerige studie, getiteld: De vorsten van Banggai ${ }^{12}$ ); hetgeen in de volgende regelen kort opgenomen is kan dus bij hem uitvoeriger worden nagelezen; hier en daar maakte ik gebruik van afwijkende aanteekeningen uit mijn memorie.

In oude tijden kwam een groote vloed over de aarde, doch in zeker land waren eenige mannen achter de dreiging gekomen en hadden zich een gesloten vaartuig, een soort kist, vervaardigd, waarin $z \mathrm{ij}$ op de golven van den zondvloed dobberden tot de kist op vasten bodem stootte; de bemanning steeg uit, de wateren zakten, het was de berg Boloekon op welks top zij zich bevonden, de hoogste berg van het eiland Banggai. De mannen hadden op een bepaalde wijze in het vaartuig gezeten, en zoo ook, in dezelfde volgorde, vestigden zij zich op het land. De hoogste, in het midden gezeten, was de vorst met den titel adi; vier mannen die paarsgewijs aan de einden der kist hadden gezeten als roeiers in een prauw, vestigden zich op dezelfde wijze, twee ten noorden en twee ten zuiden van de vestiging van den adi. Dit viertal kreeg ieder den titel tomoendo (verg. blz. 26), in deze sfeer beschouwd te zijn van lager rang dan adi. De vorst verbleef te Linggaboetoen, op den berg Boloekon gelegen; het viertal vormde een adviesraad voor den adi, samengevat als tomoendo sangkap (aki: sangkap $=$ vier). Ieder hunner had een zeker gebied, en daarnaar spreekt men van de tomoendo van Lombongan, van Singgolok, van Oloe en van Kakini.

Op Banggai zelve zegt men graag, dat deze kist van Java kwam;

11) Adriani-Kruyt, Bare'e III, blz. 14-15.

12) Opgenomen in Koloniaal Tijdschrift 20 (1931), blz. 505-529 en 605-624. 
er gaat een ander verhaal, dat stelt dat het vaartuig met zijn inhoud uit Oost-Peling kwam; dit zou dan beteekenen dat het eiland Banggai vanuit dat gedeelte van Peling zou zijn bevolkt. Men preciseert het verhaal wel dat de adi en zijn tomoendo van den Toemoesi kwamen, den bekenden berg uit Oost-Peling, waarmee vooral het basaloschap Pelei (blz. 29) verbonden is. Overigens zegt de traditie niet waar de mannen uit de kist hun vrouwen, dan wel hun onderdanen vandaan haalden. In Sambioet weet men dat de eerste vrouwen geestendochters waren, en dat de vier vorsten hun bevolking verwierven, doordat zij dorpen ontdekten, bevolkt door mensch geworden „djinns” (geesten). Op Sambioet ook stelt men den adi lager in rang dan de tomoendo, zulks in tegenstelling tot de lezing in Banggai.

$\mathrm{Er}$ wordt achtereenvolgens een viertal adi genoemd, voor een zekere adi Lambal zijn intrede doet. In de lezing van Sambioet zou dit een geestenkind zijn geweest, als zoon angenomen door een regeerend tomoendo, wiens dochter hem bovendien tot vrouw werd gegeven; doch de pleegzoon maakte zich van de macht over het geheele eiland Banggai meester ten koste van zijn pleegbroers. Op Banggai vertelt men echter dat deze adi als knaap op een lichtend stuk amber (aki : lambal) over zee kwam aandrijven; door deze bovennatuurlijke gaven werd hij door de vier tomoendo onmiddellijk als hun vorst erkend, terwijl de regeerende vorst vrijwillig afstand deed en hem bovendien zijn dochter tot vrouw gaf. Kruyt ziet in dezen adi Lambal den verdreven vorst van Bongganan, dan wel diens zoon, die na den val van Bongganan een goed heenkomen zocht naar het eiland Banggai, waar hij trachtte een nieuw vorstendom op te bouwen (verg. blz. 22) ${ }^{13}$ ).

Tijdens adi Lambals bewind komt een vreemde vorst, wiens naam verloren is gegaan; omdat hij gezegd wordt op Java te zijn overleden kent men hem als moemboe doi Djawa. De titel adi verdwijnt, moemboe, in velerlei combinaties, wordt de gebruikelijke aanduiding voor de vorsten. Adi Lambal erkende den vreemdeling als zijn meerdere en bood hem het bestuur aan. Deze noemboe doi Djawa moet als grondlegger van het Banggaische rijk worden beschouwd; hij onderwierp Peling en den Vaste-Wal van Balantak tot Kandari, regelde het bestuur in de onder zijn bewind gebrachte streken en bracht den Islam met zich. Het eiland Banggai maakte hij tot zetel van zijn bewind; den laatsten adi, Lambal, stelde hij terug tot zijn rijksbe-

13) Kruyt, Vorsten, blz. 511, 516, 606. 
stuurder, onder verleening aan hem van den Ternataanschen ambtsnaam djogoegoe $\left.{ }^{14}\right)$. De vier tomoendo kregen eveneens een lageren titel, nl. paoe basal (waaruit zich later, naar analogie met de betiteling der Pelingsche hoofden, basalo ontwikkelde); ook gaf hij hun andere namen. Zoo werd de voormalige tomoendo Oloe paoe basal Dodoeoeng; Kakini werd Tano Bonoenoengan, Singgolok heette in den vervolge Monsoongan en Lombongan leverde Gong-Gong. De benaming paoe basal (aki : paoe = kind, zoon; basal = groot) is te beschouwen als eeretitel, omdat deze een vader-zoon-verhouding tusschen den moemboe en het viertal legde; hun gebied werd nieuw aangegeven, vanuit den heuvel Boengkoeko Tatandak, waar de vorst een paleis bouwde voor een zijner echtgenooten. Bij deze gebiedsindeeling werd er echter voor gezorgd, dat de gebieden zoo over het eiland verdeeld kwamen te liggen als hun voorvaders, de tomoendo, in de kist hadden gezeten in het verleden. De vier paoe basal genoten hoog aanzien bij den moemboe en zijn opvolgers; zij vormden een adviesraad, welks invloed zich even ver als des moemboe's macht uitstrekte.

Men beschouwt moemboe doi Djawa als een Javaansch vorst; sommigen willen hem als sultan van Banten erkend zien, anderen noemen hem Hadji Soko (verg. Adjiçoko).

Moemboe doi Djawa had een drietal echtgenooten; één op Ternate had of verwachtte haar zoon, den lateren Banggaischen vorst Mandapaar. Deze echtgenoote is in de traditie bekend als een Portugeesche prinses, eene Kastella. Een andere echtgenoote was de Ternataansche prinses Noeroe Sapa (verg. blz. 25), die een zoon zou krijgen, Aboe Kasim, om wien de belangrijke balakat van Boniton is ontstaan (blz. 29). Als derde vrouw nam hij de dochter van paoe basal Dodoeoeng, die een dochter, Poetri Saleh, zou baren. Wijl de Ternataansche, Noeroe Sapaa voortdurend twistte met de Banggaische vrouw, vertrok Moembo doi Djawa van Banggai, keerde naar Java terug, zijn derde vrouw met zich nemend.

$\mathrm{Na}$ het vertrek van den grooten vorst brak een periode van onrust en regeeringloosheid aan; achtereenvolgens worden acht moemboe genoemd. $Z$ ij zijn geen van allen bekend bij hun naam, doch slechts onder een aanduding die een typische eigenaardigheid moet inhouden. Drie hunner staan opgeteekend als moemboe dinadaat (aki: dinadaat

14) Ternataansch: djooe $=$ heer; goegoe $=$ vasthouden; verg. De Clercq, Ternate, blz. 264, 302. 
$=$ vermoord). Een merkwaardige trek uit deze periode wordt gemeld, waar de legende luidt dat men een kat ten einde raad op den troon plaatste. De koning-kat miauwde, hetgeen de Banggaiers als aoe hoorden, den naam van een bamboesoort; de onderdanen nu brachten groote hoeveelheden van dit gewas en legden het bij het dier neer; doch dit bleef steeds maar aoe, aoe roepen; zoo begreep men dat de kat als vorst ook niet de ware was. Deze eigenaardige legende zou ik niet vermeld hebben als niet van Peling hetzelfde bekend was (zie blz. 21), terwijl ook uit Zuid-Celebes gemeld wordt, dat een kat daar een magisch belangrijke plaats blijkt te kunnen innemen ${ }^{15}$ ).

Een oude vrouw bracht uitkomst; zij wees de vier paoe basal er op, dat moemboe doi Djawa nog een zoon achterliet te Banggai. Zij herkenden hem aan een gouden tolkoord en dwongen hem vorst te worden. $\mathrm{Hij}$ onttrok zich er echter aan, zeggende eerst vorstelijke kleedij van zijn vader op Java te willen gaan halen. Hij vroeg een vaartuig met twaalf zuigelingen, die hij omtooverde tot volwassen roeiers en vertrok naar Java. Hier ontvlamde hij, in het paleis van zijn vorstelijken vader gekomen, in liefde voor zijn halfzuster Poetri Saleh. De vorst lichtte zijn zoon in, dat hij te Ternate nog een nakomeling had, die, zoo Aboe Kasim geen vorst te Banggai wilde worden, dit ambt zou kunnen bekleeden. Met deze boodschap keerde de jonge prins naar Banggai terug, terwijl Poetri Saleh met hem meereisde. Daar hij begreep dat de liefde die hij voor zijn halfzuster had opgevat, verboden was, zocht hij den dood. Hij werd de belangrijke balakat van Boniton (zie blz. 29, 38). In dezen tijd legt de legende ook het ontstaan van de basalo van Poetal en Boneaka. De eerste basalo Poetal zou een oom van Aboe Kasim zijn geweest, die met hem naar Banggai reisde; zijn volgelingen, de menschen van Poetal, bewaarden gedurende vele generaties het ambacht van zilver- en kopersmid en touwslager. Verder zou Poetri Saleh een groep hofdames met zich gevoerd hebben, die allen huwden met Banggaische mannen, doch een eigen dorp bleven vormen, Boneaka. Men vertelt dat de vrouwen van dit dorp zich tot heden door haar lichte huidskleur onderscheiden. (De legende verklaart niet waarom in dit dorp ook de zoo belangrijke balakat, van Bongganan afkomstig, bewaard wordt; zie blz. 28 v.).

Twee ongenoemde moemboe worden nu genoemd, totdat de paoe basal het advies van moemboe doi Djawa opvolgden, en naar Ternate

15) Arb. XXXI, blz. 269. 
gingen om daar den oudsten zoon van den Javaanschen vorst als hun heer te gaan erkennen. Door een list gelukte het hun den prins uit Ternate naar Banggai te brengen waar hij ingehuldigd werd als vorst; als Mandapaar is hij bekend. Van dezen vorst af is er meer regelmatigheid in den stamboom der vorsten van Banggai.

Mandapaar wordt na zijn vader als de grootste Banggaische vorst erkend; hij herstelde zijn gezag overal en vestigde te Banggai een centraal bestuur. De grondslag voor geregelder toestanden werd gelegd, al heeft er vermoedelijk tijdens zijn eerste opvolgers nog veel bloed gevloeid.

Vanaf Mandapaar telt men tot en met den in 1939 aan het bewind zijnden Hadji Awaloeddin 18 vorsten; de meesten hunner kent men bij naam, sommigen worden aangeduid naar de plaats waar zij stierven en begraven werden (b.v. moemboe doi Mendono, de te Mendono overleden vorst).

$\mathrm{Na}$ Mandapaar komen achtereenvolgens zijn beide zoons moemboe doi Kintom en moemboe doi Benteng aan het bewind; vervolgens Moelang, ook genaamd moemboe doi Balantak, zoon van moemboe doi Kintom. Na hem noemt men moemboe doi Mendono, zoon van moemboe doi Benteng. Dan vermeldt men Aboe Kasim, die dus dezelfde namen voerde als zijn legendarische voorvader. Nà hem vinden we een ongenoemden vorst, moemboe doi Padongko; zijn familieverhouding tot de overige vorsten noteerde Kruyt niet, doch aangenomen mag worden, dat hij van moemboe doi Benteng afstamt. $\mathrm{Hij}$ wordt opgevolgd door zijn beide zoons, Mandaria en Atondeng. $\mathrm{Na}$ den laatsten kent men Agama, moemboe doi Boegis, achterkleinzoon van Moelang. Vervolgens komen achtereenvolgens twee broers, Laoeta en Tadja, achterneven van Agama. Na een zeer korstondige regeering vinden we Tatoe Tonga, kleinzoon van Mandaria; vervolgens Soak, kleinzoon van Laoeta; dan Noerdin, zoon van Tatoe Tonga, kleinzoon van Mandaria; vervolgens Soak, kleinzoon van Laoeta; dan Noerdin, zoon van Tatoe Tonga; na hem Abdoel Aziiz, zoon van Soak; dan nog Abdoerrahman, zoon van Atondeng en ten slotte Hadji Awaloeddin, zoon van Abdoel Aziiz.

Ik nam dit uittreksel uit de geslachtslijst op om er een korte karakteristiek der opvolging uit te kunnen putten. In de eerste plaats is dus nimmer een vrouw vorstin van Banggai geweest. Verder vinden we slechts zeer zelden dat de vader door zijn zoon wordt opgevolgd (nl. alleen bij Mandapaar en moemboe doi Padongko). Veeleer treffen we aan dat na elkaar twee zoons, dan wel twee kleinzoons van 
een vorst achtereenvolgens aan het bewind kwamen. Het komt dus zeer veel voor, dat uit één generatie meer dan één persoon vorst wordt; men gaat pas over tot de volgende generatie als de vorige uitgeput is, d.w.z. als die vorige geen geschikte personen meer levert. Dit systeem is kortweg te karakteriseeren als: erfrecht met electie. (Er zijn verder flauwe aanwijzingen over een tweedeeling in de vorstenfamilie, twee helften van een stamboom, waarvan om beurten een lid aan het bewind moet komen; dit is niet voldoende onderzocht, zoodat het hier verder onbesproken blijve).

In de legendarische geschiedenis ligt niet de verklaring van het feit dat Banggai vazal was van Ternate; moemboe doi Djawa kwam weliswaar van Ternate, maar hij is in de traditie een Javaansch vorst. Slechts de omstandigheid dat Mandapaar door de vier paoe basal van Banggai zelve als hun vorst van Ternate gehaald werd, wijst in de richting dat Ternate aan Banggai zijn vorstenhuis gaf. Doch Mandapaars moeder was geen Ternataansche prinses; zij was, zooals ik hooger reeds mededeelde, eene Kastella, waarmee een Portugeesche prinses bedoeld wordt. Waarschijnlijk hebben we hier te maken met de afstammeling van een Portugees.

Uit historische gegevens echter blijkt, dat Banggai door verovering onder Ternate's suprematie was gekomen en dat derhalve de vorst tribuut schuldig was aan den sultan in een verhouding zooals overal in den Archipel te vinden was. Kruyt stelt echter, dat aanvankelijk, toen de verwantschap tusschen beide vorstenhuizen nog gevoeld werd, Banggai geen huldegift aan Ternate opbracht ${ }^{18}$ ).

Over den naam Banggai doet te Banggai een verhaal de ronde dat sterk naar volksetymologie riekt. Het eiland zou indertijd nl. zoo dicht bevolkt zijn geweest, dat het een bosch maden geleek; in het Ternataansch werd dit weergegeven met banga gaai, hetgeen later tot Banggai werd samengetrokken ${ }^{17}$ ). Anderen zeggen dat de Ternatanen van de bevolking gesproken hebben als wurmen (bagai), zoo kriewelden de menschen door elkaar. Kruyt stelt dat banggai een algemeener beteekenis moet hebben gehad dan het woord nu heeft, waar het thans alleen slaat op het eiland waar de vorst woont. In enkele Pososche verhalen wordt gesproken van Banggai lanto, hetgeen volgens de Toradja's eiland beteekent. Banggai zal dus wellicht beteekend hebben: het eiland bij uitnemendheid, doch in welke taal dit woord thans voorkomt in de beteekenis van eiland is unbekend;

16) Kruyt, Vorsten, blz. 612.

17) Goedhart, Drie landschappen, blz. 442. 
uit de Banggaische spreektaal is het woord verdwenen ${ }^{18}$ ); men gebruikt in het aki togong ter aanduiding van eiland.

\section{Historische gegevens.}

Voor zoover den Archipel betreft moge ik verwijzen naar mijn artikel: Geschiedkundige aanteekeningen betreffende Banggai en Gapi, opgenomen in B.K.I. 1943.

Voor den Vaste-Wal beschikken we slechts over zeer weinig historische gegevens.

De bevolking van de landstreek Boalemo (Tilamoeta) in de onderafdeeling Gorontalo is er zich nog bewust van dat zij voorheen aan de overzijde van de Tominibocht woonde, en wel op de noordkust van den Vogelkop. Zij werd daar bestookt door Ternatanen en Tobelo's, en verhuisde derhalve naar de huidige onderafdeeling Gorontalo, waar zij zich onder bescherming stelde van Gorontalo en Limboto. De Limbotosche hoofden bejegenden hen echter als slaven, en derhalve vertrok hun hoofd in 1787 naar Ternate om zich (bij den Gouverneur aldaar) te beklagen. Toen in 1790 de Gouverneur der Molukken te Gorontalo kwam beval deze o.m. deze lieden van Boalemo niet te onderdrukken.

Door samenvatting van deze en andere gegevens plaatst Kruyt den val van Boalemo tusschen 1750 en $1780^{19}$ ). Doch m.i. moet deze aanzienlijk eerder worden gesteld, want reeds in 1730 gaven sommigen der als slaven meegevoerden aanleiding tot moeilijkheden; een gedeelte hunner was nl. gevlucht naar Bwool, waardoor tusschen dit vorstendom en Limboto (welks hoofden zich als de eigenaren der krijgsgevangenen beschouwden) twist rees ${ }^{20}$ ). Aan den Gouverneur te Ternate werd in 1730 ter zake reeds eenmaal een beslissing gevraagd, en blijkbaar later, aan het einde van die zelfde eeuw, nog eens.

Indien dit van Riedel afkomstige bericht geloofwaardig is, moet de val van Boalemo dus veel eerder gesteld worden, wellicht nog in de 16e eeuw, hetgeen ook beter uitkomt met de historische gegevens en die opgenomen in paragraaf 2 . Dat eventueel het tijdsverloop niet geheel overeen zou stemmen met het aantal generaties der hoofden (één der wijzen waarop Kruyt tot zijn schatting komt) mag m.i. niet

18) Kruyt, Vorsten, blz. 505.

19) Kruyt, To Loinang, blz. 342, 343, 346.

20) J. G. E. Riedel, De oorsprong en de vestiging der Boalemoërs op NoordCelebes; B. K. I. 4e vr. 10e deel, blz. 495. 
te zwaar tellen, daar in de traditie zoo licht een aantal namen wordt vergeten.

4. Transmigraties en immigraties (mededeelingen uit mijn memorie).

a. Bangkoeloe. Bevolkt vanuit West-Peling in twee instroomingen, t.w. één van ongeveer zeven generaties geleden uit Boeoeko (Sea-Sea) en één van ongeveer vier generaties geleden uit Boelagi; daarnaast menschen van het eiland Banggai, wellicht in twee golven overgekomen. Bovendien vestigden zich vele vreemdelingen hier.

De eerste transmigranten hebben tot heden een eigen balakat, de balakat Sasange. Als uiterlijk teeken is hiervan te vinden op een bergtop achter Bone-Bone een groote schelp waarin een menschenschedel, een stukje van een zwaard, resten van beenderen, kraaltjes e.d. Hier zou de laatste rustplaats zijn van de dochter van een vorst, (tomoendo) wiens naam men mij niet wilde zeggen; deze vorst zou het geheele eiland Bangkoeloe onder zich hebben gehad. Een der kinderen van dezen vorst werd balakat, een ander werd stamvader der basalo Boelagi, een derde werd stamvader der vorsten van Banggai; de vorst zelf kwam uit Boeoeko. Deze balakatvorm is wel merkwaardig, want in het Soa-Soagebied treffen we de balakat Daloe aan, de resten van een primitieve steenen doodkist, waarin eveneens een vorstenkind zou zijn begraven. Bij vereering van de balakat Sasange roept men een pilogot van Sea-Sea aan (Bisatinano; aki: de groote magische kracht; ook wel Boloitolong); tevens noemt men de balakat van Boeoeko, Boelagi, Banggai en Toropot (Bwokan). Hier wordt dus wederom verband gelegd tusschen vorstenhuizen elders en het eigen land, zooals we dat reeds op blz. 20 aantroffen.

De tweede instrooming betreft menschen van Boelagi. De dochter van basalo Boelagi kwam naar Bangkoeloe; zij was gehuwd met eveneens een Boelagiër; bij het huidige of feren aan beiden wordt de pilogot Boelagi voor beiden opgeroepen. $\mathrm{Na}$ haar vertrek uit Boelagi was daar geen basalo meer; slechts zijn familieleden woonden daar nog. Dat het hoofd van Boelagi in dien tijd op Bangkoeloe verbleef vindt zijn bevestiging in de mededeeling, dat de aan den vorst van Banggai op te brengen huldegift van Boelagi door het op Bangkoeloe wonende hoofd te Boelagi gehaald en tezamen met die der lieden van Bangkoeloe naar Banggai gebracht werd. De derde dezer Boelagische hoofden op Bangkoeloe werd door Tobeloreesche zeeroovers gedood, en nadien waren er geen basalo meer op Bangkoeloe; hij verbleef 
sinds dien op Boelagi zelf, de huldegift der op Bangkoeloe wonende Boelagiërs werd door hem op zijn reis naar Banggai opgehaald.

Deze groep Boelagiërs heeft een eigen balakat, den berg Boengkoeko Maaling; de basalo verbleef meestal te Balolombitan, waarnaar hij ook genoemd wordt. Vermoedelijk ook gaven de Boelagiërs den naam aan het eiland; op den Boengkoeko Maaling (aki: slechte, lastige berg) worden nl. vele duizendpooten (aki: bangkoeloe) aangetroffen, die den berg onbewoonbaar maken. (Thans wordt het eiland vooral door vreemdelingen veelvuldig Bangkoeroeng genoemd).

Resumeerende : basalo Boelagi verhuisde met een groep volgelingen naar Bangkoeloe toen het veilig was op zee en te land, doch hij keerde terug naar Boelagi toen door de strooptochten der Tobeloreezen die veiligheid verdween; van zijn volgelingen bleven echter aanzienlijke groepen in het nieuwe land achter.

De verhouding tusschen de lieden van Boeoeko en van Boelagi ontwikkelde zich op eigenaardige wijze. De Boelagiërs namen de vereering van balakat Sasange wel over, doch maakten die ondergeschikt aan de vereering van hun eigen balakat Boengkoekoe Maaling. Wellicht kozen sommige Boelagiërs zich vrouwen uit de eerste groep transmigranten, waardoor de nazaten zich gebonden voelden aan beide magische centra.

Thans kunnen we, ook duidelijk naar het uiterlijk, vaststellen dat van de oorspronkelijke Boeoeko-groep slechts zeer weinigen resteeren, en dat de Boelagi-groep het grootste deel der bevolking heeft geleverd.

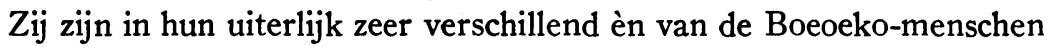
èn van de thans nog te behandelen Banggaiers.

Deze Banggaiers zijn vermoedelijk in twee golven overgekomen. Als oorsprong van de oudste groep geeft men een vorst te Banggai, die te Lantiboeng op Bangkoeloe is overleden en wiens graf thans nog balakat is voor deze Banggaiers. Een zijner kinderen zou Lipoeadino zijn geworden, een ander vorst van Banggai, een derde djogoegoe (rijksbestierder; zie blz. 38); ook werd er één salakan te Tadoeno op Bangkoeloe, eertijds in de bergen gelegen, doch thans aan het strand (Salakan is Ternataansch en beteekent: stedehouder); later spreekt men van den toemboe salakan, ook toemboe selekan. (Is deze toevoeging van toemboe wellicht een aanduiding van vorstelijke waardigheid?). De zich om hem vormende groep, waarvoor de balakat Lantiboeng als geestelijk centrum fungeerde, bleef rechtstreeks onder Banggai staan, had niets te maken met de Boelagiërs van Balolombitan. Uitsluitend uit de nakomelingen der stichters van Tadoeno 
mogen tot heden toe eenige mannelijke en vrouwelijke functionarissen genomen worden die bij de vereering van balakat Lantiboeng optreden. Er zijn weliswaar ook Boelagiërs die aan de vereering van deze balakat meedoen, doch zij kunnen nimmer eenige functie daarbij bekleeden, zijnde geen rechtstreeksche afstammelingen van de stichters.

De redenen tot verhuizing der Sea-Sea en Boelagiërs waren vermoedelijk alleen economische: gebrek aan goede gronden en goed drinkwater in het stamland, terwijl er van beide op Bangkoeloe voldoende beschikbaar is. Wat de redenen van de verhuizing der Banggaigroep betreft, kunnen we slechts gissen dat de groep zich als een vereeringsgemeenschap bij de heilige plaats Lantiboeng vestigde.

$\mathrm{Na} 1908$ heeft verdere instrooming plaats gehad, eveneens grootendeels uit West-Peling, o.a. lieden uit Palabatoe (onder den Lipoeadino). Bovendien vindt men er thans diverse vreemdelingen, zooals Boetonneezen, Gorontaleezen, Badjo's.

$b$. Labobo. De naam van het eiland is door lieden van Banggai gegeven, niet door kolonisten, want labobo beteekent in het aki links (gelegen); het ligt vanuit de hoofdplaats Banggai gezien inderdaad links.

Er valt een eerste instrooming te melden van Soeit, een basalo van den Lipoeadino.

Naast deze groep meldt men instrooming van Midden-Peling, (Liang en Apal), en Oost-Peling (Papiisi en Tinangkoeng); ook eenige Boelagiërs treft men er aan, doch de MiddenPelingers zijn het talrijkst.

Merkwaardig is dat te Sagoemanoes eenige lieden wonen die uiterlijk zeer veel op Lingketingers gelijken; zij beweren af te stammen van vluchtelingen van Boalemo die dertien geslachten geleden door hun vijanden als slaven werden meegevoerd, doch die wisten te ontvluchten, waarna ze door den geheelen archipel zwierven om tenslotte in Sagoemanoes terecht te komen. $\mathrm{Zij}$ onderscheiden zich door lichte huidskleur en mongolenplooi (oogen).

c. Bwokan. Een allereerste instrooming wordt gevormd door een groep lieden van Soeit (West-Peling) die via Labobo naar Bwokan is getrokken; het betrof hier echter slechts een gering aantal lieden.

$\mathrm{Na} 1880$ moet een sterke instrooming hebben plaats gehad van Midden-Belingers, die aan een krijgsexpeditie tegen Tobeloreesche zeeroovers deelnamen; vooral Liang schijnt hierin een zeer werkzaam aandeel te hebben gehad. Een deel der deelnemers bleef, eenmaal in 
den Bwokan-archipel aangekomen, voor den landbouw achter; later voegden zich lieden van Banggai bij hen. Toen eenmaal de veiligheid ter zee verzekerd was (en dat was pas na 1908) kwamen er nog vele menschen van Liang, die thans het hoofdbestanddeel der bevolking uitmaken; slechts het eiland Timpaoes is geheel vanuit West-Peling bevolkt. De bevolking van de hoofdplaats Boengin bestaat uit lieden van Midden- en Oost-Peling (Liang, Totikom, Paisoeoeloeno) en Banggaiers.

$d$. Poat. Hier vinden wij thans vier administratieve kampongs; Gomoeo werd gevormd door lieden van Saloean, Tampe door menschen van Padang; in Balaigondi wonen mian Pona, afstammelingen van slaven (zie blz.35), terwijl Badjo-Powat gevormd werd door Badjo's, zuivere immigranten.

e. Badjo's, Boegineezen en Gorontaleezen. Goedhart bespreekt in 1908 de bevolking en verdeelt haar in inheemsche bevolking en vreemdelingen. De eerste groep werd in dien tijd veel enger opgevat dan thans en beteekende alleen: de autochthone, gezeten bevolking van Banggai. Vreemdelingen waren dus niet alleen Chineezen en Arabieren, doch ook Boegineezen, Gorontaleezen en andere geimmigreerde Indonesiërs (vergelijke Goedharts opsomming op blz. 475). Deze vreemdelingen woonden verspreid door het landschap en waren slechts in kustplaatsen gevestigd.

Een goed deel van die kuststrook was onbewoond, met name de Tominibocht. De bosanjoschappen van den Vaste-Wal lagen aan de zuidzijde van de waterscheiding; wel hadden eenige hunner ten noorden daarvan, hetzij door aldaar gevestigde onderhoorige groepen, hetzij door uitzwerming derwaarts, invloed, doch deze strekte zich niet uit tot het noorderstrand. Alle berichten uit de vorige eeuw spreken van onveiligheid ter zee, zoowel in den Archipel als in de Tominibocht. Slechts zij die over moed en wapenen beschikten konden zich in die gevaarlijke tijden daar handhaven; het waren voornamelijk Boegineezen, die aan die voorwaarden voldeden en die dan ook eenige vestigingen aan de Tominibocht maakten. De bevolking des lands woonde landinwaarts, doch ook daar wisten zeeroovers haar op hun strooptochten te vinden.

Nog in Goedharts tijd staan al deze vreemdelingen als onderhoorigen van het Gouvernement onder diens vertegenwoordiger, in dien tijd den posthouder te Banggai; zij waren ook aangeslagen in de Gouvernements- (hoofdelijke) belasting. Slechts de Badjo's, in feite evenzeer vreemdelingen, maakten een uitzondering. Goedhart schrijft over 
hen ${ }^{21}$ ) : „Oorspronkelijk gestaan hebbende onder het gezag van de „radja's van Goa, verwisselden zij dit later - tijdens het bestuur ,van den grooten Aroe Palaka Tori Sompat, vriend van den admiraal „Speelman - tegen dat van de Bonische radja's, een van wie hen ,toestond zich in de naar hun genoemde kampong Badjowe, de „havenplaats van Watampone, te vestigen. Hier kwamen alstoen te „wonen hun hoogste hoofd, den titel van Lolo voerende, en de hem „ondergeschikte mindere hoofden als de Poenggawa en de Galarang. „Dit bleef zoo tot omstreeks acht jaren geleden (d.i. \pm 1900 , Schr.), „toen de Lolo en de Galarang, de willekeurige handelingen van de „Bonische anakaroengs tijdens Lapawawoi's wanbestuur moede, „Badjowe verlieten om zich respectievelijk in Kendari en op Sala„,bangka (Boengkoe's gebied) te vestigen; hun voorbeeld werd $2 \frac{1}{2}$ ,jaar geleden (omstreeks 1905, Sch.) gevolgd door den Poenggawa. „Uitsluitend zeevarend volk als zij waren - en nog zijn - hadden „,hun onderhoorigen zich intusschen reeds lang te voren over geheel „Celebes verspreid. Zoo waren langzamerhand ook in de Banggaische ,wateren Badjokampongs verrezen, die onder een gemeenschappelijk „hoofd met den titel van Poenggawa werden gesteld"; enz.

Thans zijn groote Badjo-vestigingen Kaloembatang (oostkust van Peling) en Pagimana (Tominibocht); verder vindt men tientallen kleinere, min of meer permanente woonplaatsen.

De Boegineezen die in de Tominibocht eenige groepen immigranten opleverden, zijn verwant met de Boegineezen van Wani en Paloe (westkust van Celebes) en van Gorontalo. Op vele plaatsen vermengden zij zich met de hoofden des lands, waarna ze weldra een vooraanstaande positie innamen, daartoe voorbestemd door meerdere beschaving, kennis en rijkdom. Eén der centra van Boegineeschen invloed in de eerste helft der vorige eeuw waren de Togean-eilanden in de Tominibocht, waar Latowale, prins van Wadjo (?) huwde met een vorstendochter, en voor zijn schoonvader, den landsvorst, het bewind als rijksbestuurder voerde, onder den titel kapitan. Daar bereikte hem een verzoek om hulp van den vorst van Banggai; de plaats werd belegerd door de Tobelo's, de vorst verkeerde in groot gevaar (historisch staat de belegering van Banggai vast; 1847). Een vloot Boegineesche prauwen vertrok naar Banggai, slaagde erin den Banggaischen vorst te ontzetten en hem te helpen ontvluchten naar de Boegineesche landen. Als dank voor de gebrachte hulp verleende

21) Goedhart, Drie landschappen, blz. $472-473$. 
de Banggaische vorst (men weet niet meer wie, vermoedelijk de vluchteling) den Boegineezen van Togean het recht zich aan de kusten van het Banggaische gebied in de Tominibocht te vestigen, oostwaarts van Tandjong Api (vergelijk blz. 1 v.), en een strook land als het hunne te beschouwen en daar tuinen aan te leggen zoo ver het land in, als men een gong, aan het strand geslagen, nog kon hooren. Latowale's zoon Boenai trok nu met een groep volgelingen naar dit nieuw verworven gebied en vestigde zich daar waar nu Boenta ligt, welke plaats door hem omstreeks 1860 gesticht werd. Met een groep meegebrachte slaven werd een sterkte gemaakt, een houten palissadeering bewapend met kanonnen. Vanuit dit centrum legden de Boegineezen langs de kust, zoowel ten oosten als ten westen van Boenta, aanplantingen van cocospalmen aan en dreven handel met de bergbewoners, de mian Doehian (Baloa-clan; zie blz. 30). Deze waagden zich tevoren niet in de onveilige kuststrook, doch bleven in hun heuvelland; dit laatste viel buiten de aan de Boegineezen toegevallen strook, die nergens veel breeder was dan 2 K.M. Er trokken ook eenige groepen Boegineezen oostwaarts langs de kust en vestigden zich te Loboe en te Pagimana.

Onderhoorigen van het hoofd der Boegineezen waren in de eerste plaats de Boegineesche volgelingen, meegekomen van elders, en dier afstammelingen; verder Gorontaleezen, in loondienst bij de Boegineesche heeren; ten slotte slaven, veelal Sea Sea van Banggai gekocht. Onderhoorig volgens het bewustzijn der Boegineezen waren dus allen die zich metterwoon gevestigd hadden in het hun toegevallen gebied.

De groep Boegineezen, die naar Pagimana trok, kan niet als stichters van deze plaats worden aangemerkt; ook in Loboe is dat niet mogelijk. De kern van dit Boegineesch gebied is Boenta met de kustvlakte rondom.

Pagimana is gesticht door eenige Boegineesche handelaren van Gorontalo, die in de tweede helft van de vorige eeuw herwaarts kwamen; ook zij verkeerden in materieel dezelfde positie als de Boegineezen van Boenta: zij hadden kapitaal, munitie, bewapende schoeners; zij brachten volgelingen met zich en maakten een sterkte te Pagimana; hierdoor hielden zij de zeeroovers op een afstand en kon zich hun handel gunstig ontwikkelen. Men erkent als stichter den Gorontaleeschen Boeginees Papai Koema (of Tamai Koema); hij moet door den resident van Ternate gemachtigd zijn geweest om alle zich voordoende geschillen tusschen de vreemdelingen op te lossen en te berechten; een schriftelijk bewijsstuk hiervan is verloren gegaan; 
doch wel toonde men mij een uit December 1895 dateerend stuk waarbij de toenmalige resident van Ternate ,den Boeginees Lagona Tomai Sanawarie, die reeds ongeveer twee jaren als zoodanig fungeert" tot kapitan van Pagimana benoemt.

De groep dezer vreemdelingen heeft een andere ontwikkeling doorgemaakt dan die te Boenta. Trad bij de laatste vrijwel geen vermenging met anderen op, de Boegineezen van Pagimana vermaagschapten zich innig met de hoofden van Padang, die den titel van imam voerden (blz. 34). De eerste immigranten namen meisjes uit dat hoofdengeslacht tot vrouw; hierdoor zijn zij daarin geheel opgegaan. Een zekere wisselwerking moeten we hierbij veronderstellen; de hoofden van Padang genoten reeds aanzien door hun afstamming van de bosanjo van Mendono; de vreemdleingen die zich een vrouw wilden kiezen, namen deze uit die vooraanstaande hoofdenfamilie, waardoor weer het aanzien van het imamgeslacht steeg. Zoo is dit laatste, dat thans uit personen bestaat, die vrijwel allen van gemengden bloede zijn (mian Mendono, vermengd met Gorontaleesche Boegineezen) hoofd zoowel over de madi-sprekers (landsbevolking) als over de van origine vreemden. $\mathrm{Na} 1908$ werden uiteraard alle deze vreemdelingen aangemerkt als zelfbestuursonderhoorigen volgens het toen aangenomen territorialiteitsbeginsel.

Kleine groepen Gorontaleezen en Moenaneezen elders zijn niet van belang voor het adatrecht. 


\section{HOOFDSTUK III.}

\section{Rechtsgemeenschappen.}

\section{Algemeene trekken.}

De studie der vormen waarin zich rechtsgemeenschappen in het adatrecht voordoen wordt door Van Vollenhoven op verschillende plaatsen van zijn werken naar voren geschoven, omdat ,omtrek en ,inhoud en snit van het betroffen recht moeten verschillen naar den „toestand zijner rechtsgemeenschappen" ${ }^{1}$ ). De uiteenloopende gesteldheid van de inheemsche rechtsgemeenschappen wordt genoemd, waarmee het verdere adatrecht in onverbrekelijk verband staat. Bij de bespreking der rechtskringen wordt van elken rechtskring vrijwel steeds het punt rechtsgemeenschappen het eerst besproken ${ }^{2}$ ).

De vraag rijst dan hoe men deze dient te definieeren. Van Vollenhoven zelf geeft de bondige karakteristiek: „Indonesische rechts„meenschappen, laag en hoog; lichamen met eigen gezag en eigen „vermogen", en geeft dan inzicht in de verscheidenheid door de volgende opsomming: „Naast de genealogische rechtsgemeenschappen „der Indonesiërs staan de territoriale: dorpen, dorpenbonden of ,autonome disctricten, ornamentschappen, waterschappen, Indonesi„sche- of Indonesisch geworden rijken (gouvernementslandschap,pen)" ${ }^{3}$ ). Hier dus een scheiding in twee groote groepen, en wel genealogische tegenover territoriale; dan een geleding van die tweede groep.

Ter Haar constateert dat bij elk Indonesisch volk de samenleving in de zeer breede benedenlaag zich voordoet te zijn gevat in verbonden groepen, welke zich tegenover de onzichtbare wereld, alsmede tegenover de buiten- en bepaalde gedeelten van de stoffelijke wereld, op een wijze gedragen, die tot uitdrukking is te brengen, door die groepen rechtsgemeenschappen te noemen. Aan tal van verhoudingen en rechtshandelingen neemt een aantal zich verbonden gevoelende

1) C. van Vollenhoven, Adatrecht III, Studie van Adatrecht, bz. 5; Adatrecht I, blz. 135.

2) C. van Vollenhoven, Adatrecht I, blz. 155-754.

3) C. van Vollenhoven, Adatrecht II, blz. 416, 420. 
personen als een eenheid deel; een reeks daden (door Ter Haar als voorbeelden genoemd) wordt door de leden der gemeenschap verricht, waaruit die binding blijkt. Het bestaan der gemeenschappen wordt gevoeld als een natuurlijke noodzakelijkheid, een metajuridische realiteit; zoo wordt b.v. niet gedacht aan de mogelijkheid de groep te ontbinden.

In die gemeenschappen blijkt de verwantschapsband, de gezamenlijke afstamming der genooten van één voorouder, nu eens van beslissend of van groot, dan weer van gering of geen belang voor haar structuur. In andere woorden, ook hier de tegenstelling tusschen genealogische en territoriale eenheden. Eindelijk geeft Ter Haar als formuleering: „Geordende groepen van blijvend karakter met eigen bewind en eigen "materieel en immaterieel vermogen" 4 ).

Indien we Van Vollenhovens definitie vergelijken met die van Ter Haar, dan blijkt wat bij den een ,eigen gezag” heet, bij den ander „eigen bewind" te worden genoemd; terwijl ,eigen vermogen” nader omschreven wordt met ,eigen materieel en immaterieel vermogen". Het rechtssubject ten slotte wordt van "lichaam" tot "geordende „groepen van blijvend karakter".

Bij de bespreking van groepen, willen we deze aanmerken als rechtsgemeenschappen, moeten we dus steeds erop letten of deze drie factoren aanwezig zijn; vinden we een groep die aan één der drie voorwaarden niet voldoet, dan kunnen we deze krachtens definitie ook niet als rechtsgemeenschap beschouwen.

\section{A. Volksordening.}

\section{Vormen.}

Wij dienen voorop te stellen dat in de structuur der volksgemeenschappen na 1908 diep is ingegrepen; ten gevolge toch van de meest intensieve bestuursbemoeienis na dien werd de bevolking gedwongen zich te vestigen in kampongs aan de kust, vaak weliswaar op door haar zelf uitgekozen plaatsen, doch die meestal verwijderd liggen van de terreinen waar zij leefde en stierf voor 1908. Slechts de to Loinang wonen thans nog gedeeltelijk op dezelfde plaatsen als weleer, terwijl ook op den Vogelkop kleine eenheden in het binnenland zijn gebleven.

Deze omstandigheid maakt dit punt van onderzoek zoo moeilijk, omdat we dus in het algemeen niet meer den natuurlijken toestand

4) Ter Haar, Beginselen, blz. 13/14. 
van voor 1908 aantreffen, doch een kunstmatig in het leven geroepen reeks kampongs voor ons zien. Alleen door af te gaan op mededeelingen van ouden van dagen kunnen we ons een (overigens onvolledig) beeld vormen van de organisatie eertijds. Ook Kruyt deelt herhaaldelijk feiten mee uit dien tijd.

a. Wij zullen eerst het gezin in beschouwing nemen.

In den Archipel stonden in den ouden tijd de huizen zeer verspreid. De band tusschen de gezinnen was vrij los. Het eene gezin van grootouders, ouders en kleinkinderen hielp het andere niet bij den huizenbouw (dit kan ook daaraan liggen dat de huizen zoo eenvoudig van constructie waren) ${ }^{5}$ ).

Op den Vogelkop woonden ook de lieden gezinswijze verspreid: men vestigde zich daar waar men zijn akkers had. Deze werden ten gevolge van den roof-(ladang)bouw elk jaar op een andere plaats aangelegd, waardoor het opzetten van een huis een bijna jaarlijks wederkeerende bezigheid was voor de menschen van Balantak. Dit oprichten was gezinszaak, men werd daarbij niet door andere gezinnen geholpen ${ }^{8}$ ).

Uit Loinang bezitten we geen speciale mededeelingen hierover, doch wij weten dat daar dorpen waren gevormd, waardoor meer contact tusschen de gezinnen bestond (en bestaat). Deze dorpen waren min of meer permanent, de huizen waren stevig, eertijds vaak voorzien van snijwerk. Van de oude huizen resteeren er thans niet veel meer; ze zijn grootendeels vervangen door woningen van een nieuw model, ingevoerd door Minahassische onderwijzers; nog steeds worden deze in dorpsverband geplaatst ${ }^{7}$ ).

Zooals in het volgende hoofdstuk nader zal blijken was het gezin heffingseenheid; de op te brengen huldegift werd door de hoofden over de huisgezinnen verdeeld; men maakte daarbij wel onderscheid tusschen die met veel en andere met weinig weerbare mannen ${ }^{8}$ ). Was dit in Loinang echter anders? Tangkilisan spreekt nl. van "plichtige” tot het opbrengen van huldegift.

Van gezinsbezit zooals zich dat kan vormen bij den landbouw was op den Archipel geen sprake; de leden van elk gezin hadden ieder hun eigen akker, ja zelfs de beide echtelieden tuinden ieder voor zich

5) Kruyt, Bewoners, blz. 71.

6) Kruyt, Balantaksche Studiën, blz. 342, 343, 344.

7) Kruyt, To Loinang, blz. 369, 366, 371 en noot 1 blz. 371.

8) Kruyt, Balantaksche Studiën, blz. 340 . 
afzonderlijk: van gemeenschappelijk bezit in het huwelijk was geen sprake $^{\theta}$ ).

In Balantak is het vieren van het oogstfeest na het snijden van de nieuwe rijst in de ereste plaats gezinszaak; pas als alle gezinnen die tot één zelfde dorpsgemeenschap behooren klaar zijn met hun eigen huiselijk feest wordt het groote gemeenschappelijke oogstfeest gevierd ${ }^{10}$ ).

De hier geschetste gezinnen zijn de bouwsteenen der hieronder te behandelen groepeeringen.

b. Binsilo, gensing; langka-langkai-schap(?).

Vage mededeelingen zijn beschikbaar over de kleinste groepeering van gezinnen, in het aki binsilo, in het sian gensing geheeten; vermoedelijk moeten we hierin verzamelingen van aan elkaar verwante gezinnen zien, die (toevallig?) in elkaars nabijheid vertoefden, b.v. voor den akkerbouw. Bij de verspreid wonende aki- en sian-sprekers kunnen we deze kleinste groepeering als gehucht beschouwen, bij de aan vaste dorpen gebonden to Loinang mogen we van wijken spreken (zooals Tangkilisan dat doet). Op Peling noemt men wel hoofden over dergelijke groepeeringen (algemeen: $\operatorname{tano}$ ), doch er zijn groepeeringen bekend met meer binsilo dan er tano waren; hadden sommige van dergelijke gehuchten dan wellicht geen hoofd? Over de gensing in Balantak meldt men wel een tonggol. De to Loinang hebben een iets duidelijker structuur in dezen, waar men b.v. spreekt van een vijftal langka-langkai-schappen, tezamen een hoogere groepeering, Pinapoean, vormend; daarbij vergelijkt men de geheele streek met een hand, nl. vijf vingers aan één hand ${ }^{11}$ ). Als hoofd kon ook een andere titularis optreden, een pabisala (Tangkilisan). Het hoofdschap over dergelijke kleine eenheden was niet gebonden aan een afstammingscriterium: ieder die capabel was kon een dergelijke functie verwerven (Tangkilisan).

Of de binsilo ingeschakeld werd bij de heffing van huldegift e.d. is niet bekend; wel duiden Kruyts mededeelingen in die richting t.a.v. de gensing van den Vogelkop. Verder spreekt hij heel duidelijk in dezen geest ten aanzien van de langka-langkai-schappen, want ,iedere ,nederzetting of langka-langkai-schap bracht een (bepaalde mand) „met rijst op" ${ }^{12}$ ). Volgens Tangkilisan werden deze manden daarna bij het hoofd van de naast hoogere groepeering verzameld.

\footnotetext{
9) Kruyt, Landbouw, blz. 477; Bewoners, blz. 71.

10) Kruyt, Rijstbouw, blz. 136.

11) Kruyt, To Loinang, blz. 356.

12) Kruyt, To Loinang, blz. 355.
} 
Het is mij niet gebleken dat deze gehuchten of wijken grondenrechten uitoefenden; grensconflicten tusschen dergelijke eenheden zijn mij niet gemeld (hetgeen niet wil zeggen dat ze zich niet hebben voorgedaan; het bestaan van deze groepeering werd mij pas duidelijk toen ik reeds voor mijn vertrek naar Europa stond, en ik geen tijd meer had hierover verder navraag te doen).

Wat de factor bestuur betreft zou ik zeer voorzichtig willen zeggen dat het erop lijkt dat niet altijd doch meestal wel, een dergelijke groep een eigen hoofd heeft, dat echter niet krachtens zijn afstamming daarop aanspraak kan maken (zulks in tegenstelling tot de hoofden der straks te behandelen groepeeringen).

Ten aanzien van het al dan niet geordend zijn dezer groepeeringen heb ik den indruk dat deze meer een toevallige dan een noodzakelijke is ; zelfs het beeld van Pinapoean, de vijf vingers aan één hand, meen $\mathrm{ik}$ voor een toevallige ordening te moeten houden, daar in het Loinangsch systeem alleen zeven-deelingen passen (zie par. 5); ik waag het deze vijf-zes-eenheid van Pinapoean voor een spitsvondigheid van het mij persoonlijk bekende en op eigen grootheid uit zijnde toenmalige hoofd van Pinapoean te houden.

c. bense, tompoek.

Kruyt meldt ten aanzien van de bewoners van den BanggaiArchipel, dat men voorheen geen verzamelingen van huizen aantrof waaraan men den naam dorp zou kunnen geven; slechts op eenige plaatsen vond men groepen woningen, daar nl. waar een kota (steenen wal, ringmuur) bescherming bood. Het bleek mij dat daar eertijds meestal de hoogste hoofden woonden (zie $d$.). De namen die op de oude kaarten voorkomen zijn over het algemeen de aanduidingen der plaatsen waar deze gevestigd waren ${ }^{13}$ ). Hun onderhoorigen waren op bepaalde wijze gegroepeerd in verbanden (bepaald door de verwantschapsverhouding) om dit middelpunt gevestigd.

Op de schetskaarten die de patrouille-commandanten uit de eerste jaren na 1908 op den Vogelkop maakten, leest men vele namen van „,dorpen”, doch er waren feitelijk in dien tijd nog geen groepeeringen die een dergelijken naam verdienden. Daar waar de hoofden verblijf hielden stonden eenige ( 3 tot 6 ) huizen, doch de onderhoorigen woonden verspreid om deze plek heen. Kruyt prefereert het daarom van dorpsgemeenschappen te spreken, die zich noemden naar de plek waar het hoofd woonde ${ }^{14}$ ).

13) Kruyt, Bewoners, blz. 71.

14) Kruyt, Balantaksche Studiën, blz. 341 v. 
Over Loinang lezen we dat elk dorp door een familie in uitgebreiden zin bewoond wordt, en omdat deze verwantengroep één gemeenschappelijken voorvader heeft, die als pilogot vereerd wordt, heeft elk dorp ook zijn eigen pilogot ${ }^{15}$ ). (Dergelijke dorpen kunnen dan verdeeld zijn in wijken, doch vereeren vermoedelijk alle den gezamenlijken voorvader).

Wordt in Loinang een dorp in dezen zin dus gevormd door een groep van aan elkaar verwante gezinnen, op den Vogelkop en in den Archipel was het niet anders, zooals mij bleek; deze verwantschap is overigens vaak een traditoneele, niet traceerbare. Dergelijke groepeeringen dragen in het aki den naam bense; op den Vogelkop worden zij ook zoo genoemd doch in het madi heeten zij tompoek. Dit laatste begrip past zoowel op de uiterlijk meer op een oord van samenwoning lijkende eenheden uit de Loinangstreek, als op de eertijds eveneens verspreid gegroepeerd wonende overige madi-sprekers.

Het woord bense wordt in de literatuur éénmaal genoemd in de beteekenis van "moederkampong” of ,verzameling van huizen”, en dan speciaal met het oog op Balantaksche verhoudingen ${ }^{\mathbf{1 6}}$ ).

De leden van zoo'n groep achten zich verwanten van elkaar; zij kunnen deze verwantschap echter niet terugvoeren tot één voorouderpaar. De onderlinge banden worden voortdurend aangehaald door practijk van huwen in dezelfde bense.

Bovendien is de groep in haar geheel steeds deel van een hooger verband; dit komt ook tot uiting in de beteekenis van het woord bense (aki), dat vertaald wordt met: deel van een grooter geheel. Middelpunt van dit hooger verband is b.v. de balakat, waaraan de bense zich groepsgewijze gebonden voelen.

De basis van samenwoning is dus een religieuze, de band tusschen de individuen is deels traditioneel, deels reëel. Het collegiale in de groepeering uit zich verder in de wijze waarop zij een hoofd over zich stelde.

Kunnen we groepen als bense en tompoek aanmerken als rechtsgemeenschappen? Bezien we eerst de factoren.

Het geordend zijn der groep is een werkelijkheid, want door het feit dat de leden aan elkaar verwant zijn (feitelijk en traditioneel) èn doordat zij hetzelfde vereeringsobject bezitten, hebben wij in deze groep een natuurlijk gegroeide (gevormde) eenheid te zien; veran-

15) Kruyt, To Loinang, blz. 401.

16) Kruyt, Balantaksche Studiën, blz. 335 . 
dering of ontbinding van een dergelijke groep is onmogelijk, het traditioneele karakter domineert.

Ook een bestuur is aanwezig; het zal blijken dat hoofden (in het algemeen als tonggol aangeduid), tezamen met een raad het bestuur voerden; de groep zelf stelde deze hoofden aan in gemeenschappelijk overleg en wees daartoe personen aan uit bepaalde hoofdenfamilies. De helpers waren wellicht soms (tevens?) binsilohoofden, doch er bestonden ook wel meer binsilo dan helpers van het hoofd aanwezig waren; er zijn ook bense zonder binsilo, doch wel zijn er altijd helpers, trawanten, van het hoofd om hem te helpen bij het bestuur. Iedere tonggol ontving inkomsten van de onder hem staande groep.

De vermogensrechtelijke zijde der vraag is echter dubieus. Pas in het zoo juist genoemd hoogere verband treden duidelijke vermogensrechtelijke factoren op (b.v. een tempel voor de, met andere bense gemeenschappelijke, balakat). Ik wil hierbij nog den nadruk leggen op de grondbeteekenis van het woord bense, nl. deel van een grooter geheel. Aan den anderen kant spreekt Kruyt van de grenzen van het gebied, behoorende tot de dorpsgemeenschappen of clans van den Vogelkop ${ }^{17}$ ).

Tangkilisan duidt het tot een tompoek behoorende gebied aan met lipoe, hetgeen we hier moeten vertalen met landstreek (en niet met dorp als in het Bare'e); het is overigens niet duidelijk of deze lipoe bij de Loinang het bebouwde en bewoonde areaal is, zooals dat geoccupeerd wordt door de leden van de groep (het totaal dus van terreinen waar leden van de groep rechten op uitoefenen), dan wel dat lipoe als zoodanig een aparte rechtsfiguur voorstelt, een tompoekareaal. Niettegenstaande alle navraag mijnerzijds, is niets gebleken van grensconflicten tusschen bense, behoorende tot een zelfde hoogere groepeering. Wel kennen de tompoek immaterieel vermogen, want als zoodanig mogen we den (dorps) pilogot beschouwen, zooals Kruyt hem beschrijft.

Op Oost-Peling is het eenige dat wijst op de aanwezigheid van bense-vermogen een heilig voorwerp (een poepoeoekon, een als hoorn in gebruik zijnde schelp), traditioneel verbonden met de stammoeder van Salangano.

Zoolang geen zekerheid over de algemeene aanwezigheid van den factor vermogen bestaat mogen we de bense niet aanmerken als rechtsgemeenschap; een argument te meer is, dat ik nimmer bense

17) Kruyt, Balantaksche Studiën, blz. 342 . 
zelfstandig aantrof, doch steeds als onderdeel van de nu te behandelen hoogcre groepeeringen.

d. basalo-, bosanjo-, bosanoschap; zelfstandig daka'njoschap.

Deze groepeeringen zijn opgebouwd uit een zeker aantal bense (tompoek), die dezelfde balakat vereeren. Het totaal der benseleden acht zich de afstammelingen, b.v. van het volkje door den Opperheer geschapen op een bergtop (West-Peling, Vogelkop), of van de huisgezinnen die onderhoorig waren aan het eerste, steeds met bovennatuurlijke krachten begiftigde, hoofd (Oost-Peling). Zij vinden dus wederom in de eerste plaats op religieus gebied haar binding. In het algemeen zeggen de legenden dat na een zeker aantal generaties nà het ontstaan der groep, de leden zich in een aantal bense deelden. (M.a.w. niet een aantal bense vereenigde zich tot een basaloschap, doch dit laatste verdeelde zich in bense).

Het aantal bense of tompoek dat op deze wijze in hooger verband vereenigd is, kan uiteraard niet willekeurig zijn; de antallen der deelnemende eenheden zijn traditioneel vastgelegd, en bedragen in het algemeen gesproken vier, zeven of twaalf. (Later kom ik hierop uitvoerig terug). Deze groepen lagen in oude tijden geschaard om het religieus centrum, elke bense of tompoek een streek bewonend. Daar waar een vierdeeling valt waar te nemen wordt de ligging vaak ongeveer volgens de windrichtingen opgegeven.

Hoe sterk de traditie in de samenstelling dezer verbanden gevoeld werd blijkt wel hieruit, dat toen eens van één der basaloschappen van de vier bense één teniet ging (uitstierf door ziekte) en er dus van dat verband maar drie resteerden, één daarvan zich splitste, waardoor het viertal weer compleet was.

Een hoogste hoofd (aki: basalo; madi: bosanjo; sian: bosano) zetelde meestal in de onmiddellijke nabijheid van het religieuze middelpunt. Dit zijn dan de hoofden waarvan het op Peling (ook in sommige deelen van den Vaste-Wal) heet, dat zij vaak in versterkte plaatsen, kota, woonden; de plekken grond, (ook vestiging zonder kota kwam voor) droegen uiteraard, zooals steeds bij de Indonesiërs, namen, en naar deze noemen zich die hoofden in het algemeen. Veranderingen waren daarbij niet uitgesloten. Toen de basalo van Tambalam gedurende vier generaties op de plek van dien naam gewoond hadden, verhuisden zij naar een streek waar veel djeroekboomen groeiden (aki: popiisi); van toen af aan heetten zij basalo Popiisi, gedurende zeventien generaties tot heden.

De onderhoorigen van zoo'n basalo noemden zich nu weer naar 
hun hoogste hoofd; zoodat in dit geval desgevraagd zoo iemand opgeeft te zijn mian Popiisi of Popiisi miano. Weliswaar bestaat het volk van Popiisi uit vier bense, doch de bensenaam is secundair; naar buiten geven de onderhoorigen, weliswaar leden van een der deelen, allereerst den naam op van het geheel. Pas na dieper doordringen deelen zij dan mede tot welke der vier bense zij behooren; binnen de engere begrenzing der bense voelt blijkbaar iedereen zich lid van die grootere, uit eenige dergelijke groepen opgebouwde, gemeenschap. Overigens treft het dat de naamgeving, zooals zoo vaak in Indonesische rechtsgemeenschappen, diffuus is en dat er geen term bestaat voor het basaloschap als geheel. Aanteekening verdient dat de naam Loinang geen eigennaam is; deze werd gegeven door strandbewoners aan menschen uit de bergen, welke laatste hem echter als scheldwoord beschouwen. $\mathrm{Zij}$ noemen zich zelf mian Lingketing, etc.

Dit hoogere verband had een eigen bestuur, waarbij het hoogste hoofd (basalo enz.) ter zijde werd gestaan door een groep helpers, meestal o.a. de hoofden der samenstellende groepen (bense enz.). De aanwijzing tot het hoofdschap geschiedde door gemeenschappelijk overleg onder de groepsleden, totdat overeenstemming was bereikt, uit een groep personen, die daartoe als rechtstreeksche afstammelingen van den stichter gerechtigd waren. $\mathrm{Na}$ de aanwijzing had er een ceremonieele inhuldiging (erkenning) plaats, waarbij pas feitelijk dit hoogste hoofd als zoodanig geinstalleerd werd. Bij deze inhuldiging werden de vergoddelijkte voorouders van het hoofd (balakat, pilogot) weder gekend, niet zelden doordat zij geschiedde op de plaats waar zich de poesaka-voorwerpen bevinden. Het op deze wijze nauw met de voorvaderen verbonden hoofd werd in dier voege de handhaver van de overgeleverde traditie. (En dit maakte ook het onderzoek in deze materie zoo lastig, omdat door van de groepsgeheimen aan anderen te vertellen $\mathrm{zij}$ zich bloot stelden aan vermindering van magische kracht, dan wel aan ontevredenheid der vergoddelijkte voorouders, zich openbarend in onweders en regens).

Ten slotte voorzag de geheele groep het gemeenschappelijke hoogste hoofd van inkomsten, waarbij voor de lagere hoofden er ook wat afviel, terwijl gezamenlijk de groep aansprakelijk was voor het opbrengen van een jaarlijksche huldegift aan den vorst van Banggai.

Eveneens bezaten deze groepen duidelijk vermogen. In de eerste plaats wel is het de landstreek, gelegen om het religieus centrum, deze grond die de voorvaderen bij hun leven voedde en hun lichamen opnam bij hun sterven, en die nu in de eerste plaats moet dienen tot 
het in leven houden van de levende leden van de groep ${ }^{18}$ ). Dit areaal heet zeer zeker op Peling lipoe, ook in Loinang; de aanduiding op den Vogelkop is niet duidelijk (wellicht in verband met het feit dat daar ook van gronden tot lagere gemeenschappen behoorend wordt gesproken). Grensgeschillen tusschen basaloschappen enz. zijn bekend.

Verder zijn zeer reëele deelen van het vermogen de tempels van Oost-Peling (aki: koesali), de poesaka-voorwerpen bij de madisprekers (vaak van den voorvader afkomstige wapens en muziekinstrumenten) die slechts met groot ceremonieel mogen worden te voorschijn gehaald, het graf van daka'njo Kamboa bij de mian Lingketing, terwijl ook balakat als die van Boniton en van Daloe duidelijke objecten zijn ten aanzien waarvan vermogensrechten door de betrokken groepen worden uitgeoefend.

Als immaterieel vermogen (in Oosterschen zin) kunnen we de vergoddelijkte stichters en eerste hoofden beschouwen, op wier hulp en zegen alle leden van de groep gelijkelijk aanspraak, tot wier vereering zij gelijkelijk verplichting hebben ${ }^{19}$ ).

Naast de groepeeringen als boven beschreven, en die onder een basalo of anderen functionaris met overeenkomstigen titel stonden, vinden we gemeenschappen die eenzelfden opbouw vertoonen, doch wier hoofd een lageren titel voert (b.v. daka'njo, mian kopian); dergelijke groepeeringen zijn, hetgeen overigens in bovenstaande regels reeds tot uitdrukking kwam, als geheel gelijkstandig met de basaloschappen enz. te beschouwen.

Ter vermijding van een te groot gebruik van Indonesische termen, en in de hoop dat daarmee dit geschrift aan leesbaarheid wint, zal, wanneer daartoe aanleiding bestaat, de binsilo ,gezinnenkring”, de bense „familiegroep”, het basaloschap „streekgemeenschap" genoemd worden.

e. kamali; pinasang, soelapa; bongoenon, lenas.

In vele, niet alle, dezer streekgemeenschappen bezat het hoogste hoofd, de basalo enz., een aparte woonwijk, gevormd door zijn naaste bloedverwanten. Dit is dus een aparte groep van adellijken, die, anders dan de leden der familiegroepen, wèl hun afstamming terugvoeren tot den vergoddelijkten stichter (balakat) of het eerste hoofd. De overleveringen van dit hoofdengeslacht worden verteld als die van de geheele streekgemeenschap. Vaak is het begin, dat een prins of een

18) Verg. ook: F. D. E. van Ossenbruggen, Verwantschapsverhoudingen, blz. 3.

19) Kruyt, To Loinang, blz. 402. 
prinses met een groep volgelingen zich ergens vestigde; elders spreekt men wel van geesten als eerste onderhoorigen. Daarentegen troffen op den Vaste-Wal de Boalemosche immigranten een oerbevolking aan, waarover zij zich als hoofden opwierpen (zie blz. 23 v.). Over het algemeen tellen de hoofdengeslachten 15 à 20 generaties tot heden.

De adelgroep zetelde meestal in de nabijheid der vereerde voorwerpen, nabij het religieus centrum dus; ten huize van het hoogste hoofd werden (en worden) de poesaka-voorwerpen vaak bewaard. Daar waar de gemeenschap over een versterkte plaats, een kota, beschikte, zetelde deze adelswijk daarbinnen.

Het bestuur over deze adelgroep berustte vaak in handen tevens van het hoogste hoofd, den basalo enz., bijgestaan door eenige trawanten uit zijn adellijke verwanten. Elders treffen we wel een afzonderlijk hoofd over dergelijke groepen aan.

Vermogen was wellicht niet aanwezig. De balakat of de poesakavoorwerpen toch waren niet speciaal bezittingen van deze groep, terwijl er geen spoor te bekennen valt van het uitoefenen van grondenrecht; de leden der familiegroepen hadden geenerlei relaties met die adelgroep te onderhouden, waren niet afhankelijk van hen in grondzaken, en waren ook niet verplicht hen van inkomsten te voorzien.

In het aki kent men den term kamali, waarmee te Banggai ook het paleis van den vorst wordt aangeduid; het madi spreekt van pinasang, op één enkele plaats soelapa; hierin ligt geen tegenstelling tusschen plaatsen al dan niet van een ringwal voorzien; op den Vogelkop heet deze groep de bongoenon of lenas van het bosanoschap.

Het feit dat het hoogste hoofd en zijn verwanten een aparte woonplaats hebben is een typisch Indonesische trek: er wordt afstand geschapen, het hoofd is de bindende factor, als bewaker en bewaarder der traditie, doch hijzelf is niet bevangen in het groepsbindende: de afzondering is een uiting van zijn gezag ${ }^{20}$ ).

$f$. de federatie.

Als zoodanig kunnen we het Lipoeadinoschap aanmerken. Het is mij niet duidelijk geworden of de kern van deze groepeering (de streekgemeenschappen Lolantang, Palabatoe en Soeit) zich vrijwillig onder den vreemden vorstentelg stelden (wellicht in verweer tegen Banggai), dan wel dat de Banggaische vorst deze drie groepen als

20) F. D. Holleman, De commune trek in het Indonesisch rechtsleven, Leiden 1935, blz. 7. 
apanage afstond, opdat de Boalemosche prins een staatsie zou kunnen voeren, overeenkomend met zijn stand (zie blz. 24 v.). Doch het feit dat b.v. Kadoepang, thans Basososol, zich vrijwillig onder hem stelde, en dat Keleke en Lo'nsom zonder meer aanvaardden dat de Lipoeadino zich als hun heer opwierp, geven grond om hier te spreken van een Indonesische federatie. Daarbij dienen we in het oog te houden, dat waarschijnlijk alle twaalf onder hem ressorteerende onderdeelen ieder voor zich een rechtsgemeenschap waren.

Werd deze federatie nu ook een rechtsgemeenschap? Wij moeten deze vraag ontkennend beantwoorden, want er ontstond geen hoogere eenheid. Toen de band die deze twaalf deelen bond, wegviel (dat was toen na 1908 de Lipoeadino geen plaats verwierf in het toen opgebouwde bestuursapparaat), viel deze federatie als los zand uiteen. De aanwezigheid van den Lipoeadino had meer het karakter van een overkapping over zeer ongelijksoortige onderdeelen gedragen, dan dat hij de representant van een nieuwe eenheid werd. De deelen van die voormalige federatie zijn zich nu nog wel bewust onder dezen hoogen edele te hebben gestaan, doch er zijn geen banden tusschen hen onderling aangeknoopt; zelfs de beide bosanjoschappen Keleke en Lo'nsom, naast elkaar gelegen op den Vaste-Wal, staan nu nog geheel los van elkaar.

Het geordend zijn van deze federatie was dus van toevalligen aard, slechts steunend op het prestige van het hoogste hoofd. Aan het bestuur over het geheel namen slechts drie der twaalf onderdeelen deel. Ten slotte is er geen spoor van gemeenschappelijk vermogen te bekennen; dit wordt nog daardoor geaccentueerd dat de Lipoeadino allen Mohammedanen zijn, doch vele der onderdanen heidenen. $\mathrm{Er}$ is geen gezamenlijke balakat; een heilig Mohammedaansch graf te Lolantang, van beteekenis voor de Lipoeadinofamilie als te zijn de laatste rustplaats van een Said die den Islam met zich bracht, is van niet het minste belang voor zijn onderhoorigen.

g. de voormalige rijkjes.

Hoe weinig ook wij van de organisatie daarvan afweten, toch is ons iets bekend waaruit we eenige gevolgtrekkingen mogen maken. Het feit dat soms een geheel rijk in oorlog kwam, waarbij het wel vernietigd kon worden, is een sterke aanduiding dat we met geordende groepen te doen hebben. Buitendien spreekt men steeds van vorsten met een precies aangegeven titulatuur, ja men weet zelfs nog iets van den raad van één hunner. Ten slotte is de vermogensfactor minstens daar aanwezig, waar als centrum van het rijk een verster- 
king was gebouwd binnen welke de vorst woonde, bij wien zich soms een heilig voorwerp bevond om welks bezit het geheele volk in strijd gewikkeld kon worden.

Zoo zien we dat in wezen de voormalige rijkjes, voor zoover we daarover kunnen oordeelen, reeds op dezelfde wijze waren georganiseerd als de huidige groepeeringen, waarvan we met zekerheid hebben kunnen zeggen dat het rechtsgemeenschappen zijn.

$h$. de stam.

Zooals reeds op blz. 4 werd medegedeeld weten we op ethnologisch terrein zeer weinig van deze streken; ik kan hier niet aangeven welke eenheden dus volkenkundig als zoodanig dienen te worden beschouwd. Slechts als hypothese wil ik de mogelijkheid naar voren schuiven dat we wellicht oorspronkelijk met een primitieve oer-bevolking te doen hadden (waarvan b.v. op den Vaste-Wal de koetoe no tano deelen waren), die door later binnengedrongen immigranten overheerscht werd. Uit vermenging van beide groepen ontstond de huidige bevolking (verg. blz.7 en de Slotbeschouwing).

$i$. het landschap.

Volledigheidshalve moet de vraag nog beantwoord worden of het landschap ook rechtsgemeenschap is. Hiertoe dienen we wederom de bekende criteria te bezien.

Dat we hier met een geordende groep te maken hebben is duidelijk. Eertijds bestond deze uitsluitend uit de onderhoorigen van de landshoofden, na 1908 (toen het territorialiteitsbeginsel doorslaggevend werd) uitgebreid met alle Indonesiërs die binnen het gebied van het zelfbesturend landschap metterwoon gevestigd waren. Deze personen erkennen subjectief, door zich te plaatsen onder de bevelen van den Banggaischen vorst, dat $z \mathrm{ij}$ weten diens bevelen te moeten opvolgen, waardoor zij zich tot leden van een hooger verband maken. Eenmaal, in 1930, is ter sprake gekomen het landschap te splitsen ${ }^{21}$ ); men dacht van het op den Vaste-Wal gelegen deel een eigen landschap te maken, en wilde dit stellen onder den toenmaligen rijksbestuurder Hanapii; het streven tot een en ander ging uit van het Europeesch bestuur. Doch op het verzet van hoofden en bevolking is dit voornemen afgestuit; het argument ontleende men daarbij aan het verleden waarin het vorstendom Banggai als een eenheid gegroeid is.

Het eigen bewind in den vorm van den vorst met adviesraden en

21) Encyclopaedie van Nederlandsch-Indië, dl. VII (de 3e Supplementband), blz. $1281 \mathrm{~b}$. 
vertegenwoordigers der bevolking elders zal nader behandeld worden in hoofdstuk V; genoeg zij dat er vrij doeltreffende organisatie bestond waardoor de vorst uit alle deelen van zijn rijk jaarlijksche huldegift ontving.

Ook de factor eigen vermogen is aanwezig. In de eerste plaats zou ik als zoodanig willen aangemerkt zien de groote balakat van het vorstenhuis, nl. die van Boneaka en van Boniton; hoe belangrijk beide zijn voor het wel en wee van vorst en volk komt o.a. tot uiting bij de plechtige inhuldiging van den vorst ${ }^{22}$ ).

Vermogensrechtelijke elementen in westerschen zin waren reeds vorige eeuw aanwezig. Er moet b.v. vóór 1908 reeds een „negeri”kas zijn geweest, waarin o.a. gerechtelijke boeten werden gestort ${ }^{23}$ ); is hieruit het door Goedhart vermelde, door den vorst bewoonde, huis aangekocht? Andere elementen uit dien tijd zijn b.v. de jaarlijks op te brengen huldegift en geschenken waartoe het landschap in de persoon van den vorst jegens den sultan van Ternate verplicht was.

$\mathrm{Na} 1908$, toen een landschapskas werd ingevoerd, nam deze vermogensrechtelijke factor een uitsluitend geldelijk karakter aan; sinds dien restitueert het landschap aan het Gouvernement van N.-I. alle uitgaven door dat Gouvernement in het rechtstreeksch belang van het landschap gedaan, terwijl het bovendien in den loop der jaren bezitter is geworden van tal van roerende, zoowel als onroerende goederen (effecten; machines, gereedschappen, gebouwen).

$j$. vereenigingen (volkssfeer).

Slechts uit Loinang bezitten we een mededeeling betreffende een bepaalden vorm van vereeniging, die de mogelijkheid in zich heeft een rechtsgemeenschap te $z$ ijn ${ }^{24}$ ). Het is de sambaba (madi), een landbouwvereeniging. Wanneer men akkers aanlegt vereenigt men zich nl. tot gezelschappen, die elk hun velden aanééngesloten, als één geheel, maken; zoo'n sambaba staat onder leiding van een voorganger (madi : tanaas of tonaas); als zoodanig kan ook een krijgsaanvoerder optreden. Die voorganger bepaalt wanneer men het werk zal beginnen; onbekend is of hij dwingende macht heeft nalatigen tot gehoorzaamheid te brengen.

Een dergelijke sambaba kunnen we niet beschouwen als rechtsgemeenschap; van het optreden naar buiten als eenheid is niets gebleken. De groepeering der leden is wellicht een toevallige, nl. van

22) Kruyt, Vorsten, blz. 613-614.

23) Goedhart, Drie landschappen, blz. 451, 470.

24) Kruyt, To Loinang, blz. 413-414. 
die personen die hun akkers aan dezelfde zijde van het dorp willen gaan aanleggen. $\mathrm{Zij}$ zit daardoor los in elkaar, beoogt slechts een bepaald eng omschreven doel en is vermoedelijk alleen van tijdelijken aard. De gezamenlijke leden richten een hut op het te beplanten veld op, waarbij een offertafeltje wordt geplaatst voor de zielen der afgestorvenen; ieder der deelnemende gezinnen legt hier zijn of ferande neer. Wij kunnen dit kwalijk aanmerken als vorming van (c.q. magisch) vermogen.

Het bestuur over het landbouwgezelschap wordt gevormd door hoogergenoemden voorman met twee assistenten (pombebe'i en pahemata); na afloop van den oogst geeft ieder gezin rijst en een hoen aan den voorganger, die daarvan aan elk zijner helpers één vijfde deel afdraagt. Hoever het gezag van dit bestuur zich uitstrekt, en hoe die voorman de vereeniging tegenover derden zou kunnen vertegenwoordigen is onbekend.

Derhalve is de sambaba geen rechtsgemeenschap.

Als wij het in de vorige bladzijden besprokene kort samenvatten, blijkt dat met de thans beschikbare gegevens alleen van de streekgemeenschappen gebleken is dat zij rechtsgemeenschappen zijn, terwijl het van de samenstellende deelen een vraag is.

Enkele feitelijke gegevens der streekgemeenschappen zullen nu besproken worden.

\section{Structuur en omvang der streekgemeenschappen.}

Hooger, op de blz. 26 v., kwamen reeds de basaloschappen ter sprake, waarvan ik toen mededeelde dat $\mathrm{zij}$ de bouwsteenen van het huidige landschap Banggai vormden en vormen. En zooals we in hoofdstuk V zullen zien sloot de bestuursorganisatie van vóór 1908 inderdaad op deze volksgemeenschappen aan. Ieder onderhoorige van den Banggaischen vorst (met uitzondering van een kleine groep familieleden van dezen) was in de eerste plaats onderhoorige van een der genoemde basalo (enz.).

Thans is deze binding der onderhoorigen aan hun oude hoofden, al heeft ons bestuur gedurende ruim 30 jaar de volksstructuur genegeerd, nog even bewust als eertijds; zooals ik op blz. 58 aangaf, drukt de onderhoorige van een basalo dit uit door zich te verklaren tot een mian.... (basalonaam).

Om de indeeling van de huidige bewoners der bestuurlijke kampongs te weten te komen, liet ik aan de hand der kohieren 1938 van de landschapsinkomstenbelasting van elken belastingplichtige nagaan, 
tot welke groep hij zich rekende; het aantal zielen is dan \pm 4 maal zoo groot ${ }^{25}$ ).

Hiermede was het mogelijk aan te geven:

1. ongeveer hoeveel zielen elke streekgemeenschap thans telt;

2. waar deze, en de samenstellende familiegroepeeringen zich thans ophouden (kampongstructuur na 1908);

3. hoeveel en welk soort vreemdelingen men in het landschap vindt (bestuurstechnisch belangrijk);

4. hoevele leden der streekgemeenschappen naar elders zijn verhuisd, en dus niet hebben meegewerkt aan de stichting der dorpen na 1908;

5. de bevolking der transmigratiegebieden (van deze gegevens maakte ik reeds gebruik voor samenstelling van par. 4 van hoofdstuk II).

Als resultaat van het onder 1 genoemde volgen hier de betreffende cijfers :

Eiland Banggai :

Tano Bonoenoengan . . . . . . . . 37 belastingplichtigen

Dodoeoeng . . . . . . . . . . . 36 id.

Gong-Gong . . . . . . . . . . . 26 id.

Monsoongan . . . . . . . . . . 48 id.

Lampa, Poetal, Boneaka . . . . . . niet opgegeven

Totaal . . . . . . . . . . . . . 147 belastingplichtigen

Op het eiland Banggai zijn rond 1300 belastingplichtigen geregistreerd; onder hen bevindt zich ook een gering aantal, grootendeels in de kampong Lompio vrezamelde, vorstentelgen. Deze kampong Lompio, ook wel genaamd Paoe Banggai, is hier kamali, en staat ten opzichte van het landschap in dezelfde verhouding als de kamali der streekgemeenschappen elders. Uit dien hoofde moet ook betwijfeld worden of de kampong Lompio thans rechtsgemeenschap is.

Eiland Peling:

Gebied van den Lipoeadino

(zonder $f$ en $g$ ) . . . . . . . . . 1378 belastingplichtigen

Tinangkoeng . . . . . . . . . . . 284 id.

Liang . . . . . . . . . . . . . 253 id.

Paisoeoeloeno . . . . . . . . . . 529 id.

Peling . . . . . . . . . . . . . 178 id.

Boelagi . . . . . . . . . 1172 id.

25) Memorie.

Verh. dl. VI. 


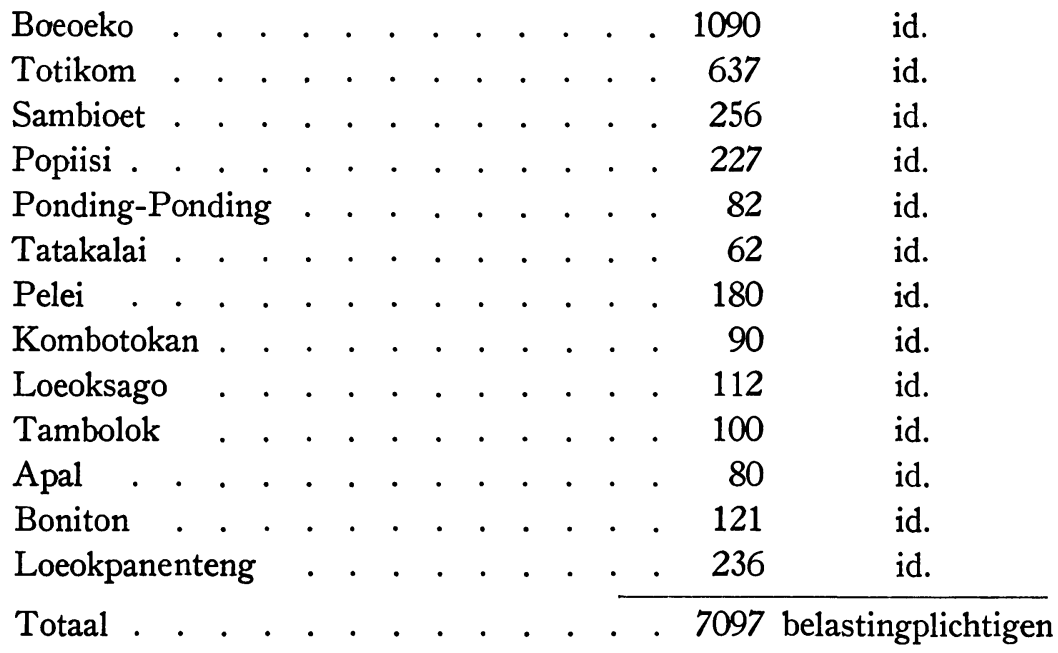

Op het eiland Peling zijn rond 9500 belastingplichtigen geregistreerd.

Vaste-Wal (zuidkust):

Batoei . . . . . . . . . . . . . 245 belastingplichtigen

Tangkiang . . . . . . . . . . . 293 id.

Kintom . . . . . . . . . . . . 331 id.

Mendono . . . . . . . . . . . . 128 id.

Lontio . . . . . . . . . . . . . 149 id.

Nambo . . . . . . . . . . . . 207 id.

Loewoek . . . . . . . . . . . . 403 id.

Keleke + Lo'nsom . . . . . . . . 407 id.

Basama . . . . . . . . . . . . 180 id.

Lamala (Tanotoeran) . . . . . . . 910 id.

Dale-Dale . . . . . . . . . . . 1184 id.

Sinohoan + Minahaki . . . . . . . niet opgegeven

Vaste-Wal (binnenland) :

Doehian (Baloa) . . . . . . . . 630 belastingplichtigen

Id. uitgezwermd . . . . . . . . . . 92 id.

Lingketing . . . . . . . . . . . 294 id.

Id. uitgezwermd

Mehangi . . . . . . . . . . . . 84 id.

Andere groepen . . . . . . . . . n niet opgegeven

Uitzwermingen id. . . . . . . . . . . n niet opgegeven

Totaal . . . . . . . . . . . . . 5818 belastingplichtigen 
Op den Vaste-Wal zijn rond 11.300 belastingplichtigen geregistreerd.

Uit het bovenstaande blijkt dat op het eiland Banggai slechts een klein gedeelte der bevolking gevormd wordt door de leden der daar gevonden streekgemeenschappen; de rest is voornamelijk uit OostPeling afkomstig. Op Peling daarentegen is het overgroote deel der bevolking begrepen in een der daar gevonden streekgemeenschappen. Op den Vaste-Wal ten slotte verblijft $\pm 50 \%$ der bevolking binnen haar streekgemeenschappen, doch groote aantallen zijn uitgezwermd naar de noordkust (zie blzz. 30 tot 35). Vogels van diverse pluimage, zooals Badjo's, Boegineezen e.d. vormen verder de bevolking van dit gedeelte van het landschap.

Waar ik tevens bij dit onderzoek de indeeling naar familiegroepen noteerde werd inzicht verworven in de structuur der streekgemeenschappen; het daarmee bereikte, bestuurlijk interessante, resultaat buiten het kader van dit werk vallend was, dat nu bekend werd in welke kampong van thans elk der familiegroepen van weleer zich bevindt.

Streekgemeenschappen op het eiland Banggai kennen geen indeeling in familiegroepen; de verklaring hiervan ligt in de traditie die zegt dat vier mannen met een vorst in hun midden op het eiland kwamen (blz.36). Indien elk dezer mannen de representant is van een familiegroep en de vorst de adelgroep voorstelt, verwondert het niet dat we geen deeling hiervan aantreffen.

Alle in origine West-Pelingsche streekgemeenschappen, zoowel de zelfstandige als de onder den Lipoeadino staande (onderscheidenlijk: Boeoeko, Boelagi, Peling; Lolantang en Palabatoe) zijn opgebouwd uit twaalf familiegroepen en een adelgroep. Slechts t.a.v. Soeit is een en ander onduidelijk.

De Oost-Pelingsche streekgemeenschappen zijn alle opgebouwd ait vier familiegroepen, evenals het weliswaar in West-Peling gelegen, doch van Banggai afkomstige Loeokpanenteng. Slechts Apal vormt een uitzondering, want het bestaat slechts uit één familiegroep; wij zagen dat het uit een gezinnenkring van Liang is ontstaan (blz. 30). Verder vond ik bij een achttal dezer Oost-Pelingsche streekgemeenschappen een aparte adelwijk.

Op den Vaste-Wal bestaat alleen Tangkiang uit drie familiegroepen. Batoei, Kintom en Mendono tellen ieder zeven van dergelijke groepen, Lontio, Nambo en Mangkiin Piala worden gevormd door vier familiegroepen. Tanotoeran en Dale-Dale tellen samen zeven groepen, 
omtrent één waarvan het onzeker is tot welke der beide streekgemeenschappen zij behoort; deze zeven groepen dienen dus vier-drie, dan wel drie-vier verdeeld te worden. Basama kent drie groepen. Alle hier genoemde streekgemeenschappen kennen bovendien een adelgroep; zeker vijf van deze waren eertijds gevestigd binnen een kota.

Van de zelfstandige onderdeelen in de bergen of aan de noordkust noemen we Doehian met acht, Awok met vier familiegroepen; Lingketing en Pokooehan ieder met zeven en Saloean met drie dergelijke groepen. Pokooehan had een aparte adelwijk, soelapa geheeten.

Sinohoan en Minahaki ten slotte, immigranten, kennen een dergelijke verdeeling niet.

\section{Rechtsgemeenschappen bij trans- en immigranten.}

Zooals we weten kunnen we in Bangkoeloe drie instroomingen opmerken, t.w. van Sea-Sea, van Boelagi en van Banggai.

We vinden hier de elementen terug die doen vermoeden dat er zich oorspronkelijk drie rechtsgemeenschappen hebben gevormd, met als onderscheiden middelpunten de balakat van Sasange, van Boengkoeko Maaling en van Lantiboeng.

Van de eerste weten we het minst; dit groepje Sea-Sea had gedurende vier generaties een tonggol, een eigen hoofd dus. De balakat was vermogensbestanddeel, het geordende van de groep ligt in de vereering tevens van dit voorwerp, en het exclusief karakter van de Sea-Sea. Verder is mij niets bekend geworden over dit groepje.

Daarentegen bouwden de Boelagiërs een organisatie op die veel trekken van overeenkomst vertoonde met die in het oorsprongland; ik vond nl. dat er zich twaalf familiegroepen hadden gevormd om een adelgroep, als hoedanig de plaats Balolombitan, aan den voet van den als balakat vereerden berg Boengkoeko Maaling, fungeerde. Opvallend is dat deze Boelagiërs, die in hun oorsprongland een verdeeling van twaalf familiegroepen kennen, eveneens een dergelijke organisatie in dit transmigratiegebied in het leven riepen. Dit is een sterk bewijs voor de natuurlijke (onbewuste?) vorming van de structuur dezer rechtsgemeenschappen. Is wellicht iedere Bangkoeloesche familiegroep de voortzetting van een der twaalf uit Boelagi? Dit lijkt onwaarschijnlijk, want dan zouden uit twaalf verschillende familiegroepen eenige gezinnen hebben moeten verhuizen naar een vreemd land. Maar voor de hand ligt, dat van een paar van dergelijke groepeeringen een flink aantal lieden wegtrok, en in den vreemde 
aangekomen, daar een organisatie stichtte, overeenkomstig de eigen in het oorsprongland bestaande; het feit dat de basalo zich bij die transmigranten bevond zal aan die wijze van opbouw niet vreemd zijn geweest. Nadat hij echter naar Boelagi was teruggekeerd veranderde er niets in de structuur; ook het eigen bewind bleef zich handhaven, nl. door middel van eenige verwanten van den basalo (waren deze daar als zijn gevolmachtigden achtergelaten?; het waren dezelfde die elders als zijn helpers en trawanten in de adelgroep werden aangeduid).

De groep Banggaiers, die zich om den balakat Lantiboeng schaarde, dient eveneens als rechtsgemeenschap te worden aangemerkt. $\mathrm{Zij}$ bezat toch een eigen bestuur, den toemboe selekan en een bepaald aantal waardigheidsbekleeders bij de vereering van den balakat in functie komend; verder droeg de groep een exclusief karakter door het feit dat men slechts toegelaten werd tot uitoefening van een der ambten als men door banden des bloeds met den stichter verbonden was (en is). $\mathrm{Bij}$ deze vereeeringsgemeenschap treffen we dus een sterke genealogie aan. Deze groep was verdeeld in vier familiegroepen; op zich zelf behoeft dit geen verwondering te baren, want de Banggaiers kenden de vierdeeling. Doch ik ben er niet zeker van of deze groepen niet eerder gezinnenkringen waren.

Overigens vond ik noch op Labobo, noch op Bwokan rechtsgemeenschappen in de volkssfeer.

De vraag stellen ten aanzien van de Badjo's is haar beantwoorden. Zelden zag ik een groep menschen, die zich in haar leefwijze zoo zeer onderscheidt van anderen als deze. De Badjo wordt geboren op zee, leeft op zee, sterft er; hij vindt in de zee zijn middelen van bestaan. De gezamenlijke belangen en gevaren, de eigen taal van dit volk, de wijze van bouwen hunner woningen in de zee op beschutte plaatsen hebben een sterker saamhoorigheidsband doen ontstaan, die dit volk stempelt tot een sterke eenheid. De dorpen hebben hun eigen hoofden (met den titel pocnggawa), bezitten vermogen in den vorm van moskeeën en dorpsprauwen, en dienen derhalve ongetwijfeld als rechtsgemeenschap te worden aangemerkt.

De Boegineezen stichtten een eigen rechtsgemeenschap in de hun toegevallen grondstrook aan de Tominibocht (blz. 47 v.). De stichters van Boenta brachten allerhand volk met zich, doch zij bleven de meesters; zij moesten toestemming verleenen aan vreemdelingen om zich daar te vestigen, en deze plaatsten zich onder de Boegineesche heeren na hun vestiging. Uit de stichtersfamilie kwam een hoofd 
voort, dat den titel kapitan voerde; en belangrijk voor de plaats die deze kapitan voor 1908 innam: hij kende geen hoogeren heer! Aan geen der radja's van de Tominibocht bracht hij huldegift, noch aan den vorst van Banggai. Er is wel gezegd dat als wij 25 jaar later in de Tominibocht waren gekomen, wij er één groot Boegineesch rijk hadden aangetroffen; zeker is dat Oena-Oena, Togean en Boenta centra van Bogineeschen invloed waren, en dat in deze landen de Boegineesche heeren een oppermachtgie positie innamen. $\mathrm{Zij}$ ontvingen huldegift, zij waren rechter en hadden bemoeienis met grondzaken; en dit alles ging buiten het Banggaisch bestuur om.

Nominaal moet de sultan van Ternate in deze streken gezag hebben gehad, doch duidelijk was dat niet, anders had men nooit vergissingen kunnen maken als in 1897 (blz. 2); met Ternate hebben de Boegineezen van Boenta naar men mij verzekerde, nimmer eenige aanraking gehad. (Het is mij overigens onbekend of de sultan van de aanwezigheid van deze Boegineezen en den rechtsgrond daarvan op de hoogte was; wij zagen dat zij wegens hulp aan een tegen Ternate opstandig Banggaisch vorst met de kuststrook beloond werden).

Om het beeld van Boenta te volmaken diene dat tevens het element vermogen duidelijk anwezig was: grond, waarmee de Boegineesche hoofden blijvende bemoeienis hadden; een zeer fraaie moskee; eertijds een sterkte met kanonnen bewapend; en nog meer materieele zaken ter hoofdplaats Boenta. Daarnaast in het bezit van de hoofdenfamilie eenige poesakavoorwerpen e.d.

Wij moeten nog een enkel woord wijden aan de uitzwermingen uit sommige streekgemeenschappen, die soms ver door het terrein trokken om zich ten slotte ergens aan de noordkust te vestigen (Pongeman, Bangkoehan, Ondjoelaan, Bojo, Baba; Kompanga, Dondalon, Bakoetan, Banoea Daka; Pona; zie blz. 32-35). Soms zijn het familiegroepen of deelen daarvan die zich verplaatsten, soms is het een deel van de adelgroep, dan weer is het een groep slaven. Over het algemeen beschikken we niet over voldoende gegevens; want al ontbreekt niet de factor "eigen bewind" (er worden steeds hoofden genoemd, die de verplaatsing entameerden), en zal eigen vermogen ontstaan zijn (in den vorm van grondbezit na vestiging van eenige jaren), over de samenstelling van de groep als zoodanig tasten we in het duister. In de gevallen dat het blijkt dat wij hier inderdaad te maken hebben met een ,geordende groep van blijvend karakter" kunnen we ze als rechtsgemeenschap aanmerken; dit zou voor elk 
dezer groepen onderzocht moeten worden, en m.i. meer van academisch dan van practisch belang zijn. Wij weten overigens dat deze groepen vermoedelijk niet een wezenlijk ander karakter kunnen dragen dan de overige rechtsgemeenschappen in het landschap.

\section{Bijzondere groepeeringen.}

Onder verwijzing wederom naar de lijst van de blz. 26 v. moge hier in het kort iets vermeld worden betreffende bepaalde combinaties van streekgemeenschappen.

De no's 1 t/m 4 zijn de vier oorspronkelijke basaloschappen van legendarisch Banggai, zooals we die op blz. 36 hebben leeren kennen; zij bekleeden een zeer voorname plaats in het staatsbestel (hfdst. V) en hadden indertijd een eenhoofdige vertegenwoordiging te Banggai.

De drie andere basaloschappen op het eiland Banggai zijn ontstaan door immigraties.

Een tweede groepeering van belang vormt het twaalftal hoofden van het eiland Peling, opgenomen onder no. $8 \mathrm{t} / \mathrm{m} \mathrm{19}$. Zij vertegenwoordigen geheel Peling bij den vorst, doch hadden geen eenhoofdigen vertegenwoordiger. Men noemt hen tezamen wel basalo songololoea (aki: songololoea $=$ twaalf); de Lipoeadino is van deze twaalf de hoogste in rang.

Naast dit twaalftal vinden we op Peling een tweede groepeering, de no's $20 \mathrm{t} / \mathrm{m}$ 26. Dit zevental, basalo popitoe (aki: popitoe = zeven) is van lager rangordening dan de basalo-12; zij worden niet meegeteld als „echte” basalo en staan eenigszins buiten de organisatie. De djogoegoe Djakaria drukte zich kernachtig uit, hen betitelende als ,basalo extra”.

De Lipoeadino had, zooals op blz. $26 \mathrm{v}$. aangegeven, zelf twaalf eenheden onder zich, waarvan vijf op Peling den titel basalo, twee op den Vaste-Wal dien van bosanjo voerden. Deze hoofden hadden echter alleen den naam gemeen met de belangrijke hoofden zooals hooger aangegeven: zij waren volkomen afhankelijk van en onderhoorig aan den Lipoeadino en hadden dan ook niet het minste directe contact met het Banggaische vorstengezag: de Lipoeadino met zijn vijf basalo, twee bosanjo en vijf mindere hoofden vormde een staatje in den staat.

De hoofden van den Vaste-Wal worden niet in één omvattende benaming samengevat: men spreekt niet van twaalf bosanjo van Tanah Besar. Wel had ieder hunner een bepaalde rangordening te 
Banggai, en legt men daar den nadruk op de aanwezigheid van twaalf eenheden op den Vaste-Wal (no's $27 \mathrm{t} / \mathrm{m} 38$ ).

Het is wellicht reeds opgevallen dat het getal twaalf frequent voorkomt in de Banggaische structuur. Boeoeko, Boelagi en Peling hebben ieder twaalf familiegroepen; de Lipoeadino had twaalf onderdeelen onder zich; van deze onderdeelen, evenals genoemde streekgemeenschappen in West-Peling gelegen, kennen twee weer een verdeeling in twaalven. De door de Boelagiërs op Bangkoeloe gestichte dochterrechtsgemeenschap had twaalf familiegroepen. Loeokpanenteng, weliswaar in West-Peling gelegen, doch vermoedelijk van Banggai afkomstig, heeft juist niet deze twaalfdeeling. Ook in Oost-Peling was oudtijds het getal twaalf bij de staatkundige organisatie bekend, want Bongganan had twaalf onderdeelen (bense); pas na den val van Bongganan kwamen de Oost-Pelingsche basalo met hun vierdeeling op den voorgrond.

Is het nu toeval dat men te Banggai ook rekening heeft gehouden met twaalf eenheden, zoowel op het eiland Peling, als op den VasteWal? Of is dit een haast metajuridische noodzaak die in de Banggaische wereldbeschouwing ligt? Ook op den Vaste-Wal kent men intern aan het getal twaalf groote beteekenis toe; zoo spreekt de bosanjo van Kintom, één der oudste en meest in aanzien staande eenheden op den Vaste-Wal, met trots van de twaalf tonggol die onder hem stonden, de tonggol sampoeloe ko'ohoea (madi); dit zijn de vijf tonggol bij de kota Kintom en de zeven tonggol van Lingketing. Ook op andere wijze vindt het getal twaalf toepassing, of kan men voor de hand liggende combinaties vormen, waarmee dit getal bereikt wordt. Zoo in Batoei, waar het aantal medebestuurders van den bosanjo, onder verschillende titulatuur, totaal twaalf bedroeg; zoo ook in Tangkiang, waar Doehian acht en Awok vier familiegroepen had. Op Banggai zelve bestond een groepeering van vorstenadel, waarbij twaalf functionarissen zijn aan te wijzen (zie hoofdstuk V par. 4).

Ook legendarisch is het getal twaalf belangrijk; als voorbeelden kunnen we aanhalen het verhaal van een man op den berg Tokolong, die twaalf vrouwen had (de stammoeders der twaalf bense?); van een vorst met twaalf kinderen, die allen schubziekte hadden; van het hoofd van Lomboan, wiens vrouw twaalf visschen en twaalf oebiknollen kocht; Aboe Kasim met zijn twaalf zuigelingen (blz. 38 v.).

Naast dit blijkbaar zoo belangrijk getal twaalf vindt men zeer vaak het getal vier optreden in allerlei combinaties. In Oost-Peling en bij 
vele bosanjo van den Vaste-Wal treft men vier familiegroepen aan; den basalo enz. staan vier verwanten ter zijde in de adelgroep; er zijn vier functionarissen die hem in het bewind ter zijde staan. De familiegroep zelf kent een raad van meestal vier ouden, die het hoofd helpen en adviseeren bij het bestuur over de groep. Op het eiland Banggai zelve vinden we een viertal, zich door hun bijzondere positie onderscheidende basalo (blz. 36).

Als laatste belangrijk getal in de organisatie vinden we zeven. Niet alleen dat er zeven extra-basalo zijn, en dat van de twaalf eenheden van den Lipoeadino, zeven een basalo als hoogste hoofd kenden, doch ook en vooral op den Vaste-Wal treedt dit getal in vele vormen op. Batoei heeft zeven tompoek, Tangkiang kent onder verschillende namen zeven functionarissen als mede-bestuurders, Kintom vindt zeven groepen koetoe no tano; werden deze de zeven familiegroepen bij de moederkampong? Lingketing heeft zeven groepen oerbevolking, en later zeven familiegroepen. Mendono kende oorspronkelijk ook zeven dergelijke groepen. Toen er twee van wegvielen, hield de bosanjo, met twee raadsheeren in de kota gezeteld, dus toch zeven hoofden over, ten behoeve van de bestuursvoering. Ten slotte hebben Dale-Dale en Tanotoeran (wellicht een oorspronkelijke eenheid) tezamen zeven familiegroepen. Het getal vier komt ook elders voor; zie de studie van Mr. van Ossenbruggen over het Javaansch begrip montjopat, berustende op de voorstelling der vijf-vier-eenheid als universeel symbool van de cardinale punten, de ruimte, het Al. Het aki voor vier, sampat (met de wisselwoorden sangkap en sanggap), door Adriani als merkwaardig gequalificeerd, heeft vermoedelijk de grondbeteekenis van: één greep ${ }^{26}$ ). 't Getal 5 treffen we nog in een voor Loinang merkwaardige combinatie aan, die ik hooger reeds aanduidde, nl. het vergelijken van Pinapoean met een hand (blz.53), en die ik, juist om haar merkwaardigheid, op haar authenticiteit betwijfel.

Het getal zeven treffen we elders op Celebes ook aan, b.v. in Bone met zijn Aroe Pitoe ( $=$ de zeven vorsten) ${ }^{27}$ ). Het getal twaalf echter, optredende in een functioneele beteekenis als hooger aangegeven, is voor zoover ik kon nagaan nog niet nadrukkelijk beschreven. $B \mathrm{ij}$ naspeuring vindt men hier en daar echter parallellen. Zoo is in Zuid-Boengkoe ook een twaalftal hoofden als een eenheid bekend,

26) F. D. E. van Ossenbruggen, Montjopat, blz. 3; Adriani-Kruyt, Bare'e III, blz. 283.

27) Arb. XXXI, blz. 30 . 
nl. de "Sengodji sepoelah doewa Tindé inia”, zooals Goedhart ze noemt, die elk een onderdistrict vormden in zijn tijd. Het twaalftal onderdistricten vat men gewoonlijk samen onder den naam Tindé inia ${ }^{28}$ ).

Elders vinden we o.a. het volgende. Op Batjan kent men oorspronkelijk ook een twaalfdeeling, althans Brumund ${ }^{29}$ ) meldt: „In „,vroeger tijden, toen Batjans' bevolking nog heidensch was, waren „aldaar twaalf negorijen. Over iedere negorij was een hoofd...." enz.; de Clerq ${ }^{30}$ ) meldt op Makian de aanwezigheid van vier sangadji's, waarvan één de hoogste was; verder zijn er nog twaalf kampongs, welker getal bewoners van 100 tot 400 bedroeg, en door bepaalde hoofden bestuurd worden. Op Morotai blijkt tijdens het onderzoek naar damarrechten dat daar twaalf kampongs liggen ${ }^{31}$ ). Ook op Hitoe wordt een twaalf-groepeering gemeld; doch het is niet duidelijk of dit een Compagnie's inzetsel is, al dan niet in aansluiting aan bestaande toestanden, als gemeld wordt ${ }^{32}$ ) dat de Vlaming van Outshoorn besloot om, teneinde ,de bewoners van Hitoe in de toe„komst behoorlijk in toom te houden, op Hitoe een eigen landraad van „twaalf leden uit hun voornaamste Orangkaja's te vormen”. Het meest met Banggai overeenkomende beeld vinden we op de Soelaeilanden; de Clerq meldt $\mathrm{nl}^{\mathbf{3 3}}$ ) hier twaalf sangadji's die als districtshoofden optreden. Naast deze twaalf districten staan drie negorijen, rechtstreeks onder den vertegenwoordiger van den sultan van Ternate. De bevolkingssterke dezer districten is zeer verschillend en varieert van 50 tot 2000 zielen. Deze twaalf districten liggen weliswaar verdeeld over de eilanden Mangole (met vier) en Soelabesi (met acht), doch te Sanana, de hoofdnegorij, standplaats van den sultansvertegenwoordiger, wonen de districtshoofden. In de Mededeelingen van het Encyclopaedisch Bureau no. XV vinden we verdere berichten over deze indeeling ${ }^{34}$ ); in dit verband wordt gesproken van stamhoofden, die meestal te Sanana woonden met hun familie; overigens bestond tusschen de stammen een vrij scherpe afscheiding,

28) Goedhart, Drie landschappen, blz. 491, 502, 511.

29) J. F. G. Brumund, Fragment mijner reize door de Molukkos; T. B. G. V (1856), blz. 376.

30) De Clercq, Ternate, blz. 80.

31) Arb. VII, blz. 110-121.

32) Heinrich Bokemeyer, Die Molukken, Leipzig 1888, blz. 245 ; zie ook den brief van de Vlaming van Oudshoorn als superintendent d.d. 14 Augustus 16 6 , opgenomen op blz. CXXXI van genoemd werk (Aanhangsel).

33) De Clercq, Ternate, blz. 113-118.

34) Mededeelingen Encyclopaedisch Bureau afl. XV, blz. 35-36, 22. 
en begaf men zich met grooten tegenzin naar ander gebied; ook werden huwelijken slechts bij hooge uitzondering buiten den stam gesloten. Elke stam bewoonde een gebied, en grensgeschillen kwamen veelvuldig voor met daaruit voortvloeiende oorlogen; de sangadji ten slotte was stamhoofd, dus natuurlijk volkshoofd. De stammen waren verdeeld in soa, soms tot 25 toe, die een bepaalde streek van het stamgebied bewoonden; aan het hoofd der soa stonden bobato. Thans heeft een zekeer versmelting der stammen plaats gehad. (Als we elken „stam” als een streekgemeenschap beschouwen vallen vele punten van overeenkomst met Banggai op).

Merkwaardig is, dat we in Zuid-Celebes het getal twaalf wederom in verschillende combinaties zien optreden ${ }^{35}$ ). Zoo wordt uit het bergregentschap Tjamba gemeld dat de organisatie daar als volgt was: een regent, een hadat van vier leden (de vier steunpilaren), en verder twaalf limpo's, staande onder de bevelen van den raad van vier. De hoofden dezer twaalf kampongs voeren allen den titel aroeng. Van het rijk Pampaoeang vindt men dat het vóór de Gouvernementsinmenging bestuurd werd door een rijksraad van twaalf leden en een vorst. Het blijkt echter dat deze twaalf niet gelijkwaardig waren, want vier hunner hadden geen stem in den rijksraad, doch mochten alleen in de baten deelen. In Bantaeng komt in de legendarische geschiedenis voor dat een uit den hemel neergedaald persoon, een Toe-Manoeroenga, twaalf aardbewoners in gehoor ontving; deze twaalf werden als de voornaamsten beschouwd. $\mathrm{Na}$ het verdwijnen van deze legendarische persoon werd een bestuursorganisatie in het leven geroepen, waarbij de twaalf djannangs, die inmiddels nederzettingen hadden gesticht, een eenhoofdige vertegenwoordiging bij den vorst kregen; deze twaalf djannangs heeten ada sampoelo-roewa; zij hadden vroeger o.a. het recht van benoeming en ontslag van den karaeng van Bantaeng. Ook Tarowang kent een hadat bestaande uit twaalf leden, eveneens ingesteld door een uit den hemel neergedaalde, een Toe-Manoeroeng; deze raad heet hier de anrongtaoe sampoelo-roewa; vier hunner zijn de voornaamsten, twee van deze functies moeten door vrouwen vervuld worden. In Pangkadjene treffen we in Labakkang ook een twaalfdeeling aan, waar gesproken wordt van twaalf oorspronkelijke kampongs ieder onder een lomo. In Gorontalo ${ }^{36}$ ) vinden we tenslotte ook een merkwaardige groepee-

35) Arb. XXXI, blz. 353 ; Arb. XXXVI, blz. 304 ; blz. 156-159; blz. 176; blz. 189-190.

36) J. Bastiaans, Batato's in het oude Gorontalo, T. B. G. 1939, blz. 23-73. 
ring, waarbij twaalf onderdeelen zijn op te merken; hier is de bouw zoodanig, dat aan één vorstengroep zich drie, elk in vieren gedeelde, volksgroepen gebonden hebben, waardoor men totaal twaalf onderdeelen aantreft, gegroepeerd om één centraal orgaan.

Op geheel ander gebied vinden we in Boeton ${ }^{37}$ ) een gebruik waar de magische waarde van het getal twaalf naar voren komt. $\mathrm{Na}$ de installatie van den sultan nl. komen een paar hoogwaardigheidsbekleeders bij hem en deelen hem mede: ,uw grootvaders komen twaalf zaken brengen met hun "schil en hun inhoud”. De schil wordt onderscheiden in drie viertallen, die onderscheidenlijk worden benoemd als de Javaansche-, de Pantjana- (van het zuiden van Moena) en de Wolio-instellingen; het zijn achtereenvolgens vier soorten eerbetuigingen, vier soorten schatting en vier soorten bedienden en dienaren. Ook de inhoud wordt onderscheiden in drie viertallen, nl. recht op vier soorten voorwerpen die de zee oplevert; vier soorten bepaalde privileges; en ten slotte vier bepaalde rechten om te straffen. Ook wordt den sultan in bloemrijke taal een twaalftal bijvrouwen aangeboden, die hij, echter slechts met toestemming zijner gemalin, tot bijvrouw mag nemen. $Z \mathrm{ij}$ behooren tot een lagen stand en worden gekozen uit de maagden in twaalf bepaalde dorpen, uit elke plaats één meisje.

Ik haal deze voorbeelden aan om op de bijzondere plaats te wijzen, die het getal twaalf magisch inneemt in eenige streken van Celebes en de Groote Oost; vermoedelijk zullen er meer voorbeelden te vinden zijn. De diepere beteekenis te doorgronden van deze rangschikking is een taak der volkenkunde; voor ons zij voldoende dat zoowel op eenige eilanden ten oosten van Celebes als in sommige streken daarvan, voornamelijk in het zuiden, het getal twaalf in het staatsbestel een belangrijke rol blijkt te spelen; en dat meer speciaal op de Soelaeilanden daarmee gepaard gaat een maatschappelijke indeeling die de Banggaische sterk benadert.

\section{B. Vorsteninvloed.}

\section{Wijzigingen in vorm of getal der lagere rechtsgemeenschappen onder invloed van het vorstengezag.}

Het Banggaische vorstenbestuur heeft zich weinig ingelaten met de interne organisatie der rechtsgemeenschappen; het is de vraag of

37) R. J. van den Berg, Adatgebruiken in verband met de sultansinstallatie in Boeton. T. B. G. 1939, blz. 520-522. 
het daartoe de macht had wat betreft die der landsbevolking. In die der vreemdelingen (Badjo's, Boegineezen) is het geen vraag; de Banggaische vorst had hier vóór 1908 niets te zeggen.

In hoofdstuk II is ons wel gebleken dat eenige der voormalige rijkjes door oorlogsgeweld ten onder zijn gegaan, en dat andere op meer vredelievende wijze hun zelfstandigheid hebben moeten opgeven; doch toen eenmaal de breede volkslaag geordend was in een aantal streekgemeenschappen zien we geen ingrijpen van den vorst meer; dit had b.v. kunnen gebeuren in den vorm dat hij last gaf een viertal famliiegroepen in te stellen ter vorming van een hoogere gemeenschap. Het eenige geval dat zooiets gebeurde (Boniton) geschiedde zulks op last van een hooger wezen, dat daarna balakat werd. Wel vinden we regelmatig dat als een groep zich afgesplitst heeft van een moeder-rechtsgemeenschap, uit die groep zelve het verzoek komt haar te erkennen in haar eigen hoofd, op welk verzoek de vorst dan goedgunstig beslist; weigering is niet bekend.

Het eenige voorbeeld van instelling eener organisatie is de stichting van het Lipoeadinoschap, dat we hooger als een federatie beschreven. Lettende op de voorstelling van zaken zooals deze legendarisch wordt gegeven, treft het ons dat geen rechtsgemeenschappen worden ingesteld, doch dat slechts een aantal hunner wordt afgezonderd en in hooger verband vereenigd.

Een mogelijkheid van vorsteninmenging is te vinden bij regeling van gerezen conflicten tusschen rechtsgemeenschappen onderling; zie hiervoor hoofdstuk VI.

Goedhart meldt nog twee bijzonderheden, die in dit verband dienen te worden gememoreerd, nl. het gebruik van den titel sengadji voor dien van basalo; en de instelling van kapitan over de bewoners der eilanden Labobo, Bangkoeloe, Bwokan en Poat ${ }^{38}$ ).

38) Goedhart, Drie landschappen, blz. 455, 456; noot 1 van blz. 455 luidt: „Vergelijk de Polynesisch-Arische combinatie Sang-adji op Java Red.”. Staat dit adji ook in verband met den vorstentitel adi? $\mathrm{Zie}_{\mathrm{ie}}$ noot $3 \mathrm{blz}$. 556 van B.K.I. 102 waar ik bij adi de volgende anteekening plaatste: „Vergelijk „Javaansch-Nederlandsch handwoordenboek van Gericke en Roorda, dl. I, blz. „73: adi $=$ uitmuntend, buitengemeen $;$ fraai, schoon. Skr. âdi $=$ uitmuntend, ,de (het) eerste. Op Celebes komt echter het woord adi voor in de beteekenis van „vorst; zie Bare'e-Nederlandsch Woordenboek van dr. N. Adriani op: 2. adi „(blz. 2), omschreven als een titelwoord, nog optredend in eigennamen en ver„taald met vorst. Dr. Adriani verwijst tevens naar het Boegineesch adji; zie „,hiervoor Boegineesch-Hollandsch Woordenboek van Dr. B. F. Matthes, blz. „841, waar onder 1 o.m. met het Javaansche adji : vorst, koning, verband wordt "gelegd". 
In de literatuur betreffende het sultanaat Ternate vindt men algemeen den titel sengadji als aanduiding van een volkshoofd; deze hoofden werden opgenomen in de Ternataansche bestuursorganisatie en namen plaatsen in zooals in Banggai beschreven voor de basalo enz. Ook Bosscher en Mathijsen ${ }^{39}$ ), en de Clerq ${ }^{40}$ ) spreken van sengad ji's, waar zij de basalo enz. beschrijven. Goedhart nu zegt dat sengadji in de Banggaische taal vertaald wordt met basalo; ik meen dit recht te mogen zetten door er op te wijzen, dat basalo de oorspronkelijke titel der hoofden is, en dat het Ternataansche, en in navolging daarvan, het Banggaische vorstenbestuur, hen waarschijnlijk, in overeenstemming met de gebruiken elders binnen het sultanaat, sengadji noemde; waar deze laatste term ingevoerd is, houd ik mij liever aan de Banggaische terminologie. De Banggaier van thans zal, Maleisch sprekende, sengadji gebruiken; doch in de landstaal verkreeg dit woord geen plaats, en worden als van ouds de termen basalo, bosanjo etc. gebezigd. Dit verkeerde gebruik van een importbenaming kreeg een bijzonder cachet, omdat de na 1908 benoemde (territoriale, veelal ambtelijke) districtshoofden ook met den titel sangadji worden aangeduid. Doch daar waar het volkshoofden betreft zal ik me aan de landstaal houden.

De door Goedhart genoemde kapitan op eenige eilanden waren een instelling van het Banggaische vorstenbestuur; op hun positie kom ik nader in hoofdstuk V terug, maar reeds thans kan medegedeeld worden dat zij geplaatst waren naast de hoofden der op Bangkoeloe beschreven rechtsgemeenschappen, en dat zij elders als territoriale hoofden fungeerden; overigens met weinig gezag, want zij hadden te kampen „met den conservatieven geest van de onder hen gestelde en ,uit zeer heterogene bestanddeelen bestaande bevolking; niet zelden „moeten zij na het geven van eenig bevel van de zijde van dat ,gedeelte der bevolking dat uit andere districten afkomstig is dan „zij, vernemen dat daaraan geen gevolg kan worden gegeven, omdat „, het niet door het eigen hoofd .... gegeven is”. Wat Goedhart conservatieven geest noemt is het saamhoorigheidsgevoel der leden eener streekgemeenschap; de aanwezigheid dezer door het vorstenbestuur aangestelde kapitan heeft dus niet tot vorming van rechtsgemeenschappen geleid.

Wij krijgen overigens den indruk dat de vorsten zich weinig bemoeiden met de interne aangelegenheden van hun onderdanen.

39) Bosscher en Mathijsen, Schetsen, blz. 92/93; verg. blz. 69.

40) De Clercq, Ternate, blz. 127, 129. 
Kruyt ${ }^{41}$ ) schrijft hierover : „Het is een opmerkelijk verschijnsel van „de vorstenhuizen in het oosten van den Indischen Archipel, die hun „ontstaan te danken hebben aan Javaansche immigranten, dat dezen „zich steeds op een klein eiland afzonderden, en vandaar uit hun „macht uitoefenden op de omwonende volken, die in beschaving en „kennis verre bij hen achterstonden. Zoo zien wij hen zich concen„treeren op Ternate, op Tidore, op Batjan en hier weer op Banggai. „Er was dus weinig onmiddellijk contact tusschen vorst en onder„danen. Deze isolatie was wel bevorderlijk voor het scheppen van „een magisch krachtigen kirng om den vorst heen, maar van invloed „uitoefenen op de omgeving kon hierdoor geen sprake zijn.

„De vorsten van Banggai hebben zich dan ook nimmer bemoeid „,met de binnenlandsche aangelegenheden van hun onderdanen. Ze „waren tevreden, wanneer dezen hun jaarlijksch tribuut kwamen „brengen, en verder aan hun soms buitensporige eischen voldeden. „Aan den geringen invloed die van het hof uitging.... enz.".

\section{Gouvernementsinvloed.}

\section{Dorpsvorming en territorialiteitsbeginsel.}

De taak waarvoor het bestuur zich in de eerste jaren na 1908 geplaatst zag was de bevolking onder intensief en doeltreffend toezicht te plaatsen, opdat orde en rust alom zou heerschen. Daartoe was in de eerste plaats noodig haar in vaste woonplaatsen te vereenigen; zij was dan gedwongen haar zwervend bestaan zoo snel mogelijk op te geven. Een eisch die gesteld werd aan die woonplaatsen was, dat zij gemakkelijk bereikbaar zouden zijn, d.w.z. dat zij aan of in de nabijheid van de kust dienden te liggen.

De hier genoemde maatregel werd vaak op weinig zachtzinnige wijze ten uitvoer gelegd; de bevolking pleegde langdurig lijdelijk verzet (dat b.v. bij de Sea-Sea nog voortduurt). Doch het gestelde doel is over het algemeen bereikt: de eertijds zwervende bevolking, die elk haar woonplaatsen met haar akkers veranderde, heeft nu over het algemeen geordende woonoorden gevormd, gelegen langs inmiddels tot stand gekomen wegen en paden langs de kusten, zoodat ze voor tourneerende ambtenaren bereikbaar zijn.

Overigens heeft een en ander een vernietigenden invloed gehad op de oorspronkelijke structuur der volksgemeenschappen. Vanuit het

41) Kruyt, Vorsten, blz. 616. 
binnenland, waar de familiegroepen eertijds verspreid waren, moest de bevolking zich langs den kortsten weg een plaats kiezen aan de kust; het gevolg was dat de binnenlanden geheel ontvolkt werden (op de Lingketing- en Doehian-groepen na); dit is te erger als men weet dat vooral in den Archipel juist in het binnenland de bouwgrond en het drinkwater in grooter hoeveelheid aanwezig en van betere hoedanigheid zijn dan aan het strand, terwijl vooral op de kleinere bewoonde eilanden de aan de kust gelegen woonoorden geteisterd worden door malaria, waarvan de binnenlanden vrij zijn.

$\mathrm{Bij}$ deze gedwongen dorpsvorming bleef soms een streekgemeenschap in haar geheel bij elkaar, en vormde een nieuwe kampong; het hoofd daarvan voert dan ook thans nog den titel basalo. Elders vormde elke familiegroep een kampong, vaak onder behoud van den ouden naam voor het nieuwe dorp (bense Baka van Tinangkoeng vormde de kampong Baka); daarentegen vinden we ook dorpen, waarvan de naam geen verband houdt met de benaming der familiegroepen (bense Bentejan van Sambioet vormde de kampong Bolonan, omdat zij zich vestigde op de plaats die van ouds zoo genoemd wordt). Zelfs komt het voor dat een dorp den naam van een andere familiegroep ontving als zij beide tot de zelfde streekgemeenschap behoorden (bense Sampaka van basalo Totikom werd de kampong Lopito; bense Salangano vormde de huidige kampongs Salangano en Sampaka). Bovendien trad hier en daar in de kuststrook menging op, waardoor thans niet meer alle streekgemeenschappen een aaneengesloten territoir hebben. Zoo bewonen b.v. de mian Totikom een vijftal dorpen; het daartusschen liggende terrein wordt echter gedeeltelijk ingenomen door een drietal dorpen waarin zich nu de mian Sambioet bevinden. Toen de streekgemeenschappen nog in haar oorsprongsland lagen was dit niet zoo.

Op den Vaste-Wal heeft zich een soortgelijk proces voltrokken, zij het dan dat daar de woonoorden zich gunstiger, niet zoo dooreen gemengd, afteekenen; slechts doet zich hier soms de eigenaardigheid voor dat bergbewoners zich aan de kust, tusschen de dorpen door de familiegroepen der bosanjoschappen gevormd, hebben gevestigd. In het algemeen treffen we ook op den Vaste-Wal dorpen aan, gevormd door een enkele familiegroep, alsook door meer, doch ik vond geen streekgemeenschap welke thans in één enkele kampong is vereenigd.

In den beginne waren basalo enz. vaak ingeschakeld gebleven in het bestuur over meerdere kampongs onder behoud van hun titulatuur. Zoo trof men in de jaren kort na 1908 nog basalo zoowel als bosanjo, 
daka'njo en andere hoofden aan, die in feite een positie innamen, overeenkomend met hun waardigheid. Doch daarna is bij het Europeesch bestuur een streven waarneembaar geworden om de ontstane dorpen ook bestuurlijk als zelfstandige eenheden te gaan erkennen. Dit uitte zich tegen het midden van het tweede decennium van deze eeuw door erkenning van dorpshoofden (meestal met den algemeenen titel kapala kampong, zelden met een adattitel), die een eigen belastingkohier, eigen heerendienstregisters en andere administratieve bescheiden kregen, en die tevens daardoor in het bezit kwamen van inkomsten uit b.v. collecteloonen. Dit ging natuurlijk ten koste van de basalo enz. uit de voorafgaande jaren ${ }^{42}$ ).

$\mathrm{Na} 1930$ vinden we dan ook slechts eenige basalo (als hoofden over kampongs die een geheel basaloschap in zich bergen, zooals Ponding-Ponding, Tatakalai e.d.), terwijl we vele hoofden vinden, die weliswaar recht hebben op dezen titel, doch slechts één dorp besturen waarin zich dan weliswaar een of meer, niet alle, familiegroepen van hun streekgemeenschap vereenigd hebben, en die daarbij vaak met een lagere titulatuur genoegen moeten nemen.

In vele der nieuw gevormde dorpen kunnen we factoren opmerken die deze tot rechtsgemeenschappen stempelen; de bewoners toch vormen geordende groepen en zijn onderling nog steeds verbonden door dezelfde banden van verwantschap die wij leerden kennen bij de bespreking der volksordening; ook de band die hen aan hetzelfde magisch centrum bindt is voor het overgroote deel, niettegenstaande allen godsdienst, nog steeds onverminderd krachtig. Eigen bewind valt op te merken daar, waar verzoeken het bestuur bereiken een eigen dorpshoofd te mogen hebben, wien meestal de algemeene titel van kapala kampong gegeven wordt, doch die ook wel in aansluiting aan werkelijke verhoudingen juister betiteld wordt.

Eigen vermogen merken we van deze woonoorden op, b.v. in den vorm van dorpsmoskeeën en dorpsbedehuizen, passantenhuizen, badplaatsen, terwijl wegen en bruggen, door de dorpelingen zelf aangelegd en gebouwd, eveneens als zoodanig kunnen worden aangemerkt. Dit proces is nog in vollen gang. Nog lang niet alle bestuurlijk erkende kampongs kunnen als rechtsgemeenschap aangemerkt worden; vele zijn louter oorden van toevallige samenwoning, waarvan de bevolking b.v. snel verloopt bij bepaalde economische constellaties.

Een aanwijzing daarvoor, dat de familiegroepen geen rechtsge-

42) Memorie.

Verh. dl. VI. 
meenschap zijn, vinden we in de omstandigheid dat b.v. dorpen die uit meer dan één familiegroep van de zelfde streekgemeenschap gevormd werden, bij bestuurlijke erkenning één hoofd over zich stellen; bestaat daarentegen een dorp uit b.v. twee familiegroepen tot verschillende streekgemeenschappen behoorend, dan vinden we wel één der familiegroephoofden als dorpshoofd, het andere als wijkhoofd (met den modernen titel van kapala djaga) erkend.

Een bijzondere plaats nemen wel de Christendorpen in. Zoowel de band die de bewoners bindt tot een geordende groep, als het vermogen van het dorp zijn meerzijdig geworden. Het inwoner-zijn van een Christendorp impliceert het lidmaatschap der Christen-gemeente; het vermogen is uitgebreider dan in de andere dorpen en omvat vaak o.m. de dorpskerk, de dorpsschool met bijbehoorende onderwijzerswoning, terwijl het vermoedelijk in vele gevallen ook tevens een financieel aspect kreeg.

$\mathrm{Na} 1908$ worden ten gevolge van het territorialiteitsstelsel ook de vreemdelingen (Badjo's, Boegineezen, Gorontaleezen) als onderhoorigen van het Landschap aangemerkt. Waren ze in voldoend aantal aanwezig, dan stichtten zij eigen rechtsgemeenschappen; zoo vond de Boegineesche immigrantengroep bij Boenta bestuurlijke erkenning gedurende tal van jaren door de vorming van een apart onderdistrict. Elders bleven Badjo's onder eigen hoofden hun typische dorpen bewonen. Daar waar Gorontaleezen een eigen kampong stichtten stelden zij daarover een hoofd, meestal met den titel major, welke lager in rang is dan de titel kapitan (als hoedanig o.a. het hoofd der Boegineezen wordt aangeduid). Men heeft dus te Boenta een major Gorontalo onder den kapitan Boegis aldaar, te Boalemo ook een major (over Gorontaleezen) en te Pagimana een major, een poenggawa en een kapala kampong, onderscheidenlijk hoofden van een Gorontaleesche, Badjosche en Saloeansche kampong.

De vraag is nog, of de streekgemeenschap, die wij binnen de volksordening ongetwijfeld als rechtsgemeenschap hebben beschreven, thans ook nog de kenmerken vertoont van dergelijke eenheden.

Ik stel voorop dat de band die de leden in het verleden bond (de gezamenlijke afstamming van een groepje volgelingen van een vergoddelijkten stichter, eerste hoofd, dan wel van een op een bergtop door den Opperheer geschapen volkje, de gezamenlijke vereering van de zelfde heilige voorwerpen, plaatsen of graven, of van de zelfde pilogot) thans nog sterk genoeg is om te spreken van blijvende groepen; deze band zal echter bij het voortschrijden der tijden ver- 
slappen. De ouden van dagen zijn zich nu nog precies bewust tot welke familiegroep niet alleen zij zelf, doch ook de jeugd gerekend moet worden; doch zal de jeugd, zelf eenmaal oud geworden, ook nog die wetenschap hebben? Als voornaamsten ontbindenden factor moet ik den godsdienst aanmerken.

Mijn indruk is dat thans nog de voorwaarden voor erkenning als rechtsgemeenschap aanwezig zijn; doch als de streekgemeenschappen niet opgenomen worden in de landschapsbestuursorganisatie zullen zij vermoedelijk straks verdwijnen en uiteenvallen in territoriale dorpen, waarvan de bewnoers weliswaar door sterke banden van onderlinge verwantschap verbonden zijn, doch wier verhouding tot andere dergelijke eenheden uit het bewustzijn gewischt is. 


\section{HOOFDSTUK IV.}

\section{Individuen.}

\section{Standen.}

In de breede benedenlaag van het volk konden we drie standen opmerken, t.w. de landshoofden, de vrijen en de slaven. Al is dan thans de slavernij opgeheven, toch bemerken we in het heden er nog sporen van.

De groote groep van vrijen, menschen niet van adel, doch ook niet van slavenherkomst, wordt aangeduid met mian poipoïsik (aki), dan wel mian ise (madi); bij de onvrijen maakte men onderscheid tusschen schuldslaven eenerzijds en erfslaven anderzijds, waarvan de laatsten het minst in tel waren. Men duidt hen als volgt aan: schuldslaven: ata (aki) of batoean (madi); erfslaven: babaaboe (aki en madi).

De schuldslaven dienen te worden onderscheiden van pandelingen, in het aki tano of kasoebiang geheeten (zie voor hun positie hoofdstuk XI) ${ }^{1}$ ).

De landshoofden, hoofden der streekgemeenschappen, vormen den plaatselijken adel : basalo of bosanjo, daka'njo en gelijkstandige hoofden. In het madi duidt men dezen stand aan met mian daka' (daka' $=$ groot). Verwanten, afstammelingen van eerstgenoemden zijn bekend als basalo paoeno (aki : paoe = kind, in dit verband ook klein) en anak $i$ bosanjo. Een dergelijke constructie in samenstelling met den titel daka'njo trof ik niet aan. Mede in dezen hoofdenstand zijn te rangschikken de hoofden der familiegroepen voor wie ik als algemeenen titel tonggol aangaf, doch waarvan het in het volgend hoofdstuk zal blijken dat eertijds een veelheid van namen bestond. In het aki kent men afstammelingen en naaste verwanten van deze hoofden ook als tonggol paoeno.

De Banggaische landsadel, nazaten der voormalige adi van Banggai (blz. 36), wordt thans samengevat onder het begrip bobato. Dit woord

1) Kruyt, Bewoners, blz. 250; Memorie. 
is Ternataansch en is volgens de Clerq $^{2}$ ) een collectieve benaming van mindere hoofden, als kamponghoofden en dergelijke. De traditie wil, dat deze titel gelijk met de vestiging van het Ternataansch gezag ingevoerd werd; hieruit blijkt dat de Ternataaansche veroveraars de $a d i$ als mindere hoofden kwalificeerden. Het spraakgebruik noemt ook hier weer de afstammelingen en verwanten der in functie zijnde bobato wel bobato-paoeno. Wij zullen in het volgend hoofdstuk zien dat er eertijds in dezen stand een zestal functionarissen aanwezig was, waarvan wellicht het in rangorde laagste tweetal bobato paoeno was.

De volgende en hoogste groep, de vorstenstand, heet in het aki banginsaa (dit woord is vierlettergrepig, nl. ba-ngin-sa-a, met de klemtoon op 1e en 3e lettergreep; van de 2e lettergreep is de klank -in- nauwelijks te hooren, zoodat Goedhart in 1908 tot de transcriptie bangsa komt; hiermee wordt phonetisch geen juist beeld gegeven. Men spreke dus uit: bàng(in)sàä. Deze vorstenadel kent een verdeeling in drieën, te weten: kaoe saoeno (aki: de vruchten van het hout)), dit zijn de lijfelijke zoons van een regeerend vorst, de prinsen van den bloede, waarvoor het Ternataansch de aanduiding djoöe ma-ngofa ${ }^{3}$ ) gebruikt. De tweede groep vorstenadel wordt gevormd door de tomoe-tomoendo paoeno (aki: de reduplicatie van tomoendo drukt het oneigenlijke karakter uit; paoe $=$ kind; het geheel is hier weer te geven met: de oneigenlijke kleine vorsten); het zijn de kleinzoons van een regeerend vorst.

Tenslotte kent men de banginsaa paoeno (aki: de kleinen van vorstelijken bloede), dat zijn de overige personen van vorstelijken bloede die den titel banginsaa voeren. Deze wordt gevoerd door alle mannelijke afstammelingen van een regeerend vorst tot en met den vijfden graad, waarbij men de afstamming volgens de vaders rekent, patrilineaal. Afstammelingen in verderen graad rekent men tot de bobato; zijn deze dan wellicht zoozeer met lieden van dezen stand vermengd, dat zij ook feitelijk daarvan deel uitmaken?

Voor zoover mij bekend is, was er geen onderscheid tusschen de kleeding van vrijen en onvrijen. Doch de banginsaa en de in functie zijnde bobato, basalo en lagere hoofden droegen, en dragen soms nog, een kleeding waaraan een deskundige den stand waartoe betrokkene behoort, kan zien. De bobato dragen een hoofddoek, op andere wijze geknoopt dan de basalo-4 van het eiland Banggai (verg. blz.38), terwijl ook weer de hoofddoek van de overige basalo enz. en der

2) De Clercq, Ternate, blz. 253.

3) De Clercq, Ternate, blz. 265. 
tonggol verschillend gevouwen wordt. Voor hoofddoek gebruikt men tegenwoordig een eenvoudigen, bedrukten katoenen lap, zooals in de winkels verkrijgbaar. Bij plechtige gelegenheden dragen echter de basalo een sabalee van zwarte stof ; dit is een in elkaar gedraaide lap katoen die als een worst om het hoofd wordt gelegd, waarbij de kruin onbedekt blijft. Deze hoofdbedekking noemt men ook wel destal (verg. het Perzisch-Maleische destar). Slechts de basalo van Tinangkoeng heeft het recht tot het dragen van een kleurige destal, gemaakt van een rooden, witten en zwarten lap, in elkaar gedraaid.

De sabalee met nog eenige andere in het volgend hoofdstuk te noemen kleedingstukken is dus ambtskleeding; voor niet-ambtelijken ligt de standaanduiding in den vorm van den hoofddoek.

Met het vorstelijk prerogatief van den witten hoofddoek maakten we reeds kennis (blz. 24). Het is gewoonte dat deze hoofddoek gegeven wordt door de familie ten tijde van de besnijdenis van den jeugdigen banginsaa. Tevoren wordt in een bijeenkomst, waaraan de vorst, de basalo- 4 en de vooraanstaande bobato deelnemen, de bloedzuiverheid der afstamming uitgemaakt; het resultaat wordt aan de familie medegedeeld die dan voor het hoofddeksel zorgt. Men placht en pleegt dezen koekoep mooete niet dagelijks te dragen; slechts de banginsaa voor zoover zij indertijd een functie vervulden te Banggai, droegen dit hoofddeksel elken dag; de overige banginsaa gebruikten dit teeken alleen bij groote godsdienstige feesten en plechitge gebeurtenissen. Thans gebruikt men het nog b.v. bij de ontvangst van den Resident.

De vorst zelve draagt somtijds eveneens den witten hoofddoek, doch hij heeft bij feestelijke gelegenheden vaak een sabalee; o.a. zag ik hem eens een dergelijke hoofdbedekking dragen, vervaardigd van groene stof. Overigens prefereert de huidige Zelfbestuurder buitenshuis een zonnehoed van gele orchideevezels vervaardigd, die eveneens slechts door hem mag worden gebruikt.

In het algemeen behoort men krachtens geboorte tot een bepaalden stand, waarbij de afstamming volgens den vader gerekend wordt. Sommige personen behooren echter tot twee standen, nl. kinderen gesproten uit een huwelijk tusschen een banginsaa en een bobato; op dit punt schijnt dus de zoo juist genoemde regel niet van kracht te zijn. Verder wil de traditie dat uit huwelijken tusschen bobato en basalo het in rang het minst in tel zijnde tweetal bobato is voortgekomen. Gegevens over menghuwelijken tusschen basalotelgen en 
vrijen ontbreken uit den Archipel, doch uit Loinang ${ }^{4}$ ) weten we dat een huwelijk van een man uit het volk met een meisje uit het tonggolgeslacht voorkwam (voorkomt?); hij moest dan eerst zijn grootheid (zijn aanzien) koopen (madi: mongoli kadaka'an). Hij deed dit in den ouden tijd door een slaaf te geven (aan den vader van het meisje? of aan het hoofd der rechtsgemeenschap?). Hoe dit nu gebeurt vermeldt Kruyt niet; wel zegt hij dat leden van de tonggolfamilies vaak met bloedverwanten van den daka'njo huwden (huwen?).

Een vrije kon door eenige oorzaken in slavernij vervallen; door schulden, door het opleggen van boeten, als straf en als krijgsgevangene, buitgemaakt op een sneltocht ${ }^{5}$ ).

In den Archipel ${ }^{6}$ ) namen gewone menschen onderling elkaar nooit om schulden tot slaaf; dit deden alleen de basalo. Het kwam voor, dat een schuldeischer voldoening van zijn vordering op een ander kwam halen bij den basalo, die dit weer verhaalde op den schuldenaar, soms met zijn geheele gezin; deze lieden werden dan zijn schuldslaven, ata. Vrijkoopen was nog mogelijk want elk voorwerp dat de man op een of andere wijze in zijn bezit kreeg kon hij den basalo in korting op de schuld geven. De positie van ata is dus werkelijk verschillend van die van pandeling, in het aki tano of kasoebiang geheeten; bij dezen ontstaat dienstverhouding ten gevolge van schuld, die een einde neemt als de man zijn schuld heeft inverdiend; zie hiervoor hoofdstuk XI.

In Balantak ${ }^{7}$ ) deelt men mee dat daar geen slaven uit eigen volk waren; er zou nooit een mian Balantak verkocht zijn, terwijl men het nooit zoover liet komen dat iemand om zijn schulden schuldslaaf dan wel pandeling moest worden bij een vreemdeling.

Ook in Loinang ${ }^{8}$ ) schijnt de schuldslavernij te zijn ingevoerd, wellicht op voorbeeld der Boegineezen van Boenta; oorspronkelijk waren er geen slaven, maar door schulden en ook door het opleggen van boeten die men niet kon betalen vervielen velen in schuldslavernij. Dergelijke schuldslaven werden vaak naar elders verkocht, doch dit geschiedde buiten weten der bosanjo om. Deze heeren waren zelf in het bezit van vele schuldslaven gekomen door de schulden te betalen

4) Kruyt, To Loinang, blz. 359, 455.

5) O.a. Memorie.

6) Kruyt, Bewoners, blz. 251.

7) Kruyt, Balantaksche Studiën, blz. 341 .

8) Kruyt, To Loinang, blz. 359-360. 
die zij aan derden hadden; zij breidden dit bezit steeds uit, doch verkochten geen menschen.

Ten gevolge van opgelegde straf konden vrijen tot slaaf worden gemaakt,, maar zij werden dan geen schuldslaaf; afkoopen zal niet mogelijk zijn geweest. In den Archipel is het voorgekomen dat een roover gedood werd, waarna de basalo zijn kinderen als slaven verkocht ${ }^{9}$ ). Uit Loinang vermeldt Kruyt een voorval, resulteerende in een gevecht met doodelijken afloop tusschen twee gezinnen; de vrouw die van alles de schuld was werd door den tonggol naar elders verkocht ${ }^{10}$ ).

De op een sneltocht buitgemaakte krijgsgevangenen werden zoowel in Doehian als in Lingketing aan den bosanjo uitgeleverd, onderscheidenlijk dien van Tangkiang en van Kintom; dit moest met alle krijgsgevangenen gebeuren ${ }^{\mathbf{1 1}}$ ).

Veelal werden ook Banggaische ingezetenen door zeeroovers ontvoerd en naar elders als slaven meegenomen. De Koloniale Verslagen uit de vorige eeuw spreken herhaaldelijk van rooftochten, ondernomen door zeeroovers, o.a. Galelareezen en Tobeloreezen ${ }^{12}$ ). Er werd dan ook in ouden tijd een levendige handel in menschen gedreven, waaraan volgens het Koloniaal Verslag van 1879/80 zelfs de Banggaische vorstenadel deelnam. Bosscher en Mathijsen deelen mee, dat in hun tijd de prijs voor een mensch op Peling veelal een gong was, ongeveer ter waarde van $\mathrm{f} 30,-^{\mathbf{1 3}}$ ). De basalo van den Archipel verkochten volgens Kruyt, als ze te veel slaven kregen, deze menschen naar den Vaste-Wal; men maakte onderscheid in lieden met en zonder schubziekte, die 4, dan wel 8 groote koperen sirihdoozen (aki: saoeba) waard waren ${ }^{14}$ ). Wellicht gingen deze vaak naar Balantak, want hier nam men veel slaven van Peling af; in Balantak noemt men hen echter ata (sian) welken term we elders voor schuldslaven vonden. Hier werd als prijs voor een mensch 60 realen of 60 koperen borden (doelang) opgegeven ${ }^{15}$ ). Ook zijn wel Banggaische slaven naar Papoea verkocht, als we Riedel mogen gelooven, waarbij twee Banggaiers geruild werden tegen drie Papoea's ${ }^{16}$ ).

9) Kruyt, Bewoners, blz. 253.

10) Kruyt, To Loinang, blz. 361.

11) Kruyt, To Loinang, blz. 360, 443.

12) Zie b.v. K. V. $1861 / 62,1871 / 72,1875 / 76,1878 / 79,1879 / 80,1880 / 81$.

13) Bosscher en Mathijsen, Schetsen, blz. 105.

14) Kruyt, Bewoners, blz. 251.

15) Kruyt, Balantaksche Studiën, blz. 341.

16) J. G. F. Riedel, Zeitschrift für Ethnologie 1885, blz. 65. 
In tegenstelling tot de handelwijze der basalo staat die der bosanjo van Kintom en Tangkiang, zooals hooger reeds aangegeven; zij verkochten nimmer slaven doch wezen allen personen die zij verwierven een plek aan waar zij konden wonen en akkers aanleggen. Zoo breidde het aantal dezer mian $i$ bosanjo zich snel uit; op blz. $34 \mathrm{v}$. noemde ik o.a. de kampong Pona door dergelijke slaven gevormd. Daarentegen verkochten de daka'njo en tonggol van Lingketing wel schuldslaven naar de Togean-eilanden, echter buiten medeweten van den bosanjo $\mathrm{om}^{17}$ ).

In het Koloniaal Verslag van 1880/81 vinden we, dat op 20 September 1879 de vrijlating der slaven in het sultanaat van Ternate feestelijk geschiedde door plechtige afkondiging ter hoofdplaats. Hierbij werden 1371 slaven vrijgelaten waarvoor ruim f 51.000 ,- uit de Indische middelen was uitgegeven. Dat deze vrijlating, bedoeld voor het gebied van het geheele sultanaat waartoe dus ook Banggai behoorde, niet aan het doel beantwoordde, blijkt uit Goedharts mededeelingen over de positie der slaven in 1908 en uit een verklaring van het Banggaische Zelfbestuur van 22 Juli 1912, waarbij genoemd Zelfbestuur vastlegde, "dat slavernij en pandelingschap in de onderafdeeling Banggai niet meer bestaan". Doch men bemerkt thans nog duidelijk wie afstammelingen van vrijen dan wel van slaven zijn.

\section{Rechten en verplichtingen.}

Zooals wij in het vorig hoofdstuk hebben gezien bestaat in de streekgemeenschappen een sterke band, waardoor de leden, in eenige familiegroepen vereenigd, groepsgewijze verbonden zijn met een gemeenschappelijk magisch centrum; bovendien vormen de hoofden, afstammelingen der vergoddelijkte stichters of eerste hoofden, een eigen genealogisch georganiseerde groep, vaak afzonderlijk gelocaliseerd. In deze streekgemeenschappen zijn van elders gekomenen vreemdelingen; Moenaneezen en dergelijke zwervers werden en worden dan ook niet daarin opgenomen. Slechts bij eenige, door immigranten gestichte territoriale rechtsgemeenschappen (Boegineezen, Gorontaleezen) bestaat de mogelijkheid dat zij door vestiging tevens lid worden der groep.

Verder bleek ons dat hier eenige groepen bergbewoners (Lingketing, Doehian) in afhankelijkheidspositie ten opzichte van de kustbewoners verkeeren; deze verhouding vinden we ook bij uitgezwermde

17) Kruyt, To Loinang, blz. 360 . 
groepen, b.v. de groep die de bergen overtrok (malaloean boengkoetnjo) en de rechtsgemeenschap der mian Saloean stichtte (blz. 33). Van de afhankelijkheidspositie der eerstgenoemde groepen, Lingketing en Doehian, is de naamgeving eveneens een bewijs : de kustbevolking noemt hen Loinang, zij zelf duiden zich aan met hun eigen groepsnamen. Dit afhankelijkheidselement ligt niet in den naam Saloean opgesloten.

De gevolgen van het verwantschaps- en huwelijksrecht voor het individu zullen in de hoofdstukken VII en VIII ter sprake komen; hooger werd reeds medegedeeld (blz. 87) dat men krachtens geboorte tot een bepaalden stand behoort, en dat men uit dien hoofde ook erfslaven kende. Volgens Riedel ontvingen de bezitters van door hen uitgehuwde slavinnen den bruidschat voor haar ${ }^{18}$ ).

Ten aanzien van het erfrecht kunnen we hier op wijzen dat bepaalde functies slechts verworven kunnen worden door individuen tot een bepaalden stand behoorend. Zoo kan als Zelfbestuurder uitsluitend een banginsaa, en nimmer een bobato optreden; voor deze laatste groep zijn echter weer andere ambten beschikbaar. Verder kunnen slechts die personen tot basalo enz. en tonggol enz. middels gemeen overleg binnen den kring der rechtsgemeenschappen aangewezen worden als zij krachtens geboorte ook tot den betreffenden stand behooren. Zoo is er zelfs een functionaris aan het Banggaische hof bekend dien men daar eertijds aantrof, den sadaha kodato, belast met het toezicht in de vorstelijke keuken, die van slavenafkomst moest zijn. Hoe is dit thans?

Het individu kan ook grondenrechten uitoefenen (zie hoofdstuk X); daarbij komt wederom duidelijk het verschil tot uiting tusschen de rechten der individuen als leden eener rechtsgemeenschap eenerzijds, en vreemdelingen anderzijds; de laatsten moesten b.v. een recognitie voldoen.

Verder zal nader in de hoofdstukken XI en XII (Schulden- en Delictenrecht) de plaats van het individu ter sprake komen.

In de oud-Banggaische wijze van opbrengen van huldegift vinden we een gegeven, dat in dien tijd het individu niet zeer op den voorgrond trad. Zooals op blz. 58 reeds medegedeeld werd moest elke basalo jaarlijks een bepaalde hoeveelheid goederen (was, koffie, rijst, oebi, geld e.d.) aan den vorst ophrengen; het hoofd der streekgemeenschap kreeg deze weer van de hoofden der familiegroepen die op hun

18) J. G. F. Riedel, Zeitschrift für Ethnologie 1885, blz. 65. 
beurt daarvoor weer aangewezen waren op de gezinnenkringen. Daarbij rustte de verplichting tot het leveren van een bijdrage niet op het individu, doch op het huisgezin. Dit hield in dat ongehuwden niet hoofdelijk tot deze lasten verplicht waren, doch binnen het kader van het gezin. De huisgezinnen worden daarbij aangeduid als babaaboe, een woord dat wij op blz.84 leerden kennen als aanduiding voor erfslaven. Toch moeten wij m.i. hierin niet zien, dat alleen de erfslaven van den basalo deze verplichting hadden, doch we moeten voor babaaboe in dit verband lezen: onderhoorige. Dit komt overeen met het gebruik van dezen term in de legenden, waarin we vinden dat bij stichting van een zelfstandige rechtsgemeenschap, b.v. een prinses een aantal huisgezinnen, babaaboe, meekrijgt van haar vader. In het Balantaksche maakt men verschil tusschen huisgezinnen met verscheidene weerbare mannen, hier $b a b a(a$ ? $) b o e$ geheeten, en met weinige hunner, sôendoeki genaamd; de verhoudingen tusschen de door hen op te brengen hoeveelheden was en gepelde rijst wordt aangegeven als $5: 3^{19}$ ).

De rechten der vrijen zijn niet uitdrukkelijk genoemd, doch wij kunnen aannemen dat zij geen andere zijn dan voortvloeiende uit het lidmaat zijn eener rechtsgemeenschap, en het vrijelijk de beschikking hebben over zelf verworven goederen.

Overigens was de positie der onvrijen zoo slecht nog niet, afgezien dan van het onaangename eventueel als koopwaar ergens anders heen gezonden te worden. In Balantak werden de gekochte menschen geheel in het huisgezin opgenomen, terwijl men hen als kind betitelde; toch is ook daar de term ata bekend ${ }^{20}$ ). Ook Goedhart kwam tot een dergelijke conclusie. want hij vond dat de onvrijen in den regel als een lid der familie werden beschouwd ${ }^{21}$ ). Uit den aard der zaak misten zij het recht om te gaan waarheen zij wilden, terwijl zij het ook waren die voor hun bezitter moesten opkomen, als deze voor het verrichten van diensten bij den basalo, dan wel bij den vorst opgeroepen werd.

Als maatschappelijke gevolgen der standindeeling kunnen we b.v. aanvoeren, dat voor een vrouw uit hooger stand meer bruidschat moet betaald worden ${ }^{22}$ ); dat bij overlijden van een hoofd (basalo, tonggol) een of ficieele rouw (aki: lalas; madi: modoso) van een

\footnotetext{
19) Kruyt, Balantaksche Studiën, blz. 340 .

20) Kruyt, Balantaksche Studiën, blz. 341 .

21) Goedhart, Drie Landschappen, blz. 480.

22) Kruyt, To Loinang, blz. 455.
} 
zeker aantal dagen werd (wordt?) uitgeschreven, zich uitende in een reeks verbodsbepalingen, waaraan de leden der rechtsgemeenschap onderworpen waren (zijn?) gedurende dien $\operatorname{tijd}^{23}$ ). Ten slotte werd het lijk van een slaaf niet zooals gewoonlijk in een kist begraven, doch slechts in een lap boomschors in den grond gestopt ${ }^{24}$ ).

Over, eventueel beperkte, handelingsbevoegdheid van onmondigen en krankzinnigen ontbreken gegevens; beperking der handelingsbevoegdheid van den pas gehuwden man treffen we aan in Balantak, waar vermeld wordt dat de man een jaar of drie bij zijn vrouw blijft inwonen, en gedurende dien tijd zijn schoonouders dient. Daarentegen blijven in Koinang de jonggehuwden een jaar bij de ouders van den man inwonen, doch in Baloa gaat het jonge paar na korter of langer tijd naar het huis van de ouders der vrouw.

Overigens zij opgemerkt dat de plaats van het individu ten opzichte van de omringende wereld niet scherp afgeteekend is in het Banggaische adatrecht ; dit is niets bijzonders, want bij primitieve gemeenschappen gaat het individu min of meer in de rechtsgemeenschap op ${ }^{25}$ ). Een bevestiging hiervan vinden we bij Goedhart waar hij mededeelt dat men eertijds wel de naaste bloedverwanten van den dader, als deze voortvluchtig was, veroordeelde ${ }^{28}$ ).

Betreffende curateele ontbreken gegevens.

\section{Naamgeving.}

In den Archipel en op den Vogelkop eenerzijds, op de rest van den Vaste-Wal anderzijds, zijn er verschillen in de wijze van naamgeving op te merken ${ }^{27}$ ).

In eerstgenoemde gebieden haast men zich niet met het geven van een naam; in Loinang daarentegen is de naam van het kind reeds vóór de geboorte bepaald, meestal door een der grootouders. De naam wordt gegeven bij het doorsnijden van den navelstreng. Zelden geven de ouders den naam, ook in den Archipel en op den Vogelkop niet; hier zijn het eveneens meestal de grootouders of anders ooms of

23) Kruyt, Ziekte en dood, blz. 165; Leven en sterven, blz. 88; To Loinang, blz. $491 / 492$.

24) Kruyt, Ziekte en dood, blz. 157.

25) C. van Vollenhoven, Adatrecht I, blz. 155.

26) Goedhart, Drie landschappen, blz. 451.

27) Kruyt, Banggaische Studiën, blz. 60; Leven en sterven, blz. 74; To Loinang, blz. 471; Adriani-Kruyt, Bare'e III, blz. 277, 280; E. Gobee, Feestbundel I, blz. 199. 
tantes die dit doen. In den Archipel kan het zeer lang duren, voor het kind een naam heeft.

Tektonymische namen zijn in de drie genoemde deelen algemeen in gebruik; in den Archipel treft men ze veelvuldiger aan in het oostelijk, dan in het westelijk deel. Zoo spreekt men daar b.v. van Koedi tamano, of tame $i$ Koedi (aki: tame = vader), en van Koedi ineno of ine $i$ Koedi (aki: ine $=$ moeder). Ook in Balantak worden vader en moeder op deze wijze met den naam van hun oudste kind aangesproken (sinana $i$ Malang $=$ de moeder van M. ; sina $=$ moeder ; tama $=$ vader $; a n a k=$ kind $;$ ngaan = naam $;$ alles sian). In Loinang is het gebruik van dergelijke namen nog uitgebreider; niet alleen de ouders (toema $i$ Goeliis, tina $i$ Goeliis; madi : toema $=$ vader, tina $=$ moeder), maar ook ooms en tantes, ja de grootouders worden op overeenkomstige wijze aangeduid (zie verder hoofdstuk VII).

Naamverandering kan noodig zijn als de priester zulks noodig oordeelt, in het geval nl. dat de kleine vaak ziek is.

Kinderen die men niet kent, of die nog geen naam hebben roept men in den Archipel met laso (aki van Oost-Peling: laso = penis), of taboe dan wel to'oe (aki van West-Peling: bet. eveneens penis), in Loinang en Balantak met tatoe (madi en sian: ventje). Kleine meisjes roept men wel met oeki (aki : vagina), oedoe of $i k i$ (madi: beteekenis?) of ili (sian: beteekenis?); in Loinang gebruikt men tatoe alleen voor knapen van goede familie.

Over naamgeving in de gekerstende streken van den Vogelkop ontbreken gegevens, doch in Loinang blijkt het dat een zekere Lalekang gekerstend werd en daarbij een Christennaam verwierf, Jacob; hij is de zoon van Koetondong, en nu heet hij zich in den vervolge Jacob Koetondong ${ }^{28}$ ). Daarnaast komt ook voor het gebruik van heidensche dubbelnamen, b.v. Talahata Lambajang; het schijnt dat Talahata de eigennaam en Lambajang de vadersnaam is; dit gebruik is wellicht ontstaan in navolging van namen als Jacob Koetondong. Het is mij niet bekend, of nu Jacobs, respectievelijk Talahata's kinderen, de namen Koetondong dan wel Lambajang als „familienaam” zullen gaan gebruiken.

28) Kruyt, To Loinang, blz. 330, 352. 


\title{
HOOFDSTUK V.
}

\section{Bestuur, rechtspraak, regeling.}

\author{
A. Bestu ur.
}

\section{Bestuursorganisatie der volksgroepeeringen.}

De vormen waarin de breede benedenlaag van het volk oorspronkelijk georganiseerd was werden besproken op de blzz. 50-64; thans zal de bestuursorganisatie dezer groepeeringen worden onderzocht, waartoe allereerst een drietal streekgemeenschappen geschetst worden ${ }^{1}$ ).

De streekgemeenschap Popiisi (Oost-Peling) bestaat uit vier familiegroepen; het is niet zeker of wij hier eertijds ook gezinnenkringen aantroffen. Als hoofden dezer familiegroepen noemt men basalo tamano, kapitan, tonggol oeloeno en potoembak. (Zie beneden voor beteekenis van deze en andere titulatuur). Ieder hunner werd in het bestuur over de betrokken groep bijgestaan door een viertal helpers, mian tangano of paoe bakalinga; deze helpers vinden we in voorkomend geval elders als hoofden van gezinnenkringen. (Er zijn dus steeds wel helpers, echter niet immer gezinnenkringen). Het hoofd der streekgemeenschap voerde den titel basalo; hij verbleef op de plaats Popiisi, in de nabijheid waarvan ook het magisch centrum te vinden is. Familieleden van den basalo, afstammelingen van den vergoddelijkten stichter, vormden, eveneens te Popiisi, een kleine kampong, de kamali (zie blz.60); over deze adelgroep voerde de basalo zelf het bestuur, daarin bijgestaan door vier leden van de adelgroep, vier basalo paoeno. Een mogelijke boodschapper droeg den titel mampangala.

De streekgemeenschap Kintom (Vaste-Wal) kende zeven groepen van rechtstreeks onderhoorigen; betref fende gezinnenkringen beschikken we niet over gegevens. Twee der familiegroepen stonden onder een daka'njo, de overige onder een tonggol; van de onder een daka'njo staande groepen Matangkas en Lala meldt men de uitzwermingen

1) Memorie; Kruyt, To Loinang, blz. 354-356, 433, 438; Nota Tangkilisan. 
naar Bojo, Baba, Tombang en naar Oendjoelaan (zie blz. 33). Deze uitzwermingen stonden onder een tonggol of pabisala; kunnen we deze transmigratiegroepen wellicht als gezinnenkringen aanmerken? Het centrum der streekgemeenschap was eertijds de kota Kintom, een vesrterkte plaats landinwaarts gelegen, waar ook de poesakavoorwerpen werden bewaard. In de kota woonde het hoofd dat den titel bosanjo voerde, tezamen met een aantal familieleden die de adelwijk vormden (pinasang; zie blz. 60). Uit deze familieleden bekleedde een viertal hooge functies; het waren de toema noe bosanjo, de kapitan tano, de kapitan bosanjo en de kapitan kompania (deze laatste functionaris verbleef kort voor 1908 te Bangkoehan; zie blz. 32. Voor het toezicht in de adelwijk was een anoematoea aanwezig; een den bosanjo ten dienste staande boodschapper is de milinoe of bobotokon. Aan Kintom onderhoorig waren Lingketing en Pokooehan (zelf streekgemeenschappen met een verdeeling in familiegroepen) en Mehangi.

Lingketing kent sedentaire gezinnenkringen; als bestuurders van dergelijke wijken noemt men langka-langkai of pabisala, doch niet elke wijk had een dergelijk hoofd. Of elke tonggol, hoofd eener verwantengroep, een of meer van deze helpers onder zich had is niet zeker. De mededeelingen van Kruyt en Tangkilisan stemmen niet overeen. Eerstgenoemde spreekt van ,iedere nederzetting of langkalangkaischap" en deelt dan mede dat in Pinapoean één tonggol en vier langka-langkai te vinden waren. Tangkilisan daarentegen zegt dat er in het geheele gebied van Lingketing vijf langka-langkai en drie pabisala bescheiden waren; onder den tonggol van Pinapoean stond slechts één pabisala. Ook over de helpers bestaat geen eenstemmigheid; Kruyt stelt dat iedere tonggol een pabisala, een mian kopian en een milinoe tot zijn beschikking had; Tangkilisan echter schrijft dat een tonggol sòms een toema noe tonggol dan wel een mian kopian, dan wel beide tot zijn beschikking had; den milinoe noemt hij niet. Het centrum der streekgemeenschap was de kampong Inetes waar de daka'njo woonde, wien eenige familieleden ter zijde stonden, nl. een toema noe daka'njo en een mian kopian, die beiden steeds hun verblijf hadden in Inetes. Of de boodschapper (milinoe) van het hoofd der streekgemeenschap ook daar woonde is niet zeker. Den daka'njo Lingketing stond een kleine legermacht ter beschikking; men noemt uit vroeger tijden talenga, sega, pongkeali en pandjolo, allen aanvoerders der krijgers (madi: to sega-sega). De talenga was de aanvoerder; in zijn naam vinden we terug dat hij acht moest slaan op vogelgeluiden (verg. mal. telinga $=$ oor); de drie anderen zijn 
assistenten van den aanvoerder. De pandjolo neemt de teekenen waar; zijn naam zal wel ontleend zijn aan mondjolo (madi : dooden). De pongkeali is afgezant van den aanvoerder, de sega representant de1 krijgers. De aanvoerder had te luisteren naar de bevelen van den doka'njo; deze maakte echter zelf nimmer een krijgstocht mee.

Deze veelheid van namen, deze „kabelbonte verscheidenheid" wordt nog grooter, indien we alle functieaanduidingen, die men kende, opsommen. In het hieronder volgend schema vindt men van die veelheid een beeld, terwijl tevens aanduiding der beteekenis wordt gegeven. Terwille der leesbaarheid echter zal in den vervolge, zoo daartoe aanleiding bestaat, aangeduid worden met $\mathrm{stree} \mathrm{kh}$ o o f d : het hoofd eener streekgemeenschap; met groepshoof $d$ : het hoofd eener familiegroep.

$a$. Helpers der groepshoofden, tevens eventueel optredend als hoofden van gezinnenkringen.

A rchipe1: tano (land; pandeling, zie blz. 84; hier: voorman van het land);

mian tangano (mensch in het midden);

paoe langkai (paoe $=$ kind; langkai $=$ oud $)$;

poe bakalinga (bakalinga $=$ rechterhand, rechterkant);

tonggol paoeno (kleine tonggol);

kapitan paoeno (kleine kapitan).

Vogelkop: tonggol.

$\mathrm{V}$ a s t e-W a 1 : langka-langkai;

pabisala (woordvoerder, spreker);

toembak (lans, steun, stut);

mian kopian (?) (goed mensch, vredestichter);

milinoe (?) (boodschapper);

toema noe tonggol (?) (vader van den tonggol).

Kruyt leidt langka-langkai af van het Morische langkai; de reduplicatie wil dan zeggen: de eenigszins groote. Ik heb echter den indruk dat de beteekenis dezelfde is als voor den Archipel opgegeven. Verder vergelijkt hij den pabisala met den woordvoerder der Boegineesche hoven ${ }^{2}$ ). Volgens Tangkilisan bestaat er tusschen beiden geen functioneel verschil, doch de eerste was steeds ouder, de tweede welbespraakt.

2) Kruyt, To Loinang, blz. 355 . 
b. Groepshoofden.

Archipe 1: tonggol;

tonggol ocloeno (voornaamste der tonggol);

loeloe batango (de stam van de huldegift);

pandalabin (die op de schoot neemt);

basalo tamano

$\left.\begin{array}{l}\text { kapitan } \\ \text { mampangala } \\ \text { potoembak }\end{array}\right\}$ zie onder $d$.

paoe bakalinga | Boelagiërs op Bangkoeloe.

basalo paoeno $\}$ (blz. 44).

Men gaf mij tonggol op te zijn afgeleid van mongototong (aki: bijeenbrengen); dr. S. J. Esser betwijfelt de juistheid daarvan.

Vogelkop: paoe basal (basal = groot);

$\left.\begin{array}{l}\text { tonggol } \\ \text { langka-langkai }\end{array}\right\}$ plaatselijk in Basama.

$\mathrm{V}$ a s te-W a 1: tonggol;

langka-langkai (m.n. in Doehian);

balangka-langkai;

daka'njo (groote,echter lager dan bosanjo);

kapitan.

Kruyt leidt tonggol af van het elders op Celebes voorkomende tongko, hetgeen in het Boegineesch dekken, bedekken beteekent. Onder de Poso-Toradja's werd met tongko een hoofd aangeduid door den radja van Loewoe of van Mori angesteld om een heele streek te vertegenwoordigen; bij de Sadan-Toradja's komt het nog voor in tongkon-an $=$ stamhuis, plaats van den tonggon (tonggol). Het valt op, dat de Loinang inderdaad vaak over tonggon spreken als zij tonggol bedoelen ${ }^{3}$ ). Tangkilisan brengt tonggol in verband met montoong bala lajat (madi : over het volk bevelen; tonggon $=$ bevel).

c. Streekhoofden $\left.{ }^{4}\right)$.

A rchipel: basalo (groote). tonggol tamano (Basosol) (?). Vogelkop: bosanjo (groote).

Vaste-Wa1: bosanjo (groote);

daka'njo (groote, minder dan bosanjo);

mian kopian (goed mensch, vredestichter) in Doehian.

3) Kruyt, To Loinang, blz. 332.

4) Vergelijk Kruyt, To Loinang, blz. 354, 346, 352.

Verh. dl. VI. 
d. Helpers der streekhoofden, medebestuurders.

Archipe 1: basalo tamano (vader van den basalo);

kapitan;

mampangala (die het wederwoord geeft);

potoembak (lans; steun, stut).

Deze functionarissen treden ook wel op als groepshoofden; het eerste tweetal is steeds verwant aan het streekhoofd, de kapitan is vaak zijn opvolger.

Vogelkop: $\left.\begin{array}{l}\text { toema oe bosano } \\ \text { tamano hosano } \\ \text { tonggol bojoko } \\ \text { langka-langkai }\end{array}\right\}$ plaatselijk.

V a s t e-W a 1: toema noe bosanjo (toema = vader);

langka-langkai;

kapitan kota;

kapitan kompania (bevelhebber van het leger);

kapitan bosanjo;

kapitan saudagar (?);

kapitan tano (tano wellicht verzamelnaam voor

lagere hoofden);

toema noe daka'njo (Lingketing, Pokooehan);

mian kopian (Lingketing);

toema noe tano (Pokooehan);

pabisala (Pokooehan);

milinoe of bobotokon (boodschapper);

talenga, pandjolo, pongkeali, sega (aanvoerders in den krijg).

Kruyt ziet in functionarissen als toema noe bosanjo en toema noe daka'njo vertegenwoordigers van een hoofdengeslacht der oorspronkelijke bevolking; hij zegt dat zij nimmer bosanjo c.q. daka'njo konden worden ${ }^{5}$ ). Tangkilisan deelt echter pertinent mede (t.a.v. Lingketing) dat zoowel de toema noe daka'njo als de mian kopian van daka'njo-familie moesten zijn, en dat zij niet alleen bij afwezigheid van het streekhoofd als zoodanig konden optreden, doch ook dat zij zelf tot vervulling van dat ambt geroepen konden worden. Dat deze functionarissen ten nauwste met elkaar verbonden waren blijkt verder uit den regel dat zij gedrieën in Inetes dienden te wonen.

$e$. Adelwijk (zoo aanwezig), zonder besturende functie. A rchipel: basalo paoeno (kleine basalo); meestal vier;

5) Kruyt, To Loinang, blz. 359. 
Vogelkop: anak oe mian (4 in Basama);

anak na mian (8 in Tanotoeran, 3 in Dale-Dale);

$\mathrm{V}$ a s te-W a 1 : anak $i$ bosanjo; zie verder onder $d$.

anoematoea (toezicht in de adelwijk, vaak zelf niet van adel).

Aanteekening verdient dat in sommige woonoorden onderhoorigen van verschillende streekhoofden gevestigd konden zijn; zoo meldt men dat onderhoorigen van den daka'njo Lingketing, in eenige plaatsen van de Tominibocht woonachtig, daar onder een toea'njo (= oudste) stonden $^{6}$ ).

Slechts de basaloschappen op het eiland Banggai vertoonen een van het bovenstaande afwijkend beeld; daar zij geen verdeeling in familiegroepen kennen (zie blz.67) zijn hier geen tonggol of dergelijke bestuurders; wel had elke basalo vier helpers, nl. twee basalo paoeno en twee paoe bakalinga. Het is dus de vraag of we deze basaloschappen als streekgemeenschappen mogen aanmerken; eerder rijst het vermoeden dat elk der Banggaische basaloschappen in wezen een familiegroep is, en dat het viertal tezamen als streekgemeenschap dient te worden beschouwd (verg. de traditie over de tot standkoming van het rijkje Banggai, blz. 36).

$f$. Het bestuur der federatie (zie blz. 60 v.) was als volgt georganiseerd: de Lipoeadino had een raad van vier naast zich, aan de leden waarvan wel de naam bobato (verg. blz. 84 v.) gegeven werd, zulks vermoedelijk in navolging van de gewoonten te Banggai (welke nader in par. 4 behandeld zullen worden). $Z \mathrm{ij}$ voerden de nvaolgende titels: gimalaha (Ternataansch: ,orang jang baik”) ; kapitan dalangon (aki : dalangon = zee; hij was vlootvoogd), kapitan tano (bewaker van het grondgebied? of : hoofd der lagere hoofden?) en loetenaan. De kapitan tano was belast met bewaking van de woonplaats van den Lipoeadino, de loetenaan was hofbeambte, doch had ook te zorgen voor bemanning en vertrek der prauwen als de Lipoeadino op reis ging; hij had twee boodschappers onder zijn bevelen, een alifiris (Portugeesch: vaandeldrager) en een pombawa.

Het bestuur over de onderdeelen waaruit het gebied van den Lipoeadino bestond, was niet wezenlijk anders georganiseerd dan hooger aangegeven; vermoedelijk zullen niet alle der op blz. 27 opgesomde onderhoorigheden van den Lipoeadino als streekgemeenschap zijn aan te merken, doch wel het grootste deel ervan (nl. Lolantang, Palabatoe, Patoekoeki Tombos, Keleke, Lo'nsom, Basosol).

6) Nota Tangkilisan. 
Het bestuur van de voormalige rijkjes en van eventueele stammen zullen we voorbijgaan, terwijl de organisatie van het landschap nader besproken zal worden in par. 4 van dit hoofdstuk. Rest ons nog iets te zeggen van het bestuur der landbouwvereenigingen. Zooals op blz. 64 medegedeeld heeft de voorganger twee assistenten, die echter volgens Kruyt bij den landbouw geen functie van beteekenis bezitten; slechts plegen zij gedrieën overleg wat de teekenen duiden. De speciale taak van den pahemata (één der assistenten) is, de regelingen, door den voorganger gemaakt, aan de akkergenooten over te brengen; die van den anderen assistent, den pombebe' $i$, is niet angegeven; heeft hij iets te maken met het mombe'i (madi : geven), dat in dit verband op het offer ziet, dat bij het begin van het planten aan de zielen der afgestorvenen wordt gebracht? ${ }^{7}$ ).

\section{Aanwijzing tot de verschillende functies ${ }^{8}$ ).}

In het algemeen geschiedde de benoeming tot een der bestuursfuncties door de leden van de groep zelve waarover dit hoofd gesteld werd, waarna goedkeuring door een hoogeren functionaris volgde.

$Z \mathrm{ij}$ die wij als helpers der groepshoofden hebben leeren kennen (blz.96) werden aangewezen door de gezamenlijke leden der familiegroep, waarbij de andere tano enz. overwegenden invloed op den uitslag der besprekingen hadden. Algemeen meldt men, en dit geldt ook voor de aanwijzing der hoogere functionarissen, dat men onderling tot overeenstemming diende te komen; was er nl. een groep die zich niet met het inzicht der overige kon vereenigen, dan bestond de mogelijkheid dat dit hoofd in die groep niets te zeggen zou hebben. Was dus door onderling overleg eenstemmigheid bereikt, dan werd het resultaat der besprekingen aan het groepshoofd medegedeeld, die op zijn beurt het streekhoofd inlichtte. Op den Vaste-Wal meldt men dat soms de besprekingen, die leidden tot aanwijzing van een langkalangkai, bijgewoond werden door een der naaste familieleden van het streekhoofd (b.v. den toema noe bosanjo); ook meldt men daar dat zelfs deze laagste functionarissen door het streekhoofd beëedigd werden, die daarbij een bepaalden hoofddoek verstrekte (madi : pasapoe); de familiegroep in haar geheel bracht een contragift aan het streekhoofd op, bestaande uit een zeker aantal blokken goed; deze gift heet posoehangan (madi : soehang-zitten ${ }^{9}$ ).

7) Kruyt, To Loinang, blz. 413/414; 419.

8) Memorie, tenzij anders vermeld.

${ }^{9}$ ) Vergelijk de toespraak vermeld op blz. 359 van Kruyt, To Loinang. 
Ter aanwijzing van een groepshoofd werd door de geheele familiegroep, onder leiding der ouden (tano), beraadslaagd wie voor vervulling der functie in aanmerking kwam. In de eerste plaats lette men op afstamming uit de tonggol-familie; het opvolgingssysteem is hetzelfde als op blz. 41 beschreven; vererving der functie met electie. Gelet werd op zuiverheid der afstamming en capaciteiten. Na bereikte eenstemmigheid (onder de hoofden der betrokken huisgezinnen?) werd de verkozene door de oudsten bij het streekhoofd voorgeleid, die de keuze bevestigde; weigering schijnt nimmer te zijn voorgekomen. Het nieuwe groepshoofd ontving van het streekhoofd ambtskleeding (toala, aki = hoofddoek; balahadada, aki = hemdjas). Een tegengeschenk (aki: pongodoedock) door de geheele familiegroep opgebracht bestond uit eenige blokken goed. Op den Vaste-Wal was een en ander niet anders geregeld; ook hier overlegden de lagere hoofden in de familiegroep met haar leden, soms onder leiding van een der hoogere, adellijke functionarissen, die tevens voor voorgeleiding bij het streekhoofd zorgde; het nieuwe groepshoofd ontving ambtskleeding (madi : pasapoe = hoofddoek; takoea $=$ hemdjas), de familiegroep bracht in haar geheel contragift op.

Soms had een groepshoofd een bode tot zijn beschikking, door dat hoofd naar luim en willekeur uit zijn onderhoorigen aangewezen, daarbij niet lettende op afstamming of wenschen der groepsleden. Bij een daartoe geschikte gelegenheid stelde hij de onderhoorigen van een en ander in kennis. Dit geldt ook voor de door Tangkilisan gemelde mian kopian en toema noe tonggol, helpers der groepshoofden in sommige familiegroepen.

Of de oudere adviseurs-medebestuurders van het streekhoofd (blz. 98-d.) door het streekhoofd zelf aangewezen werden, dan wel of dit in overleg met de onderhoorigen geschiedde, is niet duidelijk; Tangkilisan zegt alleen dat mian kopian en toema noe daka'njo van Lingketing door dat streekhoofd werden aangesteld. Elders vond ik dat bij de aanstelling van een toema noe bosanjo of een kapitan alleen de adelwijk voor de contragift zorgde; deze hoofden ontvingen van het streekhoofd de gebruikelijke kleeding, vermeerderd met een kniebroek (madi : saloean). Bij de plechtigheid waren de groepshoofden wel aanwezig.

Boodschappers en eventueele hoofden der adelwijken werden aangewezen buiten medeweten van en zonder overleg met de onderhoorigen; bij een geschikte gelegenheid werden zij aan den kleinen man voorgesteld. 
De aanwijzing tot streekhoofd in den Archipel ging op plechtige wijze. Als het vorige streekhoofd overleden was, gingen boden door het gebied met een witten lap in de hand en deden kond van de droeve mare; tevens werden allen uitgenoodigd tot het doodenfeest. Tijdens deze plechtigheid werd door de groepshoofden, onder leiding der basalo paoeno en andere familieleden van den overledene (b.v. basalo tamano), overlegd wie als nieuw streekhoofd zou optreden. De groepshoofden overtuigden zich terdege van de instemming hunner onderhoorigen, omdat men eenheid van gevoelen eischte. Gelet werd op zuiverheid der afstamming en geschiktheid tot het bekleeden van het ambt, terwijl men uit dezelfde generatie als waartoe de overledene behoorde, eerst diegenen uitzocht die aan deze voorwaarden voldeden, voor men er toe overging onder een jongere generatie te gaan zoeken. Vaak werd de kapitan, zelden de basalo tamano tot opvolger aangewezen.

Op den Vaste-Wal geschiedde de voorziening in vacature van een nieuw streekhoofd niet op wezenlijk andere wijze. Kruyt meldt dat men in Lingketing na het overlijden van den daka'njo een soort interim-bestuur kent, omdat vanaf zijn sterven tot tweemaal zeven dagen dàarna, wanneer het doodenfeest gevierd moet worden, de toema noe daka'njo het bewind uitoefende ${ }^{\mathbf{1 0}}$ ). In dien tusschentijd pleegden de lagere hoofden overleg met de leden van de adellijke families en met hun onderhoorigen, zoodat op den dag van het doodenfeest bekend was, wie als nieuw hoofd gewenscht was. Volgens Tangkilisan konden zoowel mian kopian als toema noe daka'njo tot nieuw streekhoofd aangewezen worden, volgens Kruyt niet (zie de slotopmerking onder par. $1-d$. van dit hoofdstuk).

Streekhoofden, den titel voerend van basalo, bosanjo of bosano, en op boven aangegeven wijze aangewezen, dienden na die aanwijzing nog door den vorst te Banggai te worden beëedigd. Dit geschiedde op plechtige wijze. Men vertrok in eenige prauwen, versierd met vaantjes naar Banggai, terwijl men medegenomen muziekinstrumenten bespeelde. Merkwaardig bij deze staatsieprauwen is, dat streekhoofden die twaalf familiegroepen onder zich hadden, ook twaalf kleine vaantjes op hun vaartuig voerden, benevens één groote vlag; men zegt dat de kleuren rood, wit en blauw waren. Andere streekhoofden voerden soms vier, soms zes vaantjes, benevens steeds één groote vlag. Te Banggai aangekomen liet men zich door een der edelen aandienen

10) Kruyt, To Loinang, blz. 358/359. 
bij den vorst; elk streekhoofd had zijn eigen toezichthouder, wiens functie nader ter sprake zal komen (baoeloeno; zie par. 4-e.).

Op den gezetten tijd ontving de vorst het nieuw aangewezen streekhoofd, dat vergezeld was van eenige familieleden, meestal o.a. van den basalo tamano, alsmede van eenige groepshoofden; de vorst zat in staatsie met zijn adviesraad, leden van den vorstenadel en geestelijkheid. De vorst sprak het nieuwe streekhoofd toe, waarna een der leden van den raad den eed afnam volgens een traditioneel formulier; vervolgens nam een der Mohamedaansche godsdienstbeambten nog een soort eed op den Korân af. Eerstgenoemde kent verschil tusschen die voor streekhoofden uit Oost- en uit West-Peling gebruikt; in het algemeen wordt een bedreiging uitgesproken met eenige soorten ongeluk of tegenspoed die den beëedigde zullen overkomen in het geval hij een onwaardig afstammeling zijner voorouders is, dan wel misbruik zal maken van zijn positie.

Hierop ontving het aldus door den vorst erkende streekhoofd uit diens handen ambtskleeding, bestaande uit een sabalee als hoofdbedekking en een balahadada (beide aki) als gewaad. De geheele streekgemeenschap bracht daarvoor een contragift op aan den vorst, bestaande uit een groot aantal blokken goed, later vervangen door een betaling in contanten; deze gift heet hier ook pongodoedoek. Hiermee was de erkenning te Banggai voltooid en keerde het gezelschap naar de eigen landstreek terug waar de feitelijke inhuldiging ten overstaan van en door het volk geschiedde, waarover aanstonds meer. Streekhoofden van den Vaste-Wal ontvingen veelvuldig een saloean (madi: korte broek) buiten de andere kleedingstukken; de contrgaift noemen zij uiteraard posoehangan.

Streekhoofden die een anderen titel voerden (b.v. daka'njo, mian kopian) en die in ondergeschiktheidsverhouding tot een ander hoofd stonden, werden echter niet te Banggai bevestigd, doch meestal in hun eigen gebied door den betrokken heer. Kruyt deelt mee dat het streekhoofd van Kintom b.v. gewoonlijk op het doodenfeest van een daka'njo Lingketing was; daar werd bekend gemaakt wie zou opvolgen krachtens gemeenschappelijk overleg; de heer van Kintom beëedigde het nieuwe hoofd terstond en voorzag hem van ambtskleeding. Het door Kruyt gegeven eedsformulier wijkt aanzienlijk af van dat in den Archipel in gebruik; het is een bede voor het welzijn van den nieuw aangestelde, zij wordt besloten met te tellen tot zeven (omdat er zeven groepshoofden zijn ?) ${ }^{\mathbf{1 1}}$ ).

11) Kruyt, To Loinang, blz. 359. 
De plechtigheden waaraan de streekhoofden van den Archipel zich na terugkeer in hun land hadden te onderwerpen dragen alle het karakter van overgangsriten. Een algemeene trek is, dat het nieuwe hoofd gebaad wordt met water dat in verband gebracht wordt met de vergoddelijkte voorouders. De traditie wil zelfs, dat voor deze speciale gelegenheid water gaat vloeien uit openingen in steenen, welke volgens de legende in verband staan met den vergoddelijkten stichter. Locale trekken zijn: (Boeoeko) één der basalo paoeno ging met de vlag van de basaloprauw, die hij gestreken had, aan wal, waarna hij een geit slachtte, dan baadde de basalo tamano het nieuwe streekhoofd; (Tinangkoeng) het nieuw benoemde hoofd werd door eenige ouden van dagen gebaad (met water besprenkeld), terwijl hij op de schoot van den tonggol oeloeno zat (verg. de straks te behandelen installatie van den vorst); (Ponding-Ponding) voor het nieuwe hoofd werd een sirihdoos geplaatst, waarop één der ouden hem verzocht iets te zeggen; men lette scherp op de eerste woorden en profeteerde uit dit orakel voor- of tegenspoed in zijn bestuur; (Tatakalai) het nieuwe streekhoofd mocht zich de eerste drie dagen na aankomst niet vertoonen; (Totikom en Popiisi) het nieuwe hoofd werd ten overstaan van zijn onderhoorigen gebaad met water dat in verband staat met de balakat; (Tombos en Pelei) hetzelfde als voor Popiisi en Totikom, doch gezegd wordt dat dit water wonderbaarlijk te voorschijn komt; (Kombotokan) koperen doos en deksel (volgens de traditie eigenhandig door een der vroegere hoofden gemaakt) werden door den basalo tamano langzaam tegen elkaar getikt, waarna het nieuwe streekhoofd iets moest zeggen; ook hier hadden de eerste woorden de waarde van een orakel; daarna werd hij, op een bepaalden steen gezeten, gebaad door de oudsten, ten overstaan van het volk; (Loeokpanenteng) de pandalabin (zie blz. 97) ging het eerst aan land, bood sirih-pinang aan, streek de vlag van de basaloprauw en slachtte een geit; wellicht zette zich daarna het nieuwe streekhoofd bij dit groepshoofd op den schoot (was deze pandalabin een vrouw? vergelijke ook Tinangkoeng).

Van de hoofden op den Vaste-Wal vermeldt men dergelijke magische handelingen niet; meestal werd het graf van den stamvader bezocht, en een oude besprenkelde dit met water, waarna het nieuwe hoofd bezworen werd een waardig afstammeling en een goed bestuurder te zijn.

Een uitzonderlijke plaats nemen weer de vier hoofden van Banggai in. Door middel van intern overleg werd onder leiding van de helpers 
uitgemaakt wie als nieuwe basalo zou optreden; de gekozene werd bij den vorst voorgeleid, die hem steeds goedkeurde. Het schijnt wel gebeurd te zijn dat hij weinig voor zijn ambt voelde, doch dat de vorst hem overhaalde het toch te aanvaarden. Vervolgens vertrok het nieuwe hoofd naar Ternate, waar de sultan hem aanstelde en liet beëedigen; tevens werden hem kleedingstukken verstrekt, o.a. hoofdbedekking, de hooger genoemde sabalee, verder een zwarte jas, roke genoemd (verg. rok) met zwarten lendendoek en een stok met zilveren knop. $\mathrm{Na}$ terugkeer van Ternate hield men een feestelijken optocht in de kampong en werd het nieuw aangestelde hoofd door een der edelen ingewijd in de geheimen van het bestuur; vele der onderhoorigen namen deel aan de daarbij gehouden feesten, waarbij geestrijke dranken rijkelijk vloeiden, zoodat menigeen 's morgens zijn roes uitsliep onder het huis van den nieuwen basalo of diens leermeester. Slechts van het hoofd van Dodoeoeng wordt gemeld, dat hij door zijn onderhoorigen gebaad werd.

De Lipoeadino ten slotte werd aangewezen op een vergadering der drie hoofden van Lolantang, Palabatoe en Soeit; het resultaat der besprekingen werd medegedeeld an den vorst, die daarop eenige edelen afzond om den Lipoeadino tezamen met zijn rijksraad af te halen en naar Banggai te begeleiden. De vorst verleende te Banggai weer kleedingstukken, o.a. een witten hoofddoek (zie blz. 24). Hierna keerde de Lipoeadino terug naar Lolantang; zijn prauw voerde twaalf vaantjes. Onderweg deed men wel eenige plaatsen aan waar onderhoorigen zetelden, doch men had te Lolantang nog de installatieplechtigheden te verrichten. Zoodra de vloot van den Lipoeadino ter reede was aangekomen voer de vlootvoogd driemaal om de schepen heen. Hierop mocht de Lipoeadino zich aan wal begeven, waarna hij naar zijn woning werd gedragen, terwijl men schoten uit een kanonnetje loste. Zoo spoedig mogelijk werd nu een groote vergadering belegd waaraan zooveel mogelijk volk en hoofden deelnamen. De Lipoeadino werd gebaad door het hoofd van Lolantang; hij was daarbij gezeten op een bepaalden steen, de overigen keken van een ringmuur toe. Dezelfde basalo bezwoer hem een waardig afstammeling en rechtvaardig bestuurder te zijn.

Het beeld dat Goedhart geeft naar den toestand van 1908 klopt met het bovenstaande niet geheel. Hij schrijft wel dat een of meer hoofden den basalo in de uitoefening van het bestuur ter zijde stonden, en dat een basalo tamano of kapitan langkai (hij schrijft langkat) dan wel anoematoea de wettige vervanger bij belet of ont- 
stentenis van den basalo was, doch over de opvolging zegt hij dat het systeem van verkiezing, eertijds binnen de streekgemeenschap gehouden door de mindere hoofden en de geestelijkheid, in overeenstemming met de wenschen der bevolking, in de laatste jaren voor 1908 verlaten was, en dat dit had plaats gemaakt voor een werkwijze waarbij de vorst meer invloed kreeg op de benoeming der streekhoofden (de rijksbestierder ontving b.v. opgave van eenige candidaten, waaruit de vorst een keuze deed; òf de vorst gaf opdracht uit eenige candidaten keuze te doen ${ }^{12}$ ). Bij mịn onderzoek in 1939 is hiervan echter niets gebleken; men verzekerde mij over het algemeen zelfs nadrukkelijk dat de vorst nimmer van de keus der streekgemeenschap af week, en steeds den gekozene bevestigde.

\section{Omvang der bestuursfuncties.}

In een primitieve maatschappij als de Banggaische zullen de bestuursfuncties niet veel omvatten. Kruyt zegt, over de streekhoofden in den Archipel sprekend, dat deze zich zelden bemoeiden met wat er in het binnenland gebeurde; zij waren vrijwel uitsluitend aan de kust gevestigd, of in de nabijheid daarvan. Wel had men lagere hoofden die tonggol heetten, en een soort oudsten, langka-langkai; maar dezen schijnen zich weinig met den loop der dingen te hebben bemoeid. Slechts als iemand zijn beklag kwam doen over een ander mengde hij zich erin; volgens Kruyt zijn deze hoofden een soort mandoers die in de eerste en vaak eenige plaats te zorgen hadden voor de schatting die aan den vorst moest worden opgebracht. In oude tijden woonde de bevolking verspreid; het waren vooral de families (verzamelingen van naaste verwanten) die een eenheid vormden, in de dagelijksche aangelegenheden zoo goed als op zich zelf aangewezen. Dit werkte het ontstaan van een krachtig hoofdengezag niet in de hand; aldus dezelfde schrijver ${ }^{\mathbf{1 3}}$ ).

Ook Goedhart zag de werkzaamheden der hoofden eenvoudig: zorg dat elk jaar de huldegift (bij hem: haçil) voor vorst en leden van het zelfbestuur bijeengebracht werd; afdoen van kleine geschillen tusschen de onderhoorigen; eens in de twee à drie jaar naar Banggai komen om de bevelen van den vorst in ontvangst te nemen ${ }^{14}$ ).

Inderdaad was een voornaam onderdeel der hoofdentaak eertijds

12) Goedhart, Drie landschappen, blz. 455/456.

13) Kruyt, Bewoners, blz. 249; 71.

14) Goedhart, Drie landschappen, blz. 460. 
het verzamelen en opbrengen van de jaarlijksche huldegift; hiervan ontvingen de hoofden zelven tevens een deel als inkomste. Zooals op blz. $90 \mathrm{v}$. medegedeeld was het gezin heffingseenheid, althans in den Archipel en op den Vogelkop; bij de Loinangs spreekt Tangkilisan echter van ,plichtige" tot het opbrengen van huldegift, doch hij geeft niet aan wie dit waren. In de eerste plaats moest gezuiverde bijenwas, verder veldgewassen, eieren, lappen katoen, later ook wel geld aan den vorst opgebracht worden; de hoeveelheden verschillen, doch elk streekhoofd moest 1 pikol $( \pm 60 \mathrm{~kg}$ ) gezuiverde bijenwas leveren. Dit hoofd verdeelde de op te brengen hoeveelheid over de groepshoofden, doch legde ieder een verplichting op die aanmerkelijk hooger was. Waren er b.v. vier familiegroepen, dan moest elk groepshoofd 40 of meer kati was bij het streekhoofd inleveren. Op zijn beurt stelde het groepshoofd vast, dat b.v. elk huisgezin 2 kati ruwe was bij hem moest inleveren; zij werd dan bij hem gereinigd en het deel, dat naar het streekhoofd moest worden gezonden, afgehouden. Het restant was voor het groepshoofd, die aan zijn helpers een deel (veelal de helft) afstond. Was op deze wijze door de vier familiegroepen totaal 160 kati zuivere was bij het streekhoofd gebracht, dan werd daarvan 1 pikol naar Banggai gebracht, doch de overige 60 kati behield het streekhoofd voor zich, daarvan aan basalo tamano en kapitan ieder een deel gevend.

Kruyt en Tangkilisan beschrijven uitvoerig hoe eertijds de huldegift in Loinang verzameld werd ${ }^{15}$ ). Elkeen die tot het opbrengen verplicht was bracht een kom rijst en een staafje was, soms rechtstreeks aan het groepshoofd, soms aan langka-langkai of pabisala; bij deze laatsten werd de rijst in een kleine draagmand verzameld, tevens een maat. De verdeeling van het eventueel meerdere had pas bij het groepshoofd plaats, want deze wist welke hoeveelheden rijst en was naar het streekhoofd gebracht moesten worden; dit meerdere was ook hier voor dat groepshoofd en zijn verwanten, medebestuurders. Verder werden bij het streekhoofd ook verzameld de giften opgebracht door zijn rechtstreeksche onderhoorigen, dat zijn dus de niet ambtelijke leden van de $d a k a^{\prime} n j o-$ familie en de overigen die elders b.v. onder een toea'njo stonden (zie par. 1-e.); men zegt dat het streekhoofd van Lingketing uit dien hoofde zeer veel was en rijst ontving. Hieruit werd een bijzonder deel van de huldegift samengesteld, nl. dat deel dat weliswaar naar den heer te Kintom zou worden

15) Kruyt, To Loinang, blz. 354-358; Nota Tangkilisan. 
gebracht, doch door dezen naar den vorst te Banggai werd doorgezonden. Wat er meer bij het streekhoofd verzameld was dan noodig bleek, kwam ook hier weer aan den daka'njo en zijn familieleden mede-bestuurders ten goede. Ten slotte werden er dus door het streekhoofd van Lingketing naar den heer te Kintom acht draagmanden met huldegift gebracht, één van den daka'njo, zeven van de zeven tonggol; deze laatste waren bestemd voor den heer te Kintom.

Overal geschiedde het brengen van tribuut op plechtige wijze. In den Archipel ging het streekhoofd, vergezeld van eenige grooten, in één of meer versierde prauwen, naar Banggai ${ }^{16}$ ). Kanonschoten waren het sein voor vertrek en voor aankomst te Banggai. Men meldde zich bij den toezichthouder en deze gaf bericht wanneer de vorst de huldegift in ontvangst zou nemen; men zegt dat vaak de vorst een deel van het opgebrachte tribuut aan het streekhoofd afstond. De hoofden van den Vaste-Wal ${ }^{17}$ ) vertrokken vaak gezamenlijk, waartoe zich te Batoei een vloot van prauwen vormde; sommigen waardigheidsbekleeders viel bijzondere eer te beurt, met name waren het de Lipoeadino en de streekhoofden van Tinangkoeng en Batoei. Deze drie plachten ook wel op elkaar te wachten bij den ingang van de baai van Banggai en dan in bepaalde formatie naar binnen te varen.

Ook het brengen van het tribuut van Loinang naar den heer te Kintom geschiedde op plechtige wijze; het streekhoofd van Lingketing, met den toema noe daka'njo en de zeven groepshoofden begaven zich gezamenlijk op weg, begeleid door een menigte mannen, onder wie de krijgslieden. Voorgeleiding bij den heer te Kintom geschiedde door den kapitan tano, voor de Lingketingers ook wel kapitan daka' genaamd (madi: $d a k a^{\prime}=$ groot). De bosanjo wachtte in zijn woning; hij hield een doek in de hand. waarvan hij een tip het Lingketingsche hoofd toewierp, om hem daarna als het ware in zijn huis te trekken. Den gast werden nu o.a. de voeten gewasschen, waarna hij plaats nam aan de rechterzijde van den bosanjo. De groepshoofden waren eveneens naar binnen gekomen, tezamen met leden van den Kintomschen adel. Men hield nu allerlei besprekingen waarbij ten slotte de huldegift overgedragen werd; het van den daka'njo Lingketing afkomstige en voor den vorst te Banggai bestemde deel werd apart gehouden. De heer te Kintom sprak vervolgens een

16) Kruyt, Vorsten, blz. 618/619.

17) Zie ook Kruyt, Balantaksche Studiën, blz. 340. 
zegenwensch uit voor het welzijn der Lingketingsche hoofden; men vierde feest en voerde krijgsdansen uit.

$\mathrm{Bij}$ hun vertrek ontvingen de Loinangsche hoofden geschenken van den heer te Kintom: lappen katoen van diverse soorten, vaak van groote traditioneele waarde (motombing; zie hfst. XI, par. 2); aarden kookpotten. Hierop vertrok het gezelschap, doch bij terugkeer in Lingketing, waarvan een schot met een donderbus het teeken was, werd nogmaals een groot feest aangericht.

Naast dit aandeel in den jaarlijkschen wasoogst en de eventueele tegengeschenken van den heer, genoten de hoofden nog andere inkomsten: rijst, oebi, klappernoten, tabak, kippen, later ook geld. Volgens Kruyt kreeg het streekhoofd van Lingketing na afloop van den oogst van elk huisgezin (!) een mandje met rijst, een bamboe met palmwijn en een hoen; van het slachten van een gemsbuffel gaf men hem vooraf kennis en men schonk hem dan vier brokken vleesch, veelal uit de halsstreek ${ }^{18}$ ).

Verder moesten diensten gepresteerd worden ten bate der hoofden; men kent hiervoor in het aki de termen balimang en tanoan, in het madi molimpoeng en hoendoehon. (Het $1 \mathrm{e}$ en $3 \mathrm{e}$ woord schijnt te slaan op algemeene, het $2 \mathrm{e}$ en $4 \mathrm{e}$ speciaal op velddiensten). Op deze wijze beschikten de hoofden geregeld over uitgestrekte akkers terwijl zoo ook de bouw van een huis tot stand kwam. Wij moeten hieraan toevoegen, dat slechts de streekhoofden recht hadden op dienstbetoon van alle onderhoorigen, de groepshoofden op dat van de eigen familiegroep alleen; noch de helpers van den één, noch die van den ander konden aanspraak maken op deze hulp. Indien zij al verleend werd dan geschiedde zij vrijwillig, uit hoofde van het aanzien of den invloed van den betrokkene ${ }^{19}$.

Andere inkomsten ontvingen de hoofden bij de uitoefening van hun bestuurstaak (rechtspraak); andere wisselvallige inkomsten in verband staande met het beschikkingsrecht zullen in hoofdstuk X behandeld worden.

Misbruiken, voortvloeiende uit de machtspositie der hoofden, kwamen voor. Goedhart meldt dat in Mendono het streekhoofd het recht had na den rijstoogst acht stukken ongebleekt katoen ter waarde van $f 1.50$ per stuk, bij de bevolking te ruilen tegen acht maal 80 bossen rijst van \pm 2 kati per bos ${ }^{20}$ ). Hierdoor verwierf dit hoofd

18) Kruyt, To Loinang, blz. 355.

19) Vergelijk Kruyt, To Loinang, blz. 359; Balantaksche Studiën, blz. 341.

20) Goedhart, Drie landschappen, blz. 459. 
dus ongeveer 13 pikol bras voor katoen ter waarde van $\mathrm{f} 12$,- ; men noemt dit baloe salah (madi beteekenis?). Voorbeelden van afpersingen en knoeierijen noemt Goedhart op blz. 461 zijner nota; van het eerste is ook het volgende een voorbeeld. Had in de vorstelijke familie een sterfgeval plaats gehad, dan stak de kapitan laoet (vlootvoogd) naar Balantak over om een heffing te doen; ook werden stukken katoen onder de bevolking verdeeld, maar er werd minstens tweemaal zooveel rijst voor gevraagd als ze waard waren. Men duidt dit aan met toeloengan (mal. : hulp ${ }^{21}$ ).

Naast deze bemoeienis met huldegift en wat daarmee samenhangt, vinden we in de literatuur verspreide mededeelingen, waaruit blijkt dat zij naast een rechterlijke taak nog andere belangrijke sociale functies te vervullen hadden, en deels nog hebben.

In den Archipel behoorden grondkwesties tot de weinige zaken die voor de groepshoofden werden gebracht; dit komt omdat dergelijke zaken gewoonlijk alleen door het houden van een godsoordeel konden worden beslist, welke procedure alleen door en voor het hoofd mocht gehouden worden (zie par. 8). Op het eiland Peling wordt in eenige plaatsen na den rijstoogst een feest gehouden, waarbij de dorpelingen van de nieuwe rijst bij het hoofd of een oud, geëerd man (paoe bakalinga?) brengen, waar deze rijst gezamenlijk genuttigd wordt nadat de zegen gevraagd is. Bij verkoop van grond of van goederen van eenigszins groote waarde zijn steeds vijf of zes lieden aanwezig, wien de kooper elk een bord geeft; door dit geschenk worden zij getuigen van den koop; men beschouwt deze niet als definitief gesloten als het getuigenloon nog niet gegeven is ${ }^{22}$ ). Als aanvulling hierop vond ik dat veelal de groepshoofden als getuigen optreden, tezamen met hun helpers; deze transacties worden thans in een koopbrief veelvuldig vastgelegd, en hier teekent het hoofd c.q. met eenige ouden, onder de aanduiding "dihadapan saksi” ( $=$ ten overstaan van getuigen). Hierdoor wordt aan de transactie bekendheid gegeven, wordt zij „terang”, zooals Ter Haar zegt ${ }^{23}$ ); doch tevens blijkt dat de positie van het hoofd in het grondenrecht van belang was en is.

Ook op ander sociaal gebied hadden de hoofden een taak te vervullen, waarvan tot in het heden nog veel behouden is en onder de oppervlakte voortleeft. Had iemand b.v. een ander beleedigd, dan

21) Kruyt, Balantaksche Studiën, blz. 341 .

22) Kruyt, Landbouw, blz. 478. 489.

23) Ter Haar, Beginselen, blz. 87. 
bracht vaak het groepshoofd verzoening tot stand tusschen de twee verbitterden ${ }^{24}$ ). Duidelijk als bewaker der sociale orde trad hij in den Archipel op als hem een geval van bloedschande ter oore kwam; dan kòn dit niet meer geschikt worden, doch mòèst een gerechtelijke procedure volgen, daar de geheele gemeenschap volgens het primitieve denken door rampen dreigde getroffen te worden als gevolg van den incest. De belangrijke plaats die het huwelijk in de maatschappij inneemt leidde er toe, dat eertijds het groepshoofd in den Archipel eventueel wel echtscheidingen uitsprak ${ }^{25}$ ) (hoe nu?).

Op den Vogelkop vinden we dat de hoofden overeenkomstige functies vervulden, deels nog vervullen. Bij bloedschande kan alleen het groepshoofd de kwade gevolgen daarvan afwenden. Hij ook controleert de grootte van den bruidschat en geeft dezen na accoordbevinding aan de familie van de bruid over. Een echtpaar dat uit elkaar dreigt te gaan tracth hij te verzoenen; lukt dat niet dan spreekt hij de echtscheiding uit. Verder is het meestal het groepshoofd dat het initiatief neemt tot het eens in de vijf à tien jaren vieren van het groote soemazi-feest. Tenslotte beslist ook hier het groepshoofd in grondzaken, terwijl een vreemdeling die uit een andere dorpsgemeenschap wil komen tuinen, daartoe aan hem toestemming moet vragen ${ }^{26}$ ).

Uit Loinang wordt uitvoeriger bemoeienis van het hoofd met het sociale leven gemeld, waarbij eenige kenmerkende verschillen zijn op te merken tusschen de Lingketing- en de Baloa-groep ${ }^{27}$ ). In Lingketing helpt het groepshoofd bij de oprichting van den hoofdpaal der woning van een zijner onderhoorigen. Vooral in de gevallen dat men contact wil maken met de geestenwereld zijn de hoofden, zoowel het streek- als het groepshoofd, noodig. De bemiddeling tusschen pilogot en zijn nakomelingen heeft plaats door het hoofd der familie waarvan de pilogot de stamvader is; wil deze iets aan zijn nakomelingen te kennen geven, dan daalt hij in dat familiehoofd neer. Bestaan er moeilijkheden waarbij de heele familie betrokken is, dan is het ook weer het hoofd dat aan pilogot raad en hulp vraagt (verg. blz. 12 en wat daar gezegd werd over de pilogot van elk dorp). Ook bij het jaarlijksche monsale (feest ter eere der stamvaders in het Lingketing-

24) Kruyt, Bewoners, blz. 251.

25) Kruyt, Banggaische Studiën, blz. 15/16, 34 .

20) Kruyt, Leven en sterven, blz. 58 v., 61, 63 v.; Balantaksche Studiën, blz. 386; Rijstbouw, blz. 125.

27) Kruyt, To Loinang, blz. 366, 402, 403, 412, 431, 438, 440-446, 447, 451, $452,453,454,458,459,461,473 / 474,490$. 
sche) berust bij hem de leiding. Heeft een ziekte uitgewoed, dan wordt te zijnen huize een dankfeest gehouden.

Interne geschillen in de Lingketing-, dan wel in de Baloagroep werden door de streekhoofden (onderscheidenlijk: daka'njo en mian kopian) beslecht; daardoor hebben de leden van deze groepen onder elkaar nimmer gevochten. Wel was er herhaaldelijk strijd tusschen beide groepen, o.a. ten gevolge van onderling koppensnellen bij het overlijden van een hoofd. Bij een dergelijken tocht bleven de streekhoofden en groepshoofden (onderscheidenlijk: daka'njo en mian kopian; tonggol en langka-langkai) thuis; doch was de troep teruggekeerd, dan hadden velerlei ceremonieën plaats met de(n) buitgemaakte(n) kop(pen), waarbij de hoofden wederom de leiding gaven. Op het koppensnellersfeest had ook het slaan tot ridder der dapperen plaats, hetgeen ook alweer door het hoofd geschiedde.

Met het privé leven der groepsleden heeft het hoofd eveneens steeds bemoeienis. Bij mogelijk dreigenden incest is hij het die de daaraan verbonden gevaren bezweert. $\mathrm{Hij}$ verricht de huwelijkssluiting en leest het jonge paar de les (brengt hen op de hoogte der wederzijdsche verplichtingen). Het hoofd draagt zorg voor de openbaarheid der aangegane verbintenis. Bij dreigende echtscheiding onderzoekt hij, met de notabelen, het geschil en tracht de kwestie te schikken; gelukt dat niet dan spreekt hij de echtscheiding uit, daarbij een zinnebeeldige handeling verrichtend. Een mogelijke latere verzoening van het gescheiden paar wordt weer door hem verricht.

Zwangerschap buiten echt kan rampen over de gemeenschap brengen; het hoofd onderzoekt dus wie de schuldige is. Bij geboorte, tandenkorten, overlijden, kortom bij alle gebeurtenissen in het leven zijner onderhoorigen is het hoofd aanwezig, luistert de feesten niet alleen door zijn tegenwoordigheid op doch schenkt aandacht aan alle veranderingen in de constellatie van zijn groep; en doordat hij ervan heeft kennis genomen heeft de groep als geheel de verandering geaccepteerd.

$\mathrm{Bij}$ dit alles treedt het traditioneele karakter zoowel der groepen als der over deze gestelde hoofden weer op den voorgrond; immers de voorouders hebben het aanzijn aan een bepaalde groepeering gegeven en bepaalde ge- en verboden ingesteld; de hoofden als nakomelingen der vergoddelijkte stichters dienen zoowel de groep in haar samenstelling voor verandering te behoeden, als tegen overtreding der van ouder op ouder overgeleverde gewoonten te waken. 
Pas indien aan deze voorwaarden is voldaan mag men hopen op zegen en bijstand der hoogere machten, en op voorspoed van de groep.

\section{De vorstensfeer.}

In par. 2 van hoofdstuk II hebben we gezien dat volgens de traditie een adi het bestuur te Banggai voerde, toen een vreemde vorst, (moemboe doi Djawa) zich van het gezag meester maakte; den adi stelde hij terug tot zijn rijksbestierder met den titel djogoegoe; den adviesraad, de vier tomoendo, handhaafde hij als zoodanig, terwijl de leden den eeretitel paoe basal ontvingen, later gewijzigd in basalo; zoo ontstond het college der basalo-4 van Banggai.

We kunnen dus duidelijk drie geledingen onderscheiden: het in origine vreemde vorstengezag met den vorstenadel (banginsaa; zie blz. 85); den inheemschen vorstenadel, teruggesteld tot dienaren van den vreemden vorst (bobato; zie blz. 84 v.); en de landshoofden, als adviseurs behouden (basalo-4).

\section{a. Titulatuur.}

Voor den vorst kent men verschillende aanduidingen ${ }^{28}$ ); is hij overleden dan noemt men hem moemboe, spreekt men van den levenden, dan gebruikt men $i$ toeoetoe (aki : de ware, de echte); men bezigt soosa als men het woord tot hem richt. Over zijn gemalin sprekende zegt men boki, veelal in samenstelling met toean; in aanspraak wordt het toean boki.

Tot de hofhouding behoorde een viertal schrijvers met de titels sekretaris, imam-sohi, chatib-djoeroetoelis en modjim-djoeroetoelis; deze personen konden uit de hooger aangeduide drie adelsgroepen genomen worden. De sekretaris was belast met het bijhouden der stamboomen bij geboorte van nieuwe vorstentelgen, de imam-sohi was kamenier-schatmeester; ook moest hij den vorst scheren en de nagels knippen. Een lid van den vorstenadel, met den titel seseba, droeg bij plechtige optochten den koninklijken zonnehoed, een viertal dienaren een zonnescherm, een stok met gouden knop, een sabel en een kris. Dit viertal heet lambanoea oeloeno en was verwant met de basalo-4; zij werden voor één jaar tot die functie aangewezen. Tot hun dagelijksche taak behoorde de zorg voor de zindelijkheid in de vorstelijke verblijven. Ten slotte was de sadaha kodato (van slavenafkomst; zie

28) Goedhart, Drie landschappen, blz. 443.

Verh. dl. VI. 
blz. 90 belast met het toezicht in de vorstelijke keuken; tevens was hij voorproever.

Eertijds woonden de vorsten van Banggai in kota Djin (geestenvesting), een plaats ten noorden van de baai van Banggai, aan den voet van den berg Boloekon (zie blz. 36). Kruyt schrijft hierover: „Vlak bij Kaoe Mambol is de oude Kota van Banggai, die den naam „draagt van Kota Djin, ,geestenvesting”. Men veronderstelt toch, "dat in den ouden tijd de vorsten omgang hadden met geesten, van „wie zij hun bovennatuurlijke macht ontvingen. Deze Kota Djin is „een smalle kuststrook, die aan den zeekant voorzien is van een wal „van klipsteenen. Deze muur moet vrij hoog zijn geweest; nu is hij „omgevallen en de brokken steen liggen in menigte in het water. Men „wijst nog de opening in den wal aan, waar de poort geweest is. De „ruimte binnen de kota is zeer beperkt; misschien kunnen er tien „huizen hebben gestaan; een heel verschil met de uitgestrekte vesting „Bebengketan. Daar stond eertijds ook het paleis van den vorst, „,kamali tanga „middelste paleis”, waarschijnlijk zoo genoemd als "staande tusschen de later opgerichte Kota Tjina en de balakat ", „Kaoe Mambol” ${ }^{29}$ ). Bij den oorlog van 1847 werd kota Djin inge„nomen en verwoest, de plek werd voorgoed verlaten. Sindsdien „wonen de vorsten op de heuvelrij ten westen van de baai van Banggai; de huidige ambtswoning staat op de plaats Lompio, waar zich ook de vorstentelgen en edelen gevestigd hebben.

Uit den vorstenadel werden indertijd een twaalftal functionarissen aangewezen, waarvan de meesten een of ficiersrang aan het Banggaische hof bekleedden; zij stonden buiten de eigenlijke bestuursorganisatie. Men duidt dit twaalftal aan met banginsaa songololoea (aki: songololoea $=$ twaalf); volgens rangordening waren $z \mathrm{ij}$ :

1. kapitan laoet (in het aki ook kapitan dalangon);

2. major ngofa; was er geen persoon beschikbaar gerechtigd tot den titel ngofa, dan heette hij major kompania;

3. major tano ;

4. kapitan ngofa;

5. loetenaan ngofa;

6. miantoeoe Palabatoe;
7. miantoeoe Batjaan;

$\left.\begin{array}{l}\text { 7. miantoeoe Batjaan; } \\ \text { 8. miantoeoe Liang; }\end{array}\right\} \begin{aligned} & \text { (miantoeoe }=\text { persoon geen vorstenzoon zijnde). } \\ & \text { bloede, gen }\end{aligned}$

29) Kruyt, Vorsten, blz. 606 . 
9. kapitan kië (kië Ternataansch voor dorp, in dit verband Lompio, woonplaats van vorstentelgen en -adel).

10. kapitan Lonas;

11. kapitan kota;

12. kapitan kapitan laoet.

Als uiterlijk teeken hunner waardigheid droegen deze of ficieren den witten hoofddoek ten bewijze hunner vorstelijke afstamming (zie blz. 86). De toevoeging ngofa bij sommige titels is Ternataansch; het beteekent in die taal eigenlijk kind, doch wordt in dit verband vertaald met lijfelijk zoon van een vorst; het Banggaische equivalent is kaoe saoeno (zie blz. 85).

De voornaamste der bobato is de rijksbestuurder, de djogoegoe. Zooals we op blz. 37 zagen was adi Lambal de eerste rijksbestuurder tijdens moemboe doi Djawa (voor djogoegoe zie noot 15 van hoofdstuk II); de latere rijksbestuurders voeren allen hun afstamming terug tot dezen eersten.

Verdere functionarissen door bobato geleverd waren: penabela langkai (later hoekoem toea); penabela Tololak (later hoekoem Tololak); penabela Boejoe (later hoekoem Boejoe); sadaha kiё (Tern. : sadaha = bewaker; $k i \ddot{e}=$ dorp); gimalaha (Tern. goed mensch).

Het laatste tweetal waren afstammelingen in de vijfde generatie van een rijksbestuurder: de penabela Tololak ontleenden hun afstamming aan een menghuwelijk tusschen bobato en familieleden van het streekhoofd van Tinangkoeng, de penabela Boejoe heetten voortgekomen te zijn uit een huwelijk tusschen een rijksbestuurder en een familielid van het streekhoofd van Boelagi.

De basalo-4 waren, zooals we op blz. 38 zagen, die van Dodoeoeng, Tanobonoenoengan, Monsoongan en Gong-Gong; zij namen vooral in den bestuursraad een belangrijke positie in, die beneden, bij de behandeling der bestuursfuncties, nader zal worden uiteengezet.

b. Aanwijzing tot de verschillende functies.

Onder par. 2 werd reeds medegedeeld dat het hier geldend opvolgingssysteem te omschrijven is als erfopvolging met electie. Uit dien hoofde zijn de voor de vorstelijke waardigheid in aanmerking komende personen uitsluitend banginsaa. Genoten daarbij wellicht eertijds de prinsen van den bloede (die den $n g o f a$-titel voerden) voorkeur boven verdere vorstelijke afstammelingen, in later tijd kwam 
dit (volgens Goedhart ten gevolge van Ternate's invloed) ${ }^{30}$ ) te vervallen, en bleef de eenige beperking dat banginsaa die in de mannelijke lijn hun afstamming terugvoeren, den voorrang genieten boven hen die langs vrouwelijke lijnen met vorsten verwant $z \mathrm{ijn}$. $\mathrm{Bij}$ de eerste groep wordt er niet op gelet of de moeder zelf banginsaa is of niet; vereischte is slechts dat het een wettig kind is uit een naar de regelen der Mohammedaansche wet gesloten huwelijk.

Eertijds werden de vorst, de kapitan laoet, de djogoegoe, eenige der voornaamste officieren en de basalo-4 door den sultan van Ternate aangesteld, het eerste drietal bovendien na verkregen goedkeuring van den Resident van Ternate. Te Banggai werd echter een voordracht opgemaakt door den aanstonds te bespreken bestuursraad, tezamen met de basalo-4 (tenzij het een keus van een dezer basalo betrof ; zie par. 2). Over de(n) voorgedragene(n) liet de sultan zich inlichten door zijn te Banggai geplaatste ambtenaren (zie par.4), waarna de candidaten opgeroepen werden naar Ternate, waar de sultan hen zelf eenigen tijd in doen en laten gadesloeg; hij had daarbij het recht zich andere dan de opgeroepenen te doen voorstellen, zoodat hij feitelijk het recht had buiten de voordracht der Banggaische hoofden om te gaan ${ }^{31}$ ).

$\mathrm{Bij}$ het plegen van onderling overleg om tot een voordracht te komen van een functionaris die van banginsaa-afstamming moest zijn, werden soms de candidaten genomen uit de twaalf, hooger opgesomde, of ficieren, doch men was volstrekt niet aan dit twaalftal gebonden. En al kende het twaalftal een rangordening, dit hield niet in dat bij uitvallen van één hunner opschuiving in rang der overigen moest plaats hebben; inschuiving, mits door een banginsaa, was evenzeer mogelijk. De kapitan laoet is dus in geenen deele als troonopvolger, de major ngofa geenszins als de a.s. kapitan laoet enz. te beschouwen.

(Eenige voorbeelden: de latere radja Abdoerrahman was eerst modjim, toen malakoe (hoofd der modjim te Banggai); hij werd achtereenvolgens miantoeoe Liang, miantoeoe Palabatoe en major tano. Door Banggai als candidaat kapitan laoet naar voren geschoven, wiens functies hij reeds uitoefende, bleef hij major tano omdat de sultan een ander tot kapitan laoet benoemde. Daarna werd hij, met voorbijgaan van den kapitan laoet, rechtstreeks tot vorst verheven. Abdoerrahman was kleinzoon van Atondeng, had uit dien hoofde niet

30) Goedhart, Drie landschappen, blz. 461.

31) Goedhart, Drie landschappen, blz. 446/447. 
het recht tot het voeren van den titel ngofa. De huidige Zelfbestuurder, Hadji Awaloeddin, is een lijfelijke zoon van radja Abdoel Aziiz; hij was eerst loetenaan ngofa, werd met voorbijgaan van den kapitan ngofa tot major ngofa benoemd, en daarna rechtstreeks tot vorst. Abdoel Aziiz was eerst chatib ngofa te Batoei, en werd met voorbijgaan der twaalf, rechtstreeks tot vorst verheven; hetzelfde deelt men mee van Soak).

De plechtige inhuldiging vond plaats in de nabijheid der oude $k$ ota Djin, op den berg Boloekan, waar zich steenresten bevinden die geacht worden met de vroegere vorsten in verband te staan (o.a. wijst men een blok met een kokervormig gat aan, vaandelhouder van adi Lambal). Kruyt beschreef de plechtigheden uitvoerig; typeerend hierbij is dat de ingehuldigde vorst bij één der basalo-4 op schoot werd gezet; deze was op zijn beurt gezeten op een steen, waarvan men zegt dat het de zetel zou zijn geweest der adi; ook komt er water aan te pas, dat zich in een holte heet verzameld te hebben en waaruit men conclusies trekt ten aanzien van den levensduur van den vorst. De penabela langkai vermaande en nam den adateed af, en men lette op de eerste woorden die de nieuwe vorst sprak als hij weer, naar beneden gedragen, in de oude kota $\mathrm{Djin}$ terug was ${ }^{32}$ ). We vinden treffende parallellen met de installatie der streekhoofden uit den Archipel; vergelijk par. 2 van dit hoofdstuk.

Kwam bij de banginsaa geen opschuiving voor, bij de bobato was dit wel het geval, met dien verstande echter dat een gimalaha of een sadaha kië nimmer tot djogoegoe of een der penabela-functies benoemd werd. Wel kon een penabela tot djogoegoe benoemd worden, indien die functie door een zijner mannelijke voorouders bezet is geweest en hij in mannelijke lijn van hen afstamt. (Iemand wiens grootvader djogoegoe, wiens vader penabela was, kan beide functies vervullen). Op blz. 86 wees ik er verder reeds op dat tusschen banginsaa en bobato een zekere menging is ontstaan, eensdeels doordat het begrip banginsaa zoo ruim is (nl. afstammelingen tot en met den vijfden graad van een vorst), anderdeels doordat vele bobato door huwelijk aan het vorstenhuis zijn vermaagschapt; vele personen zijn, als men de verwantschapsbanden zoowel naar den vader als naar de moeder rekent, uit dien hoofde gerechtigd tot beide soorten functies.

Eenige voorbeelden: Radja Noerdin was zoowel bobato als banginsaa, hij was eerst djogoegoe, werd toen verheven tot vorst. D jogoegoe

32) Kruyt, Vorsten, blz. $611-614$. 
Eeha was eerst miantoeoe Palabatoe (banginsaa), toen rijksbestuurder. Hanapii was eerst chatib, daarna miantoeoe Batjaan, dan djogoegoe; hij behoorde feitelijk zelfs geheel tot de banginsaa, waaruit men te Banggai wel de conclusie wil trekken dat vorstentelgen wel bobatofuncties kunnen vervullen, doch omgekeerd niet. Djakaria was eerst douane-oppasser, toen penabela langkai (reeds hoekoem toea geheeten) en werd aansluitend hierop djogoegoe; hij is echter evenzeer verwant aan de vorstenfamilie en is dan ook gerechtigd tot het dragen van den witten hoofddoek. Ali Hamid was eerst chatib, toen imam, en werd vervolgens tot hoekoem toea benoemd; hij is echter evenzeer banginsaa, want voert zijn afstamming terug tot moemboe doi Boegis.

Uiteraard was opschuiving onder de basalo-4 niet mogelijk; de rangordening thans is zooals door mij aangegeven, doch is in den loop der tijden wel eens gewijzigd.

c. Taak.

De kapitan laoet was in oorlogstijd opperbevelhebber, in vredestijd de persoon die in den regel op onderzoek werd uitgezonden wanneer in een der Banggaische onderhoorigheden een ernstig misdrijf was gepleegd ${ }^{33}$ ). Te Banggai was hem verder het toezicht op den raadzaal opgedragen, waarin hij werd bijgestaan door major tano, kapitan Lonas en kapitan kapitan laoet. Deze raadzaal, aangeduid met djagaan, werd in navolging van Ternate vaak ngaralamo (Tern. : groote poort) genaamd. Hier nam de raad zitting, werd recht gesproken, was de kampongpolitie te vinden en kon een misdadiger opgesloten worden. Dagelijks hadden hier dienst een bobato, een der basalo-4, een imam, een chatib en een modjim; deze personen werden dagelijks verwisseld. Als commandant der politie was hier verder aanwezig een loetenaan, met een genti (van saragenti $=$ sergeant) en vier baroebaroe (soldaten). Gedurende één week werd bij toerbeurt uit een der vier kampongs van de basalo-4, bovendien uit Lompio, deze kleine politiemacht aangewezen. Dezelfde groep kwam dus eens in de vijf weken in dienst. Permanent aangewezen waren bovendien een loetenaan adjoedaan en een alifiris (Port.: vaandeldrager); zij waren verwant aan de basalo-4. Het toezicht op de dorpspolitie was ook den kapitan laoet toevertrouwd; hij werd daarin bijgestaan door major ngofa (c.q. major kompania), kapitan ngofa, loetenaan ngofa en

33) Goedhart, Drie landschappen, blz. 444, 445. 
kapitan kië. Verder noemen we nog den kapitan kota, wien het dagelijksch toezicht ter hoofdplaats Banggai was opgedragen, waarbij hij echter te luisteren had naar den rijksbestuurder; hem was een mirinoe (oppasser), uit den vrijen stand, toegevoegd. De drie miantoeoe ten slotte hadden de delicate taak de feestelijkheden in het paleis te regelen en den gasten de hun toekomende plaatsen aan te wijzen.

De functies door de zes bobato uitgeoefend, zijn als volgt aan te geven:

Over den rijksbestuurder schreef Goedhart: „Bovendien moeten ,alle zaken voordat zij ter kennisse van den radja worden gebracht, ,aan den djogoegoe worden gerapporteerd. Deze is bij ontstentenis „van den radja de tijdelijke bestuurder en mag zich alsdan slechts ,in de uiterste gevallen van het eiland Banggai verwijderen. Dit „laatste geldt ook wanneer de radja zich tijdelijk buiten het landschap „ophoudt" ${ }^{34}$ ). Men verklaarde mij nog dat de djogoegoe de man is, die alles wat met het volk te maken heeft, regelt; men noemt hem wel den heer van alle volken op Banggaischen bodem, naar hem luistert de echte Banggaier dan ook eerder dan naar den vorst. Deze laatste mag zelfs niet rechtstreeks aan volk of hoofden bevelen, want alle regelingen dienen te geschieden door tusschenkomst van den rijksbestuurder. De vorst bevindt zich in een andere orde; hij is de magische bindkracht, welke mensch en dier, aarde en water, geesten en goden in harmonisch evenwicht houdt.

De penabela langkai bekleedde in oud-Banggai de functie van beëediger van vorst en hoofden bij hun aanstelling te Banggai. Hij was verder rechter na den djogoegoe en nam bij diens afwezen zelfstandig beslissingen. Legendarisch was de eerste penabela langkai rechter die door zijn magische gaven wist wie van twee twistenden gelijk had ${ }^{35}$ ). Goedhart noemt hem als rechter.

De beide andere penabela zijn helpers van den rijksbestuurder geweest; zij konden als gevolmachtigden ergens heen worden gezonden om plaatselijke geschillen te berechten. De namen Tololak en Boejoe vinden hun oorsprong in twee voormalige woongroepen van dien naam, waarover zij tevens hoofd waren; Tololak ziet op lieden van Kandari (Z.-O. Celebes). Goedhart vermeldt hen ook als helpers van den rijksbestuurder.

Dit viertal bobato vormde een bestuursraad, waarover aanstonds uitvoeriger.

34) Goedhart, Drie landschappen, blz. 443/444.

35) Kruyt, Vorsten, blz. 610/611; verg. ook blz. 613. 
De sadaha kië had toezicht te houden over en leiding te geven aan de bobato voor zoover deze geen ambtelijke functie bekleedden; hij trad op als hun vertegenwoordiger bij beraadslagingen van den raad. $\mathrm{Hij}$ kon echter ook door den rijksbestuurder op onderzoek gezonden worden.

De gimalaha ten slotte was vertegenwoordiger en vertrouwensman der basalo-4; te Banggai trad hij als hoofd van dit college op. Beslissingen van vorst of rijksbestuurder moest hij hun overbrengen, uitleggen en mogelijke bezwaren uit den weg ruimen, hen zoo noodig van de noodzaak der genomen maatregelen overtuigen.

\section{d. De koemis-ampat (koemisi-sangkap).}

Goedhart schrijft: „In de uitoefening van het bestuur wordt (de ,vorst) bijgestaan door de zoogenaamde koemis-sampat (= de vier „kommiezen; er zijn er echter vijf)”... Hij noemt dan den rijksbestuurder, den kapitan laoet en de drie penabela. Over de verhouding tot de basalo-4 schrijft hij verder: „Bij de beraadslagingen over „belangrijke kwesties worden altijd de sengadji ampat gehoord; dezen „zijn naast den djogoegoe de oorspronkelijke landshoofden van Banggai" enz. ${ }^{36}$ ).

Het doet eigenaardig aan te lezen dat er wordt gesproken van een raad van vier die uit vijf leden zou bestaan. Kruyt bestrijdt Goedhart's mededeelingen, heeft echter bij zijn critiek de samenstelling van 1930 op het oog in welk jaar ten gevolge van Gouvernementsinvloed dit college een geheel onjuiste samenstelling had gekregen; er waren toen inderdaad vier leden, doch twee banginsaa en twee bobato. Verder spreekt Kruyt over den raad van vier rijksgrooten, welke volgens hem aangevuld kan worden tot zeven leden. $\mathrm{Mij}$ is hiervan niets bekend geworden; zeker hebben de basalo van Lampa, Poetal en Boneaka nimmer invloed gehad op het bestuur ${ }^{37}$ ).

In werkelijkheid heeft de zaak zich geheel anders toegedragen. Oorspronkelijk waren de raadsleden van den vorst uitsluitend vier bobato en vier basalo; de banginsaa waren ornament, hadden geen bestuurlijke functies, hoogstens een politioneele.

De naam koemis-sampat (in het aki ook koemisi sangkap) werd waarschijnlijk pas in het einde der vorige eeuw ingevoerd, door Ternataansche dan wel Nederlandsche ambtenaren. Het instituut van

36) Goedhart, Drie landschappen, blz. 443, 444.

37) Kruyt, Vorsten, blz. 611, noot 8. 
den bestuursraad bestond echter reeds lang doch het droeg geen bepaalden naam; zitting namen als leden twee groepen van vier waardigheidsbekleeders (vier bobato en vier basalo). Als toehoorders, eventueel adviseurs, werden wel personen toegelaten die de belangen te behartigen hadden van bepaalde groepen; als zoodanig namen aan de vergaderingen wel deel de kapitan laoet (vertegenwoordiger van den vorstenadel), de sadaha kië (representant der niet ambtelijke bobato) en de gimalaha (leider van de basalo-4). In de jaren voor 1908 is de naam koemis-sampat echter reeds dusdanig ingeburgerd op Banggai, dat Goedhart hem in 1908 reeds dadelijk noemt.

Hoe de kapitan laoet in de koemis-sampat werd opgenomen kon ik historisch nagaan; op 1 April 1908 werd de Korte Verklaring onderteekend, waarop de djogoegoe, de penabela langkai en de penabela Boejoe hun handteekening stelden; de vierde bobato was (toevallig) op reis naar Balantak. Omdat de Nederlandsche ambtenaren aandrongen op vervollediging van het stuk teekende als vierde man de kapitan laoet, representant van den vorstenadel. Slechts zij die de Korte Verklaring mede-onderteekend hadden werden in de komende bestuursorganisatie als lid van het Zelfbestuur erkend en kregen bezoldiging uit de opgerichte landschapskas. De overige functionarissen werden genegeerd, bij afsterven werden zij niet vervangen. De eenige uitzondering hierop vormde Hadji Awaloeddin, toenmalig major ngofa en ernstig troonpretendent in 1903; hij werd in het genot eener toelage gesteld. Het interessante is dus dat van meet af aan de koemis-sampat verkeerd was samengesteld, nl. met den kapitan laoet op de plaats van den penabela Tololak. Dit bleef zoo later; in 1909 werd de kapitan laoet wegens knevelarijen ontslagen en vervangen door den major ngofa, Hadji Awaloeddin. De penabela Boejoe overleed in 1916; hij werd niet meer vervangen. Vanaf dien tijd waren er dus nog maar twee bobato (de rijksbestuurder en de penabela langkai) in den raad.

In 1924 werd de major ngofa, Hadji .Awaloeddin, belast met de functiën van Zelfbestuurder; tevens werden een nieuwe major ngofa en een nieuwe kapitan laoet benoemd, deze laatsten den toestand van 1908 indachtig.

In 1929 en 1930 moesten de beide banginsaa-leden van het Zelfbestuur ontslag nemen; sindsdien bestaat dit dus uit vorst met djogoegoe en penabela langkai.

Er zullen wel persoonlijke- en familiebelangen bij in het spel zijn geweest toen de kapitan laoet eerst, en later de major ngofa zich in 
de koemis-sampat indrongen; bij Europeesche auteurs zal de gedachte hebben post gevat dat dit juist was, omdat elders, in andere vorstendommen, de kapitan laoet wèl organiek een plaats inneemt in een overeenkomstig bestuurscollege. Doch Banggai heeft nu eenmaal een andere organisatie tengevolge van de vermenging van vreemden vorstenadel met inheemsche landshoofden. Of het hooger geschetste uit-, dan wel vergroeiing van de koemis-sampat is kunnen we niet beoordeelen.

De taak van den bestuursraad gaf Goedhart als volgt weer: „Geen „maatregel van eenig belang wordt door den radja genomen, geen ,bevel vąn eenigszins verstrekkende gevolgen door hem gegeven of „hij beraadslaagt daarover vooraf met de „koemis sampat”. Is een„maal een besluit genomen, dan zorgt de djogoegoe voor de uitvoering ,daarvan, zijnde alsdan alle hoofden gelijkelijk verplicht de hun door ,den djogoegoe gegeven instructies op te volgen" ${ }^{38}$ ). Het bestuur is dus niet eenhoofdig doch berust bij den vorst met zijn koemis-4; men spreekt over dit meerhoofdig bestuur wel als het Zelfbestuur van Banggai; dit ziet dan op de technische beteekenis van die uitdrukking. Daarnaast kan zelfbestuur ook slaan op de rechtsgemeenschap, het landschap, Banggai.

De vorst nam slechts aan de vergaderingen deel als de Gouvernementsvertegenwoordiger (de sedert 1880 te Banggai geplaatste posthouder) bij de beraadslagingen aanwezig was. In tegenovergesteld geval werd de vorst van het besprokene door den loetenaan adjoedaan op de hoogte gehouden, terwijl de beraadslagingen dan onder leiding van den djogoegoe plaats vonden. (Hoe was dit vóór 1880? Nam de vorst toen wellicht nimmer aan de vergaderingen deel en berustte dit stuk van de bestuurstaak geheel bij den rijksbestuurder?) ${ }^{39}$ ); verg. echter par. 5.

De belangrijkste kwesties waarop Goedhart doelt als hij meldt dat hierover ook het advies der basalo-4 wordt ingewonnen waren:

$a$. het opmaken van een voordracht, tezamen met de koemis-4, tot een nieuwen radja, kapitan laoet, djogoegoe, en eenige andere of ficieren (zie blz. 116);

$b$. bijleggen van een mogelijk ontstaan geschil tusschen den vorst en de koemis-4;

c. het geven van advies in bestuurlijke aangelegenheden betreffende onderhoorigen buiten het eiland Banggai;

38) Goedhart, Drie landschappen, blz. 443.

38) Goedhart, Drie landschappen, blz. 445. 
$d$. het bijleggen, tezamen met een der leden van de koemis-4 van een gerezen geschil tusschen streekhoofden elders in het landschap;

$e$. het handhaven van de banden tusschen vorstenhuizen en onderhoorigen, het handhaven van het gezag;

$f$. het bijwonen van de vijf maal per jaar te Banggai te houden vergadering ter bespreking van belangrijke bestuurlijke en godsdienstige aangelegenheden het geheele landschap betreffende.

Men noemde mij te Banggai een adatspreuk (naam hiervan onbekend) waaruit blijkt dat men het bestuursapparaat met een huis vergelijkt; daarvan zijn de basalo-4 de stijlen, de koemis-4 de wanden, de vorst het dak. (Andere adatspreuken noteerde ik niet).

\section{e. Inkomsten.}

In deze primitieve autocratie omvatte het bestuur niet veel; het richtte zich, naast de uitoefening van rechterlijke functies, op zorg voor eigenbelang der bestuurders, zorg dat de onderhoorigen aan hun verplichtingen jegens den heer voldeden en dus op tijd en in voldoende mate de jaarlijksche huldegift opbrachten (aki: loeloe; sian: roeroe; madi : hoehoe, bagi toempoe) ${ }^{40}$ ). De meeste der op blz. 114 en 115 genoemde functionarissen waren te dien einde met het toezicht over één of meer streekgemeenschappen belast; als uitvoerders van de vorstelijke macht deelden zij in de inkomsten welke de vorst genoot uit de onder hun toezicht gestelde gebieden. Het aki kent voor dezen toezichthouder den term baoeloeno. Als toezichthouder waren zij niet alleen verantwoordelijk voor de huldegift, doch zij zorgden ook voor het contact tusschen het Zelfbestuur en de streekhoofden. De nieuw verkozen basalo wendden zich te Banggai in de eerste plaats tot hun baoeloeno om gehoor te krijgen bij den vorst; ook deden dit eventueele onderhoorigen die zich te Banggai bevonden. De toezichthouder was zelfs verplicht hen voeding en huisvesting te verstrekken. Ten slotte kon de toezichthouder deelnemen aan rechtzittingen over de onderhoorigen der aan zijn zorgen toevertrouwde streekhoofden. Goedhart noemt den term baoeloeno niet, doch wel beschrijft hij nauwkeurig de inkomsten die zij genoten; hij geeft op: was, contanten, geiten, rijst, oebi, kokosnooten, stukken ongebleekt katoen, klapperolie in flesschen, keukenstroop; verder dagelijks een zeker antal huisbedienden, lambanoea $^{41}$ ) (verg. blz. 113; de huisbedienden van den vorst, evenzeer

40) Kruyt, Vorsten, blz. 618; Balantaksche Studiën, blz. 339; To Loinang, blz. 355 .

41) Goedhart, Drie landschappen, blz. 465-470. 
lambanoea geheeten, stonden onder hoofddienaren, lambanoea oeloeno).

De volgende functionarissen hadden ieder de achter hun rang vermelde streekgemeenschappen onder hun toezicht:

djogoegoe: Pelei, Loeokpanenteng, Dodoeoeng, Boneaka, Sinohowan,

Minahaki, Batoei, Lontio, Loewoek, eilanden Labobo en Bangkoeloe.

penabela langkai: Peling, Boniton, Monsoongan, Kintom.

penabela Tololak: Tinangkoeng.

penabela Boejoe: Boelagi.

gimalaha: Ponding-Ponding, Tatakalai, Poetal, Lampa.

sadaka kië: Tambolok.

kapitan laoet: Apal, Gong-Gong, Mendono, Basama, Lamala, Dale-

Dale (Balantak).

major ngofa: Tanobonoenoengan en Tangkiang.

major tano: Loeoksago.

miantoeoe Palabatoe: Lipoeadino.

miantoeoe Batjaan: Paisoeoeloeno.

miantoeoe Liang: Liang.

sadaha kodato: Boeoeko.

Uit dit overzicht blijkt eenerzijds dat niet alle functionarissen met het toezicht over een streekgemeenschap waren belast; anderzijds dat een viertal streekgemeenschappen (Sambioet, Popiisi, Totikom, Kombotokan) geen vasten toezichthouder hadden; als zoodanig toch kon de vorst naar luim en willekeur een der ambtenaren aanwijzen, waaraan uiteraard de gewone voordeelen verbonden waren. Zoo meldt men als toezichthouder over:

Sambioet: imam sohi, sadaha kië;

Totikom: sekretaris en loetenaan ngofa;

Popiisi : imam sohi en major ngofa;

Kombotokan : kapitan Lonas en sekretaris.

Goedhart becijfert dat de djogoegoe jaarlijks f $700,-$ aan vaste en f 170 ,- - aan wisselvallige inkomsten ontving, benevens dagelijks twee huisbedienden (aki: lambanoea). Anderen moesten zich met minder tevreden stellen; de major tano b.v. ontving volgens denzelfden schrijver slechts $f 10,-$ voor dat eerebaantje.

De wisselvallige inkomsten verkregen de toezichthouders door hun eertijds erkend recht om in gevallen van geldgebrek aan de hun toegewezen streekgemeenschap(pen) een geschenk te vragen; in de practijk had dit verzoek de kracht van een bevel.

Bracht een baoeloeno een bezoek aan één zijner onderhoorigheden, 
dan moest haar bevolking voor vaartuigen en roeiers zorgen, die bovendien op kosten der bevolking werden gevoed. Ook de inspecteerende ambtenaar leefde op haar kosten, terwijl hem zoowel bij aankomst als bij vertrek geschenken moesten worden aangeboden. Zoo noemde men mij de gift pololoboti (aki: wat gegeven wordt bij aankomst), bestaande uit een geit en oebi; de bezoeker moest eerst van de oebi gegeten hebben voor hij aan den wal ging. Verder kent men de gift papalos doeangan mbojoko (aki: wat dient om den steven van de prauw te wenden), even groot als de gift bij aankomst. Was deze afscheidsgave nog niet opgebracht, dan bleef de toezichthouder op kosten der bevolking wachten tot ervoor gezorgd was.

Ten slotte bewoonden de toezichthouders huizen te Banggai, opgericht door de onderhoorige streekgemeenschappen; zij beschouwden deze wel als hun bezit, doch ten rechte zijn deze gebouwen een onderdeel van het vermogen der streekgemeenschappen die ze oprichtten.

De inkomsten der Banggaische vorsten voor 1908 zijn door Goedhart uitvoerig opgesomd; 20 pikol was, opgebracht door 20 streekgemeenschappen, vormen wel het voornaamste bestanddeel ervan. Verder noemt hij: contanten, gestampte rijsț, bossen padi, maleoeieren, oebi, sago, geiten, kokosnooten, flesschen klapperolie, gerookte visch, kippen, kippeneieren. Goedhart berekent dit op f $2.700,-$ per jaar. Wisselvallige inkomsten waren o.m. een deel van het plantrecht dat de sultan van Ternate hief voor het verleenen van vergunningen tot het planten van klapperboomen aan niet tot de inheemsche bevolking behoorende personen (zie par. 5); financieele hulpverleening voor feesten of bij moeilijkheden van den vorst; dan werd bij verschillende streekhoofden om geld aangeklopt, vaak werd ongebleekt katoen opgebracht. Ook had de vorst het recht voor zich, zonder betaling, rotan op het eiland Peling te doen snijden.

Onbetaalde arbeidskrachten, lambanoea, stonden den vorst dagelijks ten getale van 10 ter beschikking; zij werden uit bepaalde streekgemeenschappen gedurende een maand aangewezen en ontvingen alleen voeding. Deze diensten werden wel afgekocht voor f 2,50 per man per maand. Reeds in Goedharts tijd bewoonde de vorst een woning, door het landschap uit de negerikas voor f 3000 ,- aangekocht; vermoedelijk bewoonde hij haar gratis ${ }^{42}$ ).

f. Districtsorganisatie.

Goedhart geeft aan dat in 1908 het landschap in 46 districten ver-

42) Goedhart, Drie landschappen, blz. 462-465; 470. 
deeld was; of het Banggaische bestuur dezen term ook gebruikte betwijfel ik. Het meerendeel dezer districten werd op blz. 26 v. als streekgemeenschappen beschreven. In 35 districten voerde het hoogste hoofd den titel sangadji, in het Banggaisch vertaald met basalo (aldus Goedhart); hij vervolgt : „De Districten heeft men niet te beschouwen „als afgeronde gebieden; van verschillende daarvan toch liggen een „of meerdere (!) kampongs geheel geënclaveerd tusschen de kam„,pongs van andere districten....". Goedhart besluit hieruit dat de bevolking oorspronkelijk bestond uit verschillende van elkaar geheel onafhankelijke stammen zonder vaste woonplaatsen (de aanduiding „stammen” laat ik voor rekening van Goedhart). Hij deelt dan mede „dat een onderhoorige van eenig district niet ophoudt onder het gezag „van dat hoofd te staan, ook al vestigt hij zich buiten diens gebied ,,in eene tot het ressort van eenen anderen sengadji behoorende kam„pong. Hij tretdt dus als het ware niet uit het eigen stamverband, „blijft mede verantwoordelijk voor de nakoming door zijn stam van „de op dezen rustende verplichtingen tegenover „,den heer”, i.c. den ",radja, en mag zich evenmin onttrekken aan de verplichting tot hulp„,betoon waartoe de leden van den stam tot hun hoofd verplicht zijn". In de overige districten voerde geen sangadji (= basalo) het bestuur, doch een kapitan ${ }^{43}$ ).

Volgens Goedhart stelde het Banggaische zelfbestuur reeds vele jaren voor 1908 kapitan over de bevolking van Labobo, Bangkoeloe, Bwokan en Poat ${ }^{44}$ ). Bij mijn onderzoek in 1938 herinnerde men zich te Lantiboeng (Bangkoeloe) en te Lipoe Lalongo en te Mansalean (Labobo) een dergelijken functionaris. De kapitan Lantiboeng was vermoedelijk een afstammeling van den op blz. 69 genoemden toemboe selekan, hoofd der Banggaiers die om balakat Lantiboeng een vereeringsgemeenschap stichtten.

De beide kapitan op het eiland Labobo duidt men aan met kapitan oeloe en kapitan bilit; of hierin een tegenstelling ligt is mij niet bekend (oeloe $=$ hoofd; bilit $=$ achterdeel; beide aki). $\mathrm{Zij}$ waren duidelijk ambtelijke hoofden; de vorst wees soms uit de anwezige bevolking, soms van elders, iemand aan van wien hij wegens zijn persoonlijke eigenschappen veronderstelde dat hij zijn belangen zou behartigen. Zoowel West- als Midden-Pelingers, en een afstammeling der toemboe selekan van Bangkoeloe hebben dergelijke functies ver-

43) Goedhart, Drie landschappen, blz. 453-455.

44) Goedhart, Drie landschappen, blz. 456. 
vuld. Noch over den kapitan in de Bwokan-Archipel, noch over dien van Poat, kon ik in 1938 eenige zekerheid bekomen.

g. Invloed van bestuurden op vorstensfeer en omgekeerd.

De belangrijke plaats door de basalo-4 ingenomen werd op blz. $122 \mathrm{v}$. reeds aangegeven; daaraan dient nog toegevoegd te worden, dat dit college het recht had zich bij wangedrag van den vorst over hem bij den sultan van Ternate te beklagen, buiten de koemis-4 om. De traditie kent twee gevallen dat ten gevolge van dergelijk beklag de vorst door den sultan werd afgezet ${ }^{45}$ ).

Het twaalftal streekhoofden van Peling (blz. 71: basalo songololoea) had als geheel geen invloed op het vorstengezag. Het betrokken streekhoofd werd gehoord in alle aangelegenheden betreffende zijn streekgemeenschap; in meeningsverschillen tusschen dit hoofd en de koemis-4 domineerde de wil van den eerste. $Z_{\mathrm{ij}}$ werden echter niet gehoord bij de keus van een nieuwen vorst, doch werden alleen met de beslissing van het kiescollege in kennis gesteld; daarbij werden zij uitgenoodigd bij het doodenfeest van den overleden en de inhuldiging van den nieuwen vorst. $Z_{\mathrm{ij}}$ hadden het recht te allen tijde toegang tot de raadszaal te eischen; bij een bezoek aan de vorstelijke woning was het hun toegestaan de voortrap te bestijgen. Bij vergaderingen in de raadzaal namen zij de rangordening aan als aangegeven op blz. $26 \mathrm{v}$.; in aanwezen van den vorst zat de Lipoeadino dan achter dezen en nam basalo Lolantang de plaats van den Lipoeadino in; was de vorst niet aanwezig dan was de Lipoeadino de eerste der streekhoofden.

Het zevental hoofden, op blz. 71 als basalo popitoe aangeduid, miste diverse dezer voorrechten; zij ontvingen geen bericht van overlijden en keus van een vorst, mochten wel tegenwoordig zijn bij de inhuldiging doch werden niet genood. Toegang tot de raadzaal hadden zij slechts na gedaan verzoek bij den toezichthouder (blz. 123); bij vergaderingen hadden $z \mathrm{ij}$ geen vaste plaats, terwijl $\mathrm{zij}$ bij betreden van de vorstelijke woning van de achtertrap dienden gebruik te maken. De meening van den toezichthouder domineerde, in tegenstelling tot de eerder genoemde twaalf, wier meening in het algemeen boven die van den toezichthouder werd gesteld.

De twaalf zelfstandige hoofden van den Vaste-Wal (inclusief

45) Kruyt, Vorsten, blz. 527 noemt één der gevallen. 
toeakana Sinohoan en basal Minahaki) ${ }^{46}$ ) namen een positie in overeenkomstig die der basalo-12 van Peling: geen invloed op vorstenkeus, slechts locaal hoofd, opkomend alleen voor de belangen van eigen onderhoorigen.

Eveneens is geen sprake van het uitoefenen van invloed der bestuurders van immigrantengroepen op de vorstenorganisatie. Teekenend is Goedharts mededeeling hoe de Badjo's in 1907 den (Gouvernements-)posthouder niet erkenden, doch zich slechts gebonden achtten aan den radja van Boni, en, naar zij zeiden, aan den sultan van Ternate; over den radja van Banggai spraken zij zelfs niet ${ }^{47}$ ).

Met de groep Boegineezen te Boenta was het anders gesteld; op blz. 70 werd reeds aangegeven dat we hier eigenlijk te maken hebben met een rijkje in wording. Slechts banden van vriendschap verbonden het met Banggai; uit dien hoofde is invloed dezer Boegineezen op het Banggaische hof niet te verwachten, hoewel dit op den langen duur wellicht anders zou zijn geworden.

Dit Boegineesche "rijkje" stond onder afstammelingen van den stichter; het hoofd voerde den titel kapitan lolo (= kapitan moeda), die, waar noodig, lagere hoofden, matoa, aanstelde. $\mathrm{Zij}$ allen ontvingen van de eigen onderhoorigen hun inkomsten; bij elk gesloten huwelijk ontving de kapitan b.v. f 2,50. Verder werden materialen geleverd voor op te richten huizen; éénmaal hebben alle Boegineezen in het gebied van Tandjong Api tot Pagimana gezamenlijk een groote prauw voor den kapitan gebouwd ter waarde van $\mathrm{f} 2500$,- . Tuindiensten worden niet gemeld: de Boegineezen hadden allen slaven die voor hen den grond bewerkten en beplantten, zoowel met voedings- als met handelsgewassen.

De positie van den vorst ten opzichte zijner onderdanen kan kort worden aangegeven met: isolatie. Kruyt's zienswijze hierover werd reeds op blz. 79 vermeld; hij vervolgt zijn daar aangehaalde woorden als volgt: „Aan den geringen invloed die van het hof uitging moet „o.m. worden toegeschreven, dat de bevolking bij haar Heidendom „bleef volharden en de Islam zich weinig uitbreidde. Eerst na de „komst van het Gouvernement een goede twintig jaar geleden heeft „deze godsdienst aan invloed gewonnen". Bij de bevolking vatte $\mathrm{nl}$. de gedachte post dat het de wensch van den nieuwen heer was dat men een godsdienst zou kiezen. Velen omhelsden den Islâm, anderen

\footnotetext{
46) Kruyt, Vorsten, blz. 619 spreekt hier van de sengadji's van Pombana (d.i. Minahaki) en Sinohoan.

47) Goedhart, Drie landschappen, blz. 473.
} 
werden Christen, zonder er iets van te weten, de laatsten uitsluitend uit afkeer tegen Banggai. Treffend is een uitlating door Kruyt aangehaald: „Daarom zijn wij hier Christenen geworden, want de Islâm „komt van Banggai” ${ }^{48}$ ).

\section{Het Ternataansche toezicht te Banggai.}

In paragraaf 2 van hoofdstuk II hebben we gezien dat in de traditie bekend is hoe Banggai onder Ternate's opperheerschappij is gekomen; de beschikbare historische gegevens bevestigen dit ${ }^{49}$ ). Zoo noemen wij dan Banggai een vazalstaat van Ternate.

Daar Ternate sedert 1683 als ,leenheffer" (de term is van Valentijn) ${ }^{50}$ ) der E. Maatschappij beschouwd werd, welke verhouding voortgezet werd in de $19 \mathrm{e}$ eeuw tusschen het Gouvernement van Nederlandsch-Indië en het sultanaat, sprak men in het begin van deze eeuw wel van Banggai (en andere Ternataansche vazalstaten) als van achterleenen van het Gouvernement; o.a. Goedhart gebruikt deze constructie in den aanhef van par. 2 van zijn genoemde nota. Tegen het gebruik van dergelijke terminologie waarschuwde Spit in 1911, ,daar het werkelijke instituut van het leenstelsel der middel„eeuwen in ontstaan, ontwikkeling en rechtsgevolgen hemelsbreed "verschilt van de hier bedoelde verhouding" ${ }^{51}$ ).

In 1689 werd een contract (het eerste) afgesloten tusschen de V.O.C. en Banggai, waarin tevens sommige punten der verhouding van Ternate tot Banggai geregeld werden ${ }^{52}$ ). Zoo legt art. 15 vast, „dat gene nieuwe bobatos, hetzy goegoegoes, capitain-lauts, hoekoms "of senghadjes" aangesteld mogen worden dan na goedkeuring der Compagnie, tezamen met den sultan van Ternate. Art. 16 bepaalt verder dat ,bij aflyvigheyt en versterf, of ook wel quaat comporte„ment en afsettinge door de E. Comp." een nieuwe vorst van Banggai wordt verkozen door middel van gemeen overleg tusschen den Gouverneur en den sultan van Ternate, met de bobato's van Banggai; ten slotte schept art. 26 de verplichting dat de vorst van Banggai jaarlijks ,homagium” behoort te doen aan den sultan van Ternate en zoodanige "schenkagie of tribut te senden, als gebruykelijk en behoorlijk is".

48) Kruyt, Vorsten, blz. 616.

49) Valentijn, deel I-b, blz. 80.

50) Valentijn, deel I-b, blz. 348.

51) Spit, De Indische Zelfbesturende Landschappen, blz. XV, Inleiding.

52) Corpus Diplomaticum N.-I., deel III No. DXIV, blz. $480-488$.

Verh. d1. VI. 
In het daaropvolgende, in 1741 afgesloten, contract vinden we diepergaande bemoeienis, waar art. 27 vastlegt dat op verzoek van den vorst van Banggai aldaar een Europeesch korporaal met vier gemeene soldaten geplaatst worden om den Banggaischen vorst behulpzaam te zijn in de uitvoering van de artikelen van deze overeenkomst (die overigens niet veel afwijkt van die van 1689), terwijl dienstplichtigen en een woning voor hem moeten worden geleverd ${ }^{53}$ ).

We vinden hier dus geen bepaling dat een Ternataansche zaakgelastigde de belangen van den sultan, doch alleen dat een Compagniesbeambte die van de Maatschappij waarneemt. Toch treffen we in de 19e eeuw hier (en elders in de Ternataansche onderhoorigheden) Ternataansche sultansambtenaren aan, wier taak het was de belangen van den sultan te behartigen, bepaalde inkomsten te innen en toezicht te houden op de gedragingen van de vazallen, zich vooral uitende in invloed op benoeming van een vorst, alsmede op zijn bestuur; hem stond gewoonlijk een geringe inlandsche legermacht ter zijde.

Volgens Bosscher en Mathijsen werd het gezag van den sultan te Banggai op precies dezelfde wijze vertegenwoordigd als te Boengkoe; dit beteekent dat er een oetoesan met eenige ambtenaren en een veertigtal soldaten geplaatst waren. De oetoesan had met drie zijner of ficieren zitting in den Banggaischen bestuursraad. Verder was te Mendono een tweede Ternataansch ambtenaar geplaatst, onderhoorig aan den oetoesan te Banggai. $\mathrm{Zij}$ allen hadden te waken dat niets ondernomen of besloten werd dat strijdig was met de belangen of bedoelingen des sultans ${ }^{54}$ ).

Toen Van der Hart op 19 Maart 1850 te Banggai aankwam, voerde de oetoesan zelfs het bestuur; de vorst was gevlucht en er was nog geen opvolger benoemd ${ }^{55}$ ).

De Clerq ${ }^{56}$ ) meldt dat te Banggai van wege den sultan een oetoesan, een djoertoelis, een kapitan kota, een alferes-krois, een alferes en eenige soldaten en oppassers geplaatst waren. Zij woonden in een bouwvallig fort, kota Tjina geheeten (waarvan thans nog de resten van één der bastions te Banggai te zien zijn; vergelijk Van Vuurens monografie ${ }^{57}$ ) voor den toestand van dit fort in het begin van deze eeuw). De oetoesan was voorzitter van den bestuursraad te

53) Corpus Diplomaticum N.-I., deel V No. DCCCLXIV, blz. 325-333.

54) Bosscher en Mathijsen, Schetsen, blz. 92 (67-69).

55) Van der Hart, Reize, blz. 91.

56) De Clercq, Ternate, blz. 126, 128, 133.

57) L. van Vuuren, Het Gouvernement Celebes, deel 1; t. o. blz. 294 en plaat XXIIIa; vergelijk ook Kruyt, Vorsten, blz. 607. 
Banggai, waar alle bijzonderheden van den dagelijkschen gang van zaken besproken werden. De Ternataansche ambtenaar te Mendono voerde eveneens den titel oetoesan.

Het scherpst is weer Goedhart ${ }^{58}$ ). In 1908 waren te Banggai een viertal Ternataansche ambetnaren, t.w. een oetoesan, zijn djoeroetoelis, de kapitan kota en de kapitan kruis; zij vertegenwoordigden onderscheidenlijk den sultan, den kadli, den djogoegoe en den kapitan laoet van Ternate, en vormen een vier-eenheid; de kapitan kota was bevelhebber der Ternataansche troepen, de kapitan kruis (krois) was de commandant van de Ternataansche kruisboot, te Banggai gestationneerd. Bovendien wees dit Ternataansche college een zaakgelastigde aan uit een der te Banggai geboren Ternatanen, die als oetoesan te Mendono optrad; hem werd meestal een Banggaier als schrijver toegevoegd, die meestal te Kintom verbleef.

De invloed van deze Ternatanen op het Banggaische bestuur was zeer groot, vooral vóór 1880, in welk jaar een posthouder te Banggai werd geplaatst. De Ternatanen hadden feitelijk het bestuur te Banggai in handen, zoowel op wereldlijk als op geestelijk gebied. Goedhart schrijft o.a. daarover : ,zonder hun voorkennis, vaak ook goedkeuring, „kon noch door het Banggaische landsbestuur, noch door de inheem„sche geestelijkheid een of andere maatregel worden getroffen dan „wel een of andere zaak worden afgedaan; hunne bemoeienis in de ",inwendige aangelegenheden van het landschap strekte zich uit tot de „minst beteekenende zaken". Wel is door de plaatsing van een posthouder veel van dien invloed teloor gegaan, doch „,de invloed van den „oetoesan is evenwel nog zoo groot, dat de radja het niet wagen zal „een bevel van den posthouder uit te voeren zonder daarover vooraf „met dien oetoesan overleg te hebben gepleegd; voorts mogen geval„len van echtscheiding niet door den kalim van Banggai, doch eenig „en uitsluitend door den djoeroetoelis van Ternate worden behandeld „en afgedaan. De verhouding van den oetoesan tot den radja wordt ,vergeleken met die van een vader tot zijn kind”, enz. Bosscher en Mathijsen ${ }^{59}$ ) deelen zelfs mede, dat de oetoesan het recht van veto had van besluiten door den radja genomen tezamen met zijn raadsmannen, als de oetoesan dit besluit strijdig achtte met des sultans belangen, terwijl het geschorst bleef tot de sultan zelve uitspraak had gedaan. De oetoesan te Mendono, die er voor te waken had dat de

58) Goedhart, Drie landschappen, blz. 447, 448.

58) Bosscher en Mathijsen, Schetsen, blz. 92 (en 68). 
hoofden op den Vaste-Wal geen handelingen pleegden in strijd met Ternate's belangen, had dit veto-recht echter niet; ook was deze ambtenaar ondergeschikt aan dien te Banggai en moest diens bevelen opvolgen.

Naast deze diepgaande bemoeienis in bestuurszaken hielden de Ternatanen eveneens toezicht op het regelmatig opbrengen van de huldegift aan den sultan.

In het contract van 1689, waarin voor het eerst over ",homagium" gesproken wordt, is niet aangegeven waaruit deze in dien tijd bestond. Bosscher en Mathijsen ${ }^{60}$ ) schrijven dat in hun tijd ${ }^{1 / 5}$ deel van de vrij aanzienlijke hoeveelheid was, die op de Banggai-eilanden verzameld werd, aan den sultan van Ternate diende te worden opgebracht als schadeloosstelling voor de slaven die hem vroeger geleverd werden, doch waarvan de sultan bij de latere met het Gouvernement gesloten contracten afstand heeft moeten doen. Officieel werd 150 pikol bijeen gebracht, hetgeen beteekent dat de sultan in 1854 een jaarlijksche huldegift van minstens 30 pikol was uit Banggai ontving. Uit inlandsche bron bezitten we een beschrijving hoe reeds in zeer oude tijden aan Ternate huldegift werd opgebracht. We lezen hoe de Ternataansche zeevoogd Ali na de Goareezen verslagen te hebben op Banggai aankwam, en hoe de Banggaische vorst een prauw gereed liet maken met allerlei lijnwaad en andere goederen, een kleedingdoos met vier stukken was, en hoe hij ook een man en een vrouw deed verzenden; daar men vrijen niet ten geschenke gaf aan anderen, zullen dit wel slaven zijn geweest.

De Clerq ${ }^{61}$ ) deelt in 1880 mede, dat toen de sultan $1 / 8$ deel van de wasproductie, door hem op 300 pikol per jaar geschat, ontving; hiermee is weer een mededeeling van Van der Crab uit 1860/61 in tegenspraak ${ }^{\mathbf{6 2}}$ ).

In 1880 werd met den sultan van Ternate een geheel nieuw contract gesloten, waarbij o.m. bepaald werd dat de sultan geen andere heffingen zou doen, dan omschreven in de bij het contract behoorende

60) Bosscher en Mathijsen, Schetsen, blz. 102; verg. Naidah, Geschiedenis van Ternate (vertaling en aanteekeningen door $P$. van der Grab), B. K. I. 4e vlgr. dl. 2, blz. 455. Kruyt's mededeeling in Vorsten, blz. 612, dat Agama (1829-1846) begon elk jaar als tribuut een slavin en 25 kati was op te brengen lijkt in dit verband niet waarschijnlijk.

61) De Clercq, Ternate, blz. 134 noot 2.

62) P. van der Crab, De Moluksche eilanden (reis van den GouverneurGeneraal in $1860 / 61)$, blz. 300 . 
opgave (art. 27) ${ }^{63}$ ). Hierbij werd o.a. bepaald dat Banggai moest leveren 60 weerbare mannen op de kora-kora's (kruisbooten) als bemanning daarvan, verder een staatsiehoed (kakoewa), een pronksirihdoos (kabila) benevens drie pikol was ${ }^{64}$ ); verder had de sultan recht op ankeragegelden, doch deze stonden buiten de Banggaische huldegift daar ze geheel door vreemdelingen werd opgebracht ${ }^{65}$ ).

In Goedharts tijd werd niet meer gesproken over de te leveren manschappen en de kruisbooten; slechts resteerden de drie pikols was, de staatsiehoed en de doos; ook de ankeragegelden ontving de sultan nog. Is het niet vorderen der kruisbooten een gevolg der ook hier doorwerkende Pax Neerlandica?

Werd deze huldegift door de Banggaische bevolking onder leiding harer eigen hoofden verzameld, doordat van de bij den vorst verzamelde was het noodige voor Ternate werd gereserveerd, terwijl de kakoewa en de kabila op last van den vorst zelven werden vervaardigd, de Ternataansche ambtenaren hadden te zorgen voor inning van eenige aan den sultan toekomende belastingen van vreemdelingen, t.w. een rifbelasting van Badjo's, ankeragegelden van Mandarsche prauwen en plantrecht voor het planten van kokosnootpalmen. De Ternataansche ambtenaren vonden zelve een deel van hun inkomsten in de inning dezer middelen.

Bij Bosscher en Mathijsen ${ }^{66}$ ) vinden we dat in Boengkoe de Badjo's $f$ 2,- per prauw moesten betalen om het recht te verwerven op de riffen te visschen; in Banggai werd echter een derde deel van hun vangst als betaling geëischt. Van der Hart ${ }^{67}$ ) geeft op dat de Badjo's een vijfde deel van hun vangst moesten afstaan als betaling van dit vischrecht. Van de Boengkoesche inkomsten vermelden eerstgenoemden dat de helft aan den sultan van Ternate en de andere helft aan de Boengkoesche hoofden kwam; de sultan had echter van zijn aandeel afgezien ten behoeve van zijn Ternataansche ambtenaren te Boengkoe, die hieruit ongeveer $f 150$,- tot $f 200$,- jaarlijks ontvingen. Ook in Banggai was de helft voor den sultan en de rest voor den vorst van Banggai ; of de sultan hier ook zijn ambtenaren zooals te Boengkoe begiftigde is onbekend. De Clerq ${ }^{68}$ ) meldt ten slotte,

63) Dit contract is opgenomen in Indische Gids 1882 (4e jaargang) deel I, blz. $693-708$.

64) Goedhart, Drie landschappen, blz. 450.

65) De Clercq, Ternate, plaat IV voor afbeeldingen kakoewa en kabila.

66) Bosscher en Mathijsen, Schetsen, blz. 91, 105, (81, 88).

67) Van der Hart, Reize, blz. 99, 100.

68) De Clercq, Ternate, blz. 132. 
dat de Badjo's jaarlijks f 4, - schatting aan den sultan van Ternate opbrachten voor het recht om te visschen in de Banggaische wateren.

Goedharts ${ }^{69}$ ) mededeelingen zijn weer het volledigst; in zijn tijd moesten de Badjo's f 4,- per prauw, dan wel f 2,- per huis, belasting betalen ter uitoefening van hun visscherijbedrijf; in Boengkoe (thans ook nog in Banggai) vond Goedhart deze belasting als bea pasi betiteld (deze was dus een niet-hoofdelijke bedrijfsbelasting). Van de opbrengst, gemiddeld $f 450$, - per jaar, werd eerst het vaste deel voor den sultan afgetrokken ad $\mathrm{f} 300$,- per jaar; het restant kwam geheel ten bate der Ternataansche ambtenaren. Wij vinden hier dus een merkwaardige tegenspraak tusschen Bosscher en Mathijsen eenerzijds en Goedhart anderzijds; volgens de eerste schrijvers kregen de landshoofden de helft van de geinde bea pasi, volgens den laatsten kwam de in Banggai van de Badjo's geinde belasting geheel aan de Ternataansche ambtenaren. Is dit wellicht een voorbeeld van onwettige inkomstenvermeerdering door de Ternatanen ten koste der landshoofden?

Met de ankerage- en havengelden, alsmede met de uitvoerrechten is het anders gegaan. Bosscher en Mathijsen vonden dat vreemde vaartuigen onderworpen waren aan ankeragegeld, ten bedrage van 10 tot 40 reaal, waarvan de waardeering plaatselijk veel verschilde; de heffing geschiedde vaak in natura, b.v. in geweven goederen ${ }^{70}$ ). Onder Boengkoe deelden de schrijvers mede, dat ankeragegeld hier laboeh batoe heette, en dat de helft ten voordeele der Boengkoesche hoofden kwam; zij meldden niet of de regeling in Banggai een zelfde was. Bij De Clerq vinden we echter bevestiging van dit laatste waar deze auteur meldt, dat het ankeragegeld $f 10,-$ bedroeg en verdeeld werd tusschen de Ternataansche en de plaatselijke hoofden ${ }^{71}$ ).

Van uitvoerrechten vinden we een enkele mededeeling bij Van der Hart, waar hij meldt, dat naast een ankeragegeld van $f 10,-$ voor elke handelsprauw, f 1,- uitvoerrecht per pikol was moest worden betaald ${ }^{72}$ ).

Zoowel de in- en uitvoerrechten en accijnzen, als de haven- en ankeragegelden werden door het Gouvernement van NederlandschIndië overgenomen, en wel onderscheidenlijk bij de suppletoire contracten met den sultan van Ternate van 10 Maart 1899 (goedgekeurd

69) Goedhart, Drie landschappen, blz. 449.

70) Bosscher en Mathijsen, Schetsen, blz. 106; 88.

71) De Clercq, Ternate, blz. 128.

72) Van der Hart, Reize, blz. 100. 
en bekrachtigd 31 Mei 1899) en van 13 Juni 1900 (goedgekeurd en bekrachtigd onder voorbehoud 12 Juni 1902), de eerste tegen een jaarlijksche uitkeering van $\mathrm{f} 1200$,- waarvan de helft voor den sultan van Ternate, en een vierde deel voor ieder der beide vorsten van Banggai en Boengkoe. De tweede soort rechten werden eveneens voor $\mathrm{f} 1200$,- overgenomen, doch daarbij werd niet vastgesteld welk deel hiervan voor de Banggaische hoofden zou zijn, hoewel zij daarop rechten hadden, zooals we hooger zagen ${ }^{73}$ ). Thans bewaart de landschapsbegrooting aan een en ander de herinnering in onderdeel 2, geheeten: „Schadeloosstelling wegens overname van tol- en scheepvaartrechten en monopoliën", groot f 300,-; het Banggaische Zelfbestuur deed bij verklaring van 18 December 1912 afstand van deze inkomsten ten bate der landschapskas van Banggai (memorie).

Het plantrecht voor vreemdelingen wordt pas voor het eerst door Goedhart genoemd ${ }^{74}$ ); hij deelt mede dat een niet tot de inheemsche bevolking van Banggai behoorend persoon aan den sultan van Ternate voor de vergunning tot den aanleg van een klapperaanplant 10 cent per (te planten?) boom moest betalen. In de practijk werd deze vergunning namens den sultan door den vorst van Banggai tezamen met den oetoesan verleend; van het recht kwam de helft aan den sultan, een kwart gedeelte aan den Banggaischen vorst en de rest aan de gezamenlijke Ternataansche ambtenaren (Wel was in art. 24 van het contract van 1880 bepaald dat de sultan geen concessies van landbouw of mijnontginning mocht verleenen, noch gronden verhuren of verkoopen aan personen, niet behoorende tot de inheemsche bevulking van het sultanaat, dan na goedkeuring en toestemming dorr het Gouvernement, doch wellicht was het verleenen van plantrecht per boom òf niet verboden òf een slinksche ontduiking van de bepalingen van art. 24).

Naast de bovengenoemde wettelijke inkomsten der Ternataansche ambtenaren te Banggai hadden zij nog andere middelen van bestaan; zoo hadden zij recht op een zeker aantal dienstplichtigen, die dagelijks tot hun beschikking stonden voor het verrichten van huiselijke dis:nsten en door hen ook op reis werden mede genomen. De Ternatanen noemden hen koki, de Banggaier noemde en noemt hen lambanoea (verg. blz. 123). Bepaalde streekgemeenschappen waren aangewezen voor levering der bedienden tot een totaal van zeventien per dag.

73) Hand. S. G., Zitt. 1899/1900, Bij1. 151, st. no. 15; en Zitt. 1902/1903, Bij1. 174, st. no. 33 .

74) Goedhart, Drie landschappen, blz. 449. 
Buitendien ontvingen de Ternatanen $10 \%$ van de waarde in geschil bij afdoening van kleine zaken en leefden zij tijdens dienstreizen op kosten der bevolking, die hun eetwaren en goederen moest opbrengen. Verder verschaften zij zich ook wel ongenorloofde inkomsten door het opleggen van geldboeten, b.v. wegens z.g. ondervonden geringschattende behandeling van de zijde der Banggaische bevolking.

De sultan genoot voor zich nog andere, wisselvallige inkomsten uit Banggaisch gebied. Zoo betaalde de Nieuw Guinea Handelmaatschappij in 1908 aan den sultan voor het uitsluitend recht tot uitoefening van de parelvisscherij in de Banggaische wateren een bepaalde som, terwijl tevens overeengekomen was, dat de Badjo's toegelaten werden. De Clerq ${ }^{75}$ ) deelde t.a.v. dit recht mede: „Het ,zoeken van parelen en paarlemoer heet in het geheele gewest een „recht dat uitsluitend aan de kroon behoort, al wordt dit in de ver„schillende contracten niet afzonderlijk vermeld". (Zie in dit verband ook de staatsbladen 1902 no. 4, thans 1916 no. 157 en 1908 no. 126).

Een tweeden vorm van inkomen trachtte de sultan zich in het einde van de vorige eeuw te verwerven door boschexploitatie. Blijkens het Koloniaal Verslag van 1896/97 had hij nl. het recht tot houtaankap en houtuitvoer voor $f 500$,- - 's jaars, en dat tot het inzamelen van boschproducten voor $f 1000$,- per jaar, beide voor zoover betreft den Vaste-Wal van Banggai, aan een firma te Gorontalo afgestaan; indien de vorst van Banggai voldoende medewerking zou betoonen bij de uitvoering van dit contract, zou hij $20 \%$ van genoemde sommen ontvangen. De Resident van Ternate schorste dit contract echter, hetgeen naderhand door de Indische Regeering werd goedgekeurd. Als grond daartoe gaf men op dat bij den handel te Gorontalo bezwaren waren gerezen tegen de wijze waarop de concessie betreffende de inzameling van boschproducten werd uitgevoerd.

Het Ternataansche toezicht was wel zeer intensief zooals blijkt uit Goedhart's op blz. 131 aangehaalde woorden en uit Bosscher's en Mathijsen's mededeeling dat de uitvoerende macht bij den radja en den stedehouder berustte. Ook uit den invloed dien de oetoesan deed gelden op de keus van een nieuwen vorst blijkt de Ternataansche macht. Op blz. 130 werd een en ander reeds aangestipt.

In het contract van 1689 vinden we dat niet alleen de vorst doch ook zijn rijksgrooten slechts aangesteld mochten worden na goedkeuring door de Compagnie, tezamen met den sultan, en dat in een

75) De Clercq, Ternate, blz. 60. 
vorstenvacature slechts voorzien mocht worden door middel van gemeenschappelijk overleg tusschen Gouverneur, sultan en Banggaische rijksgrooten. Uit de bewoordingen van art. 16 blijkt verder dat de V.O.C. het recht had den Banggaischen vorst bij wangedrag af te zetten.

Tot 1908 is hierin geen wezenlijke wijziging gekomen, met dien verstande echter dat de rechten van Gouverneur te Ternate werden uitgeoefend door den Resident aldaar, en dat de goedkeuring der Indische Regeering noodig was indien het voorziening van een vorstenvacature betrof.

$\mathrm{Bij}$ vacature van vorst, rijksbestierder of zeevoogd werd een voordracht van twee of drie personen te Banggai opgemaakt; de oetoesan te Banggai mocht weliswaar geen invloed op de voordracht zelve uitoefenen, doch hij kon wel een bepaalden candidaat aanbevelen. Zooals reeds hooger medegedeeld (blz. 116) werden daarna de voorgedragenen naar Ternate gezonden waar de sultan hen in doen en laten gadesloeg, eventueel zich andere candidaten liet voorstellen, om ten slotte een keuze te doen ${ }^{76}$ ).

Van „quaat comportement en afsettinge” (blz. 129) zijn historisch eenige gevallen bekend. Atondeng (1808-1829) verzette zich tegen den sultan daar hij zich los wilde maken van Ternate's overheersching. De hoofden beloofden hem steun, doch allen, op bosanjo Batoei na, vielen af, toen de Tobeloreezen verschenen. Atondeng werd gevangen genomen en verbannen. Ook zijn opvolger, Agama, verzette zich in 1846, hetgeen eindigde met zijn vlucht naar Bone in 1847. De historisch niet terug te vinden opvolgers van Agama, Laoeta en Tadja, moesten beiden eveneens afgezet worden; de eerste omdat hij de basalo-4 van Banggai beleedigde, waarover dit college zich bij den sultan beklaagde, waarop hij Laoeta afzette; de tweede omdat hij opstand pleegde, waarop hij verbannen werd naar Halmahera ${ }^{77}$ ).

Voor Banggai, als onderhoorig aan Ternate, waren uiteraard de bepalingen der contracten, afgesloten tusschen het Gouvernement van Nederlandsch-Indië en den sultan, mede van beteekenis, tenzij het tegendeel uitdrukkelijk vermeld werd. Zoo zijn van belang:

contract van 30 October 1880 , waarbij de bepalingen van een suppletoire overeenkomst van 1873 (houdende dat sultansonderhoorigen voor bepaalde categorieën van misdrijven terecht zouden

76) Vergelijk: Bosscher en Mathijsen, Schetsen, blz. 92; De Clercq, Ternate, blz. 126; Goedhart, Drie landschappen, blz. 447.

77) Kruyt, Vorsten, blz. 525; 527. 
staan voor een rechtbank, recht sprekende in naam des Konings) gehandhaafd werden; tevens werden bepalingen in verband met de afschaffing der slavernij opgenomen, terwijl een einde werd gemaakt aan het pandelingschap ${ }^{78}$ );

suppletoir contract van 5 Juli 1889, waarbij in- en uitvoer van vuurwapenen, buskruit en ammunitie, niet gedekt door schriftelijke vergunning van den bevoegden ambtenaar, verboden werden in de tot het grondgebied van den sultan van Ternate behoorende landschappen; tevens werden mogelijke overtreders van deze bepalingen onttrokken aan de jurisdictie der sultansrechtspraak ${ }^{79}$ );

suppletoir contract van 21 Maart 1889, waarbij bepaald werd dat straf- en rechtsvorderingen ter zake van misdrijven, overtredingen en rechtsverkortingen met betrekking tot telegraaflijnen en -kabels, gelegen binnen dan wel buiten het sultansgebied, en gepleegd door sultansonderhoorigen, zouden worden behandeld door Gouvernementsrechtbanken volgens Gouvernementsbepalingen ${ }^{80}$ );

suppletoir contract van 20 Juli 1893 waarbij art. 24 van het contract van 1880 vervangen werd door nieuwe bepalingen betreffende het verleenen van vergunningen tot het doen van mijnbouwkundige opsporingen en concessiën tot mijnontginning binnen het sultanaat. Het Gouvernement behield zich deze rechten voor, doch het Zelfbestuur zou eventueel de helft van de cijns ontvangen; ook werd het recht van het Gouvernement vastgelegd om opsporingen te doen verrichten te eigen bate ${ }^{81}$ );

suppletoir contract van 29 September 1897, houdende aanvulling van het suppletoir contract van 20 Juli 1893, waarbij alle twijfel werd opgeheven omtrent de vraag of de Nederlandsch-Indische mijnverordeningen o.a. op het sultanaat Ternate en deszelfs ingezetenen toepasselijk zijn ${ }^{82}$ );

de op blz. $134 \mathrm{v}$. genoemde suppletoire overeenkomsten van 10 Maart 1899 en 13 Juni 1900, waarbij het Gouvernement het recht tot het heffen van in- en uitvoerrechten en accijnzen in de afdeeling Banggai, respectievelijk de haven- en ankeragegelden in dat gebied van het sultanaat Ternate overnam.

Aan de Ternataansche overheersching van Banggai is een einde

78) Hand. S. G., Zitt. 1881/1882, Bijl. 100, st. no. 17.

79) Hand. S. G., Zitt. 1890/1891, Bijl. 112, st. no. 26.

$80)$ Hand. S. G., Zitt. 1890/1891, Bijl. 112, st. no. 25.

81) Hand. S. G., Zitt. 1894/1895, Bijl. 110, st. no. 13.

82) Hand. S. G., Zitt. 1898/1899, Bijl. 166, st. no. 4. 
gekomen op 1 April 1908. Bij suppletoir contract van 23 Maart 1907 deed de sultan van Ternate aan het Gouvernement afstand van Banggai, Boengkoe en Mori tegen een jaarlijksche schadeloosstelling van $\mathrm{f} 6000$,-; dit contract trad 1 April 1908 in werking ${ }^{83}$ ). Het landschap werd niet bij het rechtstreeks bestuurde gebied ingelijfd, de indirecte bestuursvorm was n.l. behouden. Zoo legde Abdoerrahman op 1 April 1908 de Korte Verklaring als bestuurder van Banggai af. Aandacht verdient dat deze K.V. uit drie artikelen bestaat, en dus niet opgemaakt is volgens het z.g. Ternate-model, bestaande uit het algemeen in zwang zijnde model, waaraan een vierde artikel is toegevoegd, waarin het recht erkend wondt van het Gouvernement om te allen tijde zelf het bestuur over het landschap in handen te nemen. Voor Ternate is dit vierde lid ongetwijfeld een uitvloeisel van art. 9 van het contract van 1880 (waarin het recht van het Gouvernement was vastgelegd om het bestuur over het geheele sultanaat, dan wel over een gedeelte daarvan, zelf in handen te nemen), doch interessant is het dat een overeenkomstige clausule niet is opgenomen in de Korte Verklaring afgelegd door den eersten zelfstandigen Banggaischen bestuurder.

\section{Gouvernementsinvloed.}

Hoe de verhouding was tusschen het Gouvernement en het sultanaat Ternate in zijn tijd geeft De Clerq (1880) weer in de volgende karakteristiek: „Het hoofdbeginsel waarop de contracten met de „vorsten van Ternate en Tidore berusten is dat eener volstrekte afhankelijkheid van het Nederlandsch-Indische Gouvernement, „gepaard met een zoo gering mogelijke inmenging van den opperheer ,in het inwendige bestuur" ${ }^{84}$ ). Te Ternate was dan ook slechts zeer weinig Gouvernementspersoneel bescheiden: een Resident, een controleur t.b., eenige lagere ambtenaren. De Resident, soms de controleur, bezocht van tijd tot tijd de tot het sultanaat behoorende landschappen, doch kon naar aanleiding zijner bezoeken den sultan slechts adviseeren, daar hij contractueel gebonden was aan die zoo gering mogelijke inmenging.

In $1880 \mathrm{kwam}$ verandering, vermoedelijk door twee oorzaken. In de eerste plaats opende de langdurige en bloedige opstand van Dano

83) Hand. S. G., Zitt. 1908/1909, Bijl. 311, st. no. 15, 16 en 18.

84) De Clercq, Ternate, blz. 322. 
Baboe Hasan de oogen van het Gouvernement voor de misstanden die onder het sultansbestuur bestonden; en verder maakten de voortdurende klachten over zeerooverij, voornamelijk in den Banggaiarchipel, maatregelen noodig. Zoo werd dan in 1880 een posthouder te Banggai geplaatst; in 1895 bij wijze van proef naar Boengkoe (onderafdeeling Kolonedale) verplaatst, was hij eind 1895 te Kintom (Vaste-Wal) ${ }^{85}$ ).

De taak van dezen posthouder is niet aangegeven. Uit Goedharts mededeelingen ${ }^{86}$ ) kunnen we echter begrijpen dat zijn eerste plicht was toezicht te houden op de handelingen der Ternataansche ambtenaren en leiding te geven aan het Banggaische Zelfbestuur; daartoe had hij het recht de bestuursvergaderingen in de raadzaal (djagaan) te presideeren. Verder vermeldt Goedhart: „Aan dezen (posthouder) ,moet het Zelfbestuur alle belangrijke voorvallen rapporteeren, terwij1 „de door hetzelve voorgenomen maatregelen vooraf ter kennisse van „dien ambtenaar moeten worden gebracht; deze heeft het recht het ,nemen van den maatregel te verbieden. Als raadsman heeft hij de ,bevoegdheid tot het Zelfbestuur voorstellen te richten, waarover in ,de ngara lamo wordt beraadslaagd". En over het andere deel van zijn werkzaamheden: „De vestiging van een Gouvernementsvertegen„woordiger heeft echter aan (het gezag der Ternataansche ambte,naren) een gevoelige knak toegebracht, omdat zij daardoor op hun ,beurt verplicht werden zich van afdoening van zaken buiten den „posthouder om te onthouden, niet meer naar hartelust boeten konden „opleggen wegens vermeende van de zijde der inheemsche bevolking „of hare hoofden ondervonden geringschattende behandeling".

Het is niet bekend of de op blz. $125 \mathrm{v}$. genoemde term districten door dezen posthouder, dan wel door de Europeesche ambtenaren van Ternate is ingevoerd. Vermoedelijk is het geschied in navolging van het Ternataansche voorbeeld; we beschikken nl. over een mededeeling uit een regeeringsrapport, welke zegt dat de sultansgebieden sedert overoude tijden verdeeld zijn in districten, waarvan de hoofden meestal den titel sengadji voeren ${ }^{87}$ ).

Nadat in 1908 Banggai was losgemaakt uit het sultanaat Ternate en als zelfstandig zelfbesturend landschap onder Korte Verklaring een eigen leven was gaan leiden, werd intensiever bestuursbemoeienis

$85)$ K. V. $1877 / 78 ; 1880 / 81 ; 1895 / 96 ; 1897 / 98$.

$\left.{ }^{86}\right)$ Goedhart, Drie landscappen, blz. 445, 448.

87) Arb. VII, blz. 162. 
onder Europeesch toezicht mogelijk. Allereerst richtte zich de aandacht op registratie en concentratie der bevolking; heerendienstregelingen werden ingevoerd en een hoofdelijke belasting (met een Boegineesch woord sima assaparang atoewong) werd met ingang van 1 Januari 1909 geheven, terwijl een rationeele districtsindeeling tot stand kwam (aldus de Koloniale Verslagen uit 1908/09 en $1909 / 10)^{88}$ ).

Het aantal van 46 districten werd in weinige jaren tot 14 teruggebracht, en in de zeer verscheiden titulatuur werd helaas een doodende uniformiteit gebracht. De districtshoofden ontvingen den titel sengadji (zie blz. 77 v.), ook wel kapala district; ook is het predicaat sengadji wel als persoonlijke titel verleend aan personen die er eigenlijk geen recht op hebben. De gevolgen van een en ander voor de rechtgemeenschappen werden reeds in par. 7 van hoofdstuk III aangegeven.

Ook het zeer groote aantal hoofden, waarop Odenwald in zijn memorie van 1909 wees, werd teruggebracht; dit ging samen met de gedwongen dorpsvorming (blz. 79 v.).

Een in Zuid-Celebes vigeerende regeling op de verkiezing van regenten en andere inlandsche hoofden ${ }^{89}$ ), met de daarop van kracht geworden aanvullingen is ook geldig geweest voor Banggai, toen dit landschap een deel uitmaakte van het Gouvernement Celebes en Onderhoorigen (1908-1924); uit oude archiefstukken bleek mij dat deze regeling ook inderdaad is toegepast. $Z_{\mathrm{ij}}$ is in zooverre verdienstelijk en aansluitend op het adatrecht dat er niet in wordt gesproken van "volstrekte meerderheid van stemmen” of dergelijke, zooals b.v. het geval was in de Manadoregeling van 1898. Overigens was het besluit te veel geijkt op toestanden uit Zuid-Celebes, dan dat het in Banggai ooit tot leven kon komen. Slechts het toen ingevoerde aanstellingsbesluit, ook voor kamponghoofden, is tot heden gehandhaafd.

De practijk thans is dat bij een vacature van kamponghoofd de bevolking van het betrokken dorp overleg pleegt met het districtshoofd, en dat deze laatste een voorstel doet aan den zelfbestuurder en den onderafdeelingschef; luiden de genomen informaties gunstig, dan wordt de voorgestelde belast met de functie van kamponghoofd

88) Zie ook Arb. IX, blz. 238/239.

89) Arb. VII, blz. 363-371; voor de Manadoregeling zie in denzelfden bundel blz. $360-363$. 
totdat het districtshoofd na eenige maanden bevestiging verzoekt, dan wel ontheffing. In het eerste geval verleent de zelfbestuurder een aanstellingsbesluit, in het tegenovergestelde dient het districtshoofd terstond een voorstel in tot een anderen functionaris. Het aantal mutaties in de ruim 300 kamponghoofden is gering.

$\mathrm{Bij}$ een vacature van districtshoofd kan geen vaste regel worden opgesteld; uiteraard wordt het gevoelen van het Zelfbestuur ingewonnen over eventueele candidaten, terwijl ook op de wenschen der bevolking uit het betrokken district wordt gelet. Doch daar ligt juist de moeilijkheid, omdat de districtshoofden geen adathoofden meer zijn; hoogstens in een deel van hun ressort kunnen zij op dien titel aanspraak maken. De veertien ambtelijke districten van thans bergen toch elk voor zich eenige der rechtsgemeenschappen, districten van weleer, in zich. Ten aanzien van hun ambtelijke taak moet uiteraard gelet worden op bepaalde eischen van kennis en bestuurspractijk. $\mathrm{Na}$ een door den onderafdeelingschef bij den Resident van Manado ingediend voorstel kan bij gunstige beschikking daarop betrokkene worden aangesteld; dit geschiedt bij Zelfbestuursbesluit dat goedkeuring van den Resident behoeft.

Het Zelfbestuur bestond oorspronkelijk, zooals op blz. 120 beschreven, uit den vorst met een viertal bobato, de koemis-4, waaraan in voorkomend geval de basalo-4 konden worden toegevoegd; deze koemis-4 is in den loop der tijden wel zeer verminkt, heeft althans zijn wezenlijk karakter (nl. raad van bobato) verloren.

Het andere gedeelte van het Zelfbestuur, gevormd door de basalo-4, is intact gebleven. Nog steeds zijn te Banggai aanwezig vier dorpshoofden, die den titel basalo voeren, en die de voortzetters zijn der basalo-4 uit de jaren vóór 1908; slechts is hun invloed ingekrompen voor wat betreft zaken buiten het eiland Banggai. Werd eertijds het contact tusschen den rijksbestuurder en hen bewerkstelligd door den gimalaha, thans is dit door het wegvallen van die functie onmiddellijk en rechtstreeks geworden. Ook thans nog werken zij mede aan het opmaken van een eventueele voordracht tot aanvulling van het Zelfbestuur, doch uiteraard beslist daarin niet meer de gouverneur en de sultan van Ternate, doch de Resident van Manado, die den candidaat bij de Indische Regeering voorbrengt.

Sedert de vorming van een landschapskas ontvangen de gehandhaafde hoofden tractement uit die kas. Merkwaardig is in dit verband een verklaring op 22 Juli 1912 door het volledig Zelfbestuur 
afgelegd ${ }^{90}$ ), waarin deszelfs leden besloten, in verband met de op 1 Januari 1909 ingevoerde hoofdelijke belasting, afstand te doen van elk recht en van alle inkomsten onder welke benaming ook door de bevolking te hunnen behoeve opgebracht, tegen toekenning eener uit de landschapskas van Banggai aan hen te betalen schadeloosstelling van ten hoogste $\mathrm{f} 4.800$, - per jaar. In tegenspraak hiermee is dat nog steeds, tot in 1939 toe, de vorst en de in functie zijnde leden van het Zelfbestuur ieder dagelijks de beschikking hebben over eenige lambanoea (zie blz. 123); deze personen worden beschouwd als te zijn vrijgesteld van heerendienst, terwijl een apart Zelfbestuursbesluit (van 20 November 1930 no. 56) de vordering dezer huisdiensten regelt. Als onvolledigheid van dit besluit moet aangestipt worden, dat daarin niet de afkoopbaarheid dezer persoonlijke diensten is vastgelegd (verg. blz. 125).

De salarissen van den zelfbestuurder en de leden van het Zelfbestuur zijn gefixeerd; eveneens zijn ambts- en reistoelagen vastgelegd. Voor de districts- en onderdistrictshoofden werd een salarisschaal opgesteld bij Zelfbestuursbesluit, waarbij rekening gehouden wordt met periodieke verhoogingen, terwijl zij ook reistoelagen en mogelijke ambts- en personeele toelagen ontvangen, alles uiteraard ten laste van de landschapskas. Geen dezer ambtelijke hoofden heeft recht op dienstbetoon door zijn onderhoorigen.

De kamponghoofden ontvangen $8 \%$ collecteloon der door hen geinde belasting- en afkoop-heerendienstgelden; in 1938 werd hierop ruim $f 160.000$,- ontvangen, zoodat den hoofden rond $f 13.000$,aan collecteloonen werd uitgekeerd. Bovendien is hun recht op dienstbetoon door de dorpsgenooten in dien vorm gehandhaafd dat $\mathrm{zij}$ het recht hebben ieder hunner tot drie dagen veldarbeid in hun tuinen op te roepen; deze diensten zijn afkoopbaar gesteld. Niet deze inkomsten in arbeid, wel echter de in geld geinde collecteloonen, plegen de hoofden der grootere kampongs te deelen met de onder hen staande lagere dorpsbeambten (wijkhoofden). Genoemde diensten werden in mindering gebracht van gevorderde "gemeentediensten”. Wanneer deze dwaze term in Banggai is ingevoerd is niet na te gaan; er werden b.v. uit dien hoofde 8 dagen per jaar gevorderd. De term is daarom dwaas, omdat men zich niet bekommerde om de vraag wat gemeenten eventueel wel konden zijn, doch zich schijnbaar beijverde om die gemeenschappen welke eventueel op dien titel aanspraak

90) Memorie. 
zouden kunnen maken, te miskennen en te vernietigen. De bevolking beschouwt deze "hemente" als een lichter soort heerendienst aan wegen en bruggen in het dorp. De dwaasheid werd nog vergroot, toen men indertijd naast deze gemeente-, ook nog z.g. pinontoldiensten vorderde. Dit laatste woord is van elders ingevoerd; men bedoelde er de persoonlijke diensten aan de hoofden mee. Thans is het in zooverre verbeterd, dat de naam pinontol vervangen is door het Banggaische woord balimang (dat ook door de madi- en siansprekers wordt begrepen), en dat deze diensten in mindering worden gebracht van de z.g. gemeentediensten.

\section{Godsdienstbeambten.}

Te Banggai geeft men gaarne naast de standen (zie blz. 136 v.) ook nog een geestelijken stand op, in het aki bangsa sjaraa genaamd; doch deze groep vormt geen stand op zichzelf, daar men er niet door geboorte doch door benoeming toe behoort. De Mohammedaansche godsdienstbeambten bekleeden in het orthodoxe Banggai een belangrijke plaats; ook buiten de hoofdplaats, in die streken welke geheel geïslamiseerd zijn, is hun invloed aanzienlijk. Het godsdienstpersoneel buiten de hoofdplaats Banggai echter wordt, voor zoover niet bestaande uit Banggaiers, niet tot de bangsa sjaraa gerekend.

Van oudsher wordt op Banggai een kalim aangetroffen, die meestal van vorstelijken bloede is. Wel is naar het adatrecht de vorst tevens hoofd van den godsdienst, doch voor kerkrechtelijke zaken heeft hij dezen kalim tot zijn beschikking; hij is tevens voorzitter van den sjarât (zie par. 12).

Eertijds trof men ter hoofdplaats een groot aantal moskeebeambten aan. Men had er o.a. een imam banginsaa (soms een imam ngofa; verg. blz. 85) en vier chatibi banginsaa (c.q. ngofa), die slechts te zorgen hadden voor de godsdienstige behoeften van vorstentelgen en adel. Verder had elk der basalo-4 een eigen imam, chatib, en modjim, terwijl men wellicht ook dergelijke functionarissen aantrof in Lampa, Poetal en Boneaka. Van oudsher was er echter slechts één moskeegebouw te Banggai. De oudste der modjim ter hoofdplaats voerde den titel saraa, de na hem komende modjim heette malakoe en was hoofd der modjim. Bovendien had men nog den sekretaris en den imam sohi, beiden speciale beambten van den vorst (zie blz. 113). Doch niet alleen te Banggai, ook elders werd veelvuldig een onmatige bezetting met masdjidpersoneel aangetrof fen. Zoo vond Goedhart in 1908 
in Batoei vier imam, zeventien chatibi en twaalf modjim, terwijl het in de overige districten niet anders gesteld was ${ }^{91}$ ).

$\mathrm{Bij}$ de organisatie van het bestuur in 1908 werd direct paal en perk gesteld aan dit groot aantal godsdienstbeambten; dit geschiedde onder aandrang van het Europeesch bestuur, gelijktijdig met de vereenvoudiging der geheele bestuursorganisatie. Thans zijn te Banggai aanwezig : één kalim, één imam, vijf chatibi en vijf modjim (één paar voor ieder der basalo-4, het vijfde voor Lompio) en één bilal (Moskeebewaarder). $\mathrm{Er}$ is nog steeds één masdjid.

Buiten de hoofdplaats treft men in de geislamiseerde gebieden de districtsimams aan (in maleisch gewoonlijk imam distrikt geheeten), en onder hen de dorpsgeestelijkheid, daar nl. waar een kampong over een eigen masdjid beschikt. De districtsimams zijn hoofd over de moskeebeambten in het betrokken district. Van waar dit instituut stamt is mij niet duidelijk geworden, doch ik vermoed dat wij in dezen penghoeloe niemand anders te zien hebben dan den eenigen imam, die vroeger naast het streekhoofd stond, in den tijd dat de streekgemeenschappen nog bestuurlijke erkenning vonden als rechtsgemeenschappen (zie blz. 126). Toenmaals moet er dus in elk district één imam zijn geweest bij de eenige masdjid die dan stond op de plaats van vestiging van het streekhoofd. Hiermee in overeenstemming is dat in de traditie er steeds melding van wordt gemaakt dat een bepaald met name genoemd hoofd als eerste den Islam omhelsde en een masdjid op zijn woonplaats bouwde.

Nadat echter ten gevolge van de gedwongen dorpsvorming overal bestuurlijk zelfstandige eenheden ontstaan waren, verkregen deze eenheden meerendeels ook eigen kampongmasdjids met voltallig personeel, zoodat de kampongs zich ook op religieus gebied zelfstandig maakten. Daarmee is dan tevens verklaard hoe in sommige administratieve districten van thans meer dan één districtsimam wordt aangetroffen: zij zijn de voortzetters van de voormalige imams der streekgemeenschappen. Zoo vinden we b.v. een districtsimam in de kampong Batoei èn in de kampong Tangkiang, beide kernen van districten van weleer, thans echter opgenomen in het vergroote administratieve district Batoei.

Door middel van dit instituut der districtsimams is een zekere decentralisatie op kerkrechtelijk gebied bereikt; men kent dan ook districtssjarâts. Verder is deze organisatie dienstbaar gemaakt aan

91) Goedhart, Drie landschappen, blz. 471. Verh. dl. VI. 
uitingen van godsdienstig leven. Zoo worden begin en einde der vasten te Banggai door vorst en kalim met de geestelijkheid in gemeen overleg vastgesteld en door den kalim aan de districtsimams medegedeeld, die de hun onderhebbende geestelijkheid weer inlicht. De kalim schijnt gezag uit te oefenen over de districtsimams.

De aanwijzing tot alle hooger genoemde ambten gaat uit van de bevolking zelve; de districtshoofden oefenen vaak veel invloed uit. Of, en zoo ja door wien, de districtsimams bevestigd worden is mij niet bekend. Eertijds werd de keus van den kalim bekrachtigd door den sultan van Ternate ${ }^{82}$ ).

Aanwijzing wie van de imams in het Landschap gerechtigd is op te treden als huwelijksbeambte en als instantie tot het kennis nemen van verstootingen en herroepingen daarvan, geschiedde bij (voor de geheele residentie uniform) Zelfbestuursbesluit; dit hield tevens regeling der voor deze handelingen te vorderen geldelijke belooningen in.

Betreffende de overige inkomsten van het masdjidpersoneel (zàkât, fitrah e.a.) ontbreken mij gegevens.

\section{B. Rechtspraak.}

\section{Rechtsbedeeling in de sfeer der volksordening.}

Kruyts mededeelingen wijken wezenlijk af van de gegevens uit mijn memorie. Hij schrijft over de toestanden in den Archipel ${ }^{93}$ ): „Als ik de menschen hoorde vertellen hoe het onder hen toeging in ,den ouden tijd, kreeg ik sterk den indruk, dat ieder zijn eigen recht ,zocht, en dat niemands leven veilig was. De trap van het huis werd ,dan ook elken avond opgehaald". De ook door hem genoemde tonggol en langka-langkai ,schijnen zich weinig met den loop der „dingen bemoeid te hebben. Alleen als iemand zijn beklag kwam doen „over een ander, mengde hij zich in de zaak. Zoo veel mogelijk was ,,ieder zijn eigen rechter". Ook de basalo, op sommige plaatsen aan het zeestrand gevestigd "bemoeien zich zelden met wat er in het „binnenland gebeurde”. Volgens Kruyt bestaat er verband tusschen deze weinig ingrijpende rechtsbedeeling en het verspreid wonen der bevolking (verg. blz. 54 v.). Hij gaat verder : ,In deze omstandigheden „was het juist goed, dat de menschen zoo ver uit elkaar ieder op „zichzelf woonden. Door den weinigen omgang, dien men met elkaar

92) Goedhart, Drie landschappen, blz. 446/447.

93) Kruyt, Bewoners, blz. 249. 
„had, ontstond niet zoo licht wrijving die tot moord en doodslag aan„leiding kon geven; daarom had men ook weinig behoefte aan hoof„den, die leiding gaven. Men had alleen met zijn eigen zaken te „maken, en die berechtte men zelf" ${ }^{94}$ ).

Over den Vogelkop vinden we: „Een gevolg van het verspreid „wonen der bevolking moet ook zijn, dat vroeger weinig gebruik werd „gemaakt van de rechtspraak van het hoofd (paoe basal, tonggol). „Doordat men niet veel aanraking met elkaar had, kwamen misdrijven „weinig voor. De kleinere misdrijven werden onder elkaar uitgemaakt".

Betreffende Loinang schrijft Kruyt echter met stelligheid ${ }^{95}$ ): „Alle geschillen werden door den tonggol beslist. Kon deze het niet „af, dan ging men er mee naar den daka'njo".

In een primitieve maatschappij als de Banggaische is het uiteraard niet te verwonderen dat afdoening buiten rechte, zoowel door minnelijke schikking als door zelfrechtverschaffing, een belangrijke plaats vervult. Doch uit Kruyts mededeelingen zou men wel haast den indruk krijgen, dat eertijds in den Archipel, in zekere mate ook op den Vogelkop, een soort anarchie heerschte. Bij mijn onderzoek vond ik hiervan echter geen bevestiging. De hoofden, in par. 3 van dit hoofdstuk reeds aangewezen als beschermers der orde, oefenden ter dege een daarmee hand in hand gaande rechtsmacht uit. Vooral in die gevallen waarin door misdragingen van leden der rechtsgemeenschappen gevaar ontstond voor het welzijn der maatschappij (voornamelijk wandaden op sexueel gebied) was van een passief afwachten der hoofden tot men hun tusschenkomst inriep geen sprake, maar traden, en treden zij nog, onmiddellijk actief op. Verder vond ik een typische competentieregeling tusschen lagere en hoogere rechters, waarbij zelfs beroep op die hoogere rechters bekend was.

Als voorbeelden van zelfrechtsverschaffing noemt Kruyt o.m. het dooden van heksen en gifmengers; het van kant maken van schuldenaars; soms de manslag ten gevolge van beleediging ${ }^{98}$ ).

Het dooden van personen, verdacht van het uitoefenen van zwarte kunst, was indertijd aan de orde van den dag. Een procedure was hiertoe niet noodig: de algemeene verdenking of het orakel had de

94) Kruyt, Balantaksche Studiën, blz. 348 .

95) Kruyt, To Loinang, blz. 360.

(0) Kruyt, Bewoners, blz. 249/250, 251; Zwarte Kunst, blz. 738 v. Verg. voor het optreden tegen schuldenaars ook: F. D. E. van Ossenbruggen, Verwantschapsverhoudingen, blz. 94 en noot 18. 
heks aangewezen als schuldige. Het dooden van zoo iemand leidde dan ook niet tot weerwraak. Ook moet het zijn voorgekomen dat een verdacht persoon door familieleden van zijn ",slachtoffers" beboet werd. Weigerde hij de boete te voldoen, of ontkende hij schuld, dan gebeurde het wel een enkele maal dat de tusschenkomst van het hoofd werd ingeroepen om onder zijn leiding een godsoordeel te doen houden.

De gang van zaken bij schulden wordt als volgt geschetst: als de schuldeischer wachtensmoe geworden was, ging hij ten slotte naar het huis van den schuldenaar om daar allerlei bezittingen van dezen weg te nemen; verzette de schuldenaar zich daarbij, dan werd hij wel gedood; ieder vond dit rechtvaardig. Ook als dit wegnemen van goederen bij familieleden plaats had (verg. ook hoofdstuk XI), hing het nog maar van het gedrag van den schuldenaar zelf af, wat er met hem gebeurde. Was hij dwars, had hij veel praatjes, dan was het einde meestal dat hij uit den weg werd geruimd.

Ten gevolge van beleediging kwam het soms ook tot het dooden van den beleediger, doch alleen als de andere in drift handelde, of als de wrok te diep zat. Meestal kwam het hoofd erbij en bracht een verzoening tot stand tusschen de beide partijen.

In al deze gevallen pleegde degene, die zichzelf recht wilde verschaffen soms persoonlijk de daad, al dan niet in gezelschap van anderen (zijn zoons b.v.), dan wel huurde hij een beroepsmoordenaar (aki: talenga) om den schuldig geachte uit den weg te ruimen. Het kwam daarbij uiteraard voor, dat de gezochte zich door de vlucht aan zijn lot trachtte te onttrekken. Men meldde mij uit Basosol, dat als hij het huis van den tonggol tamano kon bereiken, hij in veiligheid was. Verzocht de wederpartij uitlevering van den vluchteling, dan bond het hoofd wel een varken of geit aan de trap van zijn huis vast, en gelastte den achtervolger dit dier te dooden, daarbij zich voorstellende dat hij zijn slachtoffer voor zich had. Daarna noodigde de tonggol tamano hem uit in zijn huis te komen waar een maaltijd werd aangerecht waaraan ook de vluchteling deelnam; na dit tezamen eten was de zaak afgedaan. Wel legde soms de tonggol tamano den vluchteling voor zijn vergrijp nog een boete op, en moest hij bovendien de geit of het varken vergoeden; zoolang dit laatste nog niet gebeurd was ,leefde" hij niet meer en was slaaf van het hoofd ${ }^{97}$ ).

Ook geeft Kruyt mededeelingen hoe men zich recht verschafte bij

97) Memorie. 
diefstal. Had iemand een kleine hoeveelheid oebi gestolen, dan had de bestolene het recht den dader een pak slaag te geven; in dit verband mogen we veronderstellen dat voornamelijk kinderen zich aan zulk soort vergrijpen schuldig maakten. Was de hoeveelheid oebi groot en was de dader zelf in het bezit van een oebi-akker (ja?), dan had de bestolene het recht naar dezen aanplant te gaan en een stuk van tien vadem in het vierkant te wieden; dit stuk met hetgeen erop groeide mocht de bestolene daarna als zijn bezit beschouwen.

Ook andere kleine misdrijven werden (en worden) vaak onder elkaar uitgemaakt. Kwam men er na een gepleegden diefstal b.v. achter wie de dader was, en bekende hij het feit gepleegd te hebben, dan legde de bestolene zelf hem wel een boete op terwijl hij het gestolen goed terugvorderde. Daarbij geldt als algemeene regel, zoowel in den Archipel als op den Vaste-Wal, dat de dief tweemaal de waarde van het gestolene moet teruggeven wanneer de zaak onder elkaar wordt uitgemaakt ${ }^{98}$ ). In Loinang meldt men in dit geval (doch overeenkomstige mededeelingen bereikten mij ook van elders uit het landschap) dat het ontstolen goed in originali moet worden teruggegeven; mocht de dief hiertoe niet in staat blijken te zijn dan wordt de boete veel zwaarder; overigens geldt ook hier dat de dief de dubbele waarde van het gestolene dient te vergoeden (m.a.w. de boete is gelijk aan de waarde van het ontvreemde goed).

Minnelijke schikkingen werden vaak door de hoofden ondernomen, hetgeen thans niet veranderd is. Hierbij treden zij dan niet zoo zeer op als rechter, doch meer als leider der rechtsgemeenschap. Zoo meldt Kruyt uit Balantak dat het hoofd vaak aan een dergelijke, door den een aan den ander opgelegde, boete meebetaalde als de dader niet bij machte was de boete geheel zelf te voldoen; ook dat het hoofd ook wel den benadeelde overhaalde zich met een mindere boete tevreden te stellen. Zoo ook in den Archipel, waar hij een verzoening tusschen twee door wrok of beleediging verbitterden tot stand trachtte te brengen ${ }^{8 \theta}$ ).

Volgens Kruyt ${ }^{100}$ ) was in oude tijden het rechterlijk ingrijpen der hoofden beperkt tot die gevallen waarbij hun tusschenkomst verzocht werd door de benadeelde partij, als nl. de vermoedelijke dader niet

88) Kruyt, Bewoners, blz. 254; Balantaksche Studiën, blz. 348; To Loinang, blz. 362.

99) Kruyt, Balantaksche Studiën, blz. 349; Bewoners, blz. 251, 254.

100) Kruyt, Bewoners, blz. 254; Balantaksche Studiën, blz. 349; To Loinang, blz. 363 . 
wilde bekennen en zijn schuld door middel van godsoordeel moest worden vastgesteld; dit mocht alleen ten overstaan van het hoofd geschieden. „Ontkent de beschuldigde hardnekkig dat hij het vermiste „heeft weggenomen, dan brengt men de zaak voor het hoofd, want „dan eindigde het eertijds gewoonlijk met het houden van een gods„oordeel, en dit was alleen geldig, als velen daarvan getuige waren; „dit was alleen mogelijk onder leiding van den tonggol" (Archipel). „Werd iemand van diefstal beschuldigd en ontkende hij het gedaan „te hebben, dan werd het een rechtszaak. Deze eindigde meestal met "het houden van een godsoordeel en dit kon alleen door het hoofd ,worden gelast en geregeld” (Vogelkop). „Wanneer er niet voldoende „,bewijzen voor de schuld waren bijeen te brengen, zat er niet anders „op, dan de zaak door een godsoordeel te doen beslissen” (Loinang). Over deze vormen van rechtsmiddelen zal in par. 9 het een en ander worden medegedeeld.

Naast dit soort bemoeienis met rechtszaken vond ik door het geheele landschap dat de hoofden-rechters steeds onmiddellijk actief optraden en ingrepen bij gevallen waar er, binnen de magisch-religieuze wereldbeschouwing, gevaar dreigde voor de rechtsgemeenschap, waar de sociale orde gevaar liep verstoord te worden en rampen de geheele groep konden treffen. Dit zijn dan b.v. bloedschande en dergelijke delicten; doch ook lichtere wandaden op zedelijk gebied, b.v. verboden omgang tusschen ongehuwden of ongepaste vrijheden van jonge menschen onderling leidden altoos tot ingrijpen; de hoofden vermaanden de delinquenten, regelden in voorkomend geval dat een huwelijk gesloten werd, troffen een schikking, bezwoeren de verstoring van het evenwicht in de groep.

In het algemeen hadden alle in paragraaf 1 van dit hoofdstuk genoemde waardigheidsbekleeders de bevoegdheid om gerezen geschillen bij te leggen. Voor velen hunner was dit het eenige dat zij individueel aan de rechtspraak bijdroegen. Hierin is geen vaste regel te geven: sommige tano (zie blz. 53) hadden wèl het recht kleine boeten op te leggen, andere niet; soms had pas het groepshoofd dit recht, dat dan collegiaal met zijn helpers werd uitgeoefend; ook kwam het voor dat het groepshoofd slechts het recht tot schikking had en dat alle rechterlijke bemoeienis door het streekhoofd aan zich was voorbehouden. In Kintom moest een der hooge adellijke functionarissen (de kapitan tano) tegenwoordig zijn als een groepshoofd een schikking trof.

In een ander onderdeel van Kintom, nl. Mehangi, waarover men 
eertijds een hoofd met den titel sega kende, nauw verwant aan de bosanjofamilie, vond ik dat zelfs deze sega geen rechtsmacht bezat; hij mocht wel schikkingen treffen doch had niet het recht te beboeten. Als typische bijzonderheid voegde men er aan toe dat de sega vaak uit eigen middelen aan de beleedigde partij een zoenboete gaf om een geschil bij te leggen dan wel om weerwraak te voorkomen. Een parallel hiervan vond ik in Pokooehan waar de daka'njo eertijds wel meebetaalde aan een opgelegde boete als deze te zwaar dreigde te worden voor den delinquent.

Een hoogere rechter legde een zwaardere boete op dan een lagere, doch hiervoor is geen algemeene regel te geven, daar er tallooze plaatselijke varianten waren. In de gevallen dat een tano het recht tot beboeting had, mocht deze tot één kandari opleggen (kandari is een gedreven koperen schaal op voet); het groepshoofd als laagste rechter moch thier één, daar drie, soms meer kandari opleggen. Op den Vaste-Wal werd de boete vaak uitgedrukt in blokken goed; hiervan mochten sommige groepshoofden tot 50 blokken als boete vaststellen. Elders trof ik aan dat de boete in toba (West-Peling : koperen sirihdoozen) werd uitgedrukt, waarvan twaalf het maximum boetebedrag voor het groepshoofd, twintig dat voor het streekhoofd vormde. In de bevoegdheid dezer laatste rechters vond ik zeer groote verschillen. Sommigen mochten gaan tot één kandari, anderen tot 6 of 10 . De boete werd ook wel in oneven bedragen uitgedrukt, b.v. 7, 9 of 11 borden, 3, 5 of 7 doelang (koperen schaal op voet, minder in waardeering dan de kandari) of 5, 7 of 9 blokken goed. Elders noemde men mij echter veel hoogere maxima, b.v. 100 tot 120 blokken. Op den Vaste-Wal wordt de boete ook wel uitgedrukt in lear (verbastering van reaal), waarvan b.v. de kapitan tano 15, de bosanjo 30 kon opleggen. In Lingketing beboetten verder de pabisala, steeds in even bedragen, en de langka-langkai tot vier staafjes was (madi: kolong), terwijl de tonggol tot vijftien mocht gaan. De mederechters van den daka'njo, nl. de mian kopian en de toema noe daka'njo konden tot 30, de daka'njo zelf echter tot 450 kolong opleggen. Men rekent één blok gelijk aan vijftien kolong. Een andere waardemeter voor boetebetalingen hier in gebruik is de motombing, een lapje grof geweven stof ter grootte van een zakdoek; de traditioneele waarde is groot doch zij werden op vier à vijf kolong gewaardeerd. Ten slotte vond ik in Pokooehan wel een zeer bijzonderen waardemeter; boeten werden daar nl. wel uitgedrukt in brokken ruw opium, die een zeer hooge waarde vertegenwoordigden. 
Wie ook overigens de rechtspraak uitoefende, of het de groepshoofden of hun helpers, dan wel het streekhoofd was, steeds werd collegiaal recht gesproken, in dier voege dat voor het groepshoofd zijn helpers adviseurs-mederechters waren, en voor het streekhoofd eenige groepshoofden, de basalo tamano, de kapitan e.a.

Steeds wordt een scherpe scheiding gemaakt tusschen de lagere en de hoogere rechters. Het hing van den aard van het delict af voor wien berechting zou plaats vinden. Als algemeenen regel gaf men op dat de lagere rechters slechts die delicten afdeden waarbij geen bloed gevloeid had, of (op moreel terrein) waarbij ongehuwden betrokken waren. In het laatste geval droegen de hoofden-rechters tevens zorg dat een huwelijk tusschen de delinquenten tot stand kwam. Had echter bloed gevloeid, of was op zedelijk gebied een vergrijp geconstateerd tusschen gehuwden of met een gehuwde vrouw, dan wel had bloedschande in den ergsten graad plaats gehad (zie hoofdstuk VIII), dan moest het streekhoofd de aangelegenheden afdoen. Was den lageren rechter een delict ter oore gekomen of voorgebracht dat hij niet meende te kunnen afdoen om een dezer redenen, dan bracht hij de zaak zelf voor bij het streekhoofd; dit overwoog naar eigen inzicht of de zaak door hem kon worden afgedaan, dan wel dat zij door den vorst te Banggai diende te worden behandeld; in dit laatste geval bracht het streekhoofd zelf de schuldigen naar Banggai. Op vele plaatsen verzekerde men mij dat steeds het groepshoofd van den beschuldigde als mede-rechter optrad; dit hield dus in dat het groepshoofd ook lid kon zijn van een rechtbank gevormd door het streekhoofd met zijn medebestuurders, ja zelfs dat hij aan eventueele zittingen te Banggai deelnam. Verder deelde men mij mee (op één plaats) dat indien een beschuldigde feitelijk uit hoofde van den aard van het gepleegde delict voor het groepshoofd moest terecht staan, hij, zoo hij dit eischte, onmiddellijke berechting door het streekhoofd kon verkrijgen. Wie de rechter was indien het een geding betrof tusschen personen uit meer dan één familiegroep is niet met zekerheid aan te geven, doch gelet op de omstandigheid dat steeds het groepshoofd aanwezig moest zijn, is het waarschijnlijk dat het streekhoofd een dergelijke aangelegenheid afdeed, waarbij de onderscheiden groepshoofden als bijzitters optraden. Hoe een dergelijk geval werd afgedaan indien het personen betrof uit verschillende streekgemeenschappen is niet bekend; wellicht zal de vorstenrechtbank te Banggai een dergelijke aangelegenheid hebben berecht.

Een regeling van hooger beroep is bekend. Hier en daar meldde 
men mij, dat het streekhoofd soms de door het groepshoofd opgelegde boeten terugbracht (vermoedelijk alleen in de gevallen dat de beboete zich daarover beklaagde); uit Boeoeko meldde men mij zelfs dat het streekhoofd een soort vernietigingsrecht over de vonnissen der lagere rechters had. In Tinangkoeng oefende echter de tonggol oeloeno (die daar ook bij de inhuldiging een bijzondere plaats innam; zie blz. 104 dit recht van beroep zelfs uit over de beslissingen van het streekhoofd. Verder gaf men algemeen de mogelijkheid van beroep op den vorst aan, dat door tusschenkomst van den toezichthouder (baoeloeno; zie blz. 123) diende te geschieden.

Uit Loinang meldt Tangkilisan een zeker forum privilegiatum; zoons van het streekhoofd, hoe klein ook hunne zaken waren, werden tenminste berecht door het groepshoofd, die als mederechters pabisala en langka-langkai nam; over misdrijven door het streekhoofd en de zijnen gepleegd zwijgt men.

Behalve het berechten van vergrijpen tegen de orde en het nemen van rechterlijke beslissingen op verzoek (blz.149 v.), hadden de hoofden ook rechtsmacht op het gebied van schuldvorderingen e.d. (uiteraard zullen we in het adatrecht geen onderscheid vinden tusschen civiele en crimineele vorderingen). Zoo meldt Kruyt, waar hij de positie van den pandeling beschrijft, dat het voorkwam dat hij genoeg arbeid meende verricht te hebben ten bate van zijn schuldeischer; om hierin een beslissing te verkrijgen riep hij dan de tusschenkomst van het groepshoofd in; het geval werd nu besproken en men berekende of de tijd gedurende welken de man pandeling was geweest lang genoeg was om de schuld af te doen, dan wel welk deel van de schuld op deze wijze was afgelost ${ }^{101}$ ).

Voor hun rechterlijke bemoeiingen genoten de hoofden speciale inkomsten; daar er meestal beboet werd deelde men mij alleen de regels mee bij toepassing van deze straf. Op welke wijze de rechters eventueel gedefrayeerd werden bij toepassing van andere straf (rotanslagen, vrijheidsstraf, doodstraf) werd niet gezegd, doch laat zich denken: verhaal op familieleden en op goederen van den delinquent. Doch van de boeten kwamen vaste deelen aan de rechters; in sommige basaloschappen bedroegen deze gerechtskosten $1 / 3$, soms $2 / 5$, ja tot de helft der boete. Dit rechtersdeel werd verdeeld tusschen degenen die aan de rechtszitting hadden deelgenomen; een enkele maal vond ik dat het streekhoofd ook een deel kreeg, ook al had hij geen zitting

101) Kruyt, Bewoners, blz. 250. 
genomen in het rechterlijk college. Normaal kreeg het groepshoofd van het rechtersdeel $1 / 3$, terwijl de resteerende ${ }^{2} / 3$ aan de gezamenlijke tano kwamen. Hierop bestonden uiteraard weer vele variaties, doch in wezen was het overal hetzelfde. Soms is het voorgekomen bij geschillen over het bezit van eenig goed, als geen der partijen haar recht kon bewijzen, dat het voorwerp in geschil aan de rechters verviel. Het rechtersdeel heet idoelaan (aki), oedjoelaa of oedjoeraa (madi), oedoeraa (sian) ${ }^{102}$ ). Ook noemt Kruyt den term soekano (aki), doch in het verband waarin wij dit woord aantreffen schijnt het de speciale belooning te zịn van een hoofd als hij een godsoordeel liet houden ter aanwijzing van een schuldige. Had het godsoordeel een persoon als schuldig aan diefstal aangewezen, dan verviel deze dus in de volgende betalingen: restitutie van het gestolene (c.q. van de waarde daarvan); boete, gelijk aan de waarde van het ontvreemde; soekano voor den rechter, eveneens van dezelfde waarde als het gestolene. (De term soekano is mij persoonlijk niet genoemd).

De waardeering van deze rechtspraak was in Westersche oogen miniem; Goedhart ${ }^{103}$ ) schrijft erover : „.... kleine geschillen tusschen „,hun onderhoorigen af te doen, waarvoor natuurlijk weder eenige ,vergoeding moet worden gegeven - groote zaken worden in naam ",onderzocht en slepende gehouden of zooals wij boven zagen met de „oplegging van een geldboete afgedaan.... enz.". Goedhart haalt dan eenige voorbeelden aan waaruit blijkt dat het boetestelsel in de laatste jaren voor 1908 hoe langer hoe meer in zwang was gekomen, ook voor zware misdrijven als moord en doodslag; kon men niet spoedig de noodige bewijzen volgens onze wet verzamelen, dan werden de familieleden van het slachtoffer tevreden gesteld met veroordeeling van den vermoedelijken dader, of, zoo deze voortvluchtig was, van diens familieleden, tot een aanzienlijke boete. Volgens Goedhart zou dit geleid hebben tot toename der onveiligheid van lijf en goederen. Overigens beantwoordde dit boetestelsel wel aan het rechtsgevoel der bevolking. Het Koloniaal Verslag 1913/1914 vermeldt dat een WestPelinger bij gepleegd verzet in de gevangenis te Banggai werd neergelegd; eenige kampongs in West-Peling werden $\mathrm{nu}$ in beroering gebracht door familieleden van dezen man; zij eischten van de menschen, die tegen dezen West-Pelinger een aanklacht hadden ingediend, tengevolge waarvan hij zich in de gevangenis bevond, een groote

\footnotetext{
102) Kruyt, To Loinang, blz. 363 ; Balantaksche Studiën, blz. 341 ; Bewoners, blz. 254.

103) Goedhart, Drie landschappen, blz. 460, 451.
} 
boete; de bloedverwanten stelden dus de aanklagers verantwoordelijk voor den dood van hun familielid. Zien wij echter boetebetaling als boetedoening door afstand van magisch vermogen aan een ander, door het afstaan van mana dus, dan wordt dit boetestelsel begrijpelijk ${ }^{104}$ ).

Latere regelingen (na 1908) hebben uiteraard diep in de hoofdenrechtspraak ingegrepen, doch zeer waarschijnlijk leeft een goed deel van de scheidsrechtspraak van weleer ook thans nog voort. Het aantal zaken toch dat voor de inheemsche rechtbank en het landschapsgerecht wordt behandeld, is zoo miniem klein in verhouding tot het bevolkingscijfer dat wij tot geen andere veronderstelling kunnen komen. Buitendien viel het mij op dat schuldvorderingen zich vrijwel uitsluitend beperken tot die zaken waarbij een vreemdeling (Chinees of Arabier) eischer is, terwijl dergelijke zaken tusschen landschapsonderhoorigen tot de uitzonderingen behooren. Bovendien trof ik herhaaldelijk gevallen aan, dat hoofden van zins waren crimineele zaken door middel van beboeting op de aloude wijze af te doen. Waar het gevallen betrof van kleine vergrijpen tegen de adat, voor zoover deze niet volgens vigeerende bepalingen door een rechtbank moesten worden afgedaan, was hiertegen geen bezwaar ; afdoening van diefstal en dergelijke delicten kon op deze wijze echter uiteraard niet gedoogd worden.

\section{De procedure (bewirjs; godsoordeel; executie).}

Het feitelijk gegeven dat een bepaald persoon een euveldaad had gepleegd was de eenvoudigste bewijsvorm (de gestolen geit wordt gevonden vastgebonden aan verdachte's woning; of deze draagt de vermiste sarong, dan wel gebruikt het verdwenen mes). Daarnaast is bloote bekentenis eveneens reeds voldoende bewijs, terwijl wat wij een aanwijzing zouden noemen, soms reeds strafbaar feit oplevert; werden in een huis eenige goederen vermist, dan was hij, die kort tevoren het huis betrad, de dief (Loinang) ${ }^{105}$ ). Wellicht ook om iemand tot bekentenis te dwingen werd door de hoofden vaak een preventieve hechtenis toegepast, waarbij de verdachte met beide voeten tusschen twee balken, van inkepingen voorzien, werd geklemd, en naar men mij zei wel eens eenige dagen aan zijn lot overgelaten. In Loinang heet dit panga'an ${ }^{108}$ ); deze hechtenis mocht hoogstens

104) Verg. Mr. F. D. E. van Ossenbruggen, „Primitieve Denken”, par. 163.

105) Nota Tangkilisan.

106) Kruyt, To Loinang, blz. 360. 
veertien dagen duren, daarna moest de zaak berecht worden. Onder de huizen van sommige hoofden trof ik hiervoor benoodigde balken nog wel aan; slechts basalo enz. mochten dit middel toepassen.

Hier en daar trof ik aan dat een der lagere hoofden als aanklager optrad; als zoodanig noemde men mij den potoembak; bij de groep Boegineezen van Boenta vervulde de imam deze functie. Was eenmaal een vonnis geveld, dan waren er eenige wijzen om het openbaar te maken; in Lingketing zorgde de milinoe (madi : omroeper, boodschapper; zie blz. 96) voor bekendmaking van de beslissing; hij klom daartoe wel in een boom en riep met luider stemme het vonnis af; elders zal het wel op overeenkomstige wijze zijn gegaan. Een bijzondere functie had de pabisala van Loinang nog te vervullen; als hij lid was van de daka'njo-rechtbank had hij de taak de partijen in geding toe te spreken en haar het vonnis mede te deelen en uit te leggen; of hij zich ook roerde tijdens de behandeling, m.a.w. of wij in hem iets mogen zien van een bijstander van partijen is niet bekend.

Terugkomende op het bewijs in eenvoudigsten vorm dient geconstateerd te worden dat bekentenis van den dader reeds voldoende was. Hiermee was tevens vaak de zaak geëindigd, daar we in de vorige paragraaf zagen dat een dergelijk geval dan buiten rechterlijke bemoeienis om kon worden geregeld, nl. doordat de benadeelde den schuldige beboette. In het andere geval, als er dus volstrekt geen bewijs was, is het, zooals ik hooger reeds mededeelde, voorgekomen dat de hoofden-rechters eenvoudig de zaak in geschil aan zich trokken, waarmee het geding geëindigd was (o.a. Tangkiang). Een vorm van bewijs in gedingen betreffende bezitsrecht meldden we reeds op blz. 110.

In de gevallen dat de benadeelde niet wist wie hem leed had toegevoegd nam men wel zijn toevlucht tot wichelen (aki: bapoelos; sian: momoelos; madi: metahi, mantahi) ${ }^{107}$ ). Hoe dit in den Archipel geschiedde is niet bekend; men is daar steeds zeer geheimzinnig met bovennatuurlijke dingen. Wel beschrijft Kruyt eenige wichelmethoden uit Balantak en Loinang. In beide streken, wellicht ook in den Archipel, kent men het wichelen met den rijstwan (madi : mongkokoese; sian : momoelos na ikiran; aki : mari); het is een spiritistisch gekleurd middel. Merkwaardig is, dat ik in mijn bestuurspractijk eenmaal, na een gepleegden diefstal waarin geen klaarheid was te brengen, het verzoek ontving van den benadeelde dit middel te mogen

107) Kruyt, Bewoners, blz. 254; Balantaksche Studiën, blz. 350; To Loinang. blz. 363,365 . 
toepassen. Dit mongkokoese is wezenlijk anders dan het wichelen dat geschiedt bij huizenbouw e.d.

Heeft het orakel op deze wijze een persoon aangewezen dan wordt hij beschuldigd (madi: mompotoka; hoe in het aki en het sian?). Doch deze aanwijzing door het orakel en de daarop volgende beschuldiging was nog geen bewijs; het had geen andere waarde dan een acte van beschuldiging. Aannemende dat de verdachte ontkende (bekende hij wel, dan kunnen we veelvuldig afdoening buiten rechte verwachten), dan trachtte hij vaak de wederpartij van zijn onschuld te overtuigen door heftig alle schuld te ontkennen; dit ging gepaard met eeden en zelfvervloekingen (aki: batotoan) ${ }^{108}$ ); gewoonlijk hechtte men echter weinig waarde aan dergelijke betuigingen van onschuld, als het orakel reeds verdenking had doen ontstaan. Men berustte er alleen in, als er geenerlei bewijzen voor de schuld waren.

Het uiteindelijk bewijs moest meestal door een godsoordeel verkregen worden, waartoe zooals reeds medegedeeld werd (blz. 150) de tusschenkomst van het hoofd vereischt was. Zijn aanwezigheid garandeerde de noodige openbaarheid.

Godsoordeel in het algemeen heet in het aki bagoensal of ginoen$\left.s{ }^{109}\right)$. Er worden daarbij eenige vormen toegepast, zooals :

godsoordeel door duiken (madi : makakiop; sian: mengkakiop; aki : bagoensal otoelak), in den Archipel echter weinig gebruikt. Niet de beschuldiger en de beschuldigde zelf, doch anderen voor hen onderwierpen zich aan de proef; in den Archipel werden ze door den tonggol aangewezen, in Balantak door partijen gehuurd omdat ze een langen adem hadden, terwijl ook in Loinang de tegenstanders zelf hun duiker meebrachten. Op een teeken van het hoofd doken de duikers der beide partijen onder water; wiens duiker het eerst boven water kwam had verloren en werd schuldig bevonden;

godsoordeel met warm water (madi: momamas, bij Tangkilisan mongkeok; aki: bagoensal paisoe nanas), waarbij een voorwerp, een steen of een duit, door elk der partijen uit een pot met kokend water moest worden gehaald; wiens hand brandwonden kreeg werd schuldig bevonden. Kregen beiden blaren dan hadden ook beiden ongelijk. Dit middel werd ook toegepast als een man er van beschuldigd werd een meisje buiten echt zwanger te hebben gemaakt; in dit geval onderging

108) Kruyt, Bewoners, blz. 255.

109) Kruyt, Bewoners, blz. 255/256; To Loinang, blz. 364/365; Balantaksche Studiën, blz. 349 v. 
hij alleen de proef, niet ook de beschuldiger. In Balantak is deze vorm van godsoordeel niet bekend;

godsoordeel met gloeiend ijzer (aki: bagoensal besi monas, of bagoensal besi sinoea; sian: mensingkom besi; madi : momamas, bij Tangkilisan montoloek lambeng); hierbij moest de beschuldigde een gloeiend gemaakt stuk metaal, een hakmes b.v., in de hand klemmen; vertoonde de palm geen brandwonden dan was hij onschuldig.

Kruyt ${ }^{110}$ ) vermeldt een wichelwijze uit Tinangkoeng die speciaal gebruikt werd om uit te maken of iemand beoefenaar van de zwarte kunst was; daarbij werd een hakmes in den grond ingegraven, zoodanig dat iets van het scherp boven de aarde uitstak; de verdachte persoon moest nu zijn voet erop plaatsen. Bleek de voetzool verwond te zijn, dan was hij schuldig. Interessant is hierbij dat Kruyt tevens vermeldt dat van te voren uitgemaakt was hoeveel de aanklagers te betalen hadden als de aanklacht valsch bleek te zijn. Of steeds een dergelijke afspraak van te voren werd gemaakt bij de andere mogelijke vormen van godsoordeel en ter gelegenheid van andere delicten is niet duidelijk.

Had het godsoordeel op deze wijze bewijs opgeleverd, dan kon het vonnis ook weldra geveld worden; na verkregen bewijs werd de verdachte schuldig verklaard, binesala (aki); dit kan ook vertaald worden met: strafbaar ${ }^{111}$ ). Niet is bekend of de schuldig bevondene nog in de gelegenheid werd gesteld voor zijn zaak te pleiten, of dat eventueel familieleden dit konden doen; ook weten we niet of de rechters in besloten kring beraadslaagden, dan wel of ten gevolge van over en weer spreken een soort communis opinio tot stand kwam. Voor openbaarheid werd gezorgd (verg. blz. 156). Van registratie der vonnissen op andere wijze dan in het volksgeheugen vond ik slechts in Boenta een aanduiding; daar zouden de rechterlijke beslissingen alle zijn opgeteekend; helaas zijn deze documenten verloren gegaan.

Betreffende de wijze van tenuitvoerlegging der vonnissen beschikken we over slechts weinig gegevens. Men gaf mij in eenige plaatsen van den Vaste-Wal op, dat daar eertijds, als een schuldig bevonden persoon veroordeeld was een dracht rotanslagen in ontvangst te nemen, een modjim of een chatib wel als executeur optrad. Om dezen goed vurig te maken moest de veroordeelde zelf eerst den executeur een rotanslag toedienen. Slechts in Loinang troffen we eertijds een persoon aan die als beul op diende te treden zoo de

110) Adriani-Kruyt, Bare'e III, blz. 282.

111) Kruyt, Zwarte Kunst, blz. 739. 
daka'njo hem daartoe last gaf; het was de talenga (zie blz.95); ${ }^{112}$ ) had een moord plaats gehad en was de dader voortvluchtig, de talenga werd er op af gestuurd. Deze kon zich doen vergezellen van zijn helpers, doch hij diende voorop te gaan. Had een groepshoofd zijn hulp noodig, dan diende deze dit eerst aan het streekhoofd te vragen; deze laatste alleen had het recht de gewapende macht te zenden waarheen het noodig was. Daarnaast is doodstraf wel eigenhandig door sommige streekhoofden uitgevoerd, o.a. nog in het einde der vorige eeuw in Tangkiang. Het slachtoffer werd door eenige personen vastgehouden, het streekhoofd sneed hem vervolgens zelf de keel open, op de wijze van ritueele slachting. Bij dergelijke gevallen zijn veel elementen van eigenrichting aanwezig; zoo deelde men mij mede dat een Badjo de vrouw van een streekhoofd had geschaakt, hetgeen hij met den dood moest bekoopen; het hoofd doodde den verleider zelf, en slechts met de grootste moeite konden familieleden van de vrouw verhinderen dat hij haar ook doodde. Kruyt ${ }^{113}$ ) noemt nog de mogelijkheid dat een persoon, op wien velen uit een streek verbitterd waren door zijn onhebbelijk en onbillijk optreden, op last van het hoofd door eenige dapperen gedood werd; dit geschiedde dan met het zwaard. Tegenover gifmengers en heksenmeesters trad men ook wel anders op ${ }^{114}$ ). Dezen werden in eerste instantie beboet; weigerden zij echter de boete te voldoen, dan werden de verdachten gedood. Gewoonlijk ging men hiertoe pas over als men overtuigd was, dat velen aan de schuld van zulk een persoon geloofden, zoodat zelden weerwraak volgde. Meestal waren het de familieleden van een der laatste slachtoffers van den toovenaar of gifmenger, die de executie ondernamen. Een andere executievorm wordt ook gemeld: wanneer eenmaal het plan was gevormd een gifmenger te gaan dooden haalde het streek- of groepshoofd de op wraak belusten wel eens over de goederen van den beschuldigde te gaan rooven doch zijn persoon ongemoeid te laten. Doch ging men hem dooden, dan was het streng verboden iets uit zijn huis weg te nemen. Vermoedelijk traden bij al deze gevallen familieleden en bloedverwanten der benadeelden als executeur op.

In oude tijden schijnt op Banggai doodstraf door wurging te zijn toegepast, althans werd deze straf door radja Manderia aan een zijner neven opgelegd wegens het verleiden zijner echtgenoote; wie als beul

112) Nota Tangkilisan.

113) Kruyt, Bewoners, blz. 252/253.

114) Kruyt, Zwarte Kunst, blz. 738 v. 
optrad is niet vermeld ${ }^{115}$ ). Ook is doodstraf door wurging bij de Boegineezen in Boenta ten uitvoer gelegd.

Vrijheidsstraffen werden meestal door het hoofd ten uitvoer gelegd in het op blz. 155 genoemde blok; ook te Banggai kende men dit strafmiddel. Overigens mochten slechts streekhoofden, ook die van Pokooehan en Lingketing, een dergelijke vrijheidsstraf ten uitvoer leggen.

Doch in de meeste gevallen bestond de straf uit boete (vergelijk ook het blz. 153 medegedeelde ten aanzien van de uitbreiding van dit strafmiddel); werd de boete niet voldaan, dan werd de veroordeelde pandeling (Loinang). Vaak betaalde de familie mee (Balantak); was deze daartoe niet in staat of niet daartoe bereid, dan betaalde zelfs het hoofd wel mee $\left.{ }^{116}\right)$. In Pokooehan heeft de daka'njo uit eigen middelen wel een aanzienlijk deel der boete op deze wijze betaald, dat hij dan wel weer terugkreeg door middel van het den rechters toekomende deel. Ook liet men de schuld wel rusten om deze later van kinderen en kleinkinderen in te vorderen. Om boeten en schulden werd men op den Vogelkop, ook in het gebied van de Baloa-groep, nimmer pandeling. De boete bij verwonding werd berekend naar den aard der toegebrachte verwonding; als bijkomende straf diende de dader in het levensonderhoud van den verwonde te voorzien gedurende zijn genezing; bij onopzettelijke doodsveroorzaking moest in sommige streken de dader de begrafeniskosten van zijn slachtoffer dragen, in andere de helft ${ }^{117}$ ).

Ten slotte haalt Kruyt een geval uit Loinang aan van een vechtpartij tusschen twee gezinnen, waarbij aan den eenen kant één doode, aan den anderen kant twee dooden vielen; de tonggol besliste dat aan beide kanten evenveel slachtoffers moesten vallen, en daarom werd de vrouw, die de oorzaak was, verkocht naar Walea, als slavin dus ${ }^{118}$ ).

\section{Vorstenrechtspraak; rijskraad Ternate (voor 1 April 1908).}

Ten gevolge van contracten, gesloten tusschen het Gouvernement van Nederlandsch-Indië en het sultanaat Ternate kwamen er eenige of ficieele regelingen tot stand, waaraan de rechtsbedeeling gebonden werd.

115) Kruyt, Vorsten, blz. 525.

116) Kruyt, To Loinang, blz. 361.

117) Kruyt, Bewoners, blz. 256; To Loinang, blz. 362; Balantaksche Studiën, blz. 352 .

118) Kruyt, To Loinang, blz. 361. 
Ter vervanging van oudere overeenkomsten (27 Mei 1824, 19 Februari 1828) werd in 1861 een nieuw contract gesloten, goedgekeurd en bekrachtigd op 24 November $1862^{119}$ ). In art. 18 daarvan werd bepaald dat de rechtspleging in zake misdrijf of overtreding, door sultansonderhoorigen begaan, „blijft opgedragen aan Rijksraad „of andere gerigten en regters volgens de instelling des lands daartoe „bevoegd"; hiervan werden echter o.a. een reeks misdrijven uitgezonderd, meerendeels gericht tegen het Gouvernement. Ten aanzien van het toe te passen recht werd bepaald, dat „de Mohammedaansche of ,andere landswetten of instellingen zooveel mogelijk toegepast „(zouden worden), al naar dat de beschuldigde Mohammedanen of „Heidenen zijn”. Art. 19 regelt de rechtspraak in civiele zaken binnen het rijk Ternate; deze wordt voor sultansonderhoorigen onderling op den bestaanden voet gehandhaafd.

Voor zaken waarin sultansonderhoorigen in civiel geding met Gouvernementsonderhoorigen betrokken waren, kwam bij Stbl. 1865 no. 117, onder nadere goedkeuring des Konings (zie considerans) een voorloopige regeling tot stand; de hierbij ingestelde rechtbank droeg den naam landraad, rechtsgebied was de geheele Residentie Ternate.

Ten gevolge van een wijziging in de artikelen 18 en 19 der contracten met de sultans van Ternate, Tidore en Batjan werd de regeling van 1865 vervangen door die opgenomen in Stbl. 1874 no. 144. Naam en samenstelling van het daarbij bedoelde rechterlijk college bleven dezelfde, echter onderging de competentie uitbreiding met die in een reeks crimineele zaken, opgenomen in art.7. Deze waren voornamelijk: moord, doodslag, menschenroof, brandstichting, muntmisdrijven, landverraad, oproer, zee- en menschenroof, verboden slavenhandel, diefstal in vereenigde of gewapende benden of met geweld gepleegd, verder al die misdrijven welke met den dood, of met de straf naast die des doods konden worden gestraft. Bovendien moesten alle misdrijven, geene uitgezonderd, gepleegd tegen dienaren van het Gouvernement, voor dezen landraad behandeld worden. Toegepast recht was het Gouvernementsrecht. Alle arresten, vonnissen en rechterlijke beslissingen droegen in strafzaken het hoofd „In naam des Konings”.

In 1882 werd echter te Ternate een landraad ingesteld als dagelijksche rechter over de Gouvernementsonderhoorigen; de naam van hooger genoemde rechtbank werd nu veranderd in Rijksraad (Stbl. 1882 no. 33).

119) Handelingen Tweede Kamer 1864/65, Bijlage XXI, stuk no. 19. Verh. dl. VI. 
Er kwamen nog eenige aanvullingen tot stand in de volgende jaren, doch deze zijn van minder belang. De reeks capitale misdrijven, zooals voor 1874 genoemd, bleef gehandhaafd. Wie als onderdaan van een der sultans voor den Rijksraad terecht zou staan, werd ten slotte als volgt omschreven (art.10): „Binnen sultansgebied geves„tigde personen worden aangemerkt als Gouvernementsonderdanen „wanneer zij het zijn krachtens de met de sultans gesloten contracten".

Om verwarring met zoo aanstonds te bespreken rechtscolleges te voorkomen wil ik er hier even op attendeeren dat tot 1861 (wellicht tot 1882) met rijksraden angeduid werden de in de sultanaten aanwezige inheemsche rechtbanken; na 1882, toen deze naam voor de te Ternate gevormde rechtbank werd gebruikt, noemde men deze inheemsche gerechten hakim sultan.

Ook te Banggai was een dergelijke inheemsche rechtbank gevestigd ${ }^{120}$ ); deze zetelde in de op blz. 118 genoemde raadzaal, djagaan. Hier werden alle rechtszaken angebracht die zich te Banggai voordeden, terwijl ook de aangelegenheden die de streekhoofden van elders (Peling en Vaste-Wal) niet konden afdoen hier door tusschenkomst van den betrokken toezichthouder werden voorgebracht. Het bezwaar werd in ontvangst genomen door den dienstdoenden basalo der basalo-4, tezamen met imam, chatib en modjim. Deze hielden een vooronderzoek, en nadat zij een bepaald inzicht hadden verworven, lichtten zij den vorst door tusschenkomst van den dienstdoenden loetenaan in. De vorst besliste nu wie de zaak zou afdoen; dat konden de dienstdoende ambtenaren van den djagaan zijn, doch het kwam ook voor dat hij het beter achtte dat de djogoegoe de angelegenheid zou berechten. Indien deze als rechter optrad koos hij zelf zijn bijzitters; het kwam voor dat hij de zaak afdeed met de anwezige ambtenaren van de djagaan, doch als hij het noodig achtte kon hij de basalo-4 en de bobato voltallig verzamelen, in welk geval zoo mogelijk ook de kapitan laoet aan de zitting deelnam.

Waar het echter groote zaken betrof ( b.v. als een persoon om het leven was gekomen) kreeg noch de djogoegoe, noch de dienstdoende ambtenaar opdracht tot berechting, doch liet de vorst eerst den Ternataanschen oetoesan (zie blz.131) inlichten; deze bepaalde dan den dag der rechtszitting, waaraan de vorst, de komies-ampat, de basalo-4, vele der adellijke officieren, de kalim en andere geestelijken deelnamen.

120) Goedhart, Drie landschappen, blz. 450/451. 
Sedert te Banggai een posthouder was geplaatst $(1880 ;$ blz. 140) werden dergelijke groote zaken echter bij hem voorgebracht, terwijl de Ternataansche ambtenaren sinds dien als lid optraden. Het zoo gevormde rechterlijk college droeg den naam hakim sultan (vermoedelijk dus sedert 1882). Justitiabel waren de inheemsche bewoners van Banggai, verdacht van misdrijf of overtreding, voor zoover deze niet waren afgedaan door het streekhoofd, en met het beding verder dat de capitale misdrijven, voorbehouden aan den Rijksraad te Ternate, voor dit laagste college zouden worden behandeld. Voorts werden door den hakim sultan alle civiele zaken behandeld waarin een tot de inheemsche bevolking van Banggai behoorend persoon gedaagde was, met dien verstande dat de eischer geen Gouvernementsonderdaan zou zijn, want dan was eveneens de Rijksraad bevoegd.

Goedhart vermeldt niet de mogelijkheid van appèl van vonnissen der lagere rechters op de hakim sultan, doch dit vinden we wel bij Bosscher en Mathijsen ${ }^{121}$ ), terwijl ik bij mijn onderzoek hierover eveneens gegevens kon verzamelen (zie bzl. 153). Genoemde auteurs spreken van een rijksraad (d.i. de latere hakim sultan), waarbij het hoogste rechterlijk gezag berustte, hoewel zijn rechtsmacht beperkt was : in strafzaken nl. tot kennisname van lichte misdrijven, in civiele zaken van vorderingen de $f 100,-$ niet te boven gaande. De appèlbevoegdheid wordt omschreven als volgt: kennisname van uitspraken der negorijraden ter zake van onwilligheid in het verrichten van negorijdiensten en vergrijpen tegen de bevelen der negorijhoofden. (Voor negorijen dienen we in dit verband streekgemeenschappen te lezen). In dien tijd werden misdrijven en civiele vorderingen, boven de bevoegdheid der toenmalige rijksraden, door den rijksraad te Ternate behandeld; dit moet een soortgelijk college zijn geweest, doch een werkelijke sultansrechtbank, een ware hakim sultan dus; aan de werkzaamheden van dit college kwam vermoedelijk een einde door de regeling van 1874. (De vonnissen van deze sultansrechtbank, zoowel in civiele als in crimineele zaken, alsook in godsdienstige aangelegenheden, werden door tusschenkomst van den Ternataanschen rijksbestuurder aan den sultan medegedeeld, die de bevoegdheid had om in hoogste ressort de vonnissen te wijzigen, ja zelfs geheel te casseeren. Bestond beroep op deze sultansrechtbank voor justitiabelen, in eersten aanleg terecht staande voor de inheemsche rijksraden?) ${ }^{\mathbf{1 2 2}}$ )

121) Bosscher en Mathijsen, Schetsen, blz. 93.

122) Arb. I, blz. 233. 
Zijn Bosscher en Mathijsens mededeelingen juist, dan mochten de streekhoofden slechts eenige kleine vergrijpen berechten, terwijl de rijksraad (later: hakim sultan) slechts lichte misdrijven en civiele zaken tot $\mathrm{f} 100$,- in behandeling mocht nemen. Bij mijn onderzoek is mij echter steeds gebleken dat de hoofden veel zwaarder delicten berechtten dan hun volgens deze gegevens toegestaan was; het zou mij dan ook niet verwonderen als de hakim sultan eveneens buiten zijn boekje zou gegaan zijn, en delicten afdeed die feitelijk niet binnen zijn rechtsmacht lagen. Wij vinden hiervan een bevestiging in Goedharts mededeelingen, waar hij de verwordingen van de rechtspraak bespreekt door het overmatig opleggen van boeten, waarbij zelfs moordenaars ten slotte beboet werden. Het is toch best mogelijk geweest dat het hier een der capitale misdrijven betrof, die rechtens voor den Rijksraad te Ternate hadden dienen te worden behandeld, doch dat men zijn toevlucht nam tot berechting voor de hakim sultan om de lastige bewijsconstructie, noodig voor den Gouvernementsrechter, te ontgaan. Zoo heb ik als algemeenen indruk gekregen dat alle rechters meer berechtten dan waartoe zij eigenlijk gemachtigd waren.

Aan deze rechtspraak kwam voor Banggai het einde toen op 1 April 1908 de onderhoorigheid aan Ternate ophield en de Rijksraad dus hier zijn rechtsmacht verloor.

\section{Zelfbestuursrechtspraak (na 1908).}

In het Gouvernement Celebes en Onderhoorigen was bij besluit van den Gouverneur van 8 Januari 1906 no. 123/7 een voorloopige regeling van de inheemsche rechtspraak vastgesteld; hierop kwamen eenige aanvullingen (23 Januari 1906 no. 422/7; 20 November 1906 no. $5392 / 7 ; 31$ October 1907 no. 5735/7) ${ }^{123}$ ).

Een tweede regeling, een concept-ordonnantie van 30 November 1907 , welke in werking zou treden met ingang van 1 Februari 1908, en de daarop voorgestelde wijzigingen van 17 November 1909 is nimmer van kracht geworden; oorspronkelijk was gedacht aan vaststelling dezer materie bij algemeene verordening ${ }^{\mathbf{1 2 4}}$ ).

De derde regeling, die in der practijk ook in Banggai is toegepast, is die opgenomen in het besluit van denzelfden Gouverneur van 25 Juli 1910 no. 5499/7, aangevuld bij dat van 30 September 1910

123) Arb. V, blz. 375-388.

124) Arb. V, blz. 388-421. 
no. 6677/7; een en ander trad op 1 October 1910 in werking ${ }^{125}$ ).

De hierbij toegepaste vorm (regelgevend zelfbestuursbesluit met aansluitende goedkeuring en uitvoeringsvoorschriften door het Hoofd van Gewestelijk Bestuur) is gekozen als gevolg van de beginselen, neergelegd in bijblad 6801.

Een vierde regeling der zelfbestuursrechtspraak kwam tot stand als onmiddellijk gevolg van het van kracht worden der Zelfbestuursregelen 1919; meer speciaal art. 17 daarvan maakte herziening der besluiten noodig ${ }^{126}$ ). Nadat deze regeling ongeveer een jaar van kracht was, kwam de afscheiding van het Gouvernement van Celebes en Onderhoorigheden tot stand, en werd Banggai bij de Residentie Manado gevoegd (Stbl. 1924 no. 365 jo. 366). De in deze Residentie vigeerende bepalingen vertoonen vele punten van overeenstemming met die van Celebes. Genoemde regeling kwam weer in denzelfden vorm tot stand, nl. legislatief Zelfbestuursbesluit met uitvoerend Gouverneursbesluit; voor het Gouvernement was dit het besluit van 20 October 1923 no. 1672/II, op welken datum deze regeling ook in werking trad.

De in de Residentie Manado vigeerende regelingen op de Zelfbestuursrechtspraak zijn niet in een der adarechtbundels opgenomen, doch ook hier treffen we weer een Zelfbestuursbesluit aan (15 Juli 1925, zonder nummer) en een uitvoerend Residentiebesluit (14 November 1925 no. 493).

I. Het Zelfbestuursbesluit wijdt art. 1 aan de scheidsrechtspraak der dorpshoofden; in de volgende artikelen wordt gesproken van landschapsgerecht(en) en inheemsche rechtbank. De landschapsgerechten worden voorgezeten door Zelfbestuurder of daartoe aangewezen districtshoofd; zij zijn alleensprekend rechter doch dienen overleg te plegen met de dorpshoofden der rechtzoekenden of terechtstaanden. In den volksmond heet dit gerecht madjelis ketjil, tegenover de inheemsche rechtbank, madjelis besar. De aanwijzing tot alleensprekend rechter geschiedt bij Zelfbestuursbesluit, waarbij de Zelfbestuurder (die volgens art. 2 van het besluit van 15 Juli 1925 deze macht uitoefent) zelf aanwijst wie hem bij belet of ontstentenis als zoodanig vervangen; dit wordt in de practijk zoo opgevat, dat in al die gevallen dat de Zelfbestuurder niet aanwezig is in het ambtsressort van een als vervangend alleensprekend rechter aangewezen districtshoofd, dit als zoodanig optreedt; is de Zelfbestuurder echter

125) Arb. V, blz. 421-441.

126) Arb. XXXI, blz. 156-170. 
wel aanwezig, dan treedt de vervangende rechter terug. Zoo treedt te Banggai de Zelfbestuurder dagelijks als alleensprekend rechter op, doch is hij op tournee dan vervangt de djogoegoe hem.

II. Het Residentiebesluit houdt de regelen in betreffende de bemoeienis van het Europeesche bestuur met de rechtspraak over de Zelfbestuursonderhoorigen; deze omvat leiding (Voorzitterschap der Inheemsche rechtbank) en contrôle der vonnissen. Het toezicht op de landschapsgerechten kan nimmer leiden tot wijziging van vonnis of strafmaat.

Het toezicht op de vonnissen der inheemsche rechtbank is geheel geregeld in art. 17 der Zelfbestuursregelen 1927; de bevoegdheid aan het Hoofd van Gewestelijk Bestuur verleend in de leden 6 jo. 4 van dat artikel gaf den Resident aanleiding te bepalen dat vonnissen van inheemsche rechtbanken, houdende veroordeeling tot een gevangenisstraf van zes maanden of langer, vóór de tenuitvoerlegging aan zijn goedkeuring dienden te worden onderworpen. Hiermee wordt dus het toezicht in crimineele zaken aanmerkelijk uitgebreid.

Het toe te passen recht was volgens de Zelfbestuursregelen 1927 nog steeds de "godsdienstige wetten, volksinstellingen en gebruiken" (art. 17 lid 1), doch de Zelfbestuursregelen 1938 stellen in art. 13 lid 3 het adatrecht voorop; hiermee heeft dan de practijk, dat vóór alles de adat wordt toegepast, wettiging gevonden.

Wie justiabel zijn voor den zelfbestuursrechter werd sedert 1919 in de Zelfbestuursregelen aangegeven (1919: art. 17 jo. 14; 1927: art. 17 jo. 13 ; 1938: art. 12 jo. 7).

Het landschap Banggai valt niet onder de jurisdictie van den Rijksraad te Manado ${ }^{127}$ ).

\section{Godsdienstige rechtspraak.}

De eenige gepubliceerde mededeeling - zij het dan in negatieven zin - over "priesterraden” in Banggai is opgenomen in een rondschrijven van den Gouverneur van Celebes en Onderhoorigheden van 19 Juli 1920, waarin het heet dat in eenige landschappen, o.a. Banggai, nog geen priesterraden waren ${ }^{128}$ ). Ik meen de juistheid van dit bericht te moeten betwijfelen; het is niet uitgesloten dat de toenmalige civiel-militaire onderafdeelingschef een mogelijke vraag ter zake verkeerd beantwoord heeft.

127) Stbl. 1910 no. 343 jo 1924 no. 466.

128) Arb. XXIX, blz. 72. 
Waar de vorstenorganisatie van het Banggaische bestuur een trouwe nabootsing was van dat te Ternate, mogen we veronderstellen dat ook op dit terrein het sultanaat als voorbeeld gediend heeft. In 1877 heet het dat in het gewest Ternate geen eigenlijk gezegde priesterraad bestaat, doch de dan volgende mededeelingen slaan uitsluitend op de toestanden in het stukje Gouvernementsgebied ter hoofdplaats Ternate. Wat de rechtspraak over sultansonderhoorigen betreft vinden we vermeld dat er naast de hooger genoemde hakim sultan (blz. 163), rechtsprekende zoowel in straf- als in civiele en godsdienstige zaken, geen andere rechtbank bestond ${ }^{\mathbf{1 2 9}}$ ).

In 1902 wordt echter gesproken van de sinds overoude tijden bestaande sjarat te Ternate, ook wel inlandsche boedelkamer genaamd. Weliswaar was dit lichaam in de eerste plaats voor Gouvernementsonderhoorigen bedoeld (instructie voor den Kapitein der Makassaren, opgenomen in Stbl. 1859 no. 20), doch ook voor gevallen van gemengde jurisdictie waren zijn beslissingen van kracht. Was een onderdaan van een der sultans $\mathrm{nl}$. bij een zaak betrokken, dan moest het advies van den kadli van het rijk, waartoe die onderdaan behoorde, worden ingewonnen; bij verschil van meening tusschen kadli en „priesterraad” werd de zaak ter kennis gebracht van den „,resident, ,die dezelve aan den Sultan, wiens onderdanen daarbij betrokken „zijn, voorstelt, met verzoek dezelve in zijne hoedanigheid van opper„priester te willen beslissen” (art. 16) ${ }^{130}$ ). Niets ligt meer voor de hand dan te veronderstellen dat de sultan die bevoegdheid heeft overgedragen aan, in handen gesteld van een ter zake competent persoon, den kalim dus, die met zijn adviseurs, imams b.v., een beslissing nam. (Vergelijk b.v. de beschikking van den Soesoehoenan Pakoeboewono IX uit 1885, waarbij deze vorst aan den pangoeloe zijn bevoegdheid als godsdienstig rechter overdraagt; het ontstaan van den sjarat (ook: inlandsche weeskamer) van Gorontalo; ontstaan en ontwikkelingsgang van de sjarat in Zuidwest-Celebes, waarbij de oorspronkelijke verhouding van adviseerend college voor den beslissenden rechter, den vorst ${ }^{131}$ ), uitbreiding onderging, doordat de sjarat een, overigens beperkt, scheidsrechterlijk karakter aannam; aan de uitspraken van dit college ontbreekt bindende kracht. De mogelijkheid van ingrijpen door den vorst is blijven bestaan; thans hanteert de Zelfbestuursrechtbank deze bevoegdheid).

129) Arg. I, blz. 233.

130) Arb. VII, blz. 202-203.

131) Arb. XXVIIII, blz. 62 ; XXIX, blz. 3 ; blz. 81. 
Zoo is het vermoedelijk ook te Ternate geweest, waarvan we bevestiging vinden in een artikel van Coolhaas uit 1916-1922 ${ }^{132}$ ). Daaruit blijkt dat voor het sultanaat Ternate van oudsher de Mohamedaansche rechtspraak in handen is van een "madjlis hakim saärah" of „sjaarah (sjar'ah)”, bestaande uit een viertal door den sultan aangestelde imams, uit wier midden de sultan wederom een kadli (kalim) benoemt, terwijl de Resident imams en kadli erkent. De kadli is waarschijnlijk de Mohamedaansche rechter, de imams zijn zijn bijzitters. Coolhaas deelt verder mede dat deze hakim saärah ook voor de tot het sultanaat Ternate behoorende gebieden buiten het eiland Ternate werkt. Deze mededeeling stamt echter uit de jaren na de afscheiding van Banggai; we kunnen hier dus niet uit afleiden, dat b.v. Banggaische zaken op het terrein van dezen rechter liggend, te Ternate zouden zijn afgedaan; dit is trouwens niet waarschijnlijk. Een mededeeling uit 1925 geeft in dezen geen nieuwe gezichtspunten ${ }^{\mathbf{1 3 3}}$ ).

Bosscher en Mathijsen spreken noch van moskeepersoneel, noch van sjarat of godsdienstige rechters. Goedhart noemt wel den kalim, doch welke functies deze precies vervulde zegt hij niet; wel legt hij den nadruk op de ondergeschikte positie der Banggaische godsdienstbeambten ten opzichte der Ternataansche. Zoo werd de Ternataansche djoeroetoelis (lid van den Ternataanschen raad van vier toezichthouders; zie blz. 131) geacht de vertegenwoordiger te zijn van den Ternataanschen kalim, en deze djoeroetoelis was het ook, niet de Banggaische kalin (merkt Goedhart op) die gevallen van echtscheiding behandelde en afdeed. Doch huwelijkssluiting en kennisname van echtscheiding behooren niet eigenaardig tot de werkzaamheden van den kalim (kadli); wie eventueele geschillen betreffende huwelijks- en erfrecht afdeed, vermeldt Goedhart echter niet ${ }^{134}$ ). Doch het is niet te veel verondersteld, als we aannemen dat in ieder geval nà 1908 de Banggaische kalim, eventueel met eenige imams ter hoofdplaats, als godsdienstig rechter is gaan optreden. Ik vond in ieder geval - in afwijking dus van de mededeeling uit 1920 - dat de meeste boedelzaken te Banggai door den kalim werden geregeld; dit behoeft uiteraard nog geen rechtspraak te zijn. Gegevens ontbreken mij. Of deze godsdienstbeambte ook bemoeienis met het huwelijksrecht heeft is mij niet bekend.

132) Arb. XXI, blz. 404-407.

133) Arb. XXIX, blz. 177.

134) Goedhart, Drie landschappen, blz. 447/448. 
Ik herinner mij uit mijn bestuurspractijk echter ook eenige gevallen dat een boedelzaak rechtstreeks bij de Zelfbestuursrechtbank werd voorgebracht; ook dat na een door den sjarat ondernomen verdeeling, een der partijen geen genoegen nemende met haar erfportie, bij de Zelfbestuursrechtbank in beroep kwam; dit college onderzocht de kwestie geheel opnieuw en volledig.

Weliswaar kennen de tweede en de derde regeling op de inheemsche rechtspraak in het Gouvernement Celebes (blz. 164) in onderscheidenlijk art. 27 en art. 7 bepalingen over de toepassing der godsdienstige rechtspraak, waarbij ook de mogelijkheid wordt geschapen de eindbeslissing van de Zelfbestuursrechtbank in te roepen, doch in Banggai kunnen deze artikelen niet geacht worden van kracht te zijn geweest, omdat toch de Gouverneur in 1920 constateerde dat er o.m. in Banggai nog geen priesterraden waren. En al betwijfel ik de juistheid daarvan, toch kunnen we uit Banggai geen vonnissen van de inheemsche rechtbanken verwachten die een boedelkwestie in behandeling nemen, nadat de sjarat een voor partijen onaanvaardbare, eerdere uitspraak had gedaan.

Overigens is het interessant genoeg uit deze regelingen even het volgende te lichten. De tweede vermeldt dat het huwelijks- en erfrecht beheerscht blijven door de terzake vigeerende adatbepalingen, c.q. de koranische voorschriften, terwijl in de derde regeling slechts sprake is van de terzake vigeerende adat. Beide artikelen hebben gemeen, dat civiele vorderingen op het gebied van het huwelijks- en erfrecht door den betrokken sjarat berecht worden, dan wel (elders) door speciaal daarvoor krachtens de adat aangewezen rechtbanken of rechters; dit geldt blijkens de toelichting meer in het bijzonder voor streken als de Toradjalanden. Eerst heette het: „,voor zooveel de „Mohamedaansche landschappen betreft”, later, en beter : „,voor zoo„ver betrokkenen den Mohamedaanschen godsdienst belijden en er ,in ons landschap priesterraden (sjarat) gevestigd zijn”.

Daarna volgt in beide regelingen de bepaling van herbehandeling der geheele kwestie voor de inheemsche rechtbank, indien een der partijen zulks verlangt. Dit laatste voorschrift sluit dus wel zoo bij het gewoonterecht aan, dat in Banggai, waar deze regeling nimmer van kracht is geweest, tot heden op deze wijze gehandeld wordt. Of is deze Banggaische gewoonte ook weer overgenomen van Ternate? De sultan toch was te allen tijde bevoegd in te grijpen in de uitoefening der godsdienstige rechtspraak door den Ternataanschen kalim; hij kon vonnissen vernietigen en opnieuw vonnis wijzen, of ook her- 
behandeling door den saärah gelasten. De opperste rechter van het landschap was dus in het geheel niet gebonden aan de beslissingen van dezen saärah ; dit lichaam heeft meer het karakter van een adviesinstantie, zonder dat overigens het uitgebrachte advies ook maar eenigszins bindend is ${ }^{135}$ ).

Plaatselijk trof ik districts- en zelfs kampongsjarats aan; of in elk district een dergelijke sjarat te vinden is, kan ik niet zeggen; zeer zeker vinden we niet in alle kampongs een dergelijk lichaam. Ik trof b.v. wel een kampongsjarat aan in een door transmigratie ontstaan woondorp (een groep menschen van Liang die verhuisd was naar Totikom); wellicht dat in dergelijke gevallen de voorwaarden aanwezig zijn voor het ontstaan van een dergelijken ,priesterraad”. Bij dezen trof ik tevens een merkwaardig geval van overschrijding van rechtsbevoegdheid aan: deze kampongsjarat had een geval van overspel door middel van beboeting en vrijheidsstraf (de laatste te ondergaan in de dorpsmasdjid!) afgedaan. Dit was den Zelfbestuurder met zijn djogoegoe aanleiding het betrokken masdjidpersoneel, dat deze sjarat vormde, te ontslaan en hen voor de Zelfbestuursrechtbank te brengen wegens misbruik van aanzien en gezag.

Voor zoover ik districts- en kampongsjarats aantrof vond ik dat zij beide bevoegdheid hebben tot het constateeren van het in vervulling gaan der voorwaarden, verbonden aan de voorwaardelijke verstooting.

\section{Regeling.}

\section{Regeling door de lagere rechtsgemeenschappen.}

De lagere rechtsgemeenschappen hebben noch voorheen, noch thans regelingen getrof fen. Zoodra de streekgemeenschappen bestuurlijke erkenning zullen verkrijgen als inlandsche gemeenten, zijn gemeenteregelingen te verwachten.

\section{Regeling door sultan of vorst.}

Van vorsten- of sultansedicten uit de jaren vóór 1908 is niets gebleken.

Uit 1938 dateert een, overigens zeer ongelukkige en geheel met de adat strijdende, regeling door den Zelfbestuurder gemaakt, waarin de maxima bruidschat voor de verschillende standen worden aan-

135) Arb. XXIX, blz. 177. 
gegeven; de bedoeling is dat dit besluit ook voor Christenen zal gelden. Het verwekte zooveel tegenstand, dat ik den Zelfbestuurder verzocht het in dien geest te wijzigen, dat de aloude adatbepalingen ter zake gehandhaafd blijven (betaling in goederen met fictieve waarde; zie hoofdstuk VIII), indien ten minste één der partijen (familie van bruidegom òf van bruid) zulks verlangt, en dat slechts bij wederzijdsche wilsovereenstemming de in contant geld uitgedrukte tarieven uit het vorstenbesluit worden toegepast.

\section{Regeling in Gouvernementssfeer.}

Sedert het landschap Banggai in rechtstreeksche verhouding tot het Gouvernement van Nederlandsch-Indië kwam te staan (1 April 1908) heeft het Zelfbestuur vele, zoowel legislatieve als administratieve, besluiten genomen. De beginselen neergelegd in bijblad 6801 zijn in deze richting gevend, hetgeen beteekent dat het Landschap als wetgever optreedt voor al die onderwerpen welke ter regeling zijn overgelaten. Op overtreding van sommige dezer legislatieve producten is straf bedreigd. Als voorbeelden noem ik de zelfbestuursbesluiten van:

10 September 1912 betreffende een boeah-tanah heffing van boschproducten;

22 November 1930 betreffende heffing van een vischrecht van niet-onderhoorigen van het Zelfbestuur; dit recht heet in Banggai bea pasi;

22 November 1930 betreffende heffing van een retributie voor niet-onderhoorigen van het Zelfbestuur voor het verzamelen van damar, rotan en andere boschproducten;

20 November 1930 no. 56 betreffende het verrichten van persoonlijke diensten ten bate van Zelfbestuurder en leden komies-ampat als lambanoea (zie blz. 123), en van pinontol-diensten, thans balimang geheeten (zie blz. 144);

17 Januari 1936 no. 4 betreffende de instelling van het wildreservaat Pati-Pati (Noordkust Vogelkop);

17 Maart 1933 betreffende het vorderen van heerendiensten.

Zelfbestuursbesluiten met financieele consequenties, waarbij na verkregen machtiging van den Gouverneur-Generaal belastingen aan de landschapsbevolking werden opgelegd zijn o.a. de besluiten van:

7 Augustus 1933 betreffende een regeling van een belasting op het inkomen; 
27 Januari 1926, 16 Mei 1934 en 31 Maart 1935 betreffende een belasting op het slachten van vee.

Het gebruik ontstond dat alle belangrijke besluiten (legislatieve en financieele regelingen, b.v. begrooting en begrootingsrekening; wijziging in de administratieve indeeling van het landschap; benoeming van districtshoofden) door den Zelfbestuurder met de (incomplete) komies-ampat werden geteekend, terwijl vele der minder belangrijke regelingen (aanstelling lager personeel, administratieve beslissingen) door den Zelfbestuurder alleen werden onderteekend. Vaak werden de besluiten van deze laatste soort, minder fraai, namens den Zelfbestuurder door den Onderafdeelingschef geteekend; dit geschiedde met het oog op de slechte postverbindingen tusschen Loewoek (standplaats onderafdeelingschef) en Banggai (woonplaats van den vorst). Daar een uitdrukkelijke, door den Zelfbestuurder daartoe afgegeven, machtiging ontbreekt, valt het te betwijfelen of deze handelwijze wettig is. 


\section{HOOFDSTUK VI.}

\section{Adatvolkenrecht.}

1. Conflicten tusschen streekgemeenschappen; verdragen en bondgenootschappen.

Wekt het in paragraaf 1 van hoofdstuk II medegedeelde den indruk dat er in oude tijden veel strijd heeft plaats gevonden, als gevolg waarvan o.a. de oude rijken op Peling hun zelfstandig bestaan hebben moeten opgeven en opgenomen zijn in het verband van grooter Banggai, in later tijden schijnt hieraan, althans voor Peling, een einde te zijn gekomen. Kruyt vermeldt dat oorlogen tusschen de bewoners van twee landstreken in den Archipel volgens algemeen getuigenis nimmer zijn voorgekomen ${ }^{\mathbf{1}}$ ). Daarentegen is het zelfstandig worden van sommige afsplitsingen wel met strijd gepaard gegaan (b.v. de afscheiding van Ponding-Ponding en Tatakalai uit Tinangkoeng).

Wel moet verzet van streekhoofden tegen den radja zijn voorgekomen; zoo meldt Kruyt dat basalo Apal niet naar de bevelen van den vorst wilde luisteren toen deze hem onder pressie van het Gouvernement verbood menschen als slaven naar Oena-Oena in de Tominibocht te verkoopen ${ }^{2}$ ). Hoe dit verzet eindigde, en met welke middelen de vorst er een einde aan makte, is niet vermeld. Overigens vond ik bij mijn onderzoek geen sporen van dergelijke opstanden, noch van gewapende conflicten tusschen twee streekgemeenschappen onderling.

Anders was het op den Vaste-Wal. Op den Vogelkop ${ }^{3}$ ) wordt melding gemaakt van een strijd tusschen de inwoners van Mantok en die van Basama; Mantok nu is blijkens mijn onderzoek een dorp der mian Boela, één der familiegroepen der streekgemeenschap Tanotoeran; Basama is de westelijk daarvan gelegen eenheid. Het moet een twist zijn geweest tusschen de groepshoofden van Mantok en van Basama; we hebben hier dus vermoedelijk niet te doen met een

1) Kruyt, Bewoners, blz. 249.

2) Kruyt, Vorsten, blz. 617.

3) Kruyt, Balantaksche Studiën, blz. 342 noot 1 . 
twist tusschen twee streekgemeenschappen, doch tusschen onderdeelen daarvan. Als strijdperk is de plaats asa'an (sian: wetsteen voor zwaarden) bekend; de oorlog duurde drie jaar en eindigde met den dood van tonggol Basama. Uit de opgegeven tijdsduur mogen we opmaken dat er tijden zijn geweest van wapenstilstand, doch wanneer dit was is niet vermeld. Wat de aanleiding tot den strijd was kon (wilde?) men Kruyt niet zeggen.

Als oorzaak van andere oorlogjes gaf men mij echter vaak grensgeschillen op. Zoo bestond er een dergelijk conflict tusschen de streekhoofden van Kintom en Mendono; en, aan de overzijde der waterscheiding, tusschen Lingketing en Pokooehan eenerzijds en Basaboengan en Lambangan anderzijds. (Aandacht verdient dat het eerste tweetal aan het streekhoofd van Kintom, het tweede tweetal aan dat van Mendono hoorig was).

Dit laatste conflict, aan de noordzijde van de waterscheiding dus, kwam driemaal tot uitbarsting, de laatste maal kort voor 1908, toen een bloedig treffen echter voorkomen werd door het ingrijpen van een Gouvernementsambtenaar der douane op tournee.

Een ander geschil meldde men mij tusschen Mendono en Nambo; het was geen grenskwestie, want beide streekgemeenschappen grenzen niet aan elkaar. Door een beleediging een man van Mendono door zijn te Nambo ingehuwden neef toegevoegd, ontstond twist tusschen twee families. Eigenaardig is, dat hierdoor oorlogstoestand ontstond tusschen twee streekgemeenschappen. Men trok elkaars gebied binnen en aan weerszijden vielen eenige dooden; hierbij verloor ten slotte Nambo één leven meer dan Mendono. De inmiddels toegesnelde posthouder (het was dus na 1880) en oetoesan regelden de aangelegenheid nu in dier voege dat Mendono aan Nambo een boete van veertig blokken goed moest opbrengen, als zoenprijs voor dat eene leven; de geheele streekgemeenschap bracht deze boete op. Vervolgens werden de goederen plechtig naar Lontio (de tusschen de strijdenden gelegen streekgemeenschap) gebracht, waar ze ten overstaan van posthouder en oetoesan aan de lieden van Nambo werden overhandigd; tevens werd verklaard dat de wederzijdsche wrok geëindigd was. Aandacht hierbij verdient dus dat het territoir van het tusschen gelegen Lontio als neutraal terrein werd gebruikt om aan den strijd een einde te maken.

Ten slotte hebben de lieden van Lingketing en van Doehian aan vele oorlogshandelingen deelgenomen, gericht zoowel tegen andere groepen, als tegen elkaar. Echter onderling hebben de dorpen van 
Lingketing, noch die van Doehian, ooit met elkaar gevochten, daar alle inwendige geschillen die daartoe aanleiding zouden kunnen geven, door daka'njo dan wel mian kopian beslecht werden ${ }^{4}$ ). De aanleiding tot het vele oorlogen zou bij deze groepen geweest zijn het zoeken naar boomhars (damar), doch Kruyt betwijfelt dit. Goedhart geeft echter de zelfde kwestie als anleiding tot een in zijn tijd gepleegden moord op Loinangs, en deelt verder mee, dat strijd tusschen bergbewoners van Lingketing en Doehian meestal veroorzaakt werd door het overschrijden van elkaars gebied bij het damar- of rotanhalen ${ }^{5}$ ). Dit stemt overeen met Tangkilisans mededeelingen, waar hij zegt dat overschrijding der onderlinge grenzen de eenige reden was waardoor men met elkaar in oorlog geraakte; een dergelijke grensoverschrijding had ook veelvuldig plaats bij de jacht op gemsbuffels (anoa).

Kruyt vermeldt verder dat men er jaarlijks op uit ging om een of meer koppen te halen (madi : mangae), hetgeen noodig werd geacht om gezond te blijven en om het gewas te doen gelukken ${ }^{6}$ ). De lieden van Lingketing trokken daarbij veelal naar Boalemo (noordelijk deel Vogelkop), de mian Doehian zochten hun slachtoffers vaak onder de to Wana, een stam in de onderafdeeling Kolonedale. Deze laatsten lieten zich niet onbetuigd en kwamen herhaaldelijk wraak nemen in het Loinangsche, waarbij ze echter niet tot in Lingketing doordrongen. Hier had men vooral last van lieden van Lambangan (onderhoorigen dus van bosanjo Mendono), die eenmaal het dorp Pinapoean (madi : waar verbrand is) in de asch hebben gelegd.

Een bijzondere gelegenhedi in het Lingketingsche, waarvoor men een kop noodig had, was het overlijden van den daka'njo of van een der tonggol, dan wel van iemand hunner (naaste?) familie. Dan gingen de Lingketingers veelal een hoofd halen bij de Doehian-groep, doch men was in geenen deele aan dit „operatie-terrein” gebonden: men kon ten slotte overal een kop gaan snellen mits het slechts niet bij mede-onderdanen van het streekhoofd van Kintom was.

Op blz. 95 kwam de kleine legermacht die het streekhoofd van Lingketing ter beschikking stond reeds ter sprake. Volgens Tangkilisan waren er hier twee talenga, één saga, twee pongkeali en één pandjolo; hij zegt dat de talenga de aanvoerder was, doch dat hij lager in rang dan de tonggol, hooger echter dan de langka-langkai

\footnotetext{
4) Kruyt, To Loinang, blz. 431.

5) Goedhart, Drie landschappen, blz. 479 .

9) Kruyt, To Loinang, blz. 433; 332. Id. De To Wana op Oost-Celebes, T.B.G. 70 (1930), blz. 404; 506/507.
} 
was. Waren vreemdelingen het gebied van Lingketing binnengedrongen, dan was het de taak van den talenga, hen tezamen met zijn medestrijders, te verjagen en eventueel te dooden (dat de talenga ook als executeur van een vonnis diende op te treden werd reeds op blz. 158 v. aangegeven). De krijgers die medegaan worden door Kruyt to sega-sega genoemd.

Zoowel in Lingketing als in Doehian kende men uiterlijke teekenen waaraan te zien was hoeveel koppen een der krijgers reeds gesneld had; het verleenen van een dergelijken rang (Kruyt spreekt over het slaan tot ridder der dapperen) geschiedde op een groot feest dat aangerecht werd als de troep na een succesvollen tocht was teruggekeerd. De onderscheidingen bestonden in bepaald gekleurde, soms met franje versierde, hoofddoeken, waarin eventueel een of twee slagtanden van het hertzwijn zijn bevestigd ${ }^{7}$ ).

Kruyt maakt verder nog melding van het gebruik van Lingketingers als tuchtigingstroepen door het streekhoofd van Kintom, nl. om een dorp of streek te gaan straffen waar men op de een of andere wijze het ongenoegen van dezen heer had opgewekt ${ }^{8}$ ).

Over vrederecht zijn weinig gegevens beschikbaar: Kruyt vermeldt slechts dat na den jaarlijkschen oorlog tusschen Lingketing en Doehian er ook telken jare weer vrede gesloten werd ${ }^{9}$ ). Wanneer dit was, of dit vrede sluiten verband hield met den landbouw of andere periodieke werkzaamheden is niet vermeld. Doch als het zoover was trokken eenige lieden van de Doehian-groep (madi : mian kopian $=$ vredestichter; was dè mian kopian, hoofd der Doehian-groep, daar ook bij?) naar den daka'njo Lingketing (nimmer omgekeerd?). Daar werd dan o.m. een maaltijd aangerecht, waarbij de balakat van den tomoendo Kintom (de magische kracht van den oervader dus) soms zelfs de balakat van soeltan Talinate (= Ternate) werd aangeroepen, en waarbij men bezwoer den vrede te zullen bewaren. Doch, volgens de Lingketingers althans, waren het altoos de lieden van Doehian die niet lang na dit vrede sluiten weer met oorlogshandelingen begonnen en zoo de gemaakte heilige afspraak schonden.

Tangkilisan vermeldt nog dat meer speciaal de mian kopian en de toema noe daka'njo als afgezanten optraden om met de vijanden vrede te gaan sluiten; zij werden dan ook door de andere groepen als hun vrienden beschouwd en werden niet aangevallen of gedood als zij zich

7) Kruyt, To Loinang, blz. 443/444; 433/434.

8) Kruyt, To Loinang, blz. 433.

9) Kruyt, To Loinang, blz. 446. 
in vijandelijk gbeied begaven. Vermoedelijk zal de milinoe niet deze voorrechten genoten hebben; hij toch mocht zich alleen vrijelijk bewegen onder de eigen onderhoorigen van den daka'njo, werd door allen ontzien en moest door alle onderhoorigen van levensmiddelen en teerkost voorzien worden, doch het is niet bekend of hij, als hij zich in vijandelijk gebied bveond, recht had op dezelfde behandeling.

Als afgezanten elders van den daka'njo zijn eveneens de toea'njo te beschouwen (zie blz. 99), die buiten Lingketing optraden als hoofden over ter plaatse gevestigde onderhoorigen van het streekhoofd.

Over andere uitingen van vrederecht (tijden of feesten gedurende welke men elkaar niet te lijf mocht; vrijplaatsen of neutraal terrein; gastrecht) ontbreken gegevens, behoudens het hooger vermelde.

Ingrijpen van het centrale vorstenbestuur in twisten tusschen rechtsgemeenschappen wordt door Goedhart gemeld; zoo heeft het Banggaische bestuur kort voor 1908 een beslissing genomen in het geschil tusschen Lingketing en Doehian over het gebied waar men damarhars inzamelde; dezelfde auteur vermeldt dat de djogoegoe in geval van twisten tusschen de rechtsgemeenschappen zelve derwaarts ging om de aangelegenheid te regelen ${ }^{10}$ ).

Als uiting van een verdrag kan men den bijstand beschouwen dien Lingketing aan Pokooean beloofde, toen dit laatste in gewapend conflict met Basaboengan en Lambangan was gekomen: de Lingketingers toch, die vermoedelijk wel het een en ander met Basaboengan hadden af te rekenen, zouden deze plaats van de landzijde aanvallen en de huizen in brand steken (de gemoetoe, vezel van den arèn-palm, was al verzameld), terwijl Pokooehan een aanval over zee zou doen ${ }^{\mathbf{1 1}}$ ).

Andere verdragsvormen (wederzijds steun verleenen tegen een gemeenschappelijken vijand; afspraken gemaakt op alle mogelijke andere gebieden tusschen hoofden van rechtsgemeenschappen) kon ik niet achterhalen, doch ze moeten wel bestaan hebben. We kunnen daarbij denken aan de verhouding tusschen de rechtsgemeenschap der Boegineezen te Boenta eenerzijds, en het streekhoofd van Tangkiang in zijn functie van opperheer over de mian Doehian anderzijds. Zoo werden kort na de komst der eerste Boegineesche immigranten eenige hunner volgelingen door lieden van Doehian gedood. Het hoofd der Boegineezen was hierover zeer gebelgd en keerde naar Togean terug, terwijl hij aan het toenmalige streekhoofd van Tangkiang liet weten

10) Goedhart, Drie landschappen, blz. 479; 444.

11) Memorie.

Verh. dl. VI. 
eerst dan terug te zullen keeren als deze rust en orde had hersteld, en maatregelen zou genomen hebben om herhaling te voorkomen. Het streekhoofd vond hierin aanleiding de schuldige bergbewoners op te doen vatten en eigenhandig te dooden; daarna ging hij persoonlijk naar Togean om Boenai, het Bogineesche hoofd, te verzoeken terug te keeren daar de moord reeds gezoend was, waarbij hij beloofde steeds voor orde en rust te zullen zorgen, zoodat de Boegineezen niet meer gestoord zouden worden in hun vestiging.

Het ligt niet in de overlevering dat het Lipoeadinoschap van Lolantang uit een bondgenootschap is ontstaan.

Geen gegevens zijn beschikbaar over de wijze waarop een eventueel bondgenootschap gesloten werd en over de eventueele bezweringen daaraan verbonden.

\section{Verhoudingen van Banggai tot andere vorstendommen. Onveilig- heid eertijds.}

„Met de vorstenbesturen (van de landschappen Todjo en Boeng,koe) onderhoudt dat van Banggai in het geheel geen betrekkingen; „familiebanden bestaan er evenmin”. Aldus Goedhart ${ }^{12}$ ). In de oudheid is dat anders geweest, althans ten opzichte van Boengkoe, vermoedelijk als gevolg van het mede-vazal zijn van den zelfden heer. In Boengkoesche traditie (niet in de Banggaische) is een contract bekend, gesloten tusschen den Banggaischen vorst Aboe Kasim (dien we stelden van 1741 tot 1773) en den toenmaligen Boengkoeschen vorst, hetgeen geschiedde ten overstaan van sultan Amir van Ternate, die tot 1751 aan de regeering was. Jaar en datum van het stuk zijn mij niet bekend, doch het moet dus vallen tusschen 1741 en 1751 . Overigens heb ik helaas het origineele stuk niet onder de oogen kunnen krijgen (wellicht bevindt het zich in het bezit van een verbannen radja van Boengkoe). Volgens den toenmaligen onderafdeelingschef van Kolonedale (Boengkoe en Mori) bevat het verdrag zeven punten. Allereerst wordt er verklaard dat er vrede bestaat tusschen contractanten (er was dus wellicht tevoren oorlog). Dan volgen eenige bepalingen over gevallen dat onderhoorigen van een der contracteerende landschappen in het andere rijkje komen handel drijven en daar gedood worden; en over het gebruik van vreemdelingen voor het uitvoeren van wraakoefeningen in een der beide rijkjes. Verder zal geen derde een der contractanten in een oorlog tegen het andere

12) Goedhart, Drie landschappen, blz. 471. 
kunnen betrekken. Ten slotte vinden we bepalingen over zoowel Tarnataansche als vreemde schepen, en hoe te handelen met door de V.O.C. tot contrabande verklaarde lading ${ }^{13}$ ).

De Aboe Kasim, die namens Banggai het contract sloot, overleed op Batjan; onbekend is wat hij daar deed, doch wellicht legde hij daar een vriendschappelijk bezoek af. $\mathrm{Hij}$ is daar in elk geval niet als banneling gestorven ${ }^{14}$ ).

Uit vroeger eeuwen bezitten we het vage gegeven dat de vorst van Banggai den sultan van Djailolo hulp tegen de Portugeezen bood, maar daar we niet weten wat of wie met dien vorst bedoeld wordt, kunnen we hieruit geen consequenties ten aanzien van het geheele vorstendom trekken.

Ander contact bestond naar de overlevering met Goa (Makassar), dat in oude tijden invloed tot op den Vogelkop uitoefende, en dat te Balantak een stedehouder had met den titel soero; op een of andere wijze (wellicht ten gevolge van het Bonggaaisch tractaat?) stond de vorst van Goa dit gebied aan den Banggaier af ${ }^{15}$ ).

In de vorige eeuw trachtte Bone zijn invloed langs de oostkust van Celebes te vergrooten. Zoo maakt Van der $\mathrm{Hart}^{16}$ ) melding van Boegineesche sahbandars te Mendono en te Balantak; De Clercq geeft, dat vermeende aanspraken van Bone op de bezittingen van Ternate in Banggai en Boengkoe door de Regeering in 1851 als onwettig werden verworpen ${ }^{17}$ ). (Ontleende Bone zijn aanspraken t.a.v. Banggai aan den in 1847 naar dat land gevluchten, opstandigen Banggaischen vorst Agama, later moemboe doi Boegis? De toenmalige Aroem Poegi in Bone was allerwegen op vergrooting van zijn machtssfeer uit) ${ }^{18}$ ).

Of de mededeeling van Riedel, dat de Mandarsche vorsten vereenigd met Parigi in 1772 een aanval op Banggai en de Soelaeilanden deden, aanspraak kan maken op historische juistheid is mij onbekend; de Banggaische traditie bewaart over dit voorval geen herinneringen ${ }^{19}$ ). (Wij kunnen het wat de dateering betreft kwalijk in verband brengen met den val van Bebengketan, hoewel onder de

13) Memorie.

14) Kruyt, Vorsten, blz. 525.

15) Memorie.

16) Van der Hart, Reize, blz. 98, verg. ook blz. 106.

17) De Clercq, Ternate, blz. 180.

18) J. A. Bakkers, Het leenvorstendom Bone, T.B.G. 15 (1866), blz. 7.

19) J. G. E. Riedel, De vestiging der Mandaren in de Tominibocht, T.B.G. XIX (1870), blz. 555. 
helegeraars ook wel lieden van Paloe, Midden-Celebes, worden genoemd; vergelijk blz. 22).

Wel is Banggaisch gebied herhaaldelijk het doel geweest van velerlei rooftochten van Tobeloreesche en andere zeeroovers, die vaak diep het land in drongen, brandend en plunderend. Uit dien hoofde waren de centra van vele streekgemeenschappen, zoowel in den Archipel als op den Vaste-Wal, omgeven door een steenen wal waarvan men thans nog de resten aanwijst als kota uit oude tijden; zij zijn meestal aangelegd op plaatsen die zich door terreingesteldheid gunstig voor verdediging afteekenen. Waren er roovers gesignaleerd, dan trokken de leden der rechtsgemeenschap zich binnen de versterking samen en waren alle mannen belast met de vẹrdediging die overigens tegen de veel dapperder en strijdvaardiger Tobelo's meestal vruchteloos bleef. Ook op de akkergemeenschappen trof men versterkingen aan; deze waren aangelegd om één of meer huizen doch droegen uiteraard een meer tijdelijk karakter.

Het ,leger" dat in sommige kota eertijds te vinden was (Batoei, Tangkiang, Kintom, Mendono), bestaande uit een veertigtal soldaten en eenige of ficieren, diende naar mijn indruk niet zoo zeer voor de verdediging van de kota (deze toch was in tijden van gevaar opgedragen aan alle strijdbare mannen), dan wel ter opluistering van belangrijke gebeurtenissen, zooals groote godsdienstige of andere feesten (het overbrengen van de poesakavoorwerpen in Kintom dient b.v. steeds vergezeld te gaan van een z.g. kabesaran, een troep krijgers, oorlogsdansen uitvoerend).

Het is wel merkwaardig dat bij dergelijke invallen het nimmer tot gezamenlijk gewapend optreden tegen de indringers gekomen is, en dat ook niet het centrale vorstenbestuur daartoe het initiatief nam. De geisoleerde positie van het Banggaische hof (zie blz. 129) is hiervan uiteraard de diepere oorzaak, doch ook wellicht de houding der Ternataansche ambtenaren, die (blijkens een mededeeling van Van der Hart) ${ }^{20}$ ) zelve met de zeeroovers heulden.

De eenige vage mededeeling betrekking hebbend op een gezamenlijk optreden tegen de zeeschuimers dateert uit de tweede helft van de vorige eeuw, toen te Banggai een vloot zou zijn verzameld, waartoe de meeste streekhoofden van Peling schepen en bemanningen leverden, en waaraan vooral Liang een werkzaam aandeel nam; deze vereenigde vloot zou naar den Bwokan-Archipel zijn gevaren en daar

2a) Van der Hart, Reize, blz. 90. 
een troep Tobeloreezen verjaagd hebben ${ }^{21}$ ). Ik bezocht de plaats waar men volgens de traditie de lijken der gedoode Tobeloreezen had neergeworpen en vond daar inderdaad vele menschelijke overblijfselen.

\section{Gevolgen van Banggai's positie als vazal van Ternate.}

Dat Banggai onder Ternate's suprematie was gekomen (hetgeen we omstreeks 1580 stelden) bracht zijn consequenties met zich mede. Eenige malen heeft een groep Banggaiers (daartoe door den vorst gelast?) actief deelgenomen aan Ternate's expedities. In Naidahs Ternate-kroniek vinden we vermeld ${ }^{22}$ ) dat tijdens sultan Mandarsah van Ternate (1648-1675) de Ternataansche kapitan laoet Ali het vorstendom Goa ging beoorlogen; hij kreeg o.a. van Banggai korakora's en zeventig man mee. Een levendige beschrijving van het ceremonieel waarmee een dergelijke sultansafgezant te Banggai werd ontvangen vinden we eveneens in deze Ternate-kroniek.

Uit de vorige eeuw dateert de deelneming door Banggai aan een tuchtigingsexpeditie door Ternate uitgerust tegen het opstandige Boengkoe; onbegrijpelijk is het vervolg der mededeeling, dat op Peling en de getrouw gebleven negorijen Kintom en Mendono alles door de Ternataansche hongi zou zijn uitgeplunderd $(1841)^{23}$ ).

In dit verband zou vermelding verdienen het pogen van eenige Banggaische vorsten zich aan het Ternataansche gezag te onttrekken (1829: verzet van Atondeng; hij weigerde huldegift op te brengen; 1847: verzet van radja Agama, die zich eveneens zelfstandig wilde maken) ${ }^{24}$ ). Van den opstand van 1829 is vermeldenswaard, dat de Banggaier zich eerst van de medewerking van alle (?) streekhoofden had verzekerd, doch dat $\mathrm{zij}$, op bosanjo Batoei na (naaste familie van den vorst) bij de nadering der Ternataansche troepen (voornamelijk Tobeloreezen) afvielen ${ }^{25}$ ). Merkwaardig voorts bij den tweeden opstand is, dat basalo Liang (van wien gezegd wordt dat hij met het sultanshuis van Tidore verwant zou zijn) aan de zijde der belegeraars streed; wellicht ook andere hoofden. Eveneens verdient hier vermelding de hulp der Boegineezen van Togean. Wel lijkt hun houding

21) Memorie.

22) Naidah, Geschiedenis van Ternate, Bijdr. T. L. \& V., 43, vlgr. 2, blz. $450 ; 455$.

23) De Clercq, Ternate, blz. 177.

24) De Clercq, Ternate, blz. 175; 178.

25) Kruyt, Vorsten, blz. 526. 
dubbelzinnig, daar sommigen spreken van de hulp door hen aan de belegeraars verleend; aan den anderen kant staat evenwel vast, dat zij het waren die den vorst hielpen ontvluchten, eerst naar Todjo, vanwaar hij vervolgens naar Bone ging. (De toen verleende hulp was de onmiddellijke aanleiding tot het stichten der Boegineesche rechtsgemeenschap te Boenta; zie blz. 48).

Mede een gevolg van de aan Ternate ondergeschikte positie van Banggai is geweest de totstandkoming der twee contracten met de V.O.C. van 26 Januari 1689 en van 9 November $1741{ }^{26}$ ); na den opstand van sultan Amsterdam van Ternate nl. en zijn daarop gevolgde onderwerping (1683) waren de bezittingen van den Ternataanschen sultan hem in leen door de Compagnie terug gegeven; doch deze wilde meteen eens poolshoogte gaan nemen in de nieuw verworven gebieden en zond daarom eind 1688 eenige gecommitteerden naar den Banggai-Archipel.

De inhoud der contracten is te verdeelen in drie rubrieken, nl. die welke het belang op het oog hebben van de V.O.C., van den sultan van Ternate, en van V.O.C. tezamen met den sultan. Tot de eerste categorie behooren de bepalingen die zien op extirpatie van nagel- en muskaatboomen, het monopolie van schildpadshoorn en vogelnestjes, en den bijstand aan de Compagnie te leveren bij oorlogen in Celebes, de Molukken, enz. Daarbij behield de V.O.C. zich het recht voor versterkingen aan te leggen in Banggaisch gebied, terwijl voorts was gestipuleerd, dat de ,koning en zijn grooten” zich met landen en onderdanen in de macht en onder de bescherming van de Edele Compagnie stelden.

De volgende categorie is vertegenwoordigd door art. 26 van het oudste contract, waarbij bepaald werd dat de Banggaische vorst jaarlijks ,homagium” aan den sultan had te doen, en zoodanige „,schenkagie „of tribut te senden” als behoorlijk en gebruikelijk was (vergelijk ook blz. 129).

De derde groep vinden we in die bepalingen welke zien op de wijze van aanstellen van Banggaische vorsten, landsgrooten, bobato's en zelfs ,,senghadjes" (sangadji's); op de mogelijkheid dat de Banggaische vorst ,bij quaat comportement" afgezet kon worden; en op de verklaring van trouw aan de Compagnie èn aan den sultan van Ternate.

Was het den Banggaischen vorst inderdaad niet mogelijk zich aan

26) Corpus Diplomaticum Neerlando Indicum, deel III no. DXIV en deel V no. DCCCI,XIV. 
de bepalingen van het eerste contract geheel te houden, zoodat hij in 1741 moest verzoeken een korporaal met vier man te Banggai te plaatsen on hem behulpzaam te zijn in de uitvoering dezer overeenkomst? (art. 27).

\section{Vestiging van het Nederlandsch gezag.}

Het Koloniaal Verslag van 1909/1910 maakt melding van lijdelijk verzet door het Banggaische Zelfbestuur gepleegd in begin 1908, toen de afscheiding van Ternate nog geen voldongen feit was; de door het Europeesch bestuur gegeven wenken en raadgevingen werden in den wind geslagen. Door legering van een kleine militaire bezetting te Banggai kwam hierin echter spoedig verbetering. In latere jaren vinden we sporadisch melding gemaakt van plaatselijk verzet, meer ten gevolge van het optreden van rooversbenden dan dat sprake was van ontevredenheid bij de bevolking. Eenige malen hebben militaire patrouilles handelend moeten optreden.

Op den Vaste-Wal is men op meer tegenstand gestuit. Het begon in 1908; lieden van Mantang, een der Doehian-dorpen in de vlakte, hadden acht menschen uit het landschap Todjo gedood; de oorzaak van deze snelpartij was vermoedelijk overschrijding der grenzen bij rotanzoeken (verg. blz. 1 v.). Een militaire patrouille vanuit Poso kwam in deze streken omdat het scheen dat Mantang de opgelegde boete niet wilde voldoen. Tot zoover het Koloniaal Verslag 1908/1909. Het vervolg van deze militaire expeditie is niet zoo geslaagd geweest. Wellicht hebben Lingketingers van de gelegenheid gebruik gemaakt om de lieden van Doehian verdacht te maken bij den patrouillecommandant, hem suggereerende dat deze laatsten verzet zouden gaan plegen. Bij den daarop volgenden tocht via Lingketing naar Baloa werden eenige der vooraanstaande groepshoofden der mian Doehian gearresteerd, en zoo het heet bij een poging tot ontvluchting, dan wel bij verzet, neergelegd. Dit heeft dusdanigen indruk op de Doehian-groep gemaakt, dat een groot deel zich in de ontoegankelijke binnenlanden terugtrok en zich slechts met de grootste moeite liet registreeren. Jarenlang heeft men met deze kwestie gesukkeld, totdat het Koloniaal Verslag van 1921/1922 kon melden, dat een der rondzwervende hoofden zich vrijwillig bij het bestuur gemeld had. Als men echter over een volledig overzicht dezer geschiedenis beschikt, blijkt daaruit dat onschuldige bergbewoners jarenlang op onbarmhartige manier zijn opgejaagd als wilde dieren; vooral eenige lagere 
militaire commandanten hebben zich op weinig fraaie wijze gedragen. Het gevolg van een en ander is geweest, dat een deel der mian Doehian, zich de Kohoemamahon noemende, tot in 1938 niet geregistreerd was en zich steeds afzijdig hield van het bestuur.

Het voorval van 1908, de arrestatie en de dood van eenige der vooraanstaande hoofden der mian Doehian, wordt bezongen in een merkwaardig product der Indonesische literatuur, de "Koloi talenga" (madi: de zang der hoofden), waarin de tragische dood der talenga wordt verhaald; erger is, dat in het gedicht (de auteur is een mian Doehian geweest, genaamd Ligis) woede en haat merkbaar zijn, en dat het grootste deel der mian Doehian thans nog met wantrouwen jegens het Nederlandsche bestuur vervuld is. De "Koloi talenga" werd door Tangkilisan op een tournee naar Doehian genoteerd, nadat hij na vele weken het vertrouwen van eenige ouden had kunnen winnen.

Overigens is de vestiging van het Nederlandsch gezag zonder bloedvergieten tot stand gekomen. 


\section{HOOFDSTUK VII.}

\section{Verwantschapsrecht.}

Pijnlijk doet zich het gebrek aan gegevens in deze materie voelen; we bezitten er slechts weinige en gebrekkige. Voor zoover deze licht werpen op de door Ter Haar aangegeven aspecten van het verwantschapsrecht ${ }^{1}$ ) zullen ze worden genoemd; doch hiermee is tevens gezegd dat dit terrein nog grootendeels braak ligt en dat nieuwe gezichtspunten, wellicht verkregen na degelijk ethnologisch onderzoek, allicht tot andere conclusies zullen voeren.

\section{De verhouding van het kind tot zijn ouders.}

Uit den Archipel geeft Kruyt het merkwaardige dat het eerste kind gerekend wordt te zijn van den vader, het tweede van de moeder, de overigen van vader èn moeder tezamen ${ }^{2}$ ) (dit laatste dus in tegenstelling tot de Boegineesche gewoonten) ${ }^{3}$ ). Het is daarbij echter mijn indruk dat Kruyt's mededeeling meer speciaal voor West-Peling geldt. Nader onderzoek zal moeten aantoonen hoe het dan wel op de rest van het eiland en verder in den Archipel is, en wat de oorzaak van deze eigenaardigheid kan zijn. Overigens bezitten we noch van den Vogelkop, noch van de rest van den Vaste-Wal eenig gegeven dat hiermee overeenstemt.

Betreffende de positie van het buiten echt verwekte kind moge worden verwezen naar paragraaf 1 van hoofdstuk VIII. (Huwelijksrecht).

Voor naamgeving zie men paragraaf 3 van hoofdstuk IV (Individuen); daaruit blijkt dat zoowel vader als moeder naar het kind genoemd worden door het gebruik van tektonymische namen; verder, dat het zelden de ouders zelve zijn die den naam geven.

Zooals bij vele Indonesische volken nemen ook hier tweelingen een bijzondere positie in. In den Archipel is men niet erg op zijn gemak

1) Ter Haar, Beginselen, blz. 141/142.

2) Kruyt, Banggaische Studiën, blz. 26.

3) Van Vollenhoven, Adatrecht I, blz. 376. 
als er een tweeling (aki : paoe pin $(g) g a$ ) geboren wordt; men meent dat uit zoo iets onheil moet voortkomen ${ }^{4}$ ). Vooral een paar kinderen van verschillend geslacht is omineus; men denkt daarbij vermoedelijk aan incest. Algemeen is het in den Archipel gewoonte een der twee kinderen, meestal het laatstgeborene, aan iemand anders ter opvoeding te geven; de vrouw die dit kind tot zich neemt, de pleegmoeder dus, mag echter geen tante van het kind zijn; hiermee bereikt men, dat de kinderen niet meer broer en zuster zijn, magisch gedacht. Het is niet nader gespecificeerd of dit verbod geldt voor moederszuster, doch ten gevolge van het classificatorische verwantschapsstelsel (zie volgende paragraaf) is dit wel waarschijnlijk; moederszuster toch wordt als moeder beschouwd. In dit verband is het dus niet zeker of genoemd verbod zich ook uitstrekt tot vaderszuster, of de vrouw van vaders- of moedersbroer.

Kruyt vermeldt niet de verdere rechtsgevolgen aan deze kindsoverdracht verbonden; het is nl. niet duidelijk of de banden met de biologische ouders geheel worden verbroken, en wat de consequenties voor huwelijks- en erfrecht zijn.

Een ander voorbeeld van de verbreking der moeder-kindverhouding geeft $\mathrm{Kruyt}^{5}$ ) in het geval dat eenige kinderen kort na de geboorte overleden zijn en de moeder dan, als ze merkt weer zwanger te zijn, belooft haar kind aan een ander, b.v. haar zuster te zullen geven (magische keering van onheil); merkwaardig is dat hier juist moederszuster, de als moeder beschouwde dus, blijkbaar preferentie geniet.

$\mathrm{Na}$ de geboorte heeft dan een duidelijke contante handeling plaats, waarbij de pleegmoeder een zeker aantal voorwerpen (pinangnoten, sirihvruchten, borden en bepaalde knollen), van alle zeven stuks en alle magisch sterke goederen, aan de lijfelijke moeder geeft tegen overdracht van het kind; zoo wordt dus het magisch evenwicht niet verbroken. Het is daarbij natuurlijk mogelijk dat de pleegmoeder niet zelf het kind kan voeden (b.v. omdat ze niet zelf een zuigeling heeft); dan mag de biologische moeder wel haar kind komen zoogen in het huis der pleegmoeder, doch het mag niet meegenomen worden naar haar huis. Een dergelijk kind heet in het aki paoe toebo. Het wordt verder geheel als een eigen kind der pleegmoeder beschouwd als deze tenminste een tante is, want het mag, groot geworden, niet met haar

4) Kruyt, Banggaische Studiën, blz. 46; verg. ook F. D. E. van Ossenbruggen, Primitieve denken, blz. 314.

5) Kruyt, Banggaische Studiën, blz. 42. 
kinderen huwen; deze, neven en nichten dus, worden als broers en zusters beschouwd.

Weliswaar maakt Kruyt geen scherp verschil tusschen pleegkind en aangenomen (adoptief) kind, doch ik meen dit onderscheid wel te mogen maken (verg. par. 4).

\section{De positie van het kind in het sociale stelsel.}

Willen we dit punt onderzoeken, dan dienen we eerst te weten wat dit stelsel inhoudt. Vooropgesteld dient te worden dat een modern ethnologisch onderzoek van deze streken ontbreekt. Kruyt gebruikt wel de woorden Lingketing- en Baloa-clan, doch niet in de beteekenis welke daaraan thans gehecht wordt ${ }^{6}$ ). Of we de enge definitie van Van Wouden ${ }^{7}$ ) volgen, dan wel ons aansluiten bij de ruimere opvatting van Coolhaas in zijn artikel over de Manggarai ${ }^{8}$ ), bij beiden dient de clan toch te zijn een traditioneele unilaterale verwantengroep; en het is m.i. te bezien of daar thans nog iets van resteert, zoo het in oude tijden al bestaan heeft. (Wel noemde Pater van den Bergh M.S.C. eenige vage aanduidingen van totemisme in Peling, doch zij zijn te onduidelijk en te weinig onderzocht om daaruit eenige conclusies te kunnen trekken).

Kruyt spreekt in de eerste plaats van gezinnen, waar hij mededeelt dat de band tusschen deze groepen vrij los was ${ }^{9}$ ). Doch hij vervolgt dan dat elke familie een eenheid vormde, waarbij hij met familie aanduidt een verzameling van naaste bloedverwanten. Een dergelijke familie-eenheid sloot zich nauw aaneen, moest zichzelf verdedigen tegen andere en was ook in de dagelijksche aangelegenheden op zichzelf aangewezen. Het is echter niet duidelijk of in deze mededeeling een tegenstelling tusschen gezin eenerzijds, familie anderzijds wordt gelegd. Of bedoelt Kruyt met familie de ruimere verwantenkring, met een leelijk germanisme in de literatuur wel groot-familie genoemd, en waarvoor we de begrippen bense en tompoek stelden (blz. 55). Voor Lingketing zegt hij dat elke familie in uitgebreiden zin zijn pilogot of stamvader heeft, en omdat elke familie in uitgebrieden zin één dorp bewoont, heeft ieder dorp ook

6) Kruyt, To Loinang, blz. 402, 403, 446, 455, 460.

7) Van Wouden, Sociale structuurtypen in de Groote Oost, blz. 5.

8) Tijdschrift Kon. Aardr. Genootschap 2e reeks deel LIX no. 3 (Mei 1942),

blz. 338 noot 51 .

9) Kruyt, Bewoners, blz. 71 . 
zijn eigen pilogot ${ }^{10}$ ). In Baloa kent men echter naast den stamvader der hoofden, hier ook pilogot geheeten, nog den stamvader van ieder gezin, bochake geheeten ${ }^{11}$ ). Hieruit kunnen we dus een tegenstelling vinden tusschen familie in uitgebreiden zin (tompoek) en gezin, verzameling van allernaaste bloedverwanten, waarvan de leden meestal hoogstens drie generaties omvatten.

De onzekerheid voor den Banggai-archipel neemt toe als we do beschrijving van het pokidoni lezen ${ }^{\mathbf{1 2}}$ ). Dit is het afzweren van een familielid bij eede, bekrachtigd door een symbolische handeling, nl. het doorhakken van de bamboevuurtang (aki: patol pakamot): beide partijen houden elk een arm van de tang vast, een derde hakt deze door. Doch als Kruyt hieraan toevoegt: „De vuurtang is het symbool „van het huisgezin, de familie” weten we niet of hij familie met huisgezin gelijkstelt.

Op bladzijde 10 kwamen de West-Pelingsche huisgoden, pilogot, reeds ter sprake. Voor het verwantschapsrecht is van belang, dat bij een huwelijk zoowel aan den pilogot van den man als aan dien van de vrouw kennis wordt gegeven van de voorgenomen verbintenis; als echter de vrouw bij het huwelijk de ouderlijke woning verlaat blijft de pilogot, gevormd door haar voorouders, daar achter. De zoon uit dat huwelijk vereert echter zoowel de pilogot van zijns vaders voorzaten als die van zijn moeder. Men vereert op deze wijze de pilogot van verschillende families in één huis; toch worden ze allen als één persoon gedacht en toegesproken. Deze verschillende pilogot verblijven allen gewoonlijk in den middenpaal van het huis ${ }^{13}$ ).

In Oostelijk-Peling heeft pilogot een ruimer beteekenis gekregen; men onderscheidt daar familie-pilogot en clan-pilogot; deze laatste beschreven we op blz. 11 als balakat ${ }^{14}$ ).

We kunnen hierin dus eenigszins een parallel vinden met de verhouding tusschen de boehake van de Baloa-clan (Doehian-groep) en de pilogot van de Lingketingers. Boehake in Doehian en pilogot in West-Peling staan beide in betrekking tot het gezin door vereering van den stamvader daarvan; na uitbreiding eventueel kunnen zij in verband staan tot den oervader van de familie. Ik veronderstel dat zij hoogstens door alle leden van een zelfde familiegroep vereerd

10) Kruyt, To Loinang, blz. 401.

11) Kruyt, To Loinang, blz. 405.

12) Kruyt, Bewoners, blz. 255.

13) Kruyt, Pilogot, blz. 118, 119.

14) Kruyt, Pilogot, blz. 122/123. 
kunnen worden. De pilogot der Lingketingers en de balakat van OostPeling houdt ten nauwste verband met den voorvader van het hoofdengeslacht, en uit dien hoofde is hij het magisch centrum van de groep waarover het hoofdengeslacht gesteld is, de streekgemeenschap.

Interessant is nog dat van de vier West-Pelingsche pilogot er drie in verhouding staan tot den stamvader, en één tot de oermoeder. Van het eerstgenoemde drietal staan er twee in verband met de geboorte van dien oervader terwijl de derde zijn leven zelf is. Algemeen bekend is dat men vruchtwater en nageboorte jongeren en ouderen broer van van het geboren kind noemt; in West-Peling leveren deze onderscheidenlijk de pilogot Mboli en Pali.

Overigens moeten we hier blijkbaar familie steeds aanzienlijk uitgebreider opvatten dan Van Wouden dit begrip defineerde; bij dezen laatsten is familie beperkt tot de naaste verwanten, broers, zusters, ouders. Als Kruyt echter schrijft dat van een familie, die te groot geworden is, kinderen en kleinkinderen wegtrekken om elders landerijen te gaan ontginnen, dan blijkt dit begrip familie uitgebreider te zijn dan door Van Wouden aangegeven ${ }^{15}$ ). Soms wordt met familie een groepeering bedoeld in den zin van bense; Kruyt zegt nl. dat het nu en dan noodig is een groot of ferfeest te vieren met de bedoeling het leven, de gezondheid van de heele familie te versterken; hij geeft dan een beschrijving van dit batong-feest (West-Peling; biok: Oost-Peling; balibang: eiland Banggai) ${ }^{16}$ ), waaruit duidelijk blijkt dat dit niet door één gezin, bezwaarlijk ook tezamen met de naaste verwanten, doch veel eerder door de levende leden eener bense gehouden kan worden.

In den Archipel bestaat binnen het kader van de familie (in uitgebreiden zin) geen verschil in de verhouding van het kind tot de verwantengroep van vader of van moeder. We hebben hier dan ook het ouderrechtelijk stelsel. Daarbij zal in het volgende hoofdstuk blijken dat dit ouderrechtelijk stelsel gehandhaafd blijft onder een practijk van huwen met bensegenooten, zelden met basaloschapsgenooten uit een andere bense, en zeer zelden met vreemden.

In samenhang met deze tweezijdige verwantenordening vinden we sterke classificatorische verwantschapswaardeering; moederszusters zijn moeders, vadersbroers zijn vaders voor het kind. De Banggaier ziet de familieverhoudingen in generaties; de gezinnen die naar alle kanten met elkaar gelieerd zijn, vormen zoo tezamen een sterke een-

15) Kruyt, Bewoners, blz. 71.

16) Kruyt, Pilogot, blz. 131. 
heid, door het spraakgebruik nog geaccentueerd; dit is de samenbundelende kracht in de bense.

Een van Pater van den Bergh M.S.C. verkregen voorbeeld moge hier gegeven worden. Stel dat er vijf zusters zijn en vijf broers, en dat de middelste der broers huwt met de middelste der zusters. Als dit paar nu een kind krijgt, zijn moederszusters allen zijn moeders, vadersbroers allen zijn vaders, doch in de benamingen komt verschil in waardeering uit. De oudste tante zal door dit kind geheeten worden ko tinanggoe babasal (aki: mijn groote moeder), de tweede $k o$ tinanggoe tanga (aki: mijn middelste moeder); de derde zuster, de echte moeder dus, is ko tinanggoe of ko tinanggoe toeoe (aki : mijn echte moeder); de vierde der zusters is ko tinanggoe paocno (aki: mijn kleine moeder), de jongste tante is ko tianggoe pioto (aki: mijn jongste moeder). De zelfde waardeering vinden we bij vaders broers: het kind zal spreken over ko tamanggoe babasal, ko tamanggoe tanga, ko tamanggoe toeoe, ko tamanggoe paoeno en ko tamanggoe pioto. Als verzamelnaam spreekt het kind, doelende op deze tantes, over zijn pinotina (aki: de tot moeder gemaakte(n), gewordene(n)) en over dergelijke ooms als over zijn pinotama (aki: de tot vader gemaakte(n), gewordene(n)).

Kruyt geeft voor vader ook tama (het stamwoord van tamanggoe), in aanspraak mama; voor moeder geeft hij tina (vergelijk tinanggoe), in aanspraak ook nene. Vaders en moeders broers zijn bij hem pipi, vaders en moeders zusters kaka (Oost-Peling) of tete (West-Peling); alles aki ${ }^{17}$ ). Is deze mededeeling wel juist? Het ligt voor de hand dat vadersbroers (,,de tot vader gemaakten”) en moederszusters (,,de tot moeder gemaakten") in andere verhouding tot het kind staan dan vaderszusters, moedersbroers, of andere personen die wij algemeen als oom of tante aanduiden, en die niet als vader, resp. moeder door het kind kunnen worden beschouwd. Het zou mij dan ook niet verwonderen dat de eerste categorie b.v. met tamanggoe en tinanggoe, de tweede daarentegen met pipi en kaka (tete) wordt aangeduid.

Door dit stelsel van classificatorische verwantschapswaardeering kan men de generatie der ouders tot die der kinderen in paoe-verhouding zien (aki : paoe $=$ kind); een dergelijke verhouding bestaat ook tusschen de generatie der grootouders en die der kleinkinderen, welke de toemboe-verhouding oplevert (aki: toemboe = kleinkind): alle oudtantes en oudooms worden als grootouders beschouwd. In

17) Kruyt, Banggaische Studiën, blz. 32 . 
aanspraak is grootvader taoea, grootmoeder tate; beide aki. Het i; mij niet bekend of er nog verschil wordt gemaakt tusschen grootouders van moeders- en van vaderszijde.

In zijn nota noemt Pater van den Bergh M.S.C. ook nog de silaboverhouding; hij meent dat deze met de positie van het stiefkind is weer te geven, doch het lijkt mij dat deze opvatting in zooverre uitbreiding behoeft dat we ,stiefkind" wederom classificatorisch hebben te zien. Nemen we b.v. aan dat een man huwt met een weduwe die uit haar eerste huwelijk een dochter heeft, terwijl hijzelf bij die vrouw nog twee kinderen verwekt. Dan bestaat er tusschen dezen man en die twee kinderen de paoe-, echter tusschen hem en de dochter zijner vrouw de silabo-verhouding. Doch ook met silabo wordt aangegeven de relatie die ontstaat tusschen een man en de dochter van zijn vrouws zuster, welke ook als stiefkind wordt aangemerkt. We kunnen dit alleen verklaren door den nadruk te leggen op het classificatorisch denken, daar het meisje haar moeders zuster als moeder ziet (pinotina, de tot moeder gewordene), en dat daardoor de man van die tot moeder geworden vrouw in een bepaalde verhouding tot het meisje komt te staan, die niet is als die van lijfelijk oom (of tante), doch welke alleen verkregen wordt door het huwelijk der als moeder (vader) beschouwde. Indien de silabo-verhouding ook ontstaat tusschen dezen man en den zoon zijner schoonzuster (hooger was steeds sprake van een dochter) waarover echter geen gegevens voorhanden zijn, zouden we de silabo kunnen definieeren als de paoeverhouding tot aangehuwden, classificatorisch bezien.

Het aki kent verschillende termen voor de afstammelingen van één ouderpaar. Kinderen van een dergelijk paar zijn elkaars oetoes; hun relatie wordt aangegeven met montoloetoes (aki: oetoes zijn). Hun kinderen, de kleinkinderen van het eerste ouderpaar dus, zijn van elkaar montolidan soesoe. De derde generatie (de achterkleinkinderen) zijn elkaars montolokoea (bij Kruyt mantolidan soesoe; dit zal wel op een vergissing berusten, daar hij de vorige generatie niet noemt). Hun kinderen staan in verhouding tot elkaar uitgedrukt door montolidan loea loeoenggon, en daarvan de kinderen zijn elkaars montolidan toloe loeoenggon ${ }^{18}$ ).

Van den Vogelkop weten we dat dawok in het sian de aanduiding voor zwager is; verder kent men hier ook de silabo-verhouding; Adriani vertaalt silabo met stiefzoon, stiefouder ${ }^{19}$ ).

18) Nota van den Bergh; Kruyt, Banggaische Studiën, blz. 32.

19) Adriani-Kruyt, Bare's III, blz. 276, 277. 
Bij de madi-sprekers noemt men anompolee de voorvaderen. Moeder is tina, in aanspraak nene; vader heet toema, in aanspraak mama'. Grootvader en grootmoeder noemt men onderscheidenlijk kai' en kele. Broer of zuster duidt men aan met oetoes, ook in aanspraak (kita to'oetoes-oetoes $=$ gij broeders); met moto'oetoes duidt men aan broer of zuster (van elkaar) zijn. Hoe nauw men zich de verwantschapsbanden denkt blijkt wel hieruit dat voor het begrip: familic van elkaar zijn, in het madi gebruikt wordt: moto'oetoes-oetoes, hetgeen dus eigenlijk beteekent: broers (zusters) zijn.

Mannen zijn tomomoane, vrouwen heeten tobobooene (stam onderscheidenlijk moane en booene); tominsan moane, tominsan booene beteekent neef en nicht ${ }^{20}$ ).

Het oudste kind heet toempe, het middelste pantonga en het jongste tampaloei; jongens en meisjes vormen echter aparte reeksen, zoodat men spreekt van toempe moane (de eerstgeboren jongen) en toempe booene (het eerstgeboren meisje); alles uiteraard madi ${ }^{\mathbf{2 1}}$ ).

\section{Kindaanneming.}

Mogen we de terminologie vertrouwen, dan is adoptie in den Archipel bekend; dit geschiedt vooral door diegenen die zelf geen kinderen hebben ${ }^{22}$ ).

We mogen dan verschil maken met het pleegkind dat in paragraaf 1 werd besproken, waarbij een kind aan een ander ouderpaar wordt gegeven om het zoodoende in leven te houden indien tevoren eenige kinderen achter elkaar zijn overleden. Dit dus in tegenstelling tot kindsoverdracht aan een echtpaar dat zelf kinderloos is. In dergelijk geval is het dus mogelijk ook het kind van een niet-bloedverwant te adopteeren. Hierbij heeft wederom een duidelijke contante handeling plaats: de adoptief ouders geven aan de biologische ouders klapperboomen, koperen borden e.d. (sterk magische goederen); deze geschenken heeten palali (aki), d.i. voor het uithalen of overbrengen van het eene gezin in het andere. Het is overigens geen gezinszaak, want aan de voorouders der adopteerenden wordt kennis gegeven door een offer aan de pilogot te brengen; deze kennisgeving geschiedt in den vorm zooals deze pleegt te geschieden bij gezinsuitbreiding door geboorte. Hoe echter de sociale openbaarheid der adoptie geregeld is wordt niet vermeld.

20) E. Gobee, Feestbundel I, blz. 190.

21) Kruyt, To Loinang, blz. 476.

2a) Kruyt, Banggaische Studiën, blz. 59. 
Het schijnt mogelijk te zijn, dat een aangenomen kind naar zijn biologische ouders terugkeert; Kruyt is niet overduidelijk want hij maakt geen verschil tusschen pleeg- en adoptiefouders ${ }^{23}$ ). Doch hij vermeldt wel dat in dergelijk geval de biologische ouders aan de pleegouders alle kosten moeten vergoeden die gemaakt zijn voor het brengen van offers in tijden dat het kind ziek was; deze worden globaal berekend op vier tot zes koperen borden. Het aangenomen kind is erfgerechtigd; blijft het dit ook na terugkeer tot zijn werkelijke ouders?

Uit Loinang wordt eveneens een soort adoptie gemeld, doch of ficieele adoptie kent men niet. Het zijn vaak verwanten die op deze wijze een ander kind opvoeden. De dorpsgenooten beschouwen het aangenomen kind en de kinderen der pleegouders als broer en zuster ${ }^{24}$ ).

Een interessant geval van adoptie maakte ik mede in mijn bestuurspractijk te Loewoek. Een Minahassisch, zoonloos echtpaar adopteerde het onwettig mannelijk kind van een Minahassisch meisje. De ongehuwde moeder verklaarde bij acte geheel afstand te doen van haar kind, het Minahassisch echtpaar verklaarde bij tweede acte het jongetje geheel als hun kind aan te nemen en dezelfde rechten als hun eigen (vrouwelijke) kinderen te zullen geven. Of de Minahassische gemeenschap te Loewoek ingelicht werd en hoe dit dan wel geschiedde, is mij niet bekend. Het betreft hier bij deze Minahassers duidelijk niet een geval van het sluiten van een verzorgingscontract, doch adoptie ter verkrijging van mannelijk oir.

23) Van adoptie in den strengen zin kan alleen sprake zijn, als het kind elke band met zijn familie absoluut, dus voorgoed, verbreekt; anders hebben we met pleegouderschap te maken (fosterage). Door adoptie wordt (kunstmatige) familievoortzetting beoogd. Nader onderzoek moet uitmaken of hier adoptie naast fosterage bestaat.

24) Kruyt, To Loinang, blz. 471. 


\section{HOOFDSTUK VIII.}

\section{Huwelijksrecht.}

Voor dit hoofdstuk zijn we uitsluitend angewezen op eenige artikelen van Dr. Alb. C. Kruyt ${ }^{1}$ ) en de nog niet gepubliceerde nota van Pater van den Bergh M.S.C.. Deze laatste behandelt meer speciaal Oost-Pelingsche verhoudingen, terwijl Kruyt veel West-Pelingsche elementen heeft verwerkt naast algemeen Banggaische.

Het ongunstig oordeel over de Banggaische bevolking opgenomen in het artikel van Bosscher en Mathijsen, als zouden de lieden van Peling geen banden van bloedverwantschap of huwelijk kennen, kunnen we rustig ter zijde schuiven; De Clerq becritiseert deze mededeelingen reeds geheel ten rechte, terwijl de hooger aangegeven literatuur ons een heel ander beeld geeft ${ }^{2}$ ).

1. Vóór-huwelijksche verhoudingen. Huwelijksverboden in bepaalde bloedverwantschappen. Voorkeurhuwelijk op bloedverwantschap gebaseerd.

De verhouding van de seksen voor het huwelijk is in den Archipel het zuiverst; huwelijksomgang voor het huwelijk (aki: pookan doi tongkoeloeng; poolilinggon; poolililinggon) ${ }^{3}$ ) is verboden; het moreel bewustzijn der bevolking verzet er zich tegen. Op den Vogelkop wordt echter gemeld dat een meisje vaak buiten echt zwanger wordt, omdat de omgang tusschen jongens en meisjes zoo vrij is; dergelijk

1) Alb. C. Kruyt, Banggaische Studiën, blz. 13-38; 46-47; Van leven en sterven, blz. 57-64; To Loinang, blz. 446-461; 469.

2) Bosscher en Mathijsen, Schetsen, blz. 97. De Clercq, Ternate, blz. 131 geeft een heel wat beter oordeel: „De ongunstige schets van de Alfoeren in het „meergenoemde tijdschriftartikel gegeven, is zeker niet van overdrijving vrij te "pleiten, en geheel onwaar is de daar geuite bewering, alsof zij geen onderlinge „,betrekkingen en bloedverwantschap of huwelijk zouden kennen. Integendeel "hebben zij gewoonlijk één vrouw, op de gewone Paiynesische wijze door be„taling van een zekeren bruidschat verkregen; terwijl twisten, die tot moord en „doodslag aanleiding geven, alleen ontstaan door de zwakke sekse, daar zij "anders rustig leven, .... enz."

3) Nota van den Bergh. 
vrij verkeer is vaak het voorspel tot een verloving $\left.{ }^{4}\right)$. Ook in Loinang is het gewoonte dat de jongeling zich daadwerkelijk van de genegenheid van zijn geliefde overtuigt door haar 's nachts te bezoeken; mag het meisje hem lijden dan staat ze toe dat hij bij haar blijft slapen. De jongeling zorgt echter voor het aanbreken van den dag te zijn verdwenen ${ }^{5}$ ).

Waar speciaal in den Archipel zoo scherp op vóór-huwelijksch verkeer gereageerd wordt kent men hier bij overtreding daarvan ook speciale regels. Zoo kan de familie van het meisje in dergelijk geval den bruidschat hoog opdrijven, verstoord als de belanghebbenden (de ouders en de met hen op één lijn staanden; zie blz. 190) zijn over de oneer hun dochter aangedaan. Eertijds had daarbij wel zelfrechtverschaffing plaats door de familie van het meisje: deze roofde uit de woning van den jongen en diens familie alles wat ze maar krijgen kon, het vee daarbij vaak doodende. De benadeelde familieleden hadden verhaal op den schuldigen jongen, die het aan hen moest vergoeden. Deze zelfrechtverschaffing heeft thans plaats gemaakt voor prijsopdrijving van den bruidschat. Bovendien vraagt in OostPeling de familie van het meisje een verzoeningsgeschenk (aki = pinda), t.w. een te offeren geit. In West-Peling is die pinda steeds bij het huwelijksgeschenk aanwezig; het is echter niet bekend of beide begrippen en gebruiken elkaar dekken. Zoo ja, dan zou men welhaast vermoeden dat in West-Peling steeds omgang voor het huwelijk heeft plaats gehad, hetgeen strijdt met het in den Archipel gebruikelijke veroordeelen daarvan.

Komt het niet tot een huwelijk (en kan er dus ook geen sprake zijn van het opdrijven van den bruidschat), dan is de schuldige verplicht een boete (aki: pemeal) te betalen; deze boete wordt vastgesteld in een familieraad door de zelfde oudsten der familie, die in normale gevallen bij het vaststellen van den bruidschat medebeslissen. De vaststelling geschiedt na onderling overleg met den schuldige, eveneens vergezeld van zijn familie. Van deze zijde tracht men tot een zoo laag mogelijke pemeal te komen. Ten slotte komt deze tot stand tusschen 6 en 15 kandari (verg. par. 3), dat is ongeveer $2 / 3$ deel van den bruidschat. De pemeal komt geheel aan de meisjesfamilie, t.w.

4) Kruyt, Leven en sterven, blz. 59. Hij gebruikt ten aanzien van Balantak in dezen den verleden tijd waar hij zegt dat de huwelijksadat na den overgang tot het Christendom veranderd is; ik behoud echter den tegenwoordigen tijd.

5) Kruyt, To Loinang, blz. 448/449. 
$1 / 3$ deel aan haar vader, $1 / 3$ deel aan haar moeder, $1 / \mathbf{6}$ deel aan vaders familie en $1 / 6$ deel aan moeders familie ${ }^{6}$ ).

Als een meisje den omgang met een jongen zoekt is dit een reden voor haar ouders om zich beschaamd te voelen; één harer ooms leest haar de les en wijst haar op het verkeerde van haar gedrag. Maar ook de ouders van den jongen apprecieeren het niet wegens het gevaar van vóór-huwelijkschen omgang en de daarmee verbonden boete ${ }^{6}$ ).

Heeft buitenechtelijk verkeer in den Archipel gevolgen, dan wordt de vader van de ongeboren vrucht gedwongen met het meisje te huwen (aki : pobaba = samen gaan, dus: huwen). Weigert hij, dan moet hij een boete betalen (aki: pobean); ook de weigering zelve heet pobean. In den ouden tijd kon de schuldige man ter hoofdplaats Banggai zelfs lijfstraffelijk gedwongen worden met het meisje te huwen door hem zoo lang in een blok te sluiten tot hij toestemde. Ook bestraffing met rotanslagen of boete bij weigering te huwen is bekend. Ontkende de man het meisje zwanger te hebben gemaakt dan moest een godsoordeel zijn onschuld uitwijzen (zie blz. 157 v.).

Het opwekken van abortus en het dooden van een voldragen vrucht komen beide op de eilanden voor; dit zal meestal geschieden indien het samenzijn van man en vrouw bloedschennig was (hetgeen bij klachte van het meisje uit zou komen). In Balantak heet het buitenechtelijk kind anak boele ${ }^{8}$ ); de ongehuwde moeder brengt het meestal op een afgelegen plek ter wereld, alwaar zij het achterlaat. In Loinang gebruikt men het woord tianan (madi) voor zwangerschap buiten echt; men schaamt er zich over ${ }^{9}$ ). Ook hier komen het opwekken van abortus en de hooger gemelde motieven voor; alles geschiedt in het diepste geheim. Wanneer een ongehuwd man een meisje zwanger maakt kunnen haar ouders zooveel bruidschat vragen als ze willen; het staat dan aan den man of hij het meisje wil huwen of niet, doch de geëischte som moet hij betalen; deze draagt hier dus het karakter van een boete.

Door het geheele landschap gelden huwelijksverboden, gegrond op te nauwe bloedverwantschap; dit laatste in uitgebreiden zin, zoodat zoowel de stiefkind-, alsook de silabo-verhouding (zie blz. 191) en de zoogbroer-zoogzusterverhouding hieronder worden gerekend. Deze verboden rusten dus op den angst voor bloedschande.

6) Nota van den Bergh.

7) Kruyt, Banggaische Studiën, blz. 42/43.

8) Kruyt, Leven en sterven, blz. 66.

9) Kruyt, To Loinang, blz. 460. 
In den Archipel kent men twee woorden ter aanduiding van het begrip bloedschande, nl. sele en sompo, het eerste nog onderscheiden in sele babasal en sele poipoisik, (aki: babasal = groot; poipoisik $=$ klein). De onderscheiding tusschen deze begrippen is niet duidelijk; slechts moge vastgelegd worden dat sele babasal nimmer, sele poipoisik en sompo eventueel wèl geaccepteerd kunnen worden ${ }^{10}$ ).

Sele babasal is huwelijksomgang tusschen ouder en kind, grootouder en kleinkind, tusschen broer en zuster, tusschen oom en oomzegster, tante en tantezegger. Een stiefkind wordt als eigen kind beschouwd. Een eigenaardige, en in verband met het op blz. 186 medegedeelde zeer ongeloofwaardige, restrictie op het huwelijk tusschen broer en zuster wordt gemeld eertijds te Banggai bekend te zijn geweest: indien een tweeling van verschillend geslacht geboren werd, prefereerde men deze broer en zuster met elkaar in den echt te vereenigen. Men dacht dat dit paar reeds in de moederschoot door pilogot was vereenigd; een huwelijk tusschen beiden was dus niets anders dan een voortzetting daarvan. Het moet indertijd meermalen zijn voorgekomen, mits men slechts gezorgd had dat beide kinderen door verschillende vrouwen gezoogd werden. Deze laatste bepaling wijst dus weer op het bekende zoogbroeder- en zoogzusterschap, dat blijkbaar eveneens huwelijksbeletsel is ${ }^{11}$ ). Overigens weet men elders in het landschap niets van dit eigenaardige (bloedschennige) tweelinghuwelijk.

Op blz. 186 v. kwam reeds ter sprake dat een kind door zijn tante opgevoed, aan wie het ter verzorging was afgestaan, niet mag huwen met een der eigen kinderen dier tante, daar deze als broers en zusters van het aangenomen kind worden beschouwd.

Algemeen geldt de regel dat cousinhuwelijken ${ }^{12}$ ) mogelijk zijn, zonder onderscheid tusschen parallel- of crosscousins. Een eerste uitzondering hierop vormt de Mohammedaansche bevolking ter hoofdplaats Banggai, waar het gewoon crosscousinhuwelijk niet geoorloofd is. Verder acht men voornamelijk in Oost-Peling elk cousinhuwelijk „warm”, terwijl het als sele poipoisik wordt aangemerkt. Het kwaad hierdoor opgewekt kan echter door een offer worden teniet gedaan; dit heet potatak sele (aki: de bloedschande uit elkaar halen, krachteloos maken). $\mathrm{Na}$ afloop van deze handeling worden in sommige

10) Nota van den Bergh; Kruyt, Banggaische Studiën, blz. 15/16.

11) Kruyt, Banggaische Studiën, blz. 90 .

12) Terminologie volgens van Wouden, Sociale structuurtypen in de Groote Oost, blz. 7. 
streken de incestueuzen als gehuwd beschouwd, doch in andere streken worden ze gescheiden, terwijl de gemeenschap het blijkbaar niet kon accepteeren als zij elkaar dan naderhand (weer) opzochten. In WestPeling ziet men echter het cousinhuwelijk juist gaarne; men gaf daarbij aan Kruyt als toelichting op dat de bruidschat dan gering zou zijn ${ }^{13}$ ), doch in par. 3 , waar het verzamelen van de bruidschat behandeld zal worden, zal blijken dat dit geen argument kan zijn.

Generatieverschil tusschen twee personen, aan elkaar verwant doch verder dan cousins, doet het huwelijk ongewenscht zijn, indien nl. de vrouw van een oudere generatie is dan de man; gebeurt iets dergelijks toch, dan is dit sompo, doch een eventueel huwelijk is aanvaardbaar. Van een tweetal personen die dus b.v. in cousinverhouding tot elkaar staan, mag de zoon van den een huwen met de kleindochter van den ander; een huwelijk van kleinzoon van den een met dochter van den ander is echter sompo ${ }^{14}$ ).

In verdere verwantschap is het huwelijk toegestaan b.v. tusschen achterneef en achternicht (cousinskinderen). Een restrictie hierop wordt uit Gonggong (eiland Banggai) gemeld: hier zou men een dergelijk huwelijk niet gaarne zien, daar men gelooft dat een dergelijk paar niet lang zal leven (aki : motolian baloe = verwantschap die het weduwnaar- c.q. weduweschap met zich brengt) ${ }^{15}$ ).

Het huwelijk van een weduwnaar met de zuster van zijn overleden vrouw, of met de dochter van die zuster (oomzegster) is eveneens sompo. De silabo-verhouding die tusschen hen bestaat (zie blz. 191) levert dus eveneens huwelijksbeletsel. Niet duidelijk is of een eventueel huwelijk aanvaardbaar kan worden gemaakt.

Twee broers mogen met twee zusters huwen, mits de oudste broer huwt met de oudste zuster; voor deze huwelijksvorm kent men in het aki den term:poalakon ototong. Men denkt zich echter dat het tweede huwelijk onheil met zich kan voeren voor het eerste, en dat het eerste paar b.v. spoedig kan sterven. Er moet dan bij het tweede huwelijk een extra groot offer gebracht worden. Huwt de jongste van twee broers met de oudste van twee zusters, dan is dit sompo ${ }^{16}$ ).

Indien van een reeds gehuwd paar de man een zuster en de vrouw een broer bezit ziet men gaarne dat deze ook een paar zullen vormen;

13) Nota van den Bergh; Kruyt, Banggaische Studiën, blz. 14; 16-18.

14) Nota van den Bergh.

15) Kruyt, Banggaische Studiën, blz. 14/15.

16) Nota van den Bergh. 
een dergelijk kruishuwelijk heet bij Kruyt poala-(kon?) bangoen ${ }^{17}$ ), in de Nota van den Bergh poalakon manoek (beide aki). Van dergelijke huwelijken kan een zekere heilzame kracht uitgaan, want als het voorkomt dat van een reeds gehuwd paar de kinderen telkens jong sterven, dan zoekt men of er wellicht een zuster of nicht (cousin?) van den man is die met een broer of neef (cousin?) van de vrouw zou kunnen huwen. In dit tweede huwelijk wordt geen bruidschat betaald.

Men huwt bij voorkeur in dezelfde familiegroep, in ieder geval in dezelfde streekgemeenschap; verschijnt een jonge man van elders afkomstig, dan eischt men ook thans nog als regel dat hij zich vestigt in het dorp zijner aangebedene en daar aan zijn burgerlijke plichten voldoet. In den ouden tijd, toen de streekgemeenscha: pen nogr geïsoleerd waren, kwam het ook wel voor dat een jongc inan van elders naar de hand kwam dingen van een meisje; maar haar familie stond niet toe dat hij zijn vrouw na het huwelijk naa: zijn eigen streekgemeenschap meenam; in dergelijk geval werd zelfs bij de huwelijkssluiting bedongen dat het paar zich zou vestigen in de familiegroep van de bruid, matrilocaal dus.

Komt de man zijn belofte niet na, gaat hij te veel en te langdurig naar zijn eigen familiegroep, dan kan deze uithuizigheid reden tot echtscheiding zijn waarbij de vrouw de beleedigde partij is; zie verder par. 8. Het komt uiteraard ook voor dat de vrouw zeer gehecht is aan haar man en hem, tegen den wil harer familie, naar zijn streekgemeenschap volgt; de familie van de vrouw heeft zich er dan bij neer te leggen, want sanctie van die zijde bestaat niet; tevreden is zij echter niet. In het geval dat de man eerder komt te overlijden dan de vrouw, keert de weduwe (en eventueele kinderen) naar haar eigen familiegroep terug. Het komt zelfs voor dat de kinderen van zulk een paar later, al zijn ze reeds volwassen, zich gaan vestigen in de familiegroep hunner moeder. Bij voorkeur echter ter gelegenheid van hun huwelijk keeren de kinderen in de familiegroep hunner moeder terug. Dit zoeken van een bruid in de familiegroep der moeder kan dus zijn òf een terugkeeren tot haar familiegroep òf een definitief inburgeren van het tweede geslacht in die groep.

Op den Vogelkop ${ }^{18}$ ) heet bloedschande sele (sian); de verboden verwantschappen zijn dezelfde als in den Archipel. Overigens mogen slechts lieden van dezelfde generatie met elkaar huwen (dit

17) Kruyt, Banggaische Studiën, blz. 15 .

18) Kruyt, Leven en sterven, blz. 57-58. 
positieve gebod ontbreekt in den Archipel). Alle vormen van cousinhuwelijken zijn geoorloofd, eveneens het huwelijk tusschen een man en een vrouw, wier zuster resp. broer reeds een paar vormen (kruishuwelijk).

Lichte gevallen van bloedschande, zooals het huwen van lieden van verschillende generatie (doch niet in de verhouding van oom of tante tot resp. oomzegster of tantezegger), kunnen aanvaardbaar gemaakt worden, doch hiertoe is een of fer noodig, waarbij het hoofd, de tonggol b.v., in functie komt; men noemt de plechtigheid die dan volgt, monsimpot gogorong (sian: de keel beschermen; men denkt zich nl. als straf dat pilogot mola de schuldigen aan bloedschande de keel afsnijdt).

Gegevens betreffende de plaats waar de jonge man zijn bruid zoekt, ontbreken.

Op den Vaste-Wal is het begrip bloedschande bekend, doch in de literatuur is de term niet vermeld. De verboden verhoudingen zijn als elders, nl. die van ouder tot kind, (grootouder tot kleinkind?) broer en zuster, oom (tante) en oomzegster (tantezegger).

Van de mogelijke cousinhuwelijken is slechts het gewoon crosscousinhuwelijk niet geoorloofd (het huwelijk nl. van broerszoon met zustersdochter); dit verbod wordt zelfs uitgebreid tot de nakomelingen van deze in de derde generatie. Pas lieden uit de vierde generatie mogen eraan denken zich in het huwelijk met elkaar te begeven, en dan alleen nadat een ontzondigingsplechtigheid heeft plaats gehad; deze wordt niet door het hoofd doch door een priester geleid ${ }^{18}$ ).

Een huwelijk van twee broers met twee zusters is geoorloofd; in Baloa moet het laatst huwende paar aan het eerder gehuwde een geschenk geven. Dit is ook vereischt als een man huwt met een meisje waarvan de tante gehuwd is met des mans broer (m.i. zal dit niet vaak voorkomen wegens optreden van generatieverschil). Men vindt deze beide vormen van huwelijk tusschen twee broers en twee vrouwen, die eveneens familie van elkaar zijn, „warm”, want het verzoeningsgeschenk moet koel zijn ${ }^{\mathbf{1 9}}$ ).

Men geeft ook hier voorkeur aan het kruishuwelijk, van zuster en broer eenerzijds met broer en zuster anderzijds dus. Dit heet monsoesoele'an lai (Lingketing: tot elkaar wederkeeren) of montolosan (Doehian : met elkaar ruilen). Wijzen wellicht deze termen op

19) Kruyt, To Loinang, blz. 446, 447. 
eenzijdige verwantenordening in oorsprong? Wanneer de ouders van zulke paren overleden zijn blijft de bruidschat gewoonlijk achterwege (wijst dit erop dat de bruidschat van een vrouwelijke wees door haar broer in ontvangst wordt genomen?) ${ }^{\mathbf{1 0}}$ ).

Zoogbroer en zoogzuster mogen niet met elkaar huwen ${ }^{20}$ ).

De op blz. 191 genoemde, in Loinang voorkomende z.g. adoptie behoeft geen gevolgen ten aanzien van een eventueel huwelijksverbod tusschen het aangenomen kind en de kinderen der pleegouders te hebben, want als een huwelijk uit anderen hoofde niet verboden is (b.v. zoogbroer en zoogzuster) is een echtverbintenis mogelijk; maar het komt zelden voor daar de dorpsgenooten de kinderen als broers en zusters beschouwen ${ }^{21}$ ).

Onder paragraaf 7 (Meervrouwendom) zal vermeld worden dat het tegelijkertijd gehuwd zijn met twee zusters in Balantak verboden is, terwijl men het in Loinang een beleediging, de dorpsgemeenschap aangedaan, vindt. Uit den Archipel ontbreken hierover gegevens.

Voor de door aanhuwelijking verkregen banden beschikken we over eenige termen. Kruyt schrijft voor den Archipel ${ }^{22}$ ): „Zoowel „de schoonouders als de aangetrouwde kinderen heeten monianan. „De broers en zusters van mijn vrouw zijn daok. Mijn broers en „zusters zijn de soloiba mijner vrouw. De echtgenoot van mijns „vrouws zuster is mijn andalan”. In Loinang heet het ${ }^{23}$ ) : „Zoowel „schoonouders als schoonkinderen heeten monian. De broers en zusters „van de vrouw (van den man) zijn de dawok van den man (van de „vrouw). De echtgenooten van die broers en zusters zijn zijn (haar) „andalan”. Op den Vogelkop heet zwager ook dawok (zie blz. 191).

\section{De normale verloving en haar rechtsgevolgen.}

Verloofd zijn heet in den Archipel bandoloj (aki) ${ }^{24}$ ). Als een meisje ten huwelijk zal worden gevraagd gebeurt dit steeds door middel van een tusschenpersoon, broer, neef of vriend van den jongen man; ook een vrouw kan als zoodanig fungeeren. Een dergelijke huwelijksgezant heet tetean (aki: brug) of bobotokon (aki : bode; vergelijk blz.95). Het is niet verboden dat de jonge man zelf om de hand van zijn aangebedene gaat vragen, doch hij is bang een blauwtje te loopen, en laat het dus liever doen.

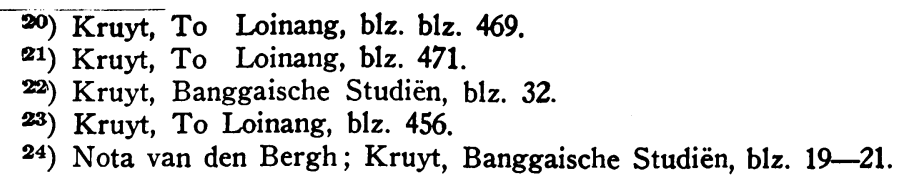


De bemiddelaar heeft een gevulde sirihdoos bij zich en tabak voor de ouders der bruid; hij legt dit geschenk voor hen neder en nu ontspint zich een gesprek waarbij de eerstgenoemde het doet voorkomen of hij land wil huren, terwijl de ouders beweren niet te weten dat $z \mathrm{ij}$ land te huur hebben; deze geven dan ten slotte tot antwoord dat de bemiddelaar het over een dag of vier, vijf wel zal vernemen of er land te huur is.

Tevoren heeft de tusschenpersoon echter reeds het meisje gepolst; hij laat nu, na beëindiging van het gesprek over landhuur, de voor het meisje medegenomen verlovingsgeschenken achter; deze heeten potinggoli (aki : wat dient om achtergelaten te worden voor iemand; montinggoli $=$ aanzoek doen). Traditioneel bestaan de geschenken uit een sirihdoos (salapa), een mes (piso), een sarong (lipa), een baadje (bokoekoem), een armband (paseda), een paar lange oorhangers (soembang); verder bevinden zich in de sirihdoos groote pinang (posos mbikoe) en sirih (soogang). Een andere naam voor deze potinggoli is balanda. Bij het overreiken der voorwerpen wordt door den bemiddelaar medegedeeld van wien zij afkomstig zijn. Na het vertrek van den gezant vragen de ouders of het meisje met den gever wil huwen; het gebruiken van dwang is daarbij tegen de adat. Ook in andere deelen van het landschap is de gewoonte overeenkomstig: het meisje mag niet gedwongen worden met een bepaalden man te huwen.

Neemt het meisje de potinggoli in ontvangst, dan is dit een teeken dat zij het aanzoek aanneemt; haar ouders berichten dit dan aan die van den jongen man. Wil zij hem niet, dan worden alle geschenken teruggebracht. Is zij het nog niet met zichzelf eens, dan laat ze de goederen onaangeroerd; als de bobotokon na drie dagen terugkomt, moet zij zich echter uitspreken. Kruyt is iets beknopter in zijn mededeelingen: het meisje geeft door te pruimen van den inhoud van de sirihdoos haar stemming ten opzichte van het aanzoek te kennen; laat ze echter den inhoud twee dagen onaangeroerd, dan is dit een teeken dat ze den jongen niet wil, waarna het geschenk wordt teruggezonden. Wacht men hiermee langer dan twee dagen, dan moet een aarden bord met de sirihdoos meegezonden worden. Bij niet terugzending weet de jonge man en zijn familie dat het aanzoek is aangenomen.

Heeft het meisje de potinggoli in ontvangst genomen, dan wel heeft zij door het gebruik uit de sirihdoos haar toestemming gegeven, dan moet zij als verloofd beschouwd worden. De verlovingstijd duurt tot 
het oogenblik van overreiken van den bruidschat bij de huwelijkssluiting.

In den verlovingstijd wordt zoo spoedig mogelijk een bijeenkomst belegd waar de grootte van den bruidschat zal worden vastgesteld; aan den bobotokon is reeds bij wijze van oriënteering tijdens het aanvaarden van de potinggoli medegedeeld op welken bruidschat gerekend wordt, hoeveel dus de longot (aki : wat aangebracht wordt) van den jongen zal zijn. Dit is echter niet definitief want de vaststelling van den bruidschat geschiedt in een familieraad, binnen een week of tien dagen na het tot stand komen der verloving (zie verder paragraaf 3 ).

Gedurende den verlovingstijd mag de jonge man zijn meisje wel in haar huis ontmoeten, doch steeds in bijzijn van anderen. Hij behoort haar in dien tijd af en toe geschenkjes te geven, kleedingstukken en snuisterijen. Voor het overhandigen daarvan heeft hij echter weer een tusschenpersoon noodig, haar ouders of broer of zuster.

De verlovingstijd mag niet te lang duren; men vat dit op als een teeken, dat de jongen maar half en half wil. Bij de bespreking van den bruidschat wordt tevens een termijn vastgesteld na welken deze verzameld moet zijn; hierna kan het huwelijk gesloten worden. Overschrijding van dien termijn zonder wettige reden kan een der oorzaken zijn voor het te niet gaan der verloving (aki : bapatol $=$ verbreken) ${ }^{25}$ ).

Redenen tot het verbreken eener verloving kunnen zijn van subjectieven dan wel van objectieven aard. Als zoodanig gelden: één der partijen is tot andere gedachten gekomen; dan wel wangedrag van één hunner, als hoedanig ook geldt het niet tijdig opbrengen van den bruidschat.

Ligt de oorzaak van het verbreken der verloving geheel aan den kant van het meisje, dan behoort zij alle geschenken die zij gedurende den verlovingstijd heeft ontvangen, tezamen met de potinggoli (het verlovingsgeschenk zelve), terug te geven; er wordt soms nog een boete bij geëischt; ter hoofdplaats Banggai heet deze inoetang en bedraagt 20 vadem katoen, dat zijn \pm 10 blokken goed; in Bongganan heet deze boete pongoetan welke gelijk staat met de helft van den bruidschat die voor het meisje zou zijn betaald. In Boelagi geeft het

25) Ter Haar meldt (blz. 158 van zijn Beginselen en stelsel) dat ook wel bij de verloving zelve de grootte der delictsbetaling in geval van verbreking der verloving, wordt vastgesteld; van een dergelijke vooruitbepaling van de papatol vond $i k$ niets. 
meisje pongoboeloeson (aki: om neer te laten), tot een bedrag van een à twee koperen schalen op voet. Het is in geen van deze gevallen duidelijk wie in feite deze boete ontvangt, $\mathrm{nl}$. de jonge man die zijn meisje kwijt is, dan wel de ouders.

Verbreekt de jongen de verloving, dan behoudt het meisje alle goederen; bovendien moet de jongen nog een boete betalen. Kruyt zegt dat dit speciaal in Boelagi het geval zou zijn, doch in OostPeling heeft men dezelfde regeling. Deze boete heet papatol (aki: waar het mee afgekapt wordt; bij Kruyt popatol); zij wordt opgelegd door den vader van het meisje en bedraagt meestal één koperen schaal op voet, welke aan de ouders van het meisje, practisch aan haar vader alleen komt $^{26}$ ).

Zijn er andere redenen in het spel (de jongen maakt een ander meisje het hof ; hij treuzelt met het verzamelen van den bruidschat), dan behoudt het meisje potinggoli èn alle ontvangen geschenken, doch haar vader legt ook een papatol op, hooger dan in het zooeven aangegeven geval, b.v. twee of drie van dergelijke schalen. Deze boete komt in theorie aan de ouders, in de practijk aan den vader van het meisje.

Ligt de schuld bij het meisje (misdraagt zij zich met een anderen jongen) dan moet zij potinggoli èn geschenken teruggeven. (Behoeft zij in dit geval geen boete te betalen, in tegenstelling tot verbreking om subjectieve redenen?).

Betreffende den Vogelkop ${ }^{27}$ ) is in de vorige paragraaf reeds medegedeeld dat nachtelijke bezoeken van een jongen man aan een meisje vaak het voorspel zijn van een verloving; slechts moet hij oppassen dat niemand hem daarbij ziet, want dan moet het huwelijk doorgaan; m.a.w. als hij erin geslaagd is de verhouding geheim te houden ontstaat hieruit nog geen huwelijksdwang.

Daarnaast erkent men ook den regelmatigen weg om tot een huwelijk te komen, nl. het aanzoek doen om de hand van een meisje. Als bemiddelaar treedt hier vader of moeder van den jongen op. Deze neemt een geschenk mee voor het meisje; indien zij het behoudt is dit een teeken dat zij het aanzoek aanneemt. De term voor verloofd zijn in het sian is niet vermeld in de literatuur.

Aanteekening verdient dat ook hier de beslissing van het meisje

26) Het zou zich pas toespitsen bij scheiding der ouders, want dan zou de moeder haar rechten op haar deel kunnen geldend maken; zie par. 8. Ook bij versterf en practische toepassing van het erfrecht wordt dit een probleem.

$\left.{ }^{27}\right)$ Kruyt, Van leven en sterven, blz. 59. 
geldt; als zij den verzoeker niet als haar toekomstige echtgenoot wil kan zij niet daartoe worden gedwongen.

Gegevens over de rechtsgevolgen verbonden aan verbreking der verloving zijn niet beschikbaar.

Ook in Loinang is het gewoonte, zooals we in paragraaf 1 zagen, dat de jongeling zich tevoren daadwerkelijk van de genegenheid van het meisje overtuigt, door geregeld bij haar, onbemerkt, den nacht door te brengen; dit heet mondolong ${ }^{28}$ ). Ook kent men den term basindoea (madi); dit ziet op jongelieden die van elkaar houden en het ten aanzien van hun aanstaande verloving eens zijn.

Heeft dit in Lingketing zoo eenigen tijd geduurd, dan deelt de jonge man aan zijn vader mee dat hij met dat meisje wil huwen; de vader, of een oom, gaat nu het aanzoek doen (madi: mompokilawa $=$ een verzoek doen). Ook hier bespreekt men de zaak niet rechtstreeks doch men verbloemt de aangelegenheid. Er wordt b.v. gezegd dat hij op het erf een kuiken heeft gezien dat hij graag zou opvoeden. Tevens geeft de bemiddelaar een geschenk, pongoosi geheeten (madi: pongoosi $=$ merkteeken dat er een bezitter is), dat uit twee deelen bestaat, nl. een kleinigheid voor het meisje zelf (b.v. een armband) en een lap katoen (madi:posoeoeon), waarvan de jongeling verwacht dat het meisje hem een kleedingstuk zal naaien. De familie moet nu over het aanzoek beslissen hetgeen in den regel niet langer dan vier dagen mag duren.

Ook hier moet het meisje zelf accepteeren en mag er geen dwang worden uitgeoefend; als zij het aanzoek heeft aangenomen (waaruit blijkt dat?) spreekt de jongeling van dohoikoe (madi : mijn verloofde; modoho $i=$ een verloofde hebben; indohoi $=$ verloofd zijn). Een tien à twintig dagen later gaat de familie van den jongen aan de ouders van het meisje een sirihdoos brengen; dit heet mantoean. Bij deze gelegenheid wordt tevens besproken dat men over vier dagen bijeen zal komen om over den bruidschat te spreken.

In Doehian echter geeft de jonge man, nadat hem feitelijk gebleken is dat het meisje hem mag, haar eenige geschenken, die hier ook pongoosi (madi: merkteeken) heeten; het zijn eenige snuisterijen voor persoonlijk gebruik door zijn aangebedene. Daarna brengt de jonge man wel bezoeken aan de ouders van het meisje zonder echter de aangelegenheid zelf te berde te brengen; meestal geschiedt dit door zijn eigen ouders, die als zij van een en ander kennis hebben

28) Kruyt, To Loinang, blz. 448—450; E. Gobée, Feestbundel I, blz. 191. 
gekregen, den jongen vragen wie hij op het oog heeft. Nu maken zijn ouders een geschenk klaar, ook hier mantoean geheeten; het bestaat uit een sirihdoos met toebehooren, waaraan eenige kleedingstukken, sieraden en een mes zijn toegevoegd. Een oom van den jongeling brengt dit na voorafgaande waarschuwing aan de ouders van het meisje, waarna ook hier weer een gesprek gevoerd wordt, b.v. over het koopen van een kip. De ouders van het meisje zenden de familie van den jongen bericht wat besloten is; ook hierbij weer geen dwang, hoogstens overreding van de dochter om het aanzoek aan te nemen.

Gedurende de verloving zijn beide jongelui verplicht de wederzijdsche aanstaande schoonouders in huis en op den akker te helpen. Tijdens de verloving zet de jongeling zijn nachtelijke bezoeken aan het meisje voort (Loinang).

Komt aan de verhouding een eind vóór het overreiken van de mantoean doch nadat de pongoosi gegeven is, dan dient deze, indien het meisje de schuldige is, door haar aan den jongen te worden teruggegeven. (En als het initiatief van den jongen uitgaat? Blijft dan wellicht de pongoosi bij het meisje?). Is de mantoean echter reeds overgedragen en is het wederom de wil van het meisje dat aan de verloving een einde komt, dan moeten pongoosi en mantoean teruggegeven worden, vermeerderd met een boete; deze boete heet pangoetang (madi: schuld) of pongapin (madi: inwikkelaar). Hoe een en ander geregeld is in de gevallen dat het initiatief van den jongen uitgaat is niet vermeld. Vermoedelijk blijven pongoosi en mantoean bij haar, doch moet hij dan ook nog een boete afgeven?

Ook mogelijk is dat aan de verloving een einde komt doordat het meisje zich misdraagt met een man; in dergelijk geval moet de man met wien zij het gehouden heeft, ook een boete betalen; Kruyt spreekt van deze als van pangaoetang; is dit wellicht een verschrijving van pangoetang? Dat er verder wordt gesproken van „ook” doet vermoeden dat het meisje een boete moet betalen gelijk aan die door den man op te brengen. Wie deze boeten ontvangt is niet aangegeven.

Hoe een en ander zich toedraagt als de verloofde jonge man het met een ander meisje anlegt is niet vermeld; op grond van analoge bepalingen bij overspel kunnen we welhaast aannemen dat het meisje met wie de verloofde jonge man zich afgeeft daarmee aan het verloofde jonge meisje een boete verbeurt.

Kinderverloving ${ }^{29}$ ). Slechts uit den Archipel wordt gemeld dat

29) Kruyt, Banggaische Studiën, blz. 18. 
het voorkomt dat twee ouderparen met elkaar afspreken om hun kinderen later een paar te laten worden. Als bindsom geven de ouders van het knaapje aan die van het meisje een geschenk ter bestrijding der opvoedingskosten; dit geschenk heet in het aki balanda (verg. maleisch belandja $=$ geld om bepaalde kosten mee te bestrijden). Bij ziekte van het jonge meisje dienen de ouders van het jongetje actief mee te werken aan het herstel der kleine, b.v. door het brengen van offers aan pilogot. Wil het meisje, groot geworden, niet met den jongen huwen, dan moeten haar ouders aan die van den jongen een geschenk geven, pongokolo besi (aki : om het zwaard te laten rusten); indien echter de jongen niet met het meisje wil huwen gebeurt er niets. Blijkbaar kunnen niet de ouders, doch alleen de belanghebbenden de gemaakte afspraak teniet doen, waarbij slechts van de zijde van het meisje een verzoeningsgeschenk moet worden opgebracht.

\section{Huwelijksgeschenk; huwelijkssluiting.}

De belangrijkste gebeurtenis die in den verlovingstijd plaats heeft is het vaststellen van het huwelijksgeschenk ${ }^{30}$ ).

Wij zagen reeds dat als in den Archipel het meisje het verlovingsgeschenk (potinggoli) heeft aangenomen, haar ouders tevens globaal mededeelen hoeveel verwacht wordt dat de verloofde zal aanbrengen (aki: longot $=$ wat aangebracht wordt). De vaststelling van de grootte van het huwelijksgeschenk dient echter te geschieden in een familieraad waaraan vertegenwoordigers van beide families deelnemen ${ }^{31}$ ).

Op den vastgestelden dag komen de jonge man met zijn vader, vergezeld van eenige mannelijke familieleden in het huis van het meisje; deze zijn b.v. broers van vaders- en moederszijde, eventueel stief vader en halfbroers, oudooms en grootvaders (vermoedelijk zijn dus de mannelijke familieleden zoowel van vaders- als van moederszijde gelijkelijk uitgenoodigd). In de woning van het meisje vindt men daar een overeenkomstige vergadering van mannelijke familieleden. Ontbreken mannen in de familie, dan nemen vrouwelijke

30) Ter Haar beperkt het begrip bruidschat tot de bruidsbetaling in de vaderrechtelijke orde, ter inlijving van de vrouw in de mansfamilie (-clan), in tegenstelling tot het door hem voorgestane begrip huwelijksgeschenk dan wel huwelijksbetaling in de ouderrechtelijke orde, waar de betaling van een zeker bedrag door bruidegom (en familie) aan de bruid (c.q. aan haar familie) geen contante handeling is: Beginselen en stelsel, blz. $86,164,166$. Ik gebruik daarom den term: huwelijksgeschenk.

31) Nota van den Bergh; Kruyt, Banggaische Studiën, blz. 22-27. 
familieleden hun plaats in; buitendien mogen deze steeds meeluisteren bij de onderhandelingen. Kruyt schrijft dat alle familieleden die eenig recht op het meisje meenen te kunnen doen gelden, op deze vergadering aanwezig zijn, waar zij den aanstaanden bruidegom allerlei geschenken vragen. Het huwelijksgeschenk heet sai, de bijkomende geschenken $k a b i$-kabi; men noemt uit dien hoofde het samenkomen om over het huwelijksgeschenk te spreken monsai, terwijl het vragen van geschenken door de familieleden mongkabi heet. Tijdens het voeren van de onderhandelingen (zoowel over het eigenlijke huwelijksgeschenk als over de bijgeschenken beide?) zwijgt de vader van het meisje, daar hij tevoren zijn familieleden van zijn wenschen op de hoogte heeft gebracht. De eindbeslissing berust echter bij hem.

Het huwelijksgeschenk, sai (aki) bestaat uit eenige deelen; Kruyt onderscheidt het eigenlijke huwelijksgeschenk van de bijgeschenken, waaronder hij ook de traditioneele geschenken aan moeder en vader der bruid rangschikt. Pater van den Bergh M.S.C. spreekt van een vierdeelige gift, nl. 1 . het traditioneele deel voor den vader; 2 . dat voor de moeder; 3 . het eigenlijke huwelijksgeschenk (aki : sai batango; batang $=$ stam) ; 4. de huwelijkskosten bestemd voor het huwelijksfeest.

Het deel van den vader (aki: olo-olo) bestaat uit eenige wapens en kleedingstukken, dat van de moeder (poliat soesoe) uit een kleedingstuk, een pronkbord, een groote sirihdoos, vaak ook een sagostoel; door dit laatste geschenk aan de moeder der bruid hoopt men mogelijke scheiding in de toekomst te voorkomen, daar de sagostoel zich steeds weer verjongt en niet afsterft. Wat de kabi-kabi betreft, die voor ooms en tantes en voor allen die daarop eenig recht hebben bestemd zijn, ontbreken ons gegevens, doch deze bestaan vermoedelijk uit borden, kleedingstukken e.d.

De sai-batango wordt uitvoerig besproken, want na veel loven en bieden komt men tot een accoord. Dit wordt vastgelegd in kajoe, loliba en kandari; een dergelijke specificatie is noodig om straks de verdeeling mogelijk te maken. De goederen waaruit het huwelijksgeschenk bestaat zijn oud koperwerk, poepoet en boeat (beide aki; als soorten kent men kandari, gong, doelang, saoeba en koeonoe), terwijl ook een gedeelte uit aardewerk bestaat, loliba; de waarde van dit aardewerk wordt uitgedrukt in kajoe (lett. hout, blok, nl. blok goed). Om een voorbeeld te geven; plaatselijk geldt een bord ter grootte van een Europeesch soepbord voor twee kajoe, hetgeen gelijk 
is aan vier kommen (aki : mangko'). Bij de onderhandelingen over het huwelijksgeschenk begint men deze uit te drukken in aardewerk (loliba) ; is hiervan het aantal bepaald, dan is dit te herleiden tot een zeker aantal kajoe, deze weer tot bepaalde soorten poepoet. Eén kandari is b.v. gelijk aan vijf kajoe. Bij de specificatie nu zorgt men dat de sai batango en dat gedeelte van de sai dat voor de verdeeling in aanmerking komt, op een dusdanige wijze in deze waardemeters is uitgedrukt dat verdeeling mogelijk is ${ }^{32}$ ).

Ten slotte wordt het laatste deel van de sai, de kosten voor het huwelijksfeest nl., vastgesteld; de grootte van dit gedeelte hangt af van het verwachte aantal gasten, de uitgebreidheid dus van beider familie; de kwaliteit is echter afhankelijk van den welstand van den jongen man. Kruyt vermeldt in afwijking hiervan dat het huwelijksfeest voor rekening van de familie der bruid komt, doch dat de jonge man als bijdrage een geit of een varken en een hoeveelheid oebi geeft. Dit dier draagt hier den op blz. 195 reeds genoemden naam pinda, aanduiding voor een verzoeningsgeschenk.

In Oost-Peling bedraagt een middelmatig huwelijksgeschenk, buiten de vaste geschenken voor de ouders der bruid, 40 tot 50 kajoe aan loliba (aardewerk), 8 à 10 kandari (poepoet; koperwerk) en kosten voor het huwelijksfeest 2 blikken rijst, 1 à 2 rijksdaalders visch, een geit en twaalf kippen. Geld behoort niet thuis in de $s a i^{\mathbf{3}}$ ).

Bij het bepalen van het huwelijksgeschenk is men in geenen deele gebonden aan hetgeen indertijd voor de moeder der bruid betaald is; voor de dochters mag men meer of minder vragen. Volgens Kruyt laat men de grootte meestal afhangen van den welstand van den

32) Het oude koperwerk bestaat uit eenige soorten, te weten kandari (min of meer versierde en bewerkte koperen schalen met voetstuk) met een traditioneele waarde van f 2.50 à f 5.-; gong van allerlei grootte, waarvan de waarde, afhankelijk van de middellijn, wordt uitgedrukt in kandari; doelang, eveneens koperen schalen met voetstuk, kleiner dan de kandari; salapa of saoeba (West-Peling: toba), antieke koperen sirihdoozen, waarvan het onderling verschil mij niet bekend is; koeonoe, antieke koperen schalen zonder voetstuk, zwaarder van uitvoering dan doelang of kandari, hoog gewaardeerd. Naast den term loliba voor aardewerk in het algemeen heeft men pinggang voor bord; mansanal wordt gebruikt ter aanduiding van een aarden bord, overigens is het verschil mij niet erg duidelijk. Kajoe is een blok van \pm 2 vadem katoen. L. B. van Straten, De Indonesische bruidschat, deelt op blz. 5 mede, dat de aard der goederen waarin de bruidschat voldaan wordt, zich weinig wijzigt. Het zijn gebruiksvoorwerpen en sieraden, liefst van magische werking; deze vormen de hoofdschotel.

33) Kruyt, Landbouw blz. 478: „een stuk van het aandeel dat iemand in dit „landbezit had, kon als bruidschat aan een ander worden weggegeven”. Waarom staat dit in den verleden tijd?

Verh. dl. VI. 
bruidegom. Deze auteur komt tot eenige andere mededeelingen, o.a. als zoude de sai tegenwoordig in geld worden voldaan; deze mededeeling is in haar algemeenheid onjuist, slechts gebruikt men thans het geld als waardemeter, waarbij de samenstellende deelen weer een aanzienlijke, in geld uitgedrukte, waarde bezitten. Plaatselijk vermeldt hij dat men steeds met drietallen rekent. (Boelagi; is dit.algemeener?); elders zou het huwelijksgeschenk slechts bestaan uit één koperen bord van het soort dat men koeonoe noemt, terwijl leege flesschen en aarden borden als waardemeter gelden, zoodat de verdeeling kan plaats vinden.

Kruyt deelt zelfs mede dat voor leden van het vorstenhuis het huwelijkksgeschenk eveneens uit koperen voorwerpen bestond (bestaat?); voor een vorst ter waarde van 100 kajoe, voor iemand uit den bobato-stand 60, en voor leden van den basalo-stand 40 kajoe.

De directe aanleiding tot het samenstellen der nota door Pater van den Bergh M.S.C. was de door den vorst van Banggai getroffen regeling (zie blz. 170 v.), waarin voor alle standen vastgelegd werd welke de maxima van het huwelijksgeschenk zouden zijn, uitgedrukt in guldens. Dit besluit wil dan regelen dat voor een vorstentelg de sai zou zijn $\mathrm{f} 100$,-, voor iemand tot den bobato-stand behoorend f 80,-, voor de dochter van een basalo f 60,-, voor die van een kapitan echter $f$ 50,-, voor de dochter van een kamponghoofd f 40,-, terwijl de gewone man niet meer zou mogen vragen dan $f 20,-$. De reactie hierop was hevig: een der ouden liet zich uit dat hij op deze wijze voor zijn dochter niet meer zou krijgen dan den prijs van een geit (historisch). Dit ligt daarin dat men b.v. een dergelijk dier voor een bepaalde hoeveelheid koperen voorwerpen kan omruilen waarvan de traditioneele waarde $f 30,-$ is, uitgedrukt in het huidige geld; wil men echter normaal met contanten een dergelijk dier koopen dan behoeft men daar niet meer dan eenige guldens voor te betalen. Doch de bevolking -rekent bij den ruil met traditioneele waarden, die veel hooger zijn dan de werkelijke marktprijzen, waardoor ook zeer hooge bedragen gevraagd worden voor het huwelijksgeschenk, hetgeen niet bezwaarlijk is zoolang deze ook in hoog gewaardeerde goederen worden voldaan.

Dat de bijkomende gaven in natura (het laatste deel) inderdaad deel uitmaken van het huwelijksgeschenk blijkt uit het verbod aan de bruid om bij het huwelijksfeest zelf er iets van te nuttigen; zij zou anders haar eigen prijs eten!

Volgens de nota Van den Bergh behooren de bijgeschenken (aki: 
$k a b i$; Kruyt spreekt van $k a b i$-kabi) niet tot de sai; het woord zelf beteekent: wat gegeven wordt. Oorspronkelijk is de $k a b i$ een vereffening van schuldverhoudingen, ontstaan tusschen de bruid en een of meer familieleden, en wel sedert haar prille jeugd, b.v. doordat deze haar steeds kleine geschenkjes gaven of op andere wijze bijzondere belangstelling voor haar toonden; ook kan de oorzaak van een dergelijke schuldverhouding b.v. liggen in een toevallige benadeeling van een familielid door het meisje welke nog niet in het reine is gebracht (b.v. het meisje heeft bij ongeluk een bord van een tante gebroken en zij heeft nog niet kans gezien het te vervangen). Aan al dergelijke schuldverhoudingen ontleenen de familieleden wien het aangaat het recht om ter gelegenheid van haar huwelijk aan de familie van den jongen of aan dezen zelf iets extra te vragen, in geld of in goed.

Dit oorspronkelijk gebruik is echter verworden doordat vele familieleden van de bruid van de gelegenheid gebruik maken allerlei vorderingen die ze op, soms zelfs verre, familieleden van den bruidegom hebben, van dezen te innen; hij moet dan maar zien hoe hij dit later met zijn familieleden vereffent. Dit ontstane misbruik wordt door ouden van dagen zeer betreurd; feitelijk hebben slechts broers en zusters, ooms en tantes, grootouders en oudooms en oudtantes het recht de $k a b i$ te vorderen en alleen wegens een schuldverhouding (in den uitgebreiden zin als hooger aangegeven) tusschen hen en de bruid $^{34}$ ).

Als bijgeschenken worden wel muizenpaden en omgevallen boomstammen (oogstplaatsen van paddestoelen), verder pisangstruiken gegeven. Als men met Kruyt de op blz. 208 genoemde traditioneele geschenken aan moeder en vader der bruid ook tot de kabi rekent, vallen de daar genoemde wapens en kleedingstukken er ook onder; doch in verband met het hooger medegedeelde lijkt het mij niet juist deze olo-olo en poliat soesoe tot de kabi te rekenen, daar de eerste in wezen iets anders zijn dan de tweede, terwijl ook de geschenken aan moeder en vader der bruid door de gewoonte vastliggen in tegen-

34) De door Pater van den Bergh gegeven interpretatie lijkt van zeer recenten aard te zijn. Ten rechte is het huwelijk familiezaak; door het huwelijk wordt een band gelegd tusschen twee families. De magische bindmiddelen (die het huwelijksgeschenk vormen) moeten zoowel eenerzijds door alle familieleden bijeengebracht, als anderzijds ook onder hen verdeeld worden. Verg. in dit verband: F. D. E. van Ossenbruggen, Primitieve denken, blz. 246; Verwantschapsverhoudingen, blz. 77/78 en noot 25 . 
stelling tot de tweede groep waarvan de hoogte na loven en bieden tot stand komt.

Is eenmaal het huwelijksgeschenk vastgesteld, dan wordt meestal den bruidegom tevens de tijd medegedeeld binnen welken hij de goederen moet verzamelen; dit wekt den indruk alsof hij er zelf voor staat de goederen alle te verzamelen, doch dit is in feite anders. Hij toch mag bij zijn familieleden aankloppen om hem te helpen, ja het wordt zelfs verwacht. Leenen voor een dergelijk doel heet modoni (aki); het tot dat doel geleende heet doni. Het is niet de bedoeling dat de jonge man, ook al is hij na eenige jaren in staat het geleende terug te geven, dit ook doet; neen, de schuldverhouding wordt bestendigd en wordt pas vereffend als b.v. een zoon van den schuldeischer zelf zijn huwelijksgeschenk moet gaan verzamelen, tot welk doel deze dan de doni kan komen opvorderen van hen, die indertijd door zijn vader werden geholpen (zie verder hoofdstuk XI) ${ }^{35}$ ).

Kruyt noemt den term babingkat; hij onderscheidt de mogelijkheid dat iemand wel door zijn familie geholpen wordt van het geval dat de bruidegom er geheel alleen voorstaat. In dit laatste geval kan hij ook van een vreemde leenen, ten gevolge waarvan hij in schuldverhouding, meestal dienstbaarheid, komt te staan; betaling geschiedt dan òf door werkzaamheden op den akker van den schuldeischer, òf doordat degene die de goederen heeft gegeven, het oudste kind uit het huwelijk als het zijne tot zich neemt.

Alles ter leen krijgen is echter niet goed; de aanstaande bruidegom moet ook de handen uit de mouwen steken en minstens de helft van de sai zelf verzamelen, anders wekt het den indruk dat hij lui en het meisje onwaardig is. Dat ongerechtvaardigd treuzelen bij het verzamelen van het huwelijksgeschenk een reden tot verbreking der verloving is werd reeds op blz. 203 medegedeeld. Het benoodigde koperwerk en de borden worden meestal geleend, daar zeker de eerste soort goederen lastig te koop is.

\footnotetext{
35) Vergelijk ook wat C. van Vollenhoven in Adatrecht I schrijft. Onder huwelijksrecht van den Toradjakring (blz. 361) staat vermeld dat het bijeenbrengen van en mededeelen in den bruidschat vaderrechtelijk gebleven is; de familie van de moeder van de bruid en van de moeder van den bruidegom staan daarbuiten; wel is soms een sagopalm onderdeel van den bruidschat. Ten aanzien van Zuid-Celebes, blz. 376: de bruidschat gaat schier altijd gepaard met andere geschenken en wordt verdeeld onder de bloedverwanten der bruid; een deel ervan wordt teruggegeven, vergezeld van weer andere geschenken. Voor den Ternate-Archipel geldt (blz. 388/389): de bruidschat wordt niet geheel, soms niet eens ten halve betaald. Dat men bij het huwelijk te doen heeft met een transactie, niet enkel van twee ouderparen maar tusschen twee families, blijkt uit allerlei giften van den bruidegom aan familieleden - in ruimen zin -
} 
Het huwelijk wordt pas gesloten als de volledige sai in staatsie naar het huis der bruid is gebracht en daar aan haar vader overhandigd (aki: mobingkakon sai $=$ de sai neerzetten; bij Kruyt molibakon $=$ doen opgaan, in het huis der bruid nl.) ${ }^{36}$ ).

Als de stoet aan de trap van het huis der bruid is aangekomen wordt deze tegengehouden door lieden (familieleden van de bruid?) die er gekookte oebi hebben gelegd; dit voedsel moet door de familieleden van den bruidegom gekocht worden met sirihdoozen; dit heet potoeonggon (aki: laten vallen), de opbrengst van den verkoop komt aan de familieleden der bruid. In andere streken wordt de oebi niet verkocht, doch aangeboden; dit heet dan binggoti (aki).

De bruid bevindt zich in een afgesloten gedeelte van het huis en blijft daar tot een korte maaltijd, in het huis zelf angeboden, afgeloopen is. $\mathrm{Z}_{\mathrm{ij}}$ wordt gehaald door twee bruidsjuffers, terwijl ook de bruidegom twee bruidsjonkers heeft; deze allen heeten sopit, plaatselijk sopiti (aki), zij mogen geen broers of zusters van het bruidspaar zijn en moeten verder ongehuwd wezen. Dit viertal (soms zijn er minder) haalt de bruid en doet haar bij den bruidegom neerzitten; soms ook zijn het eenige ooms die haar halen. Het gelaat der bruid is bedekt met eenige doeken; familieleden lichten deze op de laatste na van het hoofd, doch voor elken doek moet de bruidegom een gift, poboeka (aki : wat dient om te openen) aan de bruid geven; de laatste, meestal vierde, doek neemt hij zelf weg.

De bruidsjonkers en -juffers blijven voortdurend bij het paar; dit biedt elkaar sirih-pinang aan en nuttigt met de sopit een kleinigheid. Soms heeft er ook een zinnebeeldige handeling plaats, als het plaatsen van pinangnooten in de hand der bruid, welke toegedekt wordt met de hand van den bruidegom.

Wederzijdsche familieleden beijveren zich het jonge paar allerlei vermaningen te geven. Hierna begeeft het zich naar een afgeschoten

der bruid, die het adatrecht kent (kende) naast den bruidschat. (Vergelijk de Banggaische kabi).

L. B. van Straten, De Indonesische bruidschat, deelt op blz. 52 mede, hoe in ouderrechtelijke streken de familie van den bruidegom, tot soms het geheele stamgenootendorp, meehelpt om den bruidschat te verzamelen; tevens vermeldt hij de banden die zoo ontstaan en het recht tot terugvordering door leden van de volgende generatie.

Ter Haar, Beginselen en stelsel, blz. 168/169: „Bij verschillende volken „bestaat een voortdurende en goed onderhouden wisselwerking tusschen mee„betalen aan een bruidschat, recht op meegenieten van een bruidschat en recht "om hulp te vorderen bij bruidschatbetaling".

36) Nota van den Bergh; Kruyt, Banggaische Studiën, blz. 27-30. 
ruimte waar het tezamen met de bruidsjonkers en -juffers den nacht doorbrengt. Soms blijven deze meer nachten, soms gaat na één nacht een tweetal weg, na de tweede nacht het tweede tweetal; men zegt dit te doen opdat de jongelieden aan elkaar wennen. Huwelijksverkeer heeft pas later plaats, zeker nadat de sopit het jonge paar verlaten hebben, vaak pas een week na de huwelijkssluiting. De sopit worden door het jonge paar beloond.

Hoe in Oost-Peling het huwelijksgeschenk verdeeld wordt is wederom uitvoerig behandeld door Pater van den Bergh M.S.C. Verdeeling van de sai is mogelijk door de wijze van opbrengen ervan, nl. in borden, kommen en koperwerk van verschillende, traditioneele waarde ${ }^{37}$ ).

De vader van de bruid verdeelt en begint met het aardewerk. De te verdeelen hoeveelheid is minder dan opgebracht als sai, daar de voor het huwelijksfeest benoodigde palmwijn met eenige borden betaald is. Het restant nu wordt direct na het feest in tweeën gedeeld; van het eerste deel worden alle familieleden zoowel van vaders- als van moederskant, bedacht, en niet alleen de aanwezige, maar ook zij die niet aan het feest konden deelnemen. Echter krijgt een aanwezig het dubbele van een afwezig familielid.

Eenige dagen later wordt het overgebleven aardewerk verdeeld, en wel in gelijke deelen onder den vader, de moeder, ooms en tantes van vaders- en ooms en tantes van moederszijde. Ontbreken deze ooms of tantes, dan krijgen vader of moeder dat deel, tenzij er iemand in de familie is, die door aanzien en ouderdom de positie van oom (tante) inneemt. De vader der bruid beslist in dezen wie als zoodanig is aan te merken.

Ook het koperwerk wordt verdeeld; hiervan komt aan den vader en aan de moeder der bruid elk $1 / 4$ deel, verder aan vaders- en aan moedersfamilie eveneens elk $1 / 4$ deel. Deze familieleden zijn weer: broers en zusters van de ouders der bruid, verder neven en nichten (cousins? vermoedelijk wel, daar zusters en broers van vader en moeder en hun cousins allen van dezelfde generatie zijn; zie vorig hoofdstuk).

Recapituleerende: de vader der bruid krijgt dus ter gelegenheid van het huwelijk van elk zijner dochters: de olo-olo (zwaard, lans, lendendoek) $+1 / 8$ deel van de netto voorraad aardewerk $+1 / 4$ van

37) In het ouderrecht past volkomen een verdeeling van het huwelijksgeschenk tusschen beide ouders der bruid en hun ouderrechtelijke verwanten; vergelijk ook L. B. van Straten, De Indonesische bruidschat, blz. 48. 
het koperwerk; de moeder ontvangt poliat soesoe (sarong, sirihdoos, pronkbord, eventueel sagostoel) $+1 / 8$ deel van het aardewerk $+1 / 4$ van het koperwerk. Vaders familie krijgt bij de eerste verdeeling van het aardewerk $1 / 4$, bij de tweede verdeeling $1 / 8$ deel, dus $3 / 8$ deel, bovendien $1 / 4$ van het koperwerk; moeders familie krijgt dezelfde hoeveelheden. Bij dit alles treedt de vader der bruid als regelaar en verdeeler op ${ }^{\mathbf{3 8}}$ ).

Niet opgegeven is wat met een eventueel opgelegde pinda wegens vóórhuwelijksverkeer gebeurt; komt deze geheel aan de bruidsfamilie, met name aan wie(n)? En als een geit als boete betaald is, wie nuttigen daar dan van?

Kruyt geeft een andere wijze van verdeeling op. Hij schrijft dat in het geval van normaal betaald huwelijksgeschenk, nl. bij de huwelijkssluiting, dit tusschen de ouders en de familieleden van de moeder verdeeld wordt; zouden dan de familieleden van den vader in het geheel niet meedeelen? Mij lijkt de door Pater van den Bergh aangegeven wijze aannemelijker, daar zij geheel past in het ouderrecht. Wellicht berust Kruyts mededeeling op plaatselijke resten van eenzijdig verwantenrecht, van vaderrecht $\mathrm{nl}$.

Ook op den Vogelkop erkent men, niettegenstaande het veelvuldige vóór-huwelijksverkeer, dat de regelmatige vorm is: verloving en huwelijk met huwelijksgeschenk ${ }^{39}$ ). In het siun heet dit geschenk pensoeo, huwen mensoeo; het is voor alle personen vrijwel gelijk, zeker voor de dochters uit één gezin. Over de deelswijze samenstelling van het huwelijksgeschenk ontbreken gegevens; het bestaat gewoonlijk uit kleedingstukken, wapens, gebruiksvoorwerpen en aardewerk; in tegenstelling tot den Archipel wordt niet een stuk akkergrond als deel vermeld. Van de goederen zijn twee speciaal aangewezen kleedingstukken voor de moeder der bruid bestemd. Bij het overreiken der goederen is gewoonlijk de tonggol aanwezig, die naziet en controleert of alle goederen wel aanwezig zijn; na die controle is hij het die ze overdraagt aan den vader der bruid. Een duidelijk bewijs levert deze bemoeienis van het hoofd voor de stelling hoe hoog men feitelijk de sociale waardeerring van het huwelijk stelt. $\mathrm{Na}$ de overdracht door den tonggol aan de familie der bruid kan het huwelijk verder worden gesloten.

38) De poliat soesoe wordt volgens Kruyt in Kindandal en Boelagi (beide West-Pelingsche cultuursfeer) slechts gegeven als de moeder der bruid weduwe is en zij het dus met de opvoeding der bruid als kind bijzonder zwaar heeft gehad.

39) Kruyt, Leven en sterven, blz. 59-62; Rijstbouw, blz. 125. 
Gegevens over de wijze van verdeeling van het huwelijksgeschenk (onder welke familieleden?) ontbreken; eveneens ontbreken gegevens nopens het ontstaan van schuldverhoudingen door hulpverleening bij het verzamelen binnen de bruidegomsfamilie.

Ook in Loinang ${ }^{40}$ ) kan men twee deelen van het huwelijksgeschenk onderscheiden, nl. kö̈ en patakon (madi); de kö̈ is het eigenlijke huwelijksgeschenk, tot de patakon behoort alles wat ooms en tantes en andere familieleden van het meisje eischen, als vergoeding voor ware of vermeende diensten die vroeger aan de bruid zijn bewezen. Kruyt rekent hiertoe in de eerste plaats een gift aan de moeder, pantana noe soesoe (madi), een vergoeding voor het zoogen van het kind. Op deze geschenken mag afgedongen worden; zij worden in onderling overleg vastgesteld doch als eenmaal overeenstemming bereikt is moet de bruidegom zich er aan houden. Hier kent men bovendien een tegengeschenk van de ouders der bruid aan die van den bruidegom, nl. vier bamboes gevuld met gedroogd vleesch van den gemsbuffel; dit geschenk heet tawa (madi).

Huwen heet in het madi moosoa. De huwelijksvoltrekking geschiedt nadat het huwelijksgeschenk met bijkomende geschenken gecontroleerd zijn door het hoofd, den tonggol, die tevens voor openbaarheid van de aangegane verbintenis zorgt.

Hoe het huwelijksgeschenk onder de bruidsfamilie wordt verdeeld valt uit de beschikbare literatuur niet op te maken; zeker is dat de moeder de meergenoemde pantana noe soesoe ontvangt. Of bij het verzamelen van het huwelijksgeschenk de familie van den bruidegom behulpzaam is door hem te leenen, is niet waarschijnlijk daar medegedeeld wordt dat het lang duurt en hij geruimen tijd moet werken voor hij de goederen bij elkaar heeft.

Heet huwen moosoa, voor het feest der huwelijkssluiting zelve bezit het madi twee termen, waarin uitgedrukt wordt of men dit van de zijde van den bruidegom dan wel van die der bruid beziet. De bruidegom spreekt van momboa (madi : geleiden, nl. het brengen van den bruidegom naar het huis der bruid), de bruid gebruikt voor dit feest pompopea (madi: wachten).

De waardemeter waarin het huwelijksgeschenk wordt uitgedrukt is stukken ongebleekt katoen (madi : balasoe); één blok telt 15 aarden borden (madi : lean). Oudtijds volstond men met één tot vier blokken ongebleekt katoen, waarvan de handelswaarde thans f 2,- à f 2,50

40) Kruyt, To Loinang, blz. $450-455$. 
per blok is; volgens Kruyt bedraagt thans het huwelijksgeschenk in Lingketing reeds $\mathrm{f} 150,-$. Wordt hij in goederen opgebracht met al dan niet traditioneele waarde, dan wel geschiedt de betaling geheel of gedeeltelijk in geld?

De kosten van het huwelijksfeest schijnen in Baloa althans niet geheel tot het huwelijksgeschenk te worden gerekend, omdat gemeld wordt dat de familieleden van den bruidegom iets medenemen als bijdrage in de te maken kosten van het huwelijksfeest (overigens is dit gezamenlijk bijdragen tot een feest een ook in deze streken welbekend verschijnsel). Verder wordt uit Baloa ook de bijzonderheid gemeld dat de vader van den bruidegom, niet de bruidegom zelf, voor het stuk balasoe zorgt dat als huwelijksgeschenk zal worden angeboden. Dat de bijgeschenken ook hier tot het huwelijksgeschenk behooren, blijkt uit het verbod aan de jonggehuwden iets daarvan of van de bijgeschenken te nuttgien, of voedsel te gebruiken dat daarmee gekocht is; het zou hen tot schuld worden aangerekend.

Bij het aldus geschetste aanzoekhuwelijk schijnt het in Oost-Peling niet voor te komen dat een paar zonder contante betaling van huwelijksgeschenk huwt, daar er altijd wel een manier is om door leenen aan de benoodigde goederen te komen. Kruyt meldt echter (uit WestPeling?), dat wel eens wordt afgesproken met de ouders der vrouw om hen bij wijze van betaling van huwelijksgeschenk het eerste kind uit het huwelijk te geven ${ }^{41}$ ). Men rekent $\mathrm{nl}$. het eerste kind van den vader, het tweede van de moeder, de overige van beiden te zijn. Is nu het oudste een meisje en was voor haar moeder geen huwelijksgeschenk voldaan, dan kan zij volgens afspraak aan haar grootouders komen; huwt zij, dan ontvangen deze ook het huwelijksgeschenk, dat zij indertijd voor hun dochter hadden moeten ontvangen. Is het oudste kind een jongen, dan wordt hij als kind aan zijn grootouders afgestaan. Een dergelijke verdeeling heeft pas jaren nadat het huwelijk gesloten is, plaats, want het kan zijn dat de man op andere wijze alsnog het noodige voor het huwelijksgeschenk heeft kunnen bijeen brengen.

In Balantak is men afkeerig van een huwelijk waarbij geen huwelijksgeschenk is betaald; men meent dat alle kinderen daaruit geboren jong zullen sterven ${ }^{42}$ ). Dit is weer een bewijs dat het huwelijksgeschenk wel als zeer magisch wordt aangevoeld; zonder dit is er van huwelijk feitelijk geen sprake. Het geven van het huwelijksgeschenk

41) Kruyt, Banggaische Studiën, blz. 26.

42) Kruyt, Leven en sterven, blz. 61. 
is vrijwel overal voorwaarde voor het recht op uit het huwelijk gesproten kinderen, op het recht tot stamvoortzetting dus.

Over het al dan niet voorkomen van huwelijken zonder contante betaling van huwelijksgeschenk in Loinang zwijgt de literatuur.

De godsdiensten hebben over het algemeen de inheemsche huwelijkssluiting onaangetast gelaten; bij de Mohamedanen heeft de Mohamedaansche huwelijkssluiting plaats onmiddellijk nadat het huwelijksgeschenk door den vader der bruid is ontvangen. Slechts in orthodox Mohammedaansche kringen te Banggai bestaat het streven dit te verlagen, aan standen te binden, en er een Mohammedaansche mahar van te maken; dit streven stuitte op ernstig verzet bij de Pelingsche bevolking (verg. blz. 210) ${ }^{43}$ ). $\mathrm{Na}$ het bovenstaande wèl begrijpelijk.

Zoowel in Zendings- als in Missiesfeer heeft men het huwelijksgeschenk behouden, en erkent men de groote waarde ervan voor versteviging der huwelijksbanden; sociaal is het bovendien van grooten invloed op de familierelaties binnen de verwantengroep.

Christeninlanders-landschapsonderhoorigen zijn niet onderworpen aan de bepalingen op het huwen van Christeninlanders in de residentie Manado ${ }^{44}$ ). Toch ziet men b.v. dat Minahassers en Sangireezen, ook Amboneezen, hoewel zij landschapsonderhoorigen zijn, op hun huwelijk het „toelis nama" toepassen, waarna ze pas de kerkelijke inzegening ontvangen. Of dit komt doordat deze z.g. ondertrouw voor den bestuursambtenaar reeds zoozeer vaste gewoonte in de Minahassa geworden is dat de Minahaser zich ook buiten zijn land vrijwillig aan de bepalingen daarvan onderwerpt vermag ik niet te zeggen. Overigens sluiten in den regel Christeninlanders-landschapsonderhoorigen eerst een adathuwelijk, waarna op getuigenis van het dorpshoofd (voor wien dit adathuwelijk vaak plaats heeft) of den voorganger der Christengemeente het huwelijk kerkelijk bevestigd kan worden. Het is mij echter niet bekend of deze soms achterwege blijft, en zoo ja, of dit veelvuldig voorkomt. Een en ander uit practijkwaarneming.

Een enkel woord nog over den invloed der standen op het aanzoekhuwelijk.

Huwelijken tusschen slaven en vrijen konden voorkomen, mits echter de vrouw een onvrije was. Buitenechtelijk verkeer tusschen een heer en zijn slavin was niet toegestaan ${ }^{45}$ ); een vreemde moest,

43) Nota van den Bergh.

44) Staatsblad 1933 no. 74.

45) Nota van den Bergh. 
wilde hij huwen met iemands slavin, daarvoor normaal een huwelijksgeschenk voldoen als ware zij een kind van den bezitter; vermoedelijk kwam dit aan den heer hetgeen door Riedel bevestigd wordt ${ }^{46}$ ). Een aanzoekhuwelijk tusschen een onvrijen man en een adellijke vrouw is echter niet te verwachten; eerder kunnen wij veronderstellen dat een paar menschen in dergelijke sociale verhouding door de vlucht zich aan ingrijpen der rechtsgemeenschap onttrok.

Uit Loinang weten we (blz. 88) dat de huwelijksvoltrekking van een lid der daka'njo- of tonggolfamilie met meer luister geschiedt dan bij den gewonen man ${ }^{47}$ ). Wil een man uit het gewone volk met een meisje van adel huwen, dan moet hij eerst zijn aanzien koopen (madi: mongoli kadaka'an). Hiertoe moest hij een slaaf geven in ouden tijd (kwam deze aan den vader der bruid? Of aan het hoofd der rechtsgemeenschap?); bovendien moet hij het voor een adellijk meisje benoodigde omvangrijker en kostbaarder huwelijksgeschenk opbrengen, waartoe in dit geval velerlei koperen voorwerpen, wapens en een zwaard met zilveren scheede behooren. Overigens verschilt de wijze van huwelijkssluiting niet van die van het gewone volk.

\section{Vluchthuwelijk ${ }^{48}$ ); andere huwclijksvormen.}

Het sluiten van een huwelijk na vlucht komt in den Arichipel voor; aanleiding kan zijn :

$a$. het meisje bemerkt dat haar ouders niets van een huwelijk mẹt den jongen man harer keuze willen weten;

$b$. het meisje vermoedt dat het voor haar gevraagde huwelijksgeschenk te hoog is voor de financieele draagkracht van den jongen, zoodat hij die nooit bij elkaar zal kunnen krijgen.

De jonge menschen spreken dan af gezamenlijk te zullen vluchten (aki : podampason: met iets wegloopen) ${ }^{48}$ ). $\mathrm{Zij}$ verbergen zich in het bosch of in de veraf gelegen woning van een bekende; uit eigen waarneming is mij verder bekend dat het gewoonterecht wil dat de jongelui zich naar het hoofd begeven en zich onder diens bescherming stellen, hem verzoekende de zaak in orde te maken. Het is dan

46) J. G. F. Riedel, Zeitschrift für Ethnologie 1885.

47) Kruyt, To Loinang, blz. 455.

48) Ter Haar, Beginselen en stelsel, blz. 161, maakt ten rechte een wezenlijk onderscheid tusschen wegloophuwelijk en het ook door hem genoemde schaakhuwelijk, welk laatste hij beperkt tot het wegvoeren van een vrouw die door verloving of huwelijk aan een anderen man gebonden is.

49) Kruyt, Banggaische Studiën, blz. 21-22. 
gewenscht dat het paar nog geen huwelijksverkeer heeft gehad. $Z$ ij worden nu door het hoofd gescheiden en het meisje blijft b.v. te zijnen huize terwijl de jongen als verblijfplaats een ander huis, bij een der dorpsnotabelen aangewezen krijgt. Dit blijft zoo totdat de aangelegenheid met beide families in het reine is gebracht. De bemiddeling van het hoofd komt er dan op neer dat hij de ouders van het meisje overhaalt den jongen man als schoonzoon te aanvaarden, en c.q. met een lager huwelijksgeschenk. genoegen te nemen. Om de verzoening tot stand te brengen meldt Kruyt het zenden van een verzoeningsgeschenk (aki : pinda; verg. blz. 195) door den jongen man aan de familie van het meisje.

Overigens staan den vader van het meisje nog andere wegen open. Hij kan b.v. in huizen van familieleden van den jongen man eenige huisdieren dooden en goederen wegnemen; de familie lijdt op deze wijze een verlies en moet bovendien de schade aan anderen vergoeden als er vee van derden is gedood; een en ander is dus een parallel van de zelfrechtverschaffing op blz. 195 beschreven in gevallen van vóór-huwelijksverkeer.

Een tweede mogelijkheid is, dat de vader zich tot het hoofd wendt en hem zijn beklag doet, onder mededeeling welk huwelijksgeschenk hij voor zijn gevluchte dochter wil ontvangen; bij zijn vertrek neemt de vader dan gewoonlijk een aan het hoofd behoorende gong mede, welke hij als boete oplegt aan den vluchteling (aki : badosa: een boete opleggen). De familie van den jongen man is nu verplicht huwelijksgeschenk èn gong op te brengen bij het te sluiten huwelijk; niet bekend is of de vader zijn eisch lager stelt dan bij een normaal aanzoek. Verder vermeldt Kruyt dat voor het geval het huwelijksgeschenk niet op deze wijze wordt voldaan, de jonge man die met het meisje gevlucht is door vader en broers van het meisje eertijds kon worden gedood dan wel als slaaf verkocht.

Een derde mogelijkheid (West-Peling?) is dat de vader de zaak op haar beloop laat in het geval dat de jonge man onvermogend is. Er komt dan uiteraard wel een verzoening tot stand, waarbij de op blz. 217 genoemde afspraak kan worden gemaakt, nl. dat het eerste kind bij wijze van betaling van huwelijksgeschenk aan de ouders der bruid zal worden gegeven. Kruyt deelt mee dat hij dit vooral in Kindandal aantrof (Midden-Peling, echter tot de West-Pelingsche cultuursfeer behoorend).

Bovendien schijnt de mogelijkheid te bestaan dat de partijen onverzoend blijven; dan wordt het meisje niet meer als kind harer ouders 
beschouwd, waarmee ze opgehouden heeft erfgerechtigd te zijn. In welke gevallen een dergelijke maatregel genomen wordt is mij niet bekend; kan dit b.v. mogelijk zijn bij verschil van godsdienst wanneer b.v. een Christelijk meisje voor haar huwelijk Mohammedaansch wordt?

Op den Vogelkop kent men voor het gezamenlijk ${ }^{50}$ ) vluchten van een paar den term mampamarerekon (sian); de gewoonte is dat het paar zich gedurende een of twee maanden verbergt; keert het daarna deemoedig terug, dan leggen de ouders zich erbij neer, omdat er toch niets meer aan te veranderen valt. (Wordt er dan nog een huwelijksgeschenk gevorderd? Is deze eventueel verlaagd c.q. verhoogd?). De jongen krijgt echter een pak slaag en het meisje wordt weer meegenomen naar huis als familie van het meisje het paar kort na de vlucht vindt. (Moet er dan een huwelijk volgen? vergelijk het op blz. 204 medegedeelde, betreffende het verborgen blijven der nachtelijke bezoeken van jongens aan meisjes. Wordt eventueel nog een boete opgelegd? En hoe staat het dan met het huwelijksgeschenk?).

Uit Loinang ontbreken gegevens over het vluchthuwelijk, doch uit eigen waarneming is mij bekend dat dit ook hier bekend is; het jonge paar begeeft zich op de bovenaangegeven wijze naar het hoofd dat de aangelegenheid in orde moet maken (door een verzoening tusschen de beide families tot stand te brengen).

Een vorm van dienhuwelijk zou men kunnen noemen hetgeen Kruyt mededeelt over het uivtoeren van een opdracht en als belooning van die opdracht de dochter van den opdrachtgever huwen zonder huwelijksgeschenk (het aangehaalde voorbeeld is dat van een gifmenger die in opdracht van een ander gedood wordt; deze andere persoon miste den moed het zelf te doen; Archipel) ${ }^{51}$ ).

Een andere eigenaardigheid noemt Kruyt, tezamen met gevallen van wanbetaling van huwelijksgeschenk; hij stelt het geval dat er maar één kind uit het huwelijk geboren wordt, terwijl voor dat huwelijk geen contant huwelijksgeschenk opgebracht is ${ }^{\mathbf{5 2}}$ ). Dan wordt dit kind wel, zooals op blz. 217 medegedeeld, aan de grootouders afgestaan. Is dat ééne kind een jongen, dan wordt hij dienstplichtig (aki : tano) aan de familie van zijn moeder, totdat de helft van het huwelijksgeschenk voor zijn moeder voldaan is. Deze kinderverdeeling komt pas jaren na het huwelijk tot stand, want het is mogelijk dat

50) Kruyt, Leven en sterven, blz. 60 .

51) Kruyt, Zwarte kunst, blz. 740 v.

52) Kruyt, Banggaische Studiën, blz. 26. 
de man na zijn trouwen alsnog het huwelijksgeschenk verzamelt en aan de rechthebbenden doet toekomen (Archipel). Onbekend is of er gedurende dien tijd door den schoonzoon ook bepaalde diensten moeten verricht worden, of welke andere verhouding gedurende dien tijd tusschen het jonge paar en de ouders der vrouw bestaat.

Ook uit Balantak ${ }^{53}$ ) wordt een dienverhouding gemeld, waar het jonge paar een jaar of drie bij de ouders der vrouw blijft inwonen, in welken tijd de man zijn schoonouders dient; eerst na afloop van dien tijd is het hun toegestaan zich een eigen woning te bouwen; is wellicht daarom het huwelijksgeschenk in Balantak zoo gering?

\section{Gemengde hurwelijken.}

De literatuur zwijgt op dit punt. Uit eigen waarneming is mij één dergelijk geval bekend, nl. het huwelijk gesloten tusschen een IndoChinees en een landschapsonderhoorige; beiden waren Katholiek. Interessant zou het zijn te weten of hier een huwelijksgeschenk betaald is, en welke andere bestanddeelen van het Banggaische adatrecht bij dit huwelijk in stand zijn gebleven.

\section{Huwelijksgoederenrecht.}

De mededeelingen hierover zijn zeer schaarsch, gepubliceerde vonnissen ontbreken, terwijl mij uit de practijk eveneens geen gevallen bekend zijn.

In den Archipel leggen dadelijk na het huwelijk zoowel man als vrouw ieder een eigen akker aan; zoolang deze nog geen vruchten oplevert, worden de pasgehuwden onderhouden door de wederzijdsche ouders. Volgens $\mathrm{Kruyt}^{54}$ ) is er geen vaste regel aan te geven waar het jonge paar de eerste jaren na het huwelijk doorbrengt; het kan bij de ouders der vrouw dan wel bij die van den man inwonen, doch ook komt het voor dat het den tijd tusschen de beide ouderlijke woningen verdeelt. Volgens Pater van den Bergh M.S.C. geeft men er de voorkeur aan in de familiegroep der vrouw te huwen, en dus daar te gaan wonen (zie blz. 199); het jonge paar woont eerst een tijd bij de ouders der vrouw. Aan dit inwonen komt echter in den regel een einde na de geboorte van het eerste, uiterlijk na die van het tweede kind. Niet duidelijk is aan wie het huis toebehoort, aan den

53) Kruyt, Leven en sterven, blz. 62 .

54) Kruyt, Banggaische Studiën, blz. 30 v. 
man of de vrouw ; vergelijk echter wat er mee geschiedt bij huwelijksontbinding (par. 8).

De beide echtelieden leggen ieder voor zich tuinen aan; wel helpen ze elkaar wederkeerig en van de opbrengst der velden wordt ook gezamenlijk genoten, maar men let er goed op of men evenveel terugontvangt als men voor den algemeenen pot heeft bijgedragen ${ }^{55}$ ).

Of er aangebracht goed is, en zoo ja wat de positie der wederkeerige echtgenooten ten opzichte van deze is, blijkt niet uit de beschikbare gegevens. De gewoonte bij begrafenis wijzen er echter op dat lijfsieraden, kleeding, wapens, onverschillig of deze zelf zijn verworven dan wel op andere wijze werden verkregen, persoonlijk bezit zijn $^{56}$ ) (b.v. het pronkbord dat de moeder krijgt bij het huwelijk harer dochter, alsmede het aan de moeder toekomend deel van het huwelijksgeschenk (van de poepoet en de loliba; zie blz. 208 v.) ; eveneens zijn de zoengaven, door den man aan zijn vrouw geschonken (b.v. na een twist) haar persoonlijk bezit.

Ieder der huwelijkspartners voert eigen rekening, want in den ouden tijd kon de vrouw zelfs pandeling worden van haar man, omdat zij op de een of andere wijze in schuld was geraakt; dit had b.v. tot gevolg dat haar aandeel in het huwelijksgeschenk harer dochters aan den man kwam; hoe nu ? ${ }^{57}$ ). Dat er echter wel degelijk een gemeene boedel moet bestaan blijkt uit mededeelingen nopens erfrecht (zie verder hoofdstuk IX). Indien nl. een echtpaar kinderloos komt te overlijden heeft een verdeeling der goederen plaats in reden van $2: 1$, in de algemeen Indonesische vorm dus van: ,sapikoel sagendong”. De wederzijdsche familie ontvangt dan deelen van den boedel, waarbij het mans aandeel op het dubbele van het vrouws aandeel wordt gewaardeerd; dit zal vermoedelijk berusten op een in het Banggaische huwelijksgoederenrecht aanwezigen regel.

Overigens rijzen vele vraagpunten die slechts na aanvullend plaatselijk onderzoek kunnen worden beantwoord.

55) Kruyt, Landbouw, blz. 477.

56) Kruyt, Ziekte en dood, blz. 155 : „Aan een man worden (bij zijn overlijden) „in de kist zijn hakmes en zijn speer meegegeven, aan een vrouw haar mes. "Zijn deze voorwerpen nog bruikbaar, dan nemen de kinderen of verwanten „die, en leggen daarvoor in de plaats een onbruikbaar stuk ijzer”. Blz. 163: „Boven op het graf worden allerlei eigendommen van den overledene gelegd: „een gong, een kookpot en allerlei eetgerei; zijn slaapmat, oebi en andere eet„waren. Ook worden van zijn aanplant enkele boomen omgehakt: een kokos„boom, een pinangboom, een sirihplant. Men hakt daartoe boomen om die nog "geen vrucht dragen."

57) Kruyt, Banggaische Studiën, blz. 36. 
Wat den Vogelkop betreft luidt de eenige mededeeling op het gebied van huwelijksgoederenrecht, dat de man bij het aanleggen der nieuwe akkers door de gezamenlijke dorpelingen er ook één voor zich en zijn vrouw kan klaarmaken. Is dit dan een akker van man èn vrouw samen? Geschenken aan de vrouw door haar schoonmoeder zijn bekend en worden o.a. gegeven bij het eerste bezoek van het jonge paar aan de ouders van den man. Verder kan bij een eventueel conflict tusschen de echtelieden de man door de vrouw beboet worden; niet bekend is of de boete aan de vrouw komt en of zij daarover vrijelijk kan beschikken; vermoedelijk wel.

Uit Loinang ontbreken vrijwel alle gegevens. Het blijkt dat de vrouw geschenken kan ontvangen van haar schoonouders, nl. bij het eerste bezoek te hunnen huize; verder dat het jonge paar de wederzijdsche ouders eerst helpt bij het akkerwerk, soms wel tot een jaar lang, en dat het zich daarna pas een eigen woning bouwt (van wie is die woning? verg. par. 8).

\section{Meervrouwendom.}

Reeds in den voortijd kwam het voor dat legendarische hoofden meer dan één vrouw hadden; zoo b.v. in West-Peling waar van eenige vorsten verteld wordt dat ze twaalf (het daar magisch belangrijke getal!) vrouwen hadden, zoo ook van daka'njo Kamboa van Lingketing, die zeven (plaatselijk magisch belangrijk!) vrouwen tegelijk had.

Meervrouwendom is ook thans nog geoorloofd, doch komt in de practijk betrekkelijk weinig voor; wat de motieven zijn waardoor mannen er al dan niet toe overgaan een tweede vrouw te nemen, is niet bekend. Dubbelhuwelijk heet in het aki ampi of tangkalabang, in het madi mongohoea; voor het sian is de term niet opgegeven ${ }^{58}$ ).

De vrouw met wie de man het eerst gehuwd is, blijft steeds een bevoorrechte positie innemen boven de latere echtgenooten; is er twist ontstaan b.v. tusschen twee echtgenooten van denzelfden man, dan moet de later gehuwde een verzoeningsgeschenk aan de andere aanbieden.

Een der redenen dat een man een tweede of meer vrouwen neemt kan gelegen zijn in de omstandigheid dat de oudste vrouw geen kinderen baart. In deze gevallen komt het voor dat deze zelf een tweede uitzoekt voor haar man; zij heeft dan meer in haar hand dat deze

58) Kruyt, Banggaische Studiën, blz. 32 v.; To Loinang, blz. 447/448. 
tweede vrouw iemand is die haar aanstaat, hoewel zij het niet tegen kan houden als haar man iemand als tweede echtgenoote neemt tegen haar wensch in. Hij is dan echter wel gehouden haar een verzoeningsgeschenk te geven (aki: tambojo: het loon; madi: pontambo: om - haar verzet - in den steek te laten).

De diverse echtgenooten leven meestal in één huis, hoewel ik uit eigen waarneming weet dat het ook voorkomt dat een man in verschillende dorpen wel eens een vrouw heeft; elk dezer vrouwen blijft dan daar wonen, terwijl de echtgenoot van tijd tot tijd bij elk harer komt logeeren. Elke vrouw behoudt haar eigen goederen en haar eigen akker; de man moet echter elke echtgenoote bij den aanleg van haar akker helpen. Door verschil in bezit en ijver kan de eene vrouw veel rijker met aardsche goederen gezegend zijn dan de andere, waardoor de mogelijkheid van het ontstaan van schuld- en dienstverhouding tusschen de echtgenooten van één man bestaat.

Zooals op blz. 201 reeds angestipt werd is het tegelijkertijd met twee zusters gehuwd zijn iets dat niet strookt met de opvattingen der bevolking (zie ook Hoofdstuk XII, par. 1). In Balantak ${ }^{59}$ ) beschouwt men een dergelijk huwelijk als een lichte vorm van bloedschande; er staat niet de sanctie op die anders tegen bloedschande bedreigd wordt, doch de dorpsgenooten reageeren erop met iets dat op adatrechtelijke doodverklaring lijkt: de man wordt afgeranseld door alle dorpsgenooten, die hem ook al zijn have en goed ontnemen, waarna men hem verder met rust laat, ook al wil hij verder zijn leven met beide zusters voortzetten. Het sian kent een aparte term voor een persoon op wien de gemeenschap haar beleedigd rechtsgevoel op een dergelijke wijze heeft geuit; hij is een tobangkas. Indien dit werkelijk een soort doodverklaring is dienen we te constateeren dat een dergelijk dubbelhuwelijk toch wel een zeer ernstig vergrijp tegen de orde is.

In Loinang stelt men het huwelijk van één man met twee zusters wel is waar niet gelijk met bloedschande, maar de leden van de dorpsgemeenschap voelen zich er toch door beleedigd ${ }^{80}$ ). De man moet in dit geval een boete aan het hoofd, den tonggol opbrengen. Laat men hem dan verder met zijn beide zusters ongemoeid en behoudt hij alle rechten? Zoo ja, dan is die boete eerder een ontzondigingsoffer.

59) Leven en sterven, blz. 57.

60) Kruyt, To Loinang, blz. 448.

Verh. di. VI. 


\section{Huwelijksontbinding.}

Op blz. 199 werd reeds medegedeeld dat uithuizigheid van den man mogelijke reden tot huwelijksontbinding kan zijn, als hij daarmee toont te veel gehecht te zijn aan zijn eigen familie. Als verdere reden worden voornamelijk genoemd: overspel; onlust (afkeer); gemeenschappelijk overleg.

In den Archipel heet echtscheiding pabaoental (aki) ${ }^{61}$ ). Verlaat de man zijn vrouw zonder dat zij daartoe anleiding heeft gegeven, dan gaat hij heen onder achterlating van de woning en de staande huwelijk verworven goederen. Is het de vrouw die zich vrijmaakt, dan laat zij al haar goederen achter, ook het gezin, nl. in die gevallen dat zij een afkeer van haar man heeft gekregen. De kinderen blijven dus voorloopig bij den man, doch als zij groot genoeg zijn geworden om een eigen keus te doen kunnen ze òf naar vader ò naar moeder gaan; uiteraard zijn hiervan de gevolgen het belangrijkst bij het huwelijk dier kinderen.

De mogelijkheid bestaat echter ook dat het paar met onderling goedvinden uiteen gaat. In deze gevallen behouden man en vrouw ieder hun eigen akker (zie blz. 222), terwijl de gedurende het huwelijk verworven goederen (vee en roerende zaken; echter niets medegedeeld ten aanzien van overjarige beplantingen) in drieën worden gedeeld, waarvan twee deelen voor den man en een voor de vrouw. De man moet bovendien de draagmand zijner vrouw met oebi vullen als zij geen aanleiding heeft gegeven dat aan het huwelijk op deze wijze een einde komt. De huwelijksontbinding zelve geschiedt door een symbolische handeling (het doorhakken b.v. van een pinangnoot), verricht door een heidenschen priester (aki: talapoe) dan wel door den tonggol.

In de gevallen dat er echter kinderen zijn die nog ouderszorg noodig hebben laat de man zijn deel voor hun opvoeding achter, terwijl ook het huis aan de vrouw komt; vermoedelijk zal hij niet meer meenemen dan zijn kleeren en zijn wapens en hakmes. De aldus met kinderen achtergebleven vrouw blijft meestal niet in de woning doch trekt met haar kroost bij haar ouders in; de woning beteekent meestal niet veel als duurzame verblijfplaats daar zij gewoonlijk slechts van zeer tijdelijke materialen is opgetrokken.

$\mathrm{Op}$ den Vogelkop heet echtscheiding powo'oli (sian) ${ }^{62}$ ). Indien

61) Kruyt, Banggaische Studiën, blz. 33-35.

62) Kruyt, Leven en sterven, blz. 63. 
de man zijn vrouw verlaat zonder dat zij daartoe gereede aanleiding heeft gegeven moet de man de woning van het gezin en de staande huwelijk door hem verworven goederen achterlaten; bovendien moet hij nog een boete betalen van 30 rear; aan wien deze komt is niet medegedeeld, vermoedelijk aan de verlaten vrouw. Interessant zou zijn te weten of haar ouders hier eventueel nog in participeeren.

Verlaat de vrouw de gemeenschappelijke woning omdat zij een afkeer van haar man heeft gekregen, dan krijgt zij niets van beider bezittingen mee; heeft zij echter de zorg voor kinderen (gaan deze dan met de moeder mee?) dan krijgt zij een (welk?) deel. Dat een dergelijk optreden niet strookt met het rechtsbewustzijn der bevolking blijkt daaruit dat in deze gevallen steeds pogingen tot verzoening worden gedaan door het hoofd.

Ook is mogelijk dat de scheiding na gemeenschappelijk overleg geschiedt; in dit geval worden de bezittingen (welke zijn dat? gezamenlijk verworven, of ook die afzonderlijk verkregen?) in twee gelijke deelen verdeeld, voor ieder der partners een deel. De man laat echter het hem toekomende bij de vrouw achter indien er kinderen zijn die door de moeder moeten worden opgevoed.

In Loinang is echtscheiding duidelijk een handeling die niet strookt met de belangen der rechtsgemeenschap; de hoofden ondernemen steeds pogingen tot verzoening ${ }^{\mathbf{B}}$ ). Zoo wordt door middel van een geschenk (boete?) de zaak weer in orde gemaakt als de oorzaak van de twist gelegen is in b.v. beleediging van één der schoonouders of mishandeling van één der echtelieden door den ander.

Indien de man niets meer om zijn vrouw geeft en hij haar uit dien hoofde alleen wil verlaten moet hij bij zijn vertrek afstand doen van al zijn goederen, zelfs van zijn baadje en zijn hakmes. Wil daarentegen de vrouw niets meer van haar man weten, dan verliest zij al haar goederen en moet $z i j$ bovendien de bruidschat vergoeden aan haar man (ook als zij reeds één of meer dochters heeft?). De scheiding is ook hier een publieke zaak en wordt (symbolisch) door het hoofd verricht (ongeveer als in den Archipel). De handeling heet in het madi mosilaakon pomangon; is dit de term voor echtscheiding zelve, dan wel voor het uitspreken daarvan? Het hoofd krijgt van die partij een belooning welke de goederen in haar bezit houdt (de vrouw) c.q. terugontvangt (de man); deze belooning (madi: oedjoelaa of bonto-bontolan) kan tot $1 / 3$ der goederen bedragen (zie ook blz. 111

63) Kruyt, To Loinang, blz. $457-459$. 
voor de bemoeienis der hoofden in Loinang en blz. 153 v. voor het rechtersdeel).

Een der eerste redenen tot echtscheiding is overspel door de vrouw gepleegd. Dwingend is dit feit als huwelijksontbindende factor echter niet daar de mogelijkheid tot verzoening bestaat. Daarentegen is overspel door den man gepleegd geen reden tot echtscheiding; de beleedigde echtgenoote kan hierin echter wel reden vinden haar man, vaak ook de medeschuldige vrouw te beboeten.

Overspel heet basalano (aki), mogora (sian), molosoki of mombolosakon (madi) ${ }^{64}$ ).

$\mathrm{Bij}$ door de vrouw gepleegd overspel kan de man zijn vrouw in genade aannemen, doch dan moet $\mathrm{zij}$ als boete éénmaal haar bruidschat aan haar echtgenoot voldoen; als zij hiertoe niet in staat is ontstaat schuldverhouding (zie hoofdstuk XI). Wil de man zich echter niet met zijn vrouw verzoenen, dan komt het tot scheiding en moeten zoowel de overspelige vrouw als haar minnaar aan den beleedigden echtgenoot éénmaal het huwelijksgeschenk als boete voldoen (de vrouw geeft dit terug, de overspeler krijgt een boete gelijk daaraan), doch hierna mag het paar zonder huwelijksgeschenk huwen. Dit voor zoover het den Archipel betreft. Slechts te Banggai (hoofdplaats) is hierin onder invloed van het Mohammedaansche hof verandering gekomen; daar toch mag het overspelige paar nimmer huwen, terwijl de goederen der overspelige vrouw aan den beleedigden echtgenoot vervallen, inclusief de kinderen.

Gevallen van overspel worden thans veelvuldig op klachte, zoowel van den beleedigden echtgenoot als van het betrokken dorpshoofd, ter kennis van de zelfbestuursrechtbank gebracht; geen dezer vonnissen is echter gepubliceerd, noch bezit ik uittreksels. Belangrijk in dezen lijkt mij de achtergrond van de klacht: dat er een klacht werd ingediend bewijst dat geen verzoening tot stand is gekomen; op welke gronden kon dit niet? Uit eigen waarneming is mij bekend dat de beleedigde echtgenoot geen bezwaar heeft tegen een huwelijk der overspelige vrouw met haar minnaar; soms wordt de scheiding in Mohammedaanschen zin onmiddellijk na het bekend maken der beslissing der rechtbank verricht.

Op den Vogelkop is bekend dat een overspelig paar mag huwen (met of zonder huwelijksgeschenk?). Over verzoening en eventueel daarbij te pas komende boeten ontbreken gegevens.

64) Kruyt, Banggaische Studiën, blz. 35-37; Leven en sterven, blz. 64; To Loinang, blz. $457-460$. 
In Loinang bestaat wel de mogelijkheid van verzoening, maar daar vormt de vrouw van den gehuwden medeplichtige aan het overspel ook een factor. Haar wordt gevraagd of zij het huwelijk met haar echtgenoot wil voortzetten. Er is dus toestemming van twee beleedigde echtgenooten noodig, hetgeen in tegenstelling is tot den hooger aangegeven regel. Blijft het echtpaar waarvan de vrouw overspel pleegde bij elkaar, dan moet de medeplichtige aan den beleedigden echtgenoot een boete voldoen; is die medeplichtige gehuwd, dan moet bovendien de overspelige vrouw aan de beleedigde echtgenoote van hem ook een boete voldoen. De boete wordt weer uitgedrukt in balasoe en bedraagt over het algemeen in Baloa het dubbele van die te Lingketing. De hoofden krijgen een deel van de boete van den overspeler aan den beleedigden echtgenoot (madi: oedjoelaa). Of ook van de boete der vrouwen onderling, de hoofden een deel krijgen is niet bekend. Het is echter ook mogelijk dat geen verzoening tot stand komt; in dit geval moet de overspelige vrouw alle huwelijksgoederen en het huwelijksgeschenk aan den beleedigden echtgenoot afstaan.

In den Archipel heeft door den man gepleegd overspel tot gevolg dat hij door zijn vrouw beboet wordt; deze boeten draagt hier het karakter van een verzoeningsgeschenk. Een speciale rechtsterm en de grootte zijn mij uit de literatuur niet bekend.

In Loinang is het mogelijk dat de man van zijn vrouw scheidt na gepleegd overspel met een ongehuwd meisje om met haar te kunnen huwen; hij moet dan aan zijn vrouw een groote som voldoen, vrijwel ter grootte van het huwelijksgeschenk. Daarnaast is het echter mogelijk dat de echtgenoote toestaat dat het meisje, mits uiteraard nog niet met een ander gehuwd, als tweede echtgenoote door den man wordt genomen. Dit gebeurt vaak in combinatie met een door de eerste vrouw tevoren gegeven toestemming aan haar man om naar dat meisje te gaan.

Hoe de verhoudingen worden indien de gehuwde man met de vrouw van een ander overspel pleegt werd zoo juist behandeld.

In Baloa wordt een misstap van een gehuwd man met een ongehuwd meisje gestraft door het paar te beboeten; de man geeft aan het hoofd (als vertegenwoordiger der rechtsgemeenschap) eenige blokken goed als boete; ook het meisje moet een dergelijke boete opbrengen aan de beleedigde echtgenoote van haar minnaar. Een vraag is het of het meisje dan alsnog als tweede vrouw door den man kan worden genomen. 
Voorwaardelijke verstooting, hoewel nergens in de literatuur genoemd, is mij uit de practijk bekend; meestal wordt bij de huwelijkssluiting vastgelegd dat de man niet zal dobbelen, of afwezig zal zijn langer dan een bepaalden tijd, waarbij vaak nog bedingen zijn opgenomen betreffende levensonderhoud; ook komt als voorwaarde voor het niet-huwen met een andere vrouw. Overschrijdt de man een der gestelde voorwaarden, dan treedt de verstooting in werking. De uitstippeling dezer voorwaarden heeft plaats bij de Mohammedaansche huwelijkssluiting. Het constateeren der overtreding van de voorwaarden heeft meestal plaats ten overstaan van dorpsgodsdienstbeambte en dorpshoofd, dan wel districtsimam en districtshoofd, bij wie de vrouw haar beklag komt doen. Terminologie is mij niet bekend (verg. blz. 170).

Hereeniging na huwelijksontbinding is mogelijk. In den Archipel neemt de gescheiden vrouw, als zij zelfstandig is gebleven, genoegen met een verzoeningsgeschenk (aki: pinda); doch het zal vaker voorkomen dat zij na de scheiding bij haar ouders intrekt, in welk geval de schoonzoon hun een geschenk behoort te geven, dat echter niet de waarde van het huwelijksgeschenk heeft. In Loinang gaat de man er wel eens toe over, als zijn vrouw eerst geen gehoor wil geven aan zijn verzoek om bij hem terug te keeren, haar een geschenk te geven ter grootte van het huwelijksgeschenk van het eerste huwelijk.

Zoowel in den Archipel als in Balantak, vermoedelijk ook in Loinang, komt een priester of het hoofd bij een dergelijke hereeniging te pas als het paar bij de scheiding zwoer niet meer bij elkaar te zullen komen. Een dergelijke eed kan worden afgelegd door het doorhakken van een vuurtang, een rotan of iets dergelijks; het hoofd of de priester moet nu dezen eed krachteloos maken.

Gegevens betreffende een adatrechtelijke iddahperiode ontbreken.

\section{Verzorging van kinderen.}

In de vorige paragraaf hebben we gezien dat bij huwelijksontbinding geen vaste regel bestaat aan welken ouder de kinderen komen; deze blijven wel zoo eenigszins mogelijk bij de moeder als ze nog niet voor zichzelf kunnen zorgen, nl. bij huwelijksontbinding na onderling overleg en goedvinden der ouders. Als de kinderen daarentegen groot zijn bepalen ze zelf hun keus. Ook als de vrouw haar man verlaat, zonder dat den echtgenoot schuld treft, dus indien dit gebeurt uit afkeer van haar man, kan het voorkomen dat zij de kinderen meeneemt; dit is afhankelijk van hun leeftijd. 
Concrete gegevens betreffende regeling en verzorging der kinderen bij overlijden van beide ouders ontbreken. Uit het erfrecht is echter bekend (zie hoofdstuk IX) dat bij overlijden der ouders een oom of een tante, van vaders- dan wel van moederszijde, de erfenis beheert; dit zal vermoedelijk tevens inhouden verzorging der weezen. Leeft echter een der ouders nog, dan beheert deze de goederen en zal vermoedelijk tevens als verzorger(ster) der jonge kinderen optreden ${ }^{65}$ ).

In het geval dat de moeder van een zoogend kind overleden of dat een vrouw in het kraambed gestorven is, wordt een zoogmoeder voor het kind gezocht ${ }^{86}$ ). Als zoodanig kan ook een tante (moederszuster? vaderszuster?) worden aangewezen. Het kind blijft zoolang bij die zoogmoeder tot het de borst niet meer noodig heeft.

De bijzondere positie van tweelingen (aki : paoe pingga; sian : rapi; madi : hapi) ${ }^{67}$ ) in het verwantschapsrecht kwam op blz. 185 v. reeds ter sprake. Slechts in Loinang hecht men aan de geboorte van tweelingen geen bijzondere waarde, doch in den Archipel en op den Vogelkop ziet men het ongaarne. De zeer merkwaardige vorm van voorkeurhuwelijk eertijds te Banggai tusschen broer en zuster van een tweelingpaar werd op blz. 197 reeds vermeld. Overigens verbreekt men de band, meestal met den laatstgeborene, door dit kind van de moeder te verwijderen en aan een ander ter opvoeding te geven. Op den Vogelkop volgde men indertijd een eenvoudiger weg: een der twee kinderen werd door verstikking om het leven gebracht. Of het de rechtsgemeenschap was die op dergelijke wijze ingreep en nog ingrijpt in de banden tusschen de ouders en het tweelingpaar is niet bekend.

\footnotetext{
65) Kruyt, Banggaische Studiën, blz. 37.

66) Kruyt, Banggaische Studiën, blz. 52.

67) Kruyt, Banggaische Studiën, blz. 46; Leven en sterven, blz. 71; To Loinang, blz. 461.
} 


\section{HOOFDSTUK IX.}

\section{Erfrecht.}

Voor dit hoofdstuk is de stof wel zeer schaarsch; er zijn slechts weinig gegevens te vinden in Kruyt's artikelen, terwijl gepubliceerde vonnissen jammer genoeg geheel ontbreken. Uit practijkwaarneming zij inmiddels medegedeeld dat het aantal boedelzaken, voor de inheemsche rechtbank berecht, zeer gering is; en de weinige die voor den rechter komen zijn grootendeels appèlzaken op uitspraken van den godsdienstigen rechter, bij wiens beslissingen, in zooverre deze strijdig zijn met het adatrecht, men zich dan blijkbaar niet wil neerleggen.

Het geringe aantal rechtszaken wettigt verder het vermoeden dat het grootste deel van op dit gebied gerezen kwesties door de nog levende hoofdenrechtspraak, in onderling overleg tusschen alle belanghebbenden, wordt afgedaan. Daarmee wordt het doel van het adaterfrecht bereikt, t.w. het bewerkstelligen van een verdeeling van goederen, welke als erfenis worden aangemerkt, op een dusdanige wijze dat allen die recht hebben op een deel van die erfenis, met de tot stand gekomen verdeeling ingenomen zijn.

\section{Onverdeeld blijven van boedelgoederen.}

Uit Baloa wordt gemeld dat de oudste zoon waarschijnlijk als beheerder van het erfgoed optreedt; niet aangegeven is wat dat erfgoed is ${ }^{1}$ ). Slechts deelt Kruyt mede dat een bepaald soort gegoten koperen spiralen, onderdeel der oorlogsuitrusting der mannen, als erfstukken worden beschouwd; deze voorwerpen heeten in het madi koelaloek $^{2}$ ). In den Archipel is de term voor erfenis poesaka ${ }^{3}$ ). Is één der ouders overleden, dan komen de goederen onder beheer van $\mathrm{de}(\mathrm{n})$ overlevende(n) ouder; komt ook deze te overlijden, dan wordt tot een zoo spoedig mogelijk verdeelen der goederen onder de kinderen overgegaan.

1) Kruyt, To Loinang, blz. 460 .

2) Kruyt, To Loinang, blz. 434.

3.) Kruyt, Banggaische Studiën, blz. 37 . 
Indien bij overlijden van beide ouders de kinderen nog klein zijn wordt de boedel niet verdeeld, doch een oom of tante, hetzij van vaders- dan wel van moederszijde, beheert het vermogen; hieruit kunnen kosten ten bate der weezen gemaakt worden (b.v. aankoop van dieren als offer aan pilogot bij ziekte der kinderen enz.).

Uit practijkwaarneming is mij wel bekend dat soms tusschen alle deelgerechtigden een afspraak wordt gemaakt den boedel bij toerbeurt te beheeren; feitelijke gegevens ten aanzien van den achtergrond van het ontstaan en het handhaven van een dergelijke afspraak zijn echter niet beschikbaar.

\section{Boedelverdeeling.}

Door het hooger reeds genoemde feit van weinig voorkomen van boedelzaken mag worden aangenomen dat de boedelverdeeling voldoet aan wat Ter Haar dienaangaande opmerkt: „De verdeeling is ,een handeling der gezamenlijke waris, gewoonlijk niet beheerscht „door strikte regelen en scherpe wenschen, maar veelal te weeg "gebracht in een geest van goedhartigheid, behulpzaamheid en bevoor„deeling der minst fortuinlijken" ${ }^{4}$ ).

Kruyt deelt mede dat vroeger gewoonlijk het lijk een paar dagen boven aarde staan bleef, omdat het niet begraven mocht worden voor alle verwanten aanwezig waren ${ }^{5}$ ).

\section{Erfgenamen.}

Trek van de ouderrechtelijke verwantenorde is dat de kinderen van beide ouders erven; zulks blijkt inderdaad duidelijk uit de beschikbare gegevens.

De mogelijkheid van ten zekere voorkeurpositie onder de erfgenamen is algemeen Indonesisch. Als voorbeeld daarvan in den Banggai-Archipel diene dat het oudste kind van een echtpaar in Tatabaoe( Sea-Sea) iets meer krijgt dan de andere kinderen, alleen omdat het de oudste is ${ }^{6}$ ). In Baloa schijnt het verder voor te komen dat de oudste zoon soms het leeuwenaandeel ontvangt, onder gelijke verdeeling van de overige goederen onder de andere erfgenamen; waarschijnlijk treedt de oudste zoon hier dan op als beheerder van het erfgoed ${ }^{7}$ ) (zie par. 1).

4) Ter Haar, Beginselen en stelsel, blz. 205.

5) Kruyt, Ziekte en dood, blz. 156.

6) Kruyt, Banggaische Studiën, blz. 37.

7) Kruyt, To Loinang, blz. 460. 
Normaal krijgen zoons en dochters gelijke erfporties, doch op het eiland Banggai krijgt een zoon het dubbele van een dochter, in Lingketing eveneens. Baloa geeft op dat zoons meer, doch niet juist tweemaal zooveel als een dochter, ontvangen.

Daarnaast staat de zoojuist geciteerde mededeeling dat de oudste zoon soms het leeuwenaandeel ontvangt, hetgeen dan gecombineerd wordt met het beheerder zijn van het erfgoed, in welk geval de overige broers en zusters gelijke erfporties ontvangen. Wellicht hebben we hier dus met twee rechtsfiguren te maken: a) er is erfgoed aanwezig, waarvan na overlijden der ouders de oudste zoon de beheerder wordt, terwijl de overige broers en zusters dan gelijke deelen krijgen; b) er is geen erfgoed, in welk geval de goederen in ongelijke deelen worden verdeeld, doch niet juist in verhouding van $2: 1$ voor zoons- en dochterserfporties.

In Balantak is de verdeeling normaal, d.w.z. broers en zusters krijgen evenveel; hetzelfde geldt voor den Archipel, waar er bijgevoegd wordt dat deze verdeeling zoo spoedig mogelijk na overlijden der ouders (en als de kinderen groot genoeg zijn) onder alle kinderen bewerkstelligd wordt. ${ }^{8}$ )

Daar op het eiland Banggai echter zoons het dubbele van dochters ontvangen kunnen we hierin invloed van den Mohammedaanschen godsdienst op het erfrecht vermoeden.

$Z$ ijn de ouders overleden en zijn de kinderen allen nog klein, dan wordt de boedel niet verdeeld, doch wordt door een oom of tante, hetzij van vaders-, dan wel van moederszijde, beheerd. (zie par. 1).

Betreffende de positie van weduwe of weduwnaar in een gezin waar kinderen zijn zij er op gewezen dat onder par. 1 reeds medegedeeld werd dat de boedel onder beheer komt van de(n) langst levende(n) echtgenoot(e); vermoedelijk zal de weduwe hieruit b.v. levenslang onderhoud kunnen genieten.

Een kinderlooze weduwe of weduwnaar neemt uiteraard een andere positie in. Hierover werd reeds op blz. 223 een en ander medegedeeld. De goederen van een echtpaar zonder kinderen worden bij overlijden van een der twee in drie deelen verdeeld; is de man overleden, dan gaan twee deelen naar zijn familie, terwijl èèn deel voor de weduwe blijft; stierf de vrouw, dan gaat èèn deel naar haar familie terwijl twee deelen voor den weduwnaar blijven. ${ }^{9}$ ) Ook

8) Leven en sterven, blz. 64.

9) Kruyt, Banggaische Studiën, blz. 37 v. 
werd aangestipt dat we niet voldoende ingelicht zijn ten aanzien van het huwelijksgoederenrecht om te kunnen zeggen of deze regel geldt alleen voor de staande huwelijk verworven goederen, of dat ook de aangebrachte goederen in deze verhouding verdeeld worden. Overigens is de regel zelf algemeen Indonesisch; de bevolking pleegt haar aan te geven met „sapikoel sagendong”; de man draagt aan weerszijden van den schouder met een draagstok, de vrouw echter alleen maar op haar rug.

In Balantak schijnt men dezen regel echter niet toe te passen want daar worden in geval van overlijden van een der huwelijkspartners van een kinderloos echtpaar de goederen in tweeën gedeeld : èèn deel voor de(n) overlevende(n) echtgenoot(e), het andere deel voor de familie van $\operatorname{de}(n)$ overledene $\left.{ }^{10}\right)$; uit deze laatste erfportie worden in den Archipel (ook in Balantak?) tevoren echter de begrafeniskosten voldaan.

Het adoptief kind is erfgerechtigd t.a.v. zijn pleegouders (niet t.a.v. zijn biologische ouders?); in den Archipel krijgt een adoptief kind de helft van het aandeel van een eigen kind. ${ }^{11}$ )

\section{Bestanddeelen van den boedel.}

Waardigheidsgoederen. Uit den Banggai-Archipel wordt gemeld dat kinderen en kleinkinderen van de heidensche priesters (aki: talapoe) vaak ook weer priester worden. $Z_{\mathrm{ij}}$ hebben een lap katoen in hun bezit, die dienst doet bij hun bezweringen (aki: kiang, liboeng of pangoan). Sterft nu een talapoe, dan mag zijn attribuut, die lap katoen, als symbool van het leven niet mee in de kist. Hij wordt bewaard totdat later een kind, neef (vermoedelijk cousin) dan wel kleinkind talapoe wordt en dan de doek gaat gebruiken. Dit speciale waardigheidsgoed is dus tevens een soort erfgoed. ${ }^{12}$ )

$\mathrm{Bij}$ de bespreking der bestuursorganisatie (hoofdstuk $\mathrm{V}$ ) werd reeds gewezen op het opvolgingssysteem, waarbij de verschillende waardigheden in bepaalde families blijven, doch niet behoeven te vererven van vader op zoon, docin in de eerste plaats van ouderen op jongeren broer, dan vaak overspringend op cousins, ook wederom van ouderen op jongeren overgaand, totdat als ten slotte een geheele generatie is afgewerkt een volgende aan de beurt komt; dit past weer geheel in het classificatorisch stelsel van verwantschapsverhoudingen.

19) Kruyt, Leven en sterven, blz. 64.

11) Kruyt, Banggaische Studiën, blz. 59 v.

12) Kruyt, Pilogot, blz. 129. 
Door een jongeren broer kunnen echter nimmer rechten op een bepaald ambt worden uitgeoefend alleen omdat een oudere broer van hem dat ambt bekleedde. Bij het vervullen van functies wordt erfrecht met electie toegepast.

Feitelijk bepaalde goederen. Men kent in den Archipel rechtstermen waarmede stellen koperwerk bij de verdeeling worden aangegeven; mengko bolito is een stel van zes kandari (zie noot 32 hoofdstuk VIII), met mengko sinapit duidt men een stel van twaalf kandari aan. ${ }^{13}$ )

Uit Loinang wordt gemeld dat de zoon de speciale bezittingen van den vader erft, zooals zijn gereedschappen, wapens, gongs, koperen borden, terwijl voor de dochters de aanplantingen (sagostoelen, kokospalmen) zijn. De woning gaat hier steeds naar een zoon, veelal naar den oudsten. ${ }^{14}$ )

Uit den Archipel wordt echter medegedeeld dat aan den doode vele gebruiksvoorwerpen worden meegegeven, en dat zelfs de familie hieraan bijdraagt. Zoo wordt het lijk soms bekleed met zeven lagen nieuwe kleeren, afkomstig van de verwanten; ook koperen borden en sirihdoozen worden door familieleden aangebracht en den doode meegegeven. Verder gaat met een man zijn hakmes en zijn speer, met een vrouw haar mes mee het graf in. Indien deze voorwerpen nog bruikbaar zijn mogen echter familieleden deze nemen en er een onbruikbaar stuk ijzer voor in de plaats leggen. ${ }^{15}$ ) Boven op het graf worden verder nog allerlei bezittingen van den overledene gelegd: een gong, een kookpot, allerlei eetgerei, zijn slaapmat, oebi en andere eetwaren. Verder worden van zijn aanplant enkele boomen omgehakt, een kokosboom, een pinangboom en een sirihplant; men neemt hiervoor zoo mogelijk niet vruchtdragende exemplaren. ${ }^{16}$ )

Uit Loinang wordt iets dergelijks gemeld: bij het uitdragen van het lijk worden verschillende gebruiksvoorwerpen meegenomen naar het graf, met eenige zaken tot het persoonlijk bezit van den overledene behoorend. $\mathrm{Bij}$ het eigenlijke doodenfeest, twee maal zeven dagen na de begrafenis, komen daar echter vele menschen uit den omtrek met het doel om onder het maken van veel misbaar de doodenziel te verjagen. $Z_{\mathrm{ij}}$ dringen daarbij het huis van den overledene binnen en eigenen zich alle eigendommen van hem die zij maar kunnen vinden, toe; ook de voorwerpen die naar het graf gebracht zijn worden door

13) Nota van den Bergh.

14) Kruyt, To Loinang, blz. 460.

15) Kruyt, Ziekte en dood, blz. 155.

10) Kruyt, Ziekte en dood, blz. 163. 
hen weggenomen. De familie van den overledene rekent er uiteraard op, door die deelen van de bezittingen van den overledene, die ze zelf wil behouden, ergens anders neer te zetten en te verbergen. Ook hier kent men verder het omkappen van eenige boomen uit het bezit van den doode; dit zou echter beperkt zijn tot aanzienlijken ${ }^{17}$ ).

Schulden vererven ook, zoowel de schuldvordering als de plicht tot terugbetaling van het geleende. Dit is van groot belang voor de af wikkeling der schuldverhoudingen die ontstaan zijn door het leenen om het huwelijksgeschenk bijeen te brengen (zie blz. 212) ${ }^{18}$ ). Deze schulden heeten in het aki : doni. Wanneer nu de schuldenaar overlijdt vòòr hij de doni heeft kunnen restitueeren komt de plicht tot voldoening daarvan op zijn nakomelingschap, of bij ontbreken daarvan, op zijn broers en zusters te rusten. Overlijdt daarentegen de schuldeischer vòòr hij de doni heeft terugontvangen, dan verandert er in feite niets, want bij het leenen is gewoonte de doni niet aan den gever doch aan diens kinderen terug te betalen, meer speciaal in de gevallen dat deze zelf voor het verzamelen van een huwelijksgeschenk komen te staan; eventueel kan een broer van den overleden schuldeischer in aanmerking komen om terugbetaling in ontvangst te nemen, anders een oomzegger van den overledene, die tot dezen in paoe-verhouding staat.

In de zeldzame gevallen dat een schuldenaar kinderloos overlijdt, en er ook geen personen zijn die er voor aansprakelijk zijn (broers, zusters; eventueel hun kinderen, die nl. in paoe-verhouding tot den overleden schuldenaar staan) wordt bij het overlijden de doni teruggegeven door dengene die de erfenis verdeelt; in dit geval wordt het dus een boedelschuld.

Onterving is mogelijk na een terzake van vluchthuwelijk onbetaald huwelijksgeschenk (zie blz. 220 v.), in dit geval nl. dat geen verzoening is tot stand gekomen tusschen den jongen man en de ouders der vrouw, en haar vader zijn schoonzoon ook geen adatboete heeft opgelegd (d.i. hem niet in de gelegenheid heeft gesteld een verzoeningsgeschenk aan te bieden). Wordt dan later de bruidsschat niet betaald, en komt ook niet op andere wijze verzoening tot stand, dan is het meisje niet meer het kind harer ouders; zij krijgt geen aandeel in de erfenis, ze heeft geen recht op de akkergronden ${ }^{19}$ ) (die dus eveneens kunnen vererven? Archipel).

Een verslagene wordt niet beërfd. Kruyt meldt dat het lijk van

17) Kruyt, To Loinang, blz. 485, 489, 490, 491.

18) Nota van den Bergh.

19) Kruyt, Banggaische Studiën, blz. 22. 
iemand die een gewelddadigen dood gestorven is zonder meer op de plek waar men het vindt in den grond wordt gestopt, met alles wat het bij zich heeft; men is nl. bang iets te bewaren of mede te nemen van iemand die op een dergelijke wijze om het leven is gekomen ${ }^{20}$ ). Wat echter met zijn goederen (huis, vaartuig, aanplantingen) gebeurt wordt niet vermeld.

20) Kruyt, Ziekte en dood, blz. 157. 


\section{HOOFDSTUK X.}

\section{Adatgrondenrecht.}

\section{Het beschikkingsrecht.}

In de literatuur vinden we weinig over dit onderwerp vermeld; in Goedharts nota b.v. wordt geen aandacht geschonken aan het grondenrecht, terwijl ook mijn memorie slechts in verwijderd verband iets in deze materie zegt. Kruyt geeft eenige punten, terwijl ter Haar in negatieven zin een gegeven vermeldt, nl. waar hij mededeelt dat misschien op de Banggai-eilanden de trekken van het beschikkingsrecht geheel ontbreken. ${ }^{1}$ ) Ik meen dit te moeten betwijfelen; al kunnen we weliswaar verre van een volledig beeld van het Banggaische adatgrondenrecht geven, de weinige feiten waarover we beschikken wettigen het vermoeden dat ook hier wederom het typisch Indonesische beschikkingsrecht, min of meer volledig, gevonden wordt.

De voornaamste oorzaak van het lastig onderkennen der verhoudingen van het grondenrecht in dit landschap is wel weer gelegen in de omstandigheid dat de volksgroepen, die dragers en handhavers van dit recht behooren te zijn, niet meer op haar oorspronkelijke plaats liggen, te midden der bouwvelden en zamelgebieden; tengevolge van de gedwongen dorpsvorming is de feitelijke rechtsbetrekking dezer groepen tot haar gronden verbroken.

Toch is de religieuze binding van rechtsgemeenschappen met bepaalde arealen hier en daar nog duidelijk merkbaar; als men navraag doet naar de afbakening der gebieden, die eertijds ter beschikking stonden der leden van de streekgemeenschappen op Peling b.v., dan treft men steeds weer aan, dat de vergoddelijkte stichter, die thans als balakat vereerd wordt, op een of andere wijze met dit terrein is verbonden; hij heeft daarin rondgezworven, heeft binnen dat gebied aan zijn volgelingen zijn bovennatuurlijke macht getoond, en is ook meestal vandaar uit onzichtbaar geworden; elders (WestPeling) staat dit grondenareaal ten nauwste in verband met de

1) Ter Haar, Beginselen, blz. 55. 
scheppingsmythen; het is daar het stuk land dat om het scheppingscentrum (een bergtop meestal) ontstond, en dat daar ook de eerste menschen voedde. ${ }^{2}$ ) In alle streken treft men verder aan de binding tusschen de levende leden der rechtsgemeenschap eenerzijds en den grond anderzijds die de lichamen der afgestorven voorouders heeft opgenomen, die hen echter bij hun leven heeft gevoed, en dit thans nog hun nazaten doet, totdat ook zij aan de schoot dezer zelfde aarde zullen worden toevertrouwd.

In de literatuur vinden we deze denkbeelden hier en daar aangegeven; Kruyt schrijft over den Vogelkop: „Het grondbezit van „elke dorpsgemeenschap was wel bekend; de grenzen werden aan"gegeven door bergen, heuvels, beken". ${ }^{3}$ ) Zoo is het ook in den Archipel naar mij bij navraag bleek; men gebruikt in het aki wel den term lipoe, ter aanduiding van het territoir dat ter uitsluitende beschikking stond van de leden van elke streekgemeenschap, en waarvan de grenzen tot in het heden bekend zijn. ${ }^{4}$ ) Kruyt vertaalt lipoe dan ook met landstreek; het werd hem ook opgegeven in den zin van aarde in tegenstelling tot hemel. ${ }^{5}$ ) Hoe de overeenkomstige term in het sian luidt is mij niet bekend. In het madi schijnt men ook lipoe te gebruiken, althans Tangkilisan gebruikt dit woord in zijn nota; hij vertaalt dit woord met ressort, en wel speciaal dat van een tonggol in Lingketing. Een vreemdeling die deze lipoe betrad moest voor den tonggol verschijnen en hem een geschenk geven (een handelaar in parangs gaf b.v. een parang). Dit is m.i. een sterke aanduiding dat de magische zijde van het adatgrondenrecht ook hier weer doorwerkt: die vreemdeling toch verbreekt bij het betreden van den beschikkingskring het magisch evenwicht, dat door een of fer moet worden hersteld; het hoofd is de drager der magische krachten en hij is uit dien hoofde de man die dit offer in ontvangst moet nemen.

Mijn indruk is dat zeker in het dichtbevolkte Oost-Peling en in de streek der groote stamdorpen aan de zuidkust van den Vaste-Wal, deze grondgebieden aan elkaar grensden; ook aan de noordkust kon dit plaatselijk het geval zijn. De moord op acht to-Lage in 1908 te Mantang gepleegd (zie blz. 183) is dan ook niets anders dan een bestraffing voor het betreden van den beschikkingskring van Doehian

2) Memorie.

3) Kruyt, Rijstbouw, blz. 124.

4) Memorie.

5) Kruyt, Bewoners, blz. 71. 
en het zonder toestemming van rechthebbenden zamelen van rotan aldaar. Het feit dat we hier vermoedelijk tevens met een snelpartij te doen hadden (in de oude rapporten wordt er althans in dien geest over gesproken) wijst er weer op, dat het verbroken magisch evenwicht hersteld diende te worden door een magische adatreactie.

Het feit verder dat we op den Vaste-Wal eenige grensconflicten konden vermelden (blz. 175 v.) moge ons een bewijs zijn dat ten minste bosanjoschappen en gelijkstandige groepeeringen een gebiedskring bezaten; verder dat deze op meerdere plaatsen aanèèn grensden.

In dit verband moeten wij het ten zeerste betreuren dat we over niet meer gegevens beschikken uit Loinang, omdat we daar te maken hebben met een volksgroep die grootendeels op haar oorspronkelijke plaats is blijven wonen. Dan hadden we zekerheid kunnen krijgen over de vraag of beneden de streekgemeenschap eventueel de tompoek ook beschikkingsrecht uitoefende, dan wel of de rechten der onderdeelen slechts bestaan uit het totaal der uitgeoefende individueele rechten. Het is mijn indruk, verkregen bij mijn onderzoek naar de verdeeling der basaloschappen, dat slechts het basaloschapsterritoir als beschikkingskring is aan te merken, en dat dus ook alleen deze hoogste der lagere rechtsgemeenschappen het daarmede samenhangende recht uitoefent. Kruyt ${ }^{6}$ ) echter spreekt over de rechten der dorpsgemeenschappen, waarmee hij in dit verband de bense bedoelt, waar hij tevoren over den tonggol sprak. Overigens geeft hij uit den Archipel geen gegevens.

Als wij nu aannemen dat in den Archipel lipoe (of overeenkomstig begrip elders) in de plaats staat van beschikkingskring, en dat de bense binnen den beschikkingskring door ontginning harer leden inlandsche bezitsrechten op deelen van dat territoir vestigden, zullen we hebben na te gaan of wij hierop voortbouwende, de kenmerkende trekken van het Indonesisch beschikkingsrecht kunnen terugvinden. ${ }^{\top}$ )

2. Uitingen van het beschikkingsrecht in zijn werking naar binnen.

In de allereerste plaats vinden we typeerende verschillen in de mate waarop individueele rechten door groepsleden op stukken van het groepsterritoir gevestigd kunnen worden.

6) Rijstbouw, blz. 124.

7) C. van Vollenhoven, Miskenningen van het adatrecht, blz. 19/20. Verh. dl. VI. 
In den Archipel schetst Kruyt den toestand als volgt: „.... elke „familie, verzameling van naaste bloedverwanten, vormde een een„heid, die zich nauw aaneensloot, ....”. Dan: „Zoo'n familie ontgon ,een stuk boschland, en daarop bleven ze ten allen tijde rechten „behouden”. Verder: „Werd de familie aan kinderen en klein"kinderen te groot, dan trokken sommigen hunner weg om een stuk „boschgrond te ontginnen, en op deze wijze nieuwe landerijen te „krijgen”. Ook heet het: „Elke familie bezat een uitgestrektheid ,gronds; deze lag gewoonlijk in de onmiddellijke nabijheid van „de woning. Men kende de grenzen van zijn bezitting. Recht op ,den grond verkreeg men door een stuk boschland te ontginnen; „dit land bleef dan in erfelijk bezit van de familie. Gewoonlijk werd ,het land niet onder de leden der familie verdeeld, maar ....." 8 ) Wij moeten hieruit dus lezen, dat door ontginning van een woest gedeelte van den beschikkingskring door en ten behoeve van een familiegroep, inlandsch bezitrecht ontstaat op dat ontgonnen stuk grond, waarbij het beschikkingsrecht sterk terugtreedt, immers wordt gesproken van het te allen tijde uitoefenen van rechten; dat dit „te allen tijde" niet juist is zullen we straks zien. Een en ander is in overeenstemming met het meer individualistisch karakter der sociale ordening in den Archipel, waar de band tusschen de familiegroepen volgens Kruyts mededeelingen tamelijk los was.

Dit gegeven staat in scherpe tegenstelling tot wat wij van Balantaksch recht op dit punt weten, waar Kruyt nl. meldt dat wel ieder lid der dorpsgemeenschap het recht heeft boschgronden, behoorende tot het dorpsareaal, te ontginnen, welke gronden dan geacht worden te zijn van den ontginner en zijn familie, doch dat op den langen duur, als de ontginner of zijn familie dat grondstuk al jaren in gebruik heeft, het geacht wordt weer te behooren tot het dorpsbezit, waardoor het vatbaar wordt voor bewerking door andere dorpers, zonder dat dezen den eersten ontginner een recht behoeven te betalen. De terugname door het dorp geschiedt onder de motiveering, dat de ontginner reeds zijn zweet van dien akker heeft gegeten, dat wil zeggen, dat de moeite van het ontginnen reeds lang beloond is. ${ }^{9}$ ) Hieruit dienen we te lezen dat het beschikkingsrecht der dorpsgemeenschappen op den Vogelkop sterker is dan in den Archipel, en dat het inlandsch bezitrecht, ontstaan door ontginning, zeer beklemd blijft in dat beschikkingsrecht. In dit verband is het

8) Kruyt, Bewoners, blz. 71.

э) Kruyt, Rijstbouw, blz. 124 v. 
tevens duidelijk dat het op den Vogelkop niet mogelijk is den grond tot voorwerp van transacties te maken (schenken van een stuk land als bruidschat, afstaan aan een ander tot delging van schuld, verkoopen aan andere families), zooals uit den Archipel wordt gemeld. ${ }^{10}$ ) Hiervan weet men in Balantak niets: de grond blijft van de dorpsgemeenschap en kan niet worden vervreemd.

In Loinang weten we dat daar landbouwvereenigingen worden aangetroffen (madi : sambaba; zie blz. 63 en 100); de akkergenooten van een dergelijke vereeniging heeten olitaoe (madi). Gezamenlijk wordt een stuk boschterrein ter ontginning uitgekozen, waarin merkteekens worden geplaatst, aangevende de deelen die ieder voor zich zal ontginnen. Als later de grond is schoongemaakt worden er stukken hout neergelegd om de grens (madi: tempas) tusschen de deelen aan te geven; eertijds plantte men wel een bepaald soort struiken ter aanduiding van de grenzen. Heeft men akkerdeelen nog niet in bewerking genomen, dan is ruiling onderling nog mogelijk; dit gebeurt b.v. als een der akkerleden een slechte droom heeft gehad. ${ }^{11}$ )

De rechten die op den grond door ontginning worden gevestigd, en die wij met inlandsch bezitrecht, genotrecht, voorkeurrecht e.d. aanduiden, zijn in de landstalen niet vertaalbaar; men kan slechts aangeven in welken feitelijken toestand zich het terrein bevindt al naar de begroeiing, c.q. beplanting. In het aki is talakajoe, ook wel poeloeng, de aanduiding voor met zwaar bosch begroeid terrein, d.i. dus grond waarop nog geen inlandsch bezitrecht rust en het beschikkingsrecht nog onbelemmerd werkt. Braakland, waarop men het vorig seizoen zijn oebi heeft geplant, heet anggal; hierop is dus wellicht inlandsch bezitrecht, zeker voorkeurrecht gevestigd. Laing is de aanduiding voor grond, die een jaar of vijf braak heeft gelegen, waarop weer licht hout is opgeschoten en die dus weer geschikt geworden is voor beplanting; we moeten aannemen, dat hierop, zoo al niet inlandsch bezitrecht, dan toch minstens voorkeurrecht rust. Alas is de aanduiding voor een stuk woesten grond, dat tot tuin zal worden ontgonnen, waarop de bewerker reeds zijn voorkeurrecht door middel van het plaatsen van verbodsteekens heeft gevestigd (memorie), terwijl komboeng de aanduiding van den akker zelf is. Een gebruikelijke lengtemaat bij tuinaanleg is laa, gelijk aan een

10) Kruyt, Landbouw, blz. 478.

11) Kruyt, To Loinang, blz. $413,416,417$. 
afstand van 100 vadem; een akker kan dus een la lang en een laa breed zijn. ${ }^{12}$ )

Geen gegevens zijn beschikbaar van den Vogelkop.

$\mathrm{Bij}$ de madi-sprekers hebben we de volgende termen: ${ }^{13}$ ) alas is de aanduiding voor onontgonnen bosch (deel van den beschikkingskring); een verlaten ladang heet togolopo (hierop rust wellicht nog inlandsch bezitrecht); jong bosch, nog niet geschikt voor ladangbouw, duidt men aan met koehat mongoeha of labong; daarnaast kent men nog oemoi, lang verlaten ladanggrond (het inlandsch bezitrecht is reeds verloren gegaan, wel rust op deze terreinen een min of meer sterk voorkeurrecht).

De plaats waar men een ladang gaat maken heet pongalale'an (voorkeurrecht door het plaatsen van verbodsteekens?); de plaats waar men een ladang gemaakt heeft noemt men pinongalale'an (kunnen we dit met inlandsch bezitrecht gelijk stellen?).

Een tuin voor groente heet bondoi (bij Kruyt bonde), een ladang voor rijst of mais noemt men ale. De inlandsche bezitter heet toempoe noe bondoi (ook toempoe noe ale?); het aanleggen van een dergelijken aanplant heet mombondoi dan wel mongale; daarnaast kent men mongkaeng dat beteekent: aanleggen van een rijsttuin. In de oogsttaal noemt men rijstveld hombola (wellicht t.r. hoonbola).

Men kon mij in den Banggai-Archipel niet opgeven wanneer het inlandsch bezitrecht op eens bewerkten grond teniet gaat en het terrein weer onder het beschikkingsrecht der gemeenschap komt; het criterium ligt in de mate van herbebossching, doch het is niet aan te geven hoe en wanneer; dit bevestigt den indruk dien we reeds hadden, nl. dat het inlandsch bezitrecht in den Archipel krachtig van aard is. Een der leden van het Zelfbestuur verzekerde mij echter, dat als op een verlaten akker weer zwaar bosch gegroeid is (hij gebruikte het aki-woord poeloeng, gelijk aan het maleische rimba), deze weer voor uitgifte zonder vergoeding aan anderen beschikbaar is.

Het komt voor dat iemands laing (zie boven: stuk grond waarop voorkeurrecht, dan wel inlandsch bezitrecht rust) door een ander ten gebruike wordt gevraagd. Kruyt vermeldt dat de houder van dit recht van den nieuwen bewerker in dergelijke gevallen een jong varken ontvangt; hij vermeldt niet of de oorspronkelijke bezitter daarmee geheel afstand doet van zijn recht, of dat er slechts een tijdelijke verhouding tusschen den lateren bewerker en den grond ont-

12) Kruyt, Landbouw, blz. 477; Memorie.

13) Kruyt, To Loinang, blz. 427; E. Gobee, Feestbundel I, blz. 194/195. 
staat. ${ }^{14}$ ) Uit mededeelingen aan mij door het genoemde Zelfbestuurslid bleek dat de houder van het voorkeurrecht zijn rechten kan behouden, dan wel deze overdragen; dit hangt er nl. vanaf wat de nieuwe bewerker van zins is met den grond te doen. Plant deze eenjarige (voedings) gewassen, dan geeft hij den houder van het voorkeurrecht telkenmale een gift, sabol (aki) geheeten, wanneer de grond beplant wordt. Dit zal in de practijk slechts éénmaal zijn, zoodat deze sabol eenigszins het karakter van eenmalige grondhuur draagt; daarbij wordt dus niet getornd aan de rechtsbetrekking tusschen den houder van het voorkeurrecht en de laing. Kruyt noemt als hoeveelheid op te brengen sabol (hij gebruikt dit woord echter niet) één draagmand (aki : bois) vol oebi, welke na den oogst wordt opgebracht. ${ }^{15}$ )

Anders wordt het als de nieuwe bewerker overjarige gewassen wil planten, waardoor de rechtsbetrekking tusschen den eersten ontginner, houder van het voorkeurrecht, en den grond verbroken zal worden. Dan is de nieuwe werker verplicht de moeite der ontginning van den eersten bewerker te koopen: olijoko bockoeno doi laing doo (aki); deze gift is steeds hooger dan de sabol, doch heeft tot rechtsgevolg dat de nieuwe ontginner een band tot stand brengt tusschen zich en het terrein, dat in laing-toestand verkeert, nl. daarop een nieuw inlandsch bezitrecht vestigt. (memorie).

Op den Vogelkop is een parallel van den sabol wèl, van de olijoko uiteraard niet bekend. Wil daar iemand uit een dorpsgemeenschap een akker aanleggen op grond die reeds bewerkt is door een andere familie uit dezelfde gemeenschap (waarop de eerste bewerkersgroep dus een familiebezitrecht heeft gevestigd), dan moet de eerste ontginner zijn toestemming geven, waarvoor hem een deel van den oogst wordt beloofd, volgens Kruyt 20 bossen rijst van de 500; dit heet monsoi (sian). ${ }^{16}$ ) Doch zooals we hooger reeds zagen werkt het beschikkingsrecht hier sterker dan in den Archipel, keert de grond dan ook eerder terug tot het dorpsareaal, zoodat het verleenen van een dergelijk genotrecht, waarvoor jaarlijksche monsoi wordt opgebracht, wat tijdsduur betreft beperkter moet zijn dan in den Archipel; geen gegevens zijn beschikbaar of het mogelijk is op gronden op deze wijze verkregen, blijvend inlandsch bezitrecht te vestigen, bv. bij voorgenomen plant van overjarige gewassen, en wat de termen en hoeveelheden der dan te betalen bedragen zijn. Het schijnt wel dat

14) Kruyt, Bewoners, blz. 71.

15) Kruyt, Landbouw, blz. 478.

16) Kruyt, Rijstbouw, blz. 125. 
de rechtsverhouding tusschen dergelijke in „huur" verkregen gronden en den "huurder" zeer zwak is; althans Kruyt meldt, dat iemand alleen recht heeft op gronden die hij niet zelf heeft ontgonnen (die hij dus op andere wijze heeft verkregen), zoolang hij die gronden gebruikt. Overigens zal het sterke beschikkingsrecht der dorpsgemeenschappen op den Vogelkop zeker aan het afslijten zijn, o.a. reeds daardoor dat ook hier uitgebreide klapperaanplantingen zijn te vinden. We kunnen moeilijk aannemen dat het kortstondig genotrecht der bouwvelden, zooals hooger aangeduid, ook op deze aanplantingen van toepassing zal zijn; dan toch zouden op een gegeven oogenblik dergelijke klappertuinen onder het beschikkingsrecht der dorpsgemeenschappen terugkeeren, althans voor zoover het den grond betreft.

In het algemeen kan de houder van het inlandsch bezitrecht zijn gronden beplanten met éénjarige (voedings) gewassen, dan wel met overjarige, die voornamelijk voor den export produceeren; gewoonte is dat eerst oebi, rijst of mais wordt geplant, en dat dan na een of twee oogsten jonge kokospalmen worden uitgezet, indien de bodem zich daartoe leent. Slaan zij aan, dan blijft een nauwe betrekking tusschen den bewerker en het beplante areaal bestaan, ook al keert de akker feitelijk tot den toestand van laing terug, omdat men zich weinig om de uitgeplante kokosboomen pleegt te bekommeren. Soms eenige malen eerder (dan wordt nog wel eens tusschen de jonge palmen een eenjarig gewas geplant), doch meestal pas tegen den tijd dat ze moeten gaan vruchtdragen (na \pm 10 jaar), wordt het terrein schoon gemaakt van het inmiddels hoog opgeschoten hout; aldus wordt de planter der klapper-, eventueel andere vruchtboomen, inlandsch bezitter daarvan.

Op drassige gronden kan men ook sagopalmen planten. Door uitstoeling vormen zich z.g. doesoen, nl. pollen van dergelijke planten, waarvan de opschietende palmen in verschillende stadia van oogstbaarheid verkeeren. Dergelijke doesoen zijn eveneens voorwerp van inlandsch bezitrecht; dit berust, tenzij hij het heeft overgedragen, bij den planter van de eerste oorspronkelijke sagopalm, waaruit de pol is voortgekomen.

Met rechtshandelingen ten aanzien van objecten op dergelijke wijze in inlandsch bezitrecht verkeerend, behoudt de gemeenschap nog bemoeienis; ik vond o.a. in Boenta, dat een dergelijke inlandsche bezitter voorkeurrecht uitoefent op tot den beschikkingskring behoorende, aan zijn bezit grenzende, woeste gronden. Wil dus een 
ander hiervan een stuk in bewerking nemen, dan zal de rechtsgemeenschap door middel van het hoofd b.v. eerst vragen of de inlandsche bezitter eventueel die gronden noodig heeft voor uitbreiding van zijn, ouder, bezit. In bevestigend geval dient hij een teeken te plaatsen, en moet hij toonen dat het hem ernst is met de bewerking een begin te maken.

Verdere bemoeienis uit zich bij overdracht der beplantingen en der gronden aan een groepslid, dan wel aan een groepsvreemde. Zulks kan niet ondershands geschieden, doch de groep dient op de hoogte te blijven van deze mutatie, hetwelk geschiedt doordat de hoofden of oudsten als getuigen daarbij optreden. In den Archipel krijgen dergelijke getuigen een bord, of nemen deel aan een maaltijd die aangerecht wordt bij de transactie, en waarbij een varken geslacht wordt; ieder die van het vleesch gegeten heeft, dan wel een bord heeft ontvangen, is verplicht getuige te zijn. Borden en varken dragen den naam poboeka (aki); zoolang dit getuigenloon nog niet gegeven is, is de koop ook nog niet definitief gesloten. ${ }^{17}$ )

De groepsleden zijn naar mededeeling aan mij, zoowel in den Archipel als bij de madi-sprekers, verplicht tot het opbrengen van een gift na afloop van den oogst, te overhandigen aan het hoofd; deze gift zal in wezen wel een gemeenschappelijk of fer aan de vooroudergeesten zijn. (Het offeren bij het begin der bewerking geschiedt familiesgewijs of individueel; hierbij wordt tevens gewicheld). Hieruit blijkt m.i. ook, dat de rechtsbetrekking tusschen bewerker en grond toch niet zoo individualistisch is, dat het beschikkingsrecht in den Archipel zijn invloed zou hebben verloren. In het aki noemt men deze gift wel bakoe toembeno, vaker sabol; op Banggai spreekt men van sabol laing, als onderdeel der inkomsten van de basalo-4; in het madi gebruikt men den term oebakoe oei, terwijl men mij daarvoor in Pokoehan saboek opgaf (memorie). Deze sabock is een vrijwillige gave, en geen plicht, doch het is onbehoorlijk haar achterwege te laten.

In dit verband is Kruyts mededeeling typeerend, dat langen tijd lieden uit Oost-Peling volhielden van hun oebioogst eerst een deel naar het graf van den vorst van Bongganan, te Bebengketan (die immers geheel Oost-Peling onder zich had) te brengen, voor zij er zelf van aten (zie blz. 22) ${ }^{18}$ ). Toen ik het graf bezocht lag er inderdaad een stapel oebi bij.

De genooten der beschikkingsgerechtigde gemeenschappen hebben

17) Kruyt, Landbouw, blz. 478.

18) Kruyt, Vorsten, blz. 512. 
bepaalde rechten in verband met het jagen en zamelen in den beschikkingskring. Zoo bestaat in den Archipel de mogelijkheid inlandsch bezitrecht te vestigen op muizenpaden, of op rottende boomstammen die met paddestoelen begroeid zijn. Men doet dit in het eerste geval door er twee aaneengebonden stokken in omgekeerde $\mathrm{V}$-vorm over heen te zetten, in het andere geval door het einde van den stam vierkant te kappen. Ook op rottende boomstammen waarop nog geen paddestoelen groeien, kan door plaatsen van een verbodsteeken inlandsch bezitrecht gevestigd worden, nl. met het zoo juist beschreven teeken in V-vorm; dit heet posoepat (aki). ${ }^{19}$ )

Ook bijennesten, die men in de wildernis aantreft, kunnen voorwerp van inlandsch bezitrecht worden; degeen die het nest vindt in een toestand dat het nog niet uitgerookt kan worden, plaatst een verbodsteeken, bestaande uit een stok, in welks boveneinde, dat gespleten is, een dwarshoutje geklemd is; dat is een teeken dat het nest een bezitter heeft gekregen. Een dergelijk teeken heet oos (aki), ook wel pongoos (vergelijk pongoosi in het madi, op blz. 205 vermeld als merkteeken, en daar speciaal geldend voor het recht in zake verloving). Het woord oos vinden we terug in den dorpsnaam Osan Paisoeno (West-Peling), letterlijk: teeken voor water, een aanduiding dus dat in deze waterarme streken water is $\mathbf{r}^{\mathbf{2 0}}$ ) het is mij niet bekend of dit tevens een verbodsteeken inhield voor anderen dan groepsleden van dit water gebruik te maken, al dan niet tegen betaling van een retributie. Oos (pongoos) heeft de algemeene beteekenis van teeken, wat tot teeken dient (aki), en wordt dus ook gebruikt voor een waarschuwingsteeken, dat ergens bv. een springlans staat opgesteld.

Eveneens kan inlandsch bezitrecht gevestigd worden op in het wild groeiende vruchtboomen, b.v. doerian; de grond onder den boom wordt schoongemaakt ten teeken dat de boom een bezitter heeft. Tegen den tijd dat de vruchten rijp zijn, en dus gaan afvallen, bouwt de inlandsche bezitter een hekje rond dit schoongemaakt terreintje; alle vruchten die binnen den heg vallen zijn dan van hem. In Loinang mag men vrij van rijpe pisang nemen of pinangnooten plukken, tenzij blijkt dat een persoon reeds bezitrechten op het gewas uitoefent; in tegenovergesteld geval is het dorpsbezit. Het verbodsteeken bij een pinangpalm bestaat uit twee banden rond den stam (Tangkilisan). Het is mij overigens niet bekend of van dergelijke in het wild

19) Kruyt, Banggaische Studiën, blz. 24 v. en noot 1.

20) Kruyt, Bewoners, blz. 259, 268. 
groeiende, waardevolle objecten eventueel een deel aan de rechtsgemeenschap of het hoofd moet worden afgestaan.

Het beschikkingsrecht strekt zich ook uit tot de kuststrook en de riffen, althans voor zoover daar sero (vischheiningen, een soort vaste fuik) kunnen worden geplaatst. Op het eiland Banggai noemde men mij als vischrechten obos (aki), die aan de basalo-4 werden opgebracht; hoe en wat deze vischrechten inhielden is mij niet bekend. Kruyt zegt, dat vischrechten alleen bestaan op het plaatsen van dergelijke sero; daarbij worden zekere grenzen in acht genomen voor de bewoners van elke streek. Er wordt echter niets van gezegd, wanneer lieden die voorbij varen, bij de sero stilhouden om een paar visschen te steken $;^{21}$ ) vermoedelijk is dit echter alleen toegestaan voor zoover deze visschen voor eigen levensonderhoud dienen. Een parallel hiervan is de algemeen geldende gewoonte dat de dorstige voorbijganger een jonge klapper mag plukken om ter plaatse zijn dorst te lesschen, dat echter medeneming van deze vruchten niet geoorloofd, en dus een strafbare handeling is. Ook afgevallen klappernoten blijven van den boombezitter, en mogen dus niet geraapt worden; dit in tegenstelling tot sommige streken in de landschappen Banawa en Tawa Eli (onderafdeeling Donggala), waar afgevallen klappernoten door iedereen mogen verzameld, vervoerd en verkocht worden.

Betreffende jachtrecht beschikken we over eenige gegevens. ${ }^{22}$ ) Het heet dat in Tinangkoeng (Oost-Peling) de basalo geen aandeel in de jachtbuit kreeg (elders wel?). Uit Loinang wordt hetzelfde gemeld; slechts als men een gemsbuffel slachtte (die meestal in het wild gevangen wordt) gaf men den daka'njo vooraf kennis en schonk hem vier brokken vleesch, veelal uit den halsstreek. Op den Vogelkop heet het echter, dat zoowel paoe basal als tonggol jachtrechten mochten laten gelden, echter alleen op gemsbuffels; van elke buitgemaakte anoa (algemeen voor gemsbuffel) moest de jager 30 reepen vleesch aan het hoofd afstaan. Eigenaardig is de mededeeling dat ieder mocht jagen waar hij wilde en dat er geen grenzen daarbij in acht genomen werden. Tangkilisan vermeldt echter t.a.v. Loinang dat juist het overschrijden der grenzen tijdens het jagen een der redenen was dat men in oorlog raakte (als dus b.v. mian Doehian in het gebied van Lingketing kwamen of omgekeerd); met andere woorden, het wild

21) Kruyt, Bewoners, blz. 270, 271.

22) Kruyt, Vorsten, blz. 512; To Loinang, blz. 355; Balantaksche Studiën, blz. 363 . 
binnen den beschikkingskring aangetroffen valt onder het beschikkingsrecht.

Betreffende weiderechten ontbreken gegevens; dit behoeft bij den geringen omvang van den veestapel niet te verwonderen. Ook beschikken we niet over gegevens ten aanzien van den rechtstoestand waarin woonerven kunnen verkeeren; slechts maakt Kruyt melding van het verwerven van een terrein van een ander, met het doel daarop een woning te plaatsen; dit geschiedt door den inlandschen grondbezitter een gift te doen, b.v. een varkentje te geven ${ }^{23}$ ).

\section{De werking naar buiten.}

Kruyt geeft geen gegevens hoe een gemeenschapsvreemde zich rechten op den grond kan verwerven. Blijkens mededeelingen aan $\mathrm{mij}$, waren vreemdelingen, die in een basaloschap grond wilden bewerken, verplicht een zekere gift op te brengen aan het hoofd, die consent gaf tot eenmalige grondbewerking van een gedeelte van het areaal. Voor dien vreemde ontstond hier dus genotrecht uit. $\mathrm{Na}$ den oogst was hij gehouden, evenals de gemeenschapsgenooten, een gift op te brengen, welke eveneens door het hoofd werd ontvangen. In het aki noemt men de eerste wel pandababakon, ook wel sabol; in het madi spreekt men van sabon ( 1 en $\mathrm{n}$ wisselen in het madi af, vergelijk tonggol en tonggon; zie blz. 97). Het woord sabol is dus hetzelfde als gebruikelijk voor het begrip huur van een met inlandsch bezitrecht belast terrein van den bezitter; zie blz. 245. Tot het opbrengen van de giften bakoe toembeno (aki) dan wel oebakoe oei (madi) waren de gemeenschapsvreemden evenzeer verplicht als de leden zelf.

Op den Vogelkop schijnt het anders gesteld te zijn; Kruyt meldt, dat als iemand uit een andere dorpsgemeenschap een tuin wil komen aanleggen, hij dit alleen aan den tonggol behoeft te vragen; rechten betaalt hij niet, maar van zoo'n vreemdeling wordt wel verwacht dat hij in vriendschap met zijn buren leeft en meehelpt bij arbeid van algemeenen aard. ${ }^{24}$ ) Dit valt m.i. alleen te rijmen met onze stelling van een sterk beschikkingsrecht op den Vogelkop, als wij aannemen dat de hoeveelheid beschikbare goede gronden hier zeer ruim voldoende is voor de behoeften der groepsleden.

Toch is een en ander niet in overeenstemming met het volgende

23) Kruyt, Bewoners, blz. 71.

24) Kruyt, Rịjstbouw, blz. 125. 
geval: de hoekoem toea, zetelend als Zelfbestuurslid te Salakan (district Tinangkoeng) en als zoodanig de rechten van den basalo van dat adatdistrict waarnemend (de werkelijke basalo Tinangkoeng zijn door het Banggaische Zelfbestuur uit de bestuursorganisatie geëlimineerd) deelde mij mede, dat toen lieden van Lamala (Vogelkop) op het eiland Bakalan, behoorende tot het district Tinangkoeng, tuinen wilden komen aanleggen en hem daarvoor behoorlijk toestemming vroegen, hem daarbij een gift in rijst kwamen aanbieden, daar zulks volgens hun adat was (memorie).

Verder heeft het basaloschap Boniton nog steeds een vordering op een Balantaksche familie, die eenige generaties terug naar OostPeling kwam, om in het gebied van basalo Pelei en Boniton tuinen te gaan aanleggen. Ieder der basalo zou van den Balantakker als betaling daarvoor hebben moeten ontvangen een mand (aki: toetoebi) met boomhars, een mand met bijenwas en een mand met geldstukken (die men mij beschreef als te zijn rond met een vierkante opening in het midden; vermoedelijk Chineesche duiten). Doch met verontwaardiging zei men mij, dat wel Pelei maar nog niet Boniton dit bedrag had ontvangen, en dat Boniton nog steeds een vordering heeft op die Balantaksche familie, die inmiddels reeds lang teruggekeerd is naar het oorsprongland (memorie).

Van het blijvend verwerven van grond langs minnelijken weg hebben we in Tinangkoeng een voorbeeld. De basalo van deze rechtsgemeenschap moest steeds, als hij de huldegift naar Banggai wilde brengen, van Sio-Siok uit naar het strand van Salakan afdalen, en van daar per vaartuig langs de noord- en oostkust van Oost-Peling varen, waar het met wind en stroom zwaar kan spoken. Om nu dichter bij Banggai te zijn, en gemakkelijker in staat te wezen zich derwaarts te begeven, kocht het basaloschap Tinangkoeng van het basaloschap Paisoeoeloeno het recht op de plaats Lomboan, gelegen midden in het territoir van laatstgenoemde rechtsgemeenschap. De prijs was volgens sommigen 15 patikeleng (aki: een soort borden), volgens anderen 120 kolono (aki: koperen ketels). Op deze plaats Lomboan ontstond, als enclave, de kampong Tinangkoeng. Hier verwierf dus een rechtsgemeenschap, optredend als gemeenschapsvreemde, zich blijvend recht op een deel van den beschikkingskring van een andere rechtsgemeenschap; dit zou een uitzondering kunnen zijn op het $6 \mathrm{e}$ kenmerk van het beschikkingsrecht, waar de drager van dat recht anders niets van het territoir blijvend mag vervreemden (memorie). 


\section{Invloed van het vorstenbestuur op het adatgrondenrecht.}

$\mathrm{Mij}$ is niets bekend dat zou wijzen op vorstelijke inmenging in deze materie. Ook hield de positie der baocloeno (zie blz. 123) niet in dat deze edelen iets te maken hadden met het grondenrecht der hun toegewezen apanages.

Slechts weten we dat de sultan van Ternate aan vreemdelingen, personen niet behoorende tot de inheemsche bevolking van het landschap, wel het recht verleende tot het planten van klapperboomen; de verleening van dit recht was door hem gedelegeerd aan den vorst van Banggai tezamen met den oetoesan, het plantrecht bedroeg $\mathrm{f} 0.10$ per boom (zie ook blz. 135) ${ }^{25}$ ). Of bij het verleenen van een dergelijke vergunning ook door den vorst het terrein werd aangewezen waar die boomen dienden te worden geplant, dan wel of de vergunninghouder zich nog met de hoofden der rechtsgemeenschappen had te verstaan betreffende den ter beschikking te stellen grond, is niet bekend. Op deze wijze kwamen eenige Vreemde Oosterlingen (IndoArabieren) in de omgeving van Boenta in het bezit van klappertuinen met inlandsche rechten.

Dorpshandvesten, door den vorst verleend, zijn niet aangetroffen. Slechts vermeldt Goedhart een grensregeling tusschen Loinang en Doehian, naar aanleiding van gerezen moeilijkheden over het bezit van damarboomen, welke regeling door het Banggaische Zelfbestuur kort voor 1908 is getroffen. ${ }^{20}$ )

Onbekend is hoe de leden van het Zelfbestuur, de vorst inbegrepen, aan de door hen zelf aangelegde klappertuinen zijn gekomen, nl. of zij den benoodigden grond verkregen langs den gewonen weg, zooals die voor gemeenschapsvreemden in de vorige paragraaf werd geschetst, dan wel of zij door het uitoefenen van pressie terreinen om niet verkregen. Daarnaast bezitten zij dergelijke aanplantingen die zij door middel van koop in inlandsch bezit verkregen. Vorsten- en kroondomein is naar het adatrecht niet aanwezig, althans niet op de eilanden buiten Banggai.

Een bijzondere positie neemt een sagobosch op het eiland Bangkoeloe in, in de nabijheid der kampong Taboelan. Naar de overlevering wil, is dit sagobosch in oorsprong geplant door djogoegoe Sapia, met de bepaling dat ieder lid der Banggaische bevolking dat in voedselmoeilijkheden verkeert, hier voor eigen voeding sago mag komen

25) Goedhart, Drie Landschappen, blz. 449.

26) Goedhart, Drie Landschappen, blz. 479. 
kloppen; het is echter verboden het gewonnen product te verhandelen. De gewasschen sago dient in twee gelijke deelen te worden verdeeld; de eene helft is voor dengene die de merg geklopt heeft, de andere dient ingeleverd te worden bij het kamponghoofd van Taboelan. Deze moet de ontvangen hoeveelheid in drieën deelen: één deel is het waakloon voor deze bosschen en komt aan genoemd hoofd; het tweede deel is ter spijziging van de armen van Taboelan zelve; het derde deel diende aan den djogoegoe te worden aangeboden. Dit geschiedde tot 1923, doch sinds het optreden van djogoegoe Djakaria is dit in onbruik geraakt; wat er dan wel met dit deel gebeurt vermeldde men niet. Dit bezit, sago tano (aki: tano = land; dus landssago) geheeten, wordt tot op heden op deze wijze geëxploiteerd. Ik teeken hierbij aan dat we dus niet te maken hebben met deelwinning van sagomerg. (memorie).

\section{Invloed van het Gouvernement op het adatgrondenrecht.}

Wij kunnen niet anders zeggen dan dat het Gouvernement sedert zijn meer intensieve bestuursbemoeienis in dit landschap een destructieven invloed heeft gehad op het adatgrondenrecht. Door de meermalen genoemde gedwongen dorpsvorming werden rechtsgemeenschappen uit het haar toekomende territoir verwijderd, werden elders administratieve grenzen getrokken dwars door zulke ressorten heen. Verder is bekend (memorie), dat het basaloschap Boniton, dat eertijds landinwaarts was gelegen en nergens aan de kust grensde, zich heeft moeten vestigen in het gebied van Paisoeoeloeno, zonder dat ter zake eenig overleg werd gepleegd met de hoofden van dit laatste basaloschap, laat staan dat het op een of andere wijze de schade werd vergoed. Ook is het gehucht Toene een gedwongen vestiging van zwervers op het gebied van Pelei, zonder toestemming van deze laatste rechtsgemeenschap tot stand gekomen. Dit is nog zoo levend, dat basalo Pelei zich bij mij erover beklaagde en vroeg of daar nu niets aan te doen was. Aan dit geval is nog een bijzondere zijde, nl. Toene bestaat geheel uit gekerstenden, wien door samenwerking van bestuur en Missie hun huidige woonplaats werd aangewezen.

Ten behoeve van de uitgifte van z.g. woeste gronden werd de these van het landschapsdomein geschapen, waartoe gerekend werden alle gronden, niet in feitelijk gebruik bij de inheemsche bevolking. Van dit landschapsdomein, een term zelfs door het residentiekantoor in of ficieele stukken gebruikt, werden deelen uitgegeven met zakelijke 
en persoonlijke rechten aan Europeanen, Chineezen en Vreemde Oosterlingen.

Uit dien hoofde werden in den loop der jaren verleend:

41 landbouwconcessies met een totaal oppervlak van 1839 H.A.;

16 erfpachten voor huizenbouw;

51 erven met recht van opstal;

12 erfpachten voor den landbouw, met een totaal oppervlak van 274 H.A.

Verder werden een groot aantal huurperceelen met een maximum looptijd van 20 jaar uitgegeven; vòòr 1932 waren er 547 dergelijke contracten afgesloten (waarbij de Zelfbestuurder als verhuurder optreedt), doch het was tevens een publiek geheim dat een groot aantal erven en tuinen onwettig geoccupeerd werden door Gouvernementsonderhoorigen - niet Inlanders.

In 1935 werd op krachtige wijze dit euvel aangepakt, met het gevolg dat toen een gehouden onderzoek afgeloopen was en de ervoor in aanmerking komende gevallen gewettigd waren, er een totaal van 1826 grondhuurcontracten bereikt was, welk aantal nog steeds toeneemt als gevolg van aanvragen tot het bouwen van huizen, schuren, klapperdroogplaatsen, e.d. zoodat medio 1939 het aantal van 2000 overschreden was. Van de 1826 contracten waren 1362 bestemd voor landbouwdoeleinden met een totaal van 1931 H.A.; men vindt hierbij tuinen van zeer verschillende grootte.

Dat op dergelijk groote schaal, onder de oogen van het Europeesch bestuur, onwettige occupatie kan ontstaan is m.i. in de eerste plaats te wijten aan het feit dat de adathoofden geheel genegeerd werden bij de uitgifte van gronden aan niet-inheemschen. De werkwijze toch was (in de gevallen dat de wettige weg gevolgd werd) dat de a.s. huurder zich tot den Onderafdeelingschef richtte met het verzoek een bepaald met name genoemd stuk grond „van het landschap” in huur te mogen ontvangen voor het aangegeven doel; dat het verzoek door den Onderafdeelingschef, dan wel door een bestuursassistent plaatselijk onderzocht werd, waarbij meestal slechts afgegaan werd op het advies van het (ambtelijke) districtshoofd, en dat bij gunstig bevinden (dat was vrijwel steeds) op het onderafdeelingskantoor de contracten kant en klaar werden opgemaakt volgens een ingevoerd, uniform model, dat wel voldoet aan de eischen van het Burgerlijk Wetboek, maar waarin aan het adatrecht geen aandacht werd geschonken. Deze werden ten slotte aan den Zelfbestuurder, die ze als „verhuurder” had te teekenen, voorgelegd, waarna de huurder 
in het bezit kwam van het voor dezen bestemde exemplaar, dat buitendien nog goedgekeurd was door den Onderafdeelingschef. Met dit bewijsstuk in handen was des huurders recht onaantastbaar. Bij deze geheele werkwijze waren echter de adathoofden genegeerd, waardoor zij vaak niet op de hoogte bleven van dergelijke mutaties, terwijl wij toch juist gezien hebben dat het hun taak was als hoofd der rechtsgemeenschap voor openbaarheid der transacties zorg te dragen, en verder ook hun eventueele financieele belangen in het gedrang kwamen (zie blz. 247).

Ik heb getracht verbetering in dien toestand te brengen door den adathoofden wederom bemoeienis met grondzaken te geven, samengaande met een herziening der ressorten waarbij, om tot een nieuwe indeeling te komen, op de beschikkingsrechten gelet dient te worden; $\mathrm{mij}$ is niet bekend of het bij een voorstel gebleven is, doch dit hield in:

a) óók de adathoofden moeten bij verzoeken tot gronduitgifte gehoord worden;

b) zij worden belast met de inning der grondhuren van reeds uitgegeven contracten en krijgen daarvoor $8 \%$ collecteloon (conform de belastingregeling).

Behalve in huur voor landbouwdoeleinden en voor bewoning, zijn gronden door het landschap ook om niet afgestaan, gewettigd door middel van een grondhuurcontract, ten behoeve van Chineesche begraafplaatsen, kerkerven van Zending en Missie e.d. Bovendien werden gronden zonder vergoeding en voor onbepaalden tijd ten gebruike afgestaan aan het Gouvernement ter oprichting van het Controleurskantoor, ter huisvesting van de officieren van het Detachement van het Koninklijk Nederlandsch-Indisch Leger en van het Detachement zelf; verder ten behoeve van een militaire veekraal, groententuin, schietbaan e.d. In het laatste geval betrof het een stuk terrein beplant met klapperboomen, waarop inlandsche bezitrechten rustten, welke door het Gouvernement werden afgekocht; de boomen werden voor zoover noodig gerooid, de overige werden ten behoeve van de menage van het Detachement geplukt.

\section{Grondtransacties.}

Eenige vormen van grondtransacties, zooals Kruyt deze opgeeft, werden op blz. $245 \mathrm{v}$. genoemd.

Verder bleek mij dat grondverpanding vrij veel voorkomt. Daarbij wordt dus een terrein waarop inlandsch bezitrecht rust en dat veelal 
beplant is, overgedragen door den pandgever aan den pandnemer, tegen een bepaalde som met recht tot inlossing van het pand tegen terugbetaling van deze pandsom; veelal treden Chineezen en Arabieren als pandnemer op.

Eenige vormen bleken mij daarbij te bestaan:

$a$. er wordt bij de transactie bepaald dat de pandgever binnen een bepaalden termijn het pand moet inlossen; zoo hij daarin nalatig is verliest hij zijn recht en komt het pand in inlandsch bezit bij den pandnemer;

$b$. hetzelfde als onder $a$., doch tevens is bepaald dat in dergelijk geval de pandnemer een bedrag bijbetaalt aan den pandgever, waarmee de eerste zijn inlandsch bezitrecht vestigt;

$c$. er is geen termijn bepaald binnen welken inlossing moet geschieden; de pandgeving blijft dus doorloopen en kan te allen tijde beëindigd worden;

$d$. inlossing mag niet plaats hebben vóór een zekere termijn verloopen is.

De onder $a$. genoemde vorm komt het meest, de overige zelden voor.

Deze pandgeving heet hier ochda (geïmporteerd woord, behoort niet eigenlijk tot een der drie landstalen); men spreekt dus van djoeal ochda, in tegenstelling tot djoeal teroes. Object van dergelijke ochda-transacties zijn meestal produceerende klappertuinen in inlandsch bezit.

Djoeal-teroes transacties treft men meestal aan bij andere objecten (zie de voorbeelden van Kruyt, genoemd op blz. 242 en de olijoko transacties van blz. 245); verder ook bij nog niet produceerende klappertuinen, en bij huizen. Overigens zijn gevallen van dergelijken grondverkoop zelden aanleiding geweest tot het instellen van rechtsvorderingen.

Zeer sporadisch trof ik overeenkomsten aan waarbij sprake was van grondverhuur met vooruitbetaalden huurschat; de weinige gevallen die mij bekend werden, betroffen wederom klappertuinen die door den inlandschen bezitter voor een of meer kwartalen (klapperboomen worden per kwartaal geplukt) aan een ander werden overgedragen, onder gelijktijdige ontvangst van den overeengekomen huurprijs. Wegens het speculatief karakter aan dit soort overeenkomsten verbonden (de copraprijzen vertoonden de laatste jaren sterke schommelingen )is deze vorm niet erg gewild onder de handelaren, en deze zijn het die tenslotte de contanten moeten leveren. 
In de gevallen dat het object van dit drietal grondtransacties (grondverpanding; grondverkoop; grondverhuur met vooruitbetaalden huurschat) zich eerst in Inlandsch bezit bevond en daarna in handen van een niet-Inlander geraakte, ontstaat onwettige occupatie (verg. Stbl. 1923 no. 475).

\section{Eenige bijzondere objecten.}

Ter onderafdeelingshoofdplaats Loewoek bevindt zich naast de (Mohammedaansche) bevolkingsbegraaf plaats een doodenakker van de Christengemeente van Loewoek; hier zijn ook eenige Europeanen begraven, zonder dat hiervoor rechten behoefden te worden betaald. Uiteraard treft men bij de meeste dorpen begraafplaatsen aan, Mohammedaansche dan wel Christelijke, al naar den godsdienst der bevolking (madi : begraafplaats $=$ polamoenan) ${ }^{27}$ ). Een kleine begraafplaats te Sambioet, in beheer bij de Missie aldaar en bestemd voor de daar wonende afstammelingen van Pilippijnsche parelduikers (die uit dien hoofde Europeanen zijn) werd door het Landschap om niet afgestaan; ook dit geschiedde weer in den vorm van grondhuurcontract zonder huurschat.

Te Loboe (Tominibocht) bevindt zich een erf met het recht van opstal uitgegeven aan een Arabier; deze maakte dit erf en het erop geplaatste gebouw tot wakaf ten behoeve der vereeniging Moehammadijah, onder bepaling dat het gebouw gebruikt zou worden als godsdienstschool in Moehammadijah-zin. Op een voorstel om het recht van opstal van dit erf te vernietigen en het in inlandsch bezit aan genoemde vereeniging af te staan, was in 1939 nog niet beslist. Ook de Gouvernementsbelastingdienst diende hierin gekend te worden in verband met de op het gebouw rustende verpondingsbelasting.

27) Gobee, Feestbundel I, blz. 200.

Verh. dl. VI. 


\section{HOOFDSTUK XI.}

\section{Schuldenrecht.}

In dit hoofdstuk zullen schuldverhoudingen, ontstaan door ongeoorloofde gedragingen waarop naast vergoeding en zoengeschenk alleen boeten staan, of waarvoor feitelijk alleen boeten worden opgelegd, niet worden behandeld; dergelijke verhoudingen komen in het volgend hoofdstuk ter sprake (zulks in tegenstelling b.v. tot den Toradja-kring, waar deze wel een deel van het schuldenrecht vormen; verg. C. van Vollenhoven, Adatrecht I blz. 365).

\section{Rechten op huizen, gewas.}

Geen gegevens; niet onderzocht (zie slot par. 7).

\section{Verkoop van roerende goederen.}

We beschikken slechts over één term, nl. mongoli (madi), welk woord we tegenkwamen op blz. 219 in de beteekenis van koopen, daar echter gebruikt ten aanzien van een onstoffelijk goed.

De mededeelingen in de literatuur, voor zoover deze betrekking hebben op koop/verkoop-handelingen (ter Haar: djoealtransacties) ${ }^{1}$ ) toonen aan dat de betaling (madi: mombajal $=$ betalen), over het algemeen nog geschiedt met eenige standaardgoederen. Eertijds kende men in Loinang bepaalde weefsels (mo)tombing ${ }^{2}$ ) (madi), die een groote waarde vetregenwoordigden, hoewel ze voor eenig gebruik feitelijk ongeschikt waren. Ze werden gebruikt zoowel voor betaalmiddel (huwelijksgeschenk, boeten) als voor ruilmiddel (waardemeter). De Clerq schrijft dat in zijn tijd geld niet erg gewild was; nog het liefst had men oude koperen duiten waarvan er 120 op een gulden gingen; in de binnenlanden van Celebes kende men haantjesduiten (360 stuks $=$ een gulden). Naast de gewone reaal van 4 soekoe's van 40 cent had de Makassaarsche reaal een figuratieve waarde

1) Ter Haar, Beginselen o.a., blz. 115, 118; Adriani-Kruyt, Bare'e III, blz. 83.

2) Kruyt, To Loinang, blz. 357 ; id. Lapjesgeld op Celebes, T.B.G. 73 (1933), blz. 178. 
van $\mathrm{f} 2$,- . Verder noteert hij dat ruilhandel het meest in zwang was, waarbij hij vooral lijnwaden als betaalmiddel noemt ${ }^{3}$ ).

Thans blijkt dat verschillende djoealtransacties nog tot stand komen waarbij met bepaalde soorten aarden borden en kommen, manden oebi, koperwerk (zie de soorten vremeld in noot 32 van hoofdstuk VIII), vee, pakken damarhars of stukken was betaald wordt; of ook thans nog blokken lijnwaad als zoodanig dienst doen is niet duidelijk ${ }^{4}$ ). Uit eigen aanschouwing is mij verder bekend dat op de inlandsche markten nog grootendeels ruilhandel plaats heeft. Plaatselijk zijn, zonder tusschenkomst van het bestuur, inlandsche pasars ontstaan; elke vijf dagen wordt daar markt gehouden (Archipel). In het aki noemt men lalabot de goederen ter verhandeling op de markt; voor pasar kent men den term labotan (aki). Veelal heeft op dergelijke ruilbijeenkomsten uitwisseling plaats van producten tusschen bergbewoners eenerzijds, en strandbewoners anderzijds ${ }^{5}$ ).

Hoe belangrijk voor het magisch evenwicht de djoealtransacties zijn blijkt wel uit het feit dat men in den Archipel niets koopt zonder voorkennis van pilogot Pali, die het materieel bezit der huisgenooten controleert $^{\boldsymbol{\theta}}$ ); geldt dit ook voor den verkooper?

Bij transacties van zaken van waarde (ook van land; verg. blz. 247) zijn steeds eenige lieden aanwezig, vijf of zes, aan wie de kooper ieder een bord geeft; hierdoor worden zij getuigen van de transactie. Soms ook wordt een maaltijd aangerecht (met een stuk vee); degenen die hieraan hebben deelgenomen zijn verplicht getuige in de zaak te zijn. Dit getuigenloon (zoowel het bord als het toebereide voedsel) heet poboeka (aki). (Beteekent dit: waarmee de zaak open(baar) wordt?) Alleen bij het verhandelen van een vaartuig heet het potaoek (aki), d.i. de schepper waarmee het lekwater uitgeschept wordt. Belangrijk is verder de regel, dat zoolang het getuigenloon nog niet gegeven is, de verkoop nog niet definitief gesloten is ${ }^{7}$ ).

\section{Deelwinning.}

Of deelwinning van vee voorkomt is niet bekend; door den geringen omvang van den veestapel zou het niet te verwonderen zijn als zich op dit punt nog geen rechtsregels hebben gevormd.

3) De Clerq, Ternate, blz. 134.

4) Kruyt, Bewoners, blz. 78, 79, 82, 83, 87; To Loinang, blz. 375, 377, 378, $379,387$.

5) Memorie.

6) Kruyt, Pilogot, blz. 121.

7) Kruyt, Landbouw, blz. 478. 
Deelwinning van sago komt voor; de helft van het gewonnen meel is voor den inlandschen bezitter van den boom, de andere helft voor dengene die de sago gewasschen heeft ${ }^{8}$ ).

\section{Leening en zekerheidsstelling.}

$a$. geldleening tegen te leveren copra. Een dergelijke schuldverhouding ontstaat als een handelaar voorschot geeft op copraoogst. Gaat het om eenigszins belangrijke bedragen, dan wordt meestal een schriftelijke schuldbekentenis opgemaakt, in het spraakgebruik veelal „segel” genoemd. Meestal is het beding opgenomen dat de schuldenaar zijn copra (gedroogd klappernotenvleesch) geheel of gedeeltelijk bij den schuldeischer moet inleveren ten verkoop, vaak gekoppeld aan een verkapt rentebeding (b.v. het recht de copra een bepaald bedrag beneden marktprijs te koopen). Het is wel voorgekomen dat de schuldgever, in gevallen dat de schuldnemer zich niet aan de afspraak hield (zijn copra aan een anderen handelaar verkocht) een bedrag bij de schuld schreef, gelijk aan de hoeveelheid te leveren copra, vermenigvuldigd met het bedongen agio. Dergelijke handelingen worden bekend als tusschen partijen een conflict is ontstaan (b.v. over onvoldoende levering) en de schuldgever zich tot den rechter wendt. Over het algemeen zijn het Chineezen en andere Vreemde Oosterlingen die als schuldgever optreden en zich op deze wijze verzekeren van geregelde hoeveelheden ter verscheping. Hierbij dient te worden aangeteekend dat de opgenomen geldbedragen vaak zoo hoog zijn dat er eenige oogsten noodig zijn voor terugbetaling; inmiddels zijn dan weer nieuwe schulden aangegaan door den inlandschen klapperbezitter, zoodat hij in een permanente schuldverhouding komt te staan. Het grootste deel der overjarige beplantingen is op deze wijze voor schuld verbonden, waaruit heel gemakkelijk onwettige occupatie van gronden ontstaat, nl. grondverpanding in den op blz. 256 onder $a$. aangegeven vorm.

$b$. rentebeding. Positief is de mededeeling dat in den Archipel een schuld door het lange wachten niet hooger wordt; wel dient de schuldenaar, telkenmale als de schuldeischer komt manen, hem een bord of een hoen ten geschenke te geven om hem over te halen nog wat geduld te hebben ${ }^{9}$ ). Kruyt beschouwt deze gift als rente van het kapitaal, doch er is m.i. meer reden haar als verzoeningsgeschenk aan te merken.

8) Kruyt, Bewoners, blz. 257. 
c. zekerheidsstelling. Niet aangegeven is of de schuldenaar bepaalde in zijn bezit zijnde goederen voor de richtige terugbetaling van zijn schuld als zekerheid stelt, met uitzondering van de gevallen onder $a$. behandeld; hier toch worden een of meer klappertuinen als zoodanig aangewezen. De kwestie der zekerheid wordt eventueel een vraag bij de gewelddadige inning van schulden zooals deze eertijds wel in zelfrechtverschaffing plaats vond (zie $f$.).

$d$. schuldverhouding ontstaan ten gevolge van het leenen van goederen voor een huwelijksgeschenk. In par. 3 van hoofdstuk VIII is reeds aangegeven dat de bruidegom een gedeelte van het huwelijksgeschenk (speciaal het antieke koperwerk) door leenen van zijn familieleden kan verwerven.

Het leenen van goederen voor een huwelijk heet modoni (aki), in de beteekenis van leenen aan („to lend to”) : babingkat (aki) beteekent leenen van („to borrow from”). Primair moet de doni (aki : wat ter leen gegeven is) terug worden gegeven, waartoe de aangewezen gelegenheid is het huwelijk van een zoon, classificatorisch gezien (verg. blz. 189 v.) van den schuldgever ${ }^{10}$ ).

Heeft het leenen van een niet-familielid plaats, dan komt de leener in een soort dienstverhouding tot den schuldeischer te staan; hij helpt hem bij akkerwerk en doet zoo nu en dan iets af van zijn schuld totdat gerekend wordt dat hij het geleende bedrag heeft vergoed. Ook wordt wel afgesproken dat degeen die de goederen ter leen gegeven heeft, het oudste kind uit dit huwelijk geboren, als het zijne nemen mag; dan bestaat genoemde dienstverhouding echter niet ${ }^{11}$ ). (Kunnen we dit beschouwen als rechtsgevolg der adoptie van blz. 192?).

Normaal wordt echter de bruidegom door zijn verwanten geholpen. We kunnen daarbij gevoegelijk aannemen dat de goederen die de bruidsvader indertijd zelf noodig had voor zijn eigen huwelijk met de bruidsmoeder, gedeeltelijk ook door leenen zijn verkregen. $\mathrm{Na}$ ontvangst van zijn aandeel in het huwelijksgeschenk kan hij dus nu zijn schuld afdoen, hetgeen dan gebeurt door aan ,zoons” van den oorspronkelijken schuldeischer dergelijke goederen te geven bij een eventueel door hen bijeen te brengen huwelijksgeschenk.

Het is echter ook mogelijk dat hij zijn oorspronkelijke schuld reeds eerder heeft kunnen afdoen; doch ook dan zal hij deze goederen gebruiken om verwanten te helpen, waardoor hij tot schuldeischer

9) Kruyt, Bewoners, blz. 251.

10) Nota van den Bergh; Kruyt, Banggaische Studiën, blz. 25.

11) Kruyt, Banggaische Studiën, blz. 25 v. 
wordt. Op deze wijze is er een voortdurend heen en weer gaan der goederen waar te nemen; zij verwisselen steeds van bewaarder, terwijl er een menigte schuldverhoudingen mee geschapen wordt. Deze strekken zich veelal over eenige generaties uit, doch allen weten, zonder eenige boekhouding, hoeveel ze aan iemand terug te geven, c.q. van een ander te vorderen hebben.

Heeft de schuldeischer geen zoons of als zoodanig beschouwden, dan wordt hem de doni niet terugbetaald, maar de schuldenaar is verplicht den schuldeischer op zijn ouden dag bij te staan, hem voortbrengselen uit zijn tuin te geven, hem te helpen bij den akkerbouw en van tabak en visch te voorzien ${ }^{12}$ ). Zooals dit hier medegedeeld wordt doet het eenigszins denken aan het verzorgingscontract van de Minahasa; interessant zou het zijn te weten of ook in den BanggaiArchipel de zorggever erfgenaam wordt van den schuldeischer-zorgtrekker.

Zie verder blz. 237 voor den gang van zaken bij overlijden van schuldgever of schuldnemer.

$e$. persoonlijk instaan voor schulden van anderen. Uit Balantak wordt gemeld dat de schuldgever wel zijn vordering laat rusten als de schuldenaar niet in staat is zijn schuld te voldoen; deze wordt dan later verhaald op kinderen en kleinkinderen ${ }^{13}$ ) (verg. het onder $d$. medegedeelde). Ter hoofdplaats Banggai werden schuldenaars eertijds in het blok opgesloten tot de familie voor hen betaald had ${ }^{14}$ ).

$f$. gewelddadige inning. Als de schuldgever wachtensmoe was geworden (dus in de gevallen dat niet een restitutie door latere generaties regel was) paste hij wel het mangalakon toe (aki: ala ::= nemen); vergelijk ook blz. 148. De schuldeischer, vergezeld van eenige makkers, ging naar het huis van den schuldenaar en nam alles weg wat hij daar vond; indien hij echter niets van waarde bezat waren er drie mogelijkheden: de schuldeischer nam de goederen van een meer vermogend familielid van den schuldenaar die dan maar zien moest hoe hij restitutie kreeg; òf de schuldeischer ging mangalakon ten huize van het hoofd; dan wel de schuldenaar werd pandeling van den schuldgever (Archipel) ${ }^{\mathbf{1 5}}$ ).

Uit Loinang deelt men mee dat het wel voorkwam dat een aanzienlijk persoon in schuld was geraakt; als hij dan niet kon betalen

12) Nota van den Bergh.

13) Kruyt, Balantaksche Studiën, blz. 349 .

14) Kruyt, Bewoners, blz. 250.

15) Kruyt, Bewoners, blz. 250. 
(en om zijn aanzien durfde men hem niet te gijzelen) trachtte de crediteur zich op slinksche wijze van een zijner kinderen meester te maken. Het kwam daarbij soms wel tot een gevecht met den vader, maar was het kind eenmaal in de macht van den ander, dan legde de vader zich er meestal bij neer en trachtte zoo spoedig mogelijk zijn schuld af te doen ${ }^{16}$ ).

De hoofden in den Archipel zagen het niet ongaarne als iemand bij hen kwam mangalakon; zij vroegen dan meer terug aan den schuldenaar. Indien deze niet kon restitueeren werd hij, soms met zijn gezin, pandeling bij den basalo (zie verder $h$.). Kruyt noemt hen ata (aki), maar dat zal wel een vergissing zijn, daar in den Archipel erfslaven met ata worden aangeduid ${ }^{17}$ ).

g. vrijwillig pandelingschap. In het aki kent men den term kasoebiang voor een vrijwillig pandeling ${ }^{18}$ ). Uit Loinang meldt men dat schuldenaars wel naar den bosanjo van Kintom vluchtten; deze betaalde dan de schulden doch de menschen werden hoorig aan dat hoofd. Hun werd een plek aangewezen voor den akkerbouw, waar de schuldenaars met hun gezin verbleven; zij werden mianibosanjo (madi : menschen van den bosanjo) ${ }^{\mathbf{1 9}}$ ). Onduidelijk is of deze hoorigheid ook voor de kinderen der schuldenaars gold, of zij erfelijk was of niet. Een vrijwillig pandeling komt dus eigener beweging in dezen staat te verkeeren, in tegenstelling tot het nu te noemen:

$h$. gedwongen pandelingschap. Het dienstbaar zijn aan een ander moet indertijd in den Archipel veelvuldig zijn voorgekomen; voor pandeling heeft men in het aki den term tano; een merkwaardig woord, omdat het eigenlijk land beteekent, terwijl we het ook tegenkwamen ter aanduiding van lagere hoofden (blz. 96). Deze pandelingen legden hun eigen akkers aan, onderhielden zich en hun gezin en namen geen opvallende positie in. Slechts bij bijzondere gelegenheden kwam hun ondergeschikte positie aan het licht; zij moesten den schuldeischer b.v. als onbetaalde kracht bij zijn akkerwerk helpen, en hem bij andere gebeurlijkheden (feesten) bijstaan door brandhout en water te halen, spijzen te bereiden, e.d. ${ }^{20}$ ).

Voor schuldslavernij in Loinang ${ }^{21}$ ) en Balantak ${ }^{22}$ ): zie blz. 87.

16) Kruyt, To Loinang, blz. 360 .

17) Kruyt, Bewoners, blz. 251.

18) Kruyt, Bewoners, blz. 250 noot.

19) Kruyt, To Loinang, blz. 360.

20) Kruyt, Bewoners, blz. 250.

21) Kruyt, To Loinang, blz. 360 .

22) Kruyt, Balantaksche Studiën, blz. 341, 349. 
Dat een zoon, geboren uit een huwelijk waarbij geen contant huwelijksgeschenk is voldaan, in pandelingschap bij zijn grootouders van moederszijde kan komen zagen we op blz. $217^{23}$ ). Voor het ontstaan van schuldverhoudingen tusschen de echtgenooten van één man zie men blz. $225^{24}$ ); de arme kan tenslotte pandelinge der rijke worden.

Ook mogelijk is dat de vrouw de pandelinge van haar eigen man wordt. In het geval b.v. dat zij overspel pleegde en daarvoor beboet werd door haar echtgenoot (zie blz. 228) en zij de boete niet kon betalen, werd zij zijn pandelinge (of dit zuiver pandelingschap was of een iets gewijzigde vorm daarvan weten we niet). Dit beteekent dat de akker dien zij aanlegt aan haar man toebehoort, dat zij geen aandeel meer krijgt in het huwelijksgeschenk harer dochters. Haar staat echter een andere weg open; zij kan nl. bij een derde het boetebedrag leenen en hiermee de schuld aan haar man afdoen. Weliswaar komt zij nu in schuld-, eventueel dienstverhouding tot dien derde te staan, doch de schuld aan hem kan zij afdoen met de opbrengst harer huwelijksgoederen waarover ze nu de beschikking behoudt, alsmede met eventueele aandeelen in het huwelijksgeschenk harer dochters. Indien ze echter sterft voor de schulden afbetaald zijn vervallen haar akkers en die aandeelen aan den schuldeischer ${ }^{25}$ ). (Geschiedt zulks altijd?)

Krachtens rechterlijk ingrijpen kon een einde komen an het pandelingschap. Een pandeling kon de tusschenkomst inroepen van den tonggol om van dezen een beslissing te krijgen of de schuld reeds inverdiend was. Het hoofd berekende of door den schuldenaar reeds voldoende gepresteerd was in verband met de hoegrootheid van de schuld, en stelde tevens een eventueel schuldrestant vast (zie ook blz. 153). Ook kon een schuldslaaf bij den basalo (na mangalakon bij dat hoofd) zich vrij koopen, maar dit gebeurde toch zelden; daartoe moest hij alles wat hij verwierf aan den basalo in korting op zijn schuld geven ${ }^{26}$ ). Ook in Loinang kon een pandeling zich vrij maken, waarvoor het madi den term batolos kent; gewoonlijk echter kwam er weinig van. De man werd als slaaf behandeld en had daarom geen gelegenheid eigendommen te verzamelen. Bovendien moest hij steeds meer terugbetalen dan de oorspronkelijke schuld bedroeg ${ }^{27}$ ).

23) Kruyt, Banggaische Studiën, blz. 26.

24) Kruyt, Banggaische Studiën, blz. 33.

25) Kruyt, Banggaische Studiën, blz. 36.

28) Kruyt, Bewoners, blz. 250, 251.

27) Kruyt, To Loinang, blz. 360. 
Aan het pandelingschap kwam (wellicht meer theoretisch dan feitelijk) een einde in 1880 bij het in dat jaar gesloten contract met sultan Ajanhar van Ternate (zie blz. 137 v. en noot 78 van hoofdstuk V). In art. 19 van dat contract werd het pandelingschap afgeschaft. Zie verder de op blz. 89 genoemde verklaring van het Zelfbestuur van Banggai van 22 Juli 1912, waarbij werd vastgelegd dat o.m. het pandelingschap in de onderafdeeling niet meer bestaat ${ }^{28}$ ).

\section{Samenwerking.}

$a$. hulpbetoon. Bij velerlei gelegenheden helpt men elkaar met dat soort werkzaamheden die gemakkelijker en sneller door velen dan door een enkeling kunnen worden verricht. In den Banggai-Archipel helpt men elkaar wederkeerig om den akker gereed te maken waarvoor het aki den term pobangkit kent ${ }^{28}$ ). Ook uit Balantak meldt men overeenkomstige handelingen ${ }^{30}$ ), terwijl men b.v. in Loinang elkaar bij diverse stadia van den huizenbouw helpt: alle dorpsgenooten helpen één dag bij het oprichten van den hoofdpaal (eventueel de andere zware stijlen ook?); allen die den beitel kunnen hanteeren helpen bij het beitelen der gaten voor de dwarsliggers onder den vloer; bij het plaatsen der daksparren komen de dorpsgenooten wederom de helpende hand bieden. Allen die aan de totstandkoming van het huis hebben medegewerkt, worden vereend bij een feestje, kasompolannjo (madi: het teneinde brengen, het slot van alles) ${ }^{31}$ ). Eigenaardig is Kruyt's mededeeling dat men in den Archipel en in Balantak niet gewend zou zijn elkaar bij den huizenbouw te helpen ${ }^{32}$ ). M.i. moet dit althans gedeeltelijk op een vergissing berusten, daar de groote woningen, die men hier en daar nog in den Archipel aantreft, en waarin een verzameling van naaste bloedverwanten bijeenwoont (in Basosol b.v. zag ik nog zoo'n huis) wel door velen moet worden opgericht; wellicht werkten aan de totstandkoming alleen de belanghebbenden mee, d.w.z. zij die hun toekomstig verblijf onder dit gezamenlijk dak zouden hebben. Overigens is mij uit eigen aanschouwing bekend dat bij de oprichting van de huidige gezinswoningen in de dorpen wel degelijk de helpende hand door de dorpsgenooten wordt gereikt.

\footnotetext{
28) Memorie.

29) Kruyt, Landbouw, blz. 481.

30) Kruyt, Rijstbouw, blz. 128.

31) Kruyt, To Loinang, blz. 367, 369.

32) Kruyt, Bewoners, blz. 71; Balantaksche Studiën, blz. 344.
} 
b. duurzame vormen van samenwerking. De Loinangsche landbouwvereeniging (madi : sambaba) werd reeds op blz. 63 v. genoemd. $\mathrm{Bij}$ de werkzaamheden is de gang van zaken als volgt: de leden van het gezelschap bewerken eerst gezamenlijk den akker van den voorganger (madi: tonaas of tanaas) ; daarna worden de individueele stukken grond bewerkt waarbij men elkaar wederkeerig helpt. Hetzelfde geschiedt bij het beplanten en oogsten der akkers. $\mathrm{Na}$ afloop van den oogst geeft elk der deelnemende gezinnen den tonaas een mandje rijst en een kip, waarvan door den tonaas aan zijn assistenten (pombebe' $i$ en pahemata; zie blz. 100) onderscheidenlijk $3 / 10$ en $1 / 10$ deel wordt gegeven. De landbouwvereeniging wordt na den oogst niet ontbonden, de voorganger blijft in functie, ten ware de oogst mislukt is, in welk geval men een anderen tonaas kiest ${ }^{33}$ ).

De Loinangsche jachttroep (men jaagt hier steeds gezamenlijk) staat eveneens onder een tonaas, die gelijknamige assistenten heeft als bij de landbouwvereeniging. De tonaas krijgt een grooter deel van de jachtbuit; de eigenaar van honden krijgt daarentegen bepaald aangewezen deelen van het wild. De tonaas behoeft geen bezitter van honden te zijn; hij is iemand die vertrouwen inboezemt. Overigens wordt de buit gelijk onder de jagers verdeeld, of zij honden hebben of niet ${ }^{34}$ ).

Het Balantaksch jachtgezelschap staat eveneens onder een voorganger, tanaas (sian); bij de verdeeling van de jachtbuit krijgen de jagers met honden meer dan zij die zonder deze dieren meegingen ${ }^{35}$ ).

De rechtsgemeenschappen kunnen krachtens het beschikkingsrecht aanspraak maken op een deel van de jachtbuit: in Loinang krijgt het dorp in welks nabijheid men een varken doodde de helft van de kop van het dier; in Balantak moet aan een ieder die er om vraagt een klein stukje van de buit gegeven worden.

De eenige mededeeling over het gezamenlijk bezitten van een vaartuig stamt uit den Archipel; als men nl. gezamenlijk een prauw maakt heeft dit tot gevolg dat men het vaartuig gezamenlijk bezit ${ }^{36}$ ). Interessant ware het te weten wat de gevolgen hiervan zijn ten aanzien van de visch die gevangen, de vracht die vervoerd wordt.

\footnotetext{
33) Kruyt, To Loinang, blz. 413-431.

34) Kruyt, To Loinang, blz. 383-386.

35) Kruyt, Balantaksche Studiën, blz. 360 .

36) Kruyt, Bewoners, blz. 268.
} 


\section{Lastgeving.}

Het kwam in den ouden tijd voor dat een persoon uit den weg moest worden geruimd, omdat hij tegen velen onhebbelijk optrad; zijn gedrag werd ook met het hoofd besproken. Het eind was dat door hem eenige dapperen op den ongewilden mensch werden afgezonden met opdracht hem te dooden. Hetzelfde geschiedde als men een persoon algemeen voor gifmenger aanzag; tot die executie werd dan wel een persoon gehuurd, indien niet één der benadeelde familieleden, die eigenlijk tot dat werkje aangewezen waren, den moed daartoe bezat. Het gewone loon waarvoor een talenga (aki : voorvechter) gehuurd werd tot het uitvoeren van dergelijke opdrachten was een of twee koperen sirihdoozen of gongs. Mocht hij zelf bij zijn poging gedood worden, dan had dit geen gevolgen voor den opdrachtgever. Het loon werd verhoogd als de voorvechter zijn taak niet had kunnen volvoeren; de opdrachtgever beloofde hem dan b.v. drie in plaats van twee gongs te zullen geven als het gelukte den aangeduiden persoon te dooden ${ }^{37}$ ).

\section{Loondienst en belooning; aanneming.}

$\mathrm{Bij}$ een geldarme maatschappij als de Banggaische wordt het grootste deel der crediethandelingen gehonoreerd in natura. Slechts werkzaamheden verbonden met de coprabereiding (plukken, schillen, drogen, fijnhakken en zakken der vruchten) worden vrijwel steeds in geld beloond; de prijzen van het product varieeren sterk, en de loonen volgen deze schommelingen. Zelden komt belooning der plukkers in natura voor; een dergelijke afspraak luidt dan dat zij van elke honderd geplukte noten er een bepaald aantal als loon voor zich mogen behouden.

Voor velerlei verrichtingen die in het dagelijksch leven voorkomen wordt een belooning in natura gegeven. We vinden hiervan in de literatuur veelsoortige voorbeelden vermeld.

Archipel. De tusschenpersoon bij verloving en huwelijk (aki : tetean; zie blz. 201) krijgt als loon een koperen schaal op voet, de bruidsjonkers en -joffers (aki : sopit; zie blz. 213) ieder twee aarden borden. Bij een bevalling krijgt een masseuze in West-Peling als loon twee borden, twee hoenders en een lap katoen; zij ontvangt dit loon echter niet als het kind binnen twee of drie dagen sterft; na verloop van dezen termijn vindt de betaling plaats. Degeen die een pasgeboren

37) Kruyt, Bewoners, blz. 253, 252; Zwarte Kunst, blz. 740. 
kind onmiddellijk na de geboorte in ontvangst neemt en het baadt krijgt daarvoor een geschenk; thans is dit een halve gulden of een lap katoen; het heet pongobonoi (aki : voor het schoonmaken). Indien de moeder het kind niet zelf kan voeden neemt een andere vrouw het voeden over waarvoor ze als loon (aki: tinambo) een koperen schaal op voet krijgt. Als de moeder overleden is wordt een zoogmoeder gezocht die een sirihdoos of een geit ontvangt; soms loopt dit loon op tot vier koperen schalen. Degeen die de besnijdenis bij een jongen verricht krijgt op sommige plaatsen alleen vleesch (achterpoot van een geit), oebi en palmwijn, elders bovendien een koperen schaal, aarden borden of hoenders als belooning. Voor elk kind dat de tanden worden gevijld krijgt de operateur een aarden bord en een kommetje ${ }^{38}$ ). Op het eiland Banggai krijgt een Mohammedaansche goeroe die over een kom rijst komt „batja do'a” later die rijst als zijn deel mee naar huis ${ }^{38}$ ). De heidensche priester die een bepaalde ritus gebruikt om bloedschande krachteloos te maken, waarbij hij met een mes eenige borden kapot hakt, krijgt na afloop dat mes mee als loon ${ }^{40}$ ). Het loon dat heidensche priesters voor hun overige bemoeienissen ontvangen hangt af van hun werkzaamheden; hebben ze slechts een enkele dag en nacht gewerkt, dan volstaat men met een bord en een hoen; dit loon heet popososi talapoe (aki : aan den priester sirihpinang geven). Soms geeft men een lap katoen, voldoende voor een baadje, en wat geld (Oost-Peling). Indien de priester den levensgeest teruggebracht heeft, behoudt hij als loon de witte aarden kom en het hoen die daarbij dienst hebben gedaan. Indien een groot feest plaats gehad heeft om de gezondheid van de heele familie te versterken (aki: batong) krijgen de priesters een bijzonder loon, patambo (aki); ook de personen die op andere wijze aan het feest hebben geholpen worden beloond. Bepaalde deelen van het geslachte vee, bepaalde soorten borden, katoen, hoenders, kokosnoten en oebi vormen de belooning voor al die diensten ${ }^{\mathbf{4}}$ ).

De makers van een doodkist krijgen als loon volop te eten met een hoen als toespijs; dit hoen is hun sinelei (aki). Alleen rijke lieden geven een koperen schaal als loon, soms twee. $\mathrm{Zij}$ die het graf gedolven hebben worden alleen met voedsel beloond; het maken van een grot van steenen om de lijkkist (o.a. te Kindandal) dient met het

38) Kruyt, Banggaische Studiën, blz. 19, 30, 20, 52, 53, 65, 66.

39) Kruyt, Ziekte, blz. 153.

40) Kruyt, Banggaische Studiën, blz. 17.

41) Kruyt, Pilogot, blz. 135. 
slachten van veel vee te worden beloond, zoodat alleen rijke lieden zich zoo iets kunnen veroorloven ${ }^{42}$ ).

Het loon voor het in gereedheid brengen van den akker bestaat in ten eten geven aan de werkers; dit heet montandan (aki) of motopai (aki), en is iets anders dan het op blz. 265 genoemde pobangkit. Als loon bij het rijstsnijden mogen de meisjes die komen helpen gewoonlijk de rijst zonder steel (aki: roentoep) behouden; anders is het loon $1 / 10$ van hetgeen zij geoogst hebben ${ }^{43}$ ).

Hij die een huis opricht en daarbij gebruik maakt van timmerlieden moet zorgen dat er elken dag vleesch en visch is, want hij moet den werklieden te eten geven. Degeen die een vaartuig voor zich zelf wil laten maken huurt daartoe werklieden; in 1932 betaalde men 50 cent per dag. Als de prauw gereed is wordt met de buren een dag afgesproken om het vaartuig gezamenlijk naar zee te trekken, waarvoor de prauwbezitter als loon een groote hoeveelheid palmwijn heeft aan te bieden. Dit gezamenlijk naar zee trekken heet bingkat (aki: oplichten); welk verband er tusschen dezen term en het op blz. 261 genoemde babingkat bestaat is mij niet bekend. Degeen die een smid iets laat maken beloont hem meestal met borden, hoenders, oebi, katoen, doch niet met een tegenprestatie in arbeid (b.v. den akker van den smid bewerken). Wil iemand zelf smid worden, dan moet hij in de leer gaan bij een volleerden smid en hem als geschenk een klein varken geven. Heeft de leerling reeds eenige vaardigheid verworven zoodat hij den meester eenig werk uit de hand kan nemen, dan wordt hij door den laatste wel beloond met een geschenk dat de meester neemt van het loon dat hij voor zijn werkzaamheden van zijn opdrachtgevers ontvangt ${ }^{44}$ ).

Vogelkop. De priesteres die bepaalde diensten verricht bij en kort na de geboorte ontvangt als belooning een hoen, een bord en een vadem ongebleekt katoen ${ }^{45}$ ). Indien de moeder haar kind zelf niet kan zoogen laat men dit door een ander doen; deze vrouw geeft men gedurende den tijd dat ze de kleine helpt te eten en aan het einde van dien tijd krijgt ze een geschenk, waarvan de grootte afhankelijk is van den welstand der betrokkenen. Het loon dat de doodenpriester voor zijn bemoeienissen ontvangt is 4 borden en 4 vadem katoen; buitendien krijgt hij bij alle plechtigheden volop te eten; het loon

42) Kruyt, Ziekte, blz. 158, 163, 164.

43) Kruyt, Landbouw, blz. 481, 489.

44) Kruyt, Bewoners, blz. 73, 268, 86.

45) Kruyt, Balantaksche Studiën, blz. 383 . 
wordt betaald na beëindiging van alle doodenriten $\left.{ }^{46}\right)$. Het loon voor de priesters bij het soemari-feest (zie blz. 111) heet batarai bolian (sian) en bestaat uit borden, lappen geklopte boomschors, hoenders en gepelde rijst. De lotoe (sian: voorzanger) krijgt een even groot aandeel als de priesters. De meester in het onderwijs tot priester ontvangt geen speciale belooning voor zijn onderricht, maar telkens als de leerling geroepen is om bijstand te verleenen geeft hij een deel van het ontvangen loon aan zijn leermeester, hetgeen hij volhoudt tot aan den dood van den laatste. Als men in Balantak de hulp van een smid inroept moet men hem met rijst beloonen; bovendien moet men zelf de houtskool leveren. De deskundige die verstand heeft van huizenbouw wordt gehuurd met twee bossen rijst per dag; hij geeft leiding aan de werkzaamheden der huisgenooten. Degeen die bij de rijstoogst helpt ontvangt als loon twee groote bossen rijst, die den naam dragen van timpa (sian). Het loon van personen met een langen adem, die voor anderen bij een godsoordeel plachten te duiken (zie blz. 157) bedroeg een paar borden of een paar el katoen ${ }^{47}$ ).

Loinang ${ }^{48}$ ). Indien de moeder haar pasgeboren kind niet kan helpen of als zij overleden is wordt de kleine door een andere vrouw gezoogd. Als deze een tante of een nabestaand familielid is, is er geen sprake van belooning; moet echter dit werk aan een ander worden overgelaten dan wordt loon gegeven, voor elke drie maanden een blok ongebleekt katoen. Bij het tandenvijlen ontvangt elke operateur een bamboekoker met vleesch, een hoeveelheid gekookte rijst, een stuk zout, een pluk tabak, en voor zijn echtgenoote die hem geholpen heeft de helft daarvan. Het loon dat de priester krijgt is afhankelijk van het werk dat hij gedaan heeft. Indien de geest alleen door zijn mond advies heeft gegeven hoe men de zieke moet behandelen ontvangt de priester alleen wat sirih-pinang, één of twee aarden borden en de pooten van het geslachte hoen. Als de priester echter ook medicijn verstrekt, of het lichaam beblaast, den buik betast, of den zieke begiet met levenskrachtig water ontvangt hij meer: gepelde rijst en een lap katoen. De helpers bij den rijstoogst worden in natura beloond, nl. met één zeer groote bos per dag of twee gewone bossen (één bos rijst heet in het madi santimpa), dan wel met een mand vol rijst zonder steel (die men niet bij elkaar heeft kunnen binden).

46) Kruyt, Van leven en sterven, blz. 73, 93.

47) Kruyt, Balantaksche Studiën, blz. 350, 377, 389.

48) Kruyt, To Loinang, blz. 469, 474, 394, 428. 


\section{Aanneming.}

In de Tominibocht komt voor dat tusschen twee personen een overeenkomst wordt aangegaan, waarbij de één belooft voor den ander een van te voren vastgesteld aantal klapperboomen te planten op een stuk grond waarvan de wederpartij de inlandsche bezitter is (c.q. de niet-inlander die op dat stuk grond een titel heeft); de grondbezitter levert buitendien meestal de jonge, gekeurde en gesproten noten ter planting. Het contract eindigt gewoonlijk drie jaar later, wanneer nl. kan worden geconstateerd of de boomen zijn gelukt of niet. De aanneemsom wordt in dier voege bepaald dat de grondbezitter de jonge boomen per stuk betaalt tegen een vooraf vastgestelden prijs; de kwaliteit van het geleverde werk wordt op deze wijze verdisconteerd in de betaling. Gedurende die drie jaar heeft de planter het recht tusschen de jonge boomen voedselgewassen te planten, doch uitsluitend éénjarige (rijst, mais, groenten), terwijl hij in dien tijd tevens geregeld den opdrachtgever geld mag komen vragen in voorschot op den straks te betalen aanneemsom. Dat dit contract vaak in den vorm wordt opgemaakt dat de opdrachtgever na den bedongen termijn de gelukte boomen van de wederpartij koopt doet m.i. niets af aan het karakter van dit aanneemcontract. Zouden we hier met een echten koop te maken hebben, dan zou hieruit kunnen blijken dat de rechten op gewas en die op grond niet in handen van denzelfden bezitter behoeven te rusten (een geval dus onder par. 1 van dit hoofdstuk behoorend); het is jammer dat ik geen aanleiding had dezen contractvorm dieper te onderzoeken. 


\section{HOOFDSTUK XII.}

\section{Delictenrecht.}

Indien we als delict beschouwen elke eenzijdige inbreuk op (materieele of immaterieele) levensgoederen van een groep, dan wel van een persoon ${ }^{1}$ ), dan kunnen we reeds aanstonds een scheiding maken in twee soorten strafbare handelingen, nl. die waarbij een groep als geheel beleedigd wordt, naast daden welke persoonlijke belangen benadeelen. De eerste soort draagt een meer publiekrechtelijk, de tweede daarentegen een eenigszins privaatrechtelijk karakter. Bij de eerste categorie móét door een zoenoffer de door de strafbare handeling opgewekte onheilstoestand, waarvan de geheele groep het slachtoffer dreigt te worden, bezworen worden; daarentegen is het te niet doen der spanningen, ontstaan tusschen dader en gelaedeerde bij de tweede soort handelingen, in de eerste plaats gericht op het herstel van den vrede tusschen beide personen; het komt neer op het tot stand brengen van een verzoening, vaak, niet altoos, met tusschenkomst der hoofden (verg. hoofdstuk V, par. 8).

\section{Delicten waardoor de groep in haar geheel bedreigd wordt.}

Als voorbeelden van deze niet zeer uitgebreide categorie kunnen we noemen: negatie der voorvaderlijke instellingen (in zekeren zin: godslastering), bloedschande en andere delicten op zedelijk gebied, tooverij (waaronder mede begrepen hekserij en gifmengen).

In den Archipel weet men dat Temeneno, het Opperwezen (zie blz. 10) voor vergrijpen tegen de adat straft; hij maakt dan de menschen ziek. Ook daar waar men beweert dat Temeneno een vrouw is en waar men haar beschouwt als de Meesteres van al het geschapene, zegt men dat $z \mathrm{ij}$ hen, die tegen de adat gezondigd hebben, ziek maakt. In Oost-Peling (waar monotheistische invloeden ten gevolge van Islam en Christendom merkbaar zijn) beweert men dat het Opperwezen, de Schepper van alles, den menschen wel een lang leven zou

1) Vergelijk Ter Haar, Beginselen, blz. 216. 
willen geven, maar dat de mensch het zelf bederft door al het kwaad dat hij doet $^{2}$ ).

Ook de vergoddelijkte voorouders (pilogot; blz. 10 v.) letten nauwkeurig op 's menschen handelingen; indien hun nazaten hen verwaarloozen worden zij hierover vertoornd ${ }^{3}$ ). Verder weet men dat door handelingen, in strijd met de voorvaderlijke zeden, automatisch een slechte invloed op het leven van den mensch ontstaat. Niet alleen door overtreding van het gewoonterecht bij volle kennis en klaar inzicht wordt een onheilstoestand opgewekt, doch ook gebeurt dit als men er onbewust tegen gezondigd heeft. Het aanwezig zijn van een dergelijken toestand uit zich door bepaalde verschijnselen, die niet alleen bij den dader, doch ook bij zijn huisgenooten of verwanten kunnen optreden ${ }^{4}$ ). Een der feiten waaruit men b.v. opmaakt dat er onheil rust op de huisgenooten, is als een barende het zwaar te verantwoorden heeft ${ }^{5}$ ).

Dreigend onheil kan nog worden afgewend (aki: kinoloboki= afgewend worden; mokoloboki $=$ afwenden). Dit zal dus worden toegepast als men een bepaald vergrijp tegen de adat heeft begaan; ook als men niet bewust is gezondigd te hebben, doch er verschijnselen zijn die erop wijzen dat pilogot verstoord is ${ }^{6}$ ).

Het zoenoffer dat gebracht moet worden als men pilogot vertoornd heeft door overtreding der overgeleverde orde heet pinalangas (aki: bapalangas $=$ zoenoffer brengen). De godentoorn is reeds losgebarsten en heeft zich b.v. geuit doordat een der huisgenooten, niet steeds de bedrijver van het kwaad overigens, ziek geworden is. Er is b.v. door een der gehuwde huisgenooten overspel gepleegd; de daardoor opgewekte onheilstoestand openbaart zich nu bij een ander. Bekent de schuldige zijn (haar) misslag aan den heidenschen priester, dan wordt de onheilstoestand opgeheven en kan de zieke beter worden; in tegenovergesteld geval moet hij echter sterven. De onheilstoestand heet balolimpat (aki ; slaat dit woord wellicht speciaal op de kwade gevolgen verbonden aan overspel?) ${ }^{7}$ ).

Treffend is verder de mededeeling dat de heidensche priester in den Archipel nimmer iets tegen de adat doen mag; dat hij verder vooral moet oppassen zich niet op sexueel terrein te bezondigen. Een

2) Kruyt, Pilogot, blz. 115

3) Kruyt, Banggaische Studiën, blz. 44.

4) Kruyt, Pilogot, blz. 120, 126, 130.

5) Kruyt, Banggaische Studiën, blz. 44.

8) Kruyt, Pilogot, blz. 127 .

7) Kruyt, Pilogot, blz. 126, 130.

Verh. dl. VI. 
en ander toch zou automatisch ziekte en dood voor hem (en waarschijnlijk ook voor de gemeenschap) met zich brengen ${ }^{8}$ ).

Voor den Vogelkop heet het dat het Opperwezen, pilogot mola, nauwkeurig let op wat de menschen doen; alle bedreven kwaad wordt door hem bestraft. Als daden die in het bijzonder zijn toorn opwekken noemt men: het afleggen van valsche eeden en het bedrijven van bloedschande, waartegen pilogot mola bovennatuurlijke straffen bedreigt die zich kunnen uitstrekken tot de kinderen van den dader ${ }^{\boldsymbol{\theta}}$ ).

In Loinang is het ook pilogot die waakt over de door hem ingestelde orde, want hier is immers pilogot wederom de vergoddelijkte stichter van de, één dorp bewonende, families in uitgebreiden zin. Van pilogot verwacht men alle mogelijke zegeningen, doch hij is het ook die streng waakt tegen alle tekortkomingen tegen de adat. Zijn macht en zijn ongenoegen openbaren zich door rampen, die een familie, een dorp, overkomen, terwijl degenen zijner nakomelingen die hij vervloekt heeft, moeten sterven ${ }^{10}$ ).

Ook de vorst staat onder een dergelijke ban; bij zijn inhuldiging wordt hij vermaand rechtvaardig te besturen, want dan zal hij een lang leven hebben. Zoo hij echter de voorschriften der voorvaderen niet zou opvolgen zou hij niets anders dan tegenspoed hebben en vroeg sterven ${ }^{11}$ ).

Reeds werd gezegd dat als een der ernstigste vergrijpen tegen de door de voorouders ingestelde orde, het plegen van bloedschande (aki en sian : sele; madi : niet opgegeven) wordt aangemerkt. De gevolgen voor de gemeenschap worden zeer gevreesd, want alles zal mislukken: de akker gedijt niet, b.v. door te groote droogte of door een varkensplaag; de jager vangt geen wild, elke onderneming faalt. Bovendien worden allerlei natuurrampen opgewekt: wolkbreuken met overstroomingen gepaard, geweldige aardstortingen, het splijten van den grond, het verzinken in de aarde van het dorp waar het kwaad bedreven werd. Aldus treffen de rampen (aki : monos; sian en madi: lioe) de geheele gemeenschap. Hier was dan ook geen verzoening mogelijk, indien bloedschande in den ergsten graad was gepleegd (zie blz. 197). Er bleef maar één weg: beide schuldigen dienden te worden gedood. In den Archipel deed men dit door verdrinking waartoe $z e$ in een groote rotan mand werden gesloten, die een eindweegs in

\footnotetext{
8) Kruyt, Pilogot, blz. 128.

9) Kruyt, Balantaksche Studiën, blz. 365 .

10) Kruyt, To Loinang, blz. 401.

11) Kruyt, Vorsten, blz. 613.
} 
zee werd geroeid, waarna men mand met inhoud over boord zette; het is ook wel voorgekomen dat zij met het zwaard werden gedood, doch het incestueuze bloed mocht daarbij niet op de aarde worden gestort; verder is wurging toegepast (aki: pook = wurgen). Ook op den Vogelkop doodde men schuldigen aan dit delict door verdrinking in zee, terwijl in Loinang beide incestueuzen door ophanging werden geëxecuteerd (madi: segot $k a$ oelajo-oelajo $=$ in de lucht ophangen). Bij al deze straffen komt het magisch gevaarlijke van het bedreven kwaad wel zeer duidelijk uit; gaf men er de voorkeur aan schuldigen in zee te brengen, mocht elders het incestueuze bloed niet op den grond worden gestort, hier mogen zij zelfs in het geheel niet meer de aarde aanraken ${ }^{12}$ ).

De ouders trachtten een geval van incest, gepleegd door hun kinderen, wel te verbergen en de gevolgen af te wenden door het op blz. 273 genoemde kinoloboki (aki). Doch als het hoofd hiervan kennis kreeg moest het recht zijn loop hebben en werd het gebruikelijke vonnis geveld. De groep als geheel wordt bedreigd, het hoofd treedt op als handhaver der orde (verg. blz.150).

Gevallen van lichtere bloedschande kunnen eventueel aanvaardbaar gemaakt worden (zie blz. 197); er dient geofferd te worden om de gevolgen af te wenden en het kwaad krachteloos te maken (aki: potatak sele $=$ de bloedschande uit elkaar halen; sian: monsimpoet gogorong $=$ de keel beschermen; madi: mongkojo' $i$ : beteekenis onbekend), welke plechtigheid in den Archipel en in Loinang door een priester, in Balantak door het hoofd geleid wordt. Niet altijd is het daarna den schuldigen toegestaan met elkaar te huwen. In sommige streken van den Archipel, ook op den Vogelkop werden (worden ?) zij gescheiden en werd (wordt?) soms de man naar een ander eiland gebracht; zochten zij elkaar daarna weer op, toonden zij zich dus onverbeterlijk, dan werden ze gedood.

Thans behandelt de Zelfbestuursrechtbank dergelijke gevallen.

Ook overspel roept een onheilstoestand in het leven en heeft dus een fatalen magischen invloed op de menschen in de omgeving, in de eerste plaats echter op de huisgenooten (Archipel); hierdoor kan een hunner ziek worden. Slechts schuldbekentenis aan den priester kan dan den zieke redden (zie blz. 273) ${ }^{\mathbf{1 3}}$ ). Uiteraard heeft bij bekend worden van overspel ook een individueele reactie plaats van $\operatorname{de}(n)$

12) Kruyt, Banggaische Studiën, blz. 15 v.; Landbouw, blz. 483/484; Leven en sterven, blz. 57 v.; To Loinang, blz. 446.

13) Kruyt, Banggaische Studiën, blz. 37. 
beleedigde(n) echtgenoot(e); deze zal echter in de volgende paragraaf worden behandeld. Op den Vogelkop en in Loinang schijnt het gemeenschapsgevoel door overspel niet dermate beleedigd te worden als in den Archipel, althans Kruyt vermeldt slechts individueele reacties; doch ook op den Vogelkop ziet men in een zware bevalling een teeken dat òf door de barende zelf, dan wel door den aanstaanden vader, overspel is gepleegd ${ }^{14}$ ).

In Loinang brengt bijzonderlijk zwangerschap buiten echt gevaren met zich voor de geheele gemeenschap; daar neemt men aan dat de veroorzaker van een dergelijken toestand de natuur getart heeft zich op ongewone wijze te openbaren; de man wordt zwaar beboet, met een boete die lioe (madi: natuurramp) heet. Dat de gemeenschap de beleedigde is komt duidelijk uit door het ongewoon groote andeel dat het hoofd als representant van de groep ontvangt; hij krijgt $\mathrm{nl}$. de helft van de uit 10 blokken katoen bestaande boete, terwijl de andere helft aan de familie der vrouw komt ${ }^{15}$ ).

Van den Vogelkop en den Archipel vinden we een dergelijke intensieve bemoeienis in zulke gevallen niet vermeld (verg. hoofdstuk VIII, par. 1 en de daar behandelde vóór-huwelijksche verhoudingen). Slechts weten we dat de gemeenschap zich met het geval bemoeit in de persoon van het hoofd, die zoo eenigszins mogelijk een huwelijk tot stand brengt. Op de hoofdplaats Banggai werd een man die weigerde het zwanger gemaakte meisje te huwen, wel gestraft met 40 stokslagen of dertig gulden boete; ook werd hij wel in een blok gesloten tot hij toestemde in het huwelijk ${ }^{\mathbf{1 6}}$ ).

Wederom in Loinang is het opwekken van abortus een ernstig delict, daar men hier aaneemt dat een natuurramp zal plaats hebben waardoor de geheele groep zal worden getroffen. Een meisje of vrouw, die haar vrucht afdreef, werd dan ook door ophanging gedood ${ }^{17}$ ).

Andere handelingen, welke in deze wereldbeschouwing gevaarlijk zijn, die dus delicten opleveren, zijn o.a.:

het tegelijk met twee zusters gehuwd zijn (Vogelkop, Loinang), waardoor de rechtsgemeenschap zich beleedigd voelt. Op den Vogelkop ziet men hierin zelfs een soort bloedschande; een man die zich hieraan schuldig maakte werd in den ouden tijd door zijn dorps-

14) Kruyt, Leven en sterven, blz. 67.

15) Kruyt, To Loinang, blz. 461.

16) Kruyt, Banggaische Studiën, blz. 42 v.

17) Kruyt, To Loinang, blz. 461. 
genooten afgeranseld, en al zijn have en goed werd hem ontnomen ( $\operatorname{sian}$ : baoebe), waarna men hem verder met rust liet, ook al zette hij zijn leven met de beide zusters voort ; zoo'n man heet een tobangkas (sian), zijn positie doet denken aan die van een adatrechtelijk doodverklaarde. In Loinang stelt men het feit niet gelijk met bloedschande, doch de groepsgenooten zijn er dermate over beleedigd, dat de man een boete moet opberngen van vier blokken ongebleekt katoen, die aan het hoofd (tonggol? daka'njo?) moeten worden overhandigd ${ }^{18}$ ). (Verg. blz. 225).

Op Peling trof ik in een dorp een paar aan dat door de gemeenschap uitgestooten was voor het volgende feit: de man was gehuwd met zijn stiefmoeder (zijn jeugdliefde overigens), nadat haar echtgenoot (des mans vader) overleden was; het geval had een onaangenamen bijsmaak omdat de vrouw zoowel van haar eersten man (den vader) als van den tweeden (den zoon) een kind had. Ik kon deze aangelegenheid door een ontzondigingsplechtigheid in het reine brengen; hieraan namen het geheele dorp eenerzijds, het jonge paar anderzijds deel.

Als laatste delict in deze groep noemde ik tooverij; hierdoor toch voelde ieder lid der gemeenschap zich bedreigd en was het een belang van velen dat aan deze bedreiging een einde kwam. In oude tijden ging men er wel toe over den schuldige te beboeten, in den Archipel met een varken en zeven draagmanden oebi, op den Vogelkop met een boete tot $f 300$,- (hoe berekend? waarin uitgedrukt?). Ontkende verdachte schuld, dan liet men een enkele keer wel eens toe dat hij zijn onschuld bewees door een godsoordeel (zie blz. 157); doch meestal doodde men den beschuldigde zonder meer, als hij weigerde de boete te voldoen. In dit geval mocht men niets uit het huis van den toovenaar wegnemen. Aandacht verdient dat men in het algemeen pas tot het dooden van zoo iemand overging, als hij de algemeene verdenking op zich had geladen, dan wel omdat het orakel hem als schuldig had aangewezen. Deze algemeene overtuiging hield tevens in dat de kans op weerwraak zeer gering was. Soms ook bepaalde men zich er echter toe, door tusschenkomst van basalo of tonggol, de goederen van den beschuldigde te gaan rooven, doch zijn persoon ongemoeid te laten; in dit geval werd echter een offer van een geit, varken of hoen gebracht om de zwarte kunst van dien mensch krachteloos te maken ${ }^{\mathbf{1 9}}$ ). Kwam hij wellicht in de positie van adatrechtelijk doodverklaarde?

18) Kruyt, Leven en sterven, blz. 57; To Loinang, blz. 448.

19) Kruyt, Zwarte kunst, blz. 738 v. 
Wellicht met den angst voor tooverij samenhangend staat het verbod in Loinang om met dieren om te gaan als of het menschen waren. Hierdoor toch worden weer natuurrrampen opgewekt, dan wel de mensch die zulks doet kan in steen veranderen ${ }^{20}$ ).

Eveneens staat misschien met vrees voor zwarte kunst in verband het optreden tegen een persoon die tegen ieder onhebbelijk optrad of meerdere menschen onbillijk had bejegend ${ }^{21}$ ); wellicht neemt men aan dat deze mensch zijn houding aan machten van buiten te danken heeft; zie verder par. 6 hoofdstuk XI.

\section{Delicten waarbij spanningen tusschen individuen ontstaan.}

$a$. verwonding. In den Archipel is het gewoonte dat degeen die een ander opzettelijk verwondt alle kosten voor de genezing van het slachtoffer betaalt; dit zijn voornamelijk die verbonden aan het brengen van offers voor het spoedige herstel van den gewonde. Ook op den Vogelkop komen alle kosten van verpleging en het bezorgen van medicijn ten laste van den dader, die bovendien nog een bepaald of fer moet brengen om de bescherming der geesten in te roepen tot spoedige genezing der verwonding. In Loinang ten slotte is het niet anders: daar wordt een boete geëischt, waarvan het bedrag zeer verschillend is en afhangt van de omstandigheden; deze zijn b.v. de verhouding waarin beide personen tot elkaar staan, de aard der verwonding en de rang en stand van den verwonde. Deze boete heet bij Kruyt tampong of pontampong (madi); aan het zeestrand gaf men mij tampol of pontampol op (madi). Deze boete werd uitgedrukt in blokken katoen; vaak, niet altijd, besliste een hoofd, nl. wanneer de beleedigde partij te veel eischte ${ }^{22}$ ).

$b$. mishandeling. De eenig beschikbare mededeeling van den Vogelkop zegt dat als een man zijn vrouw slaat, hij beboet wordt (sian: looetang); vermoedelijk legde de vrouw de boete op. In Loinang wordt iemand die een ander een klap geeft met de volle hand (,.met vijf vingers") dienovereenkomstig beboet met vijf blokken was. Indien bij een geval van zware mishandeling beide partijen zwaar gewond zijn, onthoudt de rechter zich van het opleggen van boete aan één hunner: beiden worden vrijgesteld (madi : poeli ${ }^{23}$ ).

20) Kruyt, To Loinang, blz. 379.

21) Kruyt, Bewoners, blz. 253.

22) Kruyt, Bewoners, blz. 256; Balantaksche Studiën, blz. 351 v.; To Loinang, blz. 362; Memorie.

23) Kruyt, Leven en sterven, blz. 63; nota Tangkilisan. 
c. dooding. Indien iemand onopzettelijk gedood wordt moet degeen die den dood veroorzaakt heeft in sommige streken van den Archipel de helft, in andere deelen alle kosten van de begrafenis betalen. Op den Vogelkop echter worden de begrafeniskosten gelijkelijk gedragen door den dader en de familie van den gedoode. In Loinang dienen weer allerlei factoren in rekening te worden gebracht. Indien partijen elkaar welgezind waren gaf de dader wel het doodskleed voor den verslagene en een bijdrage tot het doodenmaal; ook werd soms een boete opgebracht ter waarde van de helft van den prijs van een mensch. Ook kwam het voor dat de dader een kind ving bij een andere groep en dit als remplaçant voor den doode, tezamen met eenige blokken goed, aan de familie van den verslagene gaf ${ }^{24}$ ).

Het aki gebruikt den term montabas voor gewelddadig van het leven berooven van een medemensch (tinabas $=$ doodgehakt).

$d$. diefstal. In den Archipel geldt algemeen de regel dat de dief zoo mogelijk het gestolen goed moet teruggeven, waarbij een boete komt gelijk aan de waarde van het gestolene, welke boete voor de benadeelde partij is. Dit alleen voor zoover de zaak tusschen deze en den dader wordt uitgemaakt. Indien de bestolene de hulp inriep van de rechters-hoofden werd aan hen een deel van het als boete opgelegde bedrag gegeven, idoelaan geheeten (aki). Kruyt vermeldt dat als men de hulp van basalo of tonggol inriep de boete tot driemaal de waarde van het gestolene verhoogd werd, want eenmaal daarvan kwam den rechters toe. Kruyt noemt dit rechtersdeel soekano (aki: zijn palmwijn), doch in het verband waarin hij deze belooning bespreekt is dit vermoedelijk de speciale belooning voor den rechter na gehouden godsoordeel (verg. blz. 154). De boeten die opgelegd worden noemt men dinenda of inoetang (aki); tusschen beide begrippen bestaat verschil. Met dinenda wordt aangegeven beboeting wegens strafbare handeling (zoengeschenk), met inoetang de ten gevolge van die handeling ontstane vordering tot restitutie ${ }^{25}$ ). (Men gaf mij deze termen alleen bij diefstal op, hetgeen niet zeggen wil dat zij in ander verband niet zouden worden gebruikt).

Diefstal van voedsel neemt steeds een bijzondere plaats in. In den Archipel wordt gezegd dat bij diefstal van een kleine hoeveelheid oebi de bestolene het recht had den dader een pak slaag te geven, hetgeen

24) Kruyt, Bewoners, blz. 256; Balantaksche Studiën, blz. 352; To Loinang, blz. 362; Adriani-Kruyt, Bare'e III, blz. 282.

25) Kruyt, Bewoners, blz. 254; Memorie. 
doet vermoeden dat vaak kinderen de daders zijn van dergelijke diefstallen. Was de ontvreemde hoeveelheid oebi echter grooter, dan gold hooger aangegeven regel; ook was mogelijk dat de bestolene in zelfrechtverschaffing een gedeelte van den akker van den dief tot zich nam; hij wiedde 10 vadem in het vierkant, waarna dit stuk met alles wat erop groeide het bezit van den benadeelde werd. Wellicht hiermee in verband staat de regel dat vreemdelingen in de verzamelschuur van de oebi niet mogen binnengaan; er staat geen sanctie bij aangegeven, slechts is de bezitter van de oebi bevreesd dat er anders veel muizen zullen komen ${ }^{26}$ ).

Men kent in den Archipel middelen om langs magischen weg zijn aanplantingen tegen diefstallen te beveiligen of den dief ongelukkig te maken ${ }^{27}$ ).

Ook op den Vogelkop is de boete normaal gelijk aan de waarde van het gestolene; dit moet worden gerestitueerd en wat er bij wijze van boete aan toe moet worden gevoegd heet oboeloes (sian). Het stelen van rijst is weer een bijzondere vorm; heeft de dief slechts enkele bossen weggenomen, dan is de boete minder dan de ontvreemde hoeveelheid. Indien er echter meer bossen zijn gestolen wordt de dief zwaar gestraft; dan wordt hem geen boete oboeloes opgelegd, doch een veel hoogere, nl. de boete motaro' (sian), welke o.m. bestaat uit borden, katoen, een kip e.d., terwijl uiteraard het gestolene moet worden gerestitueerd. Met het hoen wordt een offer aan de rijstgodin gebracht, terwijl het bloed van het dier op de hoofden van het bestolen gezin wordt gestreken ${ }^{28}$ ). Uit deze magische handeling spreekt wel zeer sterk het bijzonder karakter van dezen vorm van diefstal:

In Loinang vinden we uiteraard overeenkomstige trekken. Bij diefstal moet het gestolene worden teruggegeven, terwijl een boete ter waarde van het gestolene werd opgelegd; die boete kon eventueel voldaan worden met motombing (madi; zie blz. 258). Verder is ook hier de regel bekend dat als het den dief niet mogelijk is het gestolene uit te leveren, te restitueeren, de boete veel zwaarder moet worden.

Het stelen van rijst is wederom een zeer ernstig delict. Men maakt onderscheid tusschen pogingen om de schuur te beklimmen of te forceeren; wegnemen van rijst van den akker; ontvreemden van rijst uit de schuur. De hiervoor opgelegde boetebedragen waren onderscheidenlijk : 8 motombing; 15 aarden borden; 30 leang (madi : reaal),

26) Kruyt, Landbouw, blz. 491.

27) Kruyt, Bewoners, blz. 254.

28) Kruyt, Balantaksche Studiën, blz. 348 v. 
welke laatste boete zelfs tot 25 blokken ongebleekt katoen kon oploopen, ook al had de dief slechts één bos weggenomen ${ }^{29}$ ).

Tangkilisan noteerde in Loinang nog de volgende bijzonderheden:

als schuldig aan diefstal wordt gestraft hij die een huis is binnengegaan als kort daarna uit die woning goederen worden vermist, ook al is die persoon niet de dief;

degeen die een kip steelt wordt minder gestraft dan hij die zich een ei toeëigent. Als reden gaf men op, dat een kip vrij rondloopt en daarbij wel eens andermans bezittingen vernielt; een ei daarentegen ligt natuurlijk bij den bezitter van de kip, zoodat hij die een ei steelt dit met opzet doet;

degeen die een rijpe pisangtros ziet en van de vruchten neemt is niet strafbaar, tenzij de boom van (bezits) teekenen is voorzien; het zelfde geldt voor een pinangpalm ${ }^{\mathbf{3 0}}$ ).

$e$. valsche aanklacht. Kon iemand, beschuldigd van het uitoefenen van zwarte kunst, zijn onschuld bewijzen (hetgeen als regel geschiedde bij godsoordeel), dan had de aanklager, die dus een valsche klacht had ingediend, een delict gepleegd; soms was reeds van te voren uitgemaakt hoeveel de aanklager te betalen zou hebben als bleek dat zijn klacht valsch was ${ }^{31}$ ).

In den Archipel moest de aanklager een boete betalen die verdeeld werd onder de hoofden, de duikers en den beschuldigde; op den Vogelkop werd hem de boete motaro' (sian) opgelegd; soms was er tevoren tusschen partijen reeds een afspraak gemaakt hoeveel ieder zou betalen als de andere gelijk bleek te hebben; het maken van een dergelijke afspraak heet batangka (sian). In Loinang had de aanklager in het geval dat de klacht valsch was, aan den verdachte een zware boete te voldoen, kinaha'i geheeten (madi), welke varieerde van 8 tot 20 blokken ongebleekt katoen ${ }^{32}$ ).

f. zedendelicten. Zooals reeds werd medegedeeld levert het verbreken van verlovings- en trouwbeloften delict op; als zoen daarop staat boete. Eveneens worden ongeoorloofde gedragingen in de vóórhuwelijksche verhouding als delicten aangemerkt (zie par. 1 en 2 van hoofdstuk VIII).

Onder par. 1 van dit hoofdstuk werd medegedeeld dat overspel ook

29) Kruyt, To Loinang, blz. 362/363.

30) Nota Tangkilisan.

31) Kruyt, Zwarte kunst, blz. 739.

32) Kruyt, Bewoners, blz. 256; Balantaksche Studiën, blz. 350; To Loinang, blz. 365 . 
individueele reacties opwekt. In den Archipel was overspel der vrouw vaak oorzaak dat de beleedigde man de overspelige en haar minnaar bij betrapping op heeterdaad in drift doodde. Gelukte het den minnaar te ontvluchten, terwijl de beleedigde echtgenoot wèl zijn vrouw doodde, dan was de voortvluchtige zijn leven niet meer zeker: hij bleef gezocht, en al vond de bedrogen echtgenoot (of zijn familie?) hem jaren later, hij werd alsnog gedood.

Uiteraard is het ook mogelijk dat het bedreven kwaad pas later ontdekt werd; dan was er geen sprake meer van het dooden der overspeligen; de mogelijkheden zijn dan òf verzoening, òf scheiding c.q gevolgd door huwelijk tusschen overspelige vrouw en minnaar. In het eerste geval wordt de vrouw door haar man beboet met een bedrag ter grootte van het huwelijksgeschenk; in het andere geval legt de bedrogen echtgenoot zoowel de vrouw als haar minnaar een boete op, ieder ter grootte van dat geschenk (zie blz. 228). Indien de man zijn vrouw bedriegt kan hij door zijn vrouw beboet worden; deze boete draagt meer het karakter van een verzoeningsgeschenk ${ }^{\mathbf{3}}$ ).

Ook op den Vogelkop is het dooden van op heeterdaad bij overspel betrapten bekend. Indien zulks niet gebeurde (en er kwam geen verzoening tot stand) werd de zaak door het hoofd berecht, die zoowel den overspeler als de overspelige vrouw beboette ${ }^{34}$ ).

Ten slotte bestond in Loinang eveneens eigenrichting bij overspel; het is niet duidelijk of deze alleen kon plaats hebben bij ontdekking op heeterdaad, dan wel of ten uitvoerlegging hiervan jaren later ook toegelaten was. De medeplichtige aan overspel kon zijn leven redden door naar het hoofd te vluchten. Beboeting is daarnaast ook mogelijk; of zulks geschiedt hangt van verschillende omstandigheden af, o.a. van de gezindheid der partijen. Interessant is dat, indien de medeplichtige zelf ook gehuwd is, er twee boeten moeten worden gegeven: één door dezen aan den beleedigden echtgenoot, en één door de overspelige vrouw aan de echtgenoote van haar minnaar (zie verder blz. 229) ${ }^{35}$ ).

In de nota Tangkilisan is bovendien nog een reeks handelingen genoemd, die in bepaalde omstandigheden delicten opleveren; zoo noemt hij o.a.:

het bezoeken van een vrouw wier man afwezig is, door een anderen man (de bezoeker dient volgens de adat zijn voeten op den grond te

33) Kruyt, Banggaische Studiën, blz. 35, 26.

34) Kruyt, Leven en sterven, blz. 64.

35) Kruyt, To Loinang, blz. 459. 
houden en zoo met de vrouw te spreken, die boven aan de trap blijft staan);

het loopen achter iemands echtgenoote op een afstand van minder dan 6 meter; bij overtreding wordt een boete van twee staven was opgelegd (madi : sangkolong tahoe: één staaf was);

het vragen dan wel aannemen van sirih-pinang van de vrouw, c.q. den man van een ander;

opzettelijk toekijken bij het baden van de echtgenoote van een ander;

het tegenover de echtgenoote van een ander staan of zitten ${ }^{36}$ ).

$g$. aantasting van het gezag der hoofden. Een ernstig vergrijp vormt het uit boosheid over het verloop van een rechtszitting wegloopen voor het einde daarvan; dit heet molengkati (madi). Het delict schijnt veelvuldig te zijn gepleegd; het werd bestraft met vrijheidsstraf door het opsluiten met de beenen in het blok, panga'an (madi) gedurende drie dagen (zie blz. 155) ${ }^{37}$ ).

In de nota Tangkilisan vinden we verder weer een reeks interessante delicten op dit gebied:

het niet afnemen van den hoofddoek, het niet sluiten van het zonnescherm als men zich voor het hoofd bevindt;

het passeeren van de woning van het hoofd met de sarong afhangend van rechterschouder naar linkerheup;

het aanraken van den hoed of van eenig ander voorwerp, het hoofd toebehoorend;

onvoldoende onthaal van een der hoofden op een feestmaal; te weinig sirih en pinang aanbieden, hen niet op de gebruikelijke wijze uitnoodigen;

het aanbieden van een leege sirih-doos aan het hoofd, ook al gebeurt dit niet opzettelijk;

het zijn rug toewenden aan het hoofd;

onvoldoende gekleed gaan of zich met een open baadje bevinden in bijzijn der bestuurders;

zich kleeden als tonggol of daka'njo.

voor de hoofden uitloopen;

met een lans over den schouder voor het hoofd staan;

spuwen, rumoer maken of vuil spreken terwijl het hoofd eet;

spuwen voor de bestuurders;

op de mat van het hoofd gaan zitten;

36) Nota Tangkilisan.

37) Kruyt, To Loinang, blz. 361. 
onbedekt rooken voor de bestuurders (de brandende cigaret dient in de kom van de hand te worden gehouden);

in onverschillige houding voor de bestuurders zitten;

zonder reden den naam van den daka'njo uitspreken;

na zonsondergang hout kappen, daar men hiermee te kennen wil geven dat men het hoofd den dood toewenscht.

(Tangkilisan noemde soms tonggol, soms daka'njo, soms beiden; ik plaatste daarvoor hoofd of bestuurder, tenzij het tegendeel aangegeven diende te worden).

Als ernstig delict in deze categorie noemt men mongenkan (madi: zich verzetten); dit delict ontstaat wanneer iemand, door den rechter in een geding als de schuldige aangewezen, zich tegen het gevelde vonnis verzet door aan de benadeelde partij de opgelegde boete niet te willen voldoen; voor dit delict wordt de schuldige nogmaals beboet, welke boete geheel aan de rechters komt ${ }^{38}$ ).

$h$. handelingen waardoor de rust in het dorp verstoord wordt. Wanneer iemand oorzaak is dat eens anders huis afbrandt geldt als regel dat die persoon alle schade vergoedt. Indien hij echter voorzorgsmaatregelen heeft getroffen bij het branden van het gevelde hout op den akker (b.v. door het waarschuwen van de bewoners der nabijgelegen huizen en hun hulp vragen bij het bewaken van het vuur) gaat de ,eigenaar van het vuur" vrij uit, ook al verbranden verscheidene huizen (Loinang) ${ }^{30}$ ).

In deze rubriek zijn ook te plaatsen handelingen die in strijd zijn met de oogstvoorschriften; indien men met den oogst bezig is en een vreemdeling komt op den akker, dan moet hij denzelfden weg terug gaan als hij gekomen is; hij mag niet rondom den akker gaan. Overtreding wordt beboet met aarden borden. Indien een voorbijganger de voorgangster bij den oogst toespreekt wordt hij beboet met een hoen, sirih, pinang en gember (Loinang) ${ }^{40}$ ).

Tangkilisan noemde nog:

zonder toestemming (van het hoofd?) feest vieren;

's middags den gong slaan;

het verontreinigen van een waterbron, b.v. door een huis in den bovenloop te bouwen; voor dit feit, montinggoeloei (madi) wordt de dader beboet met 8 staven was;

38) Nota Tangkilisan.

39) Kruyt, To Loinang, blz. 362 .

40) Kruyt, To Loinang, blz. 426. 
rumoer maken binnen veertien dagen na een sterfgeval in het dorp; dit delict heet moeloebalewali (madi);

fluisteren in gezelschap;

iemand doen schrikken of bang maken;

in zijn huis bergen van een dronken man;

steeds buiten het dorp op de akkers wonen.

Doch ook: dragen van een korte broek zoodanig dat de knieën onbedekt blijven ${ }^{\mathbf{4 1}}$ ).

$i$. benadeeling van individuen (ook magisch).

Kwaadspreken (madi : mohait) levert een delict op waarvoor eertijds den dader eenige motombing of lapjes gewoon goed als boete werden opgelegd;

betreden van het binnen-(slaap)vertrek van een woning zonder toestemming; den ongenooden bezoeker kan (door de huisbewoners?) een boete van 4 motombing worden opgelegd;

onvoldoende onthaal van gasten; vindt b.v. bij een bruiloftsmaal een der gasten een bakje met toespijs ongevuld, of met een stukje pinangschil erin, dan is dit een beleediging; hij verwijdert zich van het feest en beboet den gastheer;

over een liggend persoon heen stappen is in ieder geval onbehoorlijk $\left.{ }^{\mathbf{4 2}}\right)$.

Komt (in den Archipel) iemand in het huis van een ander te overlijden, dan zijn de verwanten, behalve dat zij voor de begrafenis hebben te zorgen, bovendien aan den huisheer nog een zoengeschenk schuldig als offer voor pilogot ${ }^{43}$ ). In Loinang maakt men verschil of de overledene eigener beweging, dan wel geroepen is gekomen. In het eerste geval moet de familie van den overledene aan den huisheer een of twee stukken ongebleekt katoen geven; in het andere geval wordt degene die den overledene geroepen heeft met vier blokken ongebleekt katoen beboet ${ }^{44}$ ).

Vroeger werd reeds medegedeeld dat het maken van schulden en in weinige gevallen ook beleediging aanleiding waren om iemand te dooden; we mogen deze handelingen dus ook als delicten aanmerken (zie blz. 148).

41) Nota Tangkilisan.

42) Kruyt, To Loinang, blz. 363, 371, 452, 463.

43) Kruyt, Ziekte en dood, blz. 155/156; zie ook blz, 367 van C. van Vollenhoven, Adatrecht I, waar onder den Toradja-kring een overeenkomstig verschijnsel gemeld wordt.

44) Kruyt, To Loinang, blz. 484. 
Met deze voorbeelden wordt niet gepretendeerd een volledig beeld van het delictenrecht van Banggai te hebben gegeven. De beschrijving is eenzijdig, omdat de voorbeelden uit Loinang talrijk, die uit den Archipel en den Vogelkop schaarsch zijn; zij is onvolledig omdat er vermoedelijk meer categorieën handelnigen zijn op te noemen die in het Banggaische rechtsbewustzijn delict opleveren. Codificatie van Indonesisch delictenrecht kan nimmer het doel van een werk als dit zijn, het zij voldoende indien een indruk van de structuur der delicten is gegeven.

\section{Algemeene leerstukken.}

Het is niet te verwachten dat in het adatdelictenrecht in het algemeen en in het Banggaische in het bijzonder, sprake is van algemeene leerstukken zooals wij die in ons strafstelsel kennen. Als b.v. onder $d$. van par. 1 medegedeeld is dat poging tot het forceeren of beklimmen van een rijstschuur strafbaar is, mogen wij daaruit niet opmaken dat het leerstuk ,„poging” in het adatrecht bekend zou zijn; eerder moeten wij het als een apart delict zien. Wel zijn, zooals bij de behandelde voorbeelden reeds duidelijk geworden is, tendenties waarneembaar, die zoowel tot verhooging als tot uitsluiting van strafbaarheid kunnen leiden.

De volgende factoren mogen wij o.a. aanwezig achten:

a. soms levert de strafbare gezindheid delict op;

b. bij de strafbepaling wordt rekening gehouden met de sociale positie zoowel van dader als van benadeelde;

c. diefstal van voedsel behoort tot een aparte categorie ernstige delicten ;

$d$. indien door de daad zelve of haar gevolgen het primitief rechtsgevoel bevredigd is, kan bij delicten van par. 2 uitsluiting van straf voorkomen;

$e$. over het algemeen wordt niet gevraagd naar opzet of schuld.

ad $a$. Als men in Loinang strafbaar stelt een poging tot het forceeren of beklimmen van een rijstschuur beteekent dit niet dat pogingen tot andere delicten eveneens strafbaar zouden zijn. Wij moeten dit voorbeeld dan ook zoodanig onderkennen dat naast het delict ,diefstal van rijst”, ook het delict ,poging tot forceeren van een rijstschuur" als aparte strafbare handeling bestaat. De strafbare gezindheid is gebleken en deze is mede ten gevolge van het onder $c$. genoemde, ernstig; dus een adatreactie volgt. 
ad $b$. Bij de aangehaalde voorbeelden is reeds duidelijk tot uiting gekomen dat vele handelingen pas delict worden als ze gepleegd worden tegen bestuurders (par. $2 \mathrm{~g}$.); als uiting daarvan geldt ook dat lasteren (madi: mohait) veel zwaarder gestraft wordt als het den tonggol geldt dan als van een gewoon mensch kwaad wordt gesproken. Zelfs kan een onbehoorlijke gedraging jegens den medemensch delict worden als zij gepleegd wordt ten aanzien van iemand van beteekenis; b.v. is dit het geval met het over iemand heenstappen ${ }^{45}$ ).

Buitenechtelijk verkeer, gepleegd door een vrije (niet-adellijke) met een adellijke vrouw beteekende in de meeste gevallen de dood voor den $\left.\operatorname{man}^{48}\right)$.

Tangkilisan deelt verder mee, dat de ware afstammelingen van een daka'njo zwaarder beboet worden dan de niet-adellijken voor het zelfde feit (,noblesse oblige”).

ad $c$. In de vorige paragraaf is onder $d$. reeds duidelijk geworden dat diefstal van voedsel overal in het landschap als een ernstig delict wordt aangemerkt: het individu wordt in zijn levensgoederen aangetast, de adatreactie is sterker dan in andere gevallen. Naar Indonesischen trant moeten eigenlijk deze delicten niet met de gewone diefstallen vereenigd worden, doch zouden ze behandeling verdienen onder een aparte alinea: diefstal van voedsel.

ad $d$. Als voorbeeld van uitsluiting der strafbaarheid noemden we onder par. $2 d$. een mishandeling, waarbij beide personen even zwaar gewond werden. Het primitief wraakgevoel is dan bevredigd, de hoofden vinden geen aanleiding één hunner nog een boete op te leggen. Ook het op blz. 88 gememoreerde voorval uit Loinang is hiervan een voorbeeld: bij een strijd tusschen twee groepen verwanten vielen aan den eenen kant twee, aan de andere zijde één doode, waarop de tonggol besliste dat, waar aan beide kanten evenveel slachtoffers moesten vallen, de vrouw die de oorzaak was van de vechtpartij als slavin naar elders verkocht moest worden ${ }^{47}$ ). Vergelijk ook het op blz. 174 genoemde conflict Nambo-Mendono, waarbij tenslotte één der partijen één menschenleven meer verloor dan de andere; bij de daarop volgende verzoening werd voor dat eene leven een zoengeschenk opgebracht. Verder geeft Kruyt nog een interessant voorval uit Loinang weer; het komt nl. voor dat in het geval dat een vrouw haar man verlaten heeft en de echtgenoot een vermoeden heeft

45) Kruyt, To Loinang, blz. 363, 463.

46) Memorie.

47) Kruyt, To Loinang, blz. 361. 
voor welken anderen man uit het dorp zij dit deed, hij een bedreiging uitspreekt (madi: pala-palangan), waaraan echter de eisch gesteld wordt dat zij door alle dorpsgenooten moet worden gehoord. Gaf de man daarna aan zijn bedreiging gevolg, dan vond men dit vanzelfsprekend en werd hij niet gestraft. Kruyt zegt daarbij niet met zooveel woorden, dat de bedreiging in ieder geval toch wel een rechtmatige, een met het rechtsgevoel strokende, moet zijn. Kruyt deelt dan het volgende mee: „De gescheiden echtgenoot zag eens zijn voor„malige vrouw met den man, dien hij in zijn pala-palangan had aan„gewezen, samen naar het water gaan. $\mathrm{Hij}$ bond toen alle dingen die „als bruidschat teruggegeven waren tot een pak bijeen, en volgde de „twee. Aan het water doodde hij ze beiden. Thuisgekomen wierp hij „den bruidschat naar buiten, en riep het Hoofd en de notabelen om „naar de verslagenen te gaan kijken. Allen legden zich bij het gebeur„de neer. De ouders van de gedoode vrouw namen den bruidschat „weer tot zich" ${ }^{48}$ ).

Vanuit dit gezichtspunt moeten we ook het optreden tegen schuldenaars beschouwen, die dwars waren of praatjes maakten; deze toch werden wel gedood. Dit was naar de algemeene meening een rechtmatige handeling, omdat eerst op alle mogelijke wijzen getracht was de schuld door manen binnen te krijgen (vergelijk ook blz. 148 en par. $2 i$. van dit hoofdstuk).

ad $e$. Bij de behandeling van overtreding der voorvaderlijke orde werd onder par. 1 o.a. medegedeeld dat onheilstoestand ontstaat, zoowel bij bewust als bij onbewust zondigen tegen het gewoonterecht. Bij de delicten van par. 2 komt uit dat men feitelijk alleen let op de voltooide rechtskrenking, op het feit dat iemand materieel of immaterieel gekrenkt is. Slechts bij het veroorzaken van brand (par. 2 h.) vinden we elementen die op aanwezigheid van schuld wijzen, waar gezegd wordt dat als de omwonenden van een akker gewaarschuwd zijn en verzocht te helpen bij het waken over het vuur, degene die het vuur ontstoken heeft vrijuit gaat, als meer verbrandt dan in feite bedoeld was.

$\mathrm{Bij}$ het verzamelen en opsporen van elementen als in deze paragraaf behandeld, zal m.i. de nadruk niet op „algemeene” moeten vallen, reden waarom ik sprak van tendenties.

48) Kruyt, To Loinang, blz. $457 / 458$. 


\section{Asylrecht.}

Van de aanwezigheid van asylrecht zijn reeds eenige voorbeelden ter sprake gekomen; op blz. 148 werd beschreven hoe eertijds wel een persoon zijn toevlucht zocht in het huis van den tonggol tamano van Basosol om zijn leven te redden. Ook bestond het gebruik dat schuldenaars, om zich zeker te stellen, naar den bosanjo, b.v. van Kintom, vluchtten; wij weten immers dat een schuldenaar als hij lang gemaand was door den schuldeischer, van zijn leven en goed niet meer zeker was (Hoofdstuk XI, par. $4 f$.).

Over andere gegevens beschikken we niet, noch over het bestaan van asylrecht bij den vorst. 


\section{SLOTBESCHOUWING.}

Zooals kon worden verondersteld, verschilt het adatrecht van Banggai (Celebes, N.O.I.) niet van het overige Indonesisch adatrecht.

De beschikbare gegevens betreffende de rechtsgemeenschappen zijn onvoldoende om een volledige beschrijving te geven, maar wij kunnen de resultaten van ons onderzoek als volgt samenvatten: streekgemeenschappen, nl. territoriale rechtsgemeenschappen, gegroepeerd rond een magisch centrum, onderverdeeld in familiegroepen. Of onder deze streekgemeenschappen nog rechtsgemeenschappen van lager orde voorkomen is niet met zekerheid te zeggen. De samenstelling der volksgemeenschappen werd door de vorsten (die grootendeels van vreemde origine zijn) niet verstoord. Sinds 1908 is echter de invloed van het Nederlandsche Bestuur ontwrichtend geweest. Dit geschiedde niet opzettelijk en was gebaseerd op politieke eischen. De rechtsgemeenschappen zijn echter nog levend genoeg om op deze groepeeringen een bestuursindeeling te kunnen bouwen.

Het individu neemt in deze rechtsgemeenschappen een onbelangrijke plaats in; zie het weinig ontwikkelde erfrecht. Aan den anderen kant is het huwelijksrecht goed ontwikkeld, hetgeen het belang van het huwelijk in deze gemeenschappen aantoont. Het grondenrecht verschilt in wezen niet van dat elders in het Indonesisch rechtsgebied.

De talen in het landschap Banggai in gebruik (onderscheiden naar de ontkenningswoorden) zijn afkomstig van Noord-Celebes. Van oorspronkelijke bronnen aldaar moet het bobongko (Togean-Archipel) zijn voortgekomen; hieruit ontwikkelde zich het madi (westelijk deel van den Vaste-Wal) waaruit het sian (oostelijk deel van den VasteWal) voortsproot. Volgens dr. N. Adriani moet het aki (BanggaiArchipel) in het sian zijn oorsprong vinden, doch latere onderzoekingen van dr. S. J. Esser vragen voor het aki een meer zelfstandige plaats. Verwantschap tusschen het aki en de taal der Soelaeilanden werd gesteld door dr. W. Ph. Coolhaas.

In het door professor C. van Vollenhoven opgestelde systeem is Banggai een deel van rechtskring XI (Zuid-Celebes); volgens prof. $B$. ter Haar behoort het tot rechtskring $X$ (Toradja). De taalovereenkomst duidt echter eerder op invloed van Noord-Celebes. 
Wij nemen aan, dat het magisch belangrijke getal 12 nauw verbonden is met de oorspronkelijke bewoners van Zuid-, Zuid-Oost-, en Oost-Celebes en de oostelijk gelegen eilanden. Van deze oorspronkelijke bevolking zijn de koeto no tano van den Vaste-Wal, de WestPelingers met Wedda-invloeden in den Banggai-Archipel, in het in dit geschrift behandelde gebied nog aanwezige restanten; een sterk overeenkomstige sociale opbouw treffen wij verder nog op de Soelaeilanden (rechtskring XII, Ternate) aan. Van deze oorspronkelijke organisatie ging veel teloor door instrooming van heerschersvolken. Voor wat betreft Banggai kan dan de door Adriani, Esser en Coolhaas aangegeven taalverwantschap duiden op een instrooming van Noord-Celebesvolken, die langs den Vaste-Wal, via den Vogelkop, langs Oost-Peling haar weg naar Banggai vonden; deze drang naar het Oosten is nog in het heden waarneembaar bij volksverplaatsingen naar meer oostelijk gelegen eilanden. De Noord-Celebesvolken lieten West-Peling en gedeelten van de binnenlanden van den Vaste-Wal terzijde liggen, waar tot heden het karakter der oorspronkelijke bevolking beter bewaard bleef dan elders in den Banggai-Archipel. Hoe verder oostelijk deze volken kwamen, des te meer namen zij van de overheerschte volken over, hetgeen m.i. de reden is dat dr. S. J. Esser voor het aki een meer onafhankelijke plaats vraagt. Het wordt dan ook begrijpelijk dat in de toporganisatie van het landschapsbestuur de twaalfdeeling weer teruggevodnen wordt, terwijl het heerschersvolk alleen een vier- (wellicht ook zeven-) deeling kende. Tevens verklaart dit waarom juist in Oost-Peling de daar aanwezige versterkte plaatsen veelal geestenvestingen worden genoemd: immers niet de huidige, doch de oorspronkelijke bevolking, heeft deze z.g. kota djin gebouwd.

Is onze stelling juist, dan is dus geheel Zuid-, Zuid-Oost- en OostCelebes in wezen adatrechtelijk menggebied. Het Zuidelijk deel onderging invloed uit het Zuiden, het Noordelijk deel uit het Noorden; het eerste kreeg door de dominante positie der heerschers een zeer eigen karakter (rechtskring XI), onderscheiden van de rest waar de vreemde invloed anders geaard was terwijl plaatselijk het oorspronkelijk karakter beter bewaard bleef. Deze rest kunnen we aanmerken als een aparte rechtsgouw van kring XI; wellicht zal het bij nader onderzoek blijken dat deze rechtsgouw, behalve het Landschap Banggai, ook het landschap Boengkoe en de Soela-eilanden (streken met een sterk overeenkomstige structuur) omvat. 


\section{CONCLUSION.}

As could be supposed, the customary law ("adatlaw") of the native kingdom of Banggai (Celebes, Netherlands East Indies) does not differ from the rest of Indonesian customary law.

The available data concerning the native juridical communities are insufficient to give a complete description, but we can summarize the results of our investigations as follows: regional communities, namely territorial communities, grouped around a magic center (the magic center is an inanimate pagan relic held by the chief of the juridical community) and subdivided into family groups. It cannot be stated with certainty if under these regional communities other communities of lower order exist. The forming of popular communities has not been disturbed by the native kings, who are for the greater part of foreign origin. Since the year 1908 the Netherlands Government has affected the national institutions in a disorganising manner. This is not done wilfully, but is a matter of political necessity. However the juridical communities are still sufficiently alive to furnish a foundation on which a division of administration can be built.

In these juridical communities the individual occupies an unimportant place; e.g. the poorly developed system of hereditary law. On the other hand matrimonial law is well developed, which demonstrates the importance attached to the institution of marriage in these communities. Agrarian law does not differ essentially from that which is in force in other parts of Indonesia.

The languages in use in the kingdom of Banggai (distinguished by the negative words) come from North-Celebes. Bobongko (TogeanIsles) is said to have developed from original sources there and out of this came madi (western part of the kingdom on the continent of Celebes), from which sian (Eastern part of the continent, the socalled "Bird's Head") originated. According to Dr. N. Adriani aki (Banggai-Archipelago) must have sprung from sian, but later researches by Dr. S. J. Esser claim for aki a more independent place. Congeniality of aki with languages on the Soela-Isles has been put forward by $\mathrm{Dr}$. W. Ph. Coolhaas. 
In the system founded by professor C. van Vollenhoven, Banggai is a part of area of law XI (South-Celebes); according to professor B. ter Haar it belongs to area of law X (Toradja). Linguistic conformity would rather point to an influence from Northern-Celebes.

We assume that the number 12 , which is of magic importance, is closely connected with the original inhabitants of Southern-, Southeastern- and Eastern-Celebes and the islands farther east. Of this original population the koetoe no tano of the continental part of the kingdom, the Western-Peling people of the Banggai-Archipelago with Wedda-influences, are the remnants still present in the area dealt with in this thesis. Furthermore we find a strongly similar social construction on the Soela-Isles (area of law XII, Ternate). Much of this original construction was lost by the inflow of dominant peoples. As far as Banggai is concerned, the linguistic affinity as indicated by Adriani, Esser and Coolhaas may point to an inflow of NorthCelebes people, who found their way along the continental part of the kingdom and the "Bird's Head" via Eastern-Peling to Banggai. This pressure towards the East is still to be noted in migrations to islands lying farther east. The people of Northern-Celebes left alone the western part of Peling and parts of the continent, where until this day the character of the original population has been preserved better than elsewhere in the kingdom. The more these people went eastward, the more they adopted from the peoples subdued, which in my opninion accounts for the fact that Dr. S. J. Esser claims a more independent place for the aki-language. Then it is easely understood that in the toporganisation of the administration of the kingdom the division of twelve is again to be found, whereas the dominating people themselves only had a division of four (perhaps also a division of seven). At the same time this explains exactly why in Eastern-Peling the fortified places there present, are mostly called spirit-fortresses, for not the present but the original population built these so-called kota-djin.

In case our supposition is right, all Southern-, Southeastern- and Eastern-Celebes form in reality an area where customary law is of a mixed character. The southern part underwent an influence from the South, the northern part from the North. By the dominant position of the rulers the former obtained a very distinct character (area of law XI), as distinguished from the rest of the land, where the foreign influence was of a different nature, while locally the original character has been better preserved. This remainder we may denote as a 
separate section of area of law XI; perhaps a further investigation will show that this section of law embraces besides the kingdom of Banggai also the kingdom of Boengkoe and the Soela-Isles, which are regions of a strongly similar construction. 


\section{Literatuur, geheel of gedeeltelijk rechtstreeks op Banggai betrekking hebbend.}

Bosscher en $P$. A. Mathijsen, $C$. - , Schetsen van de rijken van Tomboekoe en Banggai op de Oostkust van Celebes; T.B.G. 2 (1854), blz. 90-107 (aangehaald als: Schetsen).

Clerq. F. S. A. de -, Bijdragen tot de kennis der residentie Ternate, Leiden 1890 (aangehaald als: Ternate).

Dormeier, J.J. - Geschiedkundige aanteekeningen betreffende Banggai en Gapi ; B.K.I. 102 (1943) blz. 555-573.

Gobee, E. - Een Loinansch verhaal, Feestbundel Koninklijk Bataviaasch Genootschap 1928 dl. I (aangehaald als : Feestbundel I).

Goedhart, O. H. -, Drie Landschappen in Celebes; T.B.G. 50 (1908) blz. $442 / 489$ (aangehaald als : Drie landschappen).

Kruyt, Dr. Alb. C. - De To Loinang van den Oostarm van Celebes ; B.K.I. 86 (1930) blz. 327-536 (aangehaald als: To Loinang).

idem De bewoners van den Banggai-Archipel; T.A.G. 1932, blz. 66-88; 249271 (aangehaald als : Bewoners).

idem De vorsten van Banggai; K.T. 20 (1931), blz. 505-528, 605-623 (aangehaald als : Vorsten).

idem De pilogot der Banggaiers en hun priesters; Mensch en Maatschappij 8 (1932), blz. 114-135 (aangehaald als : Pilogot).

idem De zwarte kunst in den Banggai-Archipel; T.B.G. 72 (1932), blz. 727741 (aangehaald als: Zwarte kunst).

idem Banggaische Studiën; T.B.G. 72 (1932), blz. 13-102.

idem De landbouw in den Banggai-Archipel; K.T. 21 (1932), blz. 473-492 aangehaald als : Landbouw).

idem Ziekte en dood bij de Banggaiers; B.K.I. 86 (1932), blz. 141-171 (aangehaald als: Ziekte en dood).

idem Balantaksche Studiën; T.B.G. 72 (1932), blz. 328-390.

idem Van leven en sterven in Balantak (Oostarm van Celebes); T.B.G. 73 (1933), blz. 57-95 (aangehaald als: Leven en sterven).

idem De Rijstbouw in Balantak (Oostarm van Celebes); T.B.G. 74 (1934), blz. 123-130 (aangehaald als: Rijstbouw).

Memoric van overgave der onderafdeeling Banggai, opgemaakt door den Controleur B.B. J. J. Dor m e i e r, afgesloten Mei 1939 (angehaald als : Memorie).

Notities over het Oost-Pelingsch adathuwelijk, opgesteld door $\mathrm{P}$ a t e r J. va n den Bergh M. S. C. te Noelion in April 1939 (aangehaald als: Nota Van den Bergh).

Mian I Sinanda (het land van de tonggol popitoe). - Verslag van een bezoek aan Lingketing door den A.I.B. Tangkilis a n (angehaald als: Nota Tangkilisan).

\section{Overige gebruikte literatuur.}

Adriani en $D r$. Alb. C. Kruyt, Dr. N. - , De Bare'e sprekende Toradja's deel III, 1914 (aangehaald als: Bare'e III).

Atlas van tropisch Nederland, talenkaart blad $9 \mathrm{~b}$.

Bakkers, J. A. - Het leenvorstendom Bone; T.B.G. 15 (1866).

Bastiaans, J. -, Batato's in het oude Gorontalo; T.B.G. 79 (1939).

Berg, R. J. van den -, Adatgebruiken in verband met de sultansinstallatie in Boeton; T.B.G. 79 (1939).

Bokemeyer, H. -, Die Molukken, Leipzig 1888. 
Brumund, J. F. G. -, Fragment mijner reize door de Molukkos; T.B.G. 5 (1856).

Coolhaas, Dr. W. Ph. - , Mededeelingen betreffende de onderafdeeling Batjan; B.K.I. 82 (1926).

idem De Manggarai; T.A.G. 1942.

Corpus Diplomaticum Neerlando-Indicum, dl. III en V.

Crab, $P$. van der -, De Moluksche eilanden (reis van den Gouverneur-Generaal in 1869/'71).

Encyclopaedie van Nederlandsch-Indië.

Friedericy, Dr. H. J. -, De standen bij de Boegineezen en Makassaren; Leiden 1933.

Haar, Mr. B. ter -, Beginselen en stelsel van het adatrecht, 1939 (aangehaald als : Beginselen).

Hart, C. van der -, Reize rondom het eiland Celebes in 1850 (aangehaald als: Reize).

Holleman, F. D. - , De commune trek in het Indonesische rechtsleven; Leiden 1935.

Hueting, A. -, De Tobeloreezen in hun denken en doen; B.K.I. 78 (1922).

Kleizveg de Zwaan, Dr.J. P. —, Bijdrage tot de Antropologie van Celebes; T.A.G. 1929.

Koloniale Verslagem.

Kruyt, Dr. Alb. C. 一, Het rijk Mori ; T.A.G. 1900.

idem Eenige ethnografische aanteekeningen omtrent de Toboengkoe en de Tomori; M.N.Z.G. 1900.

idem Lapjesgeld op Celebes; T.B.G. 73 (1933).

idem De To Wana op Oost-Celebes, T.B.G. 70 (1930).

Kruyt, J. -, De Moriërs van Tinompo; B.K.I. 80 (1924).

Mededeelingen Encyclopaedisch Bureau no. XIII (Halmahera en Moratai).

idem no. XV (Soela-eilanden).

Naidah, Geschiedenis van Ternate (vertaling en aanteekeningen door P. van der Crab); B.K.I. 4e vr., d1. 2 (1878).

Ossenbruggen, Mr. F. D. E. van -, De oorsprong van het Javaansche begrip Montjapat; Verslagen en Mededeelingen der Koninklijke Akademie van Wetenschappen, Afd. Letterkunde 1917 (aangehaald als Montjapat).

idem Het primitieve denken zooals dit zich uit voornamelijk in pokkengebruiken op Java en elders; B.K.I. 71 (1916), blz. 1-370 (aangehaald als : Primitieve denken).

idem Het oeconomisch-magisch element in Tobasche verwantschapsverhoudingen: Mededeelingen der Koninklijke Akademie van Wetenschappen, Afdeeling Letterkunde deel 80, serie B, no. 3, blz. 63-124 (aangehaald als: Verwantschapsverhoudingen).

Riedel, J. G. E. -, De oorsprong en de vestiging der Boalemoërs op Noord Celebes; B.K.I. $4 \mathrm{e}$ vr., dl. 10 (1885).

idem Zeitschrift für Ethnologie 1885.

idem De vestiging der Mandaren in de Tominibocht; T.B.G. 19 (1870).

Spit, Mr. H. J. - , De Indische Zelfbesturende Landschappen; Leiden 1911.

Straten, Dr. L. B. van -, De Indonesische bruidschat; Leiden 1924.

Valentijn, Oud- en Nieuw Oost-Indiën, dl. I-b.

Volkstelling 1930, dl. V.

Vollenhoven, $M r$. C. van -, Het adatrecht van Nederlandsch-Indië (aangehaald als : Adatrecht).

idem Miskenningen van het adatrecht.

Vuuren, L. van -, Het Gouvernement Celebes, d1. I.

Wouden, Fr. A. E. van -, Sociale structuurtypen in de Groote Oost; Leiden 1935.

Afkortingen :

Arb.

Adatrechtbundel.

B.K.I. Bijdragen tot de Taal-, Land- en Volkenkunde van NederlandschIndië, uitgegeven door het Koninklijk Instituut voor de Taal-, Land- en Volkenkunde van Nederlandscli Indië. 
K.T. Koloniaal Tijdschrift.

K.V. Koloniaal Verslag.

M.N.Z.G. Mededeelingen Nederlandsch Zendings Genootschap.

T.A.G. Tijdschrift van het Koninklijk Aardrijkskundig Genootschap.

T.B.G. Tiidschrift voor Indische Taal-, Land- en Volkenkunde, uitgegeven door het Koninklijk Bataviaasch Genootschap van Kunsten en Wetenschappen.

vr. volgreeks.

di. deel.

Hand. S-G. Handelingen Staten-Generaal.

zitt. zitting.

bijl. bijlage.

st. stuk

stbl. Indisch staatsblad.

\section{Registers van inheemsche termen.}

$\dot{a}=$ lange $a ; d=$ korte $a ; \dot{e}=$ lange $e ; \dot{e}=$ korte $e ; e=$ toonlooze $e$; $o ́=$ lange o; $\dot{o}=$ korte $o$; verdubbeling van klinker geeft scheiding van lettergreep aan (aanduiding uit de herinnering genoteerd).

Termen-aki*)

ádi $26,36,37,77$ nt. $38,84,115,117$. bálólimpàt 273 .

áki 6.

álá 262.

álàs 243 .

alfèrès 130 .

alfèrès-krois 130 .

álifiris $99,118$.

àmpi 224.

àndálàn 201.

ànggàl 243.

átá $84,87,263$.

bábááboe 84, 91.

bábàsàl 197.

bábingkàt 212, 261, 269.

bádósá 220.

bágoensàl 157.

— besi mónàs 158.

- besi sinoeá 158 .

- òtoelàk 157.

- paisoe nánàs 157.

bákálingá 96 .

bákoe 8 .

bákoe toembènò 247, 250 .

báláhádádá 101, 103 .

bálákàt $10-13,21,22,29.30,38-45$, $55-60,63,68,104,126,188,239$. bálàndá 202, 207 . bálibàng 189 .

bàndólòj 201.

bànginsáá $85,86,90,113,115-118,121$.

- paoenò 85.

- sòngòlòloeá 114 .

bàngkoeloe 44 .

bàngsá sjáráá 144 .

baoeloenò 103,123, 124, 153, 252.

bápálàngás 273 .

bápátòl 203.

bápoelòs 156 .

bároe-bároe 118 .

bàsàl $38,128$.

básálánò 228 .

básálò 20 nt. $1,23,26,28,29,30,38$, $43,44,57-59$; 64, 69-73, 77-81, $84-91,94,97,102,105,113,120,121$, $123,126,146,156,173,181,210,249$, $251,253,263,264,277$.

- paoenò 84, 94, 97, 99, 102, 104.

- pòpitoe 71, 127.

- sàngkàp (vier) 113-122,127, 137, 142, 144 v., $162,247,249$.

- sòngòlòloea $71,127 \mathrm{v}$.

- támánò 94, 97, 98, 102-107, 152.

bátàng 208.

bátòng $189,268$.

bátótóàn 157 .

*) Voor de termen aki, madi en sian zie blz. 6. 
béá pàsi 134. 171.

bênse $54-58,72,80,187,189,241$.

bilit 126 .

binesálá 158.

binggòti 213 .

bingkàt 269 .

binsilò 53-56.

biòk 189 .

bóbátò 84 v., $86,90,113,115,117-121$, $142,162,210$.

- paoenò 85.

bòbòtókòn 95, 98, 201, 203.

boeàt 208 .

bois 245 .

bòki 113 .

bòkoekoem 202.

chátib bànginsáá 144 .

- djoeroetoelis 113

- ngófá 144.

dálàngòn 99.

dáwòk 201.

dèstàl 86 .

dinádáát 38 .

dinèndá 279 .

djágáàn 118, 140, 162.

djoeroetoelis 130 v., 168 .

djógoegoe $28,38,44,113-124,162$, $166,170,177,252$.

doelàng 88, 151, 208, 209 nt., 32.

doesoen 246 .

dóni 212, 237, 261, 262.

gènti 118.

gimaláhá 99

ginoensàl 157 .

gòng 208, 209 nt. 32.

hoekoem toeá

- Boejoe zie : pénábèlá

idoeláán 154, 279.

imám bànginsáá 144 .

- ngófá 144.

- sòhi 113. 124, 144.

iné, iné i 93.

inènò 93 .

inoetàng 203, 279.

kábi (-kábi) 208, 210, 211, 212 nt. 35. kábilá 133 .

kájoe 128, 208-210.

káká 190.

kákoewá 133.

kálim 144, 146, 162, 168.

kámáli $60,65,94$.

- tàngá 114 .

kànlári 151, 195, 208, 209, 236.

kaoe saoenò 85 . kàpitàn $29,77,78,94,97,98,101,107$, $126,152,210$.

- bilit 126 .

- dálàngòn 99, 114.

- kàpitàn laoet 114, 116, 118.

- kié 114, 118.

- kòtá 115, 119, $130 \mathrm{v}$.

- krois (kruis) 131

- làngkai $98,105$.

- laoet $110,114,115$ v., 118-124, 162.

- Lónàs $69,115,118,124$.

- ngófá 114, 117.

- oeloe 126.

- paoenò 96.

- tanò 99.

kásoebiàng 84, 87, 263.

kiàng 235 .

kié 115.

kinólóbòki 273, 275.

koekoep móoeté $24,86$.

koemis-àmpàt

koemis-sàmpàt $120-123,142,162$.

koemis-sàngkàp

koeònoe 208, 209 nt. 32, 210.

koesáli $11,59$.

kòlònò 251 .

kòmboeng 243.

kòtá, - djin 54, 57, 60, 114, 117, 291, 293.

láá $243 \mathrm{v}$.

lábòbò 45 .

lábòtàn 259.

laing 243, 245.

lálábòt 259.

lálàs 91 .

2. làmbàl 37 .

làmbánoeá 124, 125, 135, 143, 171.

- oeloenò $113,124$.

làngká-làngkai 106 v., 146.

làngkai 96.

lásò 93.

liboeng 235.

lipá 202.

lipoe 59, 240, 241.

Lipoeádinò $.24-28,60$ v., $65-67,71,73$, $77,99,105,108,127,178$.

loeloe 123.

— bátàngò 97.

loetenáán 99, 118, 162.

- àdjoedáán 118, 122.

- ngófá 114, 117, 124.

lólibá 208 v.

lòngòt 203, 207.

májòr kòmpániá 114, 124.

- ngófá 114, 117, 118, 121, 124.

- tánò 114, 116, 118, 124.

málákoe 116, 144.

màmá 190.

màmpàngálá 94,98 .

màngkò' 209. 
màngálákòn 262, 264 .

mànsánàl 209 nt. 32.

máwi 156.

mèngkò bòlitò 236 .

- sinápit 236.

miàn 20 nt. $1,49,58,64$.

- poipóisik 84 .

- tàngánò 94, 96.

miánò 58 .

miàntoeoe 114, 116, 119, 124.

mirinoe 119.

móbingkákòn sai 213.

mòdjim djoeroetoelis 113 .

módóni 212, 261.

moemboe 25, 26, 37-39, 113.

- dinádáát 38 .

mòkòlòbòki 273.

mòlibákòn 213.

mòngkábi 208.

mòngòtòtòng 97.

móniánàn 201.

mónòs 274.

mònsai 208.

mòntábàs 279 .

mòntàndàn 269.

mòntinggóli 202.

mòntóliàn báloe 198 .

mòntólidàn loeá loeònggòn 191 .

- soesoe 191.

- tòloe loeònggòn 191.

mòntóloetòs 191.

mòntòlòkoeá 191.

motópai 269.

nènè 190.

ngárálámò 118.

ngófá 114-117.

óbòs 249.

oeki 93.

oeloe 126.

oetoes 191 .

oetoesàn 130,131, 135-137, 162, 252.

ólijòkò 245, 256.

- boekoenò doi laing dóó 245 .

òlò-òlò $208,211,214$.

óós 248.

pákànggi 11.

páláli 192.

pàndábábákòn 250.

pàndálábin 97, 104.

pàngóàn 235.

paoe 84, 96. 190 v., 237.

- bákálingá 94, 96, 97, 99.

- bàsàl $38-41,113$.

- làngkai 96.

二 pinggá

- toebò 186. pápálòs doeàngàn mbòjòkò 125 .

pápátòl 203 nt. 25, 204.

pásédá 202.

pátàmbó 268.

pàtikèlèng 251 .

pátòl pákámòt 188 .

peméàl 195.

pénábèlá 117, $119 \mathrm{v}$.

- Boejoe 115, 121, 124.

- langkai 115-119, 121, 124.

- langkai 115-119, 121, 124.

- Tólólàk 115, 121, 124.

pilógòt $10-13,43,82,187-189,192$, 197, 233, 259, 273 v., 285.

pinálàngàs 273 .

pindá 195, 209, 215, 220, 230.

pinggàng 209 nt. 32.

pinótámá 190 .

pinótiná 190, 191.

pipi 190.

pisò 202.

póálákòn bàngoen 199.

- mánoek 199.

- òtòtòng 198.

póbábá 196.

póbàngkit 265, 269.

póbaoentàl 226.

póbéàn 196.

póboeká 213, 247, 259.

pódàmpásòn 219.

poeloeng 243.

poepoeoekòn 56 .

poepoet 208 v., 223.

poesáká 232

poipóisik 197.

pókidóni 188.

póliàt soesoe 208.

pólólóbóti 125.

pòmbáwá 99.

pòngòboeloesòn 204.

pòngòbònoi 268.

pòngòdoedoek 101, 103.

174, pòngoetàn 203.

pòngòkòlò besi 207.

pòngóós 248.

póók 275.

póókàn doi tingkoeloeng 194.

póólilinggòn

póólililinggòn 194.

pónátòl (zie: pàpátòl).

pòpiisi 57.

pòpitoe 71 .

pòpòsòsi tálápoe 268 .

pòsoepàt 248.

pòsòs mbikoe 202.

pótaoek 259.

pótátàk séle 197, 274.

pótinggóli 202-204, 207.

pótoembàk 94,97 v., 156.

pótoeònggòn 213 . 
roentoep 269.

ròké 105.

sábálèè 86,105 .

sábòl 245, 247, 250.

- laing 247.

sádáhá kié 115, 124.

— kòdátò 90,113, 124.

ságó tánò 253 .

sai 208-213.

- bátàngò 208, 209.

sálákàn 44.

sálápá 202, 209 nt. 32.

sàmpàt

sàngkàp 36,73 .

sànggàp

saoebá 88, 208, 209 nt. 32.

sáráá 144 .

sekretáris 113, 124, 144.

séle 197, 274.

- bábàsàl 197.

- poipóisik 197.

selékàn (zie : sálákàn).

séró 249.

sesébá 113.

silabó 191, 196, 198.

sineléi 268.

soekánò 154, 279.

soembang 202 .

sóloibà 201.

sòmpò 197, 198.

sòngòlòloeá 114 .

sóógàng 202.

sòòsá 113.

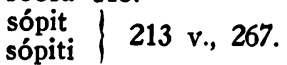

táboe 93.

tálákájoe 243.

tálápoe 11, 226, 235.

tálèngá 148, 267.

támá 190.

támànggoe 190.

- bábàsàl 190.

- tàngá 190.

- toeoe 190.

- paoenò 190.

- piòtò 190.

támánò 73.

tàmbójó 225.

támé, tamé i 93.

tàngkálábàng 224.

tánò $53,84,87,96,100$ $221,253$.

tánóàn 109.

taoeá 191.

táté 191.

tènggòl 15 (zie ook tònggòl).

tètè 190. tétéán 201, 267.

tinàmbó 268.

tiná 190.

tinábàs 279 .

tinànggoe 190.

- bábàsàl 190.

- tàngá 190.

- toeoe 190.

- paoenò 190.

- piòtò 190.

tóálá 101.

tóbá 151, 209 nt. 32.

toeàn bòki 113 .

toeloengan 110.

toeoetoe (i) 113.

toemboe 44, 190.

- sálákàn 44.

- selékàn 44, 69, 126.

toetoebi 251 .

tógòng 42.

tòmoendò $26,36-43,85$.

- sàngkàp 36,113 .

tòmoe-tòmoendò paoenò 85 .

tònggòl $53,55,68,84,90,97,101,106$, 146, 150, 157, 226, 241, 264, 277.

- oeloenò 94, 97, 104, 153.

- paoenò 84, 96.

— támánò 97, 148, 289.

tò'oe 93.

Termen-madi. *)

álàs 244.

álé 244 .

ànàk $\mathrm{i}$ bósánjò 84,99 .

àndálàn 201.

ánoe mátoe'á 33, 95, 99.

ánòmpóléé 192.

bábááboe 84 .

bági toempoe 123 .

bálákàt 176.

bálàngká-làngkai 97 .

bálásoe 217, 229.

báloe sáláh 110 .

básindoeá 205.

bátoeàn 84 .

bátòlòs 264 .

bòbòtòkòn 95,98 .

boeháké 188.

bòndé

bòndoi 244

bòntó-bòntólàn 227.

bóoené 192.

bósánjò $23,25,30-35,49,57,71$ v.v., 78 v., 84, 88, 95, 97 v., 102, 108, 137, $151,175,181,263,289$.

*) Zie blz. 6 . 
dáká' $84,108$.

miàn isé 84 .

dáká'njò 13,23 v., 31 v., 59, 80, 84, 87, - kòpiàn 59, 95-98, 101-103, 112, $94-99,102$ v., $108,112,147,151,156,151,175$ v.

159 v., 175 v., $224,249,277,283$ v. - sáloeàn $33,90$.

dáwòk 201.

dòhoikoe 205.

hápi 231.

hoehoe 123.

hoendoehòn 109.

hòmbólá

244.

hóónbólá

iki 93.

imàm 26, 34 .

indóhoi 205 .

isé 84 .

kai' 192.

kàpitàn 97, 98, 101.

- bósánjò 55, 95.

- dáká' 108.

- kòmpániá 32, 95, 98.

- kòtá 98.

- làngkai 98.

- saudágàr 98 .

- tánò 95, 98, 108, $150 \mathrm{v}$.

kásòmpólánnjò 265.

kèlè 192.

kináhá'i 281.

kitá tò oetoes-oetoes 192 .

milinoe 95-98, 156, 177.

móáné 192.

mòdòhoi 205.

mòdòsò 91 .

moeloebáléwáli 285 .

mòhait $285 \mathrm{v}$.

mólèngkàti 283.

mòlimpoeng 109.

mòlòsòki 228

mòmamàs 157.

mòmbájàl 258.

mòmbé'i 100.

mòmbóá 216.

mòmbólósákòn 228.

mòmbòndoi 244 .

mòmpókiláwá 205.

mómpótóká 157.

mòndjòlò 96.

mòndòlòng 205.

mòngálé 244.

mòngènkàn 284 .

mònkáèng 244.

mònkéòk 157.

mònkójó'i 275.

mòngkòkoesé 156

mòngòhoeá 224 .

mòngóli 258.

koé 216.

koehàt mòngoehà 244 .

koeláloek 232.

- kádáká'àn 87, 219.

móniàn 201.

mònsálé 111 .

koetoe nò tánò $24,31-35,62,73,291$, mònsoesoeléàn lai 200 .

293.

kóloi tálèngá 184 .

kòlòng 151 .

kota $57,60,95,180$.

lábong 244 . mósiláákòn pómàngòn 227.

móntinggoeloei 284.

mòntoloek làmbèng 158 .

móntòlòsàn 200.

mòntòòngi bálá lájàt 97 .

móósóá 216.

làngka-làngkai $53,95-98,100,107,112$, mótòmbing $109,151,258,280,285$.

$151,153,175$.

léàn

léàng 151, 216, 280.

léàr

lioe 274.

lipoe 56.

mádi 6.

mákákiòp 157.

máláloean boengkoetnjò 33,90 .

màmá' 192.

màngáé 175.

màntáhi 156.

màntoeàn $205 \mathrm{v}$.

métáhi 156.

mòtò'oetoes 192

mòtò'oetoes-oetoes 192.

nènè 192.

oebákoe oei $247,250$.

oedjoeláá

oedjoeráá

154, 227, 229.

oedoe 93 .

oemoi 244.

oetoes 192 .

òlitaoe 243.

249.

miàn i bósánjò 89, 263.

— dáká' 84.

pábisálá | 33, 53, 95 v., 98, 107, 151, pábisárá | $153,156$.

184, páhémàtà 64. 100, 266.

pálá-pálàngàn 288.

pàndjòlò 95 v., 98, 175.

pàngá'àn $155,283$. 
pàngoetang 206.

pàntáná noe soesoe 216.

pàntòngá 192.

pásápoe $100 \mathrm{v}$.

pátákòn 216.

pilógòt 12 v., 55 v., 58, 82, 111, 274.

pinásàng 59 v., 95.

pinòngáláléàn 244 .

poeli 278.

pólámoenàn 257.

pòmbébé'i $64,100,266$.

pòmpópéá 216.

pongáláléàn 244.

pòngápin 206.

pòngkéáli 96, 98, 175.

pòngóósi $205 \mathrm{v}$.

pòntàmbó 225.

pòntàmpòl

\begin{tabular}{l|l} 
pòntàmpòng & 278.
\end{tabular}

pòsoehàngàn 100, 103.

pòsoeoeòn 205 .

sábòek 247.

sábòn 250.

sáloeàn 33, 101, 103.

sàmbábá 63 v., 243, 266.

sàmpoeloe kò'òhoeá 72 .

sàngkòlòng táhoe 283.

sàntimoá 270.

ségá $95,98,151,175$.

ségòt ká oelájò-oelájò 275 .

soeháng 100.

sioeknjò 34 .

soelápá $59,60,68$.

tákoeá 101.

tálèngá 95, 98, 159, 176, 184.

tàmpáloei 192.

\begin{tabular}{l|l} 
tàmpòl & 278.
\end{tabular}

tánáás 64, 266.

tánò 98, 263.

tátoe 93.

táwá 216.

tèmpàs 243.

tiánàn 196.

tiná 93, 192.

tóbóbóoené 192.

toeá'njò 99,107, 177.

toemá (i) $93,192$.

- noe bósanjò $95,98,100 \mathrm{v}$.

- noe dákánjò $95,98,102,108,151$, 176.

- noe tánò 95, 98.

- noe tònggòl 95, 96, 101.

toembàk 96 .

toempé 192 .

- bóoené 192.

- móáné 192.

toempoe noe bòndoi 244 . toetoei 26,31 .

tògòlòpò 244 .

tòmbing (zie: mótòmbing).

tóminsàn bóoené 192 .

- móáné 192.

tòmoendò 176 .

tómómóáné 192.

tòmpoek $53-57,73,187,241$.

tònáás (zie: tánáás).

tònggòl $13,72,84,86,88,94$ v., 97,108 ,

$112,147,151,160,175,215$ v., 225 ,

240 v., 249 v., 277,283 v., 287.

- sàmpoeloe kò'òhoeá 72 .

tònggòn 97, 250.

tó ségá-ségá 95, 176.

Termen-sian. *)

ànàk 93.

- boelé 196.

- ná miàn 99 .

- oe miàn 99 .

ásáàn 174.

átá 88 .

bábááboe 91 .

bálá 35 .

baoebé 277.

bàsàl 97.

bátàngká' 281 .

bátárai bóliàn 270 .

bènse $54-58,187$.

berkàt 12 .

bòngoenòn 60 .

bósánó 57, 97, 102.

dáwòk 191, 201.

gensing 53 .

ili 93.

kòsiàn 6.

làngká-làngkai 97 v.

lénàs 60 .

lioe 274.

lóoetàng 278.

lòtoe 270 .

màmpámárèrèkòn 221.

màngkákiòp 157.

mensingkòm besi 158 .

mensoeò 215.

miàn 87,173 .

mógòrá 228.

momoèlòs 156 .

— na ikiràn 156.

*) Zie blz. 6 . 
mònsimpòt gògòròng 200, 275 . mònsoi 245. mótárò' 281.

ngáàn 93.

óboelòs 280

oedoeráá 154 .

paoe bàsàl $97,147,249$.

pensoeò 215.

pilógòt 12.

- mólá 12, 200, 274.

pówóóli 226.

rapi 231.

réár 227.

roeroe 123 siàn 6.

silábó 191.

siná 93.

sináná 93.

soemáwi 111, 270.

soèndoeki 91 .

soerò 179.

támá (i) 93, 98.

támánò bósánó 98 .

tátoe 93.

timpá 270.

tóbàngkàs 225, 277.

toemá 98.

toemá oe bósánó 98 .

tònggòl $53,88,96$ v., 147, 174, 200, 215 v., 249 v.

- mbòjòkò 98 . 


\section{Wijzer der plaatsnamen.}

Hoofdletters en cijfers correspondeeren met de coördinaten van de schetskaart.

Apal (no. 24) G 4

Awok (no. 28-b) D 2

Baba (no. 29-g) ?

Bakoetan (no. 30-e) C 2

Balantak: zie Dale-Dale

Balingara A 3

Banggai (eiland) G/H 5/6

Banggai (plaats) G 5

Bangkoehan (no. 29-d) D 2

Bangkoeloe F 6

Bangkoeroeng $=$ Bangkoeloe

Basaboengan: zie Saloean

Basama (no. 34) F 2

Basosol (no. 8-i) F 4

Batoeanano (no. 8-k) F/G 5

Batoei (no. 27) D 4

Belalon (no. 8-h) F 5

Boalemo (voormalig rijkje) F 1

Boelagi (voormalig rijkje) F 4

Boelagi (no. 13) E/F 4

Boengkoe (Landschap) A 5

Boeoko (voormalig rijkje) E 4

Boeoko (no. 14) E 4/5

Bojo (no. 29-f) ?

Boneaka (no. 7) G 5

Boniton (no. 25) G 5

Bongganan (voormalig rijkje) G 4

Bwokan (Bokan; Toropot) H 6/7

Dale-Dale (no. 36) G 2/3

Dodoeoeng (no. 2) G 5

Doehian (no. 28-a) C 3

Dondalon (no. 30-d) E 2

Gong-Gong (no. 4) G 5

Gori-Gori (voormalig rijkje) C 4

Inetes (Lingketing) (no. 29-a) C 2

Kadoepang (voormalig rijkje) F 4/5

Keleke (no. 8-f) E 3

Kintom (no. 29) D 3

Koewajang (no. 30-c) E 2

Kombotokan (no. 21) $\mathrm{H} 4$

Labobo G 6

Lamala : zie Tanotoeran
Lambangan: zie Padang

Lampa (no. 5)) G 5

Liang (no. 10) F/G 5

Lingketing : zie Inetes

Lipoeadino (no. 8) E/F 4/5)

$\mathrm{F} / \mathrm{G} 4 / 5)$

E $2 / 3$ )

Lipoetomoendo (voormalig rijkje) F/G 5

Loeokpanenteng (no. 26) E/F $3 / 4$

Loeoksago (no. 22) G 4

Loewoek (plaats) E 3

Loewoek: zie Mangkiin Piala

Lolantang (no. 8-a) F 4

Lontio (no. 31) E 3

Lo'nsom (no. 8-g) E 2

Mangkiin Piala (no. 33) E 2/3

Masoni K 6

Mehangi (no. 29-b) D 2

Mendono (no. 30) D 3

Minahaki (no. 38) C 4

Monsoongan (no. 3) G 5

Motindok-Bola-Lowa (voormalig rijkje) C/D 4

Nambo (no. 32) E 3

Ondjoelaan (no. 29-e) E 2

Padang (Lambangan) (no. 30-b) $\mathrm{D} / \mathrm{E} 2$

Paisoeoeloeno (no. 11) G 4/5

Palabatoe (no. 8-b) E 5

Papadang (no. 8-j) F 5

Patoekoeki (no. 8-d) F 4

Pelei (no. 20) G 4

Peling (eiland) E/H $3 / 5$

Peling (voormalig rijkje) F 4

Peling (no. 12) $\mathrm{F} 4$

Poat D 1

Poetal (no. 6) G 5

Pokobondolong: zie Dale-Dale

Pokoeehan (no. 29-c) D 2

Pona (no. 30-f) D 3

Ponding-Ponding (no. 18) G 4

Pongeman (no. 28-c) F 1

Popiisi (no. 17) G 4

Salaoewe (?) 


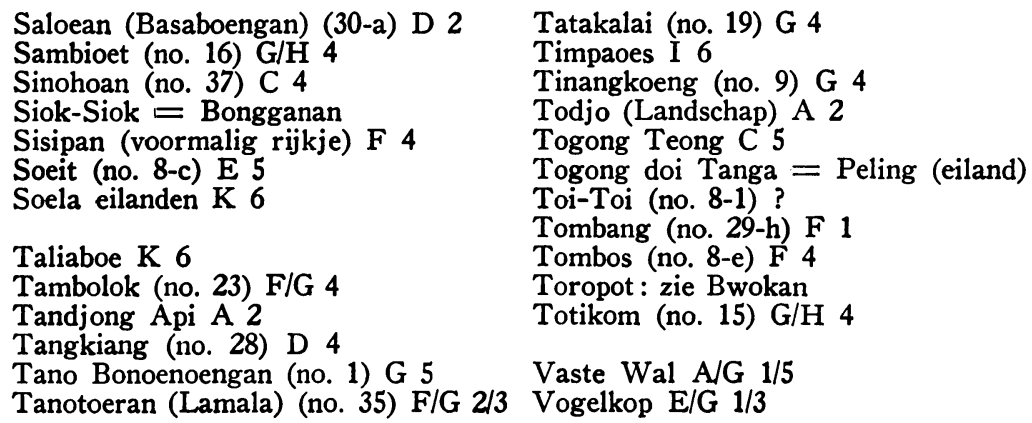




\section{Toelichting bij de schetskaart van het landschap Banggai.}

Namen tusschen haakjes beteekenen voormalige rijkjes. - Pijlen wijzen op volksverplaatsingen of uitzzvermingen. - De nummers zijn dezelfde als gebruikt in par. 1 van Hoofdstuk II (blz. 26 v.); zij geven ongeveer de ligging der streekgemeenschappen aan.

Eiland Banggai :
1. Tano Bonoenoengan
5. Lampa
2. Dodoeoeng
3. Monsoongan
6. Poetal
4. Gong-Gong
7. Boneaka

Eiland Péling :
8. Gebied van den Lipoeadino, omvattende :
8-c. Lolantang Tombos

\begin{abstract}
8-b. Palabatoe
8-c. Soeit

8-d. Patoekoeki
\end{abstract}
9. Tinangkoeng
10. Liang
11. Paisoeoeloeno
12. Peling
13. Boelagi
14. Boeoeko

$$
\begin{aligned}
& \text { 8-f. Keleke } \\
& \text { g-g. Lo'nsom } \\
& \text { 8-h. Belalon }
\end{aligned}
$$
15. Totikom
16. Sambioet
17. Popiisi
18. Ponding-Ponding
19. Tatakalai
20. Pelei
8-i. Basosol
8-j. Papadang
8-k. Batoeanano
8-1. Toi-Toi
21. Kombotokan
22. Loeoksago
23. Tambolok
24. Apal
25. Boniton
26. Loeokpanenteng

Vaste Wal :

27. Batoei

28. Tangkiang; 28-a Doehian

28-b Awok

28-c Pongéman

29. Kintom; 29-a Inetes (Lingketing)
29-b Mehangi
29-c Pokooehan
29-d Bangkoehan
29-e Ondjoelaan
29-f Bojo
29-g Baba
29-h Tombang

30. Mendono; 30-a Saloean (Basaboengan)

30-b Padang (Lambangan)

30-c Koewajang (Kompanga)

30-d Dondalon

30-e Bakoetan

31. Lontio

30-f Pona

32. Nambo

33. Mangkiin Piala (Loewoek)

34. Basama

35. Tanotoeran (Lamala)

36. Dalé-Dalé (Pokobondolong of Balantak)

37. Sinohoan

38. Minahaki. 


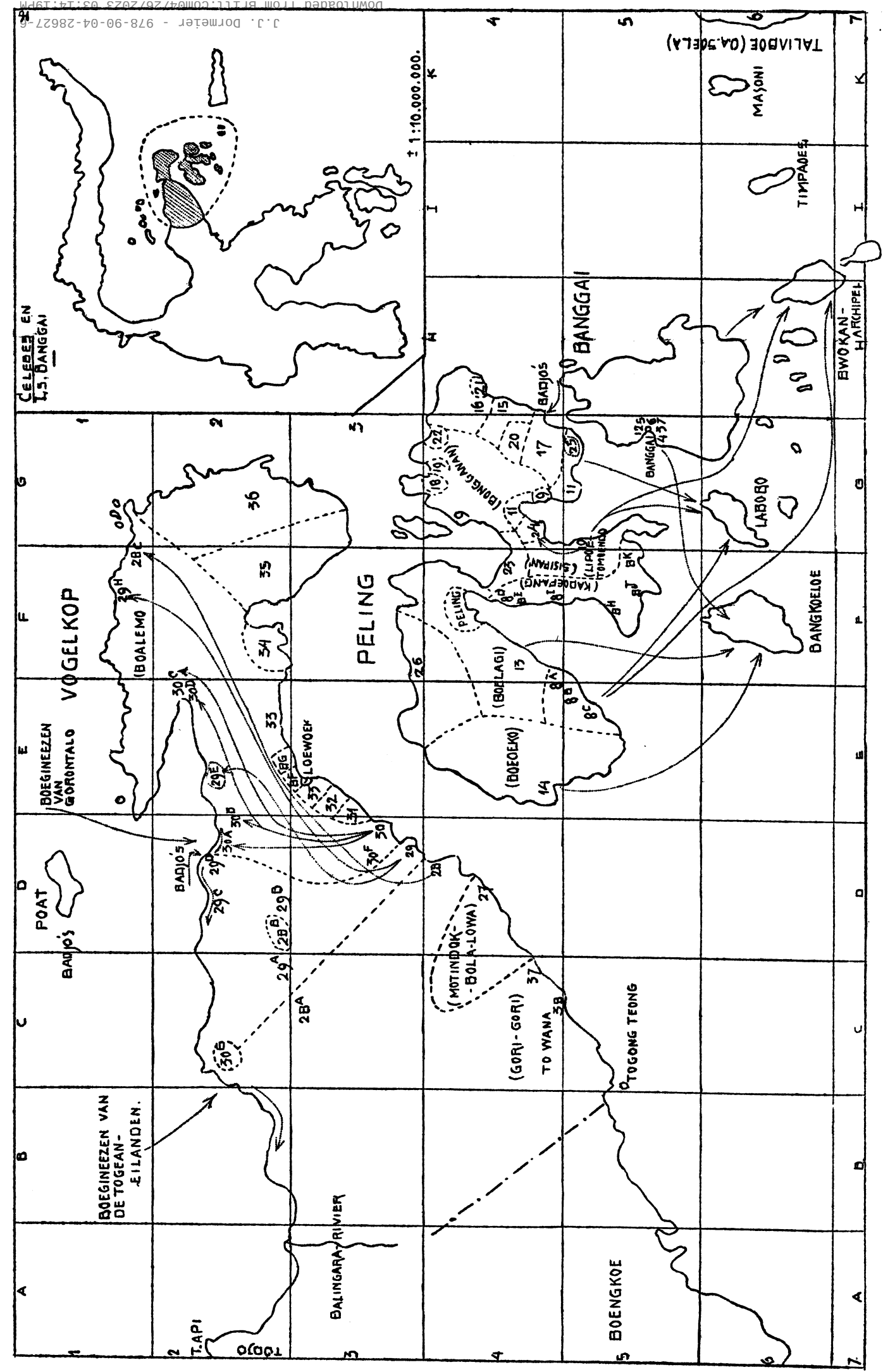

